\title{
凤招請講演 I
}

\section{Clinical Applications of Flow and Image Cytometry :Complementary or Competing Technologies}

\author{
JAMES B. HENDRICKS, PH.D. \\ Department of Pathology and Laboratory Medicine, \\ University of Florida Diagnostic Referral Laboratories \\ U.S.A.
}

The two major technical approaches to the measurement of individual cells and cellular constituents are flow and image cytometry. Both techniques have gained universal acceptance in the clinical laboratory. In flow cytometry, cells are measured in a monodisperse suspension. The basic mechanics consist of injecting a suspension of cells through a nozzle and into a stream of flowing sheath fluid. The principal clinical measurements are: (1) normal and neoplastic surface antigens (immunophenotyping) and (2) DNA ploidy and proliferation. In image cytometry, cells or tissue are measured on a glass slide. The basic mechanics consist of scanning an image, with closely spaced spot measurements taken along each scan line. The principal clinical measurements are: (1) quantitative immunohistochemistry, (2) DNA ploidy, and (3) texture measurements (malignancy associated changes).

Although flow and inage cytometry measure similar properties, they should be considered complementary technologies. Clinical samples should be triaged to take advantage of the unique features of each technology: flow cytometry offers rapid analysis of large numbers of cells: image cytometry offers microscope guided selective cell analysis.

A new technology has recently emerged which combines the unique advantages of image and flow cytometry - laser scanning cytometry. Laser scanning cytometry. provicles objective, automated, multi-color analysis of very small samples with visual examination of individual cells both during and after analysis. 


\title{
曰招請講演 II
}

\section{Clinical Applications of Image Cytometry: DNA-Ploidy Analysis and its Clinical Relevance}

\author{
Heinz K. Grohs, M.D.,Executive Director \\ International Institute for Applied Cyto Science Incorporation \\ U.S.A.
}

\section{Educational Objective(s):}

This course will present the applications of DNA-ploidy and cell cycle analysis, the construction of DNA histograms and their clinical interpretation regarding diagnosis of cancer and assessment of tumor prognosis from cytologic specimens.

Summary of Content:

In the introduction, the rationale for subjective quantitation of cytologic specimens (micromorphometry and microspectrometry) is given, followed by a brief discussion of the technical basics of image cytometry.

Under clinical application, the participants will become familiar with the normal and abnormal cell cycle, the interpretation of DNA-ploidy histograms and the relevant parameters in histogram interpretation-ploidy balance, proliferation index and hyperploidy index: using normal and abnormal histograms as examples, the importance of their interpretation for diagnosis, prognostication and therapy of ncoplastic disease will be presented, with special reference given to bladder, prostate and breast carcinoma in addition to the discussion of other malignancies; DNA-histogram distribution patterns according to the Stockholm (Auer) classification and the relevance of this classification scheme to patient survival will be shown. 


\section{邓特別講演}

老化之癌化

静岡県立大学生体生理制御学部門

加治和彦 $(\mathrm{PhD})$

多細胞動物の体細胞は個体発生、細胞交代、 修復に際して分裂して、その数を目的に応じ て増やす。細胞分裂した娘細胞は、その母細 胞とは全く同じ性質を持った細胞ではない。 これを細胞加齢という。細胞加齢に伴い細胞 機能の変化が見られる。さらに体細胞は有限 回の分裂の後分裂能力を失う。これを細胞老 化という。個体は加秢が進むにつれて、分裂 加歯が進んだ細胞や、分裂能力を失った細胞 から構成されるようになる。これが個体の生 理的老化の主要因になっていると思われる。

体細胞は生理的な老化に到るまでの間に、 それから逸脱し、無限増殖能を獲得し不死化 することがある。この細胞はさらに正常な増 殖調節機能を失い悪性化し、最終的に癌細胞 となる。細胞の老化の機構之不死化への転換 の機構が、細胞の老化と癌化の鍵を握ってい いるものと思われる。

細胞の老化は、種々の物理化学的ストレス スや、生物学的な因子の影響を部分的にしか 受けないことから、遺伝的にプログラムされ た過程であると思われる。細胞老化に関与す る遗伝子が探索され、多くの候補遺伝子が報 告されてきている。それらは、（1）老化を 刻む時計としての遺伝子と、（2）老化の実 行遺伝子の 2 つのグループに分けて検討すべ きであろう。我々は加齢時計の役割をする遺 伝子としてテロメアとテロメラーゼを検討し た。また、後者に関しては、TMIG-2DPAGE (老人研二次元電気泳動蛋白質データベータシ ステム）を開発し、加齡度の異なった細胞、 老化細胞および不死化細胞の蛋白質を解析し 始めたところである。今回は、これらの成績 を中心に提示し議論したい。

\section{凶教育講演}

蛍光インサイツーハイブリ

ダイゼーション(FISH)と細胞診

岩手医科大学産婦人科松田壯正 (MD)

蛍光インサイッーハイブリダイゼーション (FISH)は染色体特異的プローブの開発に伴い、 臨床の場でその応用範囲が急速にひろがってき た。細胞標本を用いたFISHには以下のような特 徵がある。1. 培養操作を必要とせずに染色体分 析ができる（間期細胞遺伝学）このことはたと え得られた細胞が少数、たとえ一個であっても 染色体分析が可能であり、また多数の細胞一つ 一つの染色体分析ができる事を意味し、臨床検 体を扱うときに強力な武器になる 2 . 通常2日の 操作時間であるが、染色体数のみ（例えば後述 のダウン症候群の診断など）の検討であれば2 時間にまで短縮できる 3.通常の蛍光顕微鏡で観 察でき、蛍光シグナル数を数えるだけで染色体 数を算定でき、結果の判断に特別な訓練を必要 としない 4.固定条件が設定しやすい

FISHの応用：1. 先天性染色体異常の出生 前診断; 出生前染色体検查は広く普及しつつあ り、羊水穿刺による胎児細胞の採取、䄉毛サン プリングのみならず臍帯血管からの胎児血のサ ンプリングも行なわれている。これらの検体を 使用して出生前に診断される多くの遺伝性疾患 は、常染色体か性染色体の增減によって引き起 こされるが、ダウン症候群はその代表であり FISHで容易に診断できる。2. 悪性腫瘍ないし その前駆病変における染色体数異常および癌遺 伝子、癌抑制遺伝子の異常の検出; 悪性腫瘍お よびその前駆病変において染色体数異常（減少 と増加）が知られており、それぞれの染色体の 増減が固有の病変に関与していることが示唆さ れている。また数の多漂で鑑別診断が行なわれ る。癌抑制遺伝子の欠失と癌責伝子の増幅が数 の変化による場合はFISHの最もよい検索対象に なる。

今後様々なプロープの開発に伴って、FISHの 有用性はますます高まっていき、より簡便で信 頼性のおける方法が確立されると考えられる。 
要望講演 I

醉秦抗体法之 ISH

長绮大学医学部解剖学 111

中根一䅼(PhD)、小路武彦 (PhD)

醉秦抗体法は通常、細胞や組辆内に存在する 抗原とこれと特異的に免疫複合体を形成する醉 素摆裁抗体とを反応させる直接法と、矛め絧胞

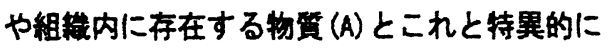
複合体を形成する物筫 (B) とで椱合体 $(A+B)$ を形 成（一次反応）させ、追って、物筫 (B)を抗原 として、これと特翼的に免废複合体を形成する

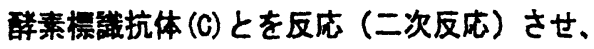
物䈯(A)の局在を証明する間接法がある。代表 的な間接法としては、物筫 (A)は抗原で、これ と特異的に免疫複合体を形成するウサギ抗体

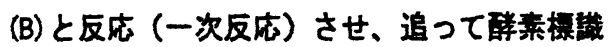
抗ウサギ $\operatorname{gG}(C)$ と反応 (二次反応) する手法が 知られている。最近では、間接法の一次反伈に 種々の物㬏間特異的結合反応を利用する手法が 開発されている。この中で最も著名なのが、in situ hybridization 法である。この手法は。 主に特定の笽基眍列を持つメッセンジャー RNA （mRNA）(A）は相禣的な塩基配列を有する一本 鎖のDNA や RNA (B) と特異的に二本鎖を形成 する性格を一次反纯として利用し、細胞内 mRNAの局在を晸明するのに使用される。畏近 韧介されたSouthwestern Histochemistry法は、

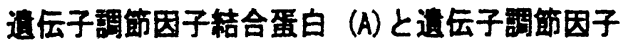
(B) 間の特異的結合反念を一次反伈として利用

\section{している。}

従って、Southwestern Histochemistry法に

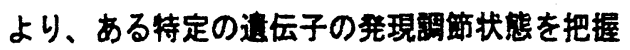
し、in situ hybridization 法によりその这层 子のmRNAへの転写状態を知り、免废粗機化学法

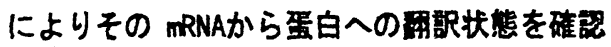
する事が可能になりつつある。

\section{曰要望講演 II}

細胞診断と画像診断

東京医大外科 1 講座、British Columbia Cancer Research Centre

加藤治文(MD), 池田徳彦(MD), 勝海東一郎(MD), Branko Palcic(PhD), Stephen Lam(MD), Calum MacAulay(MD)

肺癌は一般に悪性度が高く多様な臨床像を示す。 その增殖能評価は肺癌診療に有益であり、現在 分子生物学や免疫組織化学などによるアプロー チが行われている。今回我々は癌細胞核の微細 構造の差によって增殖能評価が可能か否かを検 討した。特に T 1 腺癌 60例（I 期 31例、II期 3例、 III期 19例、IV 7例）を対象とした。切除材料の 捺印標本を High Resolution Image Cytometer で各 症例につき500個以上の癌細胞核を計測した。個々 の核につき57項目の微細構造を計測した。 Discriminnt Function Analysis の結果、悪性度の高 い細胞に特徵的な3項目が得られた。このような 細胞の出現頻度と病期には高い相関が認められ た。また、術後 5 年以内に癌死した 27 例のうち 22 例（81\%）は高悪性度の細胞の出現頻度が $50 \%$ 以上であった。

また新しい概念として Malignancy Associated Changes (MAC) が増殖能評価に有用かどうかを 検討した。MACとは悪性腫瘍を有する症例の腫 瘍から十分に離れた正常部位の細胞と、正常人 の正常細胞は光顕レベルでは差は発見されない が、実際にはわずかな差があるという概念であ る。我々は気管支鏡下に正常部位の擦過材料 75 例 (進行癌24例、早期癌 8 例、中等度以上の異型 化生14例、軽度の化生 17例、正常者12例）を対 象とし、High Resolution Cytometry 者用いて、各 症例でのMACの陽性率を比較した。進行癌症例

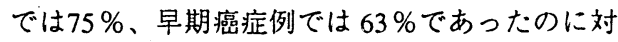
し、化生では $40 \%$ 、正常者では30\%であった。

以上のように、High Resolution Cytometryによ る核の微細構造の解析は肺癌の增殖能評価に有 用であることが示唆された。 
凶要望講演 III

惡性腫瘍の機能分化と細胞診

東海大学医学部病態診断系病理学

O長村義之（MD，F I A C)

細胞の分化を論ずる際に、我々は主として細胞の 形態と物質産生（機能）の面で “分化”をとらえ て来ていると思われる。特に後者は産生物質の面 から分化を見ることであり免疫組織化学の普及に よるところが大きいと言えよう。成熟組織では、

細胞形態と機能分化は相関することが多い。この 細胞形態は、我々が日常の細胞診断で遭遇するも のであり、早くより細胞の分化の指標と目されて きた諸要因である。超微構造的にも、分化に伴っ て細胞内小器官に特徵的が現れる。また、細胞の 機能分化の指標ともなる物質産生も、大別すれば 血清蛋白のように細胞外へ分泌される場合と、細 胞骨格のように細胞内にとどまって機能する場合 があり両者とも免疫組織化学、In situ hybridization により検出可能である。正常状態では、 細胞は遺伝子により制御を受け、周囲の組織・細 胞と harmony を保ちながら分化すると考えられ る。癌細胞は、autonomy を持った異常増殖と定 義されるが、しばしば細胞の分化異常も伴ってい る。特に、一般的に分化に伴い低下する核面積は、 癌細胞では増加しクロマチンも増量して細胞異型 として悪性細胞の criteria となっている。細胞 異型が高く、細胞形態・構造など分化の指標に乏 しい場合、細胞診断は困難となり、その診断は産 生物質の証明による機能診断に委ねられる（例、 小細胞からなる悪性腫瘍：小細胞癌、悪性リンパ 腫、肉尰など）。この際、免疫組織化学による上 皮マーカー、リンパ球表面マーカー、細胞骨格な どの分化の指標の検出が極めて重要となる。この ように、細胞の形態分化と機能分化が必ずしも一 致しないのも癌細胞の特徵であり我々が細胞診断 上最も留意すべき点である。本講演では、細胞診 断に焦点を当てつつ癌細胞の形態分化、機能分化 を論じてみたい。
会長講演 イメージサイトメトリー VS

フローサイトメトリー

会長講演

岩手医科大学産婦人科

西谷 橄 (MD)

細胞診は、鋭敏な癌の検出法として評価は高 いが、診断法としての特異性はいまだ未完成で ある。G. N. Papanicolaou以来これまで70年にお よぶ先人の英知と努力によって癌細胞の形態学 的情報が集稓され、細胞診指導医や㭘查士の細 胞判定の拠りどころとなってきた。

近年、痁細胞に特有の gynotype とくに、DNA ploidy や steroid receptorsなどの phenotypeにかか わる研究が目覚ましく進歩した。これによって、 增殖因子や遺伝子あるいは遺伝子産物が計量で きるようになり、これらの不均衡が診断上の重 要な情報となりつつある。この細胞計量に重要 な役割を果しているのが Image cytometry (ICM) と Flow cytometry(FCM)である。そこで、細胞計量 の細胞診への応用に向けてICMとFCMに対して (1)両者の技術開発の歷史的変遷 (2)測定精度よ りみた両者の価値と限界 (3) DNA ploidyおよび phenotypic markers 測定の優劣 (4)相互の相補な う能力よりみた利点と欠点 (5)両者の現状評価 と今後の見通しなどを明らかにする。

さて、21世紀の細胞診はいかにあるべきか。 形態所見に依存した細胞診から、客観化、自動 化そして能率化をもたらす計量細胞診の確立へ 向けて、会長講演の要旨としたい。 
இシンポジウム I

シ I - 1 HPV16型感染陽性の子宮頝部異形成に おけるp53蛋白発現, bc1-2蛋白発現と細胞の增殖 特性抢よび消退特性との関連性

愛知医科大学産婦人科

○綮下廣光 $(M D)$, 古谷 博 (MD), 野口昌良 (MD)， 中西正美 $(M D)$

【目的】HPV16型(HPV16)感染による子宮䅡癌の発 症機序を明らかにする目的で, HPV16感染陽性の子 宮頝部異形成(異形成)における細胞の消退特性 (Apoptosis細胞比率：\%Apo) および増殖特性 (PCNA 陽性細胞比率: \% WF) と, p53蛋白 (p53) pbcl-2蛋白 (bcl-2)の発現との関連性を検討した。【方法】異 形成44例を対象とし，その10\%緩衝 formal in固定 paraffin包埋組織を材料とした。HPV16はDNA probeを用いた in situ hybridization法にて， p53，bcl-2の発現抢よびPCNA陽性細胞はmicrowave 処理後, 免疫組織化学染色法にて, Apoptosis細胞 はTUNEL法にて検出した。 p53，bcl-2の発現は，5\% 以上の細胞が染色された場合を陽性とし，\%Apo，\% GFは500細胞以上中に占める染色陽性細胞の百分率 とした、【成績】1）HPV16は23例(52\%)に検出さ れ，そのうちp53陽性は13例 (57\%)，bcl-2陽性は7 例 (30\%)であった。 \%Apoはp53陽性群と陰性群の間 で差はないが, bcl-2陽性群 (4.12士3.07\%)では陰 性群(8.26士3.93\%)に比し有意な低値を示した。\% GFはp53陽性群 (18.38土7.56\%)では陰性群 (15.24士 9.98\%)に比し高値を示したが, bcl-2陽性群と陰性 群の間で差はなかった，2）HPV16は中層から表層 の異型細胞やKoilocyteに検出され，Apoptosis緗 胞は中層から表層に, PCNA陽性細胞は旁基底層か ら中層に局在し，p53は旁基底層と一部中層の細胞 に，bcl-2は中層の細胞に検出された。なお， HPV16陽性細胞のほとんどは, TUNEL法でも染色さ れた。【結論】HPV16感染細胞はApoptosisに陷 る。しかし, 異形成ではbcl-2発現による Apoptosisの抑制と p53発現に伴う增殖特性の元谁 とにより練胞增殖動態が增准する。

\section{シ I-2 子宮頝部異形成におけるテロメラー ぜ活性}

広島大学産婦人科, 同総合薬学科*

○永井宣隆 (MD)，村上順子(MD)，大濱紘三(ND)， 田原栄俊 $(\mathrm{PhD})^{*}$

[目的]近年, 不死化した細胞株, 痹組織由来細 胞ではテロメラーゼ活性が検出され，テロメラ 一ゼ発現と発癌との関連性が注目されている。 今回, われわれは PCRを用いた Telomeric Repeat Amplification Protocol(TRAP)アッセイ 法により子宮頝部異形成および上皮内複におけ るテロメラーゼ活性を测定し, 子宮預部異形成 とテロメラーゼ活性との関連性を検討した.

[方法]子宮頝部を摖過して得た細胞珳材料18例 (class II 12例, class II b 3 例, class N 3例)

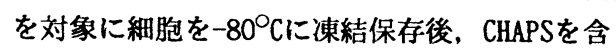
む溶解バッファーで溶解し, 遠沈後上清中蛋白 を測定した. TRAPアッセイ法は 1 検体あたり細 胞抽出液 $6 \mu \mathrm{g}$ 蛋白にPCRバッファー, $\alpha-{ }^{32} \mathrm{P}-\mathrm{dC}$ TP,TSプライマーを加え, テロメラーゼによるプ ライマー上でのTTAGGG鎖の延長を $20^{\circ} \mathrm{C}, 30$ 分間 行いCXプライマー(5'-CCCTTACCCTTACCCTTACCC TTA-3')を加えPCRでテロメラーゼ産物を増幅し， 電気泳動後オートラジオグラフィーにて判定し た.

[成績]テロメラーゼは6塩基のラター形成とし て認められ，class Nの 3 例 ( $100 \%)$ ，class II bの 3 例 $(100 \%)$, class 四の 8 例 $(66.7 \%)$ に強陽性 が観祭され，class I 4例には弱陽性がみられた。 [結論]子宮䫋部の摖過細胞材料よりテロメラー ぜ活性を测定し, 高度翼形成から上皮内澡が推 察されるclass II b，Nで高率に強いテロメラー ぜ活性を検出し, 異形成の進行に伴う生物学的 活性とテロメラーゼ活性との関連性が示唆され た. 
シIー3CGHおよびLCを用いた是形成から

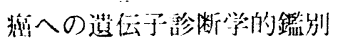

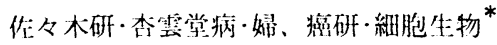

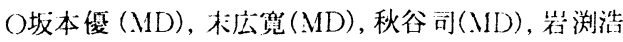

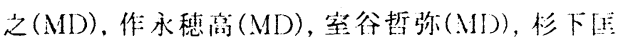
(MD), 天神美夫 $(\mathrm{MD})$, 野田哲生 (MD)*

子宫㸚部発癌過程における未知の遗伝学的変化在 解明するため、各段階に相当する細胞株および臨床 検体に対してCGH分析を施行した。対象は正常斋 部組織 3 例、買形成 4 例、上皮内癌 2 例、浸润矮 7 例より樹立した細胞株16例ならびに臨床検体（漫 潤癌） 4 例の計 20 例であった。遺伝子コピ一数異 常を示した染色体領域（CNA）の総数の平均值は 正常では 0 , 異形成 7 , 癌 13 であり、癌化過程の進 行に伴い増加した。異形成においては、軽度や中等 度と比較し高度異形成の方がCNAの総数が多かっ た。子宮頸癌において13個の遗伝学的变化が高頻 度に認められた。そのうち、19q+, $20 \mathrm{q}+, 8 \mathrm{q}+$, $3 \mathrm{q}+, 3 \mathrm{p}-, 4 \mathrm{q}-, 16 \mathrm{q}-$ は異形成より認められ早期の 遗伝学的変化である可能性が示唆された。特に、 $19 \mathrm{q}+, 4 \mathrm{q}-1$, 16 $\mathrm{q}$-は軽度・中等度基形成にはみられ ず高度異形成以後に認められ、発癌に関わる重要な 変化であると考えられた。また、5p+, 万q,$+ 1 \mathrm{q}^{+}$. $9 \mathrm{q}+, 17 \mathrm{q}+$ は上皮内癌以前には認められず浸潤癌 のみに認められ、子宮项癌の浸潤・進展に関わる後 期の変化である可能性が示唆された。次に、頝栢の 子宮顸部擦過標本に対してPI単独染色後、ISC (Laser Scanning Cytometry) を用いて綀胞形態 と緗胞周期との相関を検剖した結果、2CかつPIヒー-

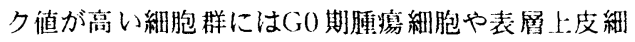
胞がみられ、2CかつPIピーク做が低い細胞群には

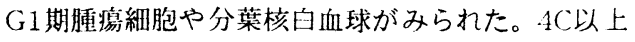
の細胞も多数みられた。さらに、CGHで蚞出され た癌化関連CNA領域に特異的なDNAフローブを用 いてFISHを行い、LSCにより FISHシグナルの定星 を行い、癌細胞や前癌細胞の検出、細胞形揸との相 関を行う予定である。
シ I-4 多段階発癌過程からみた子宮頸部異 形成由来培荃細胞株の細胞生物学的特性

癌研病院婦人科 ${ }^{12}$ 、同細胞診断部 ${ }^{2}$ 、癌研細胞生物部 ${ }^{3)}$ 、同病理部 ${ }^{4)}$ 東京医大産婦人科 ${ }^{5}$

○平井康夫 $(\mathrm{MD})^{122) 3}$ ) 方立瑟 $(\mathrm{MD})^{335)}$, 白石賢也 $(M D)^{355)}$ 、河口徳 ${ }^{4}$ ， 北川知行 $(M D)^{4}$ 、加藤友康 $(M D)^{122}$ 、荷見勝彦 $(M D)^{122)}$ 、古田則行 $(C T)^{2}$ 、坂谷敬 子(MD) $)^{3)}$ 、柴田浩行 $(M D)^{3)}$ 、野田哲生 $(M D)^{3)}$

ヒト子宮頸部扁平上皮激は扁平一円柱上皮接合 部および円柱上皮下に分布する「予備細胞」が発 生母地となり、前癌病変である異形成、上皮内癌 を経て浸潤癌に移行するとされている。しかしな がら、この多段階発癌がいかなる因子により、い かなる機構で進行するのかはほとんど解明されて いない。これらの多段階発癌の各段階の病変、特 に、異形成に由来する培羔細胞が利用出来れば、 発癌の各段階に関与する外的因子や遺伝子変異の 同定およびその機能解析に応用出来る。我々は、 独自に開発したヒ卜子宮顓部異形成由来培養細胞 7 株を継代維持しているので、各々の樹立過程と その細胞生物学的性格について報告する。

異形成由来培盖細胞 7 株は、営光抗体法による keratine subtypeの染色では扁平上皮系の性格を 有し、いづれもHPV·DNAが検出された。浸潤虎 由来培羡細胞に較べると、 N/C比が極端に低く、 growth rate やsaturation densityも低かった。 in vivo三次元培養法では、上方に向かって分化 傾向を示し、培養細胞の維抹Papanicolaou染色標 本ではHPV 感染細胞特有のkoilocytosis様の変化 がみられた。TGF $\beta$ 1に対する反応性は保たれ、 ヌードマウスへの造腫瘍性はみられなかった。す なわち、我々の細胞株は、前癌病変である異形成 の性格を保持していると考えられた。異形成は微 小なためしばしば解析が制限されるが、本培養細 胞により均質な材料が得られるので、今後、異形 成の遗伝子変異の解析、apoptosis、浸潤・転移の 機構解明に応用の予定である。 
凤シンポジウムII

シII- 1 客観的核異型度評価による甲状腺乳頭 癌リンパ節転移予測

千葉大学第一外科

○長嶋 健、鉿木正人、押田正規、橋本秀行、 矢形 寛、中島伸之 (以上MD)

検診の普及等により比較的早期の甲状腺癌症例 は增加しているが、甲状腺乳頭癌はリンパ節転移 が高率であり、各種画像診断によっても微小なリ ンパ節の質的診断はしばしば困難であるため、甲 状腺切除に加え頝部リンパ節隔清を併施している のが現状である。今回我々は画像解析装㯰を用い て術前細胞診検体より細胞核異型度の客観的評価 を行い、リンパ節転移予測の可能性につき検討を 行ったので報告する。

対象は1987年6月から1994年12月までに当科に おいて手術を施行した初発甲状腺乳頭癌症例のう ち䅡部リンパ節郭清を併施した 89 例、及び1995年 の症例24例である。術前細胞診にて採取された細 胞核を画像解析し、平均核面積 - 周囲長 - 円形 度・針状比、及び大小不同性の客観的指標として 核面積変異係数（NA.CV）を算出した。また従来 の形態学的因子である核溝 ·核内細胞質封入体の 出現率を求めた。組織検体でも同様の計測を行っ た。

リンパ節転移の有無別に見ると、NA.CVにおい

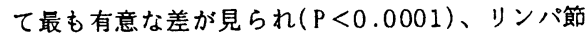
転移個数との間にも相関を認めた。また計測値は 組織検体を良く反映していた。NA.CVのcut of $f$ 值を $22 \%$ と定め、1995 年の症例をもちいて prospectiveに検討すると、NA.CV高值群と低値 群ではリンパ節転移との間に有為な差を認めた $(p<0.01) 。 ま た$ 再発例はすべてNA.CV高値群で あった。

客観的核異型度NA.CV値は術前リンパ節転移予 测の指標となり、術式決定の一助となる可能性が 示唆された。

\section{シII-2 体腔液材料におけるテロメ} アーゼ活性の検討

岐阜大学 - 医 - 第一病理1)、厚生連岐北総 合病院 2 )

○吉見直己(MD) 1)、戸島 敏(CT) 2)、新井 正(MD) 2)、安田 洋(MD)2)、高橋京子(CT) 1）、井野夏子(MD) 1）、森下由紀雄(MD) 1)、 杉江茂幸(MD) 1)、田中卓二(MD) 1)

近年、染色体末端に存在するテロメアは細 胞の寿命に関与すると言われ、癌細胞では その短縮化が認められ不死化に関与すると されている。テロメアーゼはテロメアを合 成する鋳型RNAをもつた逆転写酵素である が、最近、 polymerase chain reaction (PCR) を利用した高感度のアッセイ系(telometric repeat amplification protocol (TRAP) assay) が 考案され、その活性の有無が腫瘍の悪性化 に関係することが報告された(Science, 266, 2011, 1994)。今回、我々はTRAP assayの 体腔液材料への応用性について、培養細胞 を使つた基礎的及び実際の胸・腹水細胞診 材料で検討した。[材料と方法]培養細胞は 大腸癌由来細胞COLO320(p53 点突然変異 を有する)を用い、健常人白血球に対し 1 10000対1の混合液を作成し、以下のテ ロメアーゼ活性の発現限界を検討した。 TRAP assayは上記のKimらの方法に従い 蛋白抽出を行った後、PCRにて増幅した。 PCR産物は15\%アクリルアミドゲルにて電 気泳動後、オートラジオグラフィーにて確 認した。加えて、体腔液細胞診時に残存す る沈椬を保存できた19サンプル(14症例)に ついて上記のTRAP assayを試みた。[結果 ・考察]今回の培養細胞によるTRAP assay の検出限界は1対100程度であった。また、 細胞診上陽性とされた6サンプルのうち4つ にTRAP陽性をみ、また疑陽性及び陰性と された13サンプルはすべて陰性であった。 検出法の改善を含め、報告する。 
シII-3 Laser scanning cytometerの細胞骖 への応用

国立がんセンター中央病院臨床検査部 ○島村香也子(MD)、前沢 直樹(CT)、野本 清明 $(C T)$ 、當銘良也 $(C T)$ 、渡部庸一 $(C T)$ 、長谷川 達朗(CT)

[目的] Laser scanning cytometer（LSC)はフロー サイトメーターと蛍光顕微鏡および光学顕微鏡 の機能を兼備した新しい細胞観察手段であり、 スライドグラス上で、きわめて短時間に、きわ めて多数の核のDNA量を測定できるとともに、 測定した個々の細胞の形態像を直接観察する

ことができる。

我々は今回、LSCについて1）日常細胞診の 補助手段としての有用性および2）過去の細胞 診材料を用いた再染色標本におけるDNA 解析の 可能性について検討した。

[材料と方法] 新鮮材料（尿 40 例、体腔液 10 例、気管支洗浄液 - 乳腺穿刺洗浄液各5例）は、 エタノール固定後オートスメアで塗抹標本とし、 RNase・Propidium iodide混合液で染色した。

また、過去の細胞診材料には20例の乳腺穿刺 塗抹標本 (Papanicolaou染色) を用い、カバー グラスを外し、脱色ののち上記の混合液で染色 した。LSCで10,000〜20,000個の細胞の核DNA 量を測定し、CV值、ploidy patternおよびDI值 を求めるとともに、DNAヒストグラムと形態像 の対比を行った。

[成績] 新鮮材料の場合、評価可能なヒスト グラムが得られたのは、尿では40例中9例、 その他の液状検体では20例中13例であった。

細胞が少ない検体、変性が強い検体、細胞の 重なりやクラスターが多い検体、粘液や壊死 物質が多い検体では見せかけのdiploidが、また、 変性が強いときは見せかけのaneuploidが発生 した。再染色標本では、20例中17例のヒスト グラムが評価不能であった。

フローサイトメトリーおよび蛍光影微測光法 との長所・短所の比較、ならびにLSCに適した 細胞標本の作製法について述べる。
シII-4 膵液細胞診とK-ras癌遺伝子診断の 対比検討

大阪府立成人病センター細胞診 ${ }^{11}$, 内科 ${ }^{21}$, 外科 ${ }^{31}$, 国立がんセンター中央病院臨床検查部 ${ }^{41}$, 内科 ${ }^{51}$ ○竹中明美 (CT $)^{11}$, 中泉明彦 $(\mathrm{MD})^{21}$ ，上原宏之 $(M D)^{21}$ ，石川治 $(M D)^{31}$, 大東弘明 $(M D)^{31}$ ，岸上義彦 $(\mathrm{MD})^{12}$, 菅野康吉 $(M D)^{4)} \cdot{ }^{5}$, 岡田周市 $(M D)^{5}$

[目的]膵液中 K-ras癌遺伝子点突然変異の検出は 膵癌の分子生物学的検查法として注目を集めてい るが, 最近では非癌症例の膵液からも検出されるこ とが判明してきた.そこで突然変異の有無と膵液細 胞診における細胞異型とを対比検討した. [対象と 方法] 膵癌 11 例, 慢性膵炎 14 例, 正常対照 5 例の計 30 例を対象とした. 内視鏡的に採取した膵液を用い てK-ras codon12点突然変異に関してEnriched PC R/Non-RI SSCP法によるスクリーニングとdirect sequenc ing法による塩基配列の決定をおこなった. 膵液細胞診はPapani colaou染色を行い, 悪性細胞, 異型細胞, 過形成細胞等の軽度異型細胞, 正常細胞 の 4 群に分類した. K-ras突然変異陽性の非癌症例 は, US·CT·ERP·膵液細胞診等にて f $0110 \mathrm{~W}-\mathrm{up}$ 中であ る. [成績] (1)K-ras 突然変異は膵癌 11 例中 10 例, 慢 性膵炎14例中7例に認められたが, 正常対照5例では 1例も検出されなかった. (2)膵液細胞診では膵癌11 例中9例に癌細胞, 2例に異型細胞を認め, 慢性膵炎 14 例中6例に異型細胞, 3例に軽度異型細胞, 5 例に正 常細胞を認めた. 正常対照群では正常細胞のみを認 めた. (3)膵液細胞診で癌細胞の検出された 9 例の内 全例にK-ras突然変異が認められた. 異型細胞およ び軽度異型細胞の認められた症例ではK-ras突然変 異がそれぞれ8例中6例, 3例中 2 例に認められた. 正 常細胞のみの認められた10例では全例K-ras突然変 異陰性であった. [結論] 膵液細胞診の細胞異型度 が強くなるにつれ，膵液中K-ras突然変異の頻度が 高くなった. 膵液細胞診はK-ras癌遺伝子診断とほ ぼ一致していた. 


\section{邓細胞検査士要望シンポジウム}

基調講演 細胞検査士要望シンポジウム

腺系細胞診シリーズ

子宮内膜

基調講演

岩手医科大学産婦人科

利部輝雄(MD)

子宮内膜は女性ホルモンの標的であり、性成熟 期婦人では、剥脱・再生・増殖・分泌とダイナミ ックな変化を示す。正常婦人の月経直後の子宮内 膜は0.5〜 1.0mmの厚さであるが、その後卵胞ホル モンの作用により約10日後に4.0〜 $5.0 \mathrm{~mm}$ の厚さ まで増殖する。子宮内膜の体積は10日ほどで約 5 倍となる。このような著しい細胞の増殖は受精卵 においても見られるが、ヒトの多くの腫湯ではこ れ以下の増殖速度である。正常性周期におけ方子 宮内膜腺細胞の増殖は速やかであるが、これは制 禦された増殖である。

正常の閉経後婦人に卵胞ホルモンを投与すると 静止期や萎縮状態にあった子宮内膜は増殖像を示 してくる。この場合の子宮内膜腺細胞の増殖は、 成熟婦人、更年期婦人や思春期女性の内因性の工 ストロゲンが過剰であるときの状況に類似してい る。

子宮内膜の腫瘍性病変では、子宮内膜腺細胞は 自律性の増殖であると考えられている。

本講演では、子宮内膜腺細胞の正常性周期にお ける制禦された増殖、内因性または外因性のエス トロゲンによる増殖、腫瘍にみられる自律性増殖 のそれぞれにおいて、通常の子宮内膜細胞診の方 法で採取され、パパニコロウ染色を行った標本で 子宮内膜腺細胞の形態をどこまで読めるかについ て検討した結果を述べることにする。

\section{要シー 1 岩手県対ガン協会における 内膜細胞診結果とその問題点}

\author{
岩手県対ガン協会 \\ 川村知正
}

子宮体部内膜を対象とした細胞診、 組織診の件数は、当施設においても年々 増加している。特に細胞診は1987年に 子宮体癌検診が老人保健法に組いれられ て以来、スクリーニングとしても多くお こなわれるようになった。

しかるに、その判定においては、い まだにその基準が確立されておらず、ま た子宮体癌発生に到る自然史にも不明な ところがあるために、日常の鏡検の中で 苦慮することも少なくない。

1986年から1995年までの10年間に とりあつかつた婦人科臨床細胞診は 298,509件で、このうち子宮内膜を対象 としたものは20,839件あり、Class I ・ 川あるいは陰性としたものは18,799件 (90.2\%)、Class III あるいは疑陽性とし たものは1,886件(9.1\%)、Class N ・V あるいは陽性としたものは154件(0.7\%) であった。一方、この間の婦人科病理組 織診は22,778件で、このうち子宮内膜 を対象としたものは5,812件あり、158 件(2.7\%)の癌亡 1,458 件(25.1\%)の增殖 症が含まれていた。

これらの結果をふりかえることによ り、現在当施設で行なっている子宮内膜 細胞診が抱える問題点を明確にし、さら に今後に向けて誤判定を少なくするため には、効率的なスクリーニングをするた めにはどうすればよいか、またパパニコ ロ一染色をもとに形態的に鑑別診断が可 能かどうかなどについて検討してみたの でその結果を報告する。 


\section{要シーஉ子宮内膜疑陽性例の検討}

宮城県対がん協会細胞診センター

O及川和子 (CT)、渡辺康子 $(\mathrm{CT})$ 、

小田切千恵 (CT)、野呂亜矢子 (CT)、

斎藤朋子 $(\mathrm{CT})$ 、及川洋恵 $(\mathrm{CT})$ 、石黒典子 $(\mathrm{CT})$ 、

佐藤信二(ID)

近年わが国でも子宮体癌が増加している。こ のような背景を踏まえて、昭和 62 年に子宮内膜 細胞彭を用いた体癌検診が老人保健法に導入さ れ、体癌検䛦の一次スクリーニングとして内膜 細胞診の位置付けが重要になってきている。老 健法による内膜細胞診の判定は陰性、疑陽性、 陽性の 3 段階法で行われているが、これは内膜 の各種増殖症や分化型腺癌の診断基準がいまだ に確立されていないなどの理由から設定された ものと思われる。日常のスクリーニング業務で も内膜細胞診の疑陽性は必ずしも内膜増殖症の 存在を推定するものに限らず、誤陰性や誤陽性 を最小限にとどめるべく、かなり幅広い概念で 診断されているのが現状と思われる。

平成 6 年度宮城県対がん協会細胞診センター で行われた内膜細胞診数は 11,585 例で、その内 訳は陰性10.892例 (94.0\%)、疑陽性423例 (3.7\%)、 陽性50例 (0.4\%)であった。疑陽性423例のうち 組織診の行われたものは329例（精検率 77.8\%） で、良性2 5 例 (77.2\%)、增殖症42例 (12.8\%)、 体癌11例 (3.3\%)、検体不適22例 (6.7\%)であった。 今回私達は、疑陽性423例のうち組織診の得 られた 307 例を再スクリーニングし、良性、増殖 症、体癌の 3 群に分類することを試み、疑陽性 の再分類の可能性につき検討したので報告する。
要シ-3 当施設における内膜細胞診成績と細 胞判定基準について 内膜擦過標本を中心に

正和ラボラトリー ${ }^{1}$ 丸山記念総合病院 ${ }^{2}$

O大野喜作(CT) ', 鈴木君義 (CT ) ${ }^{1}$, 木村恒子(CT ' ${ }^{\text {, }}$, 塚原和夫 (WD $)^{1}$, 丸儿山正義 (MD $)^{2}$

はじめに : 体内膜細胞診の需要が増える一方で、 検診では採取器具が多種類であること、検査機関 による標本作製の違い、また検査目的の違いで細 胞判定方法が異なることなどが、細胞診断を困難 にしていると考える。そこで、当院嫚人科で施行 した内膜細胞診と、当ラボラトリーにおける体が ん検診の内膜細胞診を検討し、その細胞診成績と 細胞胞判定基準について述べる。

（1）当院では1990年〜 1995年に、体がん46例、增 殖症90例が組織診断されていた。そのうちで細胞 診が施行されていたのは体がん40例（切除例）亡 増殖症45例であった。体がん40例の細胞判定は॥ 1 例, III 3 例, III 4 例, IIb 3 例，IV 2 例, V 27 例 であり、增殖症45例の細胞判定は、川14例、川 14例, II 10 10例， III 3 例， IIb 1 例，IV 2 例， V 1 例 であった。体がん40例と增殖症45例の細胞診断と 組織診断を対比し検討する。

（2）春日部市における体がん検診(施設検診)で19 90年〜 1994年に施行された内膜細胞診は1232例で、 体がん11例、増殖症10例が発見された。体がん11 例の細胞判定は、疑陽性 3 例、陽性 7 例で， $\vee 1$ 例（頙部）あり、增殖症12例の細胞判定は疑陽性 10例であった。細胞像を検討するとともに施設検 診での検診方法についても加え報告する。

(3) (1)(2)で発見された体内膜腺癌 $\mathrm{G} 1$ 亡增殖症の 細胞像の・背景の異常（壊死，好中球の数，好中 球の上皮内侵入像，上皮細胞優位）・構造の異型 （細胞集団の異形，核の重積性，結合性の欠如）、 細胞の異型（核の大小不同, 核形不整, クロマチ ンの増量）等について検討し、内膜擦過法による 内膜細胞診の当施設の細胞判定基準について報告 する。 
要シー4 子宮内膜細胞診による子宮体癌診断 成績の再検討

北里大学産婦人科

上坊敏子(I. D.)

子宮体猺の診断における子宮内膜細胞診の有用 性については論を待たない。しかし、内膜細胞所 見の「読み」そのものは未だ完成されたものとは いい難く、診断上の問題点もいくつか指摘されて いる。そこで、北里大学病病院産婦人科における 内膜細胞診による体癌診断の成績を、組絰所見、 筋層浸閵と関連させて報告する。さらに、伪陰性 の標本を再検討することにより、内膜細胞診の問 題点を明らかにし、正診率の向上を計るためのポ イントを指摘したい。なお、検討した標本はすべ てエンドサイト法によって採取された初回細胞診 検体である。

体癌全体における成績は、陰性15.6\% 、クラス III23. 7\%、クラスIV6. 7\%、クラスV54.6\% という 結果であった。組緒型別の伪陰性率をみると、G1、 G2、G3腺澏および腺楝細胞癌で、19.2\%、18.0\%、 3.6\%、15.0\% と、分化度の高いもの、腺欶細胞癌 （すなわち予後良好とされるもの）で高い煩向に あった。また筋層浸閏との関連でみると、浸潤の ないもの、 $1 / 3$ 末満のもの、1/3-2/3 のもの、2/ 3 以上のものの伪陰性率は、 $36.8 \% 、 8.5 \% 、 26.1$ ※、10.3\% であった。筋層浸淍のない分化型体痹 の組繏所見を検討してみると、70\% 以上の症例が 增殖症を合併しており、摘出標本中に占める癌部 分の拉がりは、増殖症や、正常内膜の部分より㹨 い㑯向にあった。この組織背景が分化型体䄆、筋 層浸渭のない体滰の正診率を低くしている大きな 要因といえよう。そこで、これらの伪陰性標本を 再検討してみると、正常細胞しか見られなかった ものが $19 \%$ 、内膜増殖症と判定される細胞の出現 を認めたものが44\% であった。したがって、この ような体癌の正診率を向上させるためには、增殖 症の細胞所見に注目する必要があると指摘したい。

\section{囚教育シンポジウム}

教シー 1 子宮内膜細胞診の報告をめぐって

東京顕微鏡院細胞病理診断科 ${ }^{1)}$, 同婦人科 2),

東京都がん検診センター ${ }^{31}$

杏林大学保健学部病理学教室 ${ }^{41}$

O石井 保吉 $(\mathrm{CT})^{1)}$ ，加藤 圭子 $(\mathrm{CT})^{1)}$, 稲村千佳子 $(C T)^{11}$, 岡 俊郎 $(C T)^{11}$, 石田 禮載 $(M D)^{2)}$, 大村 峯夫 $(M D)^{3)}$, 佐藤 伸子 $(\mathrm{MD})^{3)}$, 小田 瑞惠 $(\mathrm{MD})^{3)}$, 藤井 雅彦 $(\mathrm{MD})^{4}$

子宮内膜細胞診の判定に際し、これまで我々は 細胞像を三次元的に観察し、構造異型をみること が重要であることを報告してきた。今回は、我々 の施設において用いている内膜細胞診の class分 類、および報告書の記載事項について述べ。

現在、当施設では内膜細胞診の classをI、II ： II b、III、IV、Vの6段階に分け報告している。す なわち、class I：異常所見を認めない。II：炎 症所見やI U D な゙による反応性変化を認める。 II b : 辺縁に間質細胞の付着を伴わない乳頭状集 塊を認めるが構造異型に乏しく、内膜增殖症まで は推定し得ない。III：構造異型を伴う乳頭状集塊 が認められ、内膜增殖症を推定する。IV：中心に 血管内皮由来と思われる紡錘形細胞の束 (stromal A）を有して分岐するように配列した樹枝状集塊 が僅かに認められ、異型增殖症以上の病変を推定 する。V : 明らかな腺哚のback to back梾構造と 樹枝状集塊が認められ、体癌を考える。

以上の判定基準を用いた過去 6 年間の内膜細胞 診と組織診の一致率をみると、class 且とされた 症例のうち $51.7 \%$ が組織学的に腺腫性增殖症と診 断され、また、class Vでは83.6\%に体癌が確認 された。

今後、内膜細胞診の精度を高めるためにも、構 造異型を中心とした判定基準の確立と、質的診断 を踏まえた報告書の作成が不可欠であると思われ る。 


\section{教シーஉ 子宮内膜細胞診の報告をめぐって}

近畿大学産婦人科

井上芳樹 (MD)

老人保健法による体癌検診では、細胞診断を、 陰性、疑陽性、陽性の 3 段階でするとされている。 これは、体癌の境界病変とされる内膜增殖症の自 然史が明らかでないこと、内膜増殖症や一部の高 分化型体癌の細胞学的な診断基準について充分意 見の一致をみておらず、病変推定につながる細胞 診断が困難であることなどによる。また、疑陽性 に限らず陽性でさえす、必ずしも体癌、内膜增殖 症などが確認されるとは限らず、報告を受けた臨 床医はその対応に苦虑することも稀ではない。

頸部細胞診では、最近、標本の適正さ、総合評 価、病変の記述的な診断に主眼をおいた Bethesda systemが提唱されてきている。体内膜細胞診に おいてもその意図するところを取り入れ、臨床に 役立つ的確な情報を提供していくことが望ましい。

そのためには、まず、臨床医から細胞検查士、 指導医への、年齢や月経歷、臨床症状、妊婦との 関係、薬物服用歴、子宮内避妊器具の使用の有無、 子宮内操作の既往、採取法、検診歴とその内容な どについての正確な臨床情報が不可欠である。そ れら充分な情報があって、はじめて、細胞検査士、 指導医から臨床医への適切なレポートが可能とな る。その内容は、まず始めに、検体の良否の判断 と不良の場合の採取法、固定法などに関しての適 切な助言、次に、陰性、疑陽性、陽性などの判定 のみでなく、推定病変の質的な解析に踏み込んだ 報告が必要であろう。つまり、体癌、内膜增殖症 などの可能性の程度、他にどのような病変が可能 性として考えられるかなどの内容を盛り込めば、 臨床医にとって、臨床に即した取り扱いが容易に なるであろう。
教シー3乳房穿刺細胞診の報告を

$$
\text { めぐって }
$$

板橋中央総合病院 - 研究所 (IML)病理 ${ }^{1)}$ 、 同 外科 2 、同 婦人科 ${ }^{3)}$ 、埼玉医科大学病理 学教室 ${ }^{4)}$ 、東邦大学医学部病理

○畠山重春 $(\mathrm{CT})^{1)}$ 、川名展弘 $(\mathrm{CT})^{1)}$ 、

末吉弘子(CT $)^{21}$ 、杉山勇治 (MO $)^{21}$

大橋浩文 $(M D)^{3)}$ 、塩田 敬 $(C T)^{4)}$ 、

三浦妙太(MD) ${ }^{5)}$

乳腺の穿刺細胞診に対する臨床の期待法、 細胞診によって根治手術にふみきる施設の增 加からも大きなものがある。一方、鏡唡する 立場からすると、必ずしも满足すべき標本を 観察している訳ではない。不本意ながら、判 定不適とせざるを得ない標本に遭遇する機会 屯少なくない。したがって、不適検体を少な くするための臨床医への働き引计む、鏡娭者 侧の大切な業務の一環となっている。この改 善努力が臨床医の誤解をなくし、精度向上の 一助になると信じるからである。不適検体を 最小限にする、最良、最短手段は、技師が穿 刺現場へ出張し塗抹処理することであろう。 ただし、施設によっては、時間的、人為的に 無理があり、その場合注電話連絡や報告書へ の記載による解決策をあげることができる。 しかし仕事量やその頻度によっては一定した 対応が困難となり、不適切な対応法と言わざ るを得ない。当施設では、細胞が塗抹されて いないなどの不適娭体には、そ心旨を報告書 へ簡単に記入するにとどめるかわり、吸引か ら固定までの説明書を貼付している。このこ とで、臨床へ一定の対応がなされ、報告側の 労力も軽減した。通常沈細胞量の程度、垒抹 処理・固定状態を付記した所見記载を心掛付 ている。良性・悪性に方少わ方可、可能な限 り詳細な病変推定を試みているが、標本状態 などを加味し、限られた情報を、客観的に受 计とめる伶静さが誤診を少なくすると考える 
教シー4 細胞診報告に関-2る検討（腺系 細胞の評価に関して)

○松本武夫 ${ }^{1}(\mathrm{CT})$ 、览玉哲郎 $2(\mathrm{MD})$ 、

横瀬智之 ${ }^{3}(\mathrm{MD})$ 、向井 清 $^{3}(\mathrm{MD})$

国立がんセンター東病院臨床検査部病理細胞診 1 同呼吸器科2、同研究所支所臨床腫瘍病理部3

細胞診診断報告は施設によってバラッキがあ り、診療形態の違い、その診断業務に関わる人 数の違い等々その方法は様々である。全ての標 本（婦人科、呼吸器、体腔液等）においてパパ ニコロウ分類による判定方法が一般的であり、

婦人科細胞診以外の報告はその分類の使用に否 定的な考えも多い。殊に、婦人科内膜、乳腺穿 刺吸引細胞診などの腺系細胞に対する判定はパ パニコロウ分類のクラス分けは馿染まないと言 われている。その大きな理由として診断困難(疑 陽性細胞、クラスIII）症例では扁平上皮におけ る異型性の基準との違いや良性病変の存在によ り明らかな悪性所見の解釈の相違が挙げられる。 そこで今回我々は、乳腺細胞診での問題点を いくつか列挙しそれらについて考察する。

1、臨床医とのコミニュケーション

具体的な取組を挙げ、その効果について

2、病理組織診と細胞診の役割

利点、欠点について検討し、双方の役割分担 が如何にあるべきかについて

3、乳腺迅速細胞診の対応

症例の選択と許容時間および報告について

3、疑陽性細胞の報告方法

クラス分類の問題点、所見、臨床への指示記 載などについて

4、組織型 (細胞亜型) 判定の限界 細胞診標本で細胞亜型がどこまでいえるか

などを中心に、我々の施設をはじめ数施設の現 状を紹介し、今後のより良い細胞診断、報告を 目指し討議したい。
教シー 5 乳腺穿刺細胞診の報告をめぐって

長野県がん検診センター 検査部 ${ }^{12}$ ，日本臨床 細胞学会「腺系の細胞診に関する小委員会」2)

$\mathrm{O}$ 土屋黄一 $(M D)^{1,2)}$, 武田鉄太郎 $(M D)^{2)}$

穿刺細胞診は病名を直接診断し得る方法であり， 臓器によっては組織診に準ずる产価を得ている.

このような状況下でのクラス分類には若干の違和 感が存在することは事実であろう. 乳腺疾患の診 断・治療は外科, 放射線, 病理・細胞診部門のス ペシャリティーが連萼を組んで初めてなされるも のであり，従来の良・悪の鑑別のみに止まる細胞 診検查では不充分で，いかにしてその質的診断に まで踏み込めるかが重要な問題と考えられる。し たがって，細胞診の報告はその診断結果を的確に 伝えることのみならず，もう一歩進んで臨床上の 対応方法まで言及すべきであろう.

そのためにはいくつかの課題が存在している. 第 1 は細胞採取上の問題で，検体不適を明確に臨 床側に伝えることである. 特に細胞成分不充分， 乾燥, 挫滅を陰性(Class I) としないことが肝要 で，その旨を報告書に正確に畫くべきであろう. 第 2 は細胞診断における判定困難な病变の取扱い で、これには乳頭状や異型の少ない線状, 索状形 態を示す病変が相当する. 診断する側の組織・細 胞像への深い理解が大きなウエイトを占めるが， 乳腺診断で最も注意すべき点は過剩診断であり， 無理な細胞診断は避け，様々な診断方法を参考に した検討が必要である．第 3 は嚼床医との治療方 針を含めた充分な情報提供・交換を図ることで, そのためにも細胞像で推定される病変の記載(組 織推定)が非常に大切である. 特に乳房温存治療 が急速に增加している現在, この組織推定は必要 不可欠なものと考えられる.これは第 2 点の診断 不確定な場合も同様であり，鑑別すべき推定組織 型の列記や，外科的生検，術中迅速診断など，臨 床側への積極的な要請も重要であろう.

以上の点を踏まえて，今回，乳腺穿刺細胞診の 報告様式を中心に, 病理・細胞診側から臨床側へ の適切な指示・記載が必要とされる病变の細胞像 についても供覧したい. 
囚ークショップ I

ワ I - 1 乳腺穿刺細胞診の精度管理より見た 穿刺細胞診の価值と限界

八戸市立市民病院病理

O方山揚誠 (MD), 高坂公雄 (MT), 熊谷幸江 (CT) 奥沢悦子 (CT)

乳腺の穿刺細胞診陰性の場合は細胞診の価値 は陽性の場合よりも低く考えられがちである. 確かに病変の組織像の推定は線維腺腫などの一 部の症例以外は困難である. しかし，陰性例で も採取された細胞の所見を記載する事により臨 床医に総合的に判断する時の参考になる．また 穿刺細胞診においては正しく病変部が穿刺され ているかどうかを確認するためにも陰性症例で の細胞所見は大切之考えられる. 実質臓器の穿 刺細胞診はスクリーニング検査ではなく, 確定 診断に近づくための検査であり, 当施設では穿 刺細胞診は陰性例でも全例指導医が鏡検して陰 性例の価値を高める努力をしている.

乳腺穿刺細胞診の 6 年間の成績を 3 年で区切 り前期と後期に分けて検討した。後期では細胞 採取の向上により判定不能は減少したが，偽陰 性率や偽陽性率は変わらなかった。偽陽性率を より低下させる事は可能でもゼロにする事は团 難である. 細胞診の限界を考え, 診断を再確認 する意味で当院では細胞診陽性でも術中迅速凍 結組織診を原則として施行している，偽陽性は 生検によって確認できるので問題は少ないが, 偽陰性は生検や手術を遅らせる事があるので臨 床的には問題が多い，偽陰性の多くは細胞採取 量の少ない標本であるが, 十分な細胞が採取さ れていても細胞異型がそしく偽陰性となる事が あり, 注意が必要である.

日常のカンファレンスでこのような症例を提 示し, 臨床側にも細胞診の限界を理解してもら う事が穿刺細胞診の価值をより高める事になる と考える。

\section{ワ I -こ乳腺穿刺細胞診の価値とその限界}

鳥取大学医学部第二病理学教室 ${ }^{\prime \prime}$, 博愛病院 外科 ${ }^{21}$, 同検査科 ${ }^{31}$, 鳥取市立病院検査科 41 ○元井 信 (MD) ${ }^{11}$, 村田陽子 (MD) ${ }^{21}$, 森田紀代 美 $(\mathrm{CT})^{2)}$, 岸本人美 $(\mathrm{CT})^{4)}$, 宮谷克也 (MD) ${ }^{4}$

[目的]近年, 乳腺穿刺細胞診は乳癌の診断と その鑑別診断に重要な検查法の一つとして汎用 されている.われわれは，最近までに経験した 症例をもとに, 乳腺穿刺細胞診の意義と限界, 特に診断不一致例の病理組織学的背景について 検討したので報告する.

[材料・方法]：細胞診断がなされ, 組織学的 診断の確定している良性疾患 272 例および乳癌 409 例を対象とした. 細胞診断はPap 染色をほ どこして鏡検し，陽性，陰性，疑陽性に判定し， 推定病変を記載した. 組織診断は通常の方法を 用い，必要に応じてアクチンを筋上皮細胞のマ 一カーとして免疫染色を併用した。

[結果] 細胞診の結果は, 良性病変 272例中陰 性 226 例, 疑陽性 34 例, 陽性12例, 乳癌 409例 陽性 309例, 疑陽性44例, 陰性40例, 判定不能 16例であった。すなわち, 乳腺穿刺細胞診では 約 $80 \%$ の症例は良・悪性の判定が可能であった しかし、20\%の症例は良・悪性の判定が困難で あった。

判定が困難であった良性病変は線維腺腫, 乳 腺症, 乳頭腫であった。これらの症例の組織像 では、線維腺腫では乳管の増生, 乳管内に上皮 の増殖が高度であった. 乳腺症では乳管上皮過 形成, 限局性乳頭腫様增殖, 末端乳管上皮の腺 様增殖がみられた。乳頭腫では, 充実性増殖し, 間質に乏しく，核が濃染傾向を示す症例である。

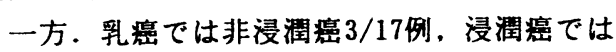
いずれの組織型でもみられたが小葉癌, 硬癌で 高率であった。これの症例の腫瘍細胞は小型で， 癌巣が小さく、多発性小結節性癌巣形成, 線維 化の強い症例であった。 
ワ I-3甲状腺穿刺吸引細胞診の価值と限界

川崎医科大学附属病院 病院病理部 ${ }^{11}$

川畸医科大学 病理学教室 ${ }^{2}$

川崎医科大学 内分泌甲状腺外科 ${ }^{3)}$

$\mathrm{O}$ 三宅康之 $(\mathrm{CT})^{1)}$, 広川満良 $(\mathrm{MD})^{2)}$, 片桐 誠 $(\mathrm{MD})^{3}$

はじめに：甲状腺の穿刺吸引細胞診は針生検と ほぼ同様の診断精度があるため、現在では穿刺吸 引細胞診が術前診断として広く用いられている。 今回われわれはその甲状腺穿刺吸引細胞診の価值 と限界を明らかにする目的で、他の術前検査との 比較検討を行ったので報告する。

対象および方法：甲状腺腫瘍に対して穿刺吸引 細胞診が行われ、その後手術にて摘出を受けた16 0 症例を検討対象亡し、術前の穿刺吸引細胞診、超 音波検查、理学所見などの診断精度をretrospectiveに比較検討した。

結果 : 穿刺吸引細胞診が行われた 160 症例におい て、その診断精度は、感度77\%、特異性 $87 \%$ 、陽性 予測値 $84 \%$ 、陰性予測値81\%であったが、十分に検 体採取された139症例における診断精度は感度 $85 \%$ 、 特異性 $99 \%$ 、陽性予測值 $98 \%$ 、陰性予測値88\%であっ た。偽陰性17例中11例に石灰化が見られ、その内 5 例が採取不良であった。触診は 127 症例の記載が あり、感度 $54 \%$ 、特異性 $93 \%$ 、陽性予測値 $86 \%$ 、陰性 予測値71\%であった。超音波診断は153症例施行さ れ、感度 $85 \%$ 、特異性78\%、陽性予測値78\%、陰性予 測値85\%であった。

考察 : 以上、われわれの施設における甲状腺術 前検查の診断精度を算出した。穿刺吸引細胞診は 比較的高い診断精度を示したが、石灰化病変では、 細胞採取率が低く、その様な症例では他の検査を 参考にすべきであると思われた。また、悪性腫瘍 の組織型判定は穿刺吸引細胞診である程度可能で あったが、細胞診では濾胞性腫瘍の良悪性の鑑別 は不可能であり、細胞診の限界と考えるべきであ る。
ワ I-4 肺末梢の小型腫瘍性病変にお ける経皮的針細胞診の評価

東京医大外科 $1 、$ 同第 2 病理 2

○平野 隆 $(M D)$ 1、柴沼弘行 $(M D)$ 1、岡田 真也 (MD) 1、过 興 (MD) 1、中嶋英治 $(M D)$ １、嘉村哲郎(MD) 1、池田徳彦 $(M D) 1$ 、 岩淵 裕 $(M D) 1$ 、斉藤 誠(MD) 1、小中千 守(MD) 1、加藤治文(MD) 1、海老原善郎 (MD) 2

肺癌検診の普及および胸部CTの普及によ り小型肺野病巣の発見機会が増加している。 腫瘍性病変を疑った時当科では積極的に経 気管支的に材料を採取し、病理診断・細胞 診断による確定診断を得るよう努力してい るが、小型肺野病巣では必ずしも適切な材 料が得られるとは限らない。確定診断が得 られなかった場合原則的に経皮的針細胞診 を施行している。2 方向レントゲン透視下 経皮的針細胞診は検査施行期間中連続的に 針の動きを観察しつつ針の操作が行える利 点があるが、陰影が淡かったり、心臓や横 隔膜に重なると一方向でしか腫瘍陰影の局 在が分からないことがある。この榚な所見 は小型病巣でしばしば認められ、 $2 \mathrm{~cm}$ 下の小型陰影に対してCTガイド下針細胞 診を1990年以降行ってきた。その結果を 以下の表に示す。

\begin{tabular}{cccc}
\hline CT-NC所見 & 陰性 & 偽陽性 & 陽性 \\
\hline 総数 & 24例 & 6例 & 7例 \\
最終診断悪性 & 0例 & 1例 & 7例 \\
\hline \multicolumn{4}{c}{$(1990.1-1995.10)}$.
\end{tabular}

施行した37症例では7例から悪性細胞（6 例の原発性肺癌、1例の転移性肺癌）を得 た。偽陽性例6例は全例胸腔鏡下にて肺部 分切除術が行われ、1例が原発性肺癌であっ た。以上よりCTガイド下針細胞診は小型 末梢肺野病変の診断に有効な方法と考える。 
ワ I-5 前縱隔腫瘍に対する経皮的針生検細 胞診の検討

千葉大学肺癌研究施設外科, 同病院病理部*

国立療養所千葉東病院外科 **

O柴光年 (MD), 山口 豊 (MD), 光永伸一郎 (MD), 飯笹俊彦 (MD), 山本直敬 (MD), 横井佐奈 (MD), 馬場雅行 (MD), 堀内文男 (CT $)^{*}$, 大木昌二 (CT $)^{*}$, 佐藤卓美 $(C T)^{*}$, 山川久美 $(M D)^{* *}$

【目的】胸腺関連腫瘍を中心とした前縦隔腫瘍は， 広い腫瘍発生母地を有し, きわめて多彩な組織像 を呈することが知られている。画像診断, 腫瘍マ一 カーや随伴免疫症候群などにより質的診断がなさ れてきているが, 病変部位からの生検は最も確実 な方法である。今回我々は前縱隔腫瘍切除例によ り fine needleによる経皮的針生検細胞診の術前 診断法としての意義を検討したので報告する。

【対象と方法】過去16年間に当施設にて切除され, 組織型の確定した前縦隔腫瘍208例を対象として, 針生㭘細胞診による診断率につき検討した。経皮 針生検は原則として2方向 X線透視下に18Gの干葉 大肺研式生検針により施行した。

【結果】208例の術後確定した組織型の内訳は胸 腺腫 (胸腺癌を含む) 121 例, 奇形腫および胚細胞腫

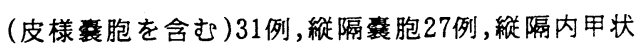
腺腫 14例, 胸腺カルチノイド4例, 悪性リンパ腫4例, その他悪性腫瘍 5 例, 良性腫瘍 2 例であった。胸腺腫 では121例中 82 例 $(67.8 \%)$ に生検が施行され, 61例 (74.4\%)で正診, 17例 (21\%)で検体不良，4例(5\%) で他の疾患と誤判定された。また奇形腫,胚細胞腫 では31例中28例に生検が施行され,21例(75\%)で 正診, 3 例 (10\%)で検体不良,2例 (7\%)で誤判定で あった。またその他の症例では誤判定例は全体で2 例と少数であった。

【まとめ】前縦隔腫瘍に対するfine needleによ る診断率は生検例全体では78.3\%と良好であった。 診断率向上のためには硬い腫瘍からも十分量の検 体を採取するエ夫が必要である。

\section{囚ワークショップII}

ワII-1

定の試み

子宮内㷬細胞診による性周划推

国非産婦人科陃院

O国非勝炤（MD）,大橋洋子（CT），

草刘裕子 ( C T )

国井クリニック

国非兵太郎 (MD)

秦野赤十字病院

高橋亨正 (MD)

我々は第28回日本阽床細抢学会総会及び第 32回同学会に於て正常各周期における細胞所 見について報告し、その内容は現在、日本隐 床細胞学会誌に投稿悟であが、今回は、そ の所見を脂いて性周期を推定し、どの程度の 適中率が得られるかについて検傠した。

対象は48才以下で子宮筋媑等で子宮摘山し た症例で、そのうち比校的月経が順調な症例 30例について手術直後に得られた内膜スミヤ と摘出子宮の組織標本について検傠を行なっ た。

細胞採取方法は增洲式收引装置及びエンド サイトを打た。

検討を行なった細胞所見は山現縕胞数、間

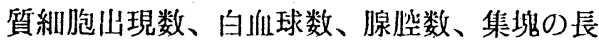
さ及び縕胞数、集塊の出現様式（乳頭状、合 胞状、シート状）、核分裂、集塊の重積性、 核下空胞、分泌、間質浮䛲、偽脱落膜变化、 絒胞質境界の明嶛、不明煌、核の大小不同、 クロマチンの性状、クロモセンター（核小体 を含む）の数、核の大きさ（腺絒抢及び䦌質 絒胞）の18項目とした。

推定した凬期と綝胞像が極端に合犼ない場 合は再切仙しを行なって検䚯した。

今回はその結果について報告する。 
ワII-2 Tamoxifenと子宮内膜

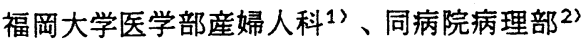
○蜂須賀徹(MD) ${ }^{12}$, 江本精(MD) ${ }^{12}$, 江口冬樹 $(M D)^{11}$, 瓦林達比古 $(M D)^{11}$, 白川光一 $(M D)^{11}$, 南部雅美 $(\mathrm{CT})^{2>}$

(目的)抗estrogen剂であるtamoxifen(TAM)を長期 服用している婦人には種々の増殖性子宮内膜病変 が発生することが知られている。そこで我々は乳 癌術後TAM服用婦人の子宮内膜について検討した。 (方法)60例の乳癌術後婦人を6力月から30力月に渡 り経過観察した。そのうち45名がTAMを服用して いた。TAMは20mg/日で6力月から86力月連日内服さ れており、3カ月または6力月ことに経腟超音波検查 にて子宮内膜の厚さを測定し、さらに子宮腟部細 胞診、子宮内膜細胞診、子宮内膜生検を行った。 (結果)TAM内服婦人を閉経前後に分けると、開経 後婦人では子宮腟部細胞診は核濃縮指数 $(K I) 、$ 細 胞成熟度指数 (MI) ともにestrogen刺激を示した。 子宮内膜細胞診では有意な集塊数の増加があり、 均一な核がシート状に配列しているが、一部に核の 大小不同や核小体が目立つ集塊や胞巣状となり分 泌期類似の像を示す集塊も認められ、TAMによる 特徵と考えられた。増殖症例では細胞の重積性が 目立った。内膜組織診は2例の増殖症を除く之萎 縮内膜であったが、 estrogen とprogesterone と のreceptor(ERとPR)を免疫組織学的に検討すると。 萎縮内膜でも腺管並びに間質共にERは発現してお り、PRは陰性であった。増殖症の2例はERとPRは 共に発現していた。閉経前婦人では多くが月経を 有しており、細胞像、組織像ともその影䇾が見ら れた。しかし月経周期の変化にかかわらずERは発 現していた。(結論)TAM内服時の子宮内膜変化は 閉経の前後で分けて考える必要がある。また閉経 後婦人の血清E2值が低値であることを考えると TAMは内膜に対して直接estrogen作用を示してい ることが推測され、細胞診はその作用を追跡する のに有用であった。

\section{ワII-3 子宮内膜癌および異型増殖症に対}

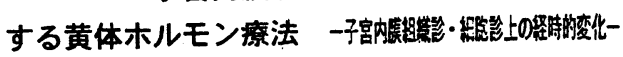

\section{東海大学産婦人科学教室}

O奥脇伸二 (MD) 平沢活 (MD) 村松俊成 (MD) 宮本壮 (MD) 篠塚孝男 (MD)

黒島䓔男 (MD) 牧野恒久 (MD) 同院病理診断科

伊藤仁 (CT) 安田政実 (MD) 梅村しのぶ (MD) 長村耧之（MD）

挙児希望にて来院し、子宮内膜組織検査の結果、 子宮内膜癌および異型増殖症の診断が得られた、 それそれ 2 例，4例に対し十分なインフォームド コンセントのもとに、medroxyprogesterone acetateM P A 璙法を行い、それらのうちの子宮内膜 癌の 1 例には癌の消失後に生児を得ることが出来 たので、これらの症例につき、黄体ホルモン投与 に伴う子宮内膜組織および同時に採取した内膜細 胞誩の経時的变化につき分析し報告する。

MPAの投与は、6 $00 \mathrm{mg} /$ dayにて行い生児が 得られた症例では、投与開始後 15 週にて癌の消 失が見られたが、MPA投与に伴う組織学的変化 としては、間啠の脱洛膜様变化と共に、腺癌部分 では腺細胞の重層化および異型性が次第に失われ 異型性の乏しい細胞が一雷に配列した腺腔が次第 に増加していった。投与開始後 6 カ月では、内膜 は菤㜚性内膜の所見となった。MPA投与に伴う もう一つの特徽的な所見としては、MPA投与前 には見られなかったadenoacanthoma様の扁平上皮 化生所見か、投与量の増加と共に著明となった症 例が 3 例に見られた。他の内膜癌の 1 例は、MP A投与に伴い、癌の消失が見られ内膜は衰胞性増 殖症の所見となったが、投与を中止し不妊治療を 施行中に再び内膜癌が出現したため、子宮全摘出 術を行い現在、術後 2 年になるが、再発の徴候も なく生存している。これらの症例につき、組織診 と同時に採取した細胞診標本についても分析し、 啹些する。 
ワII-4 子宮内膜増殖症に対するホルモン療 法における内膜細胞影の重要性

\section{大阪医科大学産婦人科}

○岡本吉明 (MD) 、猪木千春 (MD) ,植木 健 (MD)，植田政嗣（MD），植木 実(MD)

子宮体部の前癌病変とされる内膜増殖症には保存 的なホルモン治療が奏功することが多いが，内 膜腺癌との鑑別も難しく，厳重な管理を要 する. われわれは，不正出血や更年期出血を認め る症例, 内膜細胞診疑陽性および陽性例に対して ヒステロスコピーを施行し，直視下に内膜組織診 を行っている. そこで検出された囊腫性増殖 症 $(\mathrm{CGH})$, 腺腫性増殖症 (ADH) および異型 増殖症 (ATH) に対しては, ホルモン治療あるい は追跡管理を行っている. . ホルモン治療には, $4 \sim 5$ カ月間のEP合剤によるPincus療法, 高用 量MPAによるプロゲステロン療法, Danazol療法, あるいはGnRHアナログによる偽閉経療法を試 みた. その結果, $\mathrm{CGH}, \mathrm{ADH}, \mathrm{ATH}$ ではいずれ も投与開始後 4 週ころよりヒステロスコピーにお けるポリープ様所見などの消失に伴って細胞診所 見では内膜細胞の大小不同や重積性の消失，核小 体の不顕性化を認めるようになり, 投与終了時に はヒステロスコピーでは内膜の平坦化, 細胞診所 見では委縮性内膜像を呈するものが多かった. $\mathrm{CGH}, \mathrm{ADH}$ では, 1 コースの治療で治癒するこ とが多いが, ATHでは, 数力月の休薬期間に再度 細胞診での内膜細胞の増殖傾向とともに組織診に て再燃が認められるものが見られた. また，ホル モン投与を行っても細胞䛦所見に改善が見られ なかった症例では, 繰返し組織診を施行すること により，腺癌を検出することができた，以上から， このような内膜増殖症におけるホルモン療法には 定期的な内膜細胞診とヒステロスコピーの施行が 不可欠であると考えられた.
ワII-5 Progestin およびTamoxifenの challenge test による内膜増殖症および 内膜癌の細胞周期と細胞診所見

岩手医科大学産婦人科学

○高村郁世（MD）、井筒俊彦（MD）、 西谷 嚴 (MD)

[目的] 子宮内膜癌（以下体癌）は、内 膜周期を逸脱した異常增殖病変より発生 し、悪性度が増すにつれてステロイドホ ルモン（以下SH）との応答能は低下して $ゆ$ く。我々は、正常子宮内膜の各周期と 比較ながらSH療法前後の内膜增殖症およ び內膜癌の細胞周期と細胞診像の変化に ついて比較検討を行った [方法] 正常子 宮内膜増殖期および分泌期50例を対照群 として内膜增殖症13例、体癌28例の細胞 周期をflow cytometryおよびMIB-1抗体を 用いて免疫組織学的にに解析した。さら に体癌25例にMedroxyprogesterone acetate (MPA) 400mg/day、14日間ある いはMPA400mg+Tamoxifen (TAM) $40 \mathrm{mg} /$ day 14日間投与し、投与前後にお ける細胞周期の变動と細胞所見を比較検 討した。

[成績] 正常子宮内膜のDNA合成期細胞 は、増殖期で27\%に増加し、分泌期では 3\%に低下した。また腺腫性増殖症がもっ とも高い増殖能を示した。体癌ではMPA 投与前 $25.9 \pm 1.9 \%(n=19)$ から投与後7.2士 1.7 と有意 $(P<0.01)$ に減少した。MPA+ TAM同時投与群ではMPA単独投与との間 に著明な差異を認めなかった。これらの 症例においてはSH療法前後の細胞診所見 の変化についても同様に検討を行ったの で報告する。 


$$
\text { இワークショップIII }
$$

\section{ワIII-1 アポトーシスとネクローシス}

\section{金沢大学第三内科}

○中村喜久 (MD)、武畐 稔 (MD)、中村忍 (MD)

【目的】細胞の死、特にアポトーシスについて は夥しい研究がなされているが、もう一つの細 胞死である壊死（ネクローシス）についての検 討はほとんどなされていない。また、日常の細 胞診でもアポトーシスとネクローシスを明確に 区別することは困難である。本研究では、両者 の鑑別のための基礎的検討として、ラットの胸 腺と脾荿に阻血などのネクローシスを生じる処 置を施し、形態学的ならびにDNAの変化を観察 した。さらに、抗癌剤により誘発されるアポ トーシスの所見と比較検討した。

【方法】3週齢Wister系雄性ラットの胸腺および 脾臓を無菌的に摘出し、室温あるいは37゚゚で1-3 日間放置した。組織を細切して得た浮遊細胞を 低融点アガロースに包埋後 proteinase $\mathrm{K}$ で処理 し、電気泳動によりDNAの観察を行なった。形 態学的変化はH-E標本とともに電顕を用いて観 察した。また各種抗癌剤を作用させて、同様の 観察を行った。

【結果】摘出後放置した組織では、細胞質の崩 壊と核の浱縮を示す、いわゆるネクローシスに 混じて、核クロマチンの特異的な凝集を示すア ポトーシスと考えられる細胞変化が、早期には 比較的多数観察された。電気泳動では、アポ トーシスと同様の“ladder”が見られた。長時間の 放置で低分子量の成分は増量したが、ネクロー シスの特徴とされている“smear”は観察されな かった。

【考察】今回の実験からはDNAの変化のみでは アポトーシスと断言できないと考えられた。ま た、阻血などによっても、一旦アポトーシスを 起こしたあとにネクローシスの形態をとる “post-apoptotic necrosis”ともいえる変化をたどる 細胞の存在が示唆された。これらの所見と細胞 診で見られる細胞像を対比するとき、臨床的に ネクローシスとして観察される変化にも、アポ トーシスが含まれている可能性も考えられる。
ワIII-こTUNEL 法による Apoptosis 細胞の 検出

下関市医師会病院病理 ${ }^{11}$

東京医科歯科大学 ${ }^{2}$

山口大学医学部検査部病理 ${ }^{31}$

同 病理学第二講座 ${ }^{4}$

O竹内隆子 $(\mathrm{CT})^{1)}$ 、藤井華子 $(\mathrm{CT})^{1)}$ 、平田祐子 (CT $)^{11}$ 、亀井美由紀 $(C T)^{11}$ 、原田美枝 $(C T)^{11}$ 、 竹内啓晃 $(\mathrm{CT})^{21}$ 、平岡芙美子 $(\mathrm{CT})^{3)}$ 、三村由香 $(\mathrm{MT})^{4)}$ 、村上知之 $(\mathrm{MD})^{4)}$

[はじめに］我々は、TUNEL 法による Apoptosis 細胞の染色に関する研究を行っている。てれまで に、固定条件の検討を培養細胞で行い、良好な結 果を得ている。今回は、腫瘍を含む各種七卜組織 （臨床材料）への応用を試みたので報告する。

[材料と方法] 新鮮組織からスメア、凍結切片扰 よびハラフィン包埋組織切片を作成し、TUNEL 法 で染色した。バラフィン包埋組織については、標 本作成に関わるいくつかの条件を検討した。

TUNEL 法には、アボフ・タグ・in situ アボフト シス検出キット（Oncor 社）を用いた。

[結果］(1)今回の症例では腫瘍細胞の陽性率は、 1\%未満がほとんどであった。(2)間質細胞、特にリ ンハ球の一部が陽性となる傾向があった。 
ワIII-3 細胞診材料におけるアポトーシ スの検出に関する基䃈的検討

日本大学医学部附属駿河台日大病院病理部1)、 同第二病理 ${ }^{2}$

$\mathrm{O}^{1,2)}$ 根本則道 $(\mathrm{MD}) 、{ }^{1,2)}$ 長田宏巳 $(\mathrm{MD})$ 、

1) 飯島和子 $(\mathrm{CT}) 、{ }^{1)}$ 古瀬慶子(CT)、"三浦千 映(MT)、 ${ }^{1)}$ 末柄 明(CT)

[目的］アポトーシス(AP)は形態形成、細胞 の成熟・分化、増殖などに密接に関与して おり、その発現には様々な経路の存在が指 摘されている。現時点では日常の細胞診検 体においてAPを検出することの臨床的意義 は明らかではない。しかし、悪性腫瘍に対 する治療法が日進月歩であることを考えれ ば、近い将来細胞診レベルにおいても治療 により誘導されるAPの発現を検討すること の臨床的意義がでて、くることが予想される。 このような観点から細胞診検体における $\mathrm{AP}$ の検出の信頼性と保存検体におけるAPの検 出の可能性を検討した。

[対象と方法] 術中迅速診断時に提出され た検体の捺印ないし圧挫標本（甲状腺腫瘍、 悪性リンパ腫、乳癌) について in situ nick end-labeling (TUNEL法)(Apop Tag, Oncor社な らびにMEBSTAIN、MBL社)によるAPの検出 を試みた。検体は95\%エタノール固定とし、 保存期間は数日〜約10か月である。なお、 一部の症例については免疫組織化学を併用

し、組織レベルの染色結果と対比検討した。

[結果と考察] 95\%エ夕ノール浸漬固定、 長期保存材料においてもAPの検出は可能で あった。しかし、背景が出やすいことに加 え細胞形態には修飾像がみられ、あまり長 期保存材料はAPの検出には不適当と思われ た。タンパク分解酵素処理は必要であった。 組織レベルとの比較では、検索対象となる 塗沫細胞が比較的均一である悪性リンパ腫 のような例では細胞診検体における結果は 組織レベルのそれをよく反映していると考 えられた。通常のエタノール固定による細 胞診材料におけるAP検出の再現性と将来の 有用性に関する可能性ついて述べたい。
ワIII-4 細胞診検体におけるアボトーシスの 検出一 TUNEL法応用の基硔的検討

東北大学医学部第二病理

○笹野公伸 (MD)

種々のヒト病変におけるアポトーシスの検索 は、その病態生理及び細胞回転の理解に大きな頁 献をしてきている。近年アボトーシスの存在と深 く関係すると思われるDNA fragmentation を病理 組織標本で比較的容易に検出出来るTUNEL (TdTmediated dUTP-biotin nick and labeling) 法かs 開発されて以来、種々のヒト組織及びその病変に おけるアポトーシスの報告が多くなされてきてい る。しかし TUNEL法は固定条件によりその結果が 影響を受ける事も事実であり、染色条件の確立が 重要となる。そこで今回我々は、組織標本に比し てあまりアポトーシスの検索がなされてはいない 細胞診検体で TUNEL法を応用する際に重要となる 固定条件を含む種々の基礎的条件を榙討した。

対象としては比留、食道扁平上皮䄈そして 卵巣澺の怜沫標本とし、以下の固定液に $2 \sim 3$ 時 間室温で固定した検体を用いた。すなわち、メタ ノール、エタノール、8\% paraformaldehyde (PFA 1、4\%PFA、そしてカルノア液である。又、風乾標 本、ギムザ及びパバニコロウ染色後の脱色標本で も検討した。そして䅅沫標本を作製した腫玩組織 を8\%PFA 又は 10\%ホルマリン固定バラフィン包埋 した標本で TUNEL法を施行し、細胞診検体での結 果と比較検討した。用いた種々の固定液の内で、 8\%及び4\%PFA で固定した漼沫標本に於いて病理組 織標本と最も一致した結果が得られ、background も低かった。メタノール、エタノール固定標本で もTUNEL 陽性細胞が榙出されたが、backgroundが 高く見られた。風乾標本、カルノア固定標本、脱 色標本では多くのfalse postive の所見が㸡察さ れTUNEL 法にはあまり適さないと思われた。以上 のようにPFA 固定並ひにアアルコール系固定液を用 いると細胞診検体でもTUNEL法を応用させる事は 可能であり、病理組織標本の採取が困難な FNA標 本等に於いてのアポトーシスの検索に有効と思わ れた。 
ワIII-5 婦人性器癌の化学療法および放射線療 法による細胞死についての基礎的、臨床的研究

自治医科大学産婦人科

O関口 勲 (MD) 、鈴木光明 (MD) 、大和田 倫孝（MD）、佐藤郁夫（MD）

[目的]化学療法、放射線療法による婦人性器癌の 細胞死の形態学的所見につき基礎的および臨床的 に検討した。[方法]卵巣癌細胞株（4株）、頚部 腺癌および頚部扁平上皮癌細胞株（4株）に対す る、シスプラチン（P）あるいは放射線の影響を 検討した。Pは $20 \mu \mathrm{g} / \mathrm{ml} 、 1 \sim 4$ 時間接触、放 射線は $0 \sim 40 \mathrm{~Gy}$ 照射とした。細胞形態を光顕お よび電顕観察した。また、in vivoではP 7.5〜 $22.5 \mathrm{mg} / \mathrm{kg}$ 、放射線は $0 \sim 40 \mathrm{~Gy}$ 照射とし、組 織・細胞所見を検討した。臨床例では頝部腺癌 $\mathrm{P}$ 動注化学療法および扁平上皮癌放射線療法例を対 象に組織診ならびに細胞診所見を検討した。 TUNEL法も施行した。

[成績]I. 基礎的検討 : 卵巣癌および顤部腺癌株で はPの濃度依存性にapoptosis（Apo）細胞が出現 した。Apo細胞はP接触後 $24 \sim 48$ 時間にピー クを示し、それ以後は細胞腫大のみられる necrosis (Nec) 細胞が増加し、二相性パターン を示した。これに対して扁平上皮癌株では $40 \mathrm{~Gy}$ 照射においてもApo細胞は殆ど出現せず、細胞死 は主にNecであった。II. 臨床的検討：動注例では P投与後 $24 \sim 48$ 時間にApo細胞が確認され、 その後Nec細胞の出現する傾向が確認された。一 方、放射線療法例ではApo細胞の出現は少なかっ た。

[結論]婦人性器腺癌に対するシスプラチン化学療 法ではApoおよびNecにより、また扁平上皮癌に 対する放射線療法では主にNecにより細胞死が生 じると考えられた。 


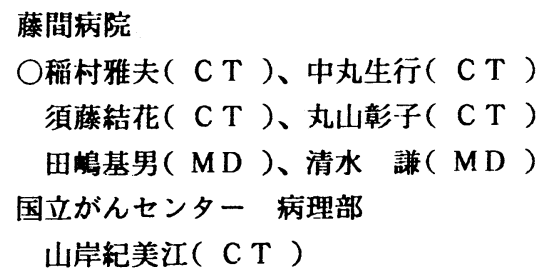

目的 : 子宮頝部の初回細胞診成績を検討し、誤診 例の原因を分析した。

材料：10年間の子宮頝部 195,228 例の Pap標本。 成績：頝部細胞診成績は陽性 243 例 $(0.12 \%)$ 、 疑陽性 1,085 例 $(0.56 \%$ ）、陰性 193.900 例 (99.32\%) であった。

陽性 243例の内、Biopsyを施行した221例は、 頝癌（CISを含む）214例で非癌が7例あった。 疑陽性（日母分類 III a、III b ） 1, 085例の内、 Biopsyを施行した 626例では、頝癌（CISを含む） は63例、高度異形成64例、軖度 -中等度異形成 200例、良性病変 299例であった。

当院で手術を施行し確認した頚癌 224例の頝部 細胞診成績は、陽性 174例、疑陽性45例で、證陰 性が 5例あった。

誤陰性は、上皮内癌 4例、I a 期癌 1例で、平 均年令39.8才、他医で 1 ヶ月前にBiopsyしたもの 1例、2 䓢間前に細胞診を施行したもの3例と細 胞が少数であったもの 1例であった。

譟陽性 7例は、高度異形成 1例、中等度異形成 4例、軽度異形成 1 例、慢性頚管炎 1例で、平均 年令 54.3 才であった。

軖度異形成と慢性頝管炎の細胞像をパターン認 識表で比較すると軽度異形成は、中問層型で胞体 緑色、核形整、クロマチン顆粒状が多い㑯向があ った。

結論：(1)我々の頝部病変に対するチェック率は、 $96.8 \%$ 。(2)譔陽性 $3.17 \%$ 、翼䧔性は $2.2 \%$ であっ た。(3)軽度異形成と慢性䅡管炎、異形成と上皮内 癌の細胞像の区別は、今後更に研究をすすめる。

\section{2 当院 10 年間の子宮顠癌検診成績の検討}

秋田県厚生連由利組合総合病院病理細胞診1)

秋田大学医学部第二病理学教室 ${ }^{21}$

秋田大学病院中央陌床検查部病理 ${ }^{31}$

O阿部一之助 (C T $)^{11}$ 、阿部媇 (C T ) ${ }^{11}$

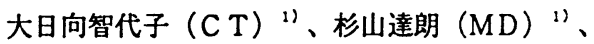
增田媇弘 (MD) ${ }^{2)}$. 提島真人 (MD) ${ }^{3)}$

1985年4月～1994年3月まての 10年間に当院で子 宮顴癌検診を受診した延べ総数52,536名のうち、 細胞診要精検者（クラス田坝上）は 382 名 $0.72 \%$ であった。このうち組織精検受診者は 373 名 97.2 \%であり追跡調查した結果、異型成 55 名 $0.18 \%$ 、 上皮内癌 21 名 $0.04 \%$ 、浸潤癌 13 名 $0.02 \%$ が確認さ れた。今回我々はこの結果について年令階級別 (5 歳每）に分け、年代別の異型成、上皮内癌、浸潤 癌の発見数（率）を見るとともに、組織診との不 一致の要因について検討したので報告する。

【結果】(1) 細胞診要精検者は373名で、クラス III a 296名 $0.56 \%$ 、II 52 名 $0.1 \%$ 、IIf 13 名 $0.02 \%$ 、 N 14名 $0.03 \% 、 V 7$ 名 $0.01 \%$ てった。(2)組穖精 検結果は、異型成（軽度 31 名 $0.06 \%$ 、中等度 20 名 $0.04 \%$ 、高度 4 名 $0.008 \%$ ）、上皮内癌 21 名 $0.04 \%$ 、 初期浸潤癌 9 名 $0.02 \%$ 、浸潤癌 3 名 $0.008 \%$ 、頸部腺 癌 1 名 $0.002 \%$ でった。(3)精検結果を年令階級 別に見ると異型成は軽度、中等度、高度に関係な く30代から60代にかけ広く均等に発見されていた か、上皮内癌は20代から40代前半と若年化傾向か 見られ、初期一浸潤癌は30代の若年者と60代の高 齢者に大きく分かれて発見された。(4)組織診との 不一致例は過小評価が8例（上皮内癌を吕 aとした

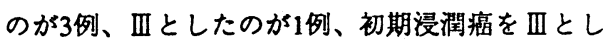
たのが1例、而bとしたのが 2例、浸潤癌を四とし たのが 1例）みられた。過大評価は2例で、中等

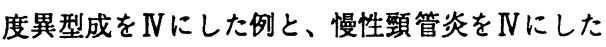
例であった。(5)過小評価した要因は、病変部から 細胞がうまく採取されていなかったものや、分化 型上皮内癌が含まれていた。過大評価した2例は 炎症が強く、核が肥大し核内変性のためクロマチ ンが増量しているように見えたのが原因であった。 
3 岩手県における子宮䅡癌 検診の現状と問題点

$\bigcirc$ 熊谷裕子 $(C T)^{1)}$ 、川村知正 $(C T)^{1)}$ 、 井筒俊彦 $(M D)^{2)}$ 、利部輝雄 $(M D)^{2)}$ 、 西谷䉷(MD) ${ }^{2)}$

1) 岩手県対ガン協会

2) 岩手医科大学産婦人科

子宮䅡癌検診は、昭和 57 年の老人保 健法の制定に伴い30 歳以上の婦人を対 象として行われている。岩手県において も子宮䅡癌検診受診者は、年々増加しつ つあるが、近年いくつかの問題点も指摘 されてきている。

今回我々は、岩手県内の子宮頚癌検診 受診者を対象として老人保健法のもとで 行われた子宮澒癌集団検診（集団検診） での結果と実地医家で施行された子宮頚 癌検診 (個別検診) の結果を比較検討し、 岩手県の子宮頚癌検診における現状と問 題点につき検討したので報告する。

集団検診における受診者数は、1986年 から1995年の10年間に 69700 人から 107176 人之増加し、受診率も18.4\%か ら20.3\%に増加した。個別検診における 受診者数も同様に10097人から 15392 人に増加した。しかし、70歳以上の婦人 の受診率は、69 歳以下の婦人のそれに 比し集団検診、個別検診でも低率であり、 これらの婦人からの進行癌発見率は両者 において高率であった。受診回数別にみ ると集団検診では、初回受診者の割合は 受診者全体の10\%にすぎず、これらの婦 人からの癌発見率は高率であった。また 個別検診の 29 歳以下の婦人では細胞診 $\mathrm{Cl}$ ass III a 以上と判定された症例が年々 増加し、異形成、上皮内癌の発見率も増 加していた。

\author{
当院における妊娠婦人に対する細胞診 \\ 4 当院における妊娠婦人に対
について(円錐切除術施行例を中心に) \\ 松阪中央総合病院産婦人科*、臨床病理 ** \\ 三重大学産婦人科*** \\ ○田中浩彦(MD)、陽川英仁(MD)* \\ 中村豊 $(C T)$ 、小山英之 $(C T)$ 、上森昭 $(C T)$ 、 \\ 石原明徳 $(M D)^{* *}$ \\ 豊田長康 $(M D)^{\star \star \star *}$
}

近年、初交年龄の低年龄化などからHPV感染の 機会が增し、若年者において子宮頚部細胞診の異 常例が增加しており、妊娠中の細胞診においても 要精検率が增加傾向にある。当院では原則として 初診時に全例細胞診を行い、妊娠初期の細胞診ま たは組織診にて高度異形成、上皮内癌、微小浸潤 癌が疑われた場合円錐切除術を施行している。今 回我々は平成5年7月から 28 か間に実施した妊 娠および産袮婦人に対する細胞診の結果について、 円錐切除術および組織診の結果もあわせて報告す る。

対象は妊娠中および産袮期に細胞診を実施した 延べ約650例(流産例、人工妊娠中絶例も含む)で、 class IIIa以上の要精検例は8例(IIIa 6例、IIIb2例) で1.2\%であった。細胞診または組織診にて、高度 異形成以上の病変が推定され円錐切除術が行なわ れた症例はこのうち4例で、微小浸潤癌が2例、上 皮内癌が2例であった。1例の上皮内癌例では細胞 診においてもその組織が推定されたが他は過小評 価であった。妊娠中の細胞診では過小評価となる ことが少なからずあり正確な診断と治療方針決定 のために円錐切除術が有用な場合があると思われ た。 
5

子宮頝部円錐切除術施行例における細胞診診断に ついての検討

国立栃木病院産婦人科" 、同 病理検查科

○菊地正晃 (MD) ${ }^{1)}$ 、長谷川寿彦 (MD) "、佐 久間雄一 $(M D)^{11}$ 、高橋峰夫 (MD) ${ }^{11}$ 、古川政 雄 $(C T)^{2)}$ 、山本工 $(C T)^{2)}$ 、清水和彦 $(M D)^{2)}$

1988年より8年間に当院で円錐切除術を行った子 宮䅡部扁平上皮悪性腫瘍症例のうち、術前狙い組 織診または術後病理組織診で上皮内癌以上と誩断 された症例につき、細胞誩、组い組織診、手術病 理組織誩の結果などを比較検討した。

症例数は83 例で、平均年柃は33.5歳、最終的な 組織診断は上皮内癌 73 例、微小浸潤癌10例であ った。

これらの術前細胞診診断はクラス I、॥が6例、 III aが19 例、III bが18 例、IVが39例、Vが1例で、 狙い組織診診断は異形成6 例、上皮内癌70例、微 小浸澗癌7例であった。

上皮内癌73例の術前細胞診診断はクラス1、\|が 5例、III a か 18 例、IIIbが17例、IVが32例、Vが 1 例、微小浸潤癌 10 例ではクラス1、॥が1例、 III aが1例、IIIbが1例、IVが7例であった。 クラスIIIbおよびVであったものを診断の一致と考 えればー致率は68.7\%であり、不一致と考えられ た症例は26例、31.3\%であった。このうちクラ ス।、川の偽陰性例は6例、 $7.2 \%$ 、林aの低評価 例は19 例、22.9\%あり、これらの細胞診標本に つき再検討を加えるとともに、III以上の77例に ついてベセスダシステムにしたがって再評価し、 手術診断との比較検討を行ったので報告する。
6 子宮頸がん検診でのトリコモ十ス発見状況

(財) 新潟県保健衛生センター 池上喜久夫 ( C T)，島垣二佳子 ( C T ) 井上博子 $(\mathrm{C} \mathrm{T})$, 難波幸子 $(\mathrm{C} \mathrm{T})$ 中野正春 ( C T)

新潟大学医学部産婦人科教室

児玉省二 $(M D)$

子宮頸がん娭診で、細胞診の標本中にトリコモ ナス腔炎所見を観察した場合は要治療と報告する。 近年のトリコモナス発見状況と推移について娭討 したので報告する。

対象は、平成2〜6年までの五年間に当センター が連続して検診を実施した51市町村、のべ145, 40 5 人である。トリコモナスの年次別発見数の推移 は、平成 2 年 112 人、3年 104 人、 4 年 101 人、 5 年 79 人、6年 41 人、全体では 437 人で、各年の発見率は、 それぞれ0.38\%、0.34\%、0.27\%、0.16\%と減少して おり平均 $0.30 \%$ であった。年齢階層別の発見数は、 34 歳以下 14 人、35-39歳 34 人、40-44歳86人、45-4 9歳109人、50-54歳111人、55-59歳40人、60-64歳 19 人、65歳以上が 24 人となった。その各年齢階層 別の発見率は、それぞれ3.20\%、7.78\%、19.68\%、 $24.94 \% 、 25.40 \% 、 9.15 \% 、 4.34 \% 、 5.50 \%$ となり、4 0歳代前半から50歳代前半に最も多い頻度で発見 されるとともに、経年的な変化は認められなかっ た。次に、都市部と農村部で発見の差異を見ると、

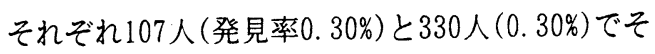
の発見率に差異は認められなかった。しかし、年 跉階層別発見率のピークは、都市部では40-44歳2 4 人 $(22.43 \%) 、 45-49$ 歳 24 人 $(22.43 \%) 、 50-54$ 歳 25 人 $(23.36 \%)$ と 40 歳代前半から 50 歳代であるのに対 し、農村部では40-44歳61人(18.48\%)、45-49\%歳8 人 $(24.55 \%) 、 50-54$ 歳 86 人 $(26.06 \%)$ とやや高い年 代であった。また、トリコモナスが繰り返し発見 された人の数は、都市部が 20 人 (24.39\%)に対し、 農村部では36人 $(12.77 \%)$ と、都市部で繰り返し発 見される傾向が認められた。 
7 子宮頝部異形成の転帰と細胞診所見に ついての検討

東京都がん検診センター婦人科 ${ }^{1}$ 検查科 21 ○ 田瑞恵 $\left.(M D)^{1}\right)$ 、武田智子 $\left.(M D)^{1}\right)$ 、柳沢弥太郎

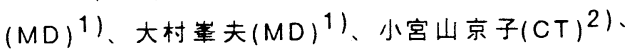
猪狩真子 $(C T)^{2)}$

東京慈恵会医科大学産婦人科田中忠夫(MD) 杏林大学保健学部病理藤井雅彦(MD)

東京顕微鏡院石田禮載(MD)、石井保吉(CT)

子宮頚部異形成は子宮頚癌の前癌病変であり、 また近年HPV感染の関連について報告されてい る。しかし日常臨床では細胞診所見で異形成を経 過観察することが多い、今回我々は異形成の転帰 を推定しうる細胞診所見について検討した。

$1984 \sim 1992$ までの 9 年間に 2 年以上経過観察 した軽度異形成 316 例から8例、中等度異形成 112 例から 23 例、高度異形成59例から 10 例の計 41 例が上皮内癌以上の病变に進行した。同様に

軽度異形成加 225 例、中等度異形成加 444 例、 高度異形成から28例の計297例は病变が寞解した 我々は細胞診所見でHPV感染細胞をkoilocytosisとは区別して、门扁平上皮化生細胞に由来 したparakeratosis,dyskeratosis, 2 核,多核、 巨細胞などを重要な所見と考えてきた。軽度異形 成 316 例の経過観察中に、(1)の所見の出現した 82 例中寛解したのは21例、出現しなおった234例中 寬解したのは204例であった。中等度・高度異形 成 171 例の経過観察中に、(1)の所見の出現した66 例中寬解したのは12例、出現しなかった105例中 寛解したのは 60 例であった。以上より(1)の所見 の出現する症例は、しない症例より寛解しずらい 傾向があった。また扁平上皮化生細胞由来の異型 細胞を成熟過程によって未熟、成熟過程、成熟し たものと分類し検討したところ、進行例では未熟 な異型化生細胞の出現率が高度であったので報告 する。

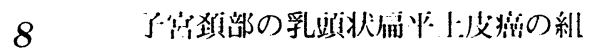 織所胃と細胞診所胃}

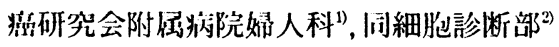

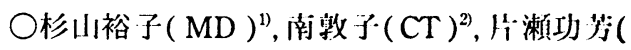
$M D)^{1)}$, 梅沢聡 $(M D)^{1)}$, 山脇孝晴 $(M D)^{11}$ ， 川 内一弘 $(\mathrm{MD})^{1)}$, 都竹正文 $(\mathrm{CT})^{2}$, 㫦兄勝党( $\mathrm{MD})^{1)}$

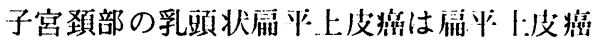
の特殊亚型として知られているが、きわめて

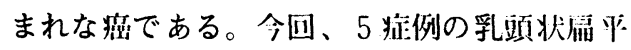
上皮癌を経験したので、その組織所見と細胞 診所見について報告する。

患者の平均作令は44蒇 (27-62荿)で、\}富㸚 癌進行期分類LI、Ib則 2 例、IIb期3例であった。 すべての症例に手術が施䘕され、術的に細胞 診と組織診が施行された。組織学的には中心 に血管茎をもつ乳頭状構造を特徴とし、10-15 層以上の未熟な基底細胞様の腫瀑細胞に被覆 されていた。その被覆上皮細狍は、移行上皮 に類似するもの、陑平上皮の棋形成の細胞に 類似するもの、扁平上皮癌細胞に類似するも のの、3っに分類できた。細饱診所見上も间 様であった。特に移行上皮に颣似するものと、 扁平上皮の㟟形成の細胞に類似するものは、 細胞診上、浸潤独と診断するのが難しく、翼 形成由来細胞と考えられやすかった。しかし、 本症例は、背景が泟い、置型細胞が乳頭状の 大きな塊で州現、異型細胞が数多く出現する、 ことなどから、買形成との区别ができると考 えられた。

乳頭状届平上皮独は一般的に、乳頭状に発 有し、組織听罗上表層は細狍然型が弱く、浸 潤巣は深い基底部に見られる。このため衣層 の生检だけでは浸润燃と診断がつかないこと が多いが今回は、術佮に細狍診を作用するこ とで診断ができた。その特徴について考祭し たので、跟望する。 
9 HPV 感染と mild dysplasia の取り 扱いについて

東京女子医科大学産婦人科1), 至誠会第二病院 産 婦人科2)

○木村祐子 ( CT ) 1) 黒瀬雅美 (MT ) 1), 矢嶋正純 (MD) 1), 井口登美子 (MD) 1), 武田佳彦 (MD) 1), 横須賀 薰 (MD) 2)

平成 5 年 7 月〜平成 7 年 7 月の間に東京女子医 科大学産婦人科外来を受診して, 子宮頸部細胞診 にてHPV 感染之診断され病理組織診 (HE 染色) が施行された症例（74例：A群），同様に軽度異 形成とされた症例（61例：B群），軽度異形成+ HPV 感染とされた症例 ( 40 例：C群)について, 細胞診と病理診との比較並びに両者の不一致例の 細胞像の検討を施行した。A群で病理診であHPV 感染とされた症例は $39.2 \%$ (29例), 異形成が認 められたのは $31.1 \%$ ( 23例), うちmild dysplasia は13例（16.6\%)であり，より高位病変が 認められたのは $13.5 \%$ であった。また，B群にお いて細胞診断と組織診断が一致したmild dysplasia 症例は, $49.9 \%$ ( 28/61例)であった。細 胞診でmild dysplasiaとされながら,病理診で陰 性之診断されたのは $37.7 \%$ (23 例)，高位病変が 認められたのは $16.4 \%$ (10例)であった。同様に C 群にみてみると, その一致率は $67.5 \%$ (27/40 例 )で, 細胞診でmild dysplasia +HPV 感染( 8 例 )とされながら, 病理診で陰性と判定されたの は 6 例, HPV 感染 2 例であり,高位病変が認められ たのは $12.5 \%$ (5例)であった。以上より, B 群とC 群におけるmild dysplasiaの細胞診の正診率壮C群 がやや高いむのの, 高位病変の合併率は殆ど差が無く, A群における高位病変の合併率も同様であったてとか ら, 高位病変の合併率という点からはmild dysplasia とHPV 感染は同等に取り扱うべきであり, Bethesda system は妥当と思われた。また，高位病変の みられた症例での見直しでは, OG 好染の dyskaryotic cel1の出現に注意を要すると考えられた。
$10 H P V$ 感染細胞の核所見について
一悪性病变進行例における核所見の解析一

杏林大学保健学部細胞診断学教室 ${ }^{11}$

同病理学教室 ${ }^{21}$

東京都がん検診センター婦人科 ${ }^{3)}$

O郡 秀一 $(\mathrm{CT})^{11}$ 、椎名義雄 $(\mathrm{CT})^{11}$ 、藤井雅彦 $(M D)^{2)}$ 、小田瑞恵 $(M D)^{3)}$ 、柳澤弥太郎 $(M D)^{3)}$ 、 大村峯夫 $(M D)^{3)}$ 、千綿教夫 $(M D)^{3)}$

Human papill loma virus(HPV)は子宮頸癌の発生 に深く関与し、宿主側の遺伝子变化等が加わって、 発癌に至ると考えられている。これまでに我々は HPV感染の細胞形態的診断は核所見（核内封入体 㨾所見、淡染均質無構造、濃染均質無構造）を観 察することが重要であると報告してきた。また、 in situ hybridization(ISH)法による c-myc RNA の検索で、異形成の上皮全層陽性の症例はHPV16/ 18型感染が多く、細胞診標本では淡染均質無搆造 核を伴う旁基底型細胞の出現が特徵的で、この細 胞が出現した症例はどのような経過をたどるか興 味ある所見であった。そこで今回は経過観察中に 異形成から悪性病变へ進行した症例を用い、経過 観察中の細胞診標本上の核所見を解析し、特徴的 所見を報告する。

[研究材料および方法]研究材料は東京都がん検診 センター婦人科で、組織学的に異形成と診断され、 経過観察中に悪性病变に進行した症例の細胞診標 本を対象とした。方法は細胞診標本上の核所見を 核内封入体梯所見、淡染均質無構造、浱染均質無 構造に分類し、旁基底型、中層型、表層型扁平上 皮細胞別に出現状況を検索した。なお、HPV感染 の証明には、SH法を用いた。

|結果・考察 これら症例では、悪性病変へ進行す る以前の異形成の段階で淡染均質無構造核を伴う 極めて N/Cの高い旁基底型細胞が出現しており、 この細胞が癌化を予測するマーカーとなる所見と 考えられた。 
11 子宮頝部擦過細胞診材料における

In situ PCR 法を用いたHPV-DNA の検出

順天堂大学浦安病院検查科 ${ }^{11}$, 同婦人科 ${ }^{21}$

$\bigcirc$ 喜納勝成 $(\mathrm{CT})^{11}$, 古谷津純一 $(\mathrm{CT})^{11}$, 岡崎哲也 $(\mathrm{CT})^{1}$ ，風間玲子 $(\mathrm{CT})^{11}$, 齊藤 啓 $(\mathrm{KD})^{1}{ }^{\prime}$, 鈴木不二彦(ND) ${ }^{11}$ ，石 和久 (MD $)^{11 ，}$ 西川香苗 $(\mathrm{KD})^{2)}$ ，久保田武美 $(\mathrm{KD})^{2 !}$;。

（目的）HPV-DNA の検出は子宮䅡部病変, 特に異 形成, 癌との関連を見る上で重要である。

前回我々は, In situ PCR 法でHPV-DNA 組み込 み培養細胞を用い基礎的な検討を行い報告した （第36回日本臨床細胞学会総会）。

今回は，臨床材料，即ち子宮頚部細胞診材料を 対象にIn situ PCR 法を施行し, 通常のIn situ hybridization(ISH)法との感度の比較およびDNA 検出態度につき検討を行ったので報告する。

（材料と方法）1987年から1990年までの間に当院 婦人科を受診し子宮䅡部病変が認められSouthern blotおよびDot blot法にてHPV-DNA（type16,18） が検出された30例を用いた。こののうちISH 法で HPV-DNA が検出されなかった14例の患者から同時 期に採取された子宮頝部擦過細胞診・組織材料に In situ PCR 法を施行し (1) ISH法との感度の比較 および(2)細胞診材料での DNA検出について検討を 行った。

（結果と考察）(11 ISH法にてHPV-DNA 陰性を示し た14例中 7例(50.0\%) でIn situ PCR 法にてHPVDNA を検出し得たが，陰性となった7例に関して は細胞の保存状態が悪かったか, もしくは感染部 位の擦過が充分ではない等の原因が推察される。

(2)細胞診材料での DNA検出については，核内に 限らず一部で胞体内にも認められた。これはPCR

による DNAの流出によるものと考えられる。 今回の結果からPapanicolaou染色標本において もHPV-DNA の局在の認識が可能であり, また, 感 度の増加は今後の研究に大きく貢献するものと思 われた。
12 子宮頚部adenoma malignum 91 例

鹿児島大学産婦人科 ${ }^{12}$,同 第 1 病理 ${ }^{2)}$

$\bigcirc$ 牛垣由美子 $(M D)^{1)}$, 小林知恵 $(M D)^{1)}$, 松 尾隆志 $(M D)^{1)}$, 森田洋一郎 $(M D)^{1)}$, 三輪勝洋 $(M D)^{1)}$, 松元保 $(M D)^{1)}$ ，沖利通 $(M D)^{1)}$, 高崎 隆志 $(M D)^{2)}$, 吉田愛知 $(M D)^{2)}$, 永田行博 $(M D)$ 1)

産婦人科領域で子宮頝部adenoma malignum は診断の困難な疾患である。今回当院で子 宮頝部adenoma malignum と診断した症例を 経験したので報告する。患者は48才の女性で 1995年 8 月頃より不正性器出血を認め, 前医 にて核所見は少ないものの組織診にて一部 CEA 染色にて陽性のため, adenoma malignum が疑われ，11月30日 当院を受診する。細胞 診では核腫大した細胞に赤色の核小体を認め, 重積性は少なかった。しかし時に腺構成を示 唆する部位も認めた。病理組織診では腺管は 拡張し，一部に周囲の間質を伴って腺管内に 乳頭状，またはへアピン状に突出する上皮の 増生が認められ, 子宮䅡部adenoma malignum と診断された。 


\section{3 子宮頚部悪性腺腫の2例}

\section{町立三国病院 ${ }^{1)}$}

\section{福井医科大学産科婦人科学教室 ${ }^{2)}$}

同 中央検査部 ${ }^{3)}$

○鈴木由里子 $(M D)^{1)}$, 吉田好雄 $(M D)^{2}{ }^{2}$, 川上由香 $(M D)^{2)}$ ，黒川哲司 $(M D)^{2)}$ ，久住健一 $(M D)^{2)}$ ，佐々木博正 $(\mathrm{ND})^{2)}$ ，紙谷尚之 $(M D)^{2)}$ ，小辻文和 $(M D)^{2)}$ ，富永敏朗 $(\mathrm{MD})^{2)}$ ，今村好章 $(\mathrm{MD})^{3)}$, 森 正樹 $(\mathrm{CT})^{3)}$

\section{非常に稀な高分化型腺茜である子宮頝部悪性腺腯}

は細胞異型が弱く，形態的にも正常澒管腺に類似 し, 診断に苦虑する疾患である。今回我々は細胞 診で本症を疑い，確診を得るのに生検を繰り返し た症例を2例経験したので報告する。

（症例1）33墄, 既婚, 未経弤婦。22歳の時より Peutz-Jeghers症候群を指摘されている。27嵗頃よ り水梯性带下を認め，その中にシート状や梅状の 集塊を示す腫䓪細胞が出現していた。腫場細胞の 核は偏在しており軽度の異型がみられた。細胞質 は広く粘液をもっていた。生検では䅡管腺の著明 な增生がみられたが腺上皮の異型は少なかった。

（症例2）71葴，5回経姡2回経産婦。多量の水㥞性 带下を自覚し受診。子宮䅡部細胞診では数個から 数十调の高円柱上皮の集塊が出現。細胞質には粘 液がみられ，核は円から類円形で偏在し，クロマ チンは微細顆状で中等量の增加を示していた。生 検では高円柱上皮よりなる腺管が乳頭状に增生し ており粘液産生がみられた。2例とも烸床症状，細 胞診，生検を桧合して悪性腺嘎と術前診断し，摘 出物の組織標本で確診した。

\section{Adenoma Malignumの一例}

鳥取大学医学部産科婦人科

○板持広明(MD), 岡田誠(MD), 程修司(MD), 入江隆 $(\mathrm{MD})$, 皆川幸久 $(\mathrm{MD})$, 紀川純三 $(\mathrm{MD})$, 寺川直樹(MD)

Adenom a Malignum(子宮頸部悪性腺腫)は内頝 部の高分化型腺癌に属する稀な疾患であり, 細胞 異型にそしいため細胞診判定基準は明確でない. 今回, Adenoma Malignumの一例を経験したので, その細胞診所見と臨床経過を報告する.

症例；47歳. 3 経弤, 3 経産.

定期的に子宮がん検診を受けていたが，異常は指 摘されなかった. 平成6年4月頃より水様性带下を 自覚するようになった. 12月のがん検診時に骨盤 内腫瘤と異常細胞診を指摘され, 当科紹介となっ た. 細胞診所見は, 粘液性背景下に腺系の細胞集 塊がシート状に出現し，一部は柵状配列を示した。 核クロマチンの增量と核小体を認め, 核異型を示 すものの核重積は著明でなく，頝部高分化型腺癌 を推定した。平成 7 年1月，子宮䅡癌 I a 期の診断 で広汎子宮全摘術を施行した。 子宮頸部に黄白色 の腫瘤を認め, 割面では小さな腺腔と大きく拡張 した谼胞状腺腔が存在した. 組織所見では, 筋層 に浸潤した高分化な腺样構造よりなる腫㕫性腺管 が不規則な形状と大きさを呈し，周囲間質にも突 出していた，腺管は一層の高円柱上皮よりなり， 異型も少なく核分裂や核の重層化はなかった。以 上の所見よりAdenoma Malignumと診断した。術 後進行期はp $\mathrm{T}(2 \mathrm{a}) \mathrm{NR}(1) \mathrm{M}(0)$ であり, 術後に化学 療法と放射線療法を追加した。術後経過は良好で， 現在のところ再発徴候を認めていない. 
15 子宮頝部腺異形成が疑われた卵管 上皮化生の 1 例

九州大学産婦人科 ${ }^{1)}$, 同中央検查部 21

○坂井邦裕(MD)!、上平謙二(MD)"

嘉村敏治 $(\mathrm{MD})^{1}$ )、重松敏之(MD) $)^{1}$ 、齋藤俊章 $(\mathrm{MD})^{1)}$ 加来恒寿 $(\mathrm{MD})^{2}$ )、古賀裕子 $(\mathrm{CT})^{2}$ )

卵管上皮化生は、子宮頸部では頝管腺領域にみ られる、正常の卵管上皮に類似した化生上皮で ある。組織学的には20-30\%にみられると報告さ れており、しばしば上皮内腺癌および腺異形成 との鑑別が問題となる。今回われわれは、子宮 頸部擦過細胞診にて異型䅡管腺上皮が疑われた 卵管上皮化生の1例を経験したのでその細胞像、 組織像を報告する。［症例］47歳、主婦。子宮 頸部中等度異形成にてレーザー蒸散術が行なわれ、 経過観察中に子宮頸部擦過細胞診で異型腺が疑 われた。コル゚ス ス 異常所見は認められなかった。そこで確定診断 のため子宮頸部円錐切除術を行なった。[細胞 所見〕きれいな背景のなかにシート状、一部柵状に 配列する腺型の細胞の集族を認めた。胞体は円 柱状で好青性に濃染していた。核は軽度肥大し、

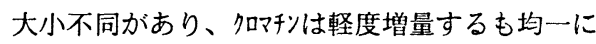
分布していた。殆どが1個の小型の核小体を有し ていた。［組織所見］摘出標本では扁平円柱上 皮接合部の表層に卵管上皮化生を認めたが、明 らかな䅡管腺上皮の異型は認めなかった。[ま 之め] 子宮䅡部擦過細胞診で卵管上皮化生由来 の細胞の出現をみた症例の細胞像の特徵を報告 するとともに、腺異形成、上皮内腺癌との細胞 学的相違についても考察する。
16 子宮頝部腺癌の検診成績および細胞 所見に関する検討

長崎大学㦃婦人科"、佐世保市立総合病院2)、 長崎県総合保健センター ${ }^{31}$

○坂井秀隆 $(M D)^{\prime \prime} 、$ 馬場寿美子 $(C T)^{\prime \prime} 、$ 高尾直大 $(\mathrm{MD})^{1)} 、$ 森山伸吾 $(\mathrm{MD})^{1)} 、$ 中島久良 $(\mathrm{MD})^{1)} 、$ 山辺 徽(MD) $)^{2}$ 、上井清美 $(C T)^{3)}$

長崎県総合保健センターの最近20年(1975-1994 年)における子宮がん検診では、延べ482,451例の 受診者より 32 例 $(0.0066 \%)$ の䅡部腺癌腺癌・扁平 上皮癌湿合型を含む)が検出されている。これは 同期間に発見された0期を含む頚癌全体(508例)の 6.3\%に相当しており、その頻度は私どもの教室 で過去26年間に経験した䅡部腺癌の頻度 $6.2 \%$ (105/1,687例)とほぼ一致していた。扁平上皮癌 では、検出例の $86 \%$ 初期癌(0期、Ia期)であった が、腺癌 32 例では 12 例 $(38 \%)$ が初期腺癌 (0期 7 例、 Ia期5例)であり、残りの20例(62\%)は明らかな浸 潤腺癌(Ib期16例、IIb期4例)であった。初回検診 時の細胞診で発見されたのは初期腺癌では $25 \%$ (3/12例)にすぎず、浸潤腺癌では60\%(12/20例)で あった。また検出時の細胞診で腺癌の疑い之診 断されていた例は初期腺癌では42\%であり、明 らかな浸潤腺癌(85\%)に比へて少なかった。

初期腺癌の細胞診標本には、炎症性背景の中 に小腺管状配列、柵状配列あるいは羽毛状辺縁 を伴う核重積性腺集群が認められた。核は類円 形で偏在しN/C比の增大を伴っていたが、大小 不同とクロマチンの增量は軽度ないし中等度で あった。核縁は一般に明暸平滑で、1個ないし2 個の小型核小体を認めた。一方、明らかな浸潤 腺癌の場合は、腫瘍性背景の中に平面的配列を 示す集群やブドウ房状の丸みをおびた匀縁を示 す集群など多彩な腺集群の他に、孤立散在性の 腺癌細胞を比較的多数伴っていた。また初期腺 癌に比へ、大小不同、クロマチンの增量、大型 核小体を伴う核が目立った。 
17 子宮頝部純粋型 I 期腺滛の細胞学的 検討

北里大学医学部産婦人科、同大学病院細胞診 ") 同医療衛生学部臨床細胞 ${ }^{21}$

○岩永久美(MD)、角田新平 (MD)、上坊敏子(MD)、 佐藤倫也 (ID)、新井正秀 (ND)、古川かつ子(ID) 脇田邦夫 (MD)、蔵本博行( MD)、横山 大(CT) ${ }^{1}$ 大野英治 $(\mathrm{CT})^{21}$

子宮頝部腺癌は近年増加傾向にあるが、同部に 発生する扁平上皮癌に比し、早期発見が困難とさ れている。これは、前癌病変を含めてその癌化過 程にいまだ不明な点が多く、診断面においてもコ ルポ診、組織診などによる早期診断が困難なため と思われる。検診を通じての早期発見のためには、 細胞診所見の把握が重要なポイントといえよう。 そこで、1971年から1994年に北里大学病院で治療 した頝癌1260例のうちの純粋型頚部腺癌89例（0 期 2 例、I 期 43 例、II 期 23 例、III期 13 例、IV 期 5 例）の中から I 期症例24例につきIa期とIb期に分 け、細胞学的に再検討し報告する。細胞標本の背 景は、正常背景 9 例、炎症性背景 1 例、腫瘍性背 景11例であったがIa期例では、全て正常背景であ った。正常䅡管腺細胞をともなうものは14例で、 Ia期例では多数の正常頚管腺細胞の出現を認めた。 異型腺細胞は、大小の集塊を形成し、シート状配 列、棚状配列、乳頭状配列、腺管構造などの立体 構造を形成していた。小集塊を示すものは、軽度 重積性を示すものが多く、大きな集塊を示すもの は重積性著明であった。なおIa期症例には重積性 著明な細胞集塊の出現は目立たなかった。5症例 では、羽毛状配列を示す部分もあり、そのうち 3 例は、花冠状配列もともなっていた。核腫大は全 例に認められ核クロマチンは、細網状ないし細顆 粒状で核小体が著明に認められた。頚部腺癌では、 早期のもの程背景がきれいで正常䅡管細胞と共存 することが多いが、核腫大、核小体、軽度重積の ある集塊に注目することにより診断可能と考えた。
18 子宮頚部腺癌の臨床的および細胞 診断学的特徴について

\section{鹿児島大学産婦人科}

沖 利通 (MD), 松元 保 (MD), 三輪勝洋 $(\mathrm{MD})$ ，家村和千代 (MD), 牛垣由美子 (MD), 小林知恵(MD), 松尾隆志 (MD), 森田洋一郎 $(M D)$, 山元慎一 (MD), 堂地 勉 (MD), 吉永 光裕(MD)，永田行博(MD)

近年、子宮䅡癌のなかでも腺癌の頻度が増 加してきているといわれる。今回、われわれ は過去 2 年間に経験した子宮頝部腺癌の症例 をretrospectiveに検討し、若干の知見を得た ので報告する。

1994年1月から1995年11月までに鹿児島大 学産婦人科学教室で診断された子宮癌の症例 を対象とした。子宮頝部扁平上皮癌5例, 子 宮頝部腺癌5例, 子宮内膜腺癌5例である。こ れら 3 群について、患者背景、臨床症状の特 徵、細胞診の診断精度などについて比較した。

最終診断に対する細胞診の正診率は、頝部 扁平上皮癌100\% (5/5)，頝部腺癌40\%（2/5）， 内膜腺癌 $80 \%(4 / 5)$ であり、頝部腺癌では 細胞診の偽陰性率が高い傾向にあった。細胞 診で偽陰性を示した頝部腺癌症例では、頝管 内擦過が不十分と思われる例が多かった。

以上より、細胞診上腺細胞系の核異型細胞 が認められる場合、子宮頚管内を確実に擦過 するように細胞診あるいは組織診を施行しな ければならないと思われた。 


\author{
関西医科大学産科学婦入科学教室 \\ 実皘真由美(MD)、梅葶圭吾(MD)、 \\ 中島德郎(MD)，神崎秀陽(MD)
}

（目的）子宮頚部腺密系病変に関しては腺異 形成、上皮内腺㾂といった前癌病変が考えられ、 細胞診でも的確に捉え得ることが報告されてい るがprospediveな診断は困難な場合が多い。今 回、細胞診にて、上皮内腺癌と診断し得た1例を

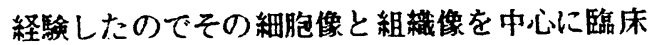
細胞診断学的な考察を加え報告する。（症例） 45墄、5回経好4回経産で既往歴は特記すべき事 はなく、家族糜に父、姉に高血圧を認めるのみ である。平成6年6月、細胞診dassIII腺異形成の 疑いと診断され他院にて精密検査を受けていた か、扁平上皮系、腺系病変等認められず、経過 橎察となっていた。平成7年6月、細胞診IIb高度 異形成の疑いにて当科紹介受診。当科練胞診で は上皮内腺癌が強く疑われ、組織診では高度腺 異形成が認められたため、平成7年9月5日子宮頝 部円錐切除を施行し、上皮认腺密の結果であっ た。(細胞像) 他院での細胞像も検討したが、 変性が強いものの、腺系異形が認められた。当 科での細胞像では、背詈が清で大小さまさまな クラスターが認められ、上皮内腺癌の細胞像の 特徴である重積性のある羽毛状集塊が認められ た。また/C比の增大、核クロマチンの堌量が 認められた。(組織像) 円錐切除標本を横軸に 連続切片を作成し検討した。扁平上皮系異常は 認められなかったが、フロント形成を伴う上皮 内腺癌と腺異形成が同時に認められた。しかし、 上皮内腺滛と異形成との連続は明らかではな かった。(結語) 細胞診において上皮内腺癌は prospectiveに診断可能である。組驖診において cancer in dysplasiaという像が見られた。故に、正

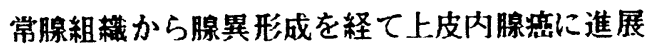
していく可能性が示唆された。

\author{
島根医科大学産婦人科 \\ 藤脇律人 $(M D)$ 、高橋健太郎( $M D)$ 、柳光寛仁 $(M D) 、$ \\ 大西雄一 $(M D)$ 、渡辺裕実 $(M D) 、$ 西木由美 $(M D)$ 、北 \\ 尾 學(MD)
}

平滑筋肉腫は、胃、小腸、子宮体部等に発生す ることが多く、子宮䅡部原発は稀であり、現在ま で数例の報告があるのみである。今回我々は、子 宮頝部に発生した平滑筋肉腫を経験したので報告 する。[症例] 61歳、3妊3 産、閉経54歳、1994 年6月、検診の胸部 $\mathrm{x}$-rayにて多発性肺腫瘤を指摘 された。他院での全身検索の結果、下腹部腫瘤が 認められたため、同年 8 月精查目的で当科紹介とな った。内診上、子宮頚管後壁に超手拳大の腫瘤を 認めた。外子宮口は腹側に著しく变位しており、 外子宮口周囲の擦過細胞診はクラスIIであったが、 内頝部の細胞診・組織診は施行できなかった。画 像診断より子宮原発の肉腫を疑い、9月1日、腹式 単純子宮全摘術十両側付属器切除術を施行した。 術中の腹腔洗浄細胞診は陰性であった。摘出標本 の病理組織診断は、子宮䅡部より発生した平滑筋 肉腫であった。術後CAP.DTIC療法を2コース施行 したが、11月19日、肺転移巣の気管支閉塞に伴う 呼吸不全で死亡した。[捺印細胞診所見]污い壊 死性背景の中に、紡錘形、類縁形の不明暸な胞体 辺縁を持つ大型細胞が散在性に出現していた。核 の大小不同は著しく、核クロマチンは顆粒状、核 小体が明暸であった。[組織所見]子宮䅡管は著 しく延長しており、割面が白色で中心部に壊死を 伴った $10 \times 10 \times 8 \mathrm{~cm}$ の腫海が、子宮頚部後壁から serosa側に突出していた。頝管粘膜面は正常であっ た。腫瘍は束状に密に増生したpleomorphismの強 い異型核をもつ細胞で構成されており、10個以上 / 10HPFの核分裂を認めた。子宮底部には3個の subserosal myomaが存在したが、卵管、卵巣は正常 であった。 
21 17歲女性の子宮頚部に発生したブド ウ状肉腫の 1 例

\author{
九州労多病院産婦人科" \\ 産業医科大学産婦人科 ${ }^{2)}$ \\ O松浦祐介(MD)"，畑中浩一(MD) $)^{2}$ ，川越俊典 \\ $(M D)^{2}$, 土岐尚之(MD) $)^{2}$, 杉原耕一郎(MD) ${ }^{2}$, \\ 柏村賀子(MD)"，柏村正道(MD) ${ }^{2}$
}

\section{ブドウ状肉腫は極めて稀な疾患で、その多く} は新生児あるいは 5 歳までの幼児の䐛に発生する 悪性非上皮性腫瘍である。今回我々は17歳女性 の子宮頚部に原発した本疾患を経験したので細胞 像・病理組織像を中心に文献的考察を加えて報告 する。

（症例）17歳、GOPO。胵内のポリープ状の腫 瘤を自覚し、変性子宮筋腫疑いで、当科紹介受診 となった。㓐内は黄灰白色のブドウの房様腫疽で 充満されており、その外観よりブドウ状肉腫を疑 った。麻酔下で精査を行なったところ腫境は子宮 頝部前䨐に荎をもつ $4 \mathrm{~cm}$ 前後の多数の房様腫瘤で あり、埊内を充満していた。組織診でブドウ状肉 睡と診断されたため、子宮頝部部分切除術（腫瘍 茥切除術）を施行した。腫滨は完全に切除された ため ( Intergroup Rhabdomyosarcoma Study Group 1)、子宮・卵巣を温存し、化学療法 (VAC) を6コース施行後、外来にて経過観察中 である。

（腫膓捺印細胞診所見）壊死性の背景の中に組 織球椂の腫偒細胞が見られた。細胞は紡鍾形で一 部には核小体が認められたが、異型の程度は軽度 であった。

(病理組織所見) 間質は浮腫状で、異型の軽い 間葉系の腫浯細胞が層状に增殖し、cambium layer を形成していた。細胞質は好酸性に染色し たが、横紋ははっきりしなかった。

（まとめ）以上、症例を呈示するとともに、細 胞診・組織診の特殊染色についても検討した。
22 Endocervical Stromal Sarcoma の 1

症例

札幌医科大学産婦人科

○武田智幸(MD), 伊東英樹(MD), 竹原正輝(MD), 山本弘(MD), 黒木勝円(MD), 長多正美(MD)、

工藤隆一(MD)

子宮頝部原発の悪性腫瘍のうち sarcoma は、き わめて稀な予後不良の疾患である。その頻度は子 宮䅡部原発悪性腫瘍の $0.5 \%$ 以下之欧米において 報告されているにすぎい。最近当院において子 宮䅡部原発の endocervical stromal sarcoma 症 例を経験したので、細胞、組織像を中心に報告す る。

[症例] 36 歳、女性。1995 年 9 月 16 日、不正 性器出血を認めたため、某産婦人科受診し精査の ため当科紹介となった。視診上、子宮䅡部後唇か ら突出し頝部全面を覆う巨大ポリープ状、 $4 \mathrm{~cm}$ 大 の易出血性、壊死性潰瘍を伴った腫瘤を認めた。 同年 10 月 13 日、準広汎性子宮全摘出術 - 雨側附 属器摘出術・骨盤内リンパ節摘出術を施行し、現 在外来経過観察中である。

[子宮䅡部擦過細胞診所見]標本上、比較的小型 で裸核状〜狭小な細胞質を伴う異形細胞が散在 性に出現している。核は円〜棈円形、核クロマチ ンは粗顆粒状〜網状、大小不同を軽度に認めた。

[摘出組織所見] 子宮頚部後唇部より超母指大の 一部壊死を伴った隆起性腫瘤を認めた。HE 染色 上、楕円核を有する spindle cell の増殖を認めた。 mitosis は $10 / 10$ high-power fields 以上認め られた。子宮頝部に限局し、壁への浸潤は $1 / 3$ 以 内であり PTrNoMoであった。免疫組織染色では、 Gitter(士)、PTAH(-)、S-100(士)、ミオシン(-)、 アクチン(ー)であり endocervical stromal sarcoma と考えられた。最後に電顕検査も行っ たので合わせて報告する。 
鹿児島大学産婦人科 ${ }^{1)}$,同 第 2 病理 ${ }^{2)}$

$\bigcirc$ 森田洋一郎(MD) ${ }^{1)}$, 牛垣由美子 $(M D)^{1)}$, 小林知恵 $(M D)^{1)}$, 中村佐知子 $(M D)^{1)}$, 三輪勝 洋 $(M D)^{1)}$, 松元保 $(M D)^{1)}$ ，沖利通 $(M D)^{1)}$ ，松 下能文 $(M D)^{2)}$, 永田行博(MD) ${ }^{1)}$

産婦人科領域で悪性リンパ腫はまれな疾患 である。今回当院で子宮に再発した悪性リン パ腫と診断した症例を経験したので報告する。 患者は61才の女性で1995年 8 月頃より不正性 器出血を認め, 前医で悪性リンパ腫疑いにて 6 月 7 日当院受診する。原発巣は副鼻腔で化 学療法をされていた。入院時所見は子宮䅡部 は超鳩卵大でびらんを認め, 持続性の出血を 認めた。子宮頝部, 内膜細胞診および組織診 でも悪性リンパ腫と診断された。全身状態覀 く, 手術不可のため, 7 月 3 日抗癌剤による 化学療法施行した。化学療法前, 超小児頭大 （臍上 2 横指）であった子宮は 7 月 4 日，臍 下 1 横指， 7 月 8 日脆下 3 横指， 7 月 18 日臍 下 5 横指に縮小した。また子宮頝部も䲥卵大 と縮小し，一見正常にみえた。細胞診所見も 7 月 5 日，7月14日ではクラス IIであった。 一般的には固形癌の場合, 化学療法の奏効率 は20〜30\%とされているのに対して，血液癌 の場合奏効率が極めて良いとされている。今 回子宮に再発した悪性リンパ腫で化学療法が 有効であった症例について，その子宮胵部細 胞診の変化について報告する。
24 子宮頚部腺癌および関連病変診断に おけるHID-AB染色とCEA染色の有用性に関する 研究

新潟大学産婦人科

O加勢宏明 $(M D)$ 、児玉省二(MD)、田中憲一 $(M D)$ 、 永井絵津子(CT)

[目的]子宮頚部の細胞異型がそしい悪性腺腫あ るいは病果把握が困難な腺異形成の診断は、通常 の浅い生検では困難であり深い生検や円錐切除術 が必要である。腺腫瘍性病变の粘液産生能の変化 之癌胎児性抗原発現の観点から初期組織診断の可 能性を明らかにすることを目的とした。[方法］ High iron diamin-Alcian blue (HID-AB) 染色 でsulfomucinとsialomucinの染色性を区別した。 carcinoembryonic antigen(CEA)免疫染色はマ ウス抗CEAモノクローナル抗体(DAKO社)による Labelled streptoavidin biotin(LSAB) 法で局 在の有無を判定した。対象は、正常頝管腺組織10 例、浸潤腺癌 31 例(内頚部型15例、悪性腺腫9例、 類内膜型7 例) であり、浸潤腺癌の内頝部型7例、 悪性腺腫7例は生検標本でも検索した。[成績] (1)HID-AB染色: 正常頚管腺組織はHIDに全例強 陽性で、AB陽性は3例であった。腺異形成は全例 がHID陽性が優位でABが混在して陽性であった。 内頚部型はHID陽性 3 例と $A B$ 全例陽性であった。 悪性腺腫はHID陽性2例と $A B$ 全例陽性で、リンパ 節と卵单の転移巣でもAB陽性であった。類内膜型 はHIDが陰性でABが腺腔側辺縁に淡く染色された。 生検組織では摘出子宮と同様な陽性所見を示した。 (2)CEA染色：正常頚管腺組織、腺異形成は全例陰 性であった。内頚部型11例、悪性腺腫8例、類内 膜型6例が陽性を示した。生検組織では内頚部型4 例、悪性腺腫了例が陽性であった。[結論]腺癌 之関連病変の組織診断は、HID染色陰性あるいは $A B$ 染色陽性であれば腺腫瘍性病变を疑い、CEA染 色の追加で局在が陽性となれば悪性病变が強く示 唆され、早期診断に有用なことが明らかとなった。 
25 捺印細胞のKi-67 染色を用いた異種移 植ヒト子宮頸部腺癌の抗癌剂効果の予測

富山医科薬科大学産婦人科

O伏木 弘 (MD), 藤村正樹 (MD), 堀 慎一 (MD), 山川義寛 (MD)，泉 陸一 (MD)

目的：子宮頸部腺癌に対する抗癌化学療法の早 期効果判定を行うために, 異種移植ヒ卜子宮頸部 腺癌株を用いて各種抗癌剂投与後の Papanicolaou 染色と Ki-67 nuclear antigenに対するMIB-1 抗 体を用いた免疫組織化学染色による増殖相細胞の 比率を比較検討した。

方法: マウス移植株として, 内頸部型腺癌 (TCO 株, TCM株), 類内膜腺癌 (TCY株) を用いた。マ ウスは各群4匹とし, 抗癌剤のレジメンはCDDP+ MMC, CDDP + paclitaxel, MMC + paclitaxel とした。投与方法は, 各薬剤につき $1 / 5 L D_{50}$ を 1 週 に 1 回腹腔内投与をし、これを 3 週繰り返した。投 与開始は, 腫瘍径が $6 \mathrm{~mm}$ を越えた時点より行い, コントロールとして生食を用いた。捺印細胞診は, 第一回目の抗癌剂投与後 7 日目に行い, Papanicolaou染色と加熱処理後にIMMUNOTECH S.A.社の MIB-1 抗体を用いた Ki-67 染色を施行し た。また腫瘍縮小の効果判定はBattelle Columbus Laboratories Protocolに従って最終 抗癌剂投与より 2 週後に行った。

結果 : 各抗癌剤の投与後 7 日目の Papanicolaou 染色像では, わずかの細胞質の膨化之核腫大の変 化がみられるにすぎず, その後の腫瘍の変化が予 測できなかったが, Ki-67染色より算出した増殖率 は $0.9 \sim 17.0 \%$ であり,コントロールに対する相対 細胞増殖比が $70.2 \%$ 以下の場合はすべて腫瘍縮小 率が有効と判定された。

結論：MIB-1 抗体を用いたKi-67染色を細胞診に 導入することにより, 簡便かつ早期に効果判定が 行える可能性が示唆された。
26 子宮頚部上皮内腫潡における DNA an eupl oidyの出現とテロメア長の变化及び予後

防衛医大産婦人科11,

千葉大医学部産婦人科21

( 石井賢治(MD)1)，杉田道夫(MD)2)，工藤一弥 $(M D)^{11}$ ，片岡良孝 $(M D)^{11}$ ，菊池公 $(M D)^{11}$ ， 永田一郎(MD) ${ }^{11}$

【はじめに】我々は子宮頚部摖過細胞を用いて上 皮内腫瘍病変におけるDNA an euploidy (DA) の出現率について検討してきた。今回はDAの出 現とテロメア長の変化及び病変の予後との関連に ついて検討した。

【対象および方法】細胞診にてclass 四以上と診 断された200症例について摖過細胞を採取し， flow cytometryを用いてDNA量を測定した。ま た，同時に細胞診およびコルポスコープ下の狙い 組織診を実施した。その後の病变の变化について も同検査により定期的に観察した。DNA量測定 用の検体はスポンジブロックにて摖過採取した新 鮮材料を用い, propidium iodide染色の後、ヒ 卜末梢血単核球を標準試料としてDNA量の測定 をBecton Dckinson社製FACScanにて行った。 DAは日本サイトメトリー学会のガイドラインに 従い，2つ以上の明かな $G_{0} G_{1}$ ビークをもつもの を判定した。また、一部の症例についてはDAを 構成する細胞をソーティングしたのち、DNAを 抽出し、サザンブロッティング法にてテロメア長 の変化について検討した。

【結果】標準試料のCV值はすべて2.1\%以下であ った。DAは病变の進行とともに出現頻度, ピー クのDIが上昇する傾向を示した。またaneuploid peakのDIが1.4以上の場合に病変は進行する頻 度が高く、また、テロメア長の短縮を認めた。 【結論】DA分析は上皮内腫瘍病变の予後判定の 精度を增すうえで有用であった。また，DAの成 因にはテロメア長の变化が関与している可能性が 示唆された。 
27 子宮頸癌の発癌過程におけるFISH法に よる 3 番染色体の数的異常の検討

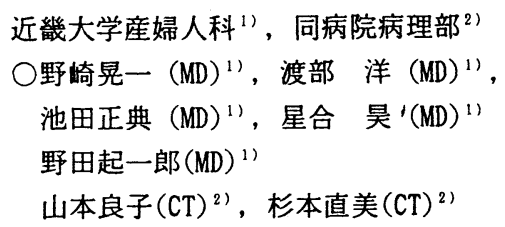

【目的】子宮頸癌の発癌過程における相対的核 DNA量 - DNA ploidy heterogeneity(Dph) 3 番 染色体の数的異常について検討した。

【方法】軽度・中等度異形成 (MD) 6 例, 高度異形 成(SD) 10 例, 上皮内癌(CIS) 9 例, 微小浸潤癌 (MIC) 6 例, 浸潤癌 (IC) 10 例の計 41 例を対象と し，各々のパラフィン包埋ブロックを用いてflow cytometoryによる DNA ploidy, Dphについて測定 し, さらに同一症例の子宮頸部擦過細胞標本を用 いて, chromosome 3 centoromere probe を用いた FISHを行い, FITC digoxygeninによりsignalの検 出をおこなった。

【結果】1, DNA aneuploidの頻度は, MD $33.3 \%$, SD 60.0\%, CIS 66.6\%, MIC 66.6\%, IC 80.0\%であ った。2,Dphの頻度は, MD O\%, SD 83.3\%, CIS $14.2 \%$, MIC 50.0\%, IC 50.0\%であった。3, 3 番染 色体のcentoromere signal数が 3 以上を示す頻度 は, MD 33.3\%, SD 40.0\%, CIS 44.4\%, MIC 50.0\%, IC 80.0\%であった。

【結論】相対的 DNA量の変化のみならず、 3 番染 色体の数的異常も子宮頸癌発癌過程の早期から起 こるイベントであることが示唆された。
28 子宮䅡部高度異形成及び上皮内癌 に対するC02 レーザー蒸散後に出現する軽度異形 成細胞類似異常細胞の特徽とその取り扱い

千葉大学産婦人科

$\bigcirc$ 三橋暁 (MD)、高野始 (MD)、杉田道夫 (MD)、関 谷宗英 (MD)

(目的)子宮䅡部レーザー蒸散治療後の組織修復過 程において間質系、及び上皮系の修復細胞の出現 は一般的であるが、我々は、治療有効例に、一時 的に細胞診にて、極めてdysplast ic cellに類似

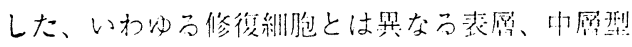

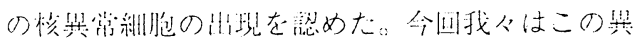

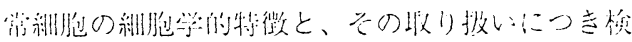
剕した。

(方法)平成5年8月より平成て作3月までに当院

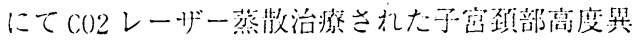
形成 8 例及び上皮内癌 28 例で、治療後 $2 、 4$ 、 8、1 12 週、以後 3 ヶ月ごとに、細胞診、コルポ スコピーを施行、異常所見のある場合必要に応じ て組織診を施行した。（成績）治療後6ヶ月以上、 細胞診、コルポ診異常認めず治癒と判定した症例 が 24 例。治療後 6 ケ月以内に細胞診、組織診異 常認めた症例は 12 例あるが、このうち $2 \sim 6$ ケ 月の経過観察にて異常が自然消失した症例 6 例。 6 例は 2〜4ヶ月時に再度レーザー、または leep を施行している。レーザー蒸散治療後の組織修復 過程において一時的に見られるdysplastic cell 様異常細胞の特徵はエオジン好性の表層、中層型 細胞で核異常、及び核縁の不整を認めた。治療前 に見られた、傍基底型の異形成及び悪性細胞や修 復細胞とは明らかに異なった。

(結論) 治療効果の判定に、一定期間をおく必要が あるとともに、この軽度異形成細胞類似異常細胞 とdysplastic cellの鑑別が重要である。 
29 子宮到癌治療における寛解導入 化学療法の細胞粗樴化学的検讨

\section{佐賀医科大学産婦人科1)}

同 検查部2),同 病理 31

O内山倫子 $(M D)^{11}$, 福田耕一 $(M D)^{11}$, 中村 聡 $(M D)^{11}$, 岩井京子 $(M D)^{11}$, 横山正俊 $(M D)^{1)}$, 岩坂 㓮(MD) ${ }^{11}$, 杉森 甫 $(M D)^{11}$, 若山一夫 $(\mathrm{CT})^{2)}$ ，次富久之 $(\mathrm{CT})^{2)}$ ，武藤文博 $(\mathrm{CT})^{3)}$ 子宮顠癌に対する治療法としては、手術と放 射線療法が主流でその方法はほほ確立されてい るが、予後に関しては長い間改善はみられない。 そこで当科では1991年より子宮顓部扁平上皮癌、 子宮顠部腺滛に対して寛解導入化学療法(MEP :MMC,Etoposide, Cisplatin, BOMP:Bleomycin, Oncovine, MMC, Cisplatinの多剤併用)を積極 的に施行し予後改善を図ってきた。今回その臨 休的評洒と同時に細胞学的検討、及びその免疫 組織化学的検討を行い若干の知見を得たのでこ こに報告する。対象は臨床進行期 Ib 期7例、II a 期 3 例、IIb期 10 例、IIIb 期 2 例、IVb期 1 例の計 23例で、年跲は32才から72才（平均50.9才）、

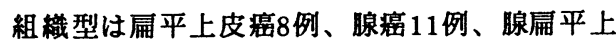
皮癌4例であった。化学療法の奏効度は日本癌 治療学会婦人科癌化学療法の直接効果判:定基準 によったが、屚平上皮癌ではCR 2例、PR 4 例、 NC 2例と奏効事は $75.0 \%$ 、腺癌ではCR 2例、 PR 3例、NC 6例であった。原則として化学療 法施行 1 クール終了時、2 クール終了後化学療 法の評価を行うと同時に細胞組穖診を施行した。 化学療法が有奻であった症例では細胞学的所見 としては、背景に白血球の增加、細胞質の多染 性と空胞化、核と核小体の腫大、核破碎、多核 細胞、核クロマチンパターンの変化が観察され た。またBOMP,MEP 1 コース終了後の生検組 機標本を用いてMIB1 とPCNA抗体により腫場の 細胞增殖能を化学療法前後で比較し、その標識 事の変化と化学療法の奏効度の相関を钼察した ので併せて供覧する。
30 動注化学療法による子宮頸部腺癌細胞 像の変化について

富山県立中央病院産婦人科"，同 唡査科病理 ${ }^{2}$,

同放射線科 ${ }^{3)}$

○佐竹紳一郎 (MD) ", 橋本慎太郎 (MD) ", 飴谷由佳 $(\mathrm{MD})^{12}$ ，大口昭英 $(\mathrm{MD})^{12}$ ，小嶋康夫 $(\mathrm{MD})^{1}$, 舟本 寛 (MD) $)^{12}$, 中野 隆 (MD) ", 舘野政也 (MD)", 宮本藤之 $(\mathrm{CT})^{2)}$, 福村 健 $(\mathrm{CT})^{2)}$, 山下弘子 $(M D)^{22}$, 三輪淳夫 $(M D)^{22}$, 出町 洋 $(M D)^{3)}$

近年, 進行子宮頸癌に対する動注化学療法の有効 性が多く報告されている。これまで比較的予後不良 とされてきた子宮頸部腺癌についても有効例が報告 され, Neoadjuvant chemotherapy としての動注 化学療法が期待されている。当院でも最近経験した 頸部腺癌3例（いずれも I b 期）および腺扁平上皮癌 1例（IIIb期）に対し, 術前にシスプラチン (CDDP) を主体とする動注化学療法を施行した後に手術を行 ったところ良好な成績が得られた。

動注化学療法は両側の内腸骨動脈にカテーテル先 端を留置し, CDDP $100 \mathrm{mg}$ one shot動注 $\times 2$ 日間 [day1，3] ならびに5FU $250 \mathrm{mg} /$ day 持続動注 [day 1-3]を1コースとした。本療法をI b 期症例

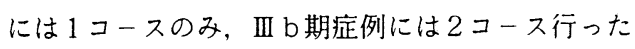
後, その終了後19-22日目に広汎性子宮全摘術を施 行した。その結果, コルポ診では 4 症例の何れも腫 瘤の明らかな縮小が認められた。術後病理診断にお いても I b 期 3 症例では何れも癌の遺残は認められ ず，III b期症例では縮小した癌組織とその周囲の器 質化がみられた。全例リンパ節転移はなく，著明な 効果が認められた。

一方, 子宮胵頸部の擦過細胞診においても化学療 法による変化が経時的に明らかとなり, 種々の変性 細胞の増加とともに異型細胞の減少がみられた。こ ういった細胞像の变化は, 子宮頸部腺癌に対する Neoadjuvant chemotherapy としての動注化学療 法の効果を判定するうえで有用な所見と考えられ， 詳細について検討し報告する。 
31

子宮頝澏における術前化学療法

(Ballon Occuluded Arterial Infusion法) 細胞学的効果判定 一第二報一

大阪市立大学医学部附属病院病理部 ${ }^{11}$

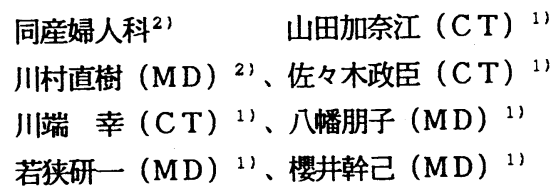

最近、綀胞学的変化を判断することで術前化学 療法の効果判定を行う試みがなされている。過去 に本学会において腫場細胞および背景に出現する 細胞の経時的変化による治療効果判定の有用性に ついて検討を行った。その結果、細胞診単独での 評価は難しく、他の臨床所見が必要であると思わ れた。今回引き続き症例を追加して検討を行い、 治療効果に対する適切な表現方法、及び採取時期、 また、追加すべき形態像について考察を加えたの で報告する。［対象］1993年4月から1995年11月 までの期間にシスブラチン $50-100 \mathrm{mg} / \mathrm{m}^{2}$ を用いた 動注化学療法を行った進行性子宮頚癌IIb期〜IV期 の18症例を対象とした。[方法］標本中の5視野 を無作意に抽出し、200倍にて200個の細胞を数え、 全細胞数に対する種々の細胞数の百分率および異 型細胞中の形態学的変化すなわち核、細胞質につ いて項目別に分類し、百分率で示した。また、背 景に出現する細胞パターンも調べた。

[結果および考察] 細胞破壊の進行過程において 細胞質の変化に比べて核の変化が早期の判定指標 になり得ると推定され、特に、再生上皮、多核組 織球、さらに当初注目しなかった背景に出現する 裸核も効果判定の際の一助となると考えられ、そ の記載も必要と思われた。さらに組織型 (腺癌、 扁平上皮癌）による細胞の形態像变化の推移につ いてもテータをもとに提示したい。また、効果判 定の時期も考慮しながら報告したい。

\section{2 胃原発䋐毛癌の 1 例}

養生会かしま病院病理1, 福島労災病院内科 2 , 同・病理 3 , いわき市立常掏病院病理4

○金子隆子 (CT) 1)，猪狩咲子 (MD) 2)， 箱崎半道 (MD) 3 ), 望月 衛 (MD) 4 )

胃に原発する䄉毛癌は極めて稀で，わが国では60 数例の報告があるにすぎない，今回我々は，短期間 に急速に発育し，診断に苦慮した胃原発絾毛癌の1 例を経験したので報告する。

庭例：75歳男性. 1992年 8 月, 胃漬湟で当院にて 入院治療. 1993年12月労作時息切れ・動悸・めまい 出現. 1994年 1 月 2 日より下血, 1 月 6 日当院入院 となった。内視鏡検查にて胃噴門部に粘膜下腫場様 病変を認め, 生検組織検查で悪性腫場が疑われた。 入院時検査で著明な貧血をみたが，肝機能検查や腎 機能検査に異常はなく, CEA, CA19-9 も正常であっ た. なお，血清HCG の測定は行っていない. 分血が 進行したため，1月26日手術が施行された。

細胞所見: 捺印細胞像：腫大したかなり大型の 類円形核，著明な核小体，厚みのある比較的豊かな 胞体をもった単核の異型細胞と多核の大きな異型細 胞が認められる。

这理組織所見：類円形，エオジン好性の豊富な 胞体と中央に大型核, 明暸な核小体を有する腫場細 胞が能道様に增生している，時に bizarre な核や多 核の細胞も出現. 電䫓的検索および各種免疫染色の 結果（特に HCG 陽性を示した）から絨毛癌と診断 された。なお，精巣の增大なく，画像上も紸隔に異 常は見られなかった事から胃原発と考えられた。

考察：本例は細胞所見より胃の低分化扁平上皮 癌, 悪性黒色腫, 及び悪性リンパ腫との鑑別が問題 となる。核は類円形で細顆粒状クロマチン, 細胞質 の層状構造は観られず, 細胞間橋も存在しない。ま た核内封入体やメラニン顆粒は認められない。 以上 より低分化扁平上皮癌, 悪性黑色腫とは鑑別でき た。さらに本例は上皮性配列を示しており, 悪性リ ンパ腫との鑑別も可能であった。 


\section{3 胃原発のGlomus腫瘍の 1 例}

鳥取大学医学部第 1 外科

O佐藤尚喜(MD)、川代豊(MD)、川口由美

$(M D) 、$ 西江浩 $(M D) 、$ 広岡保明 $(M D) 、$

貝原信明 (MD)

Glomus腫瘍は、細小動静脈の吻合部の糸球 体に由来し、手指の爪甲の下に最も多くみら れ、疼痛を伴うことも多い腫瘍である。今 回、我々は胃壁に発生したGlomus腫瘍の 1 例 を経験したのでその細胞像を中心に報告す る。

症例）36歳、女性。1994年10月頃より上腹部 不快感を自覚し近医を受診した。上部消化管 内視鏡検査が施行され、粘膜下腫瘍を認め当 科紹介となった。上部消化管内視鏡検査、胃 透視で約4 c mの腫瘍を認め胃粘膜下腫瘍の診 断で1995年 2 月 3 日胃切除術が施行された。 切除標本肉眼所見）胃体部前壁に存在する3.5 $\times 4.2 \mathrm{c} \mathrm{m}$ の腫瘍をみとめ周囲との境界明瞭で 弾性硬であった。 捺印細胞像）小型の細胞が散在性に認めら れ、細胞は裸核状あるいは不明瞭な細胞質を 有していたが、核は円形で異型は認められ ず、クロマチンも軽度増量しているのみであ った。

組織所見）胃の筋層より生じており、腫瘍細 胞は均一な大きさの円形の核を有し胞体は淡 明で細胞境界は明瞭であり、Glomus腫瘍と診 断された。酵素抗体検査では、 $\alpha$-smooth muscle actin $(+) 、$ デスミン(ー)、ビメンチン (土)、S-100(一)、NSE(一)、クロモグラニンA (一)、EMA(一)であった。 まとめ) 胃壁に発生したGlomus腫瘍の 1 例を 経験したので報告する。
34 胃生検捺印塗洙標本における Helicoba cter Pylori 検出の有用性

鳥取赤十字病院 中検病理 ${ }^{1)}$, 同内科 ${ }^{2)}$, 同外科 ${ }^{3)}$, 川崎医科大学病理学教室 ${ }^{4}$

○植嶋しのぶ $(\mathrm{C} \mathrm{T})^{1)}$, 植嶋輝久 (C T $)^{1)}$, 山村章次 $(M T)^{1)}$, 安陪隆明 $(M D)^{2)}$, 工藤浩史 $(M D)^{3)}$, 広川満良 $(M D)^{4)}$

Helicobacter Pylori (以下HP) 感染の診断法 には鏡検法, 培養法, ウレアーゼテスト等がある が，最近はその診断に迅速性，簡便性が要求され つつある. わ执れは, 胃生検の捺印塗沫標本で は, 容易に H P を確認できることに着目し, その 有用性について他の迅速的な検查法と比較検討した。 〔対象・方法〕当院にてCL0テスト, 尿素培地培 養を実施した 49 例, 106 力所の胃生検材料を対象 とした. 前庭部大弯側, 体部大弯側, 及び病変部 の粘膜より採取した生検材料をCLOテスト, 尿素培 地培養に供し,さらに同一部位の採取材料を捺印 した後，パラフィン包埋組織切片を作製した。組 織切片はHE, ギムザ, 抗 $\mathrm{H} \mathrm{P}$ 抗体免疫染色を行 った. 捺印標本はパパニコロウ，ギムザ, Diff Quik 染色 (16例, 39 力所) を行った後, Mount-Quick で細胞転写したギムザ標本とパパニコロウもどし標 本の免疫染色を行った。 また, 捺印標本の背景に 出現する炎症細胞の分類を行った.

〔結果〕 H P 陽性率は捺印ギムザ $62 \%$, CLOテス ト $51 \%$, 組織免疫染色 $55 \%$ で,一致率は捺印ギム ザとCL 0 テストで $78 \%$ ，捺印ギムザと組織免度染 色で $90 \%$ であったＨＰ陽性例の背景には優位に 好中球, リンハ球などの炎症細胞が多くみられた。 H P 陽性例の $82 \%$, H P 陰性例の $35 \%$ 亿好酸球の 出現を認め, その数は前者では炎症細胞 100 個中 $2 \sim 49$ 個 (平均 7.8 個) 後者では 1 ～個であった 〔まとめ〕捺印標本ではH P の観察が短時間でで き, 確認しやすかった. 背景の好酸球は H P 存在 の指標の一つになった. 
35 乳腺穿刺吸引法における良悪性の 練胞集塊形に関する検討

$$
\begin{gathered}
\text { 久留米大学病院病理部1) 同第一外科2) } \\
\text { 同第一病理3) } \\
\quad \text { 同第二病理4) }
\end{gathered}
$$

○横山俊朗 $\left.(C T)^{2}\right)$ 吉田友子(CT $)^{2}$ 杉島節夫(CT $)^{\mu}$ 河原明彦 $(C T)^{2}$ 古賀棇啓(MD) 鹿毛政義 $(M D)^{3}$ 中島明彦(MD) 森松 秢(MD)

【目的】乳腺における腫瘍紐胞の良悪性の判定は 個々の細胞所見を中心に総合的に判定がなされて いる。しかし細胞異型が弱い腫瘍の場合、決め手 となる所見にそしく判定に苦虑する場合が多い、 今回われわれは、それらの問題に対して補助的な 指針となり得ると思われる細胞集塊形Outlineに 着目し、その特徴について検討を行った。 【材料および方法】1989年〜1995年に久留米大 学乳腺外来において穿刺吸引細胞診を施行し組織 学的に検索され、また細胞成分が十分に探取塗抹 された症例を対象とした。

方法は標本中の細胞集塊をデジタル画像として取 り込み、Outlineを抽出し細胞集塊の特徽を大きさ、 細胞集塊の複雑さ、集塊の円形度などのバラメー夕 を使ってバターン分析し検討を行った。

【結果】悪性細胞の集塊形状は複雑で比較的円形 に近い細胞集塊が多く見られ、また円形集塊の集 まった多房状集塊が出現していた。集塊辺縁は 凹凸が多く、大小の集塊を認めた。

良性細胞の集塊の形状は杆状〜円形状の集塊か 多く、集塊辺縁直線成分を持つ比較的単純な集塊 形態を呈していた。

【考察】良悪性の判定において、個々の細胞異型、 核小体の有無、核不整等の所見に加え、細胞集 塊形態も有用な積極的判定所見になり得ると思 われた。
36 当院における乳房温存術時の術中摘 出標本断端迅速摖過細胞診の成績

船橋市立医療センター検査科 ${ }^{11}$ 、同 外科 ${ }^{21}$ 日本大学松戸歯学部 ${ }^{31}$

加藤 拓 (C T ) "、高橋久雄 (C T ) "、安藤 智子（M T ） " 、井田喜博 (M T ) "、唐司則之 $(M D)^{2)}$ 、渡包義二 $(M D)^{2)}$ 、佐藤裕俊 $(M$ D) ${ }^{21}$ 、松本 敬 $(\mathrm{C} \mathrm{T})^{3}$

近年、乳房温存術の普及に伴って、癌の進展が 切除断端にまで及んでいるのかどうかの術中検索 は必要不可欠になってきた。今回我々は術中に摘 出標本の切除断端を丑速擦過細胞診を行い対応し たので、その成績について報告する。

[対象と方法]

1993年 4月から1995年 3月までに乳房温存術を 行ったのは18例あり、その全例の摘出標本 4 断端 （乳頭側、上側、下側、末梢側）に対し術中迅速 擦過細胞診を行い、陽性部位ではさらに追加切除 を行った。摘出標本は後日、乳頭と腫留を結ぶ線 に直角に $5 \mathrm{~mm}$ 幅の全割にして組織学的梌索を行い 断端への癌の進展を調へ、細胞診の結果と比较し た。

[結果]

1. 細胞診陰性は53断端で、組織学的検索にも全断 端陰性であった。細胞診陽性は19断端で、組織学 的には15断端に癌細胞巣を認め、4断端は陰性で

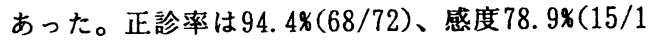
9)、特異度 $100 \%(53 / 53)$ であった。

2. 陽性を示す癌細胞は乳管内進展によるもので、 そのほとんどは小円形で異型がそしく、良性の乳 管上皮增殖性病変との鑑別が必要であった。

3. 癌細胞の平均的乳管内進展距離は乳頭側が最も 多く21.7mm、次に下側 $9.2 \mathrm{~mm}$ 、上側 $8.4 \mathrm{~mm}$ 、末梢 側 $7.1 \mathrm{~mm}$ であった。 
37 乳房温存術における

術中迅速断端擦過細胞診の不一致例について
はじめに : 近年, 患者のQuality of Lifeを高める 一つの手段として乳癌に対する温存術が増加してい る。当院では温存術適応を確認するために患者側の 乳腺切離面における癌細胞の有無を術中迅速断端擦 過細胞診で検索している。細胞診的に癌細胞が陰性 であれば温存術が行われ，陽性の場合は追加切除を 行うか乳房全摘出術に術式が変更される。今回温存 術における細胞診の成績（不一致例）を報告する。 对象：'91年6月〜' 95年11月までに温存術を行い術 中迅速断端擦過細胞診を実施した113症例とした。

方法 : 術中に患者側の乳腺切離面（乳頭側とそれを 挟んだ上下の計 3 方向）を滅菌スライドがラスで擦過し 各部位の湿潤, 乾燥固定標本を作成した。乾燥標本 に迅速ギムザ染色を行い鏡検した。結果はパパこコ㕫 のクラス分類は使用せず細胞所見を記載し予備報告と した。湿潤固定標本は翌日パパこ㕫染色後, 迅速ギム ザ標本と共に鏡検し最終報告とした。摘出組織は固 定後,腫瘍と乳頭を結ぶ線に垂直方向で約4mm幅に全 割しHE染色を行い,腫瘍組織の進展をマッピ゚グ゙し組織 診断端と細胞診の結果を比較検討した。

結果, 考察：113例中 組織診との一致例は97例。 不一致16例中2例は擦過部位以外の組織断端が陽性 であった。また細胞診で癌細胞がみられたが組織診 断端陰性の 1 例を除くと真の正診率は $88 \%$ だった。 不一致例は誤陽性9例で乳頭状集塊や大型細胞の誤 判定が原因と思われる。また誤陰性は4例で異型細 胞の見落としや構造異型を悪性と判定しきれなかつ た。細胞診は短時間(約20分)で広範囲を検索でき有 用と思われるが, 導管内増殖病変が疑われた時は迅 速組織診を併用することが望ましい。
38

乳腺穿刺細胞診における 質的診断の意義と問題点

\author{
長野県がん検診センター 検査部 ${ }^{11}$, 同 検診部 ${ }^{21}$ \\ O町田智恵" ${ }^{\prime}$ ( C T ), 渡辺達男" ${ }^{2}$ ( C T ), \\ 石井恵子"（MD）, 土屋真一" ( ${ }^{\prime}$ (MD), \\ 寺井直臌 ${ }^{2}(M D)$, 小池綏男 ${ }^{2)}(M D)$
}

【はじめに】現在, 穿刺細胞診は従来のclass分類 とともに，直接病名(組織型)に迫る質的診断を求 められつつある. 今回われわれは乳腺穿刺細胞診 における正診率に加えて，不一致例を含めた組織 型推定の現状と問題点について検討したので報告 する.

【材料および方法】検討症例(1995年5月〜 12月)は ピンポイント穿刺法で得られた乳腺穿刺材料 125 例で, 組織学的診断かなされた良性47例(乳腺症 12例，線維腺腫28例，その他 7 例)，悪性78例 (孚 頭腺管癌21例，充実腺管癌14例，硬癌28例，小葉 癌 4 例，その他11例)である．これらに相当する 細胞診標本を各々ブラインドにて検討し，class I，IIを良性，classIV，V を悪性，class III領域は 厳密を期する上で㮇判定とした。 そこで良・悪性 の診断合致率, およひ推定された組織型の合致率 を検討し、さらにどのような症例が細胞診・組緒 診断で不一致を生しでたかの解析を行った。

【結果およひ考察】良・悪性の診断合致率は良性: 80.9\%, 悪性: $88.5 \%$, 正診率: $85.6 \%$ であった。 次に細胞診での組織型推定と組織診断の合致率は, 良性: $68.1 \%$ ，覀性:69.2\%であった. 不一致症例 には“硬癌”が関与したものが最も多く認められた。 これは乳頭腺管癌や充実腺管癌加間質に硬性漫洞 を来した広義の硬癌を乳頭、充実腺管癌と細胞診 断したものである．また，非浸润疾の乳頭型，充 実型をそれそれ乳頭腺管癌や充実腺管癌とした症 例も認められた. 良性疾患では細胞診で線維腺腫 であった症例が組織学的には乳腺症の線維腺腫症。 また逆に, 乳腺症と診断したものが乳腺症型の線 維腺腫であった症例が大部分を占めていた，睡瘍 組織の全体像で診断を行う組織診に比へて、睡場 のこく一部の材料で判断する細胞診には常にこの 問題点が存在すると考えられる. 
東京医科菌科大学第 1 外科 ${ }^{1)}$ 、同病院病理部 ${ }^{21}$ ○長瀨慈村 $(M D)^{1}{ }^{1)}$ 、森園英智 $(M D)^{11}$ 、山本嘉 $子(C T)^{2)}$ 、森山美澍 $(C T)^{2)}$ 、明石巧(MD) ${ }^{2)}$ 、 江石義信 $(M D)^{2)}$ 、遠藤光夫(MD) ${ }^{11}$

乳腺疾患の諰断において細胞診が最終診断となり うる条件は、理学的所見、画像猃断（マンモグうフィ、 超音波、乳管造影、乳管内視鏡等）と細胞診の診 断が、推定組織型まで一致することであるとわれ われは考えている。そこで今回、細胞猃において 組織型推定が可能であるか否かを試みた。当科で ここ 1 年程の間に組織診断のついた乳癌20例（乳 頭腺管癌 : 8 例、充実腺管癌 : 5 例、硬癌 : 4 例、 非浸潤性乳管癌：3例）および良性疾患10例（乳 管内乳頭腫 および乳頭腫症：6 例、線維腺腫：3 例、乳輪下乳頭腫症：1 例) につき検討した。う ち経皮的穿刺吸引細胞㟝が17例、乳管内視鏡下生 検細胞診が13例であり、細胞誩における推定組織 型と病理組織診断との一致率は、前者か529.4\%、 後者は $53.8 \%$ であった。乳頭腺管癌（微小浸潤） と非漫閏性乳管癌を同組織型とすると、一致率は それぞれ 41.2\%と8 4.6\%であり、さらに乳癌だ けに限るならば $30.8 \% 、 100 \%$ 、乳管内視鏡下 生検細胞䛦での組織型診断は正確であった。さて、 では経皮的穿刺吸引細胞㟝における組織型推定は 役に立たないのだろうか。ここには乳痁の組樴型 はモザイクであることが絡んでいる。乳頭分泌を 有する乳癌では、乳管内視鏡下生検細胞診により 原発巣の性格を最も反映した部位から細胞採取が 可能であり組織型診断が正確なものとなる。分泌 のない乳癌でも組織型を推定した画像影断をし、

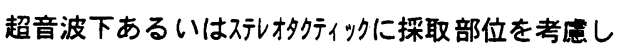
た穿刺吸引細胞診を行うことにより組織型診断を 可能にしうると考える。細胞診が最終診断として 成り立つためには、組織型診断が必要不可欠であ る。

\section{0}

産婦人科乳房外来に㧍ける架制吸引

細胞颜

北海道大学医学部颜妌人科

O山用萗玧(MD)、佐川 正(MD)、藤本征一郎 (MD )

わが国では長い間、乳癌検診はもっぱら外科医 によって行われてきたが、産婦人科には他科より も多くの文性患者が受診するため乳癌検診を行う ことは非常に意義があると考えられる。当科では 平成 2 年 6 月より乳房外来を開設し 1 次・ 2 次検 診および自己検診の指導を行ってきたが、2 次検 讋中でもその有効性が非常に高いと思われる穿刺 吸引紐胞部の成綪について検討を加えたので報告 する。

対象としたのは平成 2 年 6 月より平成 7 年: 10 月までに乳房外来を初影した1988名である。 そのうち問診および視・触診による1次検診の後、 穿刺吸引細胞診を施行したのは 119 人 $(6.0$ \%)であった。穿刺吸引細胞診の結果はClass I : 49 人 ( $1.2 \%)$ 、class II : 34 人 ( $28.6 \%)$ 、 class II R : 2 人 $(1.7 \%) 、$ class III : 2 人 ( 1 . $7 \%)$ 、 class IIIa: 16 人 (13.4\%)、 class III b : 2 人 $(1.7 \%)$ 、class $\mathrm{V}: 0$ 人 $(0 \%)$ 、 class V: 14 人（11.8\%）であった。その後、 北海道大学第 1 外科に紹介し malignancy が確認さ れたものはclass Vの 14 例（（100.0\%）、class 四bの 1 例 $(50.0 \%)$ 、class I の 1 例 $(2.0 \%)$ の計 16 例であった。

class IIIb以をを陽性とするとSensitivityは 93.8 \%、Specificityは $99.0 \%$ \%であり非常に有効であ ることが確悲された。また、malignancyが確認さ 机た 16 例のうち 1 例に子宾体癌、1例に子宮䅡

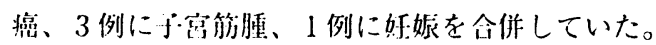


41 乳腺原発 lipid secreting carcinomaの 1 例

済生会今治病院病理1), 香川医科大学第一病理2)

, 済生会今治病院外科 3$)$, 同内科4)

$\mathrm{O}$ 野間勝之 $(\mathrm{CT}) 1)$, 矢野好人 $(\mathrm{CT}) 1)$, 羽場礼次

(MD)1)，小林省二(MD)2), 黒河達雄(MD)3), 梅田

政吉(MD)4)

乳腺原発のlipid secreting carcinomaは非常に稀な疾 患であり，その細胞学的な報告は少ない，今回乳 腺原発のlipid secreting carcinomaの 1 例を経験した ので特徵的な細胞像を報告する.

【症例】約1年半前から右乳房に腫瘤を自覚して いた 36 歳の女性が, 腫瘤の增大傾向を主訴に来 院した．腫瘤は右 $\mathrm{c}$ 領域にあり， $2.0 \times 1.5 \mathrm{~cm}$ の大 きさで境界は不明瞭であった．また腋下リンパ節 は患側で大豆大のものを 3 個触知した. 術中迅速 䛦断は乳癌で，拡大乳房切除術が行われた，術後 化学療法が施行されたが, 全身骨転移, 卵巣転 移, 癌性腹膜炎, 癌性胸膜炎により約 3 年後に死 亡した.

【細胞所見】再発時の胸・腹水之も同様の像で， 孤立散在性やシート状を示す細胞集団がみられ た． 円形を基調とする核は細胞の中心に位置して おり, ライトグリーンに焱染するか，あるいは泡 沫状を呈する非常に豊富な細胞質を有していた。

【病理組織所見】冈形の核で，淡明あるいは弱好 酸性の豊富な細胞質を有する腫瘍細胞が充実性や 索状あるいはびまん性に增殖していた。特殊染色 ではOilred O染色陽性, AB-PAS染色陰性であっ た.また酵素抗体法ではlactoferrin， EMA，cytokeratinが陽性反応を示した.

【考察】今回の症例では, 胸・腹水の細胞像から 浸潤性乳管癌の転移, 腺癌の転移, 恶性中皮腫な どが鑑別にあげられたが, 細胞は散在性に多数認 められ, 核は円形で細胞の中心に位置し, 細胞質が 非常に豊富で泡沫状を呈するなどの特徴的な細胞 所見に着目すれば胸・腹水細胞像からでも組織型 の推定が十分可能であると考えられた
42 乳腺原発印環胞癌の 1 例

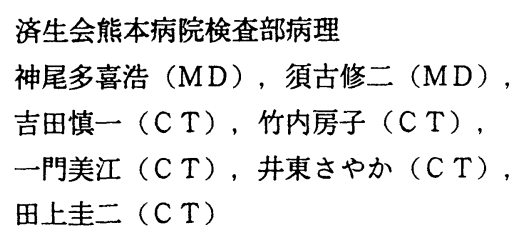

乳腺原発の印環細胞癌はきわめてまれで，これ まで 33 例報告されており，それらの由来は浸潤 性小葉癌または浸閵性乳管癌といわれている。今 回われわれは呀刺細胞診で浸潤性小葉癌または印 環細胞癌が疑われ，摘出標本にて印環細胞癌之診 断し，しかも浸潤性乳管癌由来之考えられた 1 例 を経験したので，細胞像をのべるとともに組織所 見および文献的考察を加えて報告する。

症例は 44 才，女性。 2 年ほど前より左乳房の 腫瘤に気ついていた。平成 7 年 3 月下旬腫瘤が增 大したため当院外科を受診。腫崲は触診上, $3 \times$ $4 \mathrm{c} \mathrm{m}$ 大で弾性硬であった。穿刺吸引細胞診およ び針生検で悪性と診断されたので，同年 4 月に左 乳房を摘出された。

穿刺吸引細胞診所見では，比較的均一な小型の 腫噋細胞が孤立散在性に多数出現し, 一部で紐胞 集塊を形成していた。胞体内に粘液が豊富で，浸 潤性小葉癌または印環細胞癌が疑われた。

摘出標本の割面では $7 \times 4 \mathrm{~cm}$ 大, 灰白色充実 性の腫場で,一部に小壊死巣を認めた。組織学的 には好酸性または粘液空胞状の胞体之均一類口形 核を有する腫瑒細胞が胞巣状, 索状に增殖し, 粘 液空胞に一致してPAS，アルシアン青染色の陽 性像を認めた。一部に通常の浸潤性乳管癌の組織 像を認め, 腫場細胞は腺管状, 篩状に增殖し, 一 部内腔に石灰沈着や壊死物を認めた。

胃を含めた消化管その他の臓器に原発巣がない ことおよび病理組織学的所見より乳腺原発の印環 細胞癌と診断し，その由来は浸潤性乳管癌と考え た。 
43

乳腺印環細胞癌の 5 症例

帝京大学医学部附属溝口病院 臨床病理科

都立府中病院検查科 *

O田中美由紀(CT), 山田正人 (CT), 福田 学

(CT), 湯澤和彦 (CT), 吉元 真 (CT),

神谷增三(ND), 水口國雄 (MD),

石澤 貢 $(\mathbf{M})^{*}$ ，中村恭二(MD)*

乳腺原発の印環細胞癌はまれであり、Lobula r originとDuctal origin の二種類があると報 告されている。今回我々は穿刺吸引細胞診で 5 例経験したので細胞像を中心に述べ、粘波組織 化学、免度組織学的に検討し、文献的考察を加 え報告する。【細胞像】 5 例中 3 例は主に散在 性で出現し、一部に柾な結合を示す平面的小細 胞集団として認められた。核は類円形から楕円 形で偏在し、増量したクロマチンは粗顆粒状均 等分布を示した。核小体は小型で 1 ～ 2 個認め た。細胞質はライトグリーン好性、泡沫状で、 一部に明らかな I C L を認めた。他の 2 例は、 散在性から重積性をともなう大小の集塊として 多数出現し、大部分の細胞質にはPap 染色で橙 黄色に染色された粘液を多量に含んでいたが背 景には粘液様物質は認められなかった。PAS、AL -B染色では細胞質全体に陽性を示した。蹦床 所見、組織診断は表に示す。

\begin{tabular}{l|l|l|c|l} 
症例 & 年・部位 & 細胞診 & \multicolumn{1}{|c}{ 組織診 } \\
\hline 1 & $60 \mathrm{~F}$ & rt. CD & $\mathrm{IV}$ & Lobular ca \\
2 & $60 \mathrm{~F}$ & $1 \mathrm{t} . \mathrm{C}$ & $\mathrm{V}$ & Ductal ca \\
3 & $55 \mathrm{~F}$ & rt. AC & $\mathrm{V}$ & Ductal ca \\
4 & $46 \mathrm{~F}$ & rt. AC & $\mathrm{V}$ & Lobular ca \\
5 & $47 \mathrm{~F}$ & rt. BC & $\mathrm{IV}$ & Lobular ca
\end{tabular}

組織での粘液染色では Sialomucin と Sulfomu cin の混在が証明され、免疫染色では CEA, S. C ，GCDFP-15 の局在を認めた。
44 核形不整の成因に関する研究 第 1 報 一印環型細胞について一

\section{杏林大学保健学部細胞診断学教室 ${ }^{11}$ \\ 同病理学教室 ${ }^{21}$}

O吉田朋美 $(M T)^{11}$ 、椎名義雄 $(\mathrm{CT})^{11}$ 、飯島淳子

$$
(\mathrm{CT})^{11} \text { 、郡 秀一 }(\mathrm{CT})^{11} \text { 、藤井雅彦 }(\mathrm{CT})^{2)}
$$

(はじめに】細胞診において、核の形態は重要な所 見に位置付けられ、殊に甲状腺乳頭癌のnuclear groove、T細胞性リンパ腫の脳回旋状核や卵巣顆 粒膜細胞腫のコーヒ一豆样核は診断に結びつく所 見として認識されているものもある。腺型湅胞の 核形態の解析や不整形核の成因に関する報告は意 外に少なく、一般に、癌例では奇怪核が出現する 頋向が高いといわれているが、乳癌では良性病変 からの細胞に比べ円形核が多くなると論ずるもの もある。核形態、特に円形や類円形から逸脱した 形態の成因を明らかにする事は重要と考え、今回 印環型細胞で細胞質内小腺腔（ I CL $)$ を有するも のと ICLを認めず、三日月形、そらまめ形や半月 形を呈する核の形態について検討した。

[研究材料および方法] 研究材料は乳腺悪性腫演の 挎印および穿刺吸引細胞診標本を用いた。対象細 胞はICLを有す細胞とICLがなく三日月形、そら まめ形や半月形の核形を示す印環型細胞で、ICL を有す細胞は核形不整を認めないものと三日月形、 そらまめ形や半月形の核形不整を示すものに分類 し、それら細胞の組織化学的性状を観察した。 【結果・考察」 ICLを有す細胞の核形は大半が三日 月形、そらまめ形や半月形であり、PAS、アルシ アン青やPNA、SBA等のレクチンにも陽性を示し たが、陰性のものもあった。一方、ICLがなく三 日月形、そらまめ形や半月形の核形を示す印環型 細胞で、多糖類染色は反応を認めないが、レクチ ンの中には反応を示すものがあった。印環型湅胞 の核形態の成因には粘液産生能以外の因子の関与 が示咬され、今後細胞骨格等の因子を考慮し、研 究を進めていきたい。 
45 乳腺の良・悪性病变における奇怪核 の出現と診断的意義

杏林大学保健学部細胞診断学教室 ${ }^{11}$

同病理学教室 ${ }^{21}$ 川崎製鉄千葉病院病理 ${ }^{3)}$

鹿島労災病院病理 ${ }^{4}$

O前田苗穂子 $(M T)^{11}$ 、椎名義雄 $(C T)^{11}$ 、

藤井雅彦 $(M D)^{2)}$ 、香山良紀 $(C T)^{3)}$ 、

福岡 貢 $(C T)^{3)}$ 、長坂宏一 $(C T)^{4)}$

ははじめに】乳腺細胞診における良・悪性の鑑別は、 上皮細胞の 2 相性、細胞配列、核小体、クロマチ ンパターン、細胞質内小腺腔 $(\mathrm{ICL})$ の所見等から 棇合的に行っている。核の形状について、高山ら は奇怪核を数種に分類し、良・悪性の鑑別に有効 な所見を報告しているが、我々も漫潤性小葉癌で 低頻度ではあるが奇怪核が出現することを報告し てきた。今回はこの様な奇怪核を含め、円または 類円形から逸脱した核の形態を詳細に分類し、乳 腺の良・悪性病变における出現頻度を検索した。 [研究材料および方法] 検索対象は線維腺腫、乳頭 腺管癌、硬癌および小葉癌の穿刺吸引標本で、各 々5例について検索した。核の形態は円・類円形 以外を切れ込み形 3 種類、凹み形 2 種類、突出形 5種類、その他に涙滴様、半月様等、分類不能を 含め23種類に分類した。

[結果・考察] 線維腺腫では類円および棈円形核が 主体で、变形核の頻度は少なかった。乳頭腺管癌 では、類円形と切れ込み形が多く、硬癌は様々な 形態の变形・奇怪核が多く、小葉癌の多くは円形 で変形・奇怪核は低頻度であった。以上の結果よ り、各組織型に出現している核の形状には、差異 が認められ、変形・奇怪核の出現は硬癌と小葉癌 の鑑別に有用と思われた。
46

乳腺浸潤性小葉癌の細胞学的特徽

一硬癌との鑑別点を中心に一

飯田市立病院検查科病理 11 ，同 外科 21

昭和大学藤が丘病院 病院病理 ${ }^{31}$

長野県がん検診・救急センター 検査部 ${ }^{4)}$

実原正明 $(\mathrm{CT})^{11}$, 北原新一 $(\mathrm{CT})^{11}$, 林美鈴 $(\mathrm{CT})^{11}$

原佳津志 (CT $)^{11}$, 千賀脩 $(\mathrm{MD})^{22}$, 北村隆司 (CT ${ }^{32}$

渡辺達男 $(\mathrm{CT})^{4)}$, 松山郁生 $(\mathrm{MT})^{4)}$, 土屋眞一(MD $)^{4)}$

【はじめに】乳房温存治療が普及する近年, 一側 多発等の臨床病理学的特徴を有する小葉癌を術前 の細胞診で診断することは，温存術適応性と関連 して重要なポイントであろう. 今回われわれは小 葉癌, 特に浸潤性小葉癌( I L C ; invasive lobul ar ca. ) の細胞学的特徴に加えて, 硬癌 ( S C : sci r r hous ca. ) との鑑別点について検討した.

【材料及び方法】検索対象は1991年〜 1995年 ( 5 年 間)に手術された原発性乳癌280例のうち病理診断 の確定した I L C : 12例, 狭義の硬癌 ( S C P : sci r rhous ca., pure type)58例, および広義の硬癌 ( S C B :scirrhous ca., broad type)42例で, 細 胞, 組織学的所見に加え, 症例を選んで微細形態 学的にも検討を行った.

【結果及び考察】। L C と S C P はともに線状, 散在または索状配列を示すことが多かったが，S CBにはこれらの配列や塊状，充実状構造も認め られた。各々の核，細胞質，およびその配列等を 詳細に観察した結果, 以下の 4 点が I L C と S C の大きな鑑別点と思われた. (1) 細胞配列：１L Cは個々の細胞質が数珠状のつながりを示すが, $S C$ ，特に S C P の細胞質は直線状の配列が目立 つ. (2) 核形, 核配列：।LCは円形〜類円形が 多いが， SCは周囲間質からの圧排により不整形 かつ縦並びの傾向を示す. (3) クロマチン：।L Cの殆どは微細顆粒状・均一であるが，SCは粗 造であり不規則に分布している。 (4) 明調一暗調 細胞：ＩＬCは明調細胞主体，SCは明調之暗調 細胞が混在している. 特に(3), (4)の所見は微細形 態学的に最も明膫に観察された. 
東京医科歯科大学第 1 外科 ${ }^{11}$

取手協同病院外科 ${ }^{2)}$ 、同病理 ${ }^{3)}$

O森園英智(MD) ${ }^{1)}$ 、長瀬慈村(MD) ${ }^{1)}$ 、川崎恒 雄 $(M D)^{2)}$ 、五十嵐健一 $(\mathrm{CT})^{3)}$ 、木下達弥 $(C T)^{3)}$ 、森田桂子 $(C T)^{3)}$ 、菊池正教 $(M D)^{3)}$ 、 遠藤光夫(MD) ${ }^{11}$

乳腺ductal adenoma は、1984年Azzopardiらに よって初めて提唱された中部〜末梢乳管から発生 する比較的まれな良性腫瘍である。 症例は64歳女性、主訴は右乳房のしこり。約 2 年前にしこりに気付き当科受診、線維腺腫の誩断 にて経過観察中、95年2月再診となる。再診時理 学所見は、右C領域に径約 $2 \mathrm{~cm}$ の比較的境界明暸 で、弾性硬な腫瘤を触机、可動性は良好、異常乳 頭分泌はなく、乳㰯腫瘤間距離は約 $3 \mathrm{~cm}$ であった。 マンモグラフィでは粗大な石灰化を伴った約 $1.4 \mathrm{~cm}$ の境 界明瞭な腫瘤陰影を認めた。超音波では約 $2 \mathrm{~cm} の$ 衰胞内に充満する低エコ一腫瘤と乳頭側へ連続す る乳管の拡張を認め管内進展を疑わせた。穿刺吸 引細胞診では、乳管上皮を認めず、間質成分と多 数の組織球のみで、class IIであった。以上より 襄胞内乳癌を疑い、腫瘦切除術を施行した。腫瘍 は充実性で白色、弾性硬、境界は明瞭であった。 病理組織学的所見では、比較的厚い線維性被膜と、 充実性部分では、ある程度方向性が保たれた大小 の腺管構造を認め、上皮細胞には軽度〜中等度の 異型性が認められたが 2 層性は保たれていた。 Ductal Adenomaは、病理組織学的には乳頭下腺 腫、管状腺腫、乳管内乳頭腫等との鑑別が、臨床 的には哀胞内乳癌との鑑別が重要で、慎重に諮断 する必要がある。さらに本症例で穿刺吸引細胞診 にて上皮成分が採取されていれば良、悪性の籃別 が可能であったと思われ、輟胞内病変の穿刺吸引 細胞猃はエコー下に施行すべきである。

\section{由来について}

川崎医科大学附属病院 病院病理部 1

川崎医科大学病理学教室

$\bigcirc$ 三宅康之 (CT $)^{11}$, 有光佳苗 (MT ${ }^{12}$, 大杉典子 $(\mathrm{CT})^{11}$, 鐵原拓雄 $(\mathrm{CT})^{11}$, 畠 榮 $(\mathrm{CT})^{11}$, 広川満良 $(\text { KD })^{2)}$

【目的】乳腺の細胞診において筋上皮細胞や双極 裸核細胞の存在は良性を強く示唆する所見として 知られている。しかし、われわれは、粘液癌症例 にて腫瘍細胞集塊の辺縁や粘液背景の中にも紡錘 形細胞が出現することに着目し、その紡鍾形細胞 の由来について検討を行うことにした。

【対象および方法】本学で経験した乳腺粘液癌 10 症例の塗抹標本および組織標本を対象とした。塗 抹標本は、8例が穿刺吸引、2例が腫瘤割面からの 擦過で、H・E染色およびパパニコロウ染色が行わ れていた。組織学的検索は、H・E染色に加えて、 vimentin、EMA、CEA、Cytokeratin、 $\alpha$-SHA など の抗体を用いて免疫組織化学的検索を行った。

【結果】塗抹標本では、全ての症例で腫瘍細胞集 塊の辺縁や粘液背景の中に紡錘形細胞を認めた。 紡錘形細胞は背景に粘液を認めない細胞集塊では 少なく、背景に粘液を認める細胞集塊では多く出 現していた。免疫組織化学的検索において、細胞 集塊辺縁の紡鍾形細胞はCEAとEMAに陽性で、粘液 内に存在する紡鍾形細胞は vimentin 陽性であっ た。Cytokeratin、 $\alpha$-SMA はいずれも陰性であっ た。

【まとめ】粘液癌では組織学的に腫韵細胞集塊辺 縁や間質内に紡錘形細胞が見られ、それらの細胞 の由来は粘液によって圧迫された腫瘍細胞や、間 質の線維芽細胞と考えられた。塗抹標本でも同様 の紡鍾形細胞が出現し、良性を示唆する筋上皮細 胞や双極裸核細胞と見誤らないべきと思われた。 
49 乳腺Mucocele-like tumor と Mucinous carcimonaとの鑑別について

盛岡臨床検查センター ${ }^{1)}$, 岩手医科大学第 2 病理 ${ }^{2)}$, 盛岡赤十字病院病理 ${ }^{3)}$

高橋一博 $(C T)^{1)}$, 高橋利成 $(C T)^{1)}$,佐藤 孝 $(M D)^{2)}$ ， 門間信博(MD) ${ }^{3}$

今回我々は、1994年〜1995年の2年間に経験 した2例のMucocele-like tumor(以下MLTとする)と 5例のMucinous carcinomaについてFNABC標本と 組織標本を用い比較検討した。症例は全例女性 でMLTは43才と31才、Mucinous carcinomaの平 均年令は68.6才であった。

【細胞診所見】MLTでは粘液と泡沫細胞を背景 に少数の腫瘍細胞がシート状集塊を形成し出現 していた。細胞異型はほとんどみられなかった。 粘液は細胞集塊に重なる様に出現していた。ま た、背景に粘液を伴わない良性の導管上皮由来 の細胞集塊も出現していた。これに対し Mucinous carcinomaでは豊富な粘液に包まれる様 にして乳頭状の細胞集塊を多数認め、細胞結合 は強く、重積性を示し、核異型は弱いもののク ロマチンは増量していた。

【組織診所見】MLTと診断された2例では、粘 液貯留を伴う cysticに拡張した導管を多数認める ものの明らかな異型性は認められず、上皮の2相 性も保たれていた。間質に粘液の漏出する所も 見られた。また、粘液中に浮遊している上皮細 胞集塊は小型で少数であった。 Mucinous carcinoma と診断された 5 例では、豊富な粘液の 中に多数の腫湯細胞が胞巣状に認められた。

【考察】MLTでは出現している細胞量や集塊の 重積性、粘液との関係、粘液を伴わずに出現す る細胞集塊の存在などMucinous carcinoma とは腫 瘍細胞の出現様式が異なっていた。また、背景 に出現する泡沫細胞、患者の年令などを考慮す れば、細胞診で鑑別可能であると考えられた。
50 乳頭分泌細胞診を契機として発見され た乳腺アポクリン癌の 1 例

東京都がん検診センター検査科 ${ }^{11}$, 乳腺科 ${ }^{2)}$, 杏林大学保健学部病理 ${ }^{3)}$

O猪狩 真子 $(\mathrm{C} \mathrm{T})^{11}$ ，小宮山京子 $(\mathrm{C} \mathrm{T})^{11}$ ， 松永 忠東 $(\mathrm{MD})^{2)}$, 藤井 雅彦 $(\mathrm{MD})^{3)}$

乳腺アポクリン癌は浸潤癌の特殊型に分類され る頻度の少ない腫瘍であるが、近年報告例が増加 している。今回我々は、乳頭分泌細胞診および内 視鏡ガイド下経乳管吸引細胞診にて発見されたア ポクリン癌の症例を経験したので報告する。

[症例] 60歳女性。右乳頭異常分泌を自覚し近医 受診、当センターを紹介された。白色粘稠な乳頭 分泌物がみられたものの、触診や超音波検査、マ ンモグラフィー上は明らかな異常所見を認めなか った。蓄乳法を併用した乳頭分泌細胞診では悪性 が疑われた。内視鏡ガイド下での経乳管吸引細胞 診においても悪性と判定され、非定型的乳房切断 術が施行された。

[細胞所見］（1）乳頭分泌細胞診: 腫瘍細胞は重 積性の少ない乳頭状集塊や平面的な集塊として、 あるいは孤立性に認められた。壊死性背景のため 細胞の変性が強く、細胞質は乏しかった。核の腫 大、大小不同、クロマチンの増量がみられたが、 核小体は目立たなかった。強い壊死性背景より面 疮癌疑いとした。（2）経乳管吸引細胞診 : 壊死 性背景に結合性の弱い腫瘍細胞の集団を認めた。 腫瘍細胞は乳頭分泌細胞診と同様の所見を有する が変性が加わっておらず、面疮癌を疑い悪性と判 定した。標本を見直すと、細胞質はより豊富であ り、好酸性顆粒などの所見がわずかに認められた が、アポクリン癌との判定は困難と思えた。

[組織所見] 組織学的には濃染する大小不同の核 と好酸性顆粒状の細胞質を有する異型細胞が主と して低乳頭状に配列し、乳管内を這うように広範 $に(6.5 \times 2.0 \times 8.0 \mathrm{~cm})$ 進展していた。一部微小な 間質浸潤がみられ、アポクリン癌と診断した。 
宮城県対がん協会細胞診センター

武田内科クリニック

東北大学医㙩技術短期大学部 ${ }^{31}$

○佐藤朋美 (C T ) ${ }^{1)}$ 、武田鐵太郎 (MD ${ }^{2)}$ 佐藤由紀 (C T $)^{1)}$ 、全野多津子 (C T ) ${ }^{1)}$ 石黑典子 $(C T)^{1)}$ 、增田高行 $(M D)^{3)}$ 佐藤信二 $(\mathrm{MD})^{1)}$

乳腺の線維腺腫内に発生した乳癌の報告は比較 的に稀である。今回我々は穿刺吸引細胞診で陽性、 病理組織診でNon-invasive ductal carcinoma in fibroadenomaと診断された症例を経験したので報告する。 【症例】 36 才、女性。右乳房C領域に $1.8 \times 1.9 \mathrm{~cm}$ の 硬い腫瘤を触知し、穿刺吸引細胞診を施行した。

【細胞所見】大型で核増大、細胞質豊富な異型細 胞の乳頭状集塊が観察された。細胞は比較的均等 に密集重積し、核は類円形を保つ傾向が強く、核 クロマチンは細顆粒状であった。悪性細胞と考え た。その他に、細胞が小型で、密集高度な集塊も 認められた。N/C比大、核は濃染し、核形は相互 圧排による不整形を呈した。間質細胞集塊と混在 する像もみられた。散在裸核細胞も認められた。

【組織所見】最大径 $1.7 \mathrm{~cm}$ 大の境界明瞭な管周囲性 線維腺腫で、その 7 割ほどの腺管内に腫瘍細胞の 進展增殖がみられた。腫瘍細胞は均一な類円形核 と比較的豊富な淡い細胞質を有し、少数ながら管 腔形成も認められた。これら腫瘳細胞は、ほぼ完 全に線維腺腫内に限局し、同腫瘍内に発生した非 浸潤性乳管癌と診断した。

【まとめ】本例は穿刺吸引細胞診で明らかな癌細 胞を多数認めたため、細胞診断は苦慮しなかった。 一般に線維腺腫内乳癌は稀であり、触診でも悪性 を疑われることは少なく、しかも穿刺吸引細胞診 陰性に終わることが多い。本例のような症例の存 在を念頭に置くことが必要と思われた。
千葉大学第一外科、千葉県がんセンター外科“ O鈴木正人（MD），押田正規（MD），長鴄 健 $(M D)$,橋本秀行 $(M D)$, 矢形 寛 $(M D)$, 中島伸之 $(M D)$, 宮内 充 $(M D)$ ", 山本尚人” (MD)

【目的】乳癌の術後補助化学療法によく用いられ るFluorouracil系薬郕に対する感受性を術前の細 胞彰検体を用いて予测し得るかを検討する。

【対象】 Neoadjuvant chemotherapyとして術前約 4 週間Doxifluridine800mg/dayを経口投与した原 発性乳癌切除例 50 例。

【方法】化学療法前後の穿刺吸引細胞晾検体を用 いて次の 2種類の検討を行った。

(1)Flow cytometry法による核DN A 量測定、およ びcell cycle解析。

(2)画像解析装置を用いた核異型度の客観的評価。 この際、客観的核異型度の指標として、核面積 (nuclear area :NA)の変異係数 (coefficient of variation: $\mathrm{CV}$ )を求めた (核面積変異係数: $\mathrm{NA.CV}$ )

$\mathrm{NA} . \mathrm{CV}=$ 核面積標準偏差/平均核面積 $\times 100(\%)$ これらの結果と摘出標本の組織学的効果との関係 を評価した。効果判定は胃癌取扱い規約に準した。 【結果】50例中18例(36\%)にGrade 1a以上の効果 を認めた。化学療法前後でDNA index、S-phase fraction(SPF)、NA.CVに有意差はなかった。組織 学的効果の有無での比較では、効果を認めた群は 認めなかった群に比して、化学療法前の細胞診検 体におけるSPF、NA.CVが有意に( $p<0.05)$ 高值であ った。すなわち、DNA 合成期の細胞が多く、細 胞核異型度の強いものほど化学療法刻に高い感受 性を示す傾向を認めた。

【結語】穿刺吸引細胞診検体を用いて、乳癌の化 学療法感受性を術前にある程度予測可能であるこ とが示唆された。 
53 細胞診材料を用いた乳癌におけ る c-erbB-2 蛋白発現の検討

大阪府立成人病センタ一細胞診断科 ${ }^{11}$ 、病理 ${ }^{2)}$ 、 外科 ${ }^{3)}$

○山登直美（C T ） ${ }^{1)}$ 、南雲サ千子 ( C T $)^{1)}$, 岸上義彦 $(M D)^{1)}$ 、春日井 務 $(M D)^{2)}$ 、 元村和由 $(M D)^{3)}$ 、小山博記 $(M D)^{3)}$

【目的】c-erbB-2 癌遺伝子蛋白発現が認めら れる乳癌は悪性度の高いものが多く、予後因子 として重要である。乳房温存療法の適用に際し て、術前にその情報を得る目的で細胞診材料で c-erbB-2 蛋白発現の有無の検索を行なった。 【対象】1994年12月～1995年 9 月までに大阪府 立成人病センターで手術された乳癌66例（乳房 温存療法55例、全切除 11例) で、腫瘍捺印材 料と病理組織の併用25例、術前腫瘤穿刺吸引材 料32例、腫湯捺印材料のみ 9例。

【方法】細胞診材料はエタノール固定。c-erbB -2蛋白のモノクロナール抗体による免疫組織化 学染色 (ABA法) を行なった。

【結果】腫瑒捺印細胞標本と病理組織標本の比 較では、c-erbB-2発現のカットオフ值を5\%とす ると、腫鹪捺印材料と病理組織標本ともに25例 中 6 例 $(24 \%)$ が陽性で $100 \%$ 一致をみた。腫湯 捺印材料と腫䇤穿刺吸引材料では66例中21例（ $32 \%$ )が陽性で、組織型は乳頭腺管癌11例、充実 腺管癌 3例、硬癌 6例、粘液癌 1例であった。 c-erbB-2蛋白発現と comedo typeとの相関は、 陽性例では $52 \%$ (11/21例) が comedo typeであ り、陰性例では $96 \%$ (43/45例) が comedo type でなく有意差が認めれられた。c-erbB-2蛋白の 検索は乳房温存療法に際しcomedo typeの乳管 内進展の存在を予測するのに役立つと思われた。 c-erbB-2蛋白陽性例の細胞所見は、比較的豊富 な細胞質を持ち核の異型性が強い細胞が多く、 c-erbB-2陰性例では、類円形の小型核で異型性 が乏しい細胞が多く認められた。
54 乳腺腫淘細胞の核DNA分布パターン

解析 一イメージサイトメトリーを用いて一

京都府立医科大学第一病理

○寺内邦彦、村田晋一 $(\mathrm{MD})$ 、浦田洋二 $(\mathrm{MD})$ 、

久保速三 $(\mathrm{MD})$ 、芦原 司 $(\mathrm{MD})$

【目的】私達が研究してきたイメージサイトメト リーは、画像処理やテクスチャ解析に基づいて細 胞内物質の量や分布を定量的に分析する形態解析 法である。今回、乳腺腫瘍に本法を応用し、良・ 悪性腫瘍細胞の核DNA分布パターンを比較検討し た。【材料・方法】対象は、乳管内乳頭腫 10 症 例、非浸潤性乳管癌 10 症例および浸潤性乳管癌 (乳頭腺管癌、充実腺管癌、硬癌) 20 症例で、 パラフィン包埋材料から単離細胞塗沫標本を作製 し、核DNA蛍光染色（DAPI）を施した。腫場細 胞を筋上皮細胞と識別するために、重なりのない 細胞集団を対象とし、その一つひとつの細胞の核 DNA蛍光濃淡像をデシタル化した。この画像デー 夕に対し、1次、2 次および高次統計量を用いて テクスチャ解析を行い、核DNA分布パターンを定 量化した。個々の症例の平均偩と標準偏差值を代 表値として、Mann-Whitney U testによる 3 群間の 比較を行った。【結果・考察】非浸潤性乳管癌は 乳管内乳頭腫に比べて、個々の細胞のDNA分布パ ターンはむしろ均一であったが、細胞間のDNA分 布パターンは多彩であった。浸潤性乳管癌は乳管 内乳頭腫と比べて、不均一なDNA分布パターンを 示し、かつ細胞間のDNA分布パターンが多彩さに 富んでいた。以上より、イメージサイトメトリー を乳腺腫皦に応用することにより、良・悪性腫瘍 細胞間におけるDNA分布パターンの違いや、乳管 癌の浸潤に伴って個々の細胞のDNA分布パターン が変化することが定量的に示された。 
55 乳腺捺印細胞診におけるAgNORs の検討

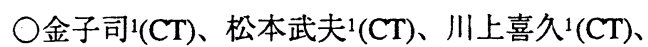
岩崎聖二 ${ }^{1}(C T)$ 、山本 誠 $1(M T)$ 、児玉哲郎 $2(M D)$ 、 横瀬智之 ${ }^{3}(\mathrm{MD})$ 、長谷部孝裕 ${ }^{3}(\mathrm{MD})$ 、向井清 ${ }^{3}(\mathrm{MD})$ 国立がんセンター東病院臨床検査部病理細胞診 1 同呼吸器科2、同研究所支所臨床腫瘍病理部3

（はじめに）一般的にNORsの数が良悪性、悪 性度と相関するという報告が多い。過去に我々 は肺癌材料を用いて、NORs数よりもNORsの面 積でより良悪性の鑑別が可能であると報告した。 そこで今回我々は、乳腺組織の捺印標本を用い てAgNORs染色を施し、AgNORs面積で良悪性の 鑑別が可能かどうか、また、乳癌の組織型（組 織学的分類）の違いによるAgNORsの数、面積の 成績を比較検討したので報告する。

(材料) 国立がんセンター東病院で切除された 癌20例（充実腺管癌9例、硬癌8例、乳頭腺管癌3 例）を対象とし、対照として正常乳腺組織5例を 用いた。

（方法）乳腺組織を捺印し、95\%エタルールで1時間 固定し、One-Step銀染色を30分間施行した。 AgNORsの測定は画像解析装置（CAS200）を用 いてAgNORsの数、面積を 1 例約 200 個の細胞を計 測した。

（結果）癌 20 例のAgNORs数は平均 $2.67 \pm 1.17$ 個、 AgNORs面積は平均4.58土2.39 $\mu \mathrm{m}^{2}$ 、正常乳腺で はAgNORs数は平均 $1.63 \pm 0.75$ 個、AgNORs面積 は平均 $2.17 \pm 1.56 \mu \mathrm{m}^{2}$ であり、数、面積とも癌例 で数值が高かった。組織型別に見ると、充実腺 管癌（数平均 $3.14 \pm 1.37$ 個、面積平均 $5.51 \pm 3.05$ $\mu \mathrm{m}^{2}$ ）、硬癌（数平均 $2.35 \pm 3.85$ 個、面積平均 $3.85 \pm 2.10 \mu \mathrm{m}^{2}$ ) 、乳頭腺管癌（数平均 $1.93 \pm$ 0.79 個、面積平均 $\left.2.18 \pm 1.02 \mu \mathrm{m}^{2}\right)$ であり、充実 腺管癌でより AgNORsの数、面積とも数值が高か った。今後さらに症例を追加し、報告する。
56 蛍光in situ hybridization (FISH) 法を用いた乳癌における第16染色体長腕の数的 変化の検出とその意義

国立がんセンター研究所病理部

津田均 (MD)、酒卷千波 (AS)、

谁伸幸 $(\mathrm{MD})$ 、広橋説雄 $(\mathrm{MD})$

[背景] 第16染色体長腕(16q)のヘテロ接合性の 消失 $(\mathrm{LOH})$ が、乳癌において高頻度で起きてい ることがサザンブロット法による解析にて示さ れた。LOHの多くが一対の対立遗伝子の一方の 欠失であると予想され、FISH法による染色体上 の特定領域における数的変化の検索はLOHの検 索と同様に乳腺腫場の悪性度の判定に有用であ る可能性がある。FISH法の結果とサザンブロ ット法によるLOHの解析結果との一致率を知る ために外科切除された乳癌 24 例を対象にFIS H 法による16qの変化を検索した。[方法] D16Z3 (16cen)とD16S154 (16q23)の 2 種のプローブ を各々digoxigenin、biotinで標識し、proteinase Kで処理した乳癌細胞に対して二色FISH法を行 い、16qの異常を娭索した。16cenとと16q23のシ グナルの比率により D (disomy, 2:2), L (loss, 2:1), M (monosomy, 1:1), P+L (polysomy+ loss, 3:1，3:2，4:2等)の 4 カテゴリーに分けた。 [結果] 各腫瘍における優位な $16 \mathrm{q}$ のパターンは 12 例 $(50 \%)$ でM, L,ないし P+Lであり、他の 12 例ではDが主体であった。11例にheterogeneity があると判断された。 LOH(-)の9例では8例がD 優位、1例がP $+\mathrm{L}$ 榎位であった。 $\mathrm{LOH}(+)$ の15例 中7例が $\mathrm{M}, 3$ 例がしで、これらの10例では一方の 対立遗伝子が欠けていることが確認されたが、 他の 4 例はD優位、1例が $\mathrm{P}+\mathrm{L}$ 優位であり、 $\mathrm{LOH}$ の機構には久失だけでなく複製、組み換え、さ らに腫瘍細胞間の heterogeneity 影幚している と考えられた。[考察] FISH法にて検出される $16 \mathrm{q}$ の変化は乳癌で高频度に見られ、その結果 はLOHの結果とよく相関した。本法の術前の第 刺吸引細胞診標本への応用が可能と考えられた 
57 子宮内膜浮遊細胞診における生理食 塩水と保存液との検討

筑波大学附属病院病理 ${ }^{11}$, 同産婦人科 ${ }^{21}$

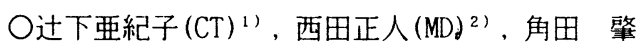
$(\mathrm{MD})^{2)}$, 深沢政勝 $(\mathrm{CT})^{11}$, 池沢 剛 $(\mathrm{CT})^{11}$, 鈴木 悦 $(M T)^{11}$ ，渡辺照男 $(M D)^{11}$

【はじめに】子宮内膜細胞診における生理食塩水 を用いた浮遊法は, 組織構築の観察が容易である など，その有用性が高く評価されている。今回我 々は, 子宮体内膜細胞診用保存液 (武藤化学) と 生食を用いた浮遊法について比較検討を行ったの で報告する。

【対象および方法】当院産婦人科で子宮内膜細胞 診を施行した良性14例，悪性 8 例の計22例を対象 とした。標本は従来どおりブラシで子宮腔内細胞 を採取，まずはスライドグラスに塗抹し，ブラシ にまだ付着している細胞を $5 \mathrm{ml}$ の保存液で強く振 盪し細胞浮遊液とした。同様に生食を用いた浮遊 液も作製し，これを当日に1500回転，5分間遠沈 し, 沈渣を各々すり合わせ法により塗抹, 浮遊細 胞診標本とし，両者の比較を行った。

【結果】保存液を用いたものでは, 生食法に比べ 細胞集率が低く, また背景の粘液様物質によりひ きのばされたような像や，混入物が集塊内に絡み 合うなど，観察しにくい傾向がみられた。核の染 色性は, 直接塗抹に比へ濃染ぎみではあるが, 生 食法よりは直接塗抹に近い染色性を示していた。 核の大きさは, 生食法と同様に直接塗抹よりやや 腫大する傾向がみられた。

【まとめ】浮遊細胞診では, 組織構築の観察, 細 胞集塊の量, 背景の状態において, 生食の方が保 存液より優れていた。今後, さらに、核所見に影 響をおよほさない保存液の開発が望まれる。 58 子宮体内膜細胞診における簡易セル
フロックの有用性

大阪労災病院 臨床病理科 1)、同産婦人科2) $\mathrm{O}$ 三村明弘 (CT) 1) 古田美知子 (CT) 1) 高水竜一(CT) 1)石垣美幸 (CT) 1) 田中育子 (MT) 1) 橋野義信 (MT) 1) 辻村 俊 (MD) 1) 川野潔 (MD) 1) 山等正人 (MD) 2)

子宮体部癌の增加と、老人保健法の適用にとも なって、内膜細胞診の検体数が増加している。し かし、子宮内膜には内膜增殖症や細胞異型の乏し い高分化腺澏があり、細胞診判定に苦虑する。 当院では、1990年より簡易セルブロック法を 行ない、内膜細胞診判定の参考とした。また、そ こから得られた細胞所見をふまえたうえで、内膜 練胞診を判定することにより、セルブロックが併 用できない症例においても診断精度の向上が認め られたので報告する。

(方法・対象) 1990 年から1994年までに 当院産婦人科で子宮内膜細胞診を行なった症例は 延 5053 件、うち簡易セルブロックを行なった のは 1207 件であった。材料は全てエンドサイ トにて採取され、スライドグラスに望抹後、95 \%エタノールで固定し、Papanicolaou染色を行な うが、染色の前後に封入困難と考えられる細胞集 塊をピンセット等で、剥離し、ナイロンメッシュ 製收納袋に回収、バラフィン包埋をしてブロック を作成、薄切後へマトキシリン・エオジン染色を 行ない標本とした。

(結語) (1)セルブロックは子宮内膜組織と同様の 所見が得られ、子宮内膜㫫症例でセルブロックを 併用しているものの正診率は $96 \%$ あっった。 (2)セルブロックから得られた練胞所見を活用する ことによって、偽陽性と判定したものから出現す る陰性例が1990年では41例であったが、1 994 年では 16 例と半減した。内膜福における 正診率も、1990年では71\%であったが、1 994 年では $88 \%$ と明らかに向上した。また、 1990 年には内膜癌 2 例、增殖症 9 例の偽陰性 を認めたが1994年には增殖症で1例の偽陰性 を認めるのみとなった。 
59

斯

子宮体秥検診における疑晹性例の検

堺市街生研究所

O野口秀榯 $(\mathrm{CT})$, 下迫純子 (CT), 松尾 光子 (CT), 狩山雅代 (CT), 岩 信造 ( $\mathrm{CT})$, 池田正典 (MD)

【はじめに】近年子宮体密は增加倾向にあるが 内膜細胞診のcriteriaが礁立されていないこと もあり，内膜増殖症や高分化腺秥などの判定に 苦虛することも多く，必然的に疑陽性の割合が 高くなっている。また老人保健法（以下，老健

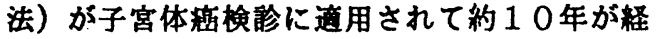
ち, 間题点も指摘されている。

今回, 我々は遄去 6 年間の子宮内膜細胞暗の 疑陽性例の精密検查（以下，精検）結果を調查 し，子宮内膜細胞琹の閶題点について検討した ので報告する。

【方法及び結果】対象は 1989 年 4 月から 1 995 年 3 月までの過去 6 年間に堺市内の各医 㙩機関において，エンドサイト法あるいは吸引 法により採取された子宮内膜細胞龍9861例 である。このうち500例が疑晹性以上で，疑 隄性が4 40 例 (4.5X)，陽性が60例 (0.6 ）であった。これらの定例の精検の結果は内膜 增殖㱏が 52 例, 体站が 23 例であった。 52 例の内膜増殖定における年軨别梌体数は，45 〜 49歳が 16 例, $50 \sim 54$ 歳が 21 例で両 者に有意差を擢めなかった。また疑陽性例の中 に，精検の結果体沾と龍断された定例は 12 例 でいずれも高分化腺站であった。その細胞像は いずれも不规則重積性を铝めたが、樹枝状集塊 は 2 例だけで核異型は軽度であった。既床所見 は23例の体痁のうち 20 例に不正性器出血を 铝めたが，3例は無症状であった。発見された

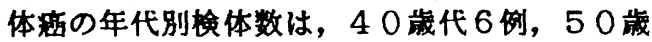
代 16 例， 60 歳代 6 例, 70 歳代 4 例であっ た。

【まとめ】現在の老健法ではその道用年龆が5 ○歲以上となっているが，40歳代にも体触を 慗めることもあり不正性器出血など臨床的に体 满が疑われるような症例に対しては積極的に子 宮内膜細胞競を施行すべきである。また高分化 型腺秥の定例では細胞所見に乏しい例もあるの で疑陽性例の取り扱いについては注意が必要で ある。
60 子宮内膜細胞診の細胞所見判定におけ ろ観察者内および観察者間の再現性の解析

信州大学産婦人科 ${ }^{1}$,国立仙台病院病理 ${ }^{2}$,仙台市立 病院産婦人科 ${ }^{3}$,宮城県対がん協会 4

土岐利彦(MD) $)^{1}$, 森 篤 $(\mathrm{MD})^{1}$, 手塚文明 $(\mathrm{MD})^{2}$, 東岩井久 $(\mathrm{MD})^{3}$, 及川洋恵 $(\mathrm{CT})^{4}$, 及川和子 $(\mathrm{CT})^{4}$, 藤井信吾(MD) ${ }^{1}$

【目的】子宮内膜細胞診の所見の判定において, 同一観察者内および複数の観察者間で,どの程度 の変動が存在するのかを検討した。【方法】観察 者内の変動の検討には10例(内膜癌7例・增殖症1 例·良性2例)各2標本ずつ計20標本,観察者間の変動 の検討には40例(内膜癌22例・增殖症3例·良性 15 例)40標本の内膜細胞診を用いた。10人のC T(経 験5１8年平均 11.8 年)に標本を鏡検してもらい， 「腫場性背景」「乳頭状構造」「細胞の不規則重積性」 「核增大」「核の大小不同」「クロマチン増量」「著明 な核小体」の 7 所見の有無を\{有\}(疑\}無\}の 3 段 階で,最終診断を\{陽性\}疑陽性\}\{陰性\}の 3 段階 で評価してもらい,各所見の判定および最終診断 につき一致率とカッパ統計值を求めた。【結果】 同一観察者での所見の一致率は全体で 49 ～80\%平 均 $71 \%$,診断の一致率は60 100\%平均 $81 \%$ であっ た。所見別にみると「乳頭状構造」「細胞の不規則 重積性」「クロマチン増量」の一致率が比較的低く, 特に悪性例でこの傾向が強く認められた。経験年 数と一致率の間に相関はなかった。各所見ごとに 検討した観察者間での判定の一致性は,「腫場性背 景」核増大」「核の大小不同」で比較的高く(カッパ 値0.39 0.41),「乳頭状構造」「クロマチン増量」では 低かった(カッパ値0.22〜0.26)。全体として所見 \{有\}\{無\}の判定の一致率は高く, \{疑\}の一致率は

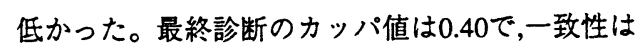
まあまあであった。【まとめ】子宮内膜細胞診の 所見として「乳頭状構造」と「クロマチン増量」は， 同一観察者内および複数観察者間の両方の再現性 に多少問題のあることが明らかになった。 
61 胃癌症例の媳人科細炮診の検討

神奈川県立がんセンター婦人科 ${ }^{1)}$, 病理 ${ }^{2)}$

O中山裕樹 (MD) ${ }^{1)}$, 土居大祐 (MD) ${ }^{1)}$, 小野瀬亮 $(M D)^{1)}$, 河合尚基 $(M D)^{11}$, 岡島弘幸 $(M D)^{1)}$, 亀田陽一 $(M D)^{2)}$, 山口正直 $(M D)^{2)}$, 飯田萬一 $(M D)^{2)}$, 原田祐子（C T $)^{22}$, 岩撫成子 $(C T)^{2)}$, 中村満美子 $(\mathrm{C} \mathrm{T})^{2)}$, 早淵洋子 (C T $)^{2)}$

[はじめに]

女性胃癌患者と婦人科との関わりは、クルッケン ベルグ腫場を始めとして、意外に機会が多い。当 院でも外科、婦人科の連携を蜜にして以来、胃癌 患者を婦人科で診察する機会が増し、思いのほか の細胞診陽性例を経験したので報告する。

[方法]

1991 年 95 年の 5 年間の婦人科初診患者 2 634 人のうち、婦人科細胞診が陽性となった胃 癌患者 8 例、クルッケンベルグ腫瘍の認められた 4 例などについて検討した。

[結果]

(1)婦人科細胞診陽性の胃癌患者 8 例のうち 5 例は、 術前に外科より紹介された。5例とも骨盤内腫湯 の疑われた例で、2 例は子宮筋腫であったが、3 例では卵巣の腫大が認められたが、いずれも子宮・ 腟には病巣がなく、癌性腹膜炎により経卵管的に 悪性細胞が出現したものと考えられた。5例とも 5 ヶ月以内に死亡した。

(2)これら8例では全て内膜細胞診で陽性で、頸部 細胞診陽性は 3 例であった。いずれもきれいな背 景に、印環細胞の小クラスターが散在する、典型 的な細胞所見であった。

(3)一方クルッケンベルグ腫崵の 4 例の卵巣はいず れも手拳大以上であるにもかかわらず、婦人科細 胞診は陰性であった。全例 1 年以上生存している。

[結詥]

胃癌患者での婦人科細胞診陽性例は、多くは癌性 腹膜炎を示唆し、予後不良群と考えられた。
62

黄色肉荡偅性子宮内脱焱の新抱像

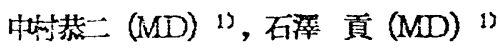

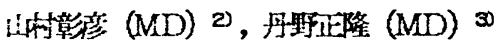

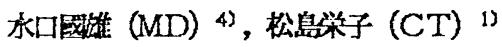
茂木作和子 (CT) "), 高山公孝 (MT) 11 石讲孝子 $(\mathrm{MT})^{11}$ ，奈良美千代 $(M T)^{1)}$

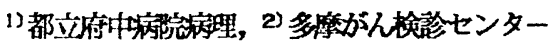

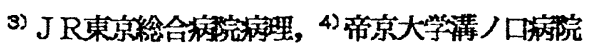
猿床病理

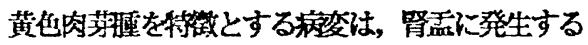
ものがよく知られているが，比輅的稀と思えれる黄

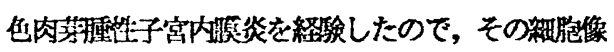
を中心に啹告する。

定例は80才の主婦で，昭和 52 年からりウマチ

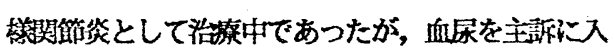

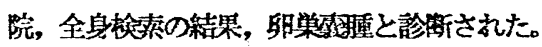

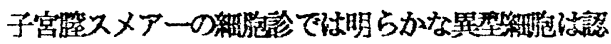

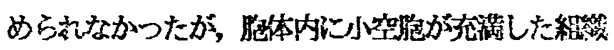

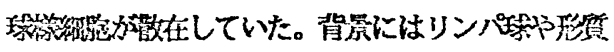

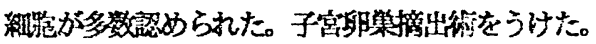

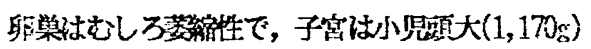

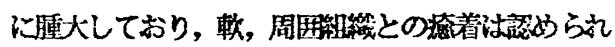

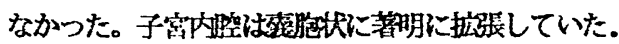

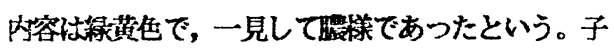

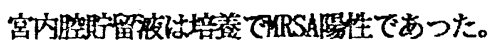

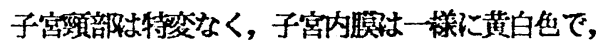

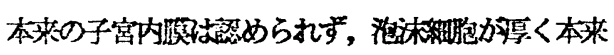
の子宮内㬴を置換していた。ときにコレステリン裂

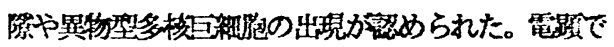
は胞体内に多数の空坨をもつた細胞がありその間に

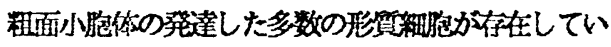
た。胞体はSudanIII陽住である。これらの种胞は多 音の脂肪を含み，子宮内腺の一部から搔出した脂筫 の分析ではCholesterol ester とPhospholipid,Free cholesterolが大部分てTriglycerideは少量であつた。

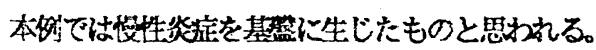


63 子宮内膜細胞診が診断のきっかけと なった閉経後結核性子宮留䐬症の 1 例

新日鐵室蘭総合病院産婦人科 ${ }^{1)}$, 旭川みずうち産科婦人科 ${ }^{2)}$, 函館五稜部病院病理科 ${ }^{3)}$ ，同 産婦人科 ${ }^{4)}$, 札幌医大産婦人科 ${ }^{5}$

O佐藤 賢一郎 (MD) ${ }^{1)}$ ，水内 英充 (MD) ${ }^{2)}$ ， 若林 淳一 $(\mathrm{MD})^{3)}$, 田中 恵 $(\mathrm{MD})^{4)}$, 伊東 英樹 (MD) ${ }^{5}$ )

（目的）閉経後結核性子宮留脹症の稀な1症例を 経倹し、その診断について若干の知見を得たので 報告する。（症例）症例は69葴で閉経は50葴、主 訴は特になし、既往歴として 10 年来慢性関節りウ マチにて内服治療を受けていた。平成6年6月30日 子宮䂓検診の目的で受診した。診察所見では子宮 はほほ正常大、経㓐超音波にて子宮脆内に hypoechoic areaが認められた。子宮䅡管は狭窄して いたが、子宮消息子の㨂入を試み脹性及び粘液性 の排泄物の流出が認められ、子宮留儾症と診断し た。同時に行ったフララ法による子宮内腽細胞診 でリンパ球漫潤、類上皮細胞とラングハンス型巨 紐胞を認め、性器結核を疑った。病理組織ではラ ングハンス型巨細胞を伴う慢性肉芽腫性病変が認 められ、抗酸菌染色陽性、ダイレクトT B 陽性、 ッベルクリン反応陽性と合わせ結核性子宮留腿症 と診断した。(結諭) 子宮留脤症症例の子宮内膜 細胞診は悪性腫璄の除外の他、結核発見のきっか けにもなり得ることが示唆され、積極的に施行す ベきであると考えられた。
64 子宮体部carcinosarcomaの 1 例

\section{東北大学産婦人科}

○結城道広(MD), 我妻理重(MD), 高野忠夫(MD), 松永弦 $(M D)$, 田野口孝二(MD), 早川清一郎( $M D)$, 伊藤梁 $(M D)$, 今野良 $(M D)$, 佐藤信二 $(M D)$,

岡本聁 (CT), 矢嶋聘 $(\mathrm{MD})$

(症例)60歳の4経奸2 経産で、閉経が52歳。既往歴 として53歳時に乳ガンの手術を受けている。家 族歴には特記すべき事はなかった。平成7年7月 に不正性器出血を主訴に近医受診。子宮体部細 胞診で疑陽性、内膜組織診でcarcinosarcoma疑い にて、同年8月当科紹介入院となる。当科体部細 胞診では、陽性であった。同月腹式単純子宮全 摘術+両側附属器切除術+骨盤内リンパ節廓清術 を施行した。 [細胞診]当科体部細胞診では乳頭状細胞集塊で出 現し、明暸な核小体を持ち腺癌を推定した。 [組織診]異型性に富む紡錘形細胞をはじめ多型、 多核巨細胞が桐状・瀜巻状あるいは不規則に増 殖したsarcomatousな部分と、明細胞癌梯な部分 との混在を認めた。

[摘出標本子宮重量は420gあり、腫堭は子宮内腔 に塊状ポリープ様に突出しており壊死を伴って いた。病理学的には、組織診と同様な所見を認 めcarcinosarcomaと診断された。 今回我々は子宮体部に発生した上記の carcinosarcomaの 1 例と、更に当科にて最近 5 年間 に経験した症例の成績を併せて報告する。 
細胞診

福井県済生会病完 ${ }^{1)}$

\section{福井医科大学産科婦人科学教室}

同中央検查部 ${ }^{3)}$

○黑川哲司 (MD $)^{12}$, 金嶋光夫 (MD $)^{11}$, 吉田好雄 $(\mathrm{MD})^{2}{ }^{2}$, 佐々木博正 $(\mathrm{MDD})^{2)}$ ，紙谷尚之 $(\mathrm{MD})^{2}$ ，富永敏朗 $(\mathrm{MDD})^{22}$, 今村好章 $\left.(\mathrm{MD})^{3}\right)^{3}$ ，森 正樹 $(\mathrm{CT})^{3}$

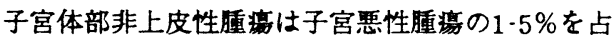
めるにすぎず，なかでも悪性ミューラー管混合腫 䍡（以下MMT）は非常に稀なものである。我々は 最近3例の本疾患を経験したので報告する。（症例 1）50歳，5回経妊4回経産婦。不正性器出血を主訴 に受診。子宮は手拳大に腫大しており子宮内膜細 胞診では出血性の背景に小集塊状を示す腺上皮と 思われる型型細胞と孤立散在性に出現する紡錐形 の異型細胞がみられ，MMMTが筑われた。組織診で

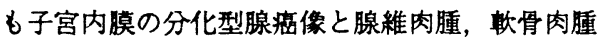
梯部分がみられた。（症例2）54嵅，2回経妊2回経 産婦。不正性器出血を主訴に受診。子宮は超手拳 大で子宮内膜細胞診では集塊状に出現した筫型細 胞に重積性がみられ，個々の耧胞は大小不同であ り核は腫大し，核小体が明億であった。組織診で

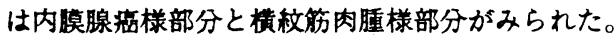
（症例3）59嵅, 2 回経妊 2 回経産婦。不正性器出血 を主訴に受診。子宮は手拳大で子宮内膜紐胞診で は腫凝性背景のなかに坬立散在性に結合の弱い小 集塊として，異型性の強い腫第細胞がみられた。 組機詥では腺䊒肉盾梾部分がみられた。以上の3症 例は摛出物の組樴検查でMMarTのHeterologous type と確定したものであるが，子宮内膜の細胞診で典 型的な腺㾌像以外の所見を認めたときにはMMMを 考虑すべと考えられた。
鳥取県保健事業団 ${ }^{11}$ 鳥取大学産科婦人科 ${ }^{21}$

O藤井和晃 $(\mathrm{CT})^{11}$ ，传藤传作 $(\mathrm{CT})^{11}$ ，八幡美智子 $(C T)^{11}$ ，冨山道弓 $(C T)^{11}$ ，岡田 誠 $(M D)^{21}$, 紀川 純三 $(M D)^{21}$

子宮体部悪性中胚葉性混合腫瘍（MMMT）は 子宮悪性腫場の 2 . $0 \%$ 以下と比較的稀な疾患で ある。今回、MMMTの3例を経験したのでその 細胞所見を中心に報告する。

症例の年齢は52歳から70歳であり、主訴は3例 とも不正性器出血であった。初診時所見では、子 宮の大きさは2例が手拳大と小児頭大に腫大して おり、1例は证常大であった。3例中、2例で内 膜細胞診でMMMTを推定し得た。

術後摘出標本の組織所見では、1. 例は低分化型 腺癌と、横紋笳肉腫・平滑筋肉腫・間質肉腫との 混在、1 例は低分化型腺癌と間筫肉腫との混在、 1 例は低分化型腺密と横紋筋肉腫との混在が認め られた。

MMMTにおける細胞所見の特尝として、背景 は炎症性あるいは腫疼性であった。不規則重積性 の集塊として出現した腺峾細胞では、細胞質はよ 一ス状、核の大小不同、核形不整およびクロマチ ンの增量と著明な核小体が見られた。非上皮性覀 性細胞は、集塊状または孤立散在性に出現してお り、核は大型、類印形で大小不同、核形不整があ ク、クロマチンは顆粒状に增量していた。以上の 成績より、上皮性成分と非上皮性成分の2相性パ 夕ーンによりMMMTの推定が可能であった。今 回の3症例のうち、2症例において 2 相性パ夕一 ンを示した。内膜細胞診で腺癌を認めた場合、詳 細にスクリーニングすることにより、MMMTの 細胞診推定は可能であると思われる。 
67 子宮体部原発 alveolar soft part sarcoma と思われる一症例

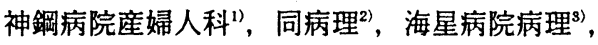
九州大学医学部第 2 病理 4

O川口恵子 (MD) ${ }^{1}$, 妹尾純子 (MD) ${ }^{11}$, 西川裕子 $(\mathrm{CT})^{2)}$, 大矢美香子 $(\mathrm{CT})^{2)}$, 中院邦彦 $(\mathrm{MD})^{32}$, 恒吉正澄 (MD) ${ }^{4)}$

alveclar soft part sarcomaは全乾部肉腫の 0 . 4 1:1\%の頻度で発生する腫場であるが，子宮に 発生する事は極めて稀である。今回我々は子宮体 部原発alveolar soft part sarcomaと思われる 症例を経験したので報告する。

症例: 28 才, $\mathrm{O}$ 姡娠 $\mathrm{O}$ 産, 平成 7 年 11 月 7 日下 腹痛のため当科外科を受診し, 卵巣共腫の疑いで 当科を紹介された。内誩にて正常大の子宮右上方 に手挙大の腫留を触知した。諸検査施行の後, 11 月 14 日開腹手術を行った。術後子宮以外の病巣の 有無について精查したが，特に異常は認められな かった。

開腹時所見 : 子宮は正常大で子宮底右側より約 $0.5 \mathrm{~cm}$ の茎を持った手挙大の被膜に包まれた腫瘍 を認めた。両側附属器は正常であった。

捺印細胞診所見 : 広い細胞質を持つ大型の細胞 や裸核状細胞が大部分は散在性に，一部は胞巣状 配列にみられた。核は棈円〜不整形で大小不同著 しく，多核のものもあった。クロマチンは細顆粒 状で，核小体がめだっていた。核分裂像はあまり 見られなかった。

病理組織所見：腫韵は $510 \mathrm{gr}$ で割面は出血が著 明であった。組織学的には腫䄈細胞は血管性の薄 い隔壁で区分され，胞巣状構造を示していた。腫 瘍細胞は大型で好酸性細顆粒状の広い細胞質を持 ち，核小体がめだっていた。核分裂像は少なく， PAS陽性顆粒が認められた。diastaseには抵抗性 を示した。
68

1 例

子宮体部原発小細胞型神経内分泌癌の

川绮市立川绮病院産婦人科1)、同検查科2)、聖マリ アンナ医科大学東横病院産婦人科3)、慶礁義塾大 学医学部病理学教室4)、神奈川県予防医学協会 5)

○木挽貢慈 $(M D)$ 1)、藏本欧美 $(M D)$ 1)、 平田さくら(MD)1)、岩田嘉行(MD)1)、 金子厚子(CT $)^{2}$ )、宮沢明子 $(C T)^{2}$ 2)、福田純也 $(M D)$ 2)、木口一成( $M D)^{3}$ 3)、向井万起男 (MD) 4)、 鈴木忠雄 $\left.(M D)^{5}\right)$

子宮に発生する小細胞型神経内分泌癌は稀な疾 患で予後不良とされ、その発生起源には諸説があ り未だ統一されていない。特に子宮体部発生の 場合は極めて稀であり、悪性中胚葉性混合腫瘍、 子宮内膜間質肉腫、神経外肧葉性腫瘍との鑑別か 困難とされている。今回我々は、子宮体部原発と 診断した小細胞型神経内分泌癌を経験したので報 告する。

【症例】 51 歳、経産婦。不正出血にて当院初診。 内浐上、子宮䅡部、体部は共に第卵大に腫大。外 子宮口に易出血性のポリープを認め、細胞彭及び 生検にて子宮䅡癌（低分化型腺癌） Stage II b之診 断し、手術（広汎子宮全摘術 + 大網部分切除術 + 両付属器切除術）施行。開腹時少量の腹水及び大 網枟移を喼め、摘出標本の病理所見より本腫瘍之 診断。その後、旰転移、DIC と急速な転慢をとり 死亡。

【細胞所見】子宮額部：小型裸核状の細胞か、、散 在性、一部粗な結合を伴って出現。核は類円形で クロマチンは増量し、細顆粒状に均等に分布。

腹水: 木目込み様配列を示す細胞集団、相互封

入像、ロゼット状配列が認められた。

【摘出標本病理所見】腫瘍は子宮内华を充満し頝 部にまで漫潤。一部はポリープ状に内子宮口から 突出。子宮体部には分化型腺痘と共存して小型未 分化細胞の增殖が珰められた。

【免疫組緥化学染色】小型未分化細胞に神経内分 泌マーカー（グリメリウス、クロモグラニンA) の陽性所見を認めた。

以上の結果より、本腫瘍を子宮体部原発の小細 胞型神経内分泌癌と診断した。 
69 Primitive Neuroectodermal Tumor

（P N E T ）と考えられた子宮肉腫の一例

筑波学園病院産婦人科 ${ }^{11}$ 同検查部 ${ }^{21}$ 筑波大学

産婦人科 ${ }^{3)}$ 同病理科 ${ }^{4}$

○河野圭子 $(M D)^{11}$, 新井ゆう子 $(M D)^{11}$, 岡本 - $(M D)^{1)}$, 岩崎寛和 (MD) ${ }^{11}$, 畠山美智子 (C T $)^{2)}$, 西田正人 (MD ${ }^{3)}$, 野呂昌弘 (MD) ${ }^{4)}$

今回我々は水腎症にて発症し, 組織型が特異な 子宮肉腫を経験したので報告する。症例は 33 歳 2 経産の婦人で急性に発症したと思われる水腎症に よる右腰背部痛により1995年6月10日緊急入院と なった．子宮後壁に $11.4 \times 7.7 \mathrm{~cm}$ の充実性腫瘍が あり超音波検查では変性を伴う子宮筋腫が考えら れた。疼痛が強かったことより6月14日腹式単純 子宮全摘術十両側付属器切除術を施行した. 腫㾴 は子宮より発生し直腸と強固に癒着していた，術 中タッチスメアでは, 裸核に近い小型の細胞が, 散在性あるいは小集塊を成して出現していた，核 は円〜類円形で，大小不同を認め, クロマチンは 粗で赤い大型の核小体を有しClassV と診断した。 病理組織は明瞭な核小体があり微細顆粒状クロマ チンを有する核を持つ細胞が一様に占めており， 分類不能子宮肉腫之猃断された. 術後化学療法施 行したが残存腫瘍は急速に増大したため，8月14 日骨盤内臟器全摘術を施行した。9月5日より全 骨盤腔放射線療法開始.9月15日肺転移出現. 9 月29日気管支動脈へadriamycinの動注を施行した が明らかな腫瘍の縮小は認められなかった。 その 後腹腔内再発, 腰椎転移あり, 肺転移巣も増大を 続け，呼吸不全にて12月12日死亡した．2回目の 手術標本での免度染色にてVimentin, NSE, CEA, Sinaptophysinが陽性で, 間葉系腫瘍で神経原性 の性質を有しており，その所見より子宮原発の Primitive Neuroectodermal Tumor (P N E T) と考えられた。
70 婦人科悪性腫瘍由来株におけるI 型 および II 型糖鎖の発現機序

慶虑義塾大学医学部産婦人科

○吉岐潤子 (MD), 久布白兼行 (MD), 馬軍 (MD), 吉田祐子( $C T$ ), 福地 剛 (MD), 三上幹男 (MD), 塚崎克己(MD)，野澤志朗 (MD)

[目的]癌化に伴って細胞膜に発現された複合糖 質は転移能に関与することが指摘されている。従 って, 癌細胞膜上の糖鎖発現の機序を明らかにす ることは細胞学的特性を解明するためにも重要で ある。糖鎖はガラクトースとNーフセチルグルュサミ ンが $1 \rightarrow 3$ 結合した I 型糖鎖と $1 \rightarrow 4$ 結合したII 型 糖鎖に大別され，両者の発現にはガラクトース転 移酵素(Gal T) が関与すると考えられている。我々 は, すでに体癌では子宮䅡癌や卵䉾癌に比べI型

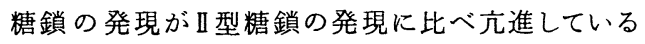
ことを明らかにしてきた。そこで今回は，I型な らびにI型糖鎖の発現機序を明らかにするため， 体癌ならびに頝癌, 卵巣癌由来培養株における Gal T 活性を検討した。[万法]体癌ならびに頝 癌, 卵巣癌由来培養株におけるI型糖鎖を合成す る $\beta 1 \rightarrow 3 \mathrm{Gal} \mathrm{T}$ 活性ならびにII 型糖鎖を合成する $\beta 1 \rightarrow 4 \mathrm{Gal} \mathrm{T}$ 活性を, I 型糖鎖ならびにII 型糖鎖に 対するモノクロナール抗体を用いて新たに確立した 薄層クロマトグラフィー免废染色法あるいはELISA 法により測定した。［成績］ $\beta 1 \rightarrow 3 \mathrm{Gal} \mathrm{T}$ 活性は, 5 種の体癌由来培養株では $40-360(\mathrm{pg} / \mathrm{\mu g} / \mathrm{hr})$ であり, 3 種の頝癌由来培養株あるいは2 種の卵巣 癌由来株は $30(\mathrm{pg} / \mu \mathrm{g} / \mathrm{hr})$ 以下であった。一方, $\beta 1 \rightarrow 4 \mathrm{Gal} \mathrm{T}$ 活性は体癌由来培養細胞株において は 10-65 (pg/ $/ \mathrm{g} / \mathrm{hr})$ であり, 澒癌由来株あるい は卵巣癌由来株では $50-90(\mathrm{pg} / \mu \mathrm{g} / \mathrm{hr})$ であっ た。[結論]体癌ではI 型桾鎖を合成する Gal T 活性はII型糖鎖を合成する Gal T 活性に比べ高い ことを初めて明らかにした。これにより体癌にお けるI 型糖鎖の発玩光進には $\beta 1 \rightarrow 3 \mathrm{Gal} \mathrm{T}$ と $\beta 1 \rightarrow$ $4 \mathrm{Gal} \mathrm{T}$ 活性が強く関与している事が判明した。 
71 子宮体癌細胞株の細胞接着分子

E-cadherinの発現と浸潤能及び細胞形態学的変 化に関する研究

\section{札幌医科大学産婦人科}

○黑木勝円 $(\mathrm{MD})$, 岡村直樹(MD), 水元久修(MD), 廖 瑛 $(\mathrm{MD})$, 藤井美穂 $(\mathrm{MD})$, 伊東英樹 $(\mathrm{MD})$ 、 工藤隆一(MD)

[目的]我々は子宮体癌細胞株を用いてinvasion assayを行い, 浸潤能とE-cadherinの発現との関係 を報告しきた。今回，E-cadherinの発現が異なる 細胞は, 光顕, 走査型電顕 (SEM), 透過型電顕 (TEM)所見でどの様な形態学的変化を示すか, ま た抗E-cadherin抗体添加により，浸潤能および形 態学的変化が認められるか否かを検討した。

[万法］高浸潤能を示しE-cadherinの発現がそし い細胞株としてNUE-1を用い，低浸潤能を示し E-cadherinの発現が著明又は中等度の細胞株とし てHEC-108，HEC-1BEを用いた。まず，これらを 培養しE-cadherinなどの免疫細胞学的検討, SEM, TEM，観察を行った。次に抗E-cadherin抗体投与 し，invasion assayを行い，その過程を主に電顕 によって観察した。

[成績] NUE-1は孤立散在性に存在する傾向が強 く，細胞間の結合性はそしかった。また不規則な 細胞表面を示し，球状に膨隆する特徽が認められ た。一方HEC-108，HEC-1BEはシート状に配列し 細胞同士が密に結合していた。そして細胞表面の 不規則性や膨隆の程度はNUE-1より著明でなかっ た。invasion assayではNUE-1はporeに偽足様突起 をのばしながら通過するのに対し，HEC-108, HEC-1BEは, poreを占拠し球状突出し通過する所 見を示した。そして，これらに抗E-cadherin抗体 を投与すると浸潤能は高まり，形態学的にも NUE-1に類似した。

[結論］子宮体癌細胞の浸潤能E-cadherinの発現 は逆相関関係であり，それぞれの細胞形態も異な ることが明らかになった。
72 吸器真菌症の 3 例

北海道大学医学部第 1 内科

○大泉咥史（MD）、小島哲弥 (MD) 、岡本佳裕 (MD) 、上村 明 (MD) 、得地令郎 (MD)、 尾島裕和（MD）、石田卓（MD）、蒲地匡文 (MD) 、花田太郎（MD）、小倉滋明（MD）、 䂺部 宏 (MD) 、川上義和 (MD)

深在性真菌症の代表である呼吸器真菌症は近年增 加傾向にあるがその祄断はいまだ困難である。今回、 我々は気管支鏡下細胞診が診断に有効であった 3 例 の肺真菌症を経験したので報告する。

（症例 1 ）19歳、女性。検診で右肺野に多発する結 節影を認め入院した。クリプトコッカス抗原が陽性 であり経気管支擦過細胞診並びに肺生検にてクリプ トコッカス菌が証明され、クリプトコッカス症と珍 断した。フルコナゾールの投与で陰影の樎小を認め た。

（症例 $2 ） 41$ 歳、男性。平成 6 年 3 月ごろから発熱、 左胸痛を認めていたが 6 月になって左上肺野に浸潤 影を指摘され入院した。入院後喀血し気管支動脈造 影を施行、慢性炎症に伴う血管增生を認め塞栓した。 止血時に施行した気管支鏡にて脤栓様物質を探取、

これより放線菌が検出され肺放線菌症と診断、ペニ シリンGの投与にて軽块した。

（症例 3 ）33藏、男性。平成 5 年 5 月に再生不良性 貿血と診断され免疫抑制剤等で治療されていた。平 成 7 年 1 月に自家骨觬移植目的に当院第 3 内科に入 院、左肺尖部に空洞を伴う浸潤影を認め同部位より の吸引練胞診にてアスペルギルスが証明され肺アス ペルギルス症と診断した。

(考察) 呼吸器真菌症は近年增加傾向である。その 背景としては化学療法の普及、AIDS等免疫不全患者 の増加が挙げられる。診断法は画像診断、血清学的 に抗原検出などがあるが確定診断は難しく、今回我々 は気管支鏡下細胞祄にて菌体の検出およひ確定部断 に至った。呼吸器真菌症が疑われた場合は積極的な 気管支鏡検査と細胞祅が有効と考えられた。 
73 肺アスペルギローマの1例

近畿大学医学部第二病理 ${ }^{1}$, 同附属病院病理部 ${ }^{2)}$

木村雅友 $(\mathrm{MD})^{1)}$, 古田朋子 $(\mathrm{MD})^{1)}$,

上杉忠雄 $(C \mathrm{C})^{2)}$, 橋本重夫 $(\mathrm{MD})^{1)}$

【はじめに】感染症における細胞診検体は一般的に 診断的価值が少ないが，真菌による感染症について は有効である. 今回われわれは細胞診でアスペルギ ルスと診断し，培養であアスペルギルスが分離され た肺アスペルギローマの1症例を報告する.

【症例】53 歳, 男性. 数日来血痰か続くため, 本 院外来を 1995 年 1 月 25 日に受診した。初彮時胸 部単純 X 線像には左肺尖後区に $45 \times 40 \mathrm{~mm}$ の結節 陰影があり，辺縁部は空洞様であった．初診時血液 検査では白血球数 $4200 / \mu \mathrm{l}$, 血沈 $5 \mathrm{~mm} / \mathrm{hr}, \mathrm{CRP}$ $0.3 \mathrm{mg} / \mathrm{d}$ 以下であり炎症所見は見られなかった．経 気管支的肺生検, 生検鉗子洗浄液細胞診とその培養 が施行された。

【細胞診所見】平面的なシート状あるいは索状に並 ぶ円柱上皮細胞や應埃細胞に混在して極めて多数の 真菌菌系塊が認められた。菌系は幅がほぼ一定で 3〜 $6 \mu \mathrm{m}$ あり, 明瞭な隔壁を有していた. またY字 状に 2 分㞳する傾向があった. 乙れらの所見からア スペルギルス感染を疑った.

【組織像】生検標本の病理組織学的検索でも細胞診 と同様の菌系塊が認められた。

【培養結果】アスペルギルスが分離された。

【考察】本症例は生検組織で真菌感染が確認され， さらに培養であアスペルギルスが分離されており， 細胞診標本中の菌系はアスペルギルスのものと信用 できる. このように信用のおける症例の細胞診標本 でアスペルギルス菌系を見慣れておくことが，アス ペルギルス症の正しい細胞診診断につながるはずで ある.

\author{
74 \\ ファンギフローラYによる菌糸の \\ 検索 \\ 近畿大学医学部第二病理 ${ }^{1)}$, 同附属病院病理部 ${ }^{2}$ \\ ○古田朋子 $(M D)^{1)}$, 木村雅友 $(M D)^{1)}$, \\ 中井由香 $(\mathrm{CT})^{2)}$, 橋本重夫 $(\mathrm{MD})^{1)}$
}

〔はじめに〕真菌を細胞診標本中に証明する事は 真菌感染症の臨床彮断の一助となるが従来のパパ ニコロー染色やライトギムザ染色での真菌の染色 性は乏しく、構造観察も難しい，また，PAS 反 応やグロコットメセナミン銀染色は時間がかかる. それに対し蛍光染色法は簡便である.

今回, ファンギフローラY (日本商事) を用いた 蛍光染色法による塗抹標本中の真菌観察を試みた.

〔方法〕培養でアスペルギルスが分離同定されて いる肺アスペルギルス症の膿汁をすり合わせ法で スライドグラス上に塗抹し，95\%エタノール固定 後ファンギフローラY液で 5 分間染色した後パパ ニコロー染色を行った．それを通常の光学顕微鏡 と蛍光顕微鏡で観察した。

〔結果〕光学顕微鏡下において菌体は無染性のむ のや，淡ライトグリーン好性のもの，あるいは淡 暗赤色染色されるものが観察された. しかし菌体 の色調は淡く、スクリーニングで菌体を検出する のはやや困難と思われた. 対照的に蛍光顕微鏡下 で観察すると典型的な 2 分枝を呈し中隔を有する アスペルギルス菌糸を容易に検出できた．

[考察〕今回試みたファンギフローラYは細胞診 標本における真菌のスクリーニングに有用である ことが分かった。ファンギフローラYは技術的に も簡便で, 菌体構造観察が容易で, しかもパパ二 コロー染色と重染色が可能で, 確実な真菌スク リーニングに有用であると思われた。 
75

肺アスペルギルス症で出現した結晶 についてー尿中ショウ酸カルシウム結晶との比較

長崎市立病院成人病センター検查部1

長崎県総合保健センター病理 2

上井 元 $(\mathrm{CT}))^{1}$ 松尾 武 $(\mathrm{MD}) \cdot 2$

〈はじめに〉ショウ酸カルシウム結晶は尿沈査に 普通に見られる物質である。アスペルギルス症の 喀痰細胞診に類似の結晶がみられることは、本邦 において数例の報告にすぎずあまり知られていな い。今回我々は糖尿病と肝障害を基礎疾患とした 患者のレントゲン像に陰影が見られ、喀痰及び擦 過細胞診に菌糸とシュウ酸カルシウム様結晶を認 めた症例を経験したので報告する。

〈症例〉 56 才、男性。糖尿病とアルコール性肝 障害で外来観察中、平成 7 年 2 月血痰を主訴とし て受診。レントゲン像右上葉に陰影。喀痰細胞診 で菌糸 (十) 結晶 (十) を認め、またその後擦過 細胞診を施行し、菌系（一）結晶 $(+)$ 。この結 果よりアスペルギルス抗体を検索したところ陽性 と判明。真菌培養検査は（一）であった。

〈細胞像〉喀痰細胞診: 好中球、組織球等を背景 に無色一淡黄色の棒状結晶が集積し束針状あるい はロゼット様を呈していた。また別の梘野には隔 壁を有する分岐した菌糸を認めた。擦過細胞診： 菌糸はみられなかったが、喀痰中と同様の結晶を おなじような形態で見る事ができた。

〈まとめ〉いくつかの報告例によれば、この結晶 が認められればアスペルギルスの存在が考えられ またtype としては、A. niger が有力であると言 われている。今回のように真菌培養検查 (一) と 報告される場合、きわめて重要な所見と考える。 尿中のショウ酸カルシウム結晶との比較について も言及する。
76 肺癌患者の喀疢細胞診における

クルシュマン螺旋体の出現状態

メスプ細胞検查研究所 ${ }^{11}$ 、

国立姫路病院研究検査科 ${ }^{2)}$ 、同内科 ${ }^{31}$

○増田敦子 (CT $)^{1)}$ 、系山光麿 $(\mathrm{CT})^{2)}$ 、三村拓郎 $(\mathrm{CT})^{2)}$ 、中原由紀子 $(\mathrm{MD})^{2)}$ 、中原保治 $(\mathrm{MD})^{3)}$ 、 桂榮孝(MD) ${ }^{2)}$.

国立姫路病院における肺癌手術症例 (平成 6 年) の喀痰細胞診のうち陰性検体 (98検体)について再 検討し、うち 3 検体にfalse negativeを認め前回 報告した。検索中、クルシュマン螺旋体が高頻度 に出現することに気付き、その出現頻度を調べた。 98検体中32検体 (32.7\%)で、dust cellを認めない 不良検体を除くと $43.2 \%$ あったた。た、細胞診陽 性検体では51検体中17検体 (33.3\%)に出現をみた。

一方、メスプ細胞検査研究所の健診症例におい ては細胞診陰性9263検体中クルシュマン螺旋体を 認めたものは95検体 (1.0\%)で、その頻度は低い。 国立姫路病院の非癌症例についても疾患別にクル シュマン螺旋体の出現状態を検討したのであわせ て報告する。

クルシュマン螺旋体は喘息患者の発作時に喀痰 中に出現することが多いといわれているが、特異 的な所見でなく、肺癌患者についての報告はない。 今回の検討で、肺癌患者の喀痰では、細胞診陽性、 陰性に関係なく、高頻度にクルシュマン螺旋体の 出現を認めた。以前からわれわれは悪性症例検体 の背景として、壊死物のほか、脂肪の出現を取り 上げてきたが、さらに、クルシュマン螺旋体の出 現も指標の1つとして注目すべきであると強調し たい。 
近幾大学医学部第二病理'，同附属病院病院病理 ${ }^{2}$ O绖間票悟 $(C T)^{3}$ ，上杉忠椎 $(C T)^{2}$ ，木村雅友 $(M D)^{1}$, 前倉俊治 $(M D)^{\prime}$, 掎本重夫 $(M D)^{\prime}$

血中G-CSF高值を示した肺大細胞癌を経駼したの で報告する. 症例)62藏男性. 平成 6 年 11 月血疼 を琶め近医受款し，胸部レ楾にて買常隆影及び白 血球增多を指摘された．情查目的で当大学病院入 院. 平成 7 年1月18日経皮肺生検にて大細胞癌と 診断された. 2 月28日左肺上葉切除術か施行され たが左胸壁への漫润した腫湟はとり切れなかった。 以後症状は改善されず5月10日永眠され病理解剖 がなされた，入院当初から好中球增多が指摘され，

5 月には $127700 / \mu$ であった. 血中G-CSF 值は 3月31日134pg/m/゙゙ちった。細胞像) 経皮肺 生検錙子洗浄液で陽性耛果であった。湅胞や核は 大きく，多形多样であった，核小体は 1 個から 数個認められ，核は類円形から棈円形であった。

一部の核は㣂在し，盷体はライトグリーンに淡染

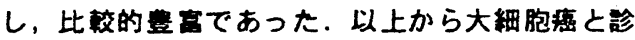
断した．背景には楼死样な部位は㒛められないが，

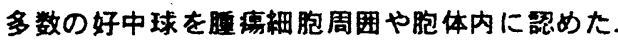

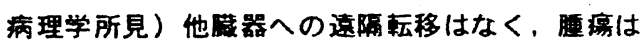

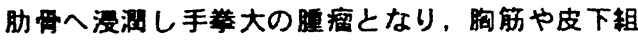

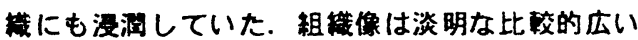
胞体と不整形で溜染する核をもち充実性，索状あ るいは一部乳頭状に增殖し価かに眿管腔の形成を

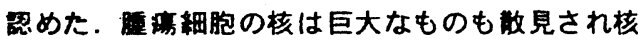
分裂像も多数認められた。腫瘄に好中球加多数漫 洞し胞体内にも琶められた. 抗G-CSF抗体を使つ た免疫染色て腫理細胞胞体か陽性であった．耛語）

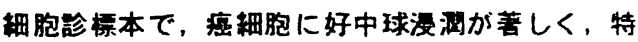
に胞体内に好中球集族を認める場合には，G-CSF

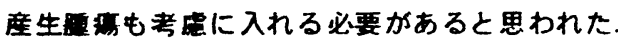

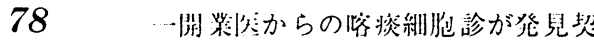

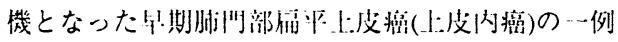

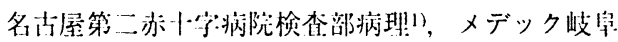
2)

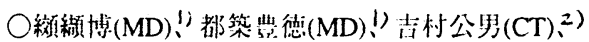
虫賀み妕 $(\mathrm{CT})^{2)}$

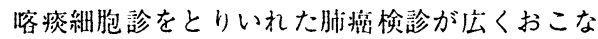
われるようになって早期肋門雇平上皮嵒の発見は 稀なものではなくなってきた。しかし第一線開業 医から送られた絊胞㟝㭘体の多くは画像診断の追 認という役割に甘んじているのが実状である。わ れわれは一開業医からの喀㾳細胞診が契機となっ て上皮内癌状態で発見された早期䏫門扁平上.疗癌 を経験したので報告し、緗胞診の再検討と受診か ら病巣確定に至る経絁を検証した。

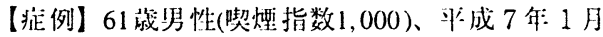
感冒症状で近医を受㟝し喀痰細胞部で疑彰とされ、 精査目的で当院に紹介され 2 月TBLBで右B6に履平 上皮癌が発見された。４月右肺全摘術が施行され た。組織学的検索でB6に径 $10 \mathrm{~mm}$ 以内の府平上皮癌 （上皮内嵒）が確認され、近傍に気管支異形成を 認めた。

3 回の喀掞細胞診は判定がいずれも疑陽性であ った。各標本には少数の、変性した比較的小型の 好橙色角化倾向を示す細胞質と濃縮不整核を有す る細胞が出現していた。これらはレトロスペクテ イブには確診も可能と思われた。

上皮内癌発見の経過には種々の幸连というべき

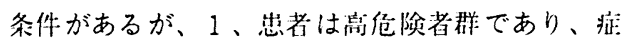
状所見の有無にかかわらず喀掞細胞診検查対象で あった。2、紐胞診判定は疑診であったが、3回 シリーズで出ており精查に呬るに十分である。精 查担当医は将状、画像上無所見にもかかわらず気 管支鏡検查を施行し、成書に記载された早期瓶像 との違和を感じっつも唯一のの有所見部粘膜発赤か ら生:検材料を採取し、㿋が検出されたこと。強調 したい。 
79 喀痰中に無数の類澱粉小体を認めた 1 例

東京都済生会中央病院 1 病理科, 2 臨床検查科, 3 内科 ○森永正二郎 (MD) 1,2 , 降幡雅子 (C T ) 2 , 河野 健史 (C T) 2 , 小林龍一郎 (MD) 3

類港粉小体は細胞診検体においては前立腺由来のも のを認めることはあるが、喀痰中に多数認めること はまれである．極めて多数の類澱粉小体を路痰中に 繰り返し認めた症例を経験したので報告する。

症例は 54 才女性で、1 0 年前より気管支喘息があ る。 1 年前より胸部レ線上びまん性陰影が指摘され ていたが、今回気胸のため緊急入院した。右気胸に 対して持続吸引を行ったところ軽快した，両側肺尖 部に多発性のブラを認めたため、再発予防のため胸 膜癒着術を施行し、以後外来で経過観察中である.

入院 5 日目に採取された喀痰細胞診標本に、扁平上 皮化生細胞、円柱上皮細胞、組織球などの他にライ トグリーンないしへマトキシリンに染まる直径 10 〜 40 ミクロンの小球状の物質を無数に認めた. は じめクリプトコッカスを疑ったが、グロコット染色 で明暸な陽性像が得られず、臨床的にもそれを疑わ せる所見は得えられなかった。この球状物質は内部 に年輪様構造を持つものが見られることから、類澱 粉小体と考えた。約 3 力月間に 4 回の喀痰細胞診が 行なわれたが、毎回この物質は認められた。始めは 小型のものが主体であったが、後に大型のものが主 体となり、また、へマトキシリンに濃染するもの、 放射状の亀裂の入るものが多く見られた.

肺の類澱粉症体は肺胞腔内分泌物の濃縮により生じ ると考えられており、肺気腫、うっ血水腫、無気肺、 肺炎などで見られることが知られている．しかし、 喀痰中の出現頻度や病的意義は明らかでない.今回 喀痰で認めたものは数が極めて多いうえに一般にい われているものより小型のものが主体であったため に、診断が困難であった。
80

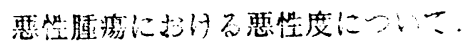

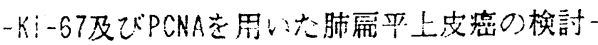

北海道大学医学部附属病院病理部”，北海道大 学医学部内秘学筮...諽座 ${ }^{2}$.

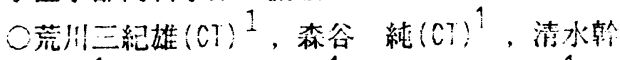
雄 $(C T)^{1}$ ，遠藤隆志(CT $)^{1}$ ，鈴木宏炽 $(M D)^{1}$ ， 藤四美俐(MD) ${ }^{1}$, 井上和秋 $(M D)^{1}$, 喽部 宏 $(N$

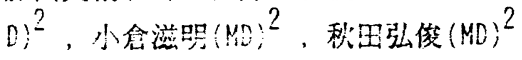

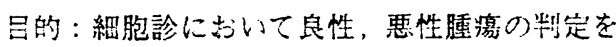

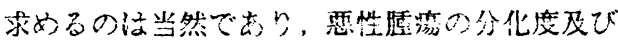

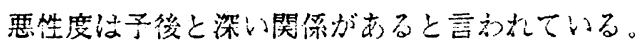

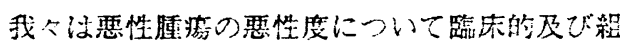
織学的検討と平行して細胞診の分野でも検傠し ている。近年，繹胞診での㦈殖能，予後の推完 のために免疫組織化学的方法を用いた検討が数

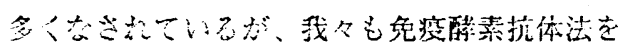
一つの方法として梌索している。今回，肺䛓严

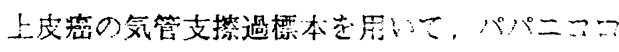
一染色脱染色後Ki-67 及びPCNAにより㤠性度を 検討したので埌告する。

対象及び方法: 肺扁平上皮癌症例22例の氛管支

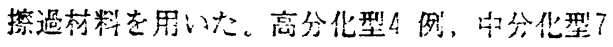

例，低分化型11例である。パパニュロー染筧! た娭体を脱色した该，マソクロウエーブ30分畎 処理を行一た。イムノテック社製のMIB-1 挖体

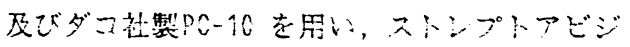
ンービオホン法で染色した。

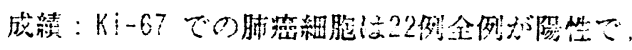
分化度別の陽性率は高分化型!例の平均発現個

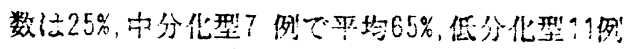
で产均72\%であのた。中分化型に低分化型の間

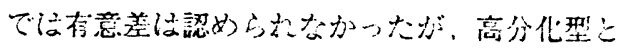

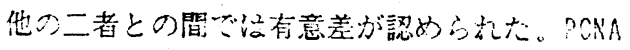

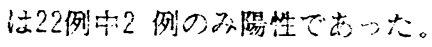


81 喀次材料からのk-ras点突然変暴

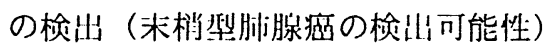

東京医科大学外科第一譛座

○中嶋英治 (MD)、清水恵理子 (MD)、嘉 村哲郎（MD）、池田徳彦 (MD)、岩淵 裕 (MD)、平野隆 (MD)、晟藤 '誠 (MD)、 中村治彦 (MD)、小中千守 (MD) 、加藤治 文 (MD)、海老原善郎 (MD)

従来の形態学にもとづいた喀痰細胞診は 中心型早期肺㿋の発見には最も有力な方法 である。しかし、未梢型小型腺癌での隰性 率は低く、太い気管支が関与するまで陽性 細胞を榆出することは困難であった。今回 MASA 法 (Mutant-Allele Specific Amplification method）を用いた喀痰材 料で、 $k$-rasの点突然変異を同定することに よって、高率に未梢型肺腺癌症例を検出し 得たので報告する。

[材料および方法］入院時無治療の原発性 肺癌患者15例（扁平上皮癌7例、腺癌6例、 腺扁平上皮癌 1 例、腺様囊胞癌 1 例）を対象 とした。喀痰は 3 日間蓄痰し、アルコール 固定した材料を用い、MASA法にて、k-ras 遗伝子codon 12 の 1st letterおよび2nd letterの点突然変異の検出を行った。 結果を下記の表に示す。

\begin{tabular}{|c|c|c|c|}
\hline & 症例数 & 1st letter & 2nd letter \\
\hline 扁平上皮㳑 & 7例 & 1例 $(14 \%)$ & 0例 $(0 \%)$ \\
\hline 腺癌 & 6例 & 5 例 (83\%) & 1例（17\%） \\
\hline 腺扁平上皮癌 & 1 例 & 例 (1 $00 \%)$ & 0例 (0\%) \\
\hline 腺様翼胞癌 & 1例 & O例 $(0 \%)$ & 0例 $(0 \%)$ \\
\hline
\end{tabular}

点突然変異を認めた7例は全て末梢型肺癌 であった。原発性腺癌症例で非常に高率に 点突然変異を認めた。点突然変異を認めた 5 例中4例は病理病期 I 期であった。摘出材料 より得られた結果も合わせ報告する。
82 原発性肺癌患者における気管支肺胞 洗浄夜中のテロメアーゼ活性についての検討

畦阜県厚生連蚑北総合病院内科 ${ }^{11}$ 、夙病理 ${ }^{21}$ 岐皁大学医学部病理学第一詊座 ${ }^{3)}$

○新井 正 $^{\prime \prime}(M D) 、$ 吉見直已 ${ }^{3)}$ (MD)、高屋忠 $丈^{1)}(\mathrm{MD}) 、$ 伊東祐二 ${ }^{1)}(\mathrm{MD}) 、$ 早川和良 ${ }^{1)}$ (MD) 、戸島 敏 ${ }^{2)}(\mathrm{CT}, \mathrm{IAC}) 、$ 安田 洋 ${ }^{1)}$ (MD)

近年染色体末端に存在するテロメアに関心が 寄せられている。テロメアは細胞の寿命と関 係があり、細胞の不死化に関与すると言われ ている。テロメアーゼはテロメアを合成する 鋳型RNAを持つた逆転写酵素であるが、最近 polymerase chain reaction(PCR)を用いた高 感度のTRAPassay(telometric repeat amplificationprotocol assay)が考案され、それ によりその活性の有無が腫㷎において測定さ れ、悪性化に関与することが報告されている 。今回我々はTRAPassayにより、テロメアー ゼ活性を原発性肺癌患者6例(扁平上皮癌3例、 腺癌3例)の気管支肺胞洗浄夜で検討した。TR APassayはKimらの方法に従い蛋白抽出を行な つた後PCRにて増愊した。その結果扁平上皮 癌 2 例、腺癌1例でテロメアーゼ活性が認めら れた。䠛床面でのテロメアーゼ活性の検討に ついては報告が少なく、その嵒床的意義は今 後の検討が必要と思われた。 
83 肺癌細胞の染色体異数性一FISH法 による組織標本と細胞診標本との相関一

防衛医科大学校病理学第一講座 O広井禎之 (CT), 河合俊明 (MD), 鳥潟親雄 (MD)

目的 : 悪性腫瘍細胞の多くに染色体異常の認 められることが知られており、各種染色体に 対するプローブを用いたFISH (fluorescece in situ hybridization）による、腫瘍細胞の 染色体異数性など、多くの報告がみられる。 今回我々は肺癌細胞の染色体異数性検索にお いて、組織切片と腫場捺印細胞診標本との相 関を目的とし、17番染色体DNAプローブを用い たFISH法により、染色体シグナル数を娭討し た。

材料及び方法: 肺癌 8 例（扁平上皮癌 1 例、 腺癌 4 例、小細胞癌 1 例、大細胞癌 2 例）の $10 \mu$ の新鮮凍結切片と腫崵捺印細胞診標本を 使用した。FISH法はジゴキシゲニン化17番染 色体 $\alpha$ satellite probe(Oncor)を用いた。八 イブリダイゼーション後ローダミン標識抗ジ ゴキシゲニン抗体と抗原抗体反応を行ない、 DAPIにて後染色した。染色体シグナル数は蛍 光顕徽鏡（オリンパス）にて鏡検し腫堭細胞 100個以上をカウントした。異数性の評価は 1 個 (monosomy)、2 個 (disomy)の及び 3 個 (trisomy)以上の細胞をカウントし、それぞれ の割合を百分率で表し、組織標本と細胞診標 本との相関を検討した。

結果 : monosomyでは組織と細胞診標本との相 関係数は $\mathrm{r}=0.98$ 、 disomy で0.91、trisomy以 上では0.98を示した。

結論 : 肺癌細胞においてFISH法による染色体 異数性の検討では、組織標本と細胞診標本で は相関の傾向を示した。
84 判定 [C]における扁平上皮系細胞像 の解析

東京都予防医学協会細胞診断科 ${ }^{11}$,

名古屋第二赤十字病院検査部 ${ }^{2)}$

○杉山田隆男 (CT $)^{11}$, 神谷昭子 (CT $)^{11}$,

野口美果 $(\mathrm{CT})^{11}$ ，坂本美穂 $(\mathrm{CT})^{11}$ ，

松山さとみ $(\mathrm{CT})^{11}$, 山田美佳 $(\mathrm{CT})^{11}$,

䋶纈博 (MD) ${ }^{21}$

肺門部早期肺がんの発見のために喀痰細胞診検 査は早期癌例の細胞のなかでatypiaの乏しい細胞 所見を把握し (D・E)判定として精査の対象とし日 常診断業務において大いにその価値を発揮してい る。さらに前段階での異型細胞を検出する努力が 成されている。しかし、(C) 判定の細胞所見が客観 性に乏しく、また、過大評価を避けるため (C) 判 定の細胞所見、criteriaの標準化を目的とし的確 な診断を行なうために光顕的検討を試みた。

対象は、集細胞法によりPa染色を施した判定 (C) について、陰性例は、5年以上経過しとくに異常を 認めないもの55例、陽性例は確定前 3 年以内とし て45例、計100 例を再 checkしatypiaのある細胞 を各標本から最大 8箇所を選択した。3年以上の 有資格者全員に判定を依頼し結果を知っていると 少なからず影響を受けると考えられるため先入観 を無くすためブラインドとした。細胞の出現様式 を陰性のみ（I群）、陰性・陽性共通（II群）、 陽性のみ（III群）に分類しそれらの細胞像につい て比較検討を試みたので報告する。 
京都桂病院検査科、同呼吸器センター・

国立療養所紫香楽病院 ${ }^{3}$

○豊山浩祥 (CT) '、小山 賢 (CT) 、 長谷川和彦 (CT) !、米村哲朗 (CT) 、 賀勧一平 (MD) '、安田雄闹 (MD): 俳藤元彦 (MD) ${ }^{3}$

我々は、忢性を疑う胸部異常陰影に対し、喀痰 や気管支鏡検查で確定診断の得られなかった症例 にはCTガイド下肺穿制吸引細胞診（以下CT下穿刺） を行ってきた。

今回、当院における過去 3 年間のCT下穿刺の成績 を検討したので報告する。

【対象および方法】

対象は1993年1月から1995年12月までの3年間に 施行したCT下穿刺のうち、確定診断の得られた悪 性病変15例、良性病変23例の計 38例である。方法 はCTにより病変の位置を確認後、針を刺入し、針 先端が病変内あることを撮影後、吸引㳂抹した。 穿刺針は22Gのスパイナル針を使用した。

【絬果】

\begin{tabular}{|c|c|c|c|c|c|c|}
\hline & $(-)$ & \multicolumn{3}{|c|}{ 組 織 診 } & 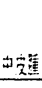 \\
\hline & $(-)$ & 23 & 1 & 1 & & \\
\hline 紐 & Ad & & 4 & & & \\
\hline 胞 & $\mathrm{Sq}$ & & & 5 & & \\
\hline 診 & $\mathrm{La}$ & & 1 & & 1 & 1 \\
\hline & Sm & & 1 & & & \\
\hline
\end{tabular}

細胞診、組䋨診ともに㓌性例は結核が11例と半 数を占めていた。その他肺化膿症や胸膜炎、クリ プトコッカス症などもみられた。細胞診偽㓌性染 は5.3\%（ $\mathrm{Ad} 、 \mathrm{Sq}$ 各1例）でいずれも細胞採取不良 が原因であった。良惡性の細胞診正診率は93.3\%、 悪性の組織型一致率は80.0\%であり、CT下穿刺は 有用な榆查法である。
北海道対がん協会旭川がん検診センター O安孫子光春 (CT) ·中山 仁 (CT) ·石田 徹 (CT) 国立療帣所道北病院内科 过 忠克 (MD) - 藤田結花 (MD) - 橋爪弘敬 (MD) 松本博之 (MD) ·藤兼俊明 (MD) ·清水哲雄 (MD)

当施設では老人保健法に基づき、肺鷹検診を実施 している。喀痰細胞診は判定基準を確立するのが難 しく、1991年に当施設の過去の細胞診成績をもとに 判定基準を再検討した。その結果、B判定で扁平上 皮㾤と諺断された中には、N/C比が軽度以上に增 加し、細胞留の肥厚又は、軽度な核形不整を示す細 胞を認める例が多かった為、この様な細胞はC判定 とし、C判定で屏平上皮虞と診断された例では比较 的細胞の異型が強い例が多く、この様な細胞は積極 的にD判定とする判定基準の見直しを行った。

この判定基準により実施した、1991年から1994年 までの肺癌検診の成績について報告する。 総受診数はのべ87, 025人で、 12,716 人 (14.6\%)に喀 痰細胞影を実施した。有効検体率は99.9\%であった。

$C$ 判定 450 人 (3. $5 \%$ ) - D 判定18人 (0.14\%) - E 判定 15 人( $0.12 \%)$ であった。肺癌は合計21人でC判定4人 (19.0\%) - D 判定8人 (38.1\%) - E判定9人 (42.9\%) であ

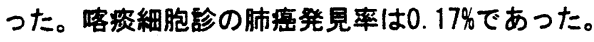
臨床病期が0期又は、I 期の早期度は14人 (66.7\%) 胸部X線撮影無所胃は13人 $(61.9 \%)$ であった。

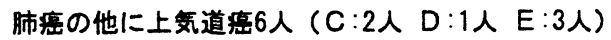

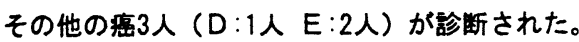

C判定は喀痰の再検查を実施し、再びCと判定さ れた96人 (21.3\%)のうち、64人に全気管支擦過を含む 気管支鏡検㚗が实施され、4人の肺癌が発見された。 C判定が3.5\%なのは、他施設に比较し高率であるが、 喀痰細胞診の再検查は比较的容易であり、C判定を 緣り返す例には、積極的に気管支鏡検查筹の精密検 査を実施する事が必要と思われた。

検診における陽性的中率の向上は重要である為、 判定基準について更に検討が必要と思われた。 
87 当院における気管支洗浄紐胞診の評価 気管支擦過練胞診との対比を中心に

山梨医科大学附属病院検查部 ${ }^{1}$ 、同第二内科 ${ }^{21}$ 、 同病理 ${ }^{3)}$ 、順天堂大学第 1 病理 ${ }^{4)}$

O石井喜雄 $(\mathrm{CT})^{11}$ 、中澤久美子 (CT) ${ }^{11}$ 、弓納持勉 (CT) " 1 、早川直美 (CT) " 、久米章司 (MD) " 、西川 圭一 $(\mathrm{MD})^{2)}$ 、小澤克良 $(\mathrm{MD})^{2)}$ 、加藤良平 $(\mathrm{MD})^{3)}$ 須田耕一(MD) ${ }^{4)}$

【目的】末梢型を中心とした肺癌における気管支 洗浄練胞診 (BW) 成績を、擦過練胞診 (BB) 成績と比 較検討した。【対象および方法】対象は、1988年 から1995年までにBWおよびBBの両法が施行され、 病理組織学的に肺䄸と診断された124例である。 症例別内訳は扁平上皮被29例、腺䖽74例、小細胞 演10例、その他悪性腫場11例である。BW法は生検 鈷子、BBの洗净被および気管支肺胞洗浄液を一括 した洗浄液を対象とした。【結果および考察】結 果は表に示すように、両法陽性 (Class NおよびV) の一致率は、124例中81例 (65.3\%) であり、BN法の み陽性が11例、BB法のみ陽性が 9 例であった。ま た、両法ともに陰性もしくは疑陽性 (Class $\mathbb{1}$ 以下) は124例中23例であった。このうち13例は、同時 に行なわれた組織生検で腫場組織が採取されてい るにも関わらず、Class 罱以下であったが、睡場 の組織型等との関連性は明確ではなかった。

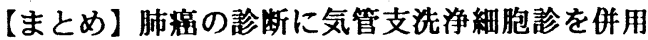
することにより、診断率の向上が期待できるもの と思われた。

\begin{tabular}{|c|c|c|c|c|}
\hline$\overline{B B}$ & II & II & TV & $\mathrm{V}$ \\
\hline & & & & \\
\hline I & $17(13.7) 2(1.6)$ & $1(0.8)$ & $1(0.8)$ & $5(4.0)$ \\
\hline I & 0 & 0 & 0 & $1(0.8)$ \\
\hline III & $1(0,8) 0$ & $2(1,6)$ & 0 & $2(1.6)$ \\
\hline N & $1(0.8)$ & 0 & $2 \pi 15$ & 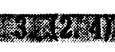 \\
\hline $\mathrm{V}$ & $3 \quad(2.4) 2(1.6)$ & $5(4.0)$ & O & 46701231 \\
\hline
\end{tabular}

（）内は\%
88 将来的な喀痰検診のシュミレーショ ン；ハイリスク群を中心として

東京医大外科 1 講座、British Columbia Cancer Research Centre

池田徳彦(MD), 勝海東一郎(MD), 金 慶 一(MD), 清水恵理子(MD), 嘉村哲郎(MD), 柴 沼弘行(MD), 平野隆(MD), 中村治彦(MD), 斉藤 誠(MD), 小中千守(MD), 加藤治文(MD), Calum MacAulay(PhD), Stephen Lam(MD), Branko Palcic(PhD)

肺癌死亡率の増加の原因は肺癌発生の増加 と発見の遅延が考えられる。肺癌制圧の条件 は早期癌の発見である。喀痰細胞診は中心型 早期肺癌発見に不可欠の手段であるが、偽陰 性の症例も存在する。また、喀痰細胞診で異 型細胞が得られても、その病巣の局在診断が 困難な場合がある。喀痰細胞診をより精密な 検査とするための我々は以下のことを試みて いる。

1）細胞診自動計測器：技師、医師の負担 を軽減するため有用と考える。

2) Malignancy Associated Changes (MAC) $の$ 応用：MACとは悪性腫瘍を有する患者の正 常部位の細胞は、正常者の正常細胞とは光顕 レベルでは鑑別不可能なわずかな形態の差が 存在するという概念である。High Resolution Image Cytometryを用いた気管支擦過材料の 検討では、肺癌症例の正常部位の細胞のみの 解析により、70\%以上の精度で癌の存在を示 唆しえた。本概念の導入により偽陰性症例を 減少させることが可能と考える。

3）蛍光内視鏡：通常の気管支鏡と併用す ることにより異型化生病巣の診断率を $40 \%$ 程 度向上させることが可能であった。これによ り局在診断の困難な症例を減少させうると考 える。

上記の手法を統合することにより、喀痰細 胞診、特に高危険度群に対する検査の質の向 上が期待しうる。 


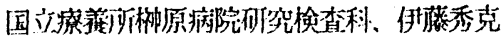

(CT) 、厚生速松阪訓央病院䛲床病理科。

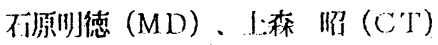

小川英记 $(\mathrm{C} T)$

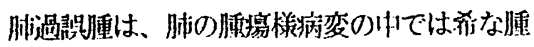

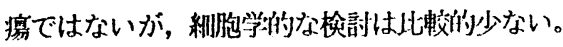

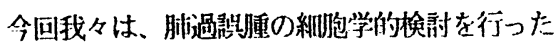
ので報告する。

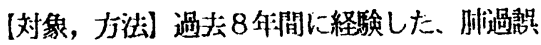
腫了例の腫病摘出標本の直接擦過法で挨討した。

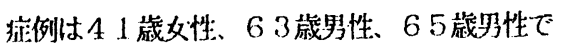

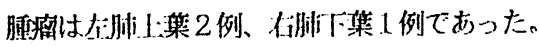

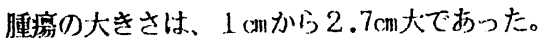
擦䢙楞本はパパニコ山染色、メイギムザ染色. $P \Lambda S$ 染色を行い、電㩆標本を作制し桧討した。

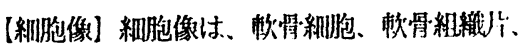

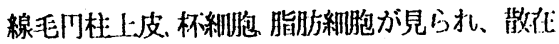

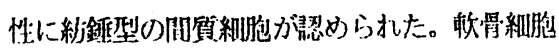
はライトクリリーン好染性で、P $\Lambda$ S染色では強 陽性に染まり、パパニコロ染色、メイギムザ染 色ではメタクロマジーが楒的机た。

【組糡像】3例とも定型的と思われる肺门軟骨

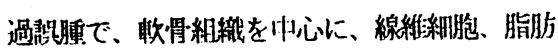
糿胞が混在し、腺管形成吉示す線毛付上皮が 恋められた。

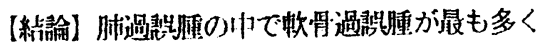
我々が秝験した 3 例も全て杴骬過䛇腫であった

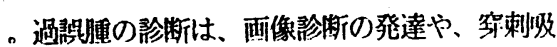
引粗胞彰の発達により比挍的容易になりつつあ るが、細訜採取が少ない場命には、診断方困難 になる。我々は衒叫迅速猃断を確実にするため に摘川標本の直接擦通法を取り入れ、組䄉診䉼と 作せて崄䉼に役玄ている。
岡谷塩巊病院 病理", 同外科 ${ }^{2)}$

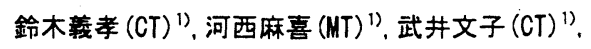
小林克 $(M D)^{22}$, 花村 直 ${ }^{2}$, 関龍幸 $(M D)^{22}$

長野県がん検診救急センター。

石井恵子, 土屋是一

【はじめに】細胞形態および組織化学的に胃粘膜 上皮に類似した肺腺癌を本多らは胃型肺癌と提唱 し報告している. 今回われわれは, 粘液産生性肺 腺癌の組織切片に対し, 胃粘膜上皮に特異性の高 いGOS (Galactose oxydase Schiff) 染色および C ○ n A (Concanavalin A paradox) 染色を施行検 討し，その細胞像についても供覧する.

【対象および方法】当院肺癌手術例中AB-PAS染色 にて陽性を示した, 粘液産生性肺腺癌17例と剖検 例 1 例を加えた18例の組織切片にGOS染色およ びC。n A染色を施行し，その一方あるいは両者 が陽性を示した 6 例を検討した.

【結果】上記胃型肺癌と考えられた 6 例は全て高 円柱状細胞よりなる高分化型の粘液産生性肺腺癌 であった。このうち3例は胸膜陥入像・中心部線 維化が認められず既存の肺胞壁に沿って增殖を示 す肺胞上皮癌の典型例であり，そのうちの2 例は GOSおよびC。n A 染色の両者が陽性を示す嘼 型肺癌の典型例でもあった．また他の非典型例 3 例でも腫瘍辺縁では肺胞上皮癌様の進展形式を示 していた.

【まとめ】円柱状細胞よりなる高分化型粘液産生 性肺腺癌, 特に杯細胞型肺腺癌の多くは形態学的 にも粘液組織化学的にも胃粘膜様の分化を示して いた.これら胃型肺癌は臨床的にも肺炎などとの 鑑別が必要な像を示すことが多いと思われ，また 細胞診断上でも異型が弱く良性細胞との鑑別困難 な細胞像を示す場合が多いため, 置型肺癌の存在 を念頭におき注意深い钼察および診断が必要と考 えられた. 
91 腫瘍径 $1.5 \mathrm{~cm}$ 以下小型肺腺癌の 細胞所見について

大阪府立成人病センター 調査部 ${ }^{11}$ 、第 4 内科 2)、細胞診断科 ${ }^{3)}$

○中山富雄 $(M D)^{11}$ 、船越俊幹 $(M D)^{21}$ 、成瀬靖 悦 $(C T)^{3)}$ 中村慎一郎 $(M D)^{21}$ 、宝来 威 $(M D)^{21}$ 、

近年胸部 CT の普及に伴い、肺野末梢の小型 腺癌が発見される機会が増え、肺腺癌のごく初 期の形態が明らかにされつつある。今回我々は、 腫瘍径 $1.5 \mathrm{~cm}$ 以下の小型肺腺癌の細胞所見につ いて検討したので報告する。

【対象】1993 年 1 月から 1995 年末までに当院 で切除された腫瘍径 $1.5 \mathrm{~cm}$ 以下の末梢型肺腺癌 15 例について検討した。

【結果】対象とした 15 例の平均腫瘍径は $12.8 \mathrm{~mm}$ (最小 $8 \mathrm{~mm}$ )であった。術前に細胞診で 確定診断が可能であったのは $12 / 15$ 例（経皮 的肺穿刺 11 例、TVブラッシュ 1 例) で、残り 3 例は試験開胸や胸腔鏡下の穿刺細胞診にて術 中に診断された。 $9 / 15$ 例は II 型肺胞上皮由来 と考えられるもので、異型の弱い小型の細胞が 平面的な配列を示し、小さな腺腔を形成してい た。また核は比較的中心に位置し、類円型、円 滑なものが多く、N/C 比も高いものが多かった。 炎症等に見られる II 型肺胞上皮の腺腫様增生 とは、核間距離の不均等、核の大小不同性など で鑑別可能であるが、採取細胞量が少ない場合 は鑑別は必ずしも容易ではない。画像診断など の臨床情報も含めた総合的判定が必要である。
92

眠野型肺癌切除例の検討

国立療養所東京病院呼吸器外科 ${ }^{11}$ 、、同病理 ${ }^{21}$ 、 同呼吸器内科 ${ }^{3)}$ 、国立療養所肺癌研究会

O小松彦太郎 (MD) ${ }^{11}$ 、宮島邦治 (MD) ${ }^{1)}$ 、 田島紹吉 $(C T)^{2)}$ 、沾木康雄 $(\mathrm{MT})^{2)}$ 、蛇 沢晶 (MD) ${ }^{2)}$ 、田村厚久 (MD) ${ }^{3)}$

眠癌切除例を対象に肺野型の扁平上皮癌 $(\mathrm{Sq})$ と腺瘭 (AD) を比較検討した。

[対象および方法］一般臨床所見は国立療養所 肺癌研究会の肺癌切除例約5000例を用い、細胞 生物学的検討は、国立療養所東京病院の肺癌切 除例190例を用いた。細胞生物学的な検討には分 化度、細胞異型（面積、核不整度）、PCNAおよ びp53発現率、血管漫襲、DNA-P10idyを用いた。

[結果］眠癌切除例における発生部位では肺門 型/肺野型 $=1 / 4$ と肺野型が多く、高龄者（75瓷 以上）では $1 / 5$ とこの傾向が強い。組織型は全体 ではADが多いが、高龄者の肺野型でSqの割合が 多い。切除例の予後を見ると肺野型ではSqの方 がAdより悪い。この㑯向は絶対的治痃切除例 (AC) でも同様である。肺野型のSqはADに比較 し、1）分化度が低い（全例およびAC例でP<0.01） 2)細胞異型が強い（全例でP<0.05）3）PCNA発現 率が25\%以上の割合が多い（AC例でP<0.01） 4) p53発現率が10\%以上の割合が多い（AC例で P <0.05）5）根治度、血管漫䘫、DNA-Ploidyでは 差が見られない。

[まとめ] 肺野型のSqはADに比較し悪性の傾向 が強い可能性がある。とくに高龄者で肺野型の Sqが多いことからさらに詳細な検討が必要であ る。 
93 肺粘表皮癌切除例の細胞像に関する検討

千葉大学垁学部肺癌研究施設外科 ${ }^{11}$ 同病理 ${ }^{21}$ 同附属 陃院流理部 ${ }^{31}$

光永伸一郎(MD) ${ }^{1}$ 、柴光年 $(M D)^{1}$ 、山口豊 $(M D)^{11}$ 、馬場 雅行 $(\mathrm{MD})^{1}$ 、横井左奈 $(\mathrm{MD})^{1}$ 、渋谷橴 $(\mathrm{MD})^{1}$ 、高野浩昌 $(\mathrm{MD})^{2)}$ 、展島健二(MD) ${ }^{2)}$ 、堀内文男 $(C T)^{3)}$ 、大椙二 $(\mathrm{C}$ $\mathrm{T})^{3)}$ 、佐藤卓美 $(C T)^{3)}$

肺粘表皮㿉は全肺癌の約 $0.2 \%$ 占める希な腫瘍で、多 くは中枢気道に発生するlow grade malignancy と考えら れている。しかし臨床的、病理学的に悪性度の高い症例に 関しては、その定義と腺扁平上皮癌との鑑別が議論されて きた。われわれは過去 10 年間に切除され、病理組織学的 に肺粘表皮癌と診断された 5 症例の細胞像について検討 した。

【症例】5 例中 2 例は中枢気管支発生のlow grade tuma で、それぞれ術後2y7mおよび8 6 再発なく生存中である。 他の3 例は末梢気管支ないし肺末梢発生で、うち2例は術 後 $1 \mathrm{y} 3 \mathrm{~m}, 5 \mathrm{~m}$ で再発死亡している。

【紼胞像】中枢発生の2 例はどちらも平面的な配列を示す $\mathrm{R}$ 類円〜稜形の胞体を有する腫㿇練胞で、細胞質はやや厚 みがあるものやレース状で粘液空胞が認められるものも あった。N/C比は比較的小さく、クロマチンはやや増量し ており、核内空胞が目立った。1例では好酸性の円形核小 体を1個認めたが、他例では核小体は目立たなかった。ど ちらも全体としては異型性は軽度であった。一方再発した 2例は平面的な配列を示し、細胞質は厚く境界明瞭で、粘 液空胞が認められた。核は大型不整型で偏在傾向を有し、 大小不同が目立った。他の一例む強い異型性を示し、低分 化腺癌之扁平上皮癌が混在した様な細胞所見を示した。 たこの5例中OG陽性の明らかな角化所見を示した症例 はなかった。

【まとめ】中枢気道発生症例は腫堭細胞は小型で異型も弱 く、粘表皮㿔として典型的な細胞像を示したが、末梢発生 例では強い細胞異型を認め、細胞像では腺扁平上皮癌との 鑑別は困難であった。
94 卵巣癌における子宮内膜細胞診陽性 症例の検討

兵庫県立成人病センター産婦人科 ${ }^{1 ;}$ 、同 検查部 病理細胞診室 ${ }^{2 ;}$

○山崎正明 (MD) ${ }^{1}$ '、北川勝 (MD $)^{1}$ '、東田太郎 (MD) ${ }^{1)}$ 、西村隆一郎 $(M D)^{1}$ 、 、大津文子 $(M D)^{1}$ 、長谷川

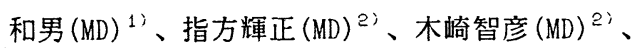
高橋満智子 $(\mathrm{CT})^{2)}$

（目的）卵巣癌症例において、治療前の子宮内膜 細胞診から癌細胞が検出される場合があることは すでに指摘されている。そこで今回我々は当施設 での治療例を対象として卵巣癌の診断における子 宮内膜細胞診の有用性について検討を行った。

（方法）対象は1990-94年の間に治療を行った卵 巣癌 57 例で、細胞診標本の採取はエンドサーチあ るいはエンドサイト法によった。(結果) 対象症 例 57 例の進行期別の内膜細胞診陽性率は I 、II 期 の31例では陽性例は 1 例むなく(0\%)、III期では 26 \%(6/23)、IV期では33\%(1/3)に陽性例が認められ、 進行例となるほど陽性率は高率となる傾向が認め られた。次に陽性例の組織型の内訳では漿液性腺 癌 3 例、類内膜腺癌 1 例、明細胞腺癌 2 例、未分化 癌1例で特に組織型との関連性はなかった。また 陽性例のうち内膜生検です癌組織が検出されたす のも3例認められた。一方、陽性例の手術時開腹 所見との関係をみると、7例中 5 例に $500 \sim 4750 \mathrm{ml}$ の腹水貯留を認め、腹水細胞診む全例で陽性を示 した。他の2例では腹水はみられなかったものの、 腹腔洗浄細胞診は2例とも陽性であった。さらに これら7例中6例では肉眼的に明らかな子宮浸潤が 認められ、その内4例はprimaryに摘出不能であっ た。しかし摘出可能であった2例の術後組織所見 は子宮筋層への直接浸潤が認められたが、内膜面 への露出はみられなかった。(結論) 卵巣癌症例 における子宮内膜細胞診は、その治療前の確定診 断のみならず進行度の推定にす有用であると考え られた。 
95 卵巣癌患者における子宮内膜細胞の 意義

鳥取大学医学部産科婦人科

岡田誠(MD), 程修司(MD), 板持広明(MD), 入江隆 $(\mathrm{MD})$, 皆川幸久 $(\mathrm{MD})$, 紀川純三( $\mathrm{MD})$, 寺川直樹(MD)

[目的] 卵巣癌患者における子宮内膜細胞診の意 義を知ることを本研究の目的とした．

[方法]卵巣癌28症例を研究対象とした. 対象の FIGO進行期は，Ia期4例，Ic期5例，III a 期 1 例, IIIb期1例，IIIc期 17例であり，組織型は，漿液性 腺癌 17 例, 粘液性腺癌 5 例, 明細胞癌 2 例, 類内 膜腺癌2例, 卵黄要腫瘍2例であった，子宮胵部と 内膜, 術中に腹水または腹腔洗浄液の細胞を採取 し, 細胞猃標本で悪性細胞の出現率を調へるとと もに, 内膜細胞診における卵巣悪性細胞の出現様 式について検討した.

[結果] 腹水細胞診は 20 例 $(71.4 \%) て ゙$, 洗浄細胞 診は2例(7.1\%)で陽性であった，卵巣悪性細胞は， 内膜細胞診では5例(17.9\%)にみられたが, 子宮腟 部細胞䛦では1例(3.6\%)にのみ検出された。これ ら5例の症例は，すへて腹水細胞䛦陽性であった。 内膜細胞診の所見では，正常内膜細胞の集塊中に 悪性細胞の小集塊が散在することや中皮細胞の存 在などから, 内膜癌との鑑別は可能であった.

[結論]子宮内膜細胞診で卯巣癌細胞が検出され たのは腹水細胞診陽性例の $25 \%$ であったことから， 卵巣癌患者における内膜細胞診の限界が示唆され た。
96 卵巣明細胞腺癌におりる腹腔内細胞 診と子宮腔内吸引細胞診所見の検討

北里大学医学部産婦人科、同医療衛生学部臨床細 胞*

O今井愛(ND), 上坊敏子(MD), 秦 宏樹(MD), 岩谷弘明( MD), 立岡和弘( MD), 新井正秀(ND), 金井督之(ND)，蔵本博行(ID)，西島正博(MD)， 大野英治 $(\mathrm{CT}) *$

卵巣明細胞腺澏は、その特徽的な組織所見を反 映した細胞所見が知られている。腹水細胞診陽性 率が高く、臨床的には抗癌剂に対する感受性が低 く予後が悪い腫瘍とされている。卵巣明細胞腺癌 45例における腹腔内細胞診所見と子宮腔内吸引細 胞診所見および予後との関連について検討し報告 する。1971年から1995年までに初回治療を行った 表層上皮性卵单悪性腫瘍 333 例に対し、明細胞腺 癌45例は13.6\% を占めていた。I 期30例（66.7\%）、 II 期 7 例（15.6\%）、III期 7 例（15.6\%）、IV期 1 例 (2. 2x) と進行期からみると早期症例の占める頻度 が高かった。腹水眝留を24例（53.3\%）に認め、I 期16例（53.3\%)、III 期 1 例 (14.3\%)、III期 6 例（ 85. 7\%)、IV期 1 例 $(100.0 \%)$ であった。それぞれの 腹水細胞診陽性率は13.3\%，14.3\%，85.7\%，100.0\% であった。さらに腹腔内の洗浄または摖過細胞診 を加えた陽性率は全症例で35.5\%，また期別每では それぞれ 26.7\%, 28.6\%,85.7\%, 100.0\% と進行期の 上昇と共に高率となっていた。腹腔内細胞診にお ける細胞所見の特徴は、明るく豊富な細胞質、大 型で大小不同の強い核、大型の核小体、微細顆粒 状の核クロマチンおよびミラーボールパターンの 出現であった。腹腔内細胞診陽性の16例中 8 例に 子宮腔内吸引細胞診を実施したところ 4 例（50.0 ※)が陽性であった。污染のないきれいな背景の中 に、正常子宮内膜と共に出現する癌細胞は、腹腔 内の腫場細胞と同一のミラーボールパターンを呈 しており、本所見は卵巣由来の明細胞腺癌の術前 診断に非常に有用であった。 
97 卵巣癌術後管理における腹膜洗净細 胞診の意義

香川医科大学母子科

○大野正文(MD), 五十嵐達也 (MD), 塩田敦子 (MD), 黒瀬高明 (MD), 半藤 保(MD)

【目的】卵巣癌の術後管理に护ける化学療法の効 果判定, 腹腔内再発の早期発見を目的として腹膜 洗浄細胞診の意義を検討した。

【方法】臨床進行期 I c 期以上の卵巣癌 17 症例を 対象とし, USG, CT, MRIによる測定可能病变の 有る群 (以下A 群, 6 例), 測定可能病変の無い群 (以下B群，11例）で検討した。腹腔内化学療法 のルートとして設置した peritoneal access system (以下PAS) を介して周期的に腹腔内より 採取した洗浄液を細胞診の検体とした、入院中の 一次管理 (画像, マーカー, 細胞診, 理学所見の すべてが陰性化するまで）と，外来での二次管理 としての再発の早期発見における腹膜洗浄細胞診 の有用性を検討した。

【成績】A群は全例が腫場マーカー陽性で, 細胞 診む陽性であり，洗净細胞診のすぐれた感度が確 認された。 5 例は化学潦法が無効で細胞変性を認 めなかったが，1例は有効で細胞診陰性となっ た。B群は全例が尰瘍マーカー陰性で, 細胞診が 陽性のもの 6 例中 4 例は化学療法が無効で細胞変 性を認めなかった。2 例は有効で細胞診陰性之 なった。また，B群のなかで二次管理に移行した 8 例中, 3 例は画像診断が陰性, 腫湯マーカー陰 性の状態で細胞診により再発の早期発見が可能で あった。

【結論】PASは，腹空内化学療法のためばかりで なく腹腔洗浄液を採取するルートになる，腹膜細 胞診は術後化学療法の効果判定に有用で，特に画 像上測定可能病变が無く, 腫湟マーカーが測定感 度以下の症例でも $54.5 \%$ (6 例 $/ 11$ 例) の陽性率 があり唯一の効果判定材料となった. 腹膜細胞診 は外来管理症例の再発早期発見手段としても有用 であることが示唆された。
98 Yolk sac tumor の腫演圧挫標本

: loose reticular patternに対応する細胞像

いわき市立常磐病院病理科1,

いわき市立総合譥城共立病院病理科 2 , 同綀胞診 3 ,

山口医院 4

望月 衛 (MD) 1) 2), 永久保守 (CT) 4)

吉田京子 (CT) 3), 蛭田道子 (CT) 3),

森 菊夫 (CT) 3 ), 山崎一樹 (MT) 2 ).

Yolk sac tumor は組織学的に多彩な像を示すた め腫韵穿刺細胞像, 捺印細胞像も多彩であり, 診断 に苦慮することが多い.他腫瑒との鑑別上 loose reticular patternは重要な病理組織学的所見であ ク，対応する紡鍾形細胞の観察は細胞診上も重要で ある. 今回我々は, 24 歳女性例の腫崵捺印標本と圧 挫標本を観察. 本腫湟の細胞診断における腫湯圧挫 標本の有用性につき考察した. 莚例：24歳女性.下 腹部痛を主訴に某病院受診. 腹水貯留. 血中 $\alpha \mathrm{FP}$ $50,000 \mathrm{ng} / \mathrm{ml}$ と異常高値であったため, 紹介受 診. 両側卵巣腫啺の診断で, 右卵管卵巣切除術, 左 卵巣粪胞部分切除術, 大網切除術を施行. 術後化学 療法を行った. 術後約 3.5 力月経過現在再発を認め ない、捺印細胞診および腫演圧挫標本細胞像： 腫韵捺印標本では, 粘液性の背景中に腺癌様の細胞 集塊を形成する立方形細胞の集塊, 紡鍾形細胞, 裸 核状細胞が出現. 出現細胞は少数であった. 腫場圧 挫標本中には紡錘形細胞が多数認められ, 立方形細 胞より構成される腺癌様の細胞集塊との移行像をみ とめた。裸核状細胞はごく少数であった。病理組

織所見: 右卵巣腫湯は約 $15 \times 10 \mathrm{~cm}$ の充実性腫場で loose reticular pattern, endodermal sinus patternの混在したyolk sac tumor と成熟奇形腫 が併存. 右卵巣裹胞は成熟奇形腫であった. 考察： 腫崵圧挫標本の観察は本腫湟の捺印細胞診の補助と して有用と考えた. その理由として, 本腫崵が粘液 成分を多く含むため捺印細胞診標本中に細胞が落ち にくく，特に loose reticular pattern と対応す る紡錘形細胞が採取されにくいこと等を考えた。 
厚生連吉四総合病院産婦人科”、䠛床病理科” (崔沖靖久 $(M D)^{1}$ 、王木正治 $(M D)^{1)}$ 、㐼藤博子 $(M T)^{2)}$ 、瀨恶患利子 $(\mathrm{CT})^{2)}$ 、吉岡孝行 $(\mathrm{CT})^{2)}$ 厚生連尾道総合病院臨床病理科” 米原修治 $(\mathrm{MD})^{3)}$

卵巣steroid cell tumorはまれな腫瘍であり、 ステロイドを産生する腫演である。今回我々は、 39蔵女性に発生した本腫瘍を経験したので、そ の組織細胞像について報告する。

平成6年3月より過多月経、不正性器出血を訴 え4月に受診し、卵笨腫湯、子宮内膜過形成と診 断した。その後も過多月経、不正性器出血続い たため、平成 7 年 1 月腹式単純子宮全摘および右 付属器摘出術を施行した。

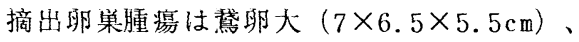
類付形で表面は平滑、橙黄色を呈した。割面で は脂肪組織に類似した黄色充実性、分葉状の腫 溜が、菲薄化した贸巣皮質に被われていた。

病理組織学的に低倍では、淡明な細胞質を持 つ腫瘍細胞と好酸性細胞質を持つ腫瘍細胞が胞 巣状に増殖し、間質にはフィブリン変性を示す 毛細血管の走行が認められた。高倍では核分裂 像が1-2/10HPFみられた。細胞質には所々に好 酸性の硝子滴が存在したが、Reinke’s crystal は認められなかった。脂肪染色は強陽性であっ た。以上よりsteroid cell tumor, unclassified typeと彰断した。

タッチスメアでは、比較的大きく索状の細胞 集塊とその周囲に散在する小集塊を多数認めた。 組織像との対応から、前者は間質を伴う腫演部 分、後者は腫瘍実質部分に相当すると考えられ た。各腫湯細胞の細胞質は淡いライトグリーン 好性で、核は類円形、約 $10 \mu \mathrm{m}$ 小さく、クロマ チンは細顆粒状、核小体は1ないし数個認められ た。また所々にライトグリーンに染まる硝子滴 を認め、現在電顥的にも検討している。
診に関する検討

国立東京第二病院産婦人科臨床研究部1), 同検查科 病理2), 国立埼玉病院産婦人科3)

$\bigcirc$ 中野孝之(MD) ${ }^{1}$, 渡辺豊治(MD) ${ }^{1}$, 沼田ますみ $(C T)^{2)}$, 大貫敬司 $(C T)^{2)}$, 小野田登(MD) ${ }^{2)}$, 竹内廣 $(\mathrm{MD})^{2)}$, 新井宏治 $(\mathrm{MD})^{3)}$, 和田とも美 $(\mathrm{MT})^{1)}$, 和泉滋 $(\mathrm{MD})^{1)}$

\section{正常大卵巣癌症候群 (normal-sized ovary}

carcinoma syndrome)は、腹腔内でびまん性に転移 巣が広がっていて、卵巣は肉眼的に正常であるか 外表が細顆粒状であるものとして提唱された。本 症候群には中皮腫、性腺外ミューラー管腫瘍、転 移性腫瘍、卵巣癌の 4 疾患が包含される。本症候 群は通常の卵巣癌より予後が不良であると考えら れているが、その細胞像に関して検討された報告 はいまだなかった。最近我々は正常大卯巣癌症候 群の 2 例を経験したのでその腹水に出現した腫愓 細胞の細胞像を中心に若干の文献的考察を加え報 告する。2 例はともに腹部膨満を主訴に受診し、 超音波断層法、CT、MRIにて腹水貯留とOmentum cakeが認められたが、両側付属器は正常大であっ た。また、両症例ともCA125は高值であった。穿 刺した腹水の細胞診では活動型中皮細胞とともに オレンジGからライトグリーン好性の細胞質を有 する異形細胞が主に乳頭状のクラスターとして出 現していた。核形は類円形から不定形で、径は中 皮細胞の 2 倍以内であった。核縁は肥厚しており、 切れ込みを有するものも散見された。核クロマチ ンは増量し、intranuclear clear areaも見られた。 また、核小体は大型で約半数の腫湯細胞で認めら れた。一部でカニバリズムの所見も散見された。 


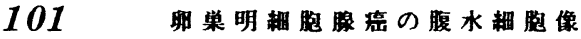

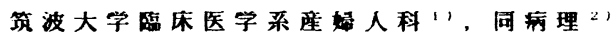

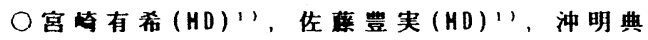

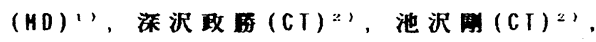

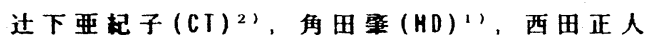
(HD)', 久保武士(HD) “

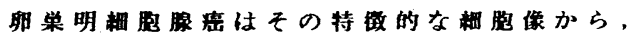
耕胞診で粗機型の推定可能な重場のひとつで

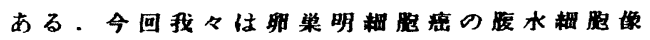
について検討を加えたので報告する。

当科にて1976年から1995年12月までに晾断

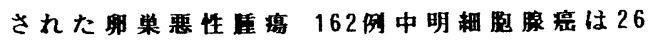

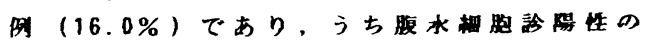
8 例（而 b 期 1 例，而c 期 4 例、IV期 3 例) を対象とした。

腹水中の耕媳像は，(1)忽体が淡明で豊富，

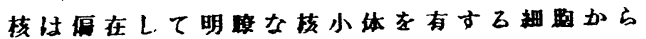
成る集塊 (2) airor ball patternを呈する

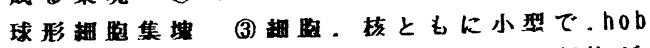
nail patternを呈する湅整集塊 (4) N/C比が 高く、クロマチンは租顆粒状、核異型の強い

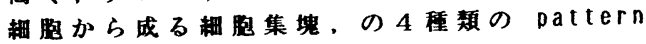
に大别され，8症例中，(1)は6例に、(2)は 4

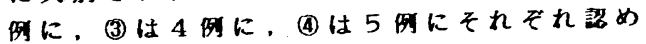

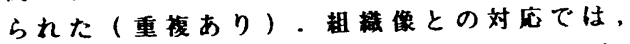
(1) は clear cell patcernを, (2) d cystic patternを, (3) hobnail patternを, (4)は darkな低分化部分を模しているものと考之 られたが，それぞれは完全に独立したもので

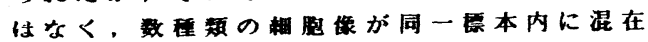
していることが殆どであった。また今回の娭

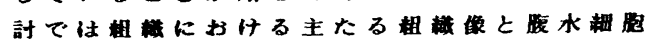
診の主たる所見の同に明らかな相阅はみられ なかった。相像との対応が困噰である理由

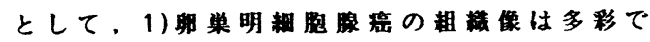

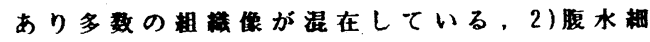

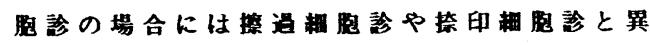

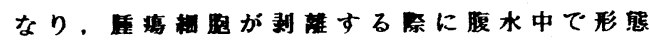
湾化する可能性がある，といった点が考え られた。
102 腹水中に腫瘍細胞を認めた卵巣未 分化胚細胞腫の2例

産業医科大学病院病理部 ${ }^{11}$,同産婦人科学教室 ${ }^{2}$

○佐藤 斉 $(\mathrm{CT})^{1}$, 岡ハル子 $(\mathrm{CT})^{11}$, 小原光祥 $(\mathrm{CT})^{11}$, 藤原 仁 $(\mathrm{CT})^{1)}$, 濱田哲夫 $(\mathrm{MD})^{12}$, 橋本 洋 $(\mathrm{MD})^{11}$, 柏村正道(MD) ${ }^{2 \prime}$,

腹水中に腫瘍細胞を認めた卵巣未分化胚細胞腫の 2例を経騃したので、同腫瘍の腹水細胞像を中心に 検討し報告する。

【症例】1）30歳女性。未妊婦。発熱で他院受診し 下腹部の腫瘤を指摘された。当院産婦人科に入院 し超音波、CTで卵巣腫瘍の診断のもと卵巣摘出術 が施行された。2）39歳女性。1妊1産。腹痛、腰痛、 腹部にしこりを自覚し他院受診、卵巣腫瘍と診断 され、当院産婦人科で卵巣摘出術が施行された。

【腹水細胞所見】両症例とも、手術時に約 $100 \mathrm{ml}$ の 腹水が認められ採取した。腫瘍細胞は弧在性ある いは小集塊状で出現し、細胞は円形ないし類円形 であった。核は円形で中心に位置し、クロマチン は細顆粒状で著明な核小体が観察された。腫瘍細 胞は全体的に多形性にそしかったＰAS染色では 一部の腫瘍細胞に陽性であった。

【組織所見】両症例とも、摘出された卵巣の重さ

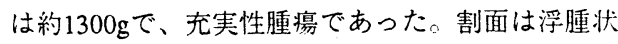
で出血・壊死も認められた。組織所見は核小体の 目立つ、やや大型円形核と好酸性の円形の細胞質 を有する腫瘍細胞が充実性に増殖していた。細胞 相互の結合性は強くなく、組織は比較的単一であ った。以上の所見より未分化胚細胞腫と診断され た。

【結語】卵宩の未分化胚細胞腫は全卵巣腫瘍の $2 \%$ と比較的稀な腫瘍であるが、的 $30 \%$ に腹水の眝留 を認め、高頻度に腫瘍細胞が出現することが知ら れている。また細胞像は特徵的で今回の腹水細胞 像においてもその特徽が確認された。同腫瘍の腹 水細胞診によりその診断は比較的容易であると考 えられた。 


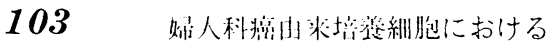

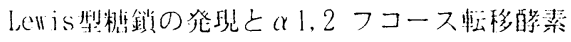

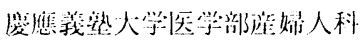

(青木大䡋(MI)), 木村佳子(IID)), 伊藤是子(MI))，

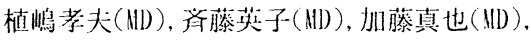
宇田川康博(ND), 野澤志朗( NID)

目的]モノクローナル抗体MSN-1は組織化学的に子 宮体癌に特罳性が高く、その認識抗原は主として

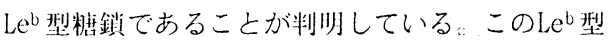
糖鎖は末端にフコースを $\alpha 1,2$ 結合で有しているこ とから、その発現には $\alpha 1,2$-フコース転移酵素 ( $\alpha 1,2$-FucT)の関与が示唆される。 $\alpha 1$ 1,2-FucTを コードする遗伝子としては、H頲伝子とSe遺伝子 の異なる 2 種の遺伝子が阰に同定されている。今 回我々はI 型糖鎖であるL $\mathrm{e}^{\mathrm{b}}$ 型糖鎖のみならず、U 型糖鎖であるLe $y$ 型惦鎖む、 $\alpha 1,2$ 結合で末端にフ コースを有することに新甘し、各種婦人科站由来

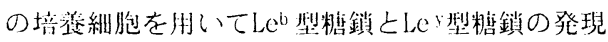

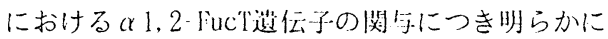
することを目的とした。才抾 H頲伝子とS遺伝 子のプローブを作製し、Northern blottingを行い 雨遺伝子の発現をmRNAのレベルで検索した。また USN-1抗体、Ley抗体を用いて货疫組織化学的榆索 を行い、各癌紼胞におけるLe b 型糖鎖抗原、Le 型 熫鋿抗原の発現を衕べた。結果 mRNAの発現の程 度は絒胞䦌で相萿があるものの、IISI-1陸性の細胞 では必ずどちらかのmRNAの発現が認められた。一

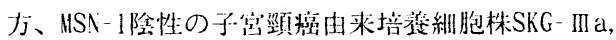
ShG-IIIbではH造伝子とSe造伝子のmRlAの発現を殆 ど涊めなかったが、Ley 抗体に対する反応は览性で あった。[考察]Leb 型榶鎖抗原の発現には、H頲伝 子あるいはS逍伝子に田来する $\alpha$ 1,2-FucTの関与 が示唆されるが、心抗体の組織化学的反応性之 mRMのの発现がー一致しない絒胞が存任したことより、

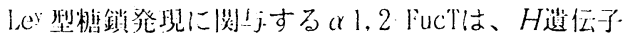
とS逍伀子以外にも行任することがホ唆された
104 TRAPアッセイ法による腹水および 腹腔洗浄紏胞のテロメラーゼ活性

広島大, 同総合薬学科*

○村上順子(MD)，承井宣隆(MD)，大濱紘三(ID)， 田原栄俊 ${ }^{*}$ (MD)

[目的]DNA末端(テロメア末端)は, 細胞の分裂寿 命, 不死化, 癌化なととの関連において最近注 目を集めている，今回我々は，腹水および腹膸 洗浄細胞のテロメラーゼ(テロメア延長を司る酵 素)活性との関係を検討する目的で， TRAP (Telomeric Repeat Amplification Protocol)法 によりテロメラーゼ活性を测定した。

[万法]卵巣癌 I c 期 1 例の腹水, 卵巣境界悪性腫 湟 I c 期 1 例の腹水, 卵巣痁 II c 期 3 例の腹水, 子宮体癌 I c 期 1 例の腹腔洗浄細胞を対象として $-80^{\circ}$ Cに凍結保存した腹水ならびに腹腔洗浄水を CHAPSを含む溶解バッファーで溶解し，遠沈後上 清中蛋白を测定した. TRAPアッセイ法は 1 検体 あたり細胞抽出液 $6 \mu \mathrm{g}$ 蛋白にPCRバッファー, $\alpha$ - ${ }^{32} \mathrm{P}-\mathrm{dCTP}, \mathrm{TS}$ プライマーを加え, テロメラーゼ によるブライマー上でのTTAGGG鎖の延長を $20^{\circ} \mathrm{C}$, 30分間行いCXプライマー( $5^{\prime}$-CCCTTACCCTTACCC TTACCCTTA-3')を加えPCRでテロメラーゼ産物を 增幅し、電気泳動後オートラジオグラフィーに て判定した。

[成績]テロメラーゼ活性は6 塩基のラダー形成 として認められ、卵巣癌 I c 期 1 例と II c 期 3 例の 腹水では高いテロメラーゼ活性が認められた。 卵巣境界悪性腫場 I c 期 1 例の腹水は弱い活性を 示した. 子宮体癌腹腹洗浄細胞にはテロメラー ゼ活性は認められなかった。

[結論]細胞款材料からもテロメラーゼ活性の検 出は可能であった。 今回の成績からテロメラー セ活性は悪性度の評研等, 癌診断の指標となる 可能性が示唆された。 
105 卵巣癌細胞のmacrophage colony-stimulating factor(M-CSF)産生能とc-fmsの発現について

自治医科大学産婦人科

○大和田倫孝( MD), 鈴木光明(MD), 関口 勲(MD)， 㟇峨 泰(MD), 薄井里英(MD), 角田哲雄(MD), 佐藤郁夫(MD),

[目的］血液細胞の発生を制御するサイトカイン のひとつであるM-CSFの卵巣癌細胞における産 生能と,その receptor である c-fms の発現につい て, in vitro培養細胞ならびに臨床材料を対象に検 討した。

[万法]1) 9 種の卵巣癌培養細胞株HMG $\cdot H R A \cdot$ $\mathrm{KF} \cdot \mathrm{KK} \cdot \mathrm{SHIN}-\mathrm{III} \cdot \mathrm{MN}-1 \cdot \mathrm{NK}-211 \cdot \mathrm{KOC}-2 \mathrm{~S} \cdot$ OMCならびに卵巣癌臨床例の組織, 捺印細胞診を 対象とした。2)培養上清中のM-CSFはELISAによ り測定した。3）c-fms mRNA の発現はNorthern blotting,RT-PCRにより施行した。4) M-CSFおよ びc-fmsの細胞,組織内局在を免疫組織化学的に検 討した。

[結果と考察] 1) 卵巣癌細胞株においては，9株 中 3 株 $(\mathrm{KK}, \mathrm{MN}-1, \mathrm{KOC}-2 \mathrm{~S})$ に培養上清中にMCSFの分泌が認められた。c-fms mRNAの発現は 3 株(KK, KF，HRA)に認められた。M-CSFとc$\mathrm{fms}$ の同時発現はKK細胞 1 株であった。免疫細胞 化学染色においても KK細胞ではM-CSF,c-fmsの両 者が細胞質に強い染色性を認めた。2)臨床例の検 討では免疫組織染色により, 卵巣癌組織にM-CSF, c-fms が染色され，両者の同時陽性例もみられた。 捺印細胞診標本については検討中である。3) 卵 巣癌細胞では M-CSF とc-fmsを同時に発現するも のがみられ, autocrine 増殖の可能性が示唆される が, 現在のところ外因性 M-CSF 投与による細胞 増殖の亢進, という現象は確認していない。
106 ラット黄体の PRL誘発 Structural luteolysisにおけるアボトーシスの検討

\section{札熀医科大学医学部産婦人科学講座}

O木谷 保(MD)、遠藤俊明(MD)、捘藤尖恵子(MD)、

伊東英樹 $(\mathrm{MD})$ 、工藤隆一 $(\mathrm{MD})$

[目的]黄体の退縮過程にはprogesterone(Prog)産生 が低下するFunctional luteolysis と、黄体組織が維小 するStructural luteolysis（以下S L) の2つのstageか 存在するが、その詳細なメカニスムについてはほ とんど報告がな。今回、我々は過排㧮幼若雌ラッ 卜にBromocryptin(Brom)とPRLを組み合わせて投与 する事でS Lを再現し、透過型電顕及びT UNE L法にてアポトーシスの関連について検討した。

[方法] 25日鮯SD系幼若雌ラットにpregnant mares serum(PMS)50I、56時間㖟にhCG25IU皮下注して過 排㚹させ、その4日目の朝よりBrom $200 \mu \mathrm{g}$ を1日2 回、7日目朝よりPRLO.5mgを1日2回皮下注を追加 した。初回PRL注射後より $24,48,72$ 時間後 $(8 、 9 、$ 10日目夕)に黄体を採取した。コントロール(Ct1) はvehicleのみの投与とした。

[成績] 黄体重堊およびDNA室はBrom+PRLを投 与した群ではCt1の約50\%に有意に滅少したか、 Brom単独、PRL単独投与では变化はなかった。 Brom+PRLを投与した群では24,48,72時間のいずれ においてもTUNE L 法にて正常な黄体細胞集団 の中にpycnoticな核を持つアポトーシス陽性細胞が 約3\%琶められ、透過型電影にてもapoptotic bodyの 形成が認められたが、他の群ではこれらをほとん ど認めなかった。

[結論] 今回、我々は黄体の PRL誘発 SLにおい てアポトーシスが関与していることが確漶できた 。また初回PRL注射後24,48,72時間捘でいずれも全 黄体細胞中の約 $3 \%$ にアポトーシスが起きており、 もし、全黄体練胞がアポトーシスて死んでいくと 仮定すると、72時間でDNA量は約50\%に減少して いることから、黄体のアホトトーシスは数時間とい う非常に速いturnoverである可能性が示唆された。 
川崎市がん検彭センター1、赤坂病院婦人科 ${ }^{2)}$

何村趢子 (CT) ")、山䛀塯美子 (CT) ${ }^{11}$ 、箕 輪尚子 (CT) ${ }^{11}$ 、小泉祐子 (CT) ${ }^{1 !}$ 、岩田正晴 $(\mathrm{MD})^{21}$ 、白井英一郎 (MD) ${ }^{11}$

[はじめに]川崎市では市主導型の子宮頸臨検診を 30 才以上の市民を対象に昭和 44 年より実施しているが 平成 7 年度より採取器具を縓拌からサイトピックに変更 し、良好な結果が得られたのて報告する。

対象]川崎市で夷施している全ての子宮项虞検診の平 成 3 年度より平成 7 年度の検晾結果。

[成績] 1)精検率は平成6年度を除いてほぼ同率であっ た。(2III a は平成6年度を除いて余り変化はみられなか った。 bの平成 7 年度の成績は平成 4 年度から平成 6年度のそれより倍の検出率であった。 (4)にについては 平成 3 年度を除いて変化はなかった。(5)Vは平成 7 年度 の検出率か明らかに高値であった。6採取不能に関して は变化が見られなかった。

[まとめ] 11綿棒からサイトピックに変更して亚bの検 出率が倍、がん発見率も高率となり、採取器具の変更は 有效であった。(2採取不能に関しては变化が見られなか ったが、移行期ということで市内の全ての検査機関力㥒 用していないためと思われる。(3)サイトピックの使い勝 手に関しては、採取時の出血・頙管内挿入時捕・老龄者 採取困䊒等の問题があげられた。

108 細菌培養用の带下検体を用いた細胞診 一非特異的腟炎における細胞変化について -

社会保陓蒲田総合病院", 東京医科大学第二病理二 ○山田昭二 ( $\mathrm{CT}$ ) “，高橋みどり $(\mathrm{CT})^{13}$, 須田和美（MT）：，清田秀昭（CT） 1)， 工藤玄惠 $(M D)=$

【目的】帯下の細菌用検体を利用して細胞診用の 標本を作成し、その細胞所見を非特異的胵炎（細 菌性腔炎）の原因菌である、Candida菌、グラム

（+）菌、グラム (-) 菌別に検索し、その所見 が細胞診に役立てられるか検討した。【方法】(1 細菌培養に提出された帯下検体（保存用培地シー ドスワブ 3 号、栄研）を用いて、スライドグラス 上に直接塗抹、ラピッドフィックス (武藤化学) を重層し固定、乾燥後、細胞診用にPap染色施行。 (2)病原性細菌陰性（以下、健常例）162例12～85才 （平均37才）、Candida陽性62例17８0才（37才）、 グラム (+) 菌陽性39例19 79才 (40才) 、グラ 厶 (一) 菌陽性42例20７5才（42才）の4群の細 胞診標本について、細菌及びCandida菌出現の有無、 扁平上皮の細胞質融解像の有無、好中球の出現数、 その他について検詰した。尚、好中球の出現数と は、対物10倍下で好中球が每視野10〜30個以下を

$(1+) 、 30$ 個以上または扁平上皮の集団を密に 取り囲む好中球像がある場合 $(2+)$ とした。そ して、（2）の標本において好中球による細菌 食食像の有無を検索した。【結果および考察】健 常例に常在菌と思われる桿菌37例、球萩7例を認め た。細胞質の空洞化や虫喰い状の所見をCandida陽 性例62例中11例に認めたが、健常例、グラム $(+)$ 菌やグラム（一）菌陽性例の検体には認められな かった。清浄度の指標であるDoderlein桿菌による と思われる扁平上皮の細胞質融解像と、炎症指標 と考元られる好中球の出現数には各群に差はなか つた。好中球の細菌貪食像はグラム $(+)$ 菌陽性

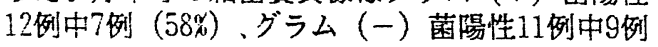

(820) とであった。細䒩食食像は健常例でも38例 中19例（50\%）に認められたが、培盖結果が陰性で ある事から少数のG.vaginalisや常在菌であるStreptococcus等の貣食と考えられた。細胞質の空洞 化や虫喰い状の所見がある場合にはCandidaが、そ して好中球の悢菌食食像がある場合は病原性細菌 の存在が各々示唆された。細胞診標本でも病原性 細菌の推定がある程度できた。細菌性胵炎の内容 を少しでも具体的に埌告することで、迅速な治寮 開始の一助になると考える。 
109

細胞診スクリーニングにおける

偽陰性例の検討

一陽性、疑陽性例の前回標本を対象として -

川崎医科大学附属病院 病院病理部 ${ }^{1}$

川䐀医科大学病理学教室 ${ }^{2}$

鐵原拓雄 (CT ${ }^{1)}$ 、有光佳苗 (MT) ${ }^{1)}$ 、

三宅康之 (CT) ${ }^{12}$ 、広川満良 (MD) ${ }^{22}$

【はじめに】細胞診精度管理の一つの方法として、 陽性症例の前回陰性標本を再スクリーニングする やり方があ。今回われわれは、子宮頸部擦過ス メアにおいてクラス而以上と報告された症例の前 回㓌性標本を再スクリーニングしてみたので、そ の結果を報告する。

【対象および方法】1989年から1995年の7年間に、 子宮钼部擦過が同一患者で2回以上行われ、初回検 査時陰性と判定され、その後の細胞診標本にて、 クラス III 上上と報告された 65 症例（III a : 55 症例、 III $\mathrm{b}: 8$ 症例、IV : 2例) を対象に、前回時の標本の 再スクリーニングを行った。

【結果】再検查時、クラス III a 䛦断された 55 症例 中19例 $(34.5 \%)$ においては、前回標本にも同様 の異型細胞が存在していた。残りの36症例の前回 標本には異型細胞はなかった。再検查時にクラス IIIb亡診断された8症例中3例にも異型細胞がみられ た。クラスIVの前回標本には異型細胞はみられな かった。

初回と再検の期間については、前回標本に異型 練胞が存在した群としなかった群の間に差は見ら れなかった。

【まとめ】クラスIII症例の前回標本における偽陰 性にはスクリーニング時の見落としやピックアッ プすべき異型細胞に対するスクリーナーの見解の 違いによることが浮彫りになった。以上の結果を 謙虚に受けとめ、より注意深くスクリーニングす るよう心がけるとともに、異型細胞に対する個人 間の認識の差を少なくすることも重要と思われた。
110 子宮頸部異形成に対するビタミンEの影 響について

水戸協同病院産婦人科 ${ }^{1)}$, 同臨床検査科 ${ }^{2)}$

○米本行範 $(M D)^{1)}$, 安蔵 充 $(C T)^{2)}$ 袴塚純一 $(\mathrm{CT})^{2)}$

近年, 癌に対する化学予防効果のある薬物として ビタミンEや $\beta$-カロチンなどか知られてきている。 子宮頸癌についても，てれらが予防に効果があった とする報告が見られる。

今回, 我々は, 軽度から中等度の異形成に対して ビタミン Eが影響を与えるかどうかを細胞診を用い て検索した。

患者さんの同意を得た上で, 10例の異形成例に対 して, ビタミン Eを $2 \sim 4$ ケ月間投与し, 子宮頸部 細胞診で異型細胞所見の変化の有無を検討した。

細胞診で異形成の細胞が消失したのは 2 例で, 8 例では異形成の高度化は認められなかったが異形成 が持続した。異型細胞の所見の変化については, 5 例で変化が認められなかったが，5例で核形不整の 軽度化やクロマチン増量の軽度化や核の膨化様変化 が極めて軽度であったが認められた。

異形成に対してビタミン $\mathrm{E}$ は全例の異型細胞を消 失させるような影響を与えなかったが、細胞診で極 めて軽度ではあるが所見の変化をもたらす例を認め た。したがって，ビタミンEが子宮頸癌に対する化 学予防の効果を持っ可能性はあると思う。 
111 子宮䫫部P A P III病変の検討 : 第二報 - 20 歳代の子宮頸部癌の検討一

\author{
和歌山市医師会病院成人病センター㭘査科 \\ 戸井直子 (CT) 土居淳子 ( C T ) \\ 国立南和歌山病院研究検査科 佐藤清 $(\mathrm{CT})$ \\ 西園寺正士 (CT) 流田智史 (MD)
}

第34回秋期大会において、紐胞哙で Pap IIIを呈 した症例の中で、Carcinoma とCondy l oma との異型 細胞所見を比較検討した。Carcinomaでは、異型 紐胞同士の接着が緩く、散在性に出現し、集塊を 認めても核間距離が不整であった。核所見、紐胞 質所見は、Carcinoma、Condy lomaの症例間で差は なかった。

今回20歳代のCarcinoma10例について細胞像及 び生検、円錐切除標本の組織像を検討した。

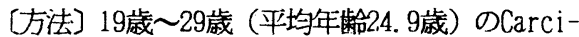
noma10例について、核、紐胞質、集塊、背景の各 所見の有無を検討した。細胞晾では Pap III 9例 IV 1例であった。

〔結果〕20歳代のCarcinoma 例でも、異型紐胞は 散在性に出現する傾向があり、集塊を認めても核 間距離は不整であった。 $\mathrm{N} / \mathrm{C}$ 比は上昇し、核ク口 マチンは、微細顆粒状で分布は均一、核縁は、不 整は見るが肥尃はなかった。またパピローマ感染 に特徵的とされる紐胞像では、Koilocytosisは 4 例、Parakeratosisは4例，多核紐胞は4例で認め られた。病理標本では、組織型は、定型十非定型 パターン8例、非定型パターン 1例、定型パター ン1 例であった。また、病変部がVagina側に偏つ ている症例洺く認められた。

[考察]1. 20歳代の子宮䫫癌は、パピローマ感 染による可能性が高いと言われているが、今回の 検討でも大部分の症例にパピローマ感染の存在が 示唆された。

2. Vagina側に偏って病変のある例があり、子宮 切除時にVagina断端に注意を要すると思われた。
112 子宮䅡部上皮内癌の細胞像に関す る検討：第 4 報一高龄者・若齢者における細胞集 塊の比較検討 --

財団法人福島県保健衛生協会

O瓶 憲俊 ( C T ) , 添明

富田 健 (MD)

福島県立医科大学㦃婦人科

森村豊 (MD), 星 和彦 (MD)。

佐藤 音 $(\mathrm{MD})$

坪井病院婦人科 羽生 忠義（MD），

これまで我々は、スパーテルで採取された子宮 䅡部上皮内癌（以下C I S ) の細胞について、後 方視的にその特徵を检討してきたが、墨性細胞の 出現状態。細胞形態に受診者の年路による相違を 認めることが出来た。散在性に出現する細胞は、 高龄者では出現数が少ないうえに膨化变性を伴う ことが多く、若龄者では症例間の所見の差が大き く C I S として特街を呈示することに苦虑した。 そこで今回は、集塊で出現する細胞について高 齢者之若齢者の比較を行ったので報告する。

(対象) 過去 6年間の集団検診において発見され たC I S のうち病理組織標本が入手可能かつ悪性 細胞が集塊状に出現していた46症例（高齢者18症 例，若龄者28症例）を対象とした。

(結果) 細胞集塊の特徽：CＩＳの特徵の一つで ある細胞構築異常 $(2 \sim 3$ 層の不規則な細胞の重 なり，不規則な核の方向性，核間の不整，細胞の ほつれ）や不均等な細胞質の倡み（濃淡の差）は 年龆を問わずほぼ全症例に観察されたが、細胞結 合の密な集塊は高齢者に多い傾向が認められた。

集塊を構成する個々の紐鸺：若齢者の核クロマ チンは $35.0 \%$ が中〜粗顆粒状を示し, 核内クロマ チンの充満感が顕著であったが、高齢者では、核 内クロマチンの充満感が不足しており、中〜粗顆 粒状を示すクロマチンは12.0\%であった。核は類 円形が主体であるが、高龄者の核は $10 \mu \mathrm{m}$ 以下が 74. 3\%を占め若齢者の核より小型で, 核の大小不 同，不整形核が多い傾向が観られた。

（まとめ）細胞診からＣＩＳを診断する場合は、 細胞集塊の出現に注目し、C I S の特徴である構 築異常および核所見を詳細に観察することが必要 である。この時、高齢者ではＣIS を示唆する所 見（核クロマチン，核内クロマチンの充満感等） の出現が若齢者よりそしいので、受診者の性ホル モンの関与に伴う細胞の変化之年踰を十分考慮し た細胞像のスクリーニングが必要と思われる。 


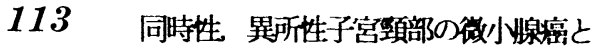

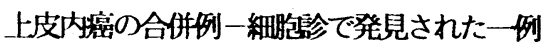

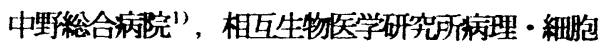
診センター2), 東京医科菌科大学病理 ${ }^{3)}$

O及川希(CT) ${ }^{1)}$, 田中昇(MD, DDS) ${ }^{2)}$

高橋信二(CT) ${ }^{1)}$, 大堟重則(CT ${ }^{2)}$ 波多野吉治(CT) ${ }^{11}$ 村田豊成 $(M D)^{1}$, , 北川昌伸 $(M D)^{3)}$, 春日孟(MD) ${ }^{3)}$

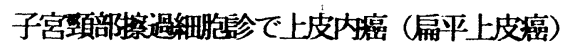

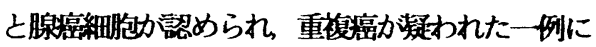
ついて細胞所見及び組維所見に加えて両者のDNA ploidy分析の成樍を報告する。【症例】47歳女性

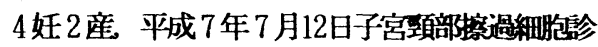
でsevere dysplasia〜CIS か凝われた その後 4

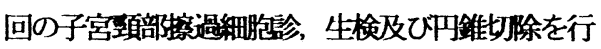
い, adeno-squamous cell carcinoma 之診断され 8月11日子宮摘出術力行われた【細胞听見】炎 症性背景に傍基底型で, N/C比涉的て高く，緊满 感がある円〜類円形核で，クロマチンは増量し, 濃染している細胞が，小集扵ないし孤立散在性に 中等数珰められたまた，一部に密集重積㑯句。

棚状列を示し，胞体内に粘液を有する練胞集塊 も認められた 以上の所見より上皮内癌之腺癌の 両方の存在を疑った【組䋨听見】 円錐切除標本 の表面の極く一部を覆う異形成上皮は上皮内癌に 該当する所見を示したが，やや異型を示す腺管の 堌生力愳められた 10個の放射状切片についての

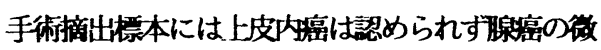
小浸閵代12時方向に認められた【DNA ploidy分 析の結果】 DAPI/HP 二重染色によるUV-影儌分光 湘光では，上皮内癌のDNA ploidyは2 4ckpeakを 有するaneuploid mode. DNA平均 3.21c 核面積平均 $57.55 \mu \mathrm{m}^{2}$, 一方分化型腺癌は2 8c, 3.8c にpeak を有し, 8cに達するhighploid cellを有する著し いaneuploid mode, DNA平均3.50c, 核面積平均61.3 $0 \mu \mathrm{m}^{2}$ と, 幽者は明らかにclone の異なる細胞起 源に基づく重複癌であることが立泟された。
114 子宮顠部細胞診にて発見された上皮内 腺癌 + C I S 一一例

大阪逓信病院第二臨床検査科 1$)$ 、同婦人科 2 ?

綾田昌弘 (MD) " 、岡本茂 $(M D)$ 1

阿倉 毫 $(\mathrm{C} \mathrm{T})^{12}$ 、畠中光恵 $(\mathrm{CT})^{13}$

坂井雅英 $(C T)^{11}$ 、塩山雅世 $(C T){ }^{1}$

向井みどり (C T ) 1

川村泰弘 $(M D)$ 2)、清野菜美 $(M D)$ 2)

子宮顒部の上皮内腺煰あるいは微小浸潤腺癌の 頻度はともに低く、両者をあわせても頝部腺澏の 数\%を占めるにすぎない。また䅡部の腺㴧は重層 扁平上皮湟のような系統的な診断法が確立されて おらず、細胞学的基準などの点でもいまだ不完全 な面があると思われる。特に分化した内頝部型腺 癌細胞の同定が困難であるため、早期の小さな腺 癌が見落とされ、そのことが臨床上腺澏が重層扁 平上皮癌より予後不良であることの主な要因と考 えられる。今回我々は頝部細胞診にて上皮内腺癌 が疑われ、手術にて上皮内腺淘とCIS９合併が 確認された症例を経験したので報告する。

症例 : 39 歳の女性で鼠径リンパ節腫大にて当院 婦人科を受診。

頝部細胞診所見：N/C比の大きい大型の核を持 つ腺細胞の集団が多数認められ、少数の異型中層 細胞も含まれておりclass IIIaと診断した。

頝部生検組織：頝部腺管に濃染した大きな核を持 つ重層化した上皮よりなる異型腺管が認められ、 正常の顒管腺と明らかな境界を形成している部分 も見られた。

組織所見 : 摘出子宮頚部を 8 分割した。腺管の中 層から上層までの偽重層化を示す中等度一高度異 形成が頝部全周に見られ、その中に重層化が強く、 桿状あるいは細長くなり濃染した核をもつ上皮内 腺祦が認められた。同時に表層部にCISを伴っ ていた。 
115 小細胞癌, 上皮内癌および上皮内 腺癌が共存した子宮頚癌の一症例

徳山中央病院病理 "), 国立岩国病院研究検査科 病理 ${ }^{2)}$ ，岩国市医療センタ一医師会病院臨床検 査部病理 ${ }^{31}$, 山口大学医学部臨床娭查医学 ${ }^{41}$ O山下吉美 (MD) ${ }^{11}$ ，山本啓子 (CT $)^{11}$ ，末永智弥 (CT) ${ }^{1}$, “岩田敏子 (MT $)^{11}$, 温品昭義 (MT) ${ }^{11}$, 佐 藤正和 (CT ${ }^{2)}$, 村上一郎 (MD $)^{2)}$ ，菅田君子 (CT) ${ }^{3)}$, 三好敏之 (CT $)^{3)}$ ，高橋睦夫 (MD $)^{4)}$

子宮頚部の小細胞癌はまれで, 今回, 小細胞 癌, 上皮内癌および上皮内腺癌が共存した子宮 頚癌を経験したので報告する。

【症例】38歳, 女性。2 ケ月前より性器出血が みられるため, 某医受診。腔スメアおよび生検 で子宮頝癌之診断された。1ケ月後, 広沉子宮 全摘術及び骨盤リンパ節廓清術施行。

【細胞診所見】壊死性背景に $\mathrm{N} / \mathrm{C}$ 比の極めて 高い小型の異型細胞が散在性または集塊で多数 みられる。核は小型で, クロマチンは粗大顆粒 状，著明に増量し，核小体は不明瞭である。一 部では核の moldingも認めら机る。一方，中心 性の核，增量したクロマチン，厚みのある細胞 質からなる扁平上皮癌を示唆する異型細胞や偏 在する核，増量したクロマチン，淡い細胞質か らなる腺癌を示唆する異型細胞も少数みられる。 【組織所見】子宮䅡部の上皮下に腫煌細胞が結 節状に増生している。それらの大多数は小型で クロマチンに富む円形〜紡釷形の核およびそし い胞体を有するリンパ球様の細胞よりなり，リ ンパ管侵熋が著明である(小細胞癌）。これら に接して, 上皮内癌と上皮内腺癌の両者が認め られる。免疫組織化学的にはNSEが小細胞癌細 胞に陽性であるが、グリメリウス染色は陰性で ある。

【電顕所見】小細胞癌の胞体はそしく，少数の 神経分泌顆粒（直径 $70 \sim 120$ n田）がみられる。 一部では中間径フィラメントの集積がみられ, 細胞間にはデスモゾームが観察される。
116 細胞診でのみ術前診断しえた 子宮壁内に特異な拡がりを示した腺癌の一 例

東京大学附属病院病理部 1 、同病理学教室 ${ }^{2}$ O福島純一 (MD) 1 、佐々朴学 (MD) 1 、 山内直子 (MD) 2、岡 輝明 $(\mathrm{MD})$ 1、瀬 田章 (CT) 1、小林裕子 (CT) 1、小川 優子 $(\mathrm{CT})$ 、坂本穆彦 $(\mathrm{MD})^{2}$

【はじめに】子宮腺癌は時に特異な拡がり を示し診断に苦慮することがある。子宮内 腔に腫瘤を形成せず子宮壁内に癌がびまん 性に浸潤したため、細狍診でのみ術前診断 可能であった腺癌の一例を報告する。

【症例】64歳女性。平成7年6月子宮癌検診 の内膜スメアにて腺癌と診断。7月18日子宮 鏡にて内膜、頚管腺に異常なし。内膜スメ アにて陰性。8月1日内膜スメア再検にて再 度腺癌と診断。8月22日内膜全面怪爬術と頚 部生榆を施行。8月30日子宮䅡管の怪爬と生 検を施行し異型細胞が検出されたため、画 像上異常所見はみられなかったが、9月14日 子宮全摘術と両侧付属器切除術施行。

【細胞所見】主として類円形、核縁不整で 核縁がやや肥厚した細胞がシート状ないし 軽い重積性を有し、結合性の比較的強い細 胞集団として出現。部分的に核の大小不同 を認めた。核のクロマチンは細顆粒状。核 小体は明嘹。胞体はライトグリーン淡染性 で、高円柱状である。背景には壊死物を混 じる。以上より腺癌と診断した。

【手術材料】子宮は $10 \times 5 \times 2 \mathrm{~cm}$ 大で軽度腫 大。頚部に择爬術後の影響と思われる㓔痕 がある他は子宮腔内は平坦で腫瘤の形成は ない。子宮筋層内には最大径 $3.5 \mathrm{~cm}$ 大まで の筋腫結節が多発。組織学的には高円柱状 の腺癌細胞が大小種々の腺管を形成しつつ、 筋層内にびまん性に浸潤している。原発部 位は確定しがたいが、頚部でやや腺管密度 が高いこと、癌細胞の性状が頚管腺に類似 することを考え合わせ、頝部原発と推定さ れた。 


\section{7 子宮頸部明細胞腺癌の 1 例}

癌研究会附属病院細胞診断部 ${ }^{12}$ 、同婦人科 21 癌研究所病理部 ${ }^{31}$

○星 利良 (C T ) "、都竹正文 (CT) " 梅沢 聡 (MD) ${ }^{21}$ 、秋山 太 $(M D)^{31}$ 、 山内一弘 $(M D)^{21}$ 、荷見勝彦 $(M D)^{21}$

今回我々は，子宮頸部原発明細胞腺澏の 1 例を 経験したので細胞所見を中心に報告する。

<症例> 47 才、 4 妊 2 産。不正出血を主訴とし て近医受診。子宮頚澏の疑いにて平成 6 年 9 月 19 日当院婦人科を紹介受診。コルポ診にて異常 は認められなかったが、細胞診及び生検組織診に て子宮頸部腺癌（明細胞腺癌の疑い）と診断され 子宮頸部癌 I b 期の診断にて、同年 10 月 25 日 広沉子宮全摘術及び骨盤内リンパ節郭清術が施行 された。

<細胞所見>好中球、リンパ球、形質細胞を背景 に腫瘍細胞を集塊状または散在性に多数認めた。 腫瘍細胞の集塊は比較的平面的で、細胞境界注明 瞭ないし不明瞭で淡明で豊富な細胞質を有してい た。また、裸核の腫啺細胞が非常に目立ち多数出 現していた。核は円〜類円形で大小不同があり、 クロマチンは微細顆粒状で密に増量し著明に腫大 した核小体を $1 〜 2$ 個認めた。

く組織所見＞淡明で豊富な細胞質を有する細胞が 管腔状に增殖している像として認められた。部分 的に hobnail patternを示す像も認められた。こ れらの腫痬細胞は、PAS (+)、A1-b (ー) で あった。

〈まとめ>子宮頸部明細胞腺癌は、卵巣、腎由来 の明細胞腺癌と同様の細胞形態を示しており、細 胞診での組織型の推定は可能と考えられた。

\section{8 Mild dysplasiaを合併した專常性 \\ 天疮痽の一例}

東京女子医科大学第二病院産䛿人科1）、皮盾科2） 至誠会第二病院産㛿人科 3 )、日本細胞病理亏ホ⿺ ラトリー4)

O木村敬(MD) ${ }^{1 ）}$ 横須賀毫 $(M D)^{3 ｝ \text { 酒井啓治(MD) }{ }^{1)}$ 高木耕一郎(MD) 1）村岡光恵 $(M D)^{1 ）}$ 平田順子(MD ${ }^{2)}$ 花岡治恵 $(C T)^{4)}$ 平田守男 $(C T)^{4)}$ 黑島淳子 $(M D)^{1)}$

難治性水疮性疾患である最常性天疮痒 (P.V.)は、口腔 粘膜疾患として報告されることの多い自己免疫疾患で ある。今回、長期の治療を受けながら外陰部にびらん を認め、子宮胵部摖過細胞診よりTzanck細胞と mild dysplasia相当の所見を認めたP.V.の一例を経験したので 報告する。

症例は48歳10経8産1993年3月よりP.V.の疑いにて検查、 follow upをうけていた。1994年4月に検梌希望にて子宮 胵部摖過細胞㟝を施行した。この時、肉眼的に外陰、子 宮腔部に病的びらんはみられず、修復細胞疑の軽度異形 細胞を認めるという細胞診判定であった。1995年7月に 外陰部びらん、帯下を主訴として再来再讋し、mild dysplasia +HPV感染疑、病理組織諳でも mild dysplasia の診断をうけた。一部ではOG好染の部分がみられた。 この二検体を見直してみると、最初の標本では、ライト グリーン好染の細胞算を有する化生細胞または修復細胞 様の細胞が平面的配列を示し、一部では○Gに好染する 部分がみられた。核は腫大し核小体が目立つが、クロマ チン増加・核緑肥厚も見られず、Tzanck細胞と判定され た。しかし、異形成の細胞は認められなかった。1年 3 ヶ月後の標本はST由来の異形扁平上皮細胞之HPV感染疑 の細胞かみられたか、、Tzanck細胞はみられなかった。 P.V.の病理組織所見、HPV感染との関俰等を含めて報告 する。 
119 C I S 術後に淮行癌として再発 左来した症例

筑波大学臨床医学系産婦人科 11 、茨城西南 医療センター病院産婦人科 2)

C高橋秀元 $\left(\mathrm{N}(\mathrm{D})^{1)}\right.$ ）角田肇 $(\mathrm{ND})^{1)}$ 、佐藤 奈加子 $(\mathrm{N} D)^{1)}$ 、佐藤豊実 $\left(\mathrm{N}(\mathrm{D})^{1)}\right.$ 、渡彴秀

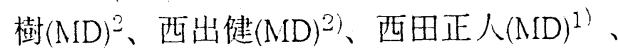
久保武士 $(\mathrm{N} I \mathrm{D})^{1)}$

子宮䅡部 C I S (Carcinoma in situ)は原則 として子宮全摘術後の再発はないものと考 えられている。今回、C I S 術後 3 年を経 て進行癌として再発を来した症例を経験し たので報告する。

症例は61歳、3 回経産婦。平成 4 年の集 団検診でClass V のため近医を受診。精査 の結果ＣＩＳと診断され、同医にて同年 7 月、腹式単純子宮全摘術及び両側付属器切 除術が施行された。患者は退院後の定期検 診の指示に従わず以後受診しなかったが、 平成 7 年10月、不正出血を主訴に再度同医 を受診。胵断端から右胵壁にかけて壊死を 伴う易出血性の明かな浸潤癌を認めた。細 胞診、組織診ともに大細胞性非角化型扁平 上皮癌であり、腫瘍マーカーも S C C は $6.0 \mathrm{ng} / \mathrm{ml}$ と高值であった。内診、C T 上、 右傍結合織への浸潤を認め、手術不能であ ったために、当院に紹介され全骨盤照射お よび右結合織へのboostによる放射線治療 を施行し、腫瘍は消失し経過良好である:

前医で摘出された標本を再検鏡したがC I S 以上の病変は認められず、surgical marginにも病変は存在しなかった。この ことから摘出時の腟壁に他の上皮内病変 (multi focal lesion)が存在し、そこから浸潤 癌へと准行していったものと推测された。
120 子宮頸部、内膜の細胞診で発見され た子宮再発乳癌の 2 症例

国立札幌病院 臨床検查科 ○松林 聡 (MT)、 土田 貴美子 (CT)、岩本 和彦 (CT)

同 臨床研究部 山下 啓子 (MD) 、 山城勝重 (MD) 同 産婦人科山下幸䄫 (MD) 国立函館病院 研究検查科平 䄫代美 (CT)

乳癌の子宮転移は比較的稀なものである。これ が臨床的に問題となることが少ないこともあって か子宮頸部、内膜の細胞診で乳潭細胞をみること は極めて稀である。国立札幌病院で経験した 2 例 を呈示する。

[症例1] 46 歳女性。2年前に右乳癌の切除 ( T 4 N2M1=Stage IV)を受け、CAF+T AMで外来 治療中であった。89年3月性器出血あり、産婦 人科外来を受診、子宮䫁部、内膜の細胞診を施行 されたところ、いづれにも悪性細胞を見た。その 後の検查で転移性子宮腫富と診断され、癌性腹膜 炎も確認された。

[症例2］59藏女性。2年前に左乳癌の切除 ( T 2aNOM0=Stage II)を受け、5Fu+TAMで外来 治療中であった。90年8月本人の希望で産婦人科 外来を受診、子宮顕部、内膜の細胞診を施行され、 いづれにも悪性細胞を認めた。その後の検査で子 宮転移、癌性腹膜炎、結腸転移と診断された。

[細胞所見と病理所見］2症例とも基本的に同 じで、比較的きれいな背景に小型でN/Cの高い細 胞が緩い結合性を示して出現し、一部にindian filing状の配列を示す。核小体は目立たず、ク口 マチンは微細、時に粗造である。胞体内小腺腔を 認めるものもある。乳癌原発部位の組織像は2例 とももinvasive lobular carcinomaであった。

[考察] 乳癌患者のsecond primary cancer と して婦人科領域の腫湯は重要である。乳癌の子宮 転移は稀であるが、報告例の多くはlobular carc inomaであり、その子宮䁰部、内膜細胞所見は特 徵的である。この点を考慮すれば2者を鑑別する ことも可能である。 


\section{1 子宮・朣転移性湩演の細胞診}

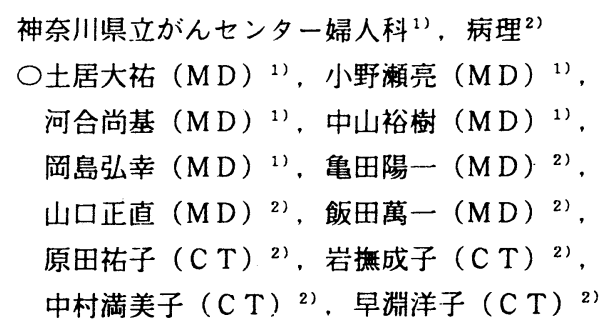

[はじめに]

外科領域の悪性腫演の腹腔内進展に伴い、婦人科 細胞診へも悪性細胞が出現することがある。その 出現形体は、癌の直接浸閏・転移によるものと、 癌性腹膜炎・卵巣転移からの細胞が経卵管的に出 現するものと二通り考えられる。当院でも岩撫、 加藤らが報告したが、その後増加傾向にあるため、 今回、前者 15 例の検討を行ったので報告する。

[方法]

1991 年 95 年の 5 年間の婦人科初診患者 2 634 人のうち、婦人科細胞診に、生殖器外葴器 悪性腫瘍細胞が出現した2 5 例で検討した。

[結果]

(1)子宮あるいは胵の直接浸潤のため悪性細胞が出 現したと考えられるのは 15 例であった。 (2)原疾患は結腸癌 6 例、直腸癌 3 例、肛門癌 1 例、 胃癌 1 例、乳癌 2 例、膀胱癌 2 例であった。 (3)浸潤・転移部位は腔 12 例、子宮腔部 1 例、子 宮・卵巣 1 例、子宮内膜 1 例であり、前二者 13 例は肉眼的に浸潤・転移所見が認められた。 (4)浸閏・転移発見後の予後は不良であった。 (5)頍部細胞診は全例陽性であった。 (6)胵浸潤のあるものは背景は污れていたが、子宮 転移例はそれほどではなかった。

(7)全例既往歴が判明していたため、診断に苦虑す ることはなかった。

(8)比較的まれな例之考えられる、乳癌の子宮・卵 巣転移例、結腸癌の子宮胵部転移例、上行結腸癌 が腟浸潤で発見された例の細胞像を供覧する。
122 子佗项活の放射線㳂療 5年後に発生し た忬盤内恕性:線維性組織球胛の1例

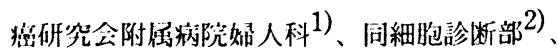

$$
\begin{aligned}
& \text { 研究所㐨理部3) } \\
& \mathrm{O}^{\circ} \text { 山脇孝晴 }(\mathrm{MD})^{1)} \text { 、古田則行 }(\mathrm{CT})^{2)} \text { 、平井康夫 } \\
& (\mathrm{MD})^{1) 2)} \text { 、石川雄- - (MD }{ }^{3)} \text { 、都竹正文 }(C)^{2)} \text { 、 }
\end{aligned}
$$

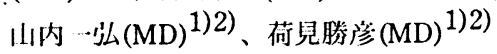

子宮䣆癌にて放射線治療を施行し、5年後、骨盤 内㳄部肉腫を生じた症例を経験した。穿刺細胞颜 を中心に報告する。

[症例] 36藏、女性。1990年、子宮頸煌 IIIb期 (角 化型裂平上皮癌)にて、放射線治療 (腔内照射 $40 \mathrm{~Gy}$ 、外照射 50Gy) を施行した。定期的に follow-upしていたところ、1995年7月、骨艋内に

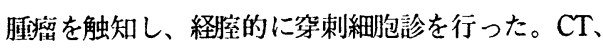
MRでは、腔、子宮の左側に、 $5 \times 4 \mathrm{~cm}$ の充実性䐺

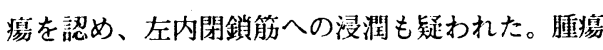
摘出術 (子宮全摘、左附属器切除、䐋 - 恥骨 - 坐 骨 - 膀胱 - 直腸部分切除)を施行した。

[穿刺細胞診所見] 血性背景に、多数の紡鍾形細 胞とともに少数の大型多形細胞が認められた。紡 鍾形細胞は、線維芽細胞に類似した形態で、細胞 集塊を形成する傾向にあり、一部に花むしろ様の 流れのある細胞配列がみられた。大型多形細胞は、 核の增大、核形不整が強く、紡鍾形細胞に混じっ て孤立散在性に少数出現していた。以上より、子 宮頸癌の再発ではなく、骨盤内肉腫と判定し、患 性線維性組織球腫(MFH)を疑った。

[摘出標本の病理組織所見] 線維芽細胞様の紡鍾 形細胞の密な增殖とともに、bizarreな大型の腫瘍 細胞が認められた。一部に花むしろ様配列がみら れ、MFH、storiform-pleomorphic typeと考えら れた。

[まとめ] Warren\&Gates、酒井に従えば、本症 例は、放射線治療後の二次癌と考えられる。子宮 頸煰の再発との鑑別に、穿刺細胞診が有用であっ たので、報告した。 


\section{3 子空頝暗カルエノイドの！例}

総合病院北見赤十字病院産婦人科, 病理, 市立札 幌病院病理, 札幌医科大学産婦人科教室

○水野均 (CT), 水沼正弘 (MD), 深澤雄一郎

(MD), 工藤隆一(MD)

子宮頸部カルチノイドは希な疾患で、予後不良 とされている。今回我々は、子宮頸部カルチノイ ドと誩断した 1 症例を経験したので、細胞像、組 織像、及び電顕像について報告する。

【症例】30歳、3 回経妊 2 回出産、平成 7 年 10 月 下腹部圧痛、性器出血のため当院産婦人科受診、 子宮頸部に $8 \mathrm{~cm}$ 大の腫瘤を認めた。細胞診にて悪 性細胞を認め、組織診を施行した。組織像は未分 化癌の像であったが、Grimelius 染色陽性及び 電顕所見より子宮頸部カルチノイドと診断された。 化学療法後、広汎子宮全摘が施行された。現在経 過観察中で、再発所見は認めていない。

【細胞所見】リンパ球の $2 \sim 3$ 倍の小型細胞が疎 な結合で散在性に出現しており、一部に細胞集塊、 ロゼット形成を伴二てて見られる。腫筥細胞は細胞 質が乏しく一部裸核状に見られた。核は核小体が 明瞭で粗顆粒状のクロマチンが均一に分布した異 型細胞が多数見られた。

【組織所見】核小体明瞭な梏巴、形謽と両染性の多 角形、又は紡鍾形胞体を有する異型細胞が充実性 の胞巣を形成しており、ロゼット形成、リボン状 配列は見られず未分化癌の組織所見を呈した。細 胞質はGrimelius 染色で好銀顆粒がみられ、免 疫染色でNSEが陽性となった。

【電顕所見】細胞質内に $100 \mathrm{nn}$ 大の神経内分泌顆 粒が多数認められた。

【考察】子宮カルチノイドは非定型的な組織像を とることが多く、杢分化癌の細胞像を示す場合、 カルチノイドの可能性を考慮して検索する必要が あると考える。

\section{4 子宮頸部に原発したMalignant} Mullerian Mixed Tumor $の 1$ 例

\author{
日本医科大学産樶人科、同病理部"

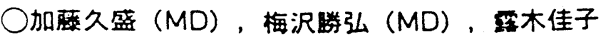 \\ (MD)，越野立夫 (MD)，荒木 勤 (MD) \\ 松本光司" (MD)，山田宣孝" (MD)
}

子宮に発生するMullerian Mixed Tumor(以下 MMT) の多くは体部であり、䅡部より発生する MMTは比較的まれである。今回我々は子宮頸部に 原発したMalignantMMTの 1 例を経験したので報 告する。症例は73衤、2 好 2 産、既往歴として 70 嵗時に結腸癌の摘出衙を受けている。今回は不 正性器出血、下腹部痛を主訴に来院した。内彭所 見は、分泌物は血性中等量て、子宮口は䦥鎖して いるものの䅡部は小鵎卵大に腫大していた。細胞 診所見は、小型でN/C比の高いクロマチンの増量 した、核異型も認める細胞を散在性あるいは集塊 状に認め非上皮性悪性腫瘍を考える所見を認めた。 組織誩では肉腫あるいは未分化政が疑われるもの の確定彭には到らなかった。子宮䅡部腫場として、 摭大子宮全摘術および両側付属器摘出術を施行し た。㸚部の割面は不整で、灰白色調を帯びた弾性 硬の充実性腫瘍により $7 \mathrm{~cm}$ 大に腫大していた。 摘出標本の病理所見は、上皮性腫場である扁平上 皮癌と腺癌の部分と、非上皮性成分では異所性成 分である软骨基啠様部分および osteoid like matrixの形成を認めた他、上皮性あるいは非上 皮性どちらにも分化していない未分化細胞よりな る腫珵成分を認めた。これらの所見より頝部原発 のMalignantMMTと診断した。免疫染色の結果は、 末分化細胞よりなる腫瘍成分はkeratin陽性と vimentin陽性の湿在パターンを示した。CEA、 AFP、 $\alpha$-actin、myoglobinは陰性であった。 全骨盤照射を ${ }^{\circ}$ Coにて41.4Gy施行し街後 5 力月経 過したが現在のところ再発鰩は認めていない。 諸家らの報告にもあるように、本症例も衍前の細

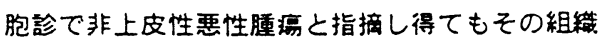
型までは推定し得なかった。 
125 子宮頸部扁平上皮内病変 $(S \mid L)$ の 免疫組織化学的検討（第 2 報）

ーサイトケラチンについてー

埼玉医大第二病理

瀬山 敦(CT), 鎌田孝一(CT), 後藤義也 (MT) 鈴木雅子(MD), 伴 慎一(MD), 清水禎彦(MD) 高演素秀(MD)

\section{【はじめに】}

中間径フィラメントの一つである種々のサィ トケラチン (CK) は, 重層扁平上皮の各居に おいて，異なった染色性を示すことが知られて いる. 今回, 我々はS I Lで増生する異型細胞 のCKについて免疫組織化学的検索を行ったの で報告する。

【材料および方法】

埼玉医科大学付属病院にて採取された子宮堙 部生検および手術材料の10\% ホルマリン固定, パラフィン包埋組織切片を用いた。

免疫組織染色は, CK13，CK14および CK19の単クローン抗体を用いLSAB法に て行った. 反応前処理として抗CK14抗体で はマイクロウェーブ処理, 抗CK13抗体およ び抗CK19抗体ではトリプシン処理を行った。 【結果】

CK 13 は，著変のない重層扁平上皮の基底 層では隆性，旁基底居より上層で陽性を示した が，S।しではその程度により基底層に陽性細 胞が出現した，CK 14 は，著変のない重層扁 平上皮の基底酋から中屠下部までに陽性細胞が 見られた。軽度異形成および中等度形成では基 底層から表層付近に陽性細胞が見られ，高度異 形成および上皮内癌の基底層付近にわずかに見 られるか消失していた，CK19は，著変のな い重層扁平上皮の基底層に陽性細胞が見られ， 高度異形成および上皮内疾では基底層から表層 にかけて陽性細胞が見られた。

【考察】

サイトケラチンを用いた免疫組織化学的検索 はS I Lにおける異型細胞の生物学的特性を知 る上でひとつの指標になると思われた.
126 子宮頝部腺癌における免疫組織・細胞 化学的検討

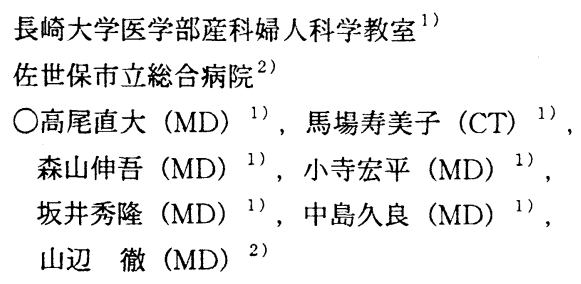

子宮頝部初期腺癌 [上皮内腺癌 $(0$ 期) - 微小浸 潤腺癌（Ｉａ期）]は比較的まれとされる。した がって, 初期腺癌に関する細胞診断基準は確立さ れておらず，また細胞診による検出率も比較的低 い. そこで今回, 初期腺癌に対する細胞診断精度 の向上を図る一鉬として，初期腺癌（7例）および 関連病変 (腺異形成6例, 浸潤腺癌10例) における PCNA，p53およびc-erbB-2の発現について，免 疫組織化学的に検索（L S A B 法）するとともに, 免疫細胞化学的にも, それらの病変における発現 状態について検討した。

免疫組織染色における正常腺上皮群の, PCNA, p53およびc-erbB-2の発現率はそれぞれ 30.0\% (3/10例），10.0\%（1/10 例）および $11.1 \%$ (1/9例) であり,また腺異形成群における発現率 はそれぞれ $50.0 \%$ (3/6例)，33.3\%（2/6例）お よび33.3\% (2/6例) であった.一方, 初期腺癌群 での，PCNAおよびc-erbB-2の発現率は著しく高 く（それぞれ7/7例および6/7例），p53の発現率 は $50 \%$ (3/6例) であった。明瞭な浸潤腺癌にお いても同様の発現傾向が認められた．細胞診標本 に対する免疫染色においても，初期腺癌および明瞭 な浸潤腺癌では, PCNA，p53およびc-erbB-2陽性 の腫瘍細胞が比較的高率に認められた. 具体的には, PCNAおよびp53は腫境細胞の核に, またc-erbB-2 は腫韵細胞の細胞質に発現が認められた。一方, 正 常腺上皮および腺異形成由来の腺細胞には, PCNA, p53およびc-erbB-2の発現はほとんど認められな かった. 
127 子宮内膜細胞診におけるエンドサ イト・生食洗い出し法の有用性について

八戸市立市民病院検査科病理 11

東京顕微鏡院細胞病理診断科 ${ }^{21}$

O熊谷幸江 ( C T $)^{11}$ ，奥沢悦子 ( C T $)^{11}$

高坂公雄 $(M T)^{11}$, 方山揚誠 (MD) ${ }^{11}$

石井保吉 $(C T)^{2)}$, 加藤圭子 $(C T)^{2)}$

わが国では子宮内膜腺癌の約 $2{ }^{\prime} 3$ は高分化 型で、その約20\%は細胞異型の乏しいタイプと されており、これらは細胞異型中心の観察では 偽陰性になる可能性がある。そのため集塊の形 状や構造異型の観察も必要となるが、その判定 基準は確立されているとは言えない現状である。

91年以前に初回内膜細胞診で偽陰性となった 当院の症例について検討してみたところ、全例 核異型に乏しく構造異型の観察の必要性が認識 された。そこで石井らの子宮腔内乳頭状增殖性 病変の特徵を反映する構造異型についての観察、 即ち免疫染色でf actor UII陽性となる細い血管成 分stromalAの束に、上皮が直角に位置する樹枝 状集塊及びstromalAの束数之分岐、乳頭状集塊、 多層化上皮細胞集塊中の腺腔形成及び腺腔内乳 頭状突出等の所見に注目し、観察していった。 しかし当院で行っていたエンドサイト直接塗抹 法では、これらの所見特に体癌の診断に有用で ある樹枝状集塊が観察され難く、その後も年に 1 例偽陰性を認めた。その為95年 4 月より、直 接倹抹法に替えて細胞採取後生食水に洗い出し、 遠心後圧挫する処理法を採用した。

この処理法による利点として、1.樹枝状集塊、 乳頭状集塊等の構造異型の観察が容易である。 2.上皮と間質細胞の同定が容易である。3.細胞 の回収量が增える。4. 背景の観察に赤血球がじ やまにならない等があげられる。この処理法に 替えてから、体癌例の偽陰性は現在のところな く、内膜細胞診の精度向上のために有用である と思われたので報告する。
128 子宮内膜細胞診における各種採取法 の比較 一特にウテロブラシ, ウテロブラシ L, エ ンドサイトでの直接塗抹法, 生食洗浄法の比較-

国立佐賀病院病理部1)，産婦人科2)

○井上輝彦(CT ${ }^{11}$, 安里昌家 (MT $)^{1)}$, 田中博志 (MD) 2 )

[目的] 子宮内膜細胞診は, 子宮体癌検診の普及 とともにその診断的意義が認められつつある。し かし, 検体採取法のちがいや検体処理法のちがい などで細胞診の評価もばらつきが生じ易いものと 思われる。また, 特に高分化型腺癌では細胞個々 の変化が少なく, 組織構築のちがいが診断の重要 な要素となる。そのためには細胞診採取時にいか に多くのまた，いかに大きな細胞集塊を採取する かが重要なポイントである。そこで子宮内膜細胞 診における各種細胞採取法および細胞処理法の比 較検討を行なった。

[方法］同一症例でウテロブラシ, ウテロブラシ L, エンドサイトで細胞採取したのち，まずプレ パラートに直接塗抹, つづいて生食洗浄法で各々 2 枚の細胞診標本を作製してパパニコロー染色を 行った。各々の症例において子宮内膜集塊数拉よ び子宮内膜集塊の大きさを測定した。

[結果] 直接塗抹法と生食洗浄法を比較すると, 諸家の報告と同様に生食洗浄法がより多くの子宮 内膜細胞集塊を採取していた。ウテロブラシ，ウ テロブラシL，あるいはエンドサイトを比較する とエンドサイトくウテロブラシく ウテロブラシ Lの順に細胞採取量が多くなる傾向にあった。と くに, 閉経後の症例ではその傾向が顕著であった。 また, ウテロブラシしは直接塗枺法においても他 に比して多くの細胞集塊を採取していた。 
129 東京顕微鏡院における内膜細胞診の成 績（職域検晾至中心に）

東京颢微鏡院細胞病理診断科 ${ }^{11}$, 同婦人科 ${ }^{2)}$

東京都がん検誩センター ${ }^{3)}$,

杏林大学保健学部病理学教室 ${ }^{4)}$

○岡 俊郎 (CT $)^{1)}$, 石井 保吉 (C T $)^{11}$, 加藤 圭子 (C T ) "), 稲村 千佳子 (C T ) "), 石田 禮载 (MD) ${ }^{2)}$, 大村 峯夫 (MD) ${ }^{3)}$, 佐藤 伸子 (MD) ${ }^{3)}$, 小田 瑞恵 (MD ${ }^{3)}$, 藤井 雅彦 $(M D){ }^{4)}$

【はじめに】東京顕微鏡院では、職域㛟㟝を主体に 婦人科検診を行っている。今回、当院で行われた内 膜細胞診の成績について蚞討した。

【刘象およで方法】当院における1991年7月か ら 1995 年 10 月までの、 4 年 3 力月間の子宮頸 がん検診総受䓂者数は 83,423 名で、49歲以 下の受診者数は 62,042 名 (7 4.4\%) であっ た。当院の受晾者数をもとに、内膜細胞診の行われ た受診者の年摽層、子宫体癌発見数および発見率、 体癌患者の年秢㟲について検討した。内膜細胞診を 行う際の検体作製法は、增淵式哦引チューブまたは エンドサイトにより採取された材料を生食内に洗 い出し、遠心沈段後、有㮎細胞層を 2 枚のスライド グラスで圧挫する方法を用いた。

【結果】当院での内膜細胞診施行数は6,069名 で、施行率は $7.3 \%$ であっ。受款者の年龄層は、 $22 \sim 71$ 歳で平均年路は 47 藏、49 歳以下の施 行人数は 4,362 名（7 1.3\%）であった。体虎 の発見数は 17 症例で発見率は $0.28 \%$ であった。 17 症例中、 50 藏以上の症例が 10 症例 ( 58 . $8 \%$ ）、49歳以下 $\sigma$ 症例が 7 症例 (4 1.2\%) であった。

【まとめ】当院での、49歳以下の体癌オ゙ $41.2 \%$ 発見されている。今回の結果から、子宫体癌の若年 化が推測される。49傶以下の若年者に対しても内 膜細胞診施行数の掋大が必要であうと考えた。
130 子宮内膜細胞診における腺管、間質比の 検討（第 2 報） ーループサイトを用いて一

東邦大学大森病院第一産婦人科", 同病院病理 ${ }^{21}$ ○平野孝幸 (MD) ", 大村 剛 $(M D)$ ", 平川 舜 (MD)", 过本志郎 (MD) ${ }^{2)}$, 三浦妙太 (MD) 2)

子宮内膜の細胞診において、高分化型腺癌は細胞異 型に乏しく、子宮内膜増殖症や正常増殖期内膜と判 定困難なことも珍しくない。子宮体部腺癌の診断で は、核の大小不同や核小体、クロマチンの性状とい った核異型だけでなく、クラスターの形や辺縁の形 態などの構造異型や、腫瘍性背景などを総合して判 断しなければならない。我々は、構造異型の中でも、 一個のクラスター内での腺管上皮と間質の比率（G ／S比）に着目し、良性子宮内膜に比べ、癌例で高 くなることを発表した。(第32 回日臨細秋季大会)

今回さらに症例を增やし、1992 年から 95 年までの良性子宮内膜 590 例之增殖症 49 例、 腺癌 42 例を比較検討した。腺管、間質比を検討 するにあたって我々は、より組織像に近い形で細 胞群を採取できるループサイト（ソフトメディカ ル社）を使用した。

腺管、間質比は、腺癌、增殖症、正常子宮内膜 の順で高く、前回と同様の結果であり、異型増殖 症と高分化型腺癌の鑑別はやはり難しいと思われ た。

子宮内膜細胞診の検体採取にあたっては、組織 診に近い形でより多くの内膜を採ることが重要で あり、スクリーニングにおいては、細胞異型のみ で判断し難いときは、腺管、間質比( $\mathrm{G} / \mathrm{S}$ 比)が 診断の一助になることが示唆された。 
131 子宮体部細胞診㜔診例の検討と反省

藤間病院病理" 、同 婦人科")、

○田嶋基男（ＭD ）'、稻村雅夫（ＣＴ）'， 中丸生行 ( C T ) '、須藤結花 ( C T ) ') 丸山彰子( C T ) " 、清水 謙 $(M D)^{21}$ 、 国立がんセンター病理、

山岸紀美江( C T )

[目的］体部腺癌に対する内膜摖過紐胞診の愦陽 性例之誤陰性例の細胞所見を初回細胞診標本につ いて検討した。

[材料] 経過追跡済みの 62,234 例の内膜擦過細胞 診の中、自院で手術し記載完備の99例の体腺缶を 対象（嗢床情報なし、標本番号のみで検鏡）

[成績］（1)陽性 $68.8 \%$ 、疑陽性 $16.1 \%$ 、陰性 16.0 \%。疑陽性以上を再検または生検組織診にするの でチェック率は $84.8 \%$ 、見落し $16.0 \%$ 、無症状の 住民検診や、ドックでは完全な見落しとなる。 (2)見落し15例では、小型淡染癌細胞の読みに問題 があり、子宮全㓐を占掛する癌例で陰性としたも のがある。核形不整、核軸のブレ、融解状核の存 在に、診断的研值を感じた。言陽性とした12例で は、核の大小不同、濃染核、著明な核小体の存在 に対する過大評仾が反省された。(3)陽性率は子宮 腔内の占拁面積に比例し、病期、分化度との関連 は余り強くなかった。

[考按] 全例中、細胞診疑陽性として生検組織診 を施行した 371例中、52.27\%は、体腺窝、䄉毛 癌、頝部異形成などであり、47.73\%は、単なる 内膜增生症、内膜症、増殖期または分必期の内膜 であった。即ち䋛胞診陽性の 3 倍の疑陽性を設定 して、尚かっ $16 \%$ の見落しがあったことを考える 之、体部癌の一次検診に細胞診が最も適当である か否か、現状では、なお慎重を要するものと考え る。
132 子宮内膜細胞の月経周期における 年台別の特徵の検討

碧南市民病院中央検查室 同婦人科

○吉田賢一(CT) 永井美佐子(CT)井上正朗 $(C T)$

西田裕一(MD)戸田繁(MD)

名古屋大学医学部検査医学講座

樑津俊明(MD) 中島伸夫(MD)

[目的] 子宮内膜細胞は、その月経周期によ り微妙に変化を絽り返している。この変化を 各Phaseごとに分け、各々のPhaseにおける20 歳台、30歳台、40歳台、50歳台の年台別の細 胞形態の違いの有無を検討した。

[材料 方法] 同時期に採取された内膜細胞 をセルブロック用とスメアー用に分け、それ ぞれH,E染色とPAP染色を行った。組織的に 陰性と確認された517例を用い、その全例の スメアーの背景、円柱上皮細胞の形態、間質 細胞の形態、胞体、核等40項目のチェック リストを作成した。

その内、組織学的に月経周期の判明した 20 歳 台14例、30歳台46例、40歳台66例、50歳台 17 例の計133例を検討した。

[結果および結論] 1、検討した40項目中、 スメアーの背景、円柱上皮細胞の重積性、内 膜腺の長さ、細胞の大きさとN/C比、核分裂 像の数、分泌様物の有無の6項目に年代別の 若干の違いがみられた。

2、スメアーの背景は40歳台、50歳台に分泌 中期から組織球を0〜1個/視野に見ることが 多くなる。

3、細胞の重積性は、20歳、50歳台で分泌中 期まで見られるが30歳、40歳代では増殖後 期以降は希である。

4、内膜腺の長さは、20歳、30歳、40歳代で は各Phaseともに差は見られないが40歳後半、 50 歳代に急激に短くなり、0.5 mmから $1.1 \mathrm{~mm}$ の長さである。胞体は20歳台が平均6.5から 12.0 ミクロン、50歳台で急に小さくなり 6.5 から8.5ミクロンである。

5、核分裂像の数は增殖中期に各年代ともに 最も頻繁に見られる。20歳代では 3個/視野が 多いが50歳代では 0〜1個/視野と溸次少なく なる。

6、分泌物の見られる時期は20歳代では增殖 後期に見るが年齢を重ねるにつれ分泌中期に なって見られるようになる。 
133 乳癌術後のtamoxifen(TAM)内服が 内性器に及ほす影響について

兵庫県立西宮、済生会富田林”、奈良県立三室 ** 星ヶ丘厚生年金***、浜岡総合 ${ }^{* * * *}$ 、病院 産婦人 科 $\mathrm{O}$ 井谷嘉男 $(M D)$ 、伊藤公彦 $(M D)$ 、堀 謙輔 $(M D) 、$ 田守陳哉 $(M D)$ 、安達 進 $(M D)$ 、新谷雅史 $(M D)$ **, 東條俊二 $(\mathrm{MD})^{* * *}$ 、野田恒夫 $(\mathrm{MD})^{* * * *}$

[目的］TAMは乳癌術後の補助療法に使用されて いるが、抗エストロゲン刻のため内性器を標的㖑 器とする可能性がある。そこでTAMの内性器に及 ほす影響を臨床的、細胞学的、内分泌学的点から 検討した。[万法］(1)乳癌術後TAM内服患者25例 の内性器と関連する副作用を調查した。(2)TAM内 服患者 25 例(月経周期 12 例:MC群、閉経期 13 例:MP 群)のmaturation index(MI) と、基礎疾患を認めな WTAM非内服症例 68例(月経周期41例、閉経期 27 例)のMIを算定しTAM内服が胠上皮に及ほす影響 を比較検討した。(3)MC群3例、MP群 7 例の血中 LH, FSH, E2, Pレベルを測定した。 [成績] (1)TAM 内服例中、8例が性器出血を、6例が月経不順を訴 えた。他覚的には子宮または卵巣腫大を 9 例に認 めた。(2)子宮内膜組織診では襄胞性萎縮内膜を 4例に、霊胞性腺腫增殖症を1例に認め、また子 宮内膜癌の発症を 1 例に認めた。(3)子宮内膜癌 発症例は 13 年間TAMを内服した 80 歳の症例で 子宮が腫大、MI0/82/18 と右方移動し、E2： $15.6 \mathrm{pg} / \mathrm{ml} 、 \mathrm{LH}: 7.9 \mathrm{mIU} / \mathrm{ml}$, FSH $: 18 \mathrm{mIU} / \mathrm{ml}$ でっ た。(4)MC群の内服期間は1 -48ヶ月、MP群の内服 期間は1-96ヶ月であった。(5)TAM非内服閉経期の

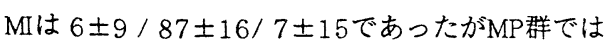

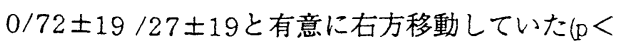
$0.05)$ 。(6)MP群の1例で血中 $\mathrm{E} 2$ が $89.4 \mathrm{pg} / \mathrm{ml}$ と上昇し ていた。[結論] TAMは内性器にホルモン様作用を 発現する可能性があること、必ずしもエストロゲン レベルを抑制しないことが示された。以上のこと はTAMの内服が子宮体癌の危険因子となりうる可 能性を示唆するものと考えられた。
134 Placental site trophoblastic Tumor (PSTT) 1 例

マツダ(株)マツダ病院臨床病理科 1 、厚生連尾道 総合病院病理研究検査科 2 , 広島大学医学部附属 病院病理部 ${ }^{31}$ 、公立三次中央病院産婦人科 4 !

O石井早苗 $(\mathrm{CT})^{11}$ 、米原修治 (MD $)^{22}$ 、 小川勝成 $(\mathrm{CT})^{3}$ 、竹原和宏 $(\mathrm{MD})^{4}$ 、宗岡宏 $(\mathrm{MT})^{13}$

PSTTはintermediate trophoblastの増殖から なる稀な腫瘍である。今回我々は子宮体部に発 生したPSTTを経験したので報告する。

【症例】23才、 3 妊 3 産。最終月経は平成 6 年 12 月 5 日。無月経を主訴として平成7年1月11日当 院受診。尿中hCGテスト陽性。1月18日人工妊娠 中絶術を受けたが、病理組織学的には間質細胞 の脱落膜様変化のみであり、䋐毛成分は認めら れなかった。その後少量出血持続し、尿中hCG値 は16,000IU/Lと高値であった。同年1月25日再掻 爬を受けるも絊毛組織は認められなかった。存 続絾毛症が疑われ2月20日子宮全摘術を受けた。 【摘出臓器所見】子宮腔後壁の左側に $3 \times 2.5 \times$ $1 \mathrm{~cm}$ 大の表面に出血を伴った脆い隆起性病変を認 めた。

【腫瘍捺印細胞診所見】中型〜大型の多角形な いし円形あるいは紡鍾形の異型細胞を認めた。 単核細胞が主体であるが多核細胞も混在してい た。細胞質は豊富で明るくライトグリーン好性 であった。核は円形ないし楕円形でクロマチン は細顆粒状、核小体は明瞭であった。免疫染色 ではこれらの細胞はhPL陽性、少仆防陽性であ り、intermediate trophoblastの性格を示した。 【病理組織所見】子宮体部には子宮内膜に intermediate trophoblastの小結節状の増殖を 認め、同trophoblastは子宮筋層内に各個単離の 浸潤を示した。以上の所見よりPSTTと診断され た。またこれらの腫瘍細胞はhPL陽性、开仆ケラチン 陽性、hCG陰性であった。 


\section{5 侵入性奇胎の一症例}

東大阪市立中央病院臨床検査科病理 $11 ，$ 同産娪人科 ${ }^{21}$, 済生会富田林病院産婦人科 ${ }^{31}$, 町立浜阔総合病院産婦人科 11

( 辻本晃男 $(C T)^{\prime}$, 车田島玲子 $(C T)^{\prime}$, 安達進 $(M D)^{3}$, 大月知子 $(\text { MD })^{2}$, 久永浩靖 $(\text { MD })^{2}$, 加藤由美子 $(\text { MD })^{2}$, 奥政孝 $(\text { MD })^{2}$, 野田恒夫(MD $)^{4}$ ，上田外幸(MD $)^{1}$

近年、䄉毛性疾患を経験する機会が少なくなっ ているが、今回我々は婦人科細胞診が診断に有用 であった侵入性奇胎を経験したので報告する。

【症例】53才、2 妊 2 産。1993年 9 月28日に 8 月 中旬より持続する性器出血を主訴に当院産婦人科 を受診し、强度の貧血により入院。子宮体部細胞 診にて䄉毛性疾患が考えられ、尿中 H C G は2000 U/Lであった。10月12日にPAGが実施され、䄉 毛癌は否定的であったが、大量の性器出血のため 緊急に单純子宮摘出術を行った。摘出子宮は妊娠 様であり、病巣は後面底部に存在し、筋層浸潤は 1/2であった。1994年 9 月に尿中H C G 50U/L陽性 を示し、化学療法施行後除性となり現在経過観察 中である。

【細胞像】子宮内膜細胞診で Arias-Stel la reac tionを示す $8 \sim 50 \mu$ の大小不同な核からなる平面 的な集団之、核クロマチンが凝集した $40 \mu$ のラン グハンス型細胞を認めた。捺印細胞診では出血性 背景を伴って合胞細胞と核の大小不同を見るラン グハンス型細胞を認め絨毛癌は否定的であった。

【組織像】子宮内膜組織診でいわゆる syncytial endometritisの像を示した。摘出組織診では出血 と壊死を伴う縺毛を認め、子宮筋層内にトロホブ ラストが侵入しており、侵入性奇胎と診断した。

【結語】婦人科細胞診が、補助的に絨毛性疾患の 診断に、有用であった症例を報告した。
136 子宮内膜細胞診が発見の端緒と なった子宮結核の一例

小千谷総合病院病理検查 ${ }^{1)}$ 、同産婦人科 ${ }^{2)}$ 新潟大学第2病理 ${ }^{3)}$

○斉藤孝久 $(\mathrm{CT})^{1)}$ 、酒井美和子 $(\mathrm{CT})^{1)}$ 、安田雅 弘 $(\mathrm{MD})^{2)}$ 、会田隆一 $(\mathrm{MD})^{2)}$ 、福田剛明(MD) ${ }^{3}$

子宮内膜細胞診にて子宮結核を疑い組織学 的、細菌学的に子宮結核と診断しえた症例を 経験したので報告する。

【症例】 57 歳女性。4妊3産。閉経 50 歳。両親 に肺結核の既往あるも本人にはなし。自覚症 状はなかったが検診目的で子宮内膜細胞診を 施行したところ子宮結核を疑う所見が得られ、 子宮内膜組織診にて子宮結核と診断された。 ヒステロスコープでは内膜は黄色調を呈し、 子宮底部にポリープが認められた。子宮内膜 組織診の抗酸菌染色は陰性であったが、子宮 内腔よりの培養にてヒト型結核菌 (DNA同定) が検出された。なお、胸部レ線上結核陰影は なく、喀痰の結核菌培養も陰性であった。

【細胞診所見】リンパ球、好中球の渗出背景 に短紡鍾型ないし類円形の類上皮細胞の集塊 とラングハンス型巨細胞が認められた。内膜 細胞に軽度の異型がみられたが炎症による反 応性の変化と考えた。

【病理組織所見】ラングハンス型巨細胞を伴 う類上皮肉芽腫で残存する萎縮した内膜腺に 軽度の核腫大を認めた。一部に好中球を混じ た壊死組織がみられたが典型的な乾酪壊死巣 は認められなかった。

【まとめ】近年、結核症の減少に伴い子宮結 核に遭遇する頻度は少なくなったが、子宮内 膜細胞診をスクリーニングする場合子宮結核 も念頭に入れておく必要があると考えられた。 
137 悪性との鑑別を要した結核性子 宮内膜炎の一例

JA神奈川県厚生連相模原協同病院検査部病 理"

同産婦人科 ${ }^{2}$

聖マリアンナ医科大学病理学教室 ${ }^{3}$.

○山本 秀巨 $(C T)^{1}$ 小俣 芳彦 $(C T)^{1}$.

樋口 正臣(MD) ${ }^{2}$ 大澤 章吾 $(M D)^{2}$.

竹内 英子 $(M D)^{3}$. 田所 衛 $(M D)^{3}$.

今回我々は、子宮体部細胞診スミアにて 一部悪性との鑑別を要した結核性子宮内膜 炎を経験したので、その細胞像と組織像を 併せて報告する。

症例は71歳、主婦。下腹部痛のため平成4 年12月28日当院産婦人科受診。同日子宮体 部細胞診さらに後日子宮内膜組織診を施 行、その結果より子宮及び両側付属器摘出 術が行われた。

子宮体部細胞診では、壊死的背景にリン パ球を伴った類円形、短紡錘形の類上皮細 胞を考える集魂及びラングハンス型類似の 巨細胞を認め結核が示唆された。しかしな がら、一部の内膜腺細胞に核小体の目立つ クロマチン中等度増量した異型細胞が認め られ悪性も否定できなかった。

子宮内膜組織診では、乾酪壊死を伴った 慢性肉芽腫性炎症の像を呈しており、結核 性子宮内膜炎とされた。摘出標本において も結核病巣が確認され、また一部に異型性 細胞を認めるが、悪性睡瘍とされる病巣は 存在していなかった。

\section{8 結核性于宮内膜炎の 1 例}

東京女子医科大学㦃婦人科

○将地愛子 (MD), 矢島正純 (MD)，木村祐子 (CT), 石巻静代 (MD)，井口登美子(MD)，武田佳彦 (MD)

近年、性器結核は極めて稀な疾患となり、明確 な症候もないため見逃される場合が多く、婦人科 領域のみならず臨床上のピットフォールとなる場 合も少なくない。今回、結核性子宮内膜炎と診断 した 1 例を経験したので報告する。

症例は58墄の女性。20歳にて肺結核の既往あり。 1989年 5 月に黄色帯下にて当科初診し、細胞診は 子宮胵部がクラス II 、内膜は炎症性背景が著しい ものの陰性、胵分泌物の一般培養は陰性で老人性 胵炎との診断であった。1991年 2 月に右下腹部痛 にて当科再来し、同様の診断を受けている。

1995年 3 月には外陰部掻廉感にて再来し、やは り多量の黄任带下を認め、内膜紐胞診はクラスIII 修復細胞様の異型腺細胞を認めた。組織診では悪 性所見はなく、類上皮細胞を主体とするgranulom atous lesionが多数認められ、一部に多核巨細胞 を認めたため結核等の抗酸菌感染症が疑われるも、 結核菌培盖は陰性であった。しかし再度の検査に て同菌培養陽性との結果を得、結核の治療を施行 中である。

本症例の経過を顧みると、6 年間にわたり黄色 帯下が断続的に見られており、内膜組織猃にて結 核が疑われるまでは老人性胵炎として治療を受け ていた。難治性胵炎の際には、内膜組織診を施行 し悪性疾患を否定すると共に、性器結核も鑑別診 断のひとつとして、肺結核の既往を問診し、必要 に応じてツ反や結核菌培養などの検索を行なうべ きであると思われた。 
胞体内赤玉物質が多数認められた

䖽肉腫の一例

卜ヨ夕記念病院臨床検查科病理'

藤田保健衛生大学医学部第一病理 ${ }^{2}$

鈴木良典 (C T ) ', 那須祐次 (MT)

田代和弘 (MD) ', 堀部良宗 (MD) 2

溝口良順 $(M D)^{2}$, 笠原正男 $(M D)^{2}$

（はじめに）子宮体部の漿液性腺癌は比較的まれで、 悪性度が高い。このため、本邦の子宮体癌取り扱い 規約では独立組織型として分類されている。

我々は、本腫瘍を 2 例経験したので若干の文献的考 察を加え報告する。

【病例 1】56 歳女性。主訴: 不正性器出血。

5 妊 2 産、閉経 52 歳。

（内膜細胞診所見）炎症性背景の中に乳頭状細胞集 塊を多数認め、砂粒体も認めた。強拡大において細 胞は2 種類認めた。一つは、N/C 比大で類円形核 を有し顆粒状のクロマチンで核小体の目立たない細 胞である。もう一つは、細胞質が豊富で明るく核が 偏在し、核形は類円形〜不整形で細顆粒状のクロマ チンを呈し核小体の目立つ細胞である。

（組織所見）腫瘍は乳頭状増殖を呈し外向性に発育 し、筋層内の脈管に著明な浸潤が見られた。また、 多数の砂粒体を有し樹枝状及びHobnai 1 様の像が存 在した。

【病例 2】54 歳女性。主訴 : 特になし。

5 妊 3 産、閉経 48 歳。

（内膜細胞誩所見）炎症性背景の中に、乳頭状細胞 集塊が多数見られ集塊のはみ出しやほつれを認め、 砂粒体も数個認めた。强应大でこの細胞は、N $/ \mathrm{C}$ 比大で核は円形〜類円形で 1 部大小不同を呈し、核 クロマチンは顆粒状で核小体は目立たない。 (組織所見) 腫場は、頸部よりやや上部にポリープ 状に存在し、1 部筋層浅部に浸潤し、また、左卵管 内に転移が認められた。組織所見は病例 1 とほぼ同 様であった。

（まとめ）槳液性腺癌の鑑別診断、及び予後不良と される病理学所見等を検討した。
埼玉県立がんセンター臨床病理部
○永宗恵子(CT) 佐々木ひろみ(CT)
江良英人 (CT) 松井武寿 (CT) 佐野裕作 (CT)
黒住昌史(MD) 桑島良夫(MD) 岸紀代三(MD)
同婦人科高橋道子(MD) 白水貄士(MD)

目的 子宮福肉腫で胞体内に赤玉物質を持つ細胞 が出現することは稀でないとされているが、これ が多数認められた症例は文献的にも少ない。紐胞 診で認められたこの物質について、電影と䤃素抗 体を用いて検討を加えたので報告したい。

症例 63歳女性 '95'8月不正出血を主訴として受 診。細胞診と生検により䅝肉腫と診断され、9月腹 式単純子宮全摘、両僛附属器摘除、骨瞥リンパ節 生検を施行。

細胞所見 EM smearは背景が污く、重積性のある

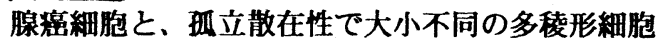
が出現していた。多稜形細胞の中には、核は不整 類円形でクロマチンが微細、核小体が1 数個認め られ、さらに細胞質頼粒状（赤血球と類佔した大 小の赤玉物質を多く含む）の緗胞が存在した。細 胞診では福肉腫または低分化腺煰を推定した。

組織所見 子宮は $500 \mathrm{~g}$ で、肉眼的に体部内腔に外 向性腫韵が充满していた。組織学的にはG1〜G2の 内膜型腺湆之肉腫成分（軟骨、骨、脂肪、横紋筋、平 滑筋）からなっていた。病理診断は体部の䅅肉腫 とした。特徽的所見として、主に肉腫成分中の胞 体内に、相大で大小不同のある PAS陽性の赤玉を 多数認めた。一部赤玉は細胞外にも認められた。 電影では、赤玉は通常のlysosomeより大型で、多 形性のある類円形のdense glanuleであった。醭 素抗体では、a1-Ant itrypsin、IgG, IgA, IgMが陽性、 AFP, GCDFP-15, CD-68, S-100, chromogran in A, Lysozymeは陰性であった。この赤玉の性格につい てはさらに検討中である。 
141 子宮体癌におけるインテグリン (fibronectin receptor, vitronectin receptor)の発現 と転移との関連

癌研究会附属病院婦人科 ${ }^{1)}$, 同 細胞診断部 ${ }^{2)}$ ○加藤友康 $(M D)^{1)}$, 荒井祐司 $(C T)^{2)}$, 荷見勝彦 $(\mathrm{MD})^{1)}$

[目的]原発巣からの癌細胞の遊離は転移形成の 第 1 段階であり，その機構には接着分子の発現の 増加または隇少が関与していることが報告されて いる。そこで, 子宮体癌原発巣に拈けるインテグ リンの発現を調べ，転移の有無との関連性を検討 した。［方法］1992年11月より1994年12月まで に当院で手術治療を行った 80 例の新鮮摘出標本の 癌巣割面の择印標本を材料とした，正常対照には 良性疾患の増殖期, 分泌期内膜を用いた。 80 例の 組織型は内膜型腺癌 $G 1$ が 48 例, G 2 が 23 例, G3 が 7 例, 明細胞癌が 1 例, 腺扁平上皮癌が 1 例であ った。付属器転移が 9 例, リンパ節転移が 10 例に 認められた. 捺印標本を $95 \%$ エタノール固定後, fibronectin receptor (FNR)のモノクローナル抗体 ( $\beta 1$ 鎖認識) と vitronectin receptor (VNR)のモ) クローナル抗体 ( $\beta 3$ 鎖認識)を用いて $\mathrm{ABC}$ 反応に 上る免疫染色を行った。[成績] FNRは陽性17例, 弱陽性 9 例, 陰性 49 例で, 判定不能 5 例であった。 VNRは陽性 36 例, 弱陽性 10 例, 陰性 33 例で, 判 定不能 1 例であった。正常内膜腺は增殖期, 分泌 期ともに陰性であった。付属器転移とFNR陽性に は有意の相関 ( $p=0.009$, Chi-square test)がみら れた. FNR陽性 17 例中6例に付属器転移がみられ たのに対し，FNR陰性 49 例中転移がみられたのは 3例であった. VNRでは付属器転移と相関関係は なかった。リンパ節転移や組織型別については， FNR, VNRの発現に一定の傾向はみられなかっ た.

[結論]子宮体癌原発巣におけるFNRの発現と付 属器転移に高い相関を認めたことから, FNRが付 属器転移に関与している可能性が示唆された。
142 Mül lerian mixed t u morの一例
磐田市立総合病院病理検査室 ${ }^{11}$, 同産婦人科 ${ }^{21}$ 浜松医科大学病理学第一講座 ${ }^{3}$ 、
袋井市民病院病理部4
○江䒯 充 (CT) ${ }^{1\rangle}$, 栗田 昭 (CT) 1)
前田 新一 (MT) ${ }^{1)}$, 鈴木 一有 (MD) 2)
新井 富生 (MD) ${ }^{3}$, 伊藤 以知郎 (MD) ${ }^{4}$

本腫癔は高齢者に多く、一般に子宮腔内への外 向性発育を示し、しばしば出血・壊死を伴う比較 的希な疾患である。

[症例] 82 才の女性で他施設で子宮内留膿腫と して初期細胞診クラス IIで子宮内洗浄を施行。 10 月当院に入院、細胞診クラス V、多くの好中 球を伴う裸核化及び変性壊死像が著明で大型円形 一榃円形の核を有し細胞質は淡染性のものが多く 、大部分平面的な配列を示し䋸やかな集合も見ら れた。奇形核や巨大核を有する細胞も認められ、 軟骨由来を示唆する細胞も認められた。組織診で はMullerian mixed tumorと診断され、11月子 宮全摘術を行った。子宮は重量750 恣、白色調で 柔らかく全体が腫瑏で占められ、左卵巣は不明で あった。組織標本では大部分非上皮性腫瘍細胞で 占められ、一部には好酸性の細胞質で明暸な横紋 を有する横紋筋肉腫成分や軟骨肉腫成分、腺痁成 分も函少量見られた。免疫染色では横紋筋肉腫部

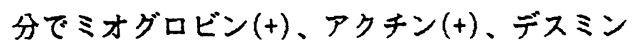
$(+)$ 、軟骨肉腫部分ではS-100蛋白 $(+)$ 、腺痖部分 ではケラチン(+)、EMA(+)、CEA(+)であった。 今回我々は子宮内膜腫瘍の中でも比較的希な Müllerian mixed tumor を経験したので細胞像と 組織像を提示し報告する。 
143 子宮体部平滑筋肉腫の 2 例

佐世保共済病院検查部病理 ${ }^{1)}$ 、同産婦人科 ${ }^{2)}$ 、 久留米大学第 2 病理 ${ }^{3)}$

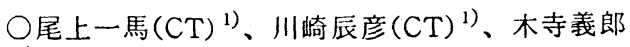
$(\mathrm{MD})^{2)}$ 、清塚康彦 $(\mathrm{MD})^{3)}$ 、中島明彦 $(\mathrm{MD})^{3)}$ 、 原田博史 $(\mathrm{DDS})^{3)}$ 、森松 稔 $(\mathrm{MD})^{3)}$

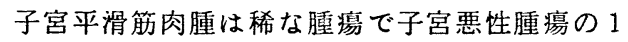
～2\%といわれている。今回我々は子宮体部に発 生した平滑筋肉腫の 2 例を経験したので報告する。

〔症例 1〕59才、7 妊 3 産、閉経53才、主訴は 黄色帯下。子宮は鵝卵大で外子宮口より、直径 3 cm大の暗赤色のポリープ様腫瑒の笑出を認めた。 内膜細胞誩：出血及び壊死を伴う背景の中に孤立 散在性及び集合性に出現した境界不明瞭な腫㕫細 胞が認められた。 $\mathrm{N} / \mathrm{C}$ 比は增大し、核形は紡錘 形一線維状を呈し、核縁は薄く、切れ込み、くび れなどが見られた。核クロマチンは細顆状一顆粒 状で核小体は小型で 1 ～2 個みられた。

組織所見：著明な中心部壊死を伴う、錯綜する平 滑筋細胞より構成され、高い細胞密度を有し、 bizarreな巨細胞が観察された。

〔症例 2〕78才、0 妊、主訴は帯下。子宮は手 拳大で胵壁は萎縮性で出血斑あり。エンドサイト の子宮腔への挿入は不可能であった。経胵プロー ブによる超音波検查で子宮内腔に直径 $3.5 \mathrm{~cm}$ 大の 円形の腫瘍性病変が認められた。摘出腫瘍の捺印 細胞診：出血性背景の中に孤立散在性及び集合性 に出現した境界不明瞭な腫瘍細胞を多数認めた。 腫場細胞はN $/ \mathrm{C}$ 比の增大、核形は類円形〜棈円 形を呈し核の切れ込み等も見られた。核クロマチ ンは細顆粒状〜顆粒状で核小体は目立たなかった。 組織所見：N/C比大で核異型の目立つ紡鍾型の 細胞が錯綜する様に増殖していた。細胞密度は高 く、核分裂像が著明であった。
子宮体部原発純粋横紋筋肉腫の一例

市立酒田病院病理

O池田晴美 (CT)、吉田幸司 (CT)、矢島美穂子 (MD) 荘内地区健康管理センター病理

斉藤清子 (MD)

子宮体部に原発する横紋筋肉腫は、極めて稀な腫 病で、その報告は非常に少ない。今回我々は、58 歳女性の子宮体部横紋筋肉腫を経験し、捺印標本 を钼察する機会を得たので報告する。

【症例】58歳女性、6妊4産、閉経47歳。

平成 7年7月中旬より不正出血、下腹部重苦感があ り近医受診。子宮体癌疑いのため紹介され7月21 日当院受診。初診時採取の子宮内容生検にて非上 皮性悪性腫曒が疑われ、9月6日子宮及び両付属器 切除術を施行した。摘出された腫曒は子宮腔にポ リープ状に突出する巨大な腫演で、高度の出血、 壊死を伴っていた。

【捺印細胞診所見】出血性及び壊死性背景の中に、 大型の核を持つ類円形から棈円形の細胞や紡鍾形 細胞、偏在核を有する横紋筋芽細胞様細胞など多 彩な像を示す腫演細胞が見られた。

【組織学的所見】多形性があり好酸性の胞体と明 らかな横紋を持つ腫痬細胞からなる部分と紡鍾形 細胞が束状、渦状に增殖する部分が見られた。免 投組織化学的には抗ミオグロビン抗体が陽性であ った。ほほ全割した標本の検索によっても他の間 葉系由来の肉腫成分、上皮性成分は認められなか った。なお、畽㴻細胞の胞体内に電子顯钽鏡的検 索で、帝様構造が認められた。

【まとめ】子宮標本に横紋筋芽細胞様細胞を見た 時には、通常 MM T を推定するが、予後不良な純 粋横紋筋肉腫の存在をも考虑する必要があると考 える。 
145 |UD拔去時の子宮染内細胞診で見つ かった子宮内膜間質肉腫の 1 例

聖刏ア疒医科大学横浜市西部病院産婦人科、病理 * ○中田洋子(MD)竹内久清(MD)飯田智博(MD) 林和彦 $(M D)$ 半田留美子 $(C T)$ ᄎ安田玲子 $(C T)^{\text {* }}$ 硬嘻秀一 $(\mathrm{CT})$ *品川俊人 $(\mathrm{MD})$ *

子宮腔内細胞誩で子宮肉腫を見出すことは希で あるか、今回我々は、UD抜去時の細胞誩により 診断し得た症例を経験したので報告する。 患者は55歳、6姡2産、敛食店経営の女性。 1995年1月性器出血を主訴として近医の紹介で 当院を受唁した。閉経は53歳。その頃前医で子宮 筋腫の診断を受けていた。当院初診時、子宮は 前傾前屈檍卵大、やや硬く可動性は良好。 両側附属器、子宮傍結合織、子宮臸部などに異常 は認めなかった。子宮睚顏部及び内膜細胞診共 クラスルだった。術前血液検查でLDH,CRP,BFP,IAP, CA125、などの異常值を認めた。画像診断では 変性あるいは壊死を伴った子宮腫瘍であった。 初診時以後性器出血無く外来経過観祭とした。 同年 5 月再度性器出血を認め、また $1 \cup D$ 挿入中 との申告が初めてあり出血の原因となり得るため 拔去を試みるも子宮壁に強く食い込んでおり除去 できなかった。この時点での子宮腔内細胞診所見 は、出血性背景の中に㻋な結合を有した腫場細胞 が出現し、核は大小不同、円形〜不整形、核緑の 肥厚は目立たなかった。クロマチンは粗顆粒大・ 核小体は数個あり、胞体はライトグリーンに淡染、 胞体の境界は不明瞕であった。これらの所見から 子宮肉腫を考えた。同年7月開腹、子宮は手拳大 に腫大、やや軟、直腸 S 状結腸と部分的に多少甞 着はあるものの、表面は平滑で両側附属器は正常 であった。病理組織誩で子宮内膜間質肉腫と診断。 術後 VAC 療法施行するも副作用が非常に強く、 患者及び家族か治療に耐えられず2クール終了後 話し合いのもとに同年 9 月退院した。
146 子宮内膜原発悪性リンパ腫の一例

聖路加国際病院 病理科

○岩田法子(CT), 菊池早苗 (CT), 佐藤命子(CT), 橋本尚子(CT), 伊藤定子(CT), 荒不章伸 (MD)， 植草利公(MD), 齋木茂樹(MD)。

子宮内膜原発の悪性リンパ腫は非常に稀であ る。今回我々は子宮内膜にびまん性に発生した 悪性リンパ腫を経験したので報告する。

【症例】55歳女性. 3 姡 3 産. 30 日周期.

【現病歴】40歳時、月経過多による貧血を主 訴に当院受診し子宮筋腫を疑われ鉄剂を投与さ れていた。 54 歳 MRIで腺筋症を指摘され経過 観察されていたが、子宮は超手拳大と増大傾向 あり、また不正出血による分血も続く為め、単 純子宮全摘出術が行われた。この間、数回の細 胞診が行われていたが、悪性リンパ腫と診断し えなかった。

【病理組織所見】子宮内膜の固有層を中心に単 一な類円形のリンパ球様細胞浸潤が著しく、箭 層内にも島状に浸潤していた。これらのリンパ 球様細胞は免疫組織学的にL 26 染色で優位に 染まりB細胞性びまん性小細胞性リンパ球様型 リンパ腫と診断された。

【細胞所見】いずれの細胞診においても子宮内 膜細胞は乏しく小型のリンバ球様細胞の集団が 多数認められた。retrospective に兒ると、こ れらの小型のリンバ球様練胞の核に軽度ながら くびれを有するものも認められた。

【考察】子宮内膜原発の悪性リンパ腫は稀で今 回のような小型の悪性リンパ腫は細胞診で診断 することは難しく我々も上皮性細胞をスクリー ニングしたため陰性と判定してしまった。この ような症例は悪性リン八腫の可能性も考慮する 必要があると思われた。 
147 腹水細胞診にて推定した子宮体部 悪性リンバ腫の 1 例

国立病院四国がんセンタ一婦人科 ${ }^{11}$, 同 病理 ${ }^{21}$

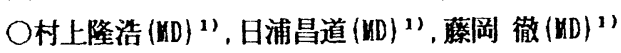
野河孝充(UD) $)^{11}$ ，千葉 丈(KD $)^{11}$ ，山内政之 (CT $)^{21}$ 龟井孝子 $(\mathrm{CT})^{21}$, 中脇珠美 $(\mathrm{CT})^{2)}$ ，香川昭博 $(\mathrm{CT})^{2)}$ 万代光一(MD) ${ }^{21}$ ，森脇昭介 (MD ${ }^{21}$

我々は、腹水細胞診にて悪性リンバ腫を疑い、 剖検にて子宮体部原発と考えられる悪性リンバ捤 の 1 症例を経験したので報告する。

【症例】73歳女性。3好1産。43歳閉経。平成7年2 月27日不正性器出血を主訴に近医を受診、子宮体 部腄瘍を指摘された。3月6日発熱、急性腹症のた め内科で精密検查を受けたが異常なく、3月26日 急性腎不全 (雨側水腎症)となり、4月5日当科紹介 受診した。内䛦にて子宮は超手拳大で碚性軟、卵 巣は瑟卵大に喠大していた。表在リンパ節腫大は なかったが超音波検查で傍大動胵リンバ節貍重大、 腹水粉瘤を認めた。入院後、腎前性腎不全が進行 し、化学療法を行う間もなく4月15日永眠された。 【血液検查】LDH $2646 \mathrm{IU} / \mathrm{I}, \mathrm{ChE} 0.15 \mathrm{IU} / \mathrm{I}, \mathrm{CCr} 20$

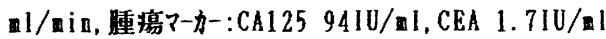
【内膜細胞診】シート状配列の委縮内膜細胞と不规 則な重積や結合性のない大小不同の異型細胞が掘 立散在性に出現。異型細胞は小型で $\mathrm{N} / \mathrm{C}$ 比大きく、 クロマチンは細顆粒状、核小体は不整型であった。

【腹水細胞診】大小不同を呈し、細胞結合性の乏 しい大型の腫瘍紐胞が出現。核は多型性でN/C比 は大きく悪性リンバ睡を跔った。

【剖検・組織所見】細胞質はそしく、不規則な核 を持ち、不整で大型の核小体を1個あるいは数個 有する腫場紐胞が、びまん性に子宮体部壁全層に

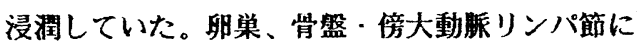
も同样の子宮腫瘍の浸潤を認めた。特殊染色では LCA (t+), EHA (-), vimentin(-), desmin $(-)$, S100(t). NSE (t)，Hx-Pan B (t)で子宮体部原発悪性リンパ腄、 びまん性、大細胞型、B細胞性と診断した。

\section{8 耳下腺原発悪性筋上皮腫の 1 例}

市立釧路総合病院検查科病理

○小関孝之 $(C T)$ 、中野勝彦 $(C T)$ 、北村 玲子 $(C T)$ 、准藤聖子 $(M T)$ 、吉田豊（M D)

筋上皮腫の発生頻度は全唾液腺腫瘍の $1 \%$ 以下 とも言われ、その悪性型はさらに少ない。今回 我々は耳下腺原発で組織学的に悪性筋上皮腫と 診断された症例を経験したので報告する。

(症例） 84 才、男性。平成6年 12 月頃より 左耳前部のしこりを自覚し定期的に通院してい たが、増大傾向が見られるため手術目的に平成 7 年 5 月入院となった。その間穿刺吸引細胞診 が施行された。

（細胞像）大小の細胞集塊と散在性に裸核状細 胞を認める。細胞形は紡鍾形で核形は円〜卵円 形、異型はさほど見られないが大小不同を認め る。クロマチンは細顆粒状、小型ながら核小体 も見られた。細胞質は薄く好酸性であった。背 景に多形腺腫に見られる粘液様物質は認めず、 壊死も見られなかった。

(組織像) 円〜卵円形核、胞体好酸性細胞の胞 巣状、渦巻状増生像を認める。出血を伴い周囲 への小結節状浸潤を認め、核分裂像も散見され た。明らかな壊死は認めなかった。免疫染色に おいてS－100、平滑筋アクチン、ケラチン が陽性で筋上皮に特徵的な染色パターンを示し PCNAは6 0〜 7 0\%の細胞で陽性であった 。以上の所見より組織学的に悪性筋上皮腫と診 断された。 
149 耳下腺の真性悪性混合腫瘍の一例

主にその細胞像について

\section{国立京都病院臨床検查科}

黒川 聡 $(C T)$ 、山本信夫 $(C T)$ 桶口佳代子 $(M D)$ 、岡本英一 $(M D)$

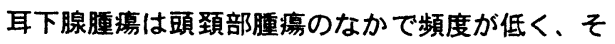
のうち悪性腫漡はさらにまれなのもとされている。 そして、良性、悪性ともに多彩な組織像を示し、細 胞学的、組繶学的に診断の困難な症例が含まれる。 多形腺腫の中には長い年月の間に悪性化するものが 知られている。今回、我々は多形腺腫の再発を繰り 返す経過中に悪性転化を来したと思われた症例を経 験したので報告する。

【症例】58才男性。34才の時、耳下腺腫䓪を指摘 され、35才で手衍した。その時の診断は多形腺董

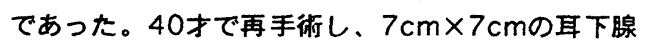
腫境を摘出。53才で再発、徐々に增大するも放置。 5 年後、平成5年9月当院耳鼻咽喉科に入院となった。 術前の穿刺吸引細胞誩で、多形腺腫亡診断されたが、 胸部 X線で多発の銭形陰影が認められたため、臨床 的に悪性が疑われた。

【細胞像】腫埴の表面部より得られた細胞は、術前 の穿刺吸引のものに類似した翼型の乏しい多形腺腫 样細胞像であった。腫瘍に割面を入れ、数カ所より 摖過標本を作製した。上皮性格の明らかな異型が強 い細胞と肉腫様細胞が認められた。

【組織像】明らかな上皮性成分と軟骨肉腫樣成分が 混在して見られ真性悪性混合腫演と揨断された。

組織学的に多樣な耳下腺腫演の中で、多形腺腫由 来の悪性腫瘄はとくに多彩な成分を含み、診断困難 な症例が見られる。今回の症例においても、術前の 穿刺吸引細胞跈では良性の多形眿㬴であったが、腫 瘄深部からは、悪性の成分が潖められた。したがっ

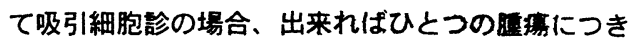
複数の場所からの吸引検体を得ることが望ましく、 正診率を高めるのに有益であると思われる。

\section{0 上咽頭癌（移行上皮癌）二例の細胞像}

済生会新潟第二病院病理 ${ }^{11}$, 耳鼻咽㬋科 ${ }^{21}$

O三木弘美 ( C T $)^{11}$, 石原法子 (MD ) ${ }^{11}$, 樋 浦賢太郎 $(C T)^{11}$, 丸山健 $(M T)^{11}$, 瀧井 尚子 $(M D){ }^{21}$

上咽頭の移行上皮癌（未分化癌，”リンパ上皮 腫”）を細胞診で経験することは比較的稀である ので報告する。

【症例】症例 1 は73才男性。心房細動, 非持続型 心室頻拍にて当院内科に通院治療中. 血疾を主訴 に喀疹細胞診が行われ陽性であった。精查の結果， 上咽頭腫瘍が発見され，生検診断は移行上皮癌で あった。肺転移はなかった。脳底に浸潤があり, Stage IV. 他院にて, 放射線治療と化学療法か施行 され，約 2 年半後の現在，生存中である。

症例 2 は45才男性. 頝部リンパ節腫大にて当院 耳菑科受診し，上咽頭腫瘍を認められた。リンパ 節穿刺吸引細胞診は陽性で, 上咽頭生検では移行 上皮癌と診断された。N3でStageNであった。患者 は他院にて放射線治療および化学療法中である。

【細胞所見】症例 1 では多数の好中球と軽度の壊 死性背景の中に核胞体比大の大型腫瘍細胞か子孤在 性または集団で出現していた。細胞境界は不明瞭 で核はクロマチンにそしく泡沫状を呈し，核小体 は明暸で，大型集塊内にリンパ球浸潤を認めた。 当初, 肺の腺癌や大細胞癌を疑ったか，生検診断 後の見直しで，上咽頭移行上皮癌と診断された。

症例 2 では壊死細胞が大部分を占め,その中に 症例 1 と極めて類似する腫瘍細胞集塊が認められ た。壊死細膳間や背景に少数のリンパ球を認めた。 上咽頭移行上皮癌が疑われた。

【生検所見】症例 1，2 共に, 典型的移行上皮癌 の所見で, 症例 1 ではリンパ球浸潤は比較的軽度 であり，腫瘍部に漬瘍形成か疑われた。症例 2 で は，高度のリンパ球漫潤を認めた。

【まとめ】上咽頭移行上皮癌は細胞所見の特徵か ら組織型の推定が可能であると考えられた。 


\section{1 壊死性ワルチン腫痬の塗抹細胞像}

川崎医科大学病理学教室 1

川崎医科大学附属病院病院病理部 2

○広川満良 ${ }^{1)}(\mathrm{MD})$, 玉井美奈子 ${ }^{2)}(\mathrm{MT})$,

鐵原拓雄 ${ }^{2}(\mathrm{C} T)$, 有光佳苗 ${ }^{2)}(\mathrm{MT})$, 坂元和宏 ${ }^{11}(\mathrm{MD})$

【目的】ワルチン腫瘍のなかには壊死性ワルチン 腫瘍と呼ばれる炎症や壊死を伴う例があり, 穿刺 吸引細胞診にて的確に診断することが困難である ことが知られている。 そこで，今回われわれは壊 死性ワルチン腫陽の診断率の向上を目的に, 定型 的ワルチン腫瘍と壊死性ワルチン腫瘍の塗抹細胞 像を比較検討したので報告する。

【対象および方法】穿刺吸引細胞診および腫瘤 割面からの捺印塗抹細胞診を行った定型的ワルチ ン腫瘍 16 例と壊死性ワルチン腫瘍 4 例を対象と し，それらの塗抹標本および組織標本を光顕的に 観察した.

【結果】ワルチン腫瘍の共通所見として，顆粒状 の細胞質を有する円柱状〜多稜形上皮細胞, リン パ球，顆粒状背景，壞死細胞などが見られた。 $50 \%$ 症例では同心円状構造を有する円型の蛋白 様物質が見られた。ギムザ染色あるいはDiffQuik染色が行われていた11症例においては，肥 満細胞が全例に，好酸球が6例に認められ，うち 1例にはシャルコーライデン結晶が多数観察され た。

壞死性ワルチン腫瘍では，上皮細胞は孤立散在 性に出現し，扁平上皮細胞が全例に見られた。背 景には壊死物質が豊富で, 多数の好中球や組織球 が観察された。また，ヘマトイジン結晶が2例に 認められた。

【まと】壊死性ワルチン腫瘍の塗抹標本では， 上皮細胞やリンパ球は壊死に陥ったものが多く, 扁平上皮細胞が高頻度に観察され，背景には好中 球, 組織球, ヘマトイジン結晶などが観察される ことが特徵で, これらは壊死性ワルチン腫瘍を示 唆する有用な所見になりえると思われた。
152 多形腺腫の塗抹細胞像 一筋上皮細胞の多彩性についてー

川崎医科大学病理学教室

○清水道生 (MD), 椛田美由紀 (MT) 広川満良 (MD)

【目的】多形腺腫は組織学的に多彩な像を呈する ため, その細胞像も多種多様で時に診断が困難な 症例がある。そこで, 今回我々は多形腺腫の多彩 な塗抹細胞像に着目し, 多形腺腫の構成細胞の中 でも特に多彩性を示す筋上皮細胞の塗抹細胞像に ついて検討したので報告する。

【対象および方法】川崎医科大学附属病院病理部 で多形腺腫と診断された38例の塗抹標本を対象 とした．標本は全例において湿固定後パパニコロ ウ染色もしくはHE染色が行われ，18例では乾 燥固定後ディフ・クイック染色も行われていた。

【結果】筋上皮細胞は, 上皮様集塊型, 形質細胞 様型, 粘液腫様型, 紡鍾形細胞型の 4 型に分類す ることができた. 上皮様集塊型は16例に観察さ れた. 樹枝状に伸びる大型の3次元的集塊として 見られ, 個々の細胞は小型で, 円型ないし類円形 の核を有し, 核・細胞質比が高かった. 形質細胞 様型は18例に見られた，偏在する核を有する類 円形細胞が散在性に出現し，あたかも形質細胞の ようにみえた。背景にはディフ・クイック染色に て異染性を示す間質性粘液が比較的豊富に見られ た. 粘液腫様型は20例に見られ，筋上皮細胞は 類円形, 紡錘形, 星茫状で, 豊富な間質性粘液の なかに埋もれるように出現していた。紡錘形細胞 型は6例に見られ，短紡錘形の核を有する細胞が 同一方向に束状配列した像として観察された。

【まとめ】多形腺腫にみられる筋上皮細胞には上 皮様集塊, 形質細胞様, 粘液腫様, 紡錘形細胞の 4 型がみられることを明らかにした。これらの各 型は症例により構成成分が異なったり，同一標本 内でも部位により違う像を示し，多彩であった が, それらに精通することにより, 多形腺腫の細 胞診断の成績の向上が期待できると思われた. 
153 大腸癌が頭蓋内随膜嫄に腾接して転 移した一症例

宗像水光会楆合病院挨查科" 同媨神経外科 ${ }^{21}$ O山中 晸二 (CT ) " 浦田涼子 (CT) " 津留 英智 $(M D)^{2)}$

（はじめに）今回我々は大腸癌か、頭蓋内の再発

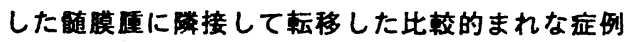
を術中稩胞診で猃断し得たので、その画像所見、 稩胞像、組織像などについて若干の文献的考察を 加えて報告する。

（症例） 57 歳、女性。既往歴: (1)昭和 58 年 跹膜原手術。(2)平成 7 年 1 月大腸痘手術。現病 歴: 平成 7 年 6 月乫然全身けいれんを起こし当院

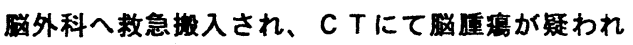
入院となる。

（画像所見）頭部MRI上、前頭蓋底より副楀腔 内に進展し造影剂にて均一に增強される厘瘦所見 と、それに腾接して左前頭菜傍矢状洞部に造影剂 にてやや不均一に增強される厘病所見を認めた。

厘熄部の C T、MR I 所見、術中写真を提示する。 （細鮀誩）最初にA 部分を生検し捺印細胞診を施 行。高円柱状の異型湅胞が腺管構造を呈しており 消化管由来の高分化腺癌亡猃断し、大腸癌の転移 が示唆されるとした。次に、B部分を生検し捺印 耘胞猃を施行。異型性が見られない細胞が渦玟状 （玉ねき状）配列で見られ随膜上皮型随瞙重と誩 断した。

（組機钐）（A）消化管由来を强く疑わせる分化 型腺虚。（B）䫓円形の比較的淡明な核を有する 紡籍形細饱が渦玟状を示す随膜上皮型随膜堹。又、 両粗樴の明らかな混在は認めなかった。

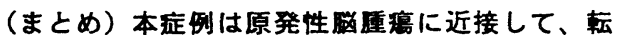

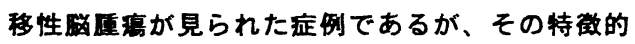
䎩胞像や既往歴などから術中䎩胞診での診断が可 能であった。
154 白血病ならび悪性リンパ腫の䯣膜浸 潤に関する検討

医療法人雪の聖母会聖マリア病院病理部 O中野祐子(CT)、大田喜孝 (CT)、伊藤園江 (CT) 原武晃子 (CT)、大田桂子 (CT)、楳田明美 (CT) 塚本孝久 $(C T)$ 、伊藤裕司 $(M D)$ 、中村康宽 $(M D)$

近年、化学療法の進歩により白血病や悪性リン ハ腫の長期寞解が可能となるとともに髄膜浸潤の 例が增加し、治療を行う上での重要な問題とされ ている。今回我々は過去 3 年間の髄膜浸潤症例を 蒐集し臨床像を背景とした細胞形態学的検討を行っ たので、若干の考案を加え報告する。

【対象と方法】対象は1993年から1995年に提出さ れた髄液細胞診292 例のうち白血病ならび悪性リ ンパ腫の髄膜浸潤を認めた8 症例で、これらの病 型, 臨床経過, 陽性㖪液の細胞数, 腫㾨細胞の割 合，出現期間について検討した。

【結果】病型の内訳はAMMOL，AML，CML，ホジキン 病が各1例、非ホジキンリンパ腫、ALL が2例ずつ

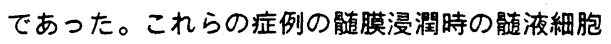
数はホジキン病、非ホジキンリンパ腫においては 1286/3 $\mathrm{m}^{3} 、 525 / 3 \mathrm{~m}^{3}$ と增加をみたか、、他の6症例に おいては正常値〜 $100 / 3 \mathrm{~m}^{3}$ にとどまった。なお、 これらの細胞診陽性の時期はすへてて化学療法後で あり、うち4例は寛解中であった。また細胞所見 は細胞数の增加を示したホジキン病、非ホジキン リンパ腫およびAMMoLでは腫瘍細胞の単一な增加を 示したが、他の症例では正常リンパ球や単球を伴っ て出現しており、腫瘍細胞の占める割合は $6.0 \%$ 〜 64.0\%であった。また7例の経過を追った細胞 診では抗癌凨の䯣液腔内投与により腫湯細胞は比 較的短期間で消失した。

【考按】白血病の漣膜浸潤は堝道液細胞数の增加に そしいことが多く、しかも腫瘍細胞の占める割合 も少ないことから一般㖪液検查のみでは娟膜浸潤 を推定することは難しく、䯣液細胞診を施行する 意義は極めて大きいと考える。 
155

悪性眽絡叢乳頭腫の 1 例

東京医科大学病理学第 2 講座 $^{11}$, 同病院病理部 ${ }^{21}$

O吳 清芳 (MD) ${ }^{11)}$, 工藤 玄恵 (MD) ${ }^{12}$,

横山 明子 $(\mathrm{CT})^{2)}$, 芹沢 博美 (MD) ${ }^{22}$,

豊田 充康（MD） ${ }^{2)}$, 海老原善郎（MD） ${ }^{1)}$.

細胞診において悪性の判定が難しかった悪性脈 絡叢乳頭腫の 1 例を報告する。

【症例】 31 歳男性。平成 3 年に頭痛出現。 4 年 5 月に第 4 脳室腫痘摘出術, 7 年 8 月には右小脳橋 角部に腫瑒再発を認め, 2 回目の腫瘍摘出術, そ の後まもなく 9 月には左側頭葉内腫瘍を認め, 3 回目の摘出術が行われた。細胞診は 7 年 9 月の手 術時と術後の 11 月に施行された。

【細胞所見】 9 月に行われた腫瘍内桽胞夜の細胞 診において腫瘍細胞は, 大小不同, 不整形な乳頭 状増殖集塊として多数出現していた。孤立性腫癔 細胞も少数見られた。腫瘍細胞は小型で, 大小不 同は目立たず，ラ仆グリー䒵性の細胞質を持つ。N/ C比やや高く, 核は小円形で, ク呼はは微細顆粒状 で軽度増量を見る，核小体は不明瞭で，核分裂像 は認められない。背景にはリンパ球と好中球の散 在を認めた。細胞数が豊富であり, 悪性を疑った が, 断定できなかった。1 1 月の喵液細胞診では 採られた細胞は極めて少なく, 認められた一個の 小集塊には極性の乱れがあり，高いN/C比，クロマチッ 増加のある異型な細胞を認めた。

【組織所見】乳頭状増殖の著明な腫瘍は立方状な いし高円柱状上皮細胞と細い血管線維性間質から なる。一部に充実性增殖傾向, 配列の乱れ, 核異 型を認めるも，明らかな核分裂や浸潤が見られな いことから，良性とされていた。しかし，7年 9 月の検体には，腫癔は明らかに脳実質内へ浸潤し， 壊死巣を有し, 浸潤部の腫瘍細胞は核異型と多型 性を示していた。悪性脈絡叢乳頭腫と診断した。

【まとめ】細胞学的に悪性と判断することの難し い悪性脈絡叢乳頭腫の存在に注意を要すると考え， ここに報告した。
156 捺印細胞診が有用であった脊㖪原発胚腫

の 1 例

都立神経病院検査科病理 ${ }^{12}$, 同脳外科 ${ }^{21}$, 東京都神経研病理 ${ }^{31}$, 東大分院検査部病理 ${ }^{4)}$

○若林 富枝 (C T $)^{11}$, 岩野 裕子 (MT) ${ }^{11}$, 山岡 愛子 (MT) ${ }^{11}$, 小田 雅也 $(M D)^{11}$, 井田 勝久 $(M D)^{22}$, 小島 英明 (MD) ${ }^{1.3)}$, 望月 衛 $(\mathrm{MD})^{3)}$, 村上 俊一 (MD) ${ }^{1.4)^{\circ}}$

胚細胞性腫瘍は、元来、性腺に好発するが性腺外 にも発生する。中枢神経系では松果体に好発するが、 脊咀に発生したという報告は極めて少ない。今回 我々は、脊喵原発胚腫を診断し得たので報告する。

【症 例】 24 才男性、進行性の小脳失調、痤性対 麻痼をきたし当院神経内科受診、原因不明の小脳変 性症、胸㵦腫瘍、Klinefelter 症候群 (47XXY) と診断 され、1991 年 4 月当院脳外科入院。小脳腫湯は認め ずTh8レベルにエンハンスされる喵内腫瘍を認め腫瘍切除 術施行。組織診のみで挣印細胞診施行せず。3 年後、 側脳室壁、小脳虫部に病変を認め、生検と捺印細胞 診施行。【細胞像】捺印細胞像では明瞭な核小体、 円形核、淡明な胞体を呈し、多数のリンパ球の混在 が認められ典型的な two cell patternを示し、胚腫 が最も考えられた。【組織像】初診時の組織診は、 核分裂像が多く、核小体明瞭、類円形細胞の増殖が みられ、診断に苦虑したが、上衣芽腫を疑った。3 年 後の生検時の組織像は、前回と同様の所見にリンパ球 浸潤を伴い胚腫と診断、A1-P (胎盤性) 陽性を示し確 定できた。【まとめ】本症例は全身の検索において 他領域に腫瘍は認めず金髄原発胚腫と考えられる。 初発時には、稀な発生部位、組織学的に典型像を示 さなかったことから診断し得なかった。中枢神経系 領域の細胞診は、発生部位を考虑せず細胞像だけで は診断に極めて苦慮する症例が多い。本症例は、逆 に発生部位から胚腫を考えることは困難だが、再発 時の迅速診において、細胞像のみで診断を推定し得 たものである。 
157 甲状腺の穿刺吸引細胞讋では確定

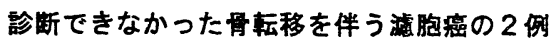

高知医科大学附属病院梌㚗部 ${ }^{11}$ 、同第一病理 ${ }^{21}$ O高橑保 (CI $)^{1}$ ，森木利昭 (MD) ${ }^{1}$ ，棈本真智子

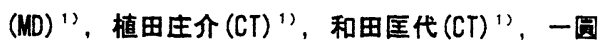

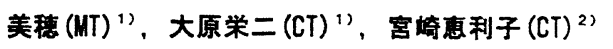

甲状腺滤胞癌は細胞診では判定困難な場合がある。 細胞診では確定できず、胸椎転移巣で発見された 2 例を経験したので報告する。また、滤胞性腫境 の細胞增殖能について検討し若キの考察を加えた。 【症例 1】75歳、女性。20年来甲状腺腫あり。歩 行不能となり胸椎及ひ肺に転移性腫瘍を認めた。 胸椎病変の生検前に甲状腺の細胞診が行われた。

【症例2】79歳、女性。急速に両下肢麻瘦が出現。 胸椎の転移性腫影が疑われた。甲状腺に腫湟を認 め穿刺吸引細胞診が行われた。

【穿刺吸引細胞像】小型の滤胞を形成する細胞集 団が症例 1 では多数、2では少数採取された。滤 胞上皮は小型で円形核を有し瀻細なクロマチンが 密に充满、核小体は小型〜不明瞭。核の重積性は 比較的軽度。細胞、構造異型に乏しいが細胞相互 の結合性はやや弱い。滤胞性腫瘍、疑陽性之判定。 【組織所見】胸椎転移巣は 2 例とも高分化濾胞癌 であった。原発巣の甲状腺はともに広沉浸淍型憈 胞癌で、部分的には低分化癌单を伴っていた。

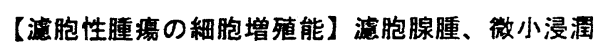
型および広汎浸洞型濾胞癌についてMIB-1を用い 細胞增殖能を検討した。眿腫と微小漫润型憈胞癌 ではほほ同じMIB-1陽性率であったが広沉浸润型 では有意に高い細胞增殖能を示した。

【考案】濾胞性腫境の良悪性の判定基準は組織学 的な浸淍、転移の有無で決定され細胞形態学的所 見のみからは爁別が困難である。細胞增殖能から みた微小漫洞癌と腺腫は区別できない。本例では 広沉浸润癌であるにもかかわらず悪性と確定でき なかった。演胞性腫湯の晾断基準について臨床細 胞病理学的な検討がさらに必要と思われる。

\section{8 甲状腺 C A S T L Eの一例}

腚川キリスト教病院 病理部 ${ }^{11}$

高梘病院 病理部 ${ }^{2)}$

○葛西里美 (C T $)^{11}$, 福島成之 (C T $)^{11}$ 田中里美 (C T $)^{11}$, 田保 徹 (C T $)^{11}$ 志田しげの (C T $)^{1)}$, 试田善樹 (MD) ${ }^{1)}$ 岩井泰博 (MD) ${ }^{2)}$

甲状腺の Carcinoma Showing Thymus-Like Dif ferent iation (CASTLE)は非常に稀な腫湯であり、 未分化癌や扁平上皮癌との鑑別を要する。今回、 我々は本腫煬を経験したので報告する。 <症例>59歳、女性。甲状腺右葉下極に腫崵を 認めたため、穿刺吸引細胞診を施行した。結果は Class V であったが、組織型は決めかねた。その 後、甲状腺右葉摘出術が施行された。

〈細胞所見〉多数のリンパ球を背景に、結合性の ある細胞境界不明暸な集団が多数みられた。胞体 は乏しいものと、扁平上皮様に広くて厚いものが みら机た。核は円〜棈円形で大小不同があり、ク ロマチンは微細顆粒状で核小体が目立っていた。 <肉眼所見>右葉下極に直径 $3 \mathrm{~cm}$ 大、割面は黄白 色で、虑合結節状であった。

<組織所見>腫場は不規則な形の小葉構造を形成 し、腫瑒被膜を形成せずに充実性に増殖していた。 リンパ球の浸潤が強く、胞巣周辺部にて角化する 傾向があり、胸腺上皮や扁平上皮への分化傾向が うかがわれた。免度染色では、サイトケラチン陽 性、CE A陽性、サイログロブリン陰性、カルシ トニン陰性であった。

く電顕所見〉トノフィラメントとデスモゾームを 認めた。

くまとめ>C A S T L Eは稀な腫瑒であり、発育 が緩徐で局所再発も遅く、低悪性度であるため、 より悪性度の高い未分化癌や扁平上皮癌との鑑別 が重要であると思われる。 
159 骨転移で発見された甲状腺滤胞癌の 1 例

岡山医学検査センター病理部11

川崎医科大学病理学教室 ${ }^{21}$

川崎医科大学附属病院病院病理部31

○杉原佳子 ${ }^{11}(\mathrm{MD})$, 西原弘治 ${ }^{2}$ (MD), 桜井孝規 21 $(M D)$, 定平吉都 2 (MD) , 広川満良 ${ }^{2)}(M D)$, 真鍋 俊明2) (MD), 調輝男 ${ }^{2)}(\mathrm{MD})$, 山口昌江 ${ }^{3)}(\mathrm{CT})$

はじめに:骨転移病巣の免疫組織化学的検索にて 甲状腺滤胞癌が示唆された1例を経験したので報 告する。

症例：59歳，女性. 2 年前より左下肢の痛みがあ り, 最近増強するため来院した。 レントゲンにて 骨盤骨に骨融解性の病変が見られた。骨生検によ り, 甲状腺滤胞癌が疑われたため, 甲状腺左葉に みられた $3 \mathrm{~cm}$ 大の腫瘤から穿刺吸引細胞診が施行 された。

細胞所見：甲状腺の穿刺吸引細胞診では，小濾胞 状に配列する異型性のそしい細胞が見られた。そ れらの細胞は小型で，大小不同にそしい類円形の 核を有し, 細胞境界は不明瞭であった。核クロマ チンは細顆粒状で均等に分布し，核小体は目立た なかった，良悪性の鑑別が困難であったため，滤 胞性腫瘍の疑いと報告した。

病理所見：骨盤骨の生検標本では，骨梁間に異型 性の乏しい腫瘍細胞が小腺腔を形成して增殖して いた．免疫組織化学的に腫瘍細胞はサイログロブ リンに陽性であった。甲状腺左葉には2.8×2.7× $2.0 \mathrm{~cm}$ 大の被膜に囲まれた充実性腫瘤が見られ た。腫瘤内には骨髄で見られたと同様の細胞が小 滤胞状に增殖しており，一部で被膜への浸潤像が 見られた。腫瘤割面からの捺印塗抹標本の免疫細 胞化学的検索にて, 多くのMIB-1陽性細胞が観察 された.

まとめ：滤胞癌を穿刺吸引細胞診にて診断するこ とはできないが，多くのMIB-1陽性細胞の出現は 濾胞癌を示唆する一助になりえるかも知れないと 思われた。
160 骨転移を生した甲状腺满胞癌 2症例 の紐胞診

浜松医療セ多一検查科、石垣りリニッグ、浜松医大病理 部 ${ }^{21}$ 、磐田市立病院検查科 ${ }^{31}$ 、獨協医大病理 ${ }^{41}$

$\mathrm{O}$ 土井久平 $(\mathrm{CT})$, 小澤享史 $(\mathrm{MD})$, 岡本一也 $(\mathrm{MD})$

石垣賽弘 $(M D)^{11}$, 三浦克敏 $(M D)^{21}$, 中島 昭 $(C T)^{21}$ 原田英一 $(\mathrm{CT})^{21}$, 江塚 充 $(\mathrm{CT})^{31}$, 山田 喬 $(\mathrm{MD})^{41}$

骨転移巣を生じた甲状腺港胞癌 2症例について、 細胞像を中心に報告する。

症例 1 43才、女性。1985年5月、甲状腺右 葉の腫瘍で来院、腫瘍摘出術施行。1993年、腰椎 の腫瘍切除術施行、甲状腺港胞癌の転移と病理診 断された。甲状腺吸引細胞診 : 孤立散在、一部集 塊として出現、細胞は比較的揃っており、核は円 形〜類円形を示し、クロマチンは細〜粗顆粒状で あった。class III と判定された。甲状腺病理診断 : 腫瘍組織像は、滤胞構造を示し、細胞異型は軽 度であった。被膜浸潤及び血管浸潤を認めず、腺 腫と診断された。

症例272才、女性。1994年、左後頭部腫張 があり、增大傾向のため、1995年7月頭蓋骨腫瘍 切除術施行。甲状腺滤胞癌の転移と病理診断され た。同年8月、甲状腺腫瘄切除術施行。頭蓋骨腫 瘍捺印細胞診 : 孤立散在性に出現する集塊には軽 度の重積があり、滤胞状配列を示すものも認めら れ、核の増大、大小不同があり、クロマチンは細 〜粗顆粒状であり、核小体の目立つ細胞が少数に 認められた。甲状腺病理診断：組織像は、溘胞構 造を示す細胞異型性の乏しい腫瘄であるが、被膜 の形成のない境界不明瞭な腫瘍であり、血管浸潤 を認め、濞胞癌と診断された。

まとめ

1)甲状腺の細胞診により少なからず悪性が疑かれ た場合、組織診断で癌の確定所見が認められな くとも、細胞診によるfollow upが重要である。 2)濾胞癌の転移巣の穿刺吸引細胞像から、逆に原 発巣を推定することが出来る。 
161 乳癌を合併し、濾胞構造への分化 を呈した甲状腺髄様癌の一症例

八戸市立市民病院病理

O奥沢悦子 (CT), 熊谷幸江 (CT)，

十文字文男 (MT), 高坂公雄 (MT), 方山揚誠 (MD)

[症例] 38歳、女性、集団検訩にて、前頱部腫 脹、及び左乳腺腫溜のため当院受診。

[細胞所見]左甲状腺：採取量は豊富で、粗な 結合性の腫瘍細胞が散在性から一部濾胞様構造 を呈していた。その核は類円形〜短紡錘形で、 偏在性、クロマチン増量、顆粒状で、なかには 大型核や少数の核内細胞質封入体像が見られた。 全体に胞体は乏しくライトグリーン淡染で顆粒 状であった。またライトグリーン濃染の同心円 状の胞体を有する単核〜 3 核の偏在性の細胞が 散見された。以上の所見より、甲状腺穿刺吸引 細胞診では㖪様癌を考えたが、一部に濾胞様構 造を認めた。乳腺穿刺吸引細胞診では甲状腺と は明らかに異なる乳頭状集塊を呈する悪性細胞 であった。

[組織所見］腫瘤は甲状腺左葉に見られ、肉眼 的に割面は黄色、大きさ $3.3 \times 1.2 \times 2.0 \mathrm{~cm}$ あった。組織学的には顆粒状の広い細胞質を持 つ腫瘍細胞が充実性に増殖しており、一部では 腺管構造や、甲状腺滤胞様構造が認められた。 腫瘍細胞の核は一部でかなり大型で奇異な像を 呈するものも見られた。グリメリウス染色は陽 性。免疫組織学的染色で C E A 、 N S E、カル シトニン、クロモグラニンAが陽性で、サイロ グロブリンは濾胞構造を含め一部に陽性であっ た。乳腺の腫㽣は甲状腺の組織像とは異なる乳 頭腺管癌であった。
162 甲状腺穿刺吸引細胞診にて診断に苦虑 した乳頭癌、瀘胞腺腫、橋本病が合併した一例

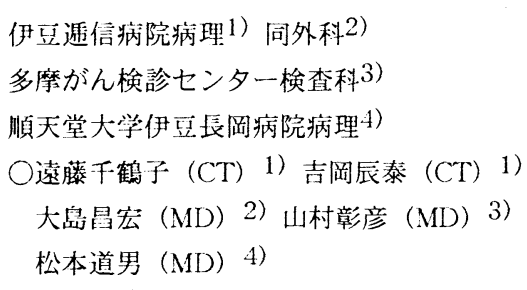

【はじめに】橋本病に乳頭癌が合併することは知 られているが甲状腺において2種類以上の腫瘍が認 められることは、比較的稀である。今回、我々は 診断に苦虑した本症例を経験したので報告する。

【症例】33歳、女性。耳鼻科受診時に甲状腺腫大 を指摘され当院外科を受診。エコーでは右甲状腺

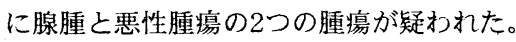

【細胞所見】1）lowエコー腫呁：リンパ球が多く 出現する中に、大型でスリガラス状の核をもち、 大小不同、不整、くびれなどの核所見が見られる 異型細胞が、乳頭状の細胞配列を示す。核内細胞 質封入体も散見され乳頭癌が疑われた。2）high工 コ一腫瘍：1）に類似した異型細胞を少数認めた。 背景にリンパ球浸潤が目立つために反応性の異型 も考え、鑑別に苦慮したが悪性を疑った。

【摘出標本の肉眼所見】甲状腺は全体に腫大し右 葉に1）右葉中央〜上極 $1 \times 0.8 \mathrm{~cm}$ 大、黄白色で 境界不明瞭な硬い腫湯 2) 右葉中央 $1.7 \times$ $1.2 \mathrm{~cm}$ 大の薄い線維性の被膜でつつまれた境界明 瞭な腫演の2つの腫瘍が認められた。

【組織所見】1）は被膜形成の兒られない境界不明 瞭な高分化型乳頭癌で、乳頭状、部分的には憈胞 状の增殖を呈した。2）は溜胞腺腫であった。1） 2）ともに周囲の甲状腺組織には、多数のリンパ球 浸潤が目立ち、コロイド濾胞の萎縮と再生をみる 橋本病の像を呈していた。また腫瘍内にもリンパ 球浸潤が及んでいた。

以上それぞれの細胞像を比較して報告する。 
163 多核巨細胞の出現を伴う乳頭癌の

2 症例

順天堂大学内科, 病理研究室 ${ }^{1)}$

都立大塚病院検査科 ${ }^{2}$ )

○石原明夫 ( $M D)$, 稗田正志 $(M D)$, 佐生 隆 $(M D)$. 河盛隆造 (MD), 古旗 淳 $(\mathrm{CT})^{1)}$, 中村㚗二 (CT ), 有輪六朗 $(M D)^{2)}$

甲状腺穿刺吸引細胞診で多核巨細胞の出現を伴う乳 頭癌の 2 症例について報告する。

症例 1 K.M. 46才。女性。主訴：左側頸部 腫瘤。家族歷：父60才クモ膜下出血で死亡。姉 57 才肺癌で死亡。現病歴: 約 10 年前から左側頸 部腫瘤に気ついていたが, 疼痛, 発熱, 圧迫など の症状がなかったので放置。1995年6月会社健診で 左結節性甲状腺腫を指摘され，9月21日当院内科 紹介受診。触診上，左葉甲状腺上極に $3.5 \times 3.0 \mathrm{~cm}$ 弹性硬の甲状腺腫, 上方の左側頸部に $3.0 \times 2.0 \mathrm{~cm}$ 大の腫瘍を認める。臨㦿検査では甲状腺機能正常. 鉄 久乏性貧血。左結節性甲状腺腫のエコークラムで, 周 辺不整形で中央部に石灰化を伴う充実性型を示す。 ${ }^{201} \mathrm{~T} 1$ シンチクラムでは，左葉甲状腺腫に集積像をみ とめる。細胞所見は，左結節性甲状腺腫では，腫場細 胞は，比較的豊富な胞体を有するシート状集団を示し， ライトクリーン好染の細胞質に微細顆粒を認め。核の 大小不同, 核縁不全. 核溝, 核内細胞質封入体などを認 め。核小体の存在の目立つ所がみとめられる。背景に 多核巨細胞の出現を伴う。左側钼部腫場では，上記同 様の所見を認める。乳頭虚とその転移巣と診断。

症例 H.Y. 19才 女性。主訴: 左頸部腫瘤。 既往歴, 家族歴：とくにない。現病歴：1993年夏に 母加左頸部腫瘤を指摘される。1994年3月.近医病院 受診し,左結節性甲状腺腫を認められる。甲状腺機能正 常, エコーグラムでは，一部石灰化を伴う内部不均一 な充実型。細胞診では，腫瘍細胞には核溝。核内細胞 質封入体の所見と背景に多核巨細胞を伴う乳頭癌と診 断。病理組織診断所見と合わせて報告する。
164

$$
\text { 甲状腺乳頭瘦・未分化癌混在の一例 }
$$

聖戈浜松病院䧗床㛟㚗センター ${ }^{1} 、$ 同病理科 ${ }^{2} 、$ 掛川市立総合病院病理㛟查 ${ }^{3}$

浅野 正宏 $(\mathrm{CT})^{1}$ 、池谷 知也 $(\mathrm{CT})^{1}$ 、山田 哲司 $(C T)^{1} 、 小$ 林 寛 $(M D)^{2} 、$ 浅井 正博(MT) ${ }^{3}$ 、

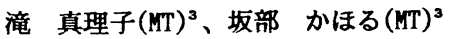

甲状腺末分化癌はその組㙨中に分化型腫煬の併 存することが知られており、組樴発生については 分化型鍾韵を発生母地とするといわれている。

今回我々は、甲状腺穿刺吸引細胞診で未分化㡹 と診断され、治療経過中に軞頭癌と診断された乳 頭癌・未分化癌混在例を経験したので報告する。

症例は68才女性、平成 7 年 5 月、前頊部董张、 咳赖を主訴に掛川市立総合病院内科を受診した。 甲状腺穿刺吸引細胞診では、筡死物質を含む血性 背景に粗クロマチンが不均等に增量した大小不同 の強い核をもつ重湯綥胞で占められており、多形 性に富む単核・多核の巨細胞や核分裂像もみられ 未分化癌が考えられた。また、針生検組瀻診でも 細胞診像と類似する細胞がみられ、未分化瘦と診 断された。

同年 6 月、放射楾治療目的に当院耳算咽诶科を 耛介受診した。化学療法を併用し、8月には画像 上董堛は半分に樎小された。穿刺吸引細胞診は化 生様細胞が散見されるも、大半が上皮性結合を示 す中小の乳頭状集塊として出現しており、部分的 に眭度重積性と核の大小不同をみる細胞は微細顆 粒状のクロマチンが增量し、核内空胞や核㴖がみ られ、乳頭腹を考える所見であった。なお、未分 化獀を考える所見は得られなかった。

同年 9 月、甲状腺全䢔出術を施行した。俥場は左

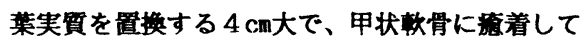
いた。病理組较診は未分化癌を伴う乳頭癌で、㭘 状敕骨組減に未分化癌の浸洞が琴められ、リンパ 節転移も椝めた。12月現在、患者は退院し経過絸 祭中である。

甲状腺患に対する穿刺吸引絧胞猃は街前に病 名を推定する上で噫床的意義は大きく、高い正診 率が期待できるが、穿刺する部位により異なる細 胞像を呈した本例のような乳頭演・末分化海混在

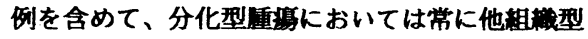
混在の可能性を念頭に置く必要もあると考えられ た。 
165

$$
\text { 甲状腺末分化癌の } 2 \text { 例 }
$$

京都大学大学院医学研究科病理系腫㾤生物学講座

$$
\text { 同基礎病態学講座 }{ }^{2}
$$

奥山隆三 $(\mathrm{CT})^{1}$ 、木下秀文 $(\mathrm{MD})^{1}$ 、幸田啨尿 $(\mathrm{CT})^{2}$

高橋 玲(MD) ${ }^{1}$

甲状腺未分化癌の発生頻度は全甲状腺癌の5\% にも满たないが、予後が覀い。また、種々の腫瘟 性先行病変を母地として発生することが知られて いる。今回我々は、乳頭癌及び滤胞癌をそれぞれ 発生母地とする甲状腺未分化癌の 2 例を経験した ので挎印細胞像、組織像を呈示するとともに癌関 連マーカー・細胞增殖マーカーを用いて免疫組織 学的に発生母地の異なる両腫瘍を比較検討したの で報告する。

[症例 1]

患者は69歳女性。1965年頃より甲状腺右葉の腫大 を自覚し、1975年11月に甲状腺癌の診断にて甲状 腺右葉を切除。術後16年後の1991年6月に再発が 確認され化学療法を行っていたが、1994年2月15 日死亡した。捺印細胞像は核・細胞ともに多形性 で異型の強い腫瘍細胞が散在的にも集合的にも認 められた。組織学的には甲状腺未分化癌と診断さ れ、一部には甲状腺濾胞を確認。また、肺や骨に 転移が認められた。

[症例 2]

患者は44歳の女性。捺印細胞像は核異型著明な巨 細胞が全般的に見られ一部の悪性細胞においては 核内細胞質封入体が確認され、以前に乳頭癌由来 の甲状腺巨細胞癌として本学会誌にて報告した症 例である。組織学的には甲状腺未分化癌（巨細胞 型）と確診されている。

以上の 2 症例を癌関連マーカーとして 553 , c-erbB-2, EGF-Rを、細胞增殖マーカーとして Ki-67,PCNAを、その他に甲状腺特異マーカーと してサイログロブリンなどを用い雨腫瘍における 発現性を比較検討して報告する。
166 甲状舌管原発と考えられた悪性リン パ腫の1例

札帨社会保険総合病院病理 1), 同耳索咽喉科2), NTT札幌病院病理 3), 札帡医科大学医学部病理学 第二講座4)

$\bigcirc$ 佐藤正幸 $(C T)^{11}$, 前島澄子 $(C T)^{11}$, 原敏浩 $(M D)^{2)}$ 金沢嶆(MD) ${ }^{2)}$ ，水無瀬尼(MD) ${ }^{3)}$, 飛岡弘敏 $(M D)^{4)}$

いわゆるMALTリンパ腫は、1983 年Isaacsonら によって提唱されて以来、これまで胃腸管、肺、 唾液腺、甲状腺、膀胱、眼蒚、皮唐などでの発生 が報告されているが、胎生期甲状腺遺残組織であ る甲状舌管からの発生例は未だ報告がない。今回 我々は、頝部腫瘤として発症し、穿刺吸引細胞診 により悪性リンパ腫と診断され、組織学的に甲状 舌管原発のMALTリンパ腫と考えられた、稀有な 1例を経験したので報告する。

[症例] 57歳、主婦。来院1 ケ月前に前頚部の腫瘤 に気付き、平成7年6月29日に当院耳罯科受診。 気管前部、甲状腺呋部頭側に最大径 $15 \mathrm{~mm}$ の結節 状腫瘤を喼め、穿刺吸引細胞診によりClass V と 判定され、腫瘤摘出術施行。腫瘤は甲状腺陕部頭 側に接しており、腫瘤のさらに頭側にのびる索状 組織を認めた。

[穿刺吸引細胞像]壊死性背景に成熟リンパ球と裸 核状の異型細胞が散在性に多数出現していた。核 は類円形〜不整形で、所々に切れ込みを認め、ク ロマチンは粗顆粒状不均等分布で、明瞭な核小体 を珰めた。

[病理組絓像]主腫瘤は、穿刺吸引細胞診で認めら れたものと同様の大型の異型リンパ球様細胞のび まん性增殖像からなり、多数の核分裂像を認めた。 腫瘤内に、僅かに濾胞を伴う甲状腺上皮を認め、 同部にlymphoepithelial lesion(LEL)を認めた。免 疫染色では、腫癔細胞はLCAおよびLー26が陽性 であったが、UCHL-1、Ki-1、EMAは陰性で、 非ホジキンリンパ腫びまん性大細胞型、B細胞型 に相当すると考えられた。主腫瘤より頭側にのび る索状組織内には、萎縮性の甲状腺組織を珰め、 小型のmonocytoid cellのびまん性浸潤を伴い、 LELを認めた。以上の所見より、本症例は気管前 部の逼残甲状腺組織すなわち甲状舌管に発生した MALTリンパ腫の高悪性転化例と考えられた。 
167 甲状腺腫瑒細胞の全セントロメアの 核内分布パターンの蛍光画像解析の試み

京都府立医科大学・第一病理1)、、同病院病理部2)

○古谷昌則1)、村田晋一 (MD)1,2), 寺内邦彦1)、

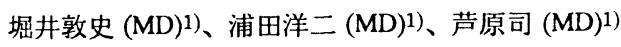

[目的] 良性・悪性甲状腺腫湯細胞の核DNA分布 のちがいを詳細に検討するために、細胞核DNAと 全セントロメア分布パターンを、蛍光画像解析法 によって、局在や細胞周期に伴う変化について数 值化することを試みた。[材料・方法］対象は、 甲状腺の濾胞腺腫、乳頭癌、滤胞癌で、パラフィ ン包埋材料から単離細胞叙沫標本を作製し、FISH (fluorescence in situ hybridization) 法による全てのセ ントロメアの染色を行った。まず、自動ステージ を用いてスライドガラス上の100個の腫㵣細胞の位 置をコンピュータに記憶させながら、それぞれの 細胞の全セントロメア蛍光染色像をテジタル画像 化した。次に、全セントロメアの蛍光染色を脱色 後、核DNA染色を行い、再び自動ステージに装着 し同じ細胞を呼び出し、核DNA蛍光染色像をデシ タル画像化した。さらに、これらの画像データを 用いて、同じ細胞の全セントロメアとDNAの蛍光 染色画像を比較するともに、テクスチャ解析を 行ってセントロメア・DNAの分布パターンを数値 化した。[結果・考察]甲状腺腫湯細胞の核DNA 栄光染色像にセントロメアの分布パターンを加味 した比較・解析、細胞周期に伴うそれぞれの分布 パターンの変化を定量的に検討できた。本解析法 は、DNAの量的異常の少ない甲状腺癌細胞におい て、DNAやセントロメアの分布異常という質的異 常の客観的解析を可能にすると考えられた。
168 気管支洗浄液における細胞診標本 作製法の検討

兵庫県立柏原病院検査部

○葛野晴夫 (C T), 岸上明美 (C T)， 石橋万亀朗 (C T), 小森和代 (C T)

兵庫県立成人病センター検査部

指方輝正 (MD)

【目的】気管支洗浄細胞診は, 気管支鏡下で病巣 が確認できない場合や組織生検, 病巣擦過細胞診 の後などに行なわれることが多く, 剥離した細胞 の検索と細菌の培養を目的としている。採取され た洗浄液の多くは, 出血を伴う液体部分と液体に 浮ぶ泡状部分 (粘液様) から成り, 遠沈しても泡 状部分の沈渣は得られにくく, これまでは上清と して処理していた。今回我々は泡状部分に着目し, 標本作製を試みたので報告する。

【材料抢よび方法】入院および外来患者の気管支 洗浄液を用い，液体部分と泡状部分の標本を作製 し，それぞれの異型細胞量を調べた。

【材料処理法】生理食塩水を入れた容器に泡状部 分を加えて十分摚抖し，遠沈した沈渣の1滴を剥 離防止処理したスライドガラス上に取り，すり合 わせ法で塗抹した。液体部分は，そのまま遠沈し 同様に処理した。

【結果】泡状部分には癌細胞が集団状で出現する ことが多く，標本作製に有用であると思われた。 特に扁平上皮癌と小細胞癌の泡状部分に多くの癌 細胞が認められたが，液体部分では細胞量は少な く散在性に見られた。

【まとめ気管支洗浄液は, 泡状部分にも考慮し て標本作製する必要があると思われた。 
169 肺癌の気管支鏡㣍断における細胞 喆梌体採取法別䜌断率の検討

岡山県健康ゔくり財団岡山龂折

O中川邦宏 (CT)，白神厚 (CT)，井手由美子(CT) 岡崎泰之(CT)，神田明美 (CT)， 小谷㣚士 (MD)，西井研治 (MD)，玄馬㩆一(MD) 岡山大学医学部附属病院病理部 原享子 (MD)

【目的】気管支羱検查による肺癌の㭋断は、 採取される細胞が少ないために困藮な場合が ある。得られた検体を最大限に利用すること を目的に我々が日常行っている各検体採取法 の有用性を検討したので報告する。

【対象及び方法】1984年から1991年までに当 施設で確定した肺癌症例892例を対象とした。

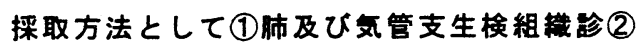
捺印細胞喆(3)生検鉗子洗浄液(4)擦過・キュレ ット禁抹(5)ブラシ・キュレット洗浄液(6)気管 支镜検查中の回収液(7)選択的気管支洗浄液 (8) 経気管支針吸引澵抹，吸引針洗浄液の8 通り であった

【結果】陽性率を各検体採取法別にみると掩 印細胞診 $83.8 \%$, 組織彭 $75.8 \%$, 生検鉗子洗浄液 $68.7 \%$, 擦過細胞款 $75.3 \%$, ブラシ洗浄液細胞歨 58. 9\%, 気管支回収液細胞款65.5\%キュレット

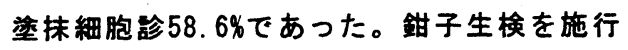
した877例の内、捺印細胞診隍性で鉜子洗浄 細胞嘐陽性例が35例，弎管支擦過を施行した8 12例のプラシ擦洞細胞款隍性でブラシ洗浄細 胞診陽性例が28例認められた。

【結諭】気管支鏡検查では、採取された検体 を最大限かつ有効に利用し肺癌の站断率の向 上を図る必要があり、この钼点から、鉗子や ブラシの洗浄細胞款は行う価值の高い検㚗法 と考えられた。
170 肺癌手很症例における榙体採取法の 䢖いによる模出率の検討

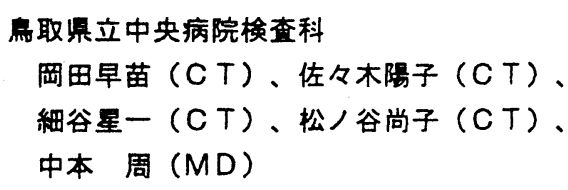

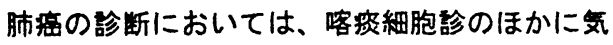
管支镜下、画像粀断下で病柴がらの検体採取がお こなわれている。今回、我々は組織型別、検体種 別に成螋を比较検封したので報告する。

対象：1990年 1月から1995年 9月までの間に手政 的に肺密と確定售断された78例（扁平上皮癌30例、 腺癌41例、小細胞㾇4例、大細胞癌3例）の手術前换 体である喀焥120件、気管支摖過物34件、気管支洗 浄液35件、C T下穿刺吸引物66件、生検組織51件 を対象とした。

結果：榙出率は、C T下穿刺吸引物 $71.2 \%$ (83.7\%) がもっとも高く、生模組織讋70.5\%(74.5\%)、気管 支撩過物52.9\%(65.2\%)、氛管支洗浄液54.3\%(58.3 \%)、喀痰は37.5\%(58.8\%)であった。( )内は、最大 評価での検出率を示す。扁平上皮癌で細胞款の検

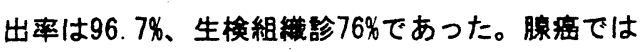
細胞款 $90.2 \%$ 、生検組織䪭 $66.7 \%$ であるか、単独の 細胞跈では、喀痰・気管支洗浄液とも50\%の模出率

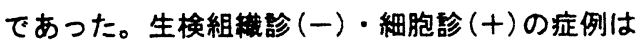
8 例（腺究 5 例、扁平上皮密 2 例）、生模組織彰 $(+) \cdot$ 細胞㓌 $(-)$ の症例は腺癌 1 例、生検組織款 (一)・細胞款(一)の症例は3例であった。細胞診 での組樴型の不一致例は 8 例あり、喀资では榙出 できず気管支洗浄液およひC下下穿刺吸引物で判 定した症例であった。

まとめ：喀茨では、被数回の検㚗が有効であった か、採取方法の適切な指望が必要とおもわれた。 C T下穿刺吸引細胞診は、検出率が高いが組穖型 推定には注意深い钼察が要求される。呼吸器細胞 診において被数回の模体採取や各種検体採取法の 併用で影断能の向上が期待できるとおもわれた。 
171 T B A Cにて推定可能であった肺粘 表皮煰の 1 . 例

所沢市市民医療センター臨床検查科病理 ${ }^{1}$

国立療養所東京病院検查科病理 2 同呼吸器外科 " 同呼吸器内科 4

○元村栄喜(CT) "'田中健次 (CT ) "田島紹吉 (CT) 漇木康雄 $(\text { MT })^{2}$ 蛇沢 晶 $(\text { KD })^{21}$ 宮島邦治 $(\text { KD })^{31}$ 小松彦太郎(MD) ${ }^{31}$ 田村厚久(KD) 41

今回我々は、経気管支鏡的吸引細胞診 (T B A C）にて推定可能であった粘表皮癌の 1 例を経験 したのでその細胞像を中心に報告する。

【症例】58歳女性。平成 7 年 5 月近医にて胸部 異常陰影を指摘される。同年 7 月精查目的のため 紹介入院となった。気管支鏡検査にて左 B 8 入口 部に易出血性ポリープ状腫瘤を認め、同時に T B A C を施行した。粘表皮癌を推定する細胞診断を 得て、同年 7 月末、左下葉切除術が施行された。

【細胞所見】背景に炎症性細胞之粘液様物質を認 め、その中にシート状、及びやや重積性のある上 皮性細胞集塊が散在性に認められた。集塊を構成 する細胞は、類円形核で中心性、ライトグリーン に好染し紡鍾形から多辺形の細胞質を持つ扁平上 皮類似の細胞之、泡沫状細胞質で粘液を有する杯 細胞様の腺系細胞で、その中間的な細胞も認めた。 いづれの細胞も核巽型は少なく細胞異型は軽度で あった。また、それらの細胞が入り交じって観察 される集塊が多く認められた。

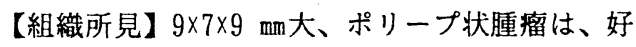
塩基性に染色される粘液細胞を伴う扁平上皮の增 生から成り立ち、充実性もしくは索状配列を示し ていた。以上より肺粘表皮癌と診断された。

【まとめ】本症例では個々の細胞異型は乏しかっ たが、扁平上皮類似細胞と腺系細胞を認め、また、 両者の混在する細胞集塊が認められるなど、特徴 的細胞所見が得られ、肺粘表皮癌が推定可能であ った。

\section{2 肺胞蛋白疜の 1 疜例}

鳥取県立中央病院 検查科

松ノ行尚子 ( C T ) 成田早苗 ( C T ) 作々木 陽子 ( C T ) 細谷星一 ( C T ) 中本 周 $(\mathrm{MD})$

肺胞蛋白疜は肺胞肹内にP A S 陽性物質の蓄積 をきたす原因不明の稀な疾患である。Surfa c t a n t （表面活性物質）の過剩生産、または 除去機能障害による肺胞内への蓄積が原因と考え られているが、まだよくわかっていない。

今回我々は、肺胞蛋白症と診断された 1 症例を 経験したので報告する。

[症例] 42 歳、男性。平成 7 年 7 月検診のX線 写真にて肺門中心に分布する異常影を指摘され、 8月に棈榃目的で当院入院となった。CTでは、 地図状にメロンの皮梾の肺野濃度上昇を認めた。

CEA 9. 8、N SE10．8と昇していた が自覚症状はなかった。

[細胞所見］気管支洗浄液（BＡＬ）中）中細胞 診では、異型のほとんどみられない小型の腺卜.皮 とライトグリーン好性の不定形物質を認めた。さ らにマクロファージの中にライトグリーン好性の 物質を会食している像が認められた。この物質は PAS陽性であった。

[組織所見] B A L F の沈渣物でセルブロックを 作製し検討した。H E 染色で弱酸性、P A S 染色 陽吽で顆粒状の不定形物質とその集合体とみられ る球状体を認め、マクロファージの中にも領食像 がみられた。

[電影所見］オスミウム好性の層状体を認めるこ とができた。

[まとめ] 稀な疾患である肺胞蛋白症を経験した ので報告した。 
173 肺異型腺腫様過形成 ( $\mathrm{AAH})$ の 細胞学的特徴

○松本武夫 ${ }^{1}(C T)$ 、児玉哲郎 $2(M D) 、$ 金子司 ${ }^{1}(C T)$

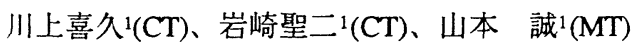

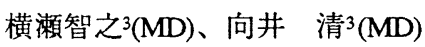

国立がんセンター東病院臨床検査部病理細胞診 同呼吸器科2、同研究所支所臨床腫瘍病理部3

異型腺腫様過形成 (Atypical adenomatous hyperplasia；以下をAAH）は、末梢の肺腺癌発生 母地との関連性が言われている。高分化腺癌と は確定できず、過形成にしては構造異型、細胞 異型を認める病变を指し、現在まで我々はAAH の形態学的検討、分子生物学的検討によりその 病变の存在と組織学的な特徵を報告している。 しかし、細胞学的にはその形態的特徴を検討し た報告は少ない。そこで今回、組織学的に孤立 性のAAH と診断した病変 4 例（捺印材料）を用 いて高分化腺癌との比較を中心に細胞学的に検 討しいくつかの知見を得たので報告する。

（結果）小型高分化腺癌は小〜大の集塊で見ら れ重積性、結合性は強く大小不同は小さい。細 胞質は中等度で泡沫状、核は円形から類円形で、 切れ込み、コーヒ一豆様の变化を見る。ク䎄は細顆 粒状で核小体は0〜数個で小さい場合が多い。 AAHは集塊で認めても数は少なく平面的で重積 性は認めない。大小不同は前者と比べ大きい。 細胞質は豊富で泡沫状である。核は円形から類 円形で核縁の不整は認めない。切れ込みは少な いものの核内封入体が多く、ク叹チンは微細顆粒状 である。時に、2 核や多核細胞の出現を見る。

(まとめ) AAHの特徴的な所見は、細胞数が少 なく、平面的で結合性は弱く散在性の出現が多 い。核は丸く、不整はなく、核内封入体が目立 つ。今後、画像診断の進歩と胸腔鏡の発達など より本病変が細胞診でも診断する機会が多くな りつつあり、更に様々な方向からの検討が不可 欠と思われる。
174 気管支顆粒細胞腫の 1 手術例·その細 胞学的所見

東京医科大学外科 1 、病理 2 ; 岡田真也 $(M D)^{1.2}$ 、 海老原善郎 $(M D)^{2} 、$ Bijayee Shrestha (MD) ${ }^{2}$ 、 若譛よしえ $(\mathrm{CT})^{2} 、$ 藤田浩二 $(\mathrm{CT})^{2}$ 、 小中千守 $(\mathrm{MD})^{1}$ 、加藤治文 $(\mathrm{MD})^{1}$

（症例）39歳、男性。健康診断にて胸部X線写 真上異常所見が指摘された。異常除影は左 $\mathrm{S}^{1+2} \mathrm{c}$ 領 域に存在し、気管支鏡では ${ }^{1+2} \mathrm{c} の$ 閉塞所見が証明 された。気管支病巣の擦過細胞診と同部の粘膜生 検から顆粒細胞腫の診断が得られ、左上区区域切 除術が施行された。

（細胞所見）病巣擦過材料及び気管支洗浄材料 には多数の正常円柱上皮細胞と少数の扁平上皮細 胞が認められた。同時に小型円形核が豊富で、結 合性の強固な線維性細胞集団が含まれており、こ の集団の辺縁では細胞密度の踈な部分で、細胞質 の粗大顆粒状物質が明らかであった。

（粘膜生検の組織所見）好酸性顆粒が充満した 多角細胞が索状に配列し、気管支粘膜固有層に涨 漫性に分布していた。核は小型、円形で異型性は なかった。免疫組織学的に腫瘍細胞はS-100蛋白 陽性であった。

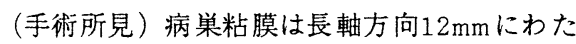
り、同心円状に乳白色に肥厚し、狭い内腔を残し ていた。

（まとめ）上皮下の良性病変の細胞学的診断に は、疾患に対する広い知識と細心の注意が必要で ある。 


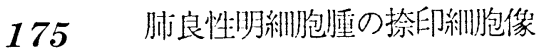

東京大学医学部付属病院病理部、同病理学教 室 ${ }^{2}$ 稲田登戸病院病理検査室 ${ }^{3}$

O阔 輝明 $(\mathrm{MD})^{1}$, 传藤 明 $(\mathrm{MD})^{1}$, 堀内 啓( $(\mathrm{MD})^{2}$ 、 福島純一 (MD) , 佐々木學(MD) ${ }^{1}$, 石田 㓮(MD) ${ }^{1}$, 黑田雅彦 $(M D)^{2}$, 森 正也 $(M D)^{2}$, 坂本穆彦 $(M D)^{2}$, 國実芳子 $(\mathrm{CT})^{3}$

【症例】56歳、女性。生来健䐂。平成5作12月、 左肺異常影を指摘され、稲田登戸病院内科で 経過観察。画像検査は過誤腫やカルチノイド を示唆。平成6年9月、診断確定のため開胸生 檢。術中迅速組織診で硬化性组管腫が疑われ た。【細胞所見】検体は術中迅速榆体の捺印 細胞。腫瘍細胞は、孤立散在性あるいは数個 の細胞が結合性の緩い小集団を作って出現。 背景は出血性だが、血鉄素や泡沐細胞は見ら れない。裸核状細胞が多いが、細胞質の保存 されているものではN/Cは低い。核は細胞質の ほぼ中心に存在し小型・類円形でよく揃って おり、クロマチンは繊細。1～2個の核小体を もつ。細胞質はライトグリーン淡染性で、レ 一ス状一微細顆粒状。【組織听見】腫瘍は直 径約 $7 \mathrm{~mm}$ 大。異型性のそしい小型核をもち、 淡明で広い胞体の紃胞が単調に增殖し、よく 発達した類洞様血管網で仕切られる。胞体は PAS陽性、粘液染色除性、一部の腫瘁縕胞は负 疫組織化学的に抗メラノーマ抗体(HMB45)陽性 を示した。以上の所見から肺良性明細胞腫と 診断。【まとめ】肺のbenign clear œll tumorは組織 起源の不明の稀な腫瘍である。組織像が腎の 明細胞癌に酷似することから、腎癌の肺転移 との鑑別が問題となる。最近、免疫組織化学 的あるいは電顕的検討から、 melanogenicな腫㿑 である可能性が示唆されている。振り返って みれば、本例の紃胞像は肺良性明䊶抱媑の监 型像と考えられ、迅速診断や針生検などに際 し絊抱学的㭘査が有用であろうと考えられた。
176 気管支洗浄液、咯痰細胞診でカリニ 原虫、㟟線虫を認めた A T L 抗体陽性の一症例

国立病院東京災害医療センタ一臨床検査科 ${ }^{11}$

国立療養所東京病院臨床娭查科 ${ }^{2}$

日本医科大学多摩永山病院病理部 31

O古谷能祥 (CT $)^{12}$ 青不貞男 (MT $)^{11}$ 林博隆 (MD $)^{12}$

山田和昭( MD $)^{1)}$ 田島紹吉 $(C T)^{2)}$ 前田昭太郎 (MD $)^{3)}$

気管支洗浄細胞診からカリ二原虫、喀痰細胞診 で䔬線虫を認めたことで免疫不全を疑い、成人病 T細胞性白血病（以下A T L ）が示唆された興味 ある症例を経験したので報告する。

【症例】49歳、主婦、広島県出身、平成 7 年 1 月 奄美大島に渡航し、その後、咳、喀痰、全身倦急、 体重減少を訴え当院を受診した。胸部X線で斑状 陰影、C T でスリガラス状陰影を指摘され、経気 管支生検および洗浄細胞診でカリニ原虫、その後 の喀痰細胞診で線虫を認めた。線虫は、糞便検査 で粪線虫と確認された。そこで、免疫不全を疑っ てHＩＶ、HＴＬＶを検索したところHＩＶ抗体 陰性、H T I V - 1 抗体陽性であった。

【細胞所見】気管支洗浄液では, 径約 $100 \mu の$ 多数 の泡沫様構造物中に径約 $5 \mu$ のライトグリーンに 淡染した類円形小体を認めた。この小体はグロコ ット染色陽性でカリニ原虫の所見であった。そこ で、モノクロナール抗体による酵素抗体法（一次 抗体はbiomeda 社のカリニ抗体) で同原虫を証明 した。さらに、その後の喀痰細胞診から䔬線虫に 相当する体長 $0.3 \mathrm{~mm}$ 前後の線虫を認めた。

【組織所見】気管支生検材料で肺胞内に無数の泡 沫状構造物が見られ、グロコット染色、酵素抗体 法でカリ二原虫が確認された。

【結語】粪線虫症は主に南西諸島にみられ、日和 見感染的性質があることやAＴＬ抗体陽性者に瞥 線虫の保有者が高いことが知られている。本症例 の如く䔬線虫を喀痰に認めることは稀であるか、、 同虫体を粪便、喀痰等に認めた時は、HI V、 A T L も検索する必要がある。 
177 喀痚中の泡沫状物質が端緒となりカ リ二肺炎と判定し得た一例

新潟県立がんセンター病理部

○泉田佳緒里（C T ）、渡辺芳明（CT）、 桜井友子 ( C T )、西村広策 $(\mathrm{C} T)$ 、宇佐見公一 ( C T )、須貝由美子 ( C T ) 、佐藤由美（C T)、 本間慶一 $(\mathrm{MD}) 、$ 根本啓一 $(\mathrm{MD})$

【はじめに】 Pneumocystis carinii肺炎は免 疫不全状態の患者に発症する日和見感染症の一つ である。我々は、37才のNon-Hodgkin lymphoma 患者の喀痰中に泡沫状物質を認め、それが端緒と なりカリ二肺炎と診断し得た一例を経験したので 報告する。

【症例】37才。男性。既往歴・家族歴に特記すへ きことなし。1995年5月頃より頸部リンパ節腫脹 ・体重隇少に気付き近医受診。リンパ節生検・C TにてNHL (Diffuse Largecell Type StageIV) と診断された。化療目的に当院受診し入院。NH $\mathrm{L}$ 治療中、10月頃より胸部 X $-\mathrm{P}$ 上に肺炎像、 C $\mathrm{T}$ では肺炎像と共に網状粒状影出現、同時に喀痰 の喀出があるためカリ二肺炎とN H L 浸潤を疑い 喀痰細胞診を行った。

【細胞像】パパニコロウ染色では軽い炎症性背景 に、ライトグリーン〜オレンジGに染まる泡沫状 物質を多数認めた為、グロコット染色を行い泡沫 状物質中にカリ二囊子を確認した。また、継続し て行われた喀痰細胞診には泡沫状物質と共に、 $\mathrm{N}$ H L由来と思われる異型細胞も認められた。

【まとめ】今回、喀痰中の泡沫状物質が端緒とな りカリ二肺炎と判定し得た。発症後72時間を過き ると急激に状態が悪化するカリ二肺炎を非侵襲的 検查である喀疾細胞診で判定し得たことは、早期 治療が必要なカリ二肺炎の診断に有意義であると 思われる。また血液疾患・癌等の治療中や、免疫 不全状態の患者に肺炎・喀痰を認めた場合は積極 的に喀痚細胞診を行い喀痚中の泡沫状物質の有無 を注意深く観察する必要があると思われた。
178 術中細胞診における偏光フィルターの 使用経験（肺硬化性血管腫 2 例亡器質化肺炎 3 例）

国立療養所刀根山病院 病理 $^{12}$ 、内科 ${ }^{27}$ 、外科 ${ }^{32}$ 智片医院 $^{43}$ 、市立豊中病院 病理 ${ }^{5}$ 、大阪がん予防 検診センター ${ }^{6}$

○橋本泰吉 $(\mathrm{CT})^{12}$ 、佐埇妒文 $(\mathrm{CT})^{12}$ 、西川㮃樹 $(N D)^{22}$, 桑原 修 $(M D)^{3)}$ 、智片英治 $(\text { MD })^{4)}$ 、花田 正人 $(\mathrm{MD})^{5)}$ 、野田 定 $(\mathrm{ND})^{6)}$

我々は前回、術前・術中捺印標本の $ヘ^{\circ} ヘ^{\circ} こ コ$ 染 色で壊死栏無構造物が認められた場合、偏光影微 鏡を用いることにより肺癌や結核に見られる壊死 物質とアミ唯”物質との鑑別が可能であることを明 らかにした。今回、硬化性血管腫 2 例、器質化肺 炎 3 例を経験し、乳頭形成を伴った間質系細胞の ペパニコ口染色で偏光顥微鏡を用いて若干の所見を 得たので報告する。

（硬化性血管腫 2 例の細胞所見）

2 例とも炎症性細胞を背景に、多核大型細胞（核 内空胞もあり）や細胞質の広い泡沫状の細胞、诖 ジデリッ頜食細胞、乳頭状細胞集団の出現が見られ た。また乳頭状細胞集塊中心に間質系細胞が見ら れ、比較的強い偏光を示した。

（器質化肺炎 3 例の細胞所見）

3 例において炎症性細胞を背景に、多核大型細胞 やへモジデリ領食細胞が見られた。また乳頭状細胞 集塊を示す間質系細胞が見られたが硬化性血管腫 に比べ偏光の強さは軽度であった。

\section{（結語）}

硬化性血管腫や器質化肺炎に見られる乳頭状細胞 集塊を伴った間質系細胞の鑑別に偏光フィルターを用い て、硬化性血管腫においてより強い偏光が見られ た。 
179 FINE NEEDLE ASPIRATION CYTOLOGY OF THE SCLEROSING HEMANGIOMA OF LUNG: A Case Report

Tokyo Medical College, Department of Pathology-2

Bijayee Shrestha MBBS, Yoshiro Ebihara MD, Motoshige Kudo MD, Hiromi Serizawa MD, Hiroyuki Shibanuma MD, Makoto Soga MD, Masato Watanabe DDM, Etsuko Koike CT.

This report presents the cytological aspects of a pulmonary sclerosing hemangioma which was initially suspected to be carcinoid or well differentiated adenocarcinoma.

$<$ History> A routine chest $X$-ray examination of a 38 year-old-male, revealed a round, well circumscribed mass in the right lung field. <Cytology> Papanicolaou stained FNAC specimen consisted mostly of the cuboidal epithelioid cells arranged in sheets, loose clusters or singly. These cuboidal epithelioid cells had bland-looking appearance, centrally placed round, uniform nuclei with inconspicuous nucleoli and little or no hyperchromasia. The cytoplasm was distinct, thick and moderate in amount. Some of the other cell populations included type 11 pneumocytes with intranuclear inclusion bodies, multinucleated cells and atypical cells. A few tissue fragments showed spindle cells admixed with epithelioid cells and collagen fibers.

<Macroscopic finding> The lobectomy specimen showed a grayish white, well defined, round, firm to hard mass of $1.8 \times 1.5 \times 0.9$ $\mathrm{cm}$ located within the parenchyma of right $\mathrm{S} 10$ segment.

$<$ Histology> The tumor consisted mainly of sclerotic areas and small cystic spaces with interdigitating papillae. The core of the papillae was made up of bland spindle cells, macrophages, lymphocytes, capillaries and pneumocytes.

$<$ Conclusion> Though the original diagnosis of FNAC suspected the lesion to be carcinoid or well differentiated adenocarcinoma, the cell cohesiveness, distinct thick cytoplasm, lack of mitosis and variety of cells favour the diagnosis of benign lesion, sclerosing hemangioma.

\section{0 肺硬化性血管腫の細胞学的検討}

横浜市立大学医学部附属病院病理部 ${ }^{1}$, 同病理 学教室 ${ }^{21}$, 横浜市立市民病院病理部 ${ }^{3)}$

O北村和久 (CT $)^{1)}$, 中谷行雄(MD) ${ }^{1)}$, 木村聖子(M D) ${ }^{1)}$, 北村 均(MD) ${ }^{1)}$, 䅔山嘉明(MD ${ }^{2)}$, 三井邦 洋 $(C T)^{3)}$, 佐野仁勇 (MD $)^{3)}$, 中村宣生(MD) ${ }^{3)}$

肺硬化性血管腫は比較的まれな良性腫瘍で、 肺胞上皮に由来するとする説が有力である。今 回我々は肺硬化性血管腫 5 列の細胞像を検討す る機会を得たので報告する。

【症例】横浜市立市民病院、横浜市立大学医学 部附属病院にて肺硬化性血管腫と組織診断され た 4 例の㴎印細胸と 1 例の穿刺吸引細胞を対象 とした。

【細胞所見】 P a p 染色では、細胞群は大別す ると以下の 4 群に分類された。(1)異型のない円 形の核を呈するやや多辺形〜立方状の細胞が、 リボン状〜シート状で平面的配列を示す細胞集 団；(2)配列は(1)群の細胞に類似するが、核は類 円形で增量した細顆粒状クロマチンと大型核小 体を有し、時に多核で核内封入体が見られ、細 胞質の厚い大型多辺形細胞集団; (3)微細顆粒状 のクロマチン、類円形〜棈円形核を有する中型 細胞が毛細血管樣構造周囲にやや乳頭状配列を 示す細胞集団；(4)慢性炎症細胞、泡沫細胞、へ モジテリン含有マクロファージ。これら4群の 細胞が各应例ことに種々の割合で混在していた。 今回検討の結果、従来報告されていない以下 の3点を比較的特徽的な所見として認めた。

1) May-Gruenwald's Giewsa染色で明瞭に識別 される多数の肥满細胞。2) 免度染色にて(3)群 紐胞に認めたプロジェステロン・レセプター陽 性核。3) (3)群の細胞から成る乳頭状構造中心 部に認められる少量の無構造基質。

【考察】肺硬化性血管腫と肺癌・カルチノイド などとの别には多彩な細胞像に加え、上記 3 㫮む有用と思われた。 
181 大腸癌肺転移との鑑別が困難であつ た肺腺癌（気管支表面上皮型腺癌）の一例

結核予防会複十字病院臨床検査科 ${ }^{1)}$, 同 呼吸器 外科 ${ }^{2)}$, 結核研究所病理 ${ }^{3)}$

O出井 禎 $(\mathrm{CT})^{1)}$, 上野真由美 $(\mathrm{C} \mathrm{T})^{1)}$,

藤山淳三 $(\mathrm{C} \mathrm{T})^{1)}$, 河又國士 $(\mathrm{C} \mathrm{T})^{11}$,

佐藤之俊 $(M D)^{2)}$, 河端美則 $(M D)^{3)}$

経気管支針吸引細胞診(TBAC)にて大腸癌肺転移 を強く疑つたが、消化器系に病変はなく、手術の 結果、原発性肺腺癌と診断された 1 例を経験した ので報告する。【症例】75歳, 男性。72歳時肺結核 にて化療を施行され，以降外来通院中であった。 平成6年11月より右肺下葉に異常影が出現し、精査 を行なったが異常所見なく、平成7年4月再精査目 的にて入院となる。胸部CT上右 $S^{9} \sim S^{10}$ に径 $4 \mathrm{~cm}$ の 腫瘤影がみられ、気管支鏡検查にて右 $\mathrm{B}^{9+10}$ 内にポ リープ状病変を認めた。TBACにて大腸癌の転移を 疑い、上下部消化管精查を行なったが異常所見な く、右肺腺癌 $\left(\mathrm{cT}_{2} \mathrm{~N}_{0} \mathrm{M}_{0}\right)$ と診断し、同年6月13日右 下葉切除術を施行した。【TBAC所見】壊死性背景の 中に、高円柱状、立方状または類円形の異型細胞が 比較的強い上皮性結合を示す集塊として出現して いた。細胞集塊は栅状配列や乳頭状配列を示す部 分が多く、これらの細胞の細胞質はライト緑に淡 染し、桶状配列部分では細胞質の一端に長く尾を 引く像を認めた。核は類〜長棈円形で大小不同や 不整形などが見られた。クロマチンは細顆粒状で、 一部に浱染が垫められた。核小体は小型で、1〜2 個有する細胞があったが、ほとんどの細胞には認 められなかった。以上の所見より、大腸㮩肺転移を 強く疑つた。【病理所見】摘出された腫籀は約 4 $\mathrm{cm}$ 大で白色充実性を呈し境界は比較的明瞭であつ た。腫篗は気管支内をポリープ状に進展增殖する 部分と肺実質内進展部分を認めた。組織学的には、 高円柱状細胞が乳頭状配列や管腔形成を示し、比 較的広い間質を有していた。以上の所見より、いわ ゆる気管支表面上皮型腺癌と診断された。

以上、免疫染色等の結果も合わせて報告する。
182 クロム肺癌 2 症例における細胞診なら びに組織診の経時的変化の検討

結核予防会椱十字病院呼吸器外科”、 癌研病院細胞診断部2)、癌研究所病理部 ${ }^{3)}$

O佐藤之俊 $(M D)^{1,2,3)}$ 、池永素子 (CT $)^{2)}$ 、 都竹正文 $(C T)^{2)}$ 、石川雄一 $(M D)^{3)}$

クロム $(\mathrm{Cr})$ 従事者では, 癌や異型病変は気管支の 分岐部で $\mathrm{Cr}$ 沈着部位に一致し発生することが多 く，また経過钼察が癌の早期発見や治癒に効果をあ げている。今回我々は, Cr肺癌例のうち, 異型病変を 内視鏡的に経過を追って镜察し，最終的に剖検にて 確認しえた例を経験したので，細胞像と組織像を対 比し報告する。【対象と方法】癌研における元Cr作 業従事者剖検例13例のうち，気管支の分岐部に異型 病変が発生し、それを定期的に経過観察した63歳男 性 (症例1) と71歳男性 (症例2)の2例を対象とし，経時 的に得られた気管支鏡下生検と摖過細胞㟝の所見を 比較した。【結果】镜察期間は症例1，2それぞれ1年 6カ月, 7 年7カ月であった。経過中症例1は重複癌と 1 異型病変を、症例2は重複癌をそれぞれ認めた。 [各症例の疾の経時的変化]

$\Delta$ 症例 1

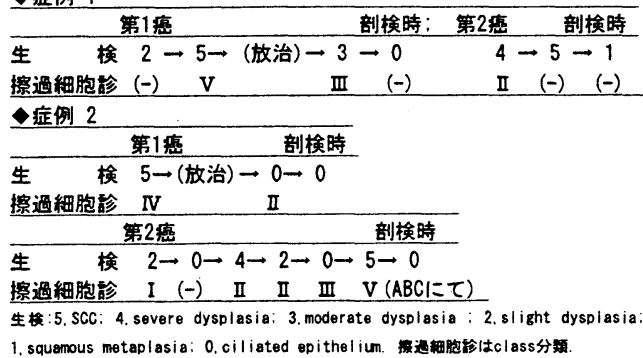

【まとめ】本対象例における生検で軽〜高度異型扁 平上皮と診断された病変の摖過細胞診では陽性例は 認められず, class II かIII と判定された。また，癌と 診断された4病変中3病変では細胞診が陽性であった ことから、検体採取上の問題はあるが，ある程度の拡 がりを有する病変に対し擦過細胞診は有用であると 思われた。また，Cr従事者では本対象例のように重 複癌例が多いため, 定期的観祭がきわめて重要であ る。(共同研究者：中川 健、土屋永寿） 
183 肉腫様変態を伴った肺原発腺癌の 4 症

例

\begin{tabular}{|c|c|c|}
\hline ○高垣 & 和代 (CT) & 中尾 幸代 (CT) \\
\hline 細川 & 珠枝 (MT) & 幸福 淳子 ( C T ) \\
\hline 前田 & 妙子 ( C T ) & 平山 裕子 ( C T) \\
\hline 田中 & 千代 (C T) & 高橋満智子（C T) \\
\hline 指方 & 輝正 (MD) & 覚 (MD) \\
\hline
\end{tabular}

原発性肺癌の中には病理組織学的に明らかな癌腫 部分と肉腫様形態を示す部分（いわゆる肉腫様変 態）とが混在する症例があることが知られている。 今回我々は、この様な症例を 4 例経険したので、 細胞像を中心に報告する。

〔症例〕 (1) 57 オ、男性。検彮で胸部異常陰影を

\section{指摘。}

(2) 58 才、男性。検診で胸部異常陰影を指摘。

(3) 67 才、男性。咳刺を自覚し、近医受診。

(4) 69 才、男性。肝機能障害で入院中に胸部異常 陰影を指摘された。

〔細胞像〕(1)腫瘍細胞が散在性あるいはシート状 に出兒し、核クロマチンは細顆粒状、核縁はうす く核の切れこみを認め、多形性を示すものもあり 核小体は1 〜数個存在していた。(2)孤立散在性に 出現し、細胞質が豊富でクロマチンは不均一分布、 顆粒状であった。(3)集団で出現し、核縁はうすく、 切れこみがあり、クロマチンは細顆粒状であった。 (4)シート状あるいは散在性に出現し、核は大小不 同であるが類川形を示すものが多数みられた。ま た同一標本内に多核巨細胞、紡鍾形細胞も混在し ていた。

〔組織所見】 4 症例とも肉腫様变態を伴った低分 化腺癌と診断された。なお症例(3)ではごく一部に 扁平上皮癌の像もみられた。以上の各症例につき、 病理組織学的所見をもあわせ報告する。
184 いわゆる細気管支肺胞上皮癌の細胞像 の検討

国立療養所東京病院 ${ }^{1)}$ 、同病理 ${ }^{21}$ 、東京医科大 学 $^{3)}$

○宮島邦治（MD） 1) 3)，小松彦太郎（MD） ${ }^{1) ， ~}$ 田村厚久 (MD) ${ }^{1)}$, 蛇沢 晶 (MD) ${ }^{2)}$, 田島 紹吉 $(\mathrm{CT})^{2)}$, 渋木康雄 (MT) ${ }^{2)}$, 小中千守 $(\mathrm{MD})^{3)}$, 加藤治文 $(\mathrm{MD})^{3)}$

いわゆる細気管支肺胞上皮癌は、“高分化乳頭状腺 癌の悪型とされているが、細胞異型の乏しいこと から悪性と断定できずfalse negativeとなる場合も 多い。細胞診断学上、過形成及びその他の腺癌と の鑑別が問題となる。

【対象】国立療養所東京病院にて、いわゆる細気 管支肺胞上皮癌のうち 24 症例 (29検体) を杯細 胞型 (Gob型) と非杯細胞型（non-Gob型）に分 けて術前診断の可能性について検討した。杯細胞 型 (Gob型) は、10症例（13検）で術前に確診 ないし疑診されたのは8症例（11検体）であった。 また、非杯細胞型（non-Gob型）は、14症例 （16検体で術前に確診ないし疑診されたのは、9 症例（11検体）であった。

【結果と考察】細胞配列は、Gob型では重積性に、 non-Gob型では平面的パターンが多く認められた。 細胞集団の結合性は、non-Gob型では八頭状やブ ドウ房状細胞集族を認めた。N/C比は、Gob型よ りnon-Gob型の方が上昇しており。細胞質は、 Gob型では泡沫状で粘液を保有する豊富であり、 non-Gob型はライトグリーンに濃染するものが多 数認められた。non-Gob型よりGob型の方が、核 の大小不同がそしかった。核縁は、平滑でくびれ を有するものが見られ、Gob型の方がnon-Gob型 よりくびれを有するものが多かった。核の偏在性 は、Gob型で強く、またnon-Gob型では核内封入 体を認めるものもあり、クロマチン構造も粗顆粒 状であった。核小体はGob型では小型のものを認 められるが、non-Gob型では確認しずらいものが 多かった。 


\section{5 細気管支肺胞上皮型腺癌と細胞診断}

国立療養所千葉東病院呼吸器外科 ${ }^{1}$, 千葉大学肺 癌研究施設外科 ${ }^{2}$

O山川久美 $(M D)^{1}$, 馬場雅行 (MD $)^{2}$, 柴 光年 (MD) ${ }^{2}$, 光永伸一郎 $(M D)^{2}$, 小高恵美子 $(M D)^{2}$, 高野浩 昌 $(M D)^{2}$, 藤沢武彦 $(M D)^{2}$, 山口 豊 $(M D)^{2}$

治療法の選択あるいは予後の推定など臨床に有 用な情報を提供できなければ組織分類の意義は半 減する.この意味からは現行の細気管支肺胞上皮 型腺癌 (BAC) が特徵ある疾患概念を示していると は言えず，この組織垔型の存在意義はそしい。こ れは BAC の診断基準が明確でないために種々雑 多の肺腺癌が BAC として扱われていることによ るもので, 従って BAC の細胞診断も一概に論ず ることは出来ない. しかしながら BAC のなかに は, 経気道性と考えられる進展様式をとり肺炎梾 の陰影を呈し進展が肺内に止まるなど組織学的に も臨床的にも通常の肺腺癌とは異なった特徵を有 する 1 群が存在することも事実で，このような 1 群を細胞診で診断することの意義は大きい.

従来よりわれわれは, 経気道性進展が示唆され る肺腺癌は大部分が細胞亜型を見ると杯細胞 (Gob) 型かあるいは非杯䋛胞型気管支表面上皮細胞(BS) 型であることを報告してきた. 自験 21 例（Gob 型 15 例, BS 型 6 例) の検討から, 気管支鏡下 の TBAC あるいは擦過細胞診標本上の, 結合の強 固な極性のそろつた高円柱状の細胞集団, 細胞質 内の粘液空胞といつた細胞所見に, 胸部 X 線写 真, CT 写真などの画像所見と臨床情報を加味す ることでこのグループの肺腺癌の診断は可能であ つた. 組織所見, 細胞所見に加えて画像所見, 臨 床像についても検討する予定である.
186 小細胞癌との鑑別に苦慮した胎児肺 型肺腺癌の一例

県立がんセンター新潟病院病理部 ○西村広栄 (CT), 渡辺芳明 (CT), 桜井友子 (CT), 宇佐見公一 $(\mathrm{CT})$, 須貝由美子 (CT), 泉田佳緒里 (C $\mathrm{T}$ ), 佐藤由美 $(\mathrm{CT})$, 本間慶一 (MD), 根本啓一 (MD)

[はじめに］稀な肺悪性腫瘍である肺芽細胞腫の 一亜型と考えられている胎児肺型肺腺癌の一例を 経験したのでその細胞学的所見を中心に報告する. [症例] 69歳女性. 1995年6月食欲隇退, 体重隇 少を主訴に他院を受診chestX-p上右中肺野にcoin lesionを指摘され当院へ紹介された.6月20日B $\mathrm{F}$ 施行するもTumor cell(-).9月5日 B F 再検に てClass V. 10月23日右 S6-8部分切除+リハパ節サンプ リリ゙が施行された。

[細胞所見]核腫大及び大小不同を伴った裸核状 の悪性細胞が弧在性〜集塊状に多数見られた。核 は類円形〜楕円形，核縁は不整で切れ込みがみら れ, 核分裂像も散見される。加对はは微細顆粒状, 分布は比較的均一で，小型の核小体が目立つ。小 細胞癌に類似したが, 一部squamoid patternや腺 腔様構造もあり組織型は確定できなかつた。

[切除標本肉眼所見] 腫瘍は右 S6-8区域間に存 在. 大きさは $1.7 \times 1.5 \times 1.5 \mathrm{~cm}$. 割面は乳白色調 を呈し, ほぼ球形, 比較的軟らかく, 境界明瞭で 圧排性增殖を示していた。

[病理組織所見] 組織学的には, 類円形核と淡明 な胞体を有する腫瘍細胞がprimitiveな腺腔を形 成しつつ充実性增殖し, 腺腔構造ではEMA+, CAM5. 2+で, 一部chromogranint, Grimelius+であり， 充実性增殖の一部ではdesmin+, MSA+であった。 以上から，胎児肺型肺腺癌と診断した。

[まとめ] pulmonary blastomaの中でも肉腫成分 を欠く胎児肺型肺腺癌は小細胞癌に類似し細胞診 学的に確診することは困難と思われる.これを疑 った場合には積極的に免疫染色を行い診断を確定 する必要がある。 
187 喀痰中に腫瘍細胞の出現をみた肺

原発yolk sac tumorの一例

\section{弘前大学医学部一病理}

○山岸晋一朗（MD）、西田尚樹（MD）、八 木橋法登 $(\mathrm{MD})$ ）黑滰日出一 $(\mathrm{MD}) 、 八 木$ 橋 操六 (MD)

今回喀痰中に腫瘍細胞の出現した稀な肺原発 yolk sac tumorの一例を経験したので報告する。

症例：17藏の女子高生。平成6年4月、学校健診 で、右下肺野の異常陰影を指摘された。CTでは、 右下肺野に多結節性の腫瘍が見られ、血清学的検 查でAFPが7670 $\mathrm{ng} / \mathrm{ml}$ と巽常高值だった。肺以 外に腫瘍病変は認められなかった。喀痰細胞診お よびCTガイド下肺生検が行われ、yolk sac tumor と診断された。化学療法および放射線治療施行後、 平成7年9月、右中下葉切除術が行われた。

摘出腫瘍の病理組織所見: 腫瘍細胞は、好酸性 ないしは淡明な細胞質を有し、核は涱染性、多形 性を示し、索状、シート状、ないし一部管腔を形 成し增生していた。血管を中心とした

Schiller-Dubal body様の部分も散見され、腫瘍細 胞の約30\%がAFP陽性を示した。

览痰細胞診所見：好中球を主体とした咨症性細 胞を背景として、いびつに腫大した核を有し、胞 体の淡明な小型の買型細胞が集塊として認められ た。核クロマチンは粗大顆粒状で、比較的均一な 細胞像であった。細胞の結合性は強く、腺腔を形 成する部分も観察された。

捺印細胞所見：腫痬細胞は胞体が淡明で、小さ な核小体を一個あるいは二個認め、円形ないし類 円形に腫大した核を有していた。核クロマチンは 細顆粒状ないし粗大楼粒状で、核縁肥厚は軽度で あった。大型の核を有する細胞も散見されたか、 比較的均一な像を呈していた。これらり細胞がシ 一ト状ないしは索状の集塊を形成し、一部管腔を 形成している部分も見られた。
188 喀痰中に出現した悪性中皮腫の一例

一 同一細胞の光顐的および電顥的観察 -

大阪府済生会中津病院 検查技術科病理 ${ }^{1)}$

阪大微生物病研究会 臨床検查部病理紐胞診 ${ }^{2)}$

O下岡純子(C T ) ! 田中ふさよ (CT).. ${ }^{1}$ 池谷武彦

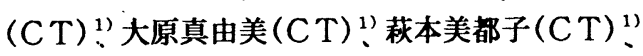
上田恵 $(\mathrm{MD})$ ? 松田実(MD) ${ }^{2)}$

我々は略疢中に悪性中皮腫の細胞が認められた 一症例を経験し、パパニコロー染色による光影的 観察を行い、その後同一細胞の電影的観察を行な つたのでその細胞所見について報告する。

67 才、男性、建築業、アスベスト暴露歴あり。 平成 6 年 5 月、職員検診にて胸部異常陰影を指摘 され当院受診した。同年 7 月、胸水細胞診にて陽 性悪性中皮腫を強く疑うと判定した。

平成 7 年 3 月、略疾細胞診にてライト緑好性の 重厚で豊富な細胞質を有する細胞が、平面的で㻋 な集団で認められた。核は類円形で中心性、単核 〜2、3核のもの がみられ、クロマチンは顆粒状 で増量し、核小体は 1 個〜数個認められた。本細 胞の電影所見は、変性著明なため微細構造はわか らないが、細胞膜表面の長い微絨毛と核周囲に中 間径織䧴と思われる栱維が認められた。

平成 7 年 8 月死亡。胸膜ネクロプシーが行なわ れた。ネクロプシー㯲本では、線䧴性結合織中に 壊死傾向の強い腫韵細胞の蜂巣状增殖が翟められ 腫場細胞は、大型で円形〜多角形の豊かな細胞質 を有し核異型が強い。アルシアン青およびコロイ ド鉄染色は、腫場細胞および間質に陽性で、この 物質はヒアルロニダーゼで消化された。ケラチン EMA，ビメンチン陽性、CEA，CA125陰

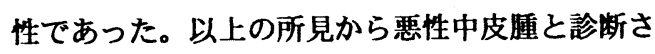
れた。 
189 骨肉腫病変の著しい肺腫瘍の一症例

杏雲堂病院 1) 東京医科大学病理2)

小瀬木輪子 $\mathrm{CT}_{1}$ ）大川裕子(T 1) 海老原善郎MD?

河手典彦MD1) 高橋英介MD1) 玉地義弘 $M D_{1}$ )

林 永信MD1)

肺に原発する肉腫は肺腫愓の $0.5 \sim 1 \%$ を占め るにすぎず、骨肉腫性病変を持ったものは非 常に稀である。気管支擦過細胞診で肉腫が疑 われ切除標本で骨肉腫の所見を示した症例を 経験したので報告する。

<症例>54歳男性。喫煙指数: 720 。H7.1月よ り咳嗽が持続。胸部レントゲン写真, CTで右下 葉 $\mathrm{S}^{10}$ 中枢側に径 $5 \mathrm{~cm}$ の腫瘤陰影、気管支鏡下に 右B10を閉塞するポリープ状病変を認めた。擦 過細胞診及び生検で悪性所見を認めた為、右 中下葉切除およびリンパ節郭清術を施行した。 <細胞所見>擦過細胞診では孤立散在性、あ るいは疎の結合性を示してシート状に配列す る腫瘍細胞を認めた。N/C比は種々であり、裸 核状のものから多形性の細胞質の豊富なもの まで多岐にわたっていた。核は桿状〜類円形 状で切れ込みや陥凹等も認められた。核クロ マチンは細顆粒状で均等に分布し、小型不整 形の核小体も数個見られた。腫瘍捺印細胞診 でも上記と同様の腫瘍細胞が見られたが、細 胞・核の異型度は増強され異常核分裂像を呈 する細胞や緑色無構造の類骨も見られた。 く組織所見〉腫瘍は壊死部分が多くみられた。 viable t issueでは間葉性軟骨肉腫様の所見、 紡鍾形細胞肉腫、あるいは類円形細胞のびま ん性増殖からなり後者では細胞間に種々の量 の類骨基質が介在した。上皮成分は明らかで なかった。

肺の原発性骨肉腫は, metaplastic osteosarcomaが否定されなければならないが、多数 切片で調べても本例には上皮性分を見出すこ とはできなかった。
190 喀痰細胞診と $2 つ の$ 肺病巣に対する第 刺吸引細胞診で多発癌が疑わ机た症例

東京医科大学病理学第 2 講座, 外科 ${ }^{2}$, 病院病理部 ${ }^{3}$, 内 科 $^{4}$

OQimangul WUSHUR(MD) $)^{1,4}$, 海老原善郎(MD) $)^{1}$, 柴沼 弘行 $(\mathrm{MD})^{2}$, 片桐仁子 $(\mathrm{CT})^{3}$, 横山明子 $(\mathrm{CT})^{3}$, 加藤治文 $(\mathrm{MD})^{1}$

[症例] : 61才, 男性。定期検診の胸部レ線写真に 2 ケの異常除影が指摘された。喀痰と右肺下葉の 2 病 肾それぞれに対する穿刺吸引細胞診が行われ，その 両方に線癌細胞が検出された。右下葉切除が行われ た。

[客疾細胞材料]：異型細胞は $\mathrm{N} / \mathrm{C}$ 比の高くない大型 細胞が重積性のある集団 (CM-1)を作って認められた。

[穿刺吸引細胞材料] : 病巣の 1 \% (CM-2) からは, 壤死物質と共に N/C の高い濃染核とレース状の細胞 質を特徴とする異型細胞が重積性のある集団を作っ て出現していた。もう1ツ(CM-3) からは, 濃染する 円形核を持つ多角形細胞がシート状配列を示して認 められた。

[手術材料所見] : 切除された上葉には計 3 ケの病巣 が認められた。第 1 病巣は $\mathrm{S}^{2}$ bに位置する $4 \times 3 \times$ $3 \mathrm{~cm}$ の灰白色半透明半透明結節性病変で, 組織学的 には粘液産生性乳頭状腺癌であった。これと接して, 異型腺様過形成性病変が認められた。第 2 病変は 2.5 $\mathrm{x} 1 \mathrm{x} 0.5 \mathrm{~cm}$ で $\mathrm{S}^{2} \mathrm{a}$ にあり, 軽い胸膜嵌入を伴ってい た。組織学的に核異型の高度な多角細胞がびまん性 增殖を示す低分化腺癌であった。第 3 病変 $(1.7 \times 1.7$ $\mathrm{x} 1.2 \mathrm{~cm})$ も $\mathrm{S}^{2} \mathrm{a}$ にあり, 異型腺様過形成性病変であっ た。以上の他に, 複数の小さな腺様過形成性病巣が 散在し、いろいろな程度の細胞異型を示した。

$\mathrm{CM}-1$ は第 1 病変, CM-2 は第 2 病変に接した異型腺 様過形成性病変, CM-3 は第 3 病変の細胞の由来が 求められた。

[まとめ]：細胞所見から複数の原発病巣が想定でき た症例である。 
191 乳腺乳頭部腺腫の1例

箕面市立病院中央検查部 11 、同外科 ${ }^{2)}$ 、同名誉

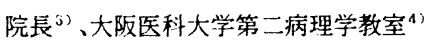

O市川宗昭(CT) 11 、山本 仁( VD $)^{2)}$ 、田村 宏 (MD) ${ }^{3)}$ 、小橋昭雄(MD)

【はじめに】乳腺乳頭部腺腫は乳頭内および 乳輪下乳管内に生じる腺腫であり、通常乳頭 部の皮疹、びらん、発赤、硬化を主症状とし、 臨床的に P aget 病との鑑別が問題になる比 較的まれな良性疾患である。

今回、我々は、術前の分泌液、腫瘤穿刺細胞 診において乳癌を否定しきれなかった一例を 経験したのでその細胞像を中心に報告する。

【症例】46歳、女性、平成 4 年12月に左乳輪 部腫馏に気ずくも放置。平成 6 年 1 月 12 日左 乳輸部精查目的で当院外科外来受診、乳管造 影にて乳頭部に腫瘤みられ、分泌液、穿刺細 胞診にて乳頭部腺腫うたがうも乳頭癌も否定 できず、腫瘤切除術施行。

【細胞診所見】赤血球、白血球、組織球、な ど cystic な背景に大小の乳頭状細胞集団が 多数認められた。細胞集団は、比較的結合力 はつよく、核は重積性、類円形からやや不整 形、大小不同、クロマチンは微細顆粒状から 顆粒状ほぼ均一で一部に凝集みられ、核小体 は概ね一つでなかには大型のものもみられた。 集団の最外層は細胞質で覆われ、細胞の境界 も概好明瞭一部不明瞭な部分もみられた。腫 瘤の存在部位も考虑にいれ、乳頭部腺腫を疑つ たが乳頭癌も否定できず、class四とした。

【組織所見】摘出された腫瘤は被膜のない限 局性の腫湯で血管を容れた間質と明瞭な二層 構造を示す乳頭状増殖像を示し、硝子様の間 質にあたかも、浸潤しているかのごとき偽浸 潤像も見られたが、上皮細胞の異型性は乏し く、壊死宩もみら机ず、乳頭部腺腫とした。
192

乳管内乳頭腫の細胞診の検討

大分県立病院 病理、外科*鳥越圭二朗(CT)、 过浩一(MD)、見悦子(CT)、上野正尚 (CT)、白坂 千秋 $*(\mathrm{md})$

乳管内乳頭腫は穿刺細胞診上の特徵的所見に 乏しい。今回われわれは病理組織学的に乳管乳 頭腫と診断された症例の術前検査の穿刺細胞診 と非浸潤性乳管癌のそれとを比較検討したので 報告する。

材料:乳管内乳頭腫 11例、非浸潤性乳管癌(乳 頭型) 15例である。穿刺細胞検查はすべてパパニ コロー染色によった。

方法:細胞集塊のあり方(結合性、配列、極性、2 相性、重積性)、孤立性細胞の性状(細胞形、N/C比、 細胞内空胞)、核の性状 (大きさ、形、大小不同、ク ロマチン、核小体)、背景(アポクリン細胞、泡沫 細胞、筋上皮細胞、双極裸核、脂肪細胞、粘液、分 泌物、壊死)などについて検討した。

結果: 管内乳頭腫: 細胞集塊は中 大型のもの が多く結合性が強い。極性のある乳頭状の集塊 形成が多く外側に配列する細胞質に厚みがあっ た。集塊辺縁にはやや染色性の異なる細胞あり、 2相性が認められた。小集塊または孤立細胞には 細胞質空胞が半数にあった。核は円形 楕円形で 核形不整、大小不同はあるが軽度で、クロマチン は細顆粒状 やや粗顆粒状で、核小体は小さいも のを1個、8例に認めた。背景には泡沫細胞や裸核 細胞があり、アポクリン細胞は少なかった。非浸 潤性乳管癌: 細胞集塊は大型が多いが、極性のな いものが多い。また2相性がない。集塊から分離 する小集塊がみられ、その小集塊の細胞には”ほ つれ”があった。細胞質空胞はない。核形は不整 で、大小不同があった。クロマチンは増量 し、粗 顆粒状で、核小体は大きく明膫であった。背景に は白血球や分泌物が多く、泡沫細胞は少ない。

まとめ:細胞集塊の性状、核所見、背景に両者 の相连が見られた。 
193 乳管癌との鑑別が難しかった乳管内 乳頭腫の細胞像の検討

富山県立中央病院臨床病理科 ${ }^{1)}$, 同検査科 ${ }^{2)}$, 同外科 ${ }^{3)}$, 同院長 ${ }^{4)}$

$\bigcirc$ 三輪淳夫 $(M D)^{11}$, 山下弘子 $(M D)^{1)}$, 福村健 $(\mathrm{CT})^{2)}$, 宮本藤之 $(\mathrm{CT})^{2)}$, 前田基一 $(\mathrm{MD})^{3)}$, 舘野政也 $(\mathrm{MD})^{4)}$

乳管内乳頭腫と乳管癌との鑑別は組織学的にも 細胞学的にも難しいとされている。われわれは組 織学的に乳管内乳頭腫と診断された 7 例の細胞像 を再検討した。そのらち乳管癌との鑑別が難しかっ た 1 例の細胞像について詳細に検討した。

[症例】 73歳閉経(48歳)女性 ( 2 児, 母乳)， 2 年 前より右乳腺にしこりを認めていて，最近，増大 傾向にあるので当院外科を受診した。右 $\mathrm{CD}$ 領域 に径 $1.5 \mathrm{~cm}$ 大の弾性硬で辺縁不整な腫瘤を触知し, 圧すと暗赤色の乳汁分泌があった。乳腺撮影にて 腫瘤陰影には spicula や石灭化はなく，USゃ CTにてリンパ節転移の所見はなかった。細胞診 にて癌が疑われ，乳房切除術が施行された。

〔細胞像〕筋上皮細胞を伴ってシート状配列を示 す細胞集塊に混じって，眯な集合性をもつ細胞集 団がみられた。部分的にほつれ現象があり，核間 距離は不均一で核の大小不同が認められた。乳頭 状集塊の辺縁に核の飛び出しがあると見做され， 乳管癌が疑われた。術後に再検討すると, 全体と して乳頭状集塊の細胞質が広いこと, 細胞集塊の 中に血管結合織性の紡鍾形細胞が認められること から乳頭腫とすべきであったと考えられる。

〔組織像】肉眼的に境界明瞭な腫瘤は乳管内にあっ て, 内腔に突出している。乳管上皮細胞と筋上皮 細胞が二相性に配列して，血管結合織を伴い乳頭 状に増殖している。瀻維性結合織の多い部分では 偽浸潤像を示す。腫瘍を構成する細胞成分は単調 ではなく, 組織学的に乳頭腫と診断された。
194 乳癌穿刺吸引細胞診における乳管内 進展の推定

新潟県立がんセンター病理部 O本間慶一 $(M D)$ 、根本啓一 $(\mathrm{MD})$ 、渡辺芳明 $(\mathrm{CT})$ 、 桜井友子 $(\mathrm{CT})$ 、西村広栄 $(\mathrm{CT})$ 、宇佐見公一 $(\mathrm{CT})$ 、 須貝由美子 $(\mathrm{CT}) 、$ 泉田佳緒里 $(\mathrm{CT})$ 、佐藤由美 $(\mathrm{CT})$

[背景] 乳癌の外科治療とし亡、乳房温存療法が 近年急速に増えつつある。温存手術を選択するに あたっては、術前画像診断での癌の乳管内進展 の検索が必須であるが、稀に画像では十分判断し 得ない症例も存在する。一方、SchnittらのEIC (extensive intraductal component)の定義にも あるように、乳管内進展の強い症例の多くは、乳 癌腫瘤内にも乳管内成分（IDC）を含んでいる。 [目的] 乳腺穿刺吸引細胞診で、乳癌の乳管内進 展が推定出来るか否かを検討する。

[対象・方法］1994年に当院で乳癌手術を施行さ れた症例のうち、術前の乳腺穿刺吸引細胞診で Class IV又はVと診断し得た98例を対象とした。 細胞診材料では、comedo 型を推定して、cell debrisの有無を、その程度によって0から3の4段 階に分類し、手術材料の乳管内進展の有無を、そ の程度によって組織学的に 0 から 3 の段階に分類 したものと比較した。

[結果] 表のように、debrisが多いほど癌の乳管 内進展の激しい症例が増加した。

\begin{tabular}{|c|c|c|c|c|c|}
\hline & 進展度 0 & 進展度| & 進展度? & 進展度 3 & 計 \\
\hline $\begin{array}{ll}\text { debris } & 0 \\
\text { debris } & 1 \\
\text { debris } & \\
\text { debris } & 3\end{array}$ & $\begin{array}{r}19 \\
10 \\
0 \\
2\end{array}$ & $\begin{array}{r}12 \\
16 \\
6 \\
6\end{array}$ & $\begin{array}{l}2 \\
8 \\
\vdots \\
8\end{array}$ & $\begin{array}{l}0 \\
1 \\
1 \\
2\end{array}$ & $\begin{array}{l}33 \\
35 \\
12 \\
18\end{array}$ \\
\hline
\end{tabular}

[結語] IDCの組織像には、comedo、cribriform、 papillary、solidの4型があるが、cell debrisの 存在から、細胞診ではcomedo型が最も推定し易い。 cell debrisに注目すれは、乳腺腫瘤の穿刺吸引 細胞診でも、癌の乳管内進展をある程度は推定可 能と思われる。 
195 捺印細胞診による乳房温存手術術中 断端検索の検討

国立大阪病院 臨床検查科" ${ }^{11}$ 同 外科 ${ }^{22}$ ○佐々木正和 (CT $)^{11}$ 、林辉子 (CT $)^{11}$ 、 竹田雅司 (MD) " 。倉田明彦 (MD) " 森田哲史 (MD) ${ }^{22}$ 、辛栄成 $(M D)^{2}$

[目的]乳房温存手術において切除断端での癌の 残存は術後再発の危険因子となる。そのため従来 代表切片における断端の術中凍結組織診断を行つ てきたが、広箅囲に断端検索が可能な拪印細胞診 が有用と考え検討したので報告する。

[対象] 1995年4月から11月までに当院で行われ た乳房温存術施行乳癌症例44例について追加切除 を含め計51回の断端拪印細胞診を行った。

[方法]断端捺印細胞診は、腫瘍本体を陽性対照 とし、切除標本の乳頭側、外倒、内側の三方向に ついて行い、陽性または陰性のどちらかに判定し た。切除標本は、乳頭側から末梢に5 mm間隔で全 割標本を作㹈し、最乳頭側の標本に癌のあるもの と、断端に虞が露出しているものを陽性、断端か ら5 mm以内に癌がみられるものを疑陽性とした。

[結果と考察]今回の検討で、疑陽性を陰性とし た場合の正診率は80.3\%(41/51)であった。誤陰性 は5例で、そのうちの4例は、最乳頭側の組織標本 に癌を認めたため陽性としたもので、乳頭側断端 面での癌の露出は確認できていない。これは組織 標本作㱔面と、細胞診診断面との乘離を示唆して いると考えられる。さらに、異型小萧過形成と小 萧内癌の鑑別が困難なため断端陽性と㟝断した 1例を除き、側方断端における誤陰性はなく、捺 印細胞診の方が真の断端の状態を示している可能 性があるとも考えられた。誤陽性は5例で、4例は 乳頭状集塊や小型異型細胞の読みすき、1例は乳 管内に脱落した畽瘍細胞を陽性とした症例であっ た。永久標本で泮陽性としたものは7例で、4例は 細胞診陰性、3例は陽性であった。 今後症例を追加し詳細な検討を加えて報告する。
196 乳腺アポクリン癌の 1 例

浜松医科大学病院病理部 ${ }^{1)}$, 同第 1 病理学教室 ${ }^{2)}$, 同第 1 外科学教室 ${ }^{3)}, \mathrm{O}$ 中島 昭 $(\mathrm{CT})^{1)}$, 原田 英一 $(\mathrm{CT})^{1)}$, 川端弥生 $(\mathrm{MT})^{1)}$.三浦克敏 $(\mathrm{MD})^{1)}$ 礒垣 淳 $(\mathrm{MD})^{2)}$, 椙村春彦 $(\mathrm{MD})^{2)}$, 吉田雅行 $(\mathrm{MD})^{3)}$

乳腺のアポクリン癌は，わが国の乳癌取扱い規約で は，アポクリン化生部が優位を占める浸潤癌で特殊型 に分類され極めて稀な腫瘍である。今回われわれは， 穿刺吸引細胞診から，アポクリン癌と診断し得た 1 例 を経験したので報告する。

【症例】69歳，女性。左乳房腫瘤を自覚したため, 平成 7 年 6 月本院受診。MMG , US で左 C 領域に 経 15 mnの悪性を疑う腫瘤が認められたため, 穿刺吸 引細胞診が施行された。以下に示寸特徵的細胞像から 細胞診によってアポクリン癌と診断した。7月，左乳 腺部分切除術がされ病理組織猃断でアポクリン癌が確 診された。

【細胞所見】シート状配列の集塊と孤在性の腫瘍細胞 が認められ，背景には僅かな壊死物質を認めた。腫瘍 細胞は類円形 多辺形で細胞質は広く，好酸性又は顆 粒状でライトグリーンに濃染した。核は類円形で単核 から三核，辺在傾向を呈しクロマチンは増量し核縁は 不正であった。核小体は好酸性大型明瞭で $1 \sim 3$ 個認 められた。

【組織所見 】大きさ $5 \times 7$ mの腫瘤で，ほとんどは管 内性で, 僅かに脂肪織内への浸潤が認められた。腫瘍 細胞は大型で好酸性に腫大した核小体を持つ空胞状の 核と，広い好酸性で細顆粒状を示す細胞質からなって いた。腫瘍は管内に向ってmonot onus な增殖を示 し, 所ヶ, 腺腔構造をとり腺腔内には好酸性壊死細胞 を認め，1ipophageが所々に集簇していた。リン ハ節への浸潤は認められなかった。

【まとめ】本例は標本でみる限り，通常の乳管癌 成分の全く認められない純粋なアポクリン癌で あった。 
197 乳腺アポクリン癌の 1 例

浜松赤十字病院検査部 ${ }^{1}$ ，同婦人科 2 ，藤田保健 衛生大学病理" , 埼玉中央病院病理"

○青山久美子（CT) "', 堀部良宗 (MD) ${ }^{3}$, 外山千恵美 (C T ) ' ，高野純一（MD）＂， 今枝義博 $(M T)$ " , 是松元子 $(C T){ }^{4}$. 村上正基（MD）行，笠原正男（MD）

乳腺アポクリン癌は比較的まれな腫瘍であるが、 最近増加傾向にあり、本学会においても症例数の 増加をみる。今回我々は乳腺穿刺吸引細胞診にて アポクリン癌の診断が得られた 1 例を経験したの で報告する。

$<$ 症例 $>40$ 藏、女性。

《現病歴〉右乳房の腫瘤を主訴に来院。C領域に 径 $14 \times 12 \mathrm{~mm}$ の境界明瞭で、一部に襄胞形成の ある腫瘤が触知された。穿刺吸引細胞診ではアポ クリン癌が示唆された。生検の結果、本症と䛦断 し非定型的乳房切断術が施行された。

<細胞所見 $>$ 腫瘍細胞は出血性背景の中に、重積 性および平面的に出現していた。細胞質は豊富で 多稜形〜細長形、細胞境界不明瞭、細胞質内に微 細な好酸性顆粒を認めた。核は中心性〜偏在性に 位置し、類円形〜不整形、また大小不同を示し、 核クロマチンは濃染性で、明瞭な大型核小体 1 個 を認めた。以上の所見より、アポクリン癌を疑つ た。

<病理組織学的所見 $>$ 腫瘍は乳頭状ないし腺管状 構造を示し、腫瘍細胞は大型で核の大小不同およ び核小体の肥大がみられ、豊富な好酸性の細胞質 を有していた。腫瘍細胞はすべてアポクリン癌で 主として乳管内に限局していたが、一部に間質へ の浸潤を伴っていた。また、周忍乳腺組織にはア ポクリン囊胞が散見された。癌細胞は、免疫組織 学的にGCDFP-15が弱陽性を示した。

本腫痬の組織発生、アポクリン化生細胞および 非浸潤性アポクリン癌についても比較検討した。

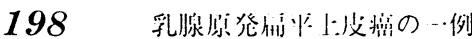

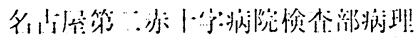

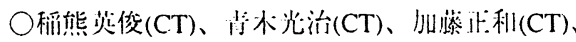

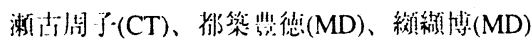

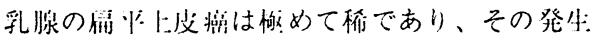
染は0.1ー0.2\%程度であると勏れている。今间

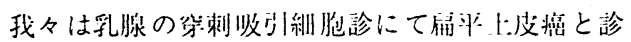
断した一例を経験したので報先する。

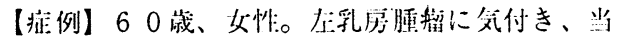
院外科外来を受唒した。エコー、マンモグラフィ 一等の諸梌企にて左乳房 $\mathrm{AB}$ 領域に $2.5 \times 2.5 \mathrm{~cm}$ 大の

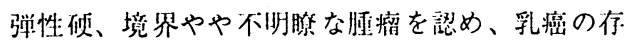
在が疑われた。伢刺吸引絒胞診施行後、(非定型) 左乳屏切除術が行われた。術後の全身检系では他

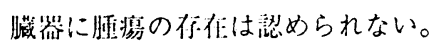

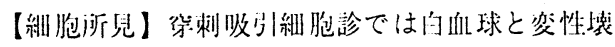

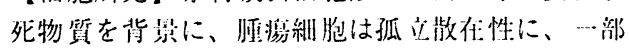

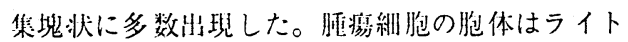
グリーン好性仪びオレンジG好性で、核は類以形や 不整形を示し、クロマチンも增加していた。紡锤 形絸胞やSnake cell等:の多彩な緗胞像が涊められた。

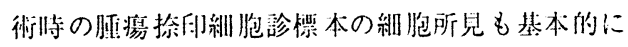
闹㥞な所兒であった。

【組絨所見】N/C比の增大した腫場細胞が明らかな

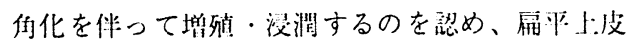

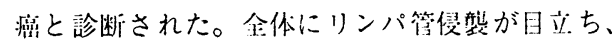
多数のリンパ節坃移が梁められた。 
199

乳腺扁平上皮癌の一例

川崎協同病院病院病理科 ${ }^{11}$

昭和大学藤が丘病院病院病理科 ${ }^{21}$

東海大学病院病理䛦断科 ${ }^{31}$

昭和大学医学部第二病理学教室 ${ }^{4)}$

O松井成明 ( C T ) ${ }^{11}$ ，北村隆司 ( C T ) ${ }^{23}$

伊藤仁 $(\mathrm{C} \mathrm{T})^{3)}$ ，滝本雅文 $(\mathrm{M} \mathrm{D})^{4}$ )

塩川章 $(M D){ }^{4)}$

乳腺扁平上皮癌は浸潤密の特殊型に分類され、 乳密全体の約 $0.1 \%$ と稀な腫湯である。本腫湯の組 織学的な由来について大多数は腺癌が扁平上皮化 生を起こしたものと考えられている。今回、われ われはこのような乳腺扁平上皮癌の一例を経験し たのでその穿刺吸引細胞像ならびに免疫組織学的 検討を加え報告する。

【症例】62才、女性。数年前より左乳房に腫瘤を自 覚していたがそのまま放置。次第に腫瘤が增大し 平成 5 年 9 月当院受診。皮㲊漬瘍を伴う腫瘤を左乳 房全域に認め穿刺吸引細胞診を施行しClass V 扁 平上皮癌が推定され、同年 9 月左乳房摘除術が施行 された(T4bN1MO, stage III b)。

【穿刺吸引細胞診所見】腫瘍細胞は壊死性背景に小 集塊〜散在性に出現していた。個々の細胞は類円 形〜紡鍾形で、細胞質はオレンジG 好染性〜ライ 卜緑濃染性を呈していた。核は中心性でクロマチ ンの增量を認めた。また一部に腺澏から扁平上皮 癌への移行像もみられた。

【病理組織所見】 $10 \times 5 \mathrm{~cm}$ 大の壊死を伴う灰白色の 腫瘤で組織学的には角化を伴い充実性に増殖する 高分化型扁平上皮癌の像であった。またこの病変 に連続して面疮癌の像もみられたが角化傾向をも つ癌胞巣は腫瘍全体において優位を占めていた。
200 乳腺扁平上皮癌の一例

昭和大学病院臨床検査部 ${ }^{2}$, 同 医学部第二病理 学教室 ${ }^{21}$, 昭和大学藤が丘病院病院病理科 ${ }^{3)}$, 東海大学病院病理診断科 41

○津田祥子 $(\mathrm{CT})^{11}$, 北村隆司 $(\mathrm{CT})^{3)}$, 伊藤仁 $(\mathrm{CT})^{41}$ 九島已樹 $(M D)^{2)}$, 五味邦英 (MD) ${ }^{21}$ ，太田秀一(MD) 2)

本邦乳癌取扱い規約にて特殊型に分類される扁 平上皮癌の大部分は腺癌の共存を認め、腺癌が扁 平上皮化生を起こしたものと考えられている。し かし、稀に腺癌要素を含まない純粋な扁平上皮癌 の報告もあり、その発生のすべてを腺癌の扁平上 皮化生とするには困難な症例も存在する。今回我 々は、このように形態的に腺癌成分を認めない純 粋高分化扁平上皮癌の一例を経験したので、その 穿刺吸引細胞像および免疫組織化学的所見につい て検討し報告する。

【症例】患者：72才，女性。既往歴：家族歴：特 記すべきことなし。現病歴 : 平成 7 年 3 月頃より 右乳房の腫瘤に気づくも放置していた。同年 4 月 24日腫瘤の増大を認め、当院外科を受診した。初 診時、右乳房 D B C 領域に $7.8 \times 5.5 \mathrm{~cm}$ の腫瘤を認 めた。穿刺吸引細胞診の結果、扁平上皮癌と診断 され、同年 5 月19日非定型乳房切除術が施行され た。

【穿刺吸引細胞所見】好中球を主体とした炎症細 胞を背景に、腫瘍細胞は孤立散在性に多数出現し ていた。個々の腫瘍細胞は核濃染性で、オレンジ G〜ライト緑好性の重厚な細胞質を有していた。 また、これらの腫瘍細胞に由来したGhost cellも 多数みられた。

【病理学的所見】腫瘤の大きさは $7.5 \times 7.0 \mathrm{~cm}$ で、 腫瘍の中心部は壊死性豊胞化を示していた。組織 学的には著明な角化傾向を示す高分化扁平上皮癌 の像で、腺癌成分は認められなかった。 
201 破骨細胞様巨細胞を伴う乳癌の 1 例

卜ヨ夕記念病院臨床検査科病理 ${ }^{12}$, 藤田保健衛生 大学医学部病理 ${ }^{23}$, 国立名古屋病院病理 ${ }^{3}$,

乙金病院 ${ }^{4)}$

$\bigcirc$ 田代和弘 $(M D)^{12}$ ，笠原正男 $(M D)^{22}$ ，漌口良順 $(M D)^{23}$, 堀部良宗 $(K D)^{22}$, 市原 周 $(K D)^{3 ;}$, 鈴木良典 $(C T)^{1)}$ ，見元裕司 $(M D)^{4)}$

【はじめに】乳癌組織内に破骨細胞様巨細胞を伴 った 1 症例を経験したので報告する。本組織分類 は、取り扱い規的, WHO 分類では特殊型とされ、 AFIPではCarcinoma with 0steoclast-like giant cells として記載されている。

【症例】 40 才, 女性. 左乳房 C領域に腫瘤を自覚 し来院。US施行し、境界明瞭, 一部 unclearな結 節が認められた。ABCを行い、classVの診断のも と、乳房切除術が施行された。

【細胞所見】背景は少量の壊死物質が存在し、乳 頭状の配列を呈す異型細胞集魂が多数認められた。 この集魂は細胞境界が不明瞭で、結合性は強く、 核の重積性, 大小不同が認められた。 $\mathrm{N} / \mathrm{C}$ 比は大 きくクロマチンは顆粒状, 核小体は1〜2個存在し た。また、この細胞集魂周辺には数個〜数10個の 核を有する多核巨細胞が多数検索された。

【肉眼所見】腫瘍は、 $16 \times 16 \mathrm{~mm}$, 弾性硬で、暗黒 色調を呈し、周囲との境界は比較的明瞭であった。 【病理組織学的所見】腫瘍は中等度に分化した浸 潤癌で、管腔形成は比較的良好, cribriform carcinoma の像も認められた。この腫瘍胞巣周囲 に多数の破骨細胞様巨細胞が観察された。また、 間質は血管が豊富で、著しい出血, ヘモジテリン 沈着, 炎症性細胞が存在した。一部には硬癌の部 位もみられた。免疫染色では癌組織部はCA-125， 巨細胞にはKP-1が陽性を呈した。

【考察】本腫瘍は乳癌の0.5〜 $1.2 \%$ 発生頻度で 比較的稀である。特徵的な所見は、暗黑色調の肉 眼像と破骨細胞様巨細胞の出現である。巨細胞は KP-1陽性より組織球由来と推定された。
厚生連高岡病院内科 ${ }^{1)}$, 同 病理科 ${ }^{2)}$

○野村将春 (MD) $)^{11}$, 武島稳 ${ }^{1)}(\mathrm{MD})$, 增田信二 $(\mathrm{MD})^{2)}$, 岩本祐子 $(\mathrm{CT})^{2)}$, 中野昌子 $(\mathrm{CT})^{2)}$, 中田千里 $(C T)^{2)}$, 寺井孝 $(C T)^{2)}$, 谷口賢司 $(M T)^{2)}$

破骨細胞樣巨細胞を伴う腫湟は、骨軟部腫瘍で 多く見られるが乳癌では稀である。さらに、この 紐胞の由来や、原疾患の予後に関してのはっきり とした位置付けもない。今回、我々は多数の破骨 細胞梯巨細胞を伴う乳癌の一例を経験した。その 穿刺吸引細胞診像、捺印細胞診像について報告す る。

【症例】44歳、女性、来院 2 力月前に左乳房 A-C領域境界部の硬いしこりに気付いた。腫場の 境界は明瞭であったが、可動性はなく、臨床的に 乳癌が疑われ、穿刺吸引細胞猃が施行された。

【細胞診像】比較的きれいな背景の中に、結合 性が強い上皮細胞の大小样々な集塊之、その周边 に、多数の破骨細胞样巨細胞を認めた。集塊は乳 頭状であった。それぞれの細胞の核は重積性、大 小不同があり、クロマチンの增量を認めた。核小 体は1ー2個であった。筋上皮細胞は認めず、以上 より腺癌と診断した。破骨細胞梯巨細胞は単核の ものから䄪30個の核を持つものまであり、胞体の 辺縁は突起を延ばしているように見えた。胞体は ライトグリーンに好染し、厚ぼったく、辺縁は明 瞭であった。核は中心性で、大きさは癌細胞と同 大かやや大きく、クロマチンに増量感はなかった。 择印細胞診像では、穿刺吸引細胞診像と同样の所 見か、より明らかに認められた。

【組織像】腫瘍細胞間に出血が存在し、癌細胞 巣に隣接して存在する破骨細胞栏巨細胞も認めら れた。脂肪織への浸閵はわずかであった。リンパ 節にも転移像と巨細胞を認めたか、その数は極め て少なかった。 


\section{3 乳腺悪性葉状腫瘍の 1 例}

市立伊丹病院病理 ${ }^{11}$ ，同外科 ${ }^{2)}$ ，大阪医科大学中 検病理 ${ }^{3)}$

○堀岡良康 $(\mathrm{CT})^{1)}$, 平尾修 $(\mathrm{NT})^{11}$, 魚住由美 $(\mathbf{M T})^{11}$, 辻求 $(\mathrm{MD})^{12}$, 森川政夫 $(\mathrm{CT})^{3)}$, 山本隆一

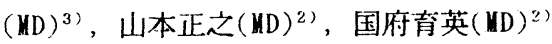

今回、比較的まれな腫煌である乳腺悪性葉状腫 瘍の 1 例を経験したので報告する。

[症例] 53 才、女性。3 年前頃より右乳腺 C $\mathrm{D}$ 領域の腫瘤に気づき、平成 7 年 2 月、当院外科 受診。超音波検査にて約 $8 \mathrm{~cm}$ 大の腫瘤を認めた。 さらに穿刺吸引細胞診（1 回目）が施行され、葉 状腫瑒を疑った。3月、腫湯摘出術施行。組織診 断は葉状腫瘍であった。その後同年 8 月、C $お ~$ よび超音波検査で創部に一致した約 $3 \mathrm{~cm}$ 大の腫瘤 を認め、2 回目の穿剌吸引細胞診が施行された。 䜤型性を示す間質細胞が多数出現しており、要性 を考えた。9月に再手術施行され、悪性葉状腫瘍 と組織診断された。

[穿刺吸引細胞診 (1 回目) 所見] シート状に配 列し、二層性を有する異型性の乏しい導管上皮の 細胞集団、および紡鍾形や類円形の間質細胞が多 数みられ、葉状腫瑒を疑った。

[穿刺吸引細胞診 (2 回目) 所見］出現細胞は紡 錘形や裸核様の間質細胞が大部分であり、明らか な上皮性結合を示す細胞はみられなかった。間質 細胞は散在性に多数出現しており、細胞筫はやや 不明瞭であった。その核は類円形や紡錘形のもの が主体で、核型の不整もみられた。核クロマチン は細顆粒状で、1 数個の核小体を有しており、 核分裂像も散見された。総合的に悪性葉状腫瑒を 考えた。

以下、組織像および考察などを加えて報告する。
204 Phyllodes tumorを基盤として発症 した骨肉腫の細胞像

東京都立大塚病院検查科 11 , 外科 2)

設楽保江 (CT $)^{12}$, 後藤昭子(CT) ${ }^{12}$, 中津川彰 (MT) ${ }^{12}$, 石川幸恵 $(C T)^{1}$, 田口博 $(C T)^{19}$ ，有输六朗 $(M D)^{13}$ ， 細川勝正, $(M D)^{2)}$ 鳥屋城男 $(M D)^{2)}$

[はじめに] Phyllodes tumorは，まれに骨、軟骨 への分化像をみる. 今回, 我々はPhyllodes tumorを基盤として発症した骨肉腫の一例を経験した ので，その穿刺細胞像を中心に報告する.

[症例] 59才, 女性. [主訴] 左乳腺腫撚. [現症] 平成 5年頃より乳房の左右差に気づく. 平成6年頃から左拜房が大きくなり始めたが放置。 平成 7 年 6 月, 成人病検診で，左乳房にしこりを 指摘され，当院紹介受診，入院となる.

[局所所見] 左乳房 $\mathrm{A}$ 領域を中心として110x110

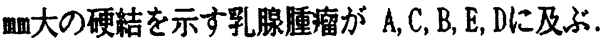

[超音波所見] 左乳房全体を占める瘇瘤の表面は 石灰沈着が強く，A領域では八つ頭状の Hypoechoic massが認められる。

[穿刺吸引紐胞診所見] 散在性に紡鍾形の細胞を 多数認める。上皮成分は認めない，核は長棈円形 で，多形成に富み，大小不同が著明. 明暸，不整 な核小体を数個認める。名咐增量した大型核， 多核，および分裂像の出現をみる。細胞筫は長剠 鍾形でラ仆グリ-ンに淡染. PAS染色陽性, vimentin陽 性．また，核周に顆粒を有する細胞を多数認め，こ の顆粒はパパこ吅染色て好酸性に、゙ムザ染色で赤 枈色に染まる．以上により， sarcoma と診断した。 [病理所見] 14.5x13.5c洇の皮属切除と 16x15x $10 \mathrm{~cm}$ 大の左嗮房. Nipple内上方を中心に $10 \times 6 \mathrm{~cm}$ の石灰化，骨化を示す腫瘤性病変の存在. 腫嘴は 乳管成分が混在する Phyllodesを示す領域と類骨 組織がびまん性に增生し，一部に骨梁形成，軟骨成 分を含む領域からなり，Expansiveな圧排，增生を

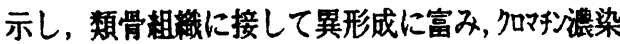
を示す型核が見られる.リンパ腺は転移なし。 
205 乳腺紡鍾細胞癌の 2 例

厚生連尾道総合病院病理研究検查科 ${ }^{12}$, 同 外科 ${ }^{21}$ ○佐々木健司 (CT) ${ }^{1)}$ ，米原修治 (MD) ${ }^{1) ， ~}$

野島裕子 (MT) ${ }^{11}$, 西原弘子 (MT) ${ }^{11}$,

黒田義則 (MD) ${ }^{21}$ ， 小橋俊彦 (MD) ${ }^{2)}$

乳腺の紡錘細胞癌は紡鍾形の腫凛練胞よりなり、 肉腫様の組織像を呈する稀な䄸腫であり、その発 生頻度は全乳癌の約 $0.1 \%$ を占めるにすきない。 ここでは、我々の経験した乳腺の紡鍾細胞癌につ いて穿刺吸引䋖胞所見を中心に述べ。

【症例 1】67歳、女性。他院にて右乳腺腫瘍を疑 われて来院した。触診では右乳房のCD A B E 領 域に6.0 $05.5 \mathrm{~cm}$ の腫㾇が認められ、左乳房 $\mathrm{A}$ 領域 にも3. $0 \mathrm{~cm}$ 大の腫瘾が触知された。右は悪性、左 は乳腺症が疑われて両側乳房の腫癐に対して穿刺 吸引細胞猃が行われた。

【症例2】45歳、女性。右乳房痛を主訴として来 院した。触診では右乳房C領域に2.0 c cm の腫痹が 触知され、穿刺吸引細胞診が行われた。

【穿刺吸引綀胞像】症例 1 の右乳房腫㾕の穿刺吸 引標本では、重積性を示す上皮性緗胞集団と紡銌 形から多角形を呈する細胞の集塊を認めた。前者 の細胞質は厚みがあるのに対し、後者では紐胞質 は淡く染色され、紐胞密度は高く、核の形も多彩 であった。一方、左乳房腫瘨の穿刺吸引標本では、 顆粒状で豊富な細胞質をもつ細胞が得られており、 つよい核異型性や大型核小体もみられた。症例 2 の穿刺吸引標本では、つよい異型性を示す上皮性 細胞集団がみられ、それらに隣接して粘液状物質 の存在を認めた。粘液状物質には短紡鏵形細胞が 浮遊しており、奇怪な核をもつ細胞もみられた。 【病理組織学的所見】症例 1 の右乳房腫瘁と症例 2 の腫場は紡銀形腫癌紐胞のびまん性增殖よりな る肉腫様の腫瘍組織と明らかな新腫の增殖よりな り、両者に移行がみられた。症例 1 の左乳房の腫 瘍組織は浸洞性乳管㿋の像であり、約半分の領域 にアポクリン化生梯变化を認めた。
206 右乳腺に発生した管状癌の一例

帝京大学市原病院病理部 ${ }^{11}$ 同外科 ${ }^{21}$ 同電顕室 ${ }^{31}$

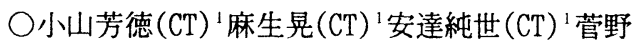
勇 (MD) ${ }^{1}$ 長尾俊孝 (MD) ${ }^{1}$ 石田康生 (MD) ${ }^{1}$ 長尾孝一 (MD )$^{1}$ 小沢邦寿 $(M D)^{2}$ 和田信昭(MD) ${ }^{2}$ 棟方滋 $(M T)^{3}$

管状癌は、特殊型浸潤癌で、そ,そ発生頻度は少 なく全乳癌の $1 \%$ \%いわれている。細胞異型の乏 しい高分化型癌で特に細胞診では推定診断が困難 な場合が多い。今回我々は、穿刺吸引細胞診にて 疑陽性、病理組織学的に管状癌とされた症例を経 験したので報告する。

（症例）51才、女性、右側の乳房 $\mathrm{C}$ 領域の腋窩近 傍に直径約0.7®の腫瘤を触知した。腫瘤辺縁は明 瞭で可動性も良好であった。穿刺吸引細胞診は 2 回行なわれ、いずれもクラス正と報告した。平成 7 年腫瘤が増大したため腫瘤摘出術が施行された (細胞所見) 穿刺吸引にて得られた細胞は、平面 性の集塊で、一部柵状配列を示し結合性の低下を 示寸像や孤立性細胞も認められていた。N/C 比の 上昇、核の軽度腫大を伴い、クロマチンは微細顆 粒状で一部に核小体を有していた。他には、結合 性のよく保たれた集塊が見られ、軽度の核腫大や 核小体の出現も認められたが、筋上皮様の双極裸 核細胞を伴っていた。総合的に、悪性を疑うには 細胞の均一性に欠ける所見で、增殖性変化を伴う 良性病変と考えた。

(病理組織所見) 組織学的に腫瘍は、線維化を伴 って放射状に浸潤增殖し、円形、卵円形の腺腔を 形成していた。細胞異型の少ない腫瘍細胞は一層 の管状に配列し、内腔面には”snouts”様突起を認 め、筋上皮細胞は不明であった。また腫場周囲に は乳腺症様の良性病変も混在していた。 S-100, Smooth muscle actin の免疫染色にて、筋上皮を 伴わない多くの腫場性腺管が証明され、電顕的に も腫崵性腺管には筋上皮細胞はなく、基底膜も多 くは不明瞭で不連続性であった。 
207 神経内分泌顆粒を認めた乳腺signet ring cell mucinous carcinoma $の 1$ 例

石心会狭山病院病理 ${ }^{\prime \prime}$, 長野県がん検診せンタ-病理 ${ }^{2)}$, 埼玉医科大学第二病理学教室 ${ }^{31}$

加賀谷晃 (CT $)^{\prime \prime}$, 藤沢美穂 (MT ) '), 中村浩子 (CT $)^{\prime \prime}$, 土屋這一 $(M D)^{2)}$, 清水禎彦 $(M D)^{3)}$, 高浜素秀 (MD $)^{3)}$

乳腺signet ring cell mucinous carcinomaは、 1941年Saphirが、mucinous carcinomaの一量型と して報告した稀な腫瘍である。今回われわれは、 神経内分泌顆粒を有するsignet ring cellからな るmucinous carcinomaの 1 例を経験したので、そ の細胞像や組織学的特徴及びその鑑別診断につい て報告する。症例：88歳、女性。平成7年5月こ 万左乳房腫瘤に気付き、7月近医受診。触診及び Sで乳癌と診断され、7月28日当院外科に紹介。左 $A B$ 領域に約 $3 \times 3 \mathrm{~cm}$ 大の可動性のある腫瘤を触知。

この時の穿刺細胞診でClass V : Mucinous carci noma と診断。8月18日年令を考慮して単純乳房切 断術を施行。細胞所見: 粘液を背景に多数の印環 型覀性細胞が孤立散在性〜集塊で出現。核は類円 形〜棈円型〜腎型で偏在し、やや豊富な細胞質に は褐色顆粒がみられ、PAS 及びAlcianblue 染 色で陽性。組織所見: 腫瘍は2.5 X $2.0 \times 1.5 \mathrm{~cm}$ 大の境界明瞭な卵円形で、割面はやや粘性で光沢 のある灰茶色。組織学的には粘液の中に充実性癌 巣が浮遊する mucinous carcinoma で、構成細胞 は印環様のものが多く、細胞質は細顆粒状〜微細 空胞状で、好酸性顆粒が充満した細胞も認められ た。PAS,Alcian blue染色共に陽性、HID陰性。一 部にロゼット様構造も認めた。免疫染色では、NS E陽性、Chromogranin A、Synaptophysin一部陽性、 CEA、S-100陰性。Grimelius一部陽性、Fontana-M asson陰性。電顕所見: 腫瘍細胞内に粘液顆粒と 神経内分泌顆粒が種々の割合で同一細胞内に認め られた。まとめ: 本症例は神経内分泌顆粒を有す るsignet ring cellからなるmucinous carcinoma で、背景の粘液が鑑別診断に有用であった。
大阪医科大学 中検病理

○中塚裕之(CT), 御宮知礼子(MT), 森川政夫(CT) 山本隆一(MD)，黒川彰夫(MD)，清水 章(MD)

乳腺のmucocele-1 ike tumor(以下MLT)は小唾液 腺に発生するmucoceleに類似した組織像を示す比

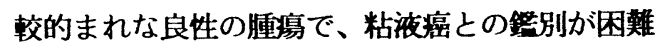
であるとされている。

今回我々は、穿刺吸引細胞診および術中の摘出

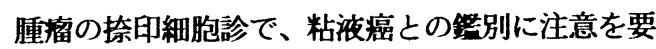
したMLTを経験したので、その細胞学的所見に ついて報告する。

[症例] 28 歳、女性。平成 7 年 10 月 6 日に 本学受診。左A領域に $1.4 \times 1.0 \mathrm{~cm}$ の腫濆を触知 した。同部腫瘤の穿刺吸引細胞診を 3 回施行した が、いずれも疑陽性と診断され、粘液癌を疑がっ た。同年 1 月 1 日に腫溜摘出術が施行され、そ の際の術中迅速診断でも粘液癌を否定できなかっ た。しかし、永久標本でML T と診断された。

[穿刺吸引および挎印細胞所見］ 3 回の穿刺吸引 および捺四細胞像は同様の所見を示し、背景に 多量の粘液が認められ、その中に極めて少量で、 異型性の乏しい導管上皮細胞がシート状の集団 または散在性に出現していたため、粘液癌を否定 できず疑陽性と診断された。

[組较学的所見] 粘液が充满した糞胞が見られ、 そのlining cell には異型性は見られず、またそ の周囲にも悪性所見は見られないためML T と診 断した。

[まとめ］ML Tは粘液癌との䟝を要する細胞 所見を示すが、数回の穿刺吸引細胞診を施行して も上皮細胞集団の出現は槡めて少なく、このこと が粘液癌との鑑別において重要な所見と考えられ た。 


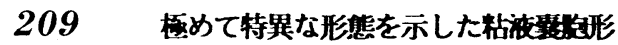 成乳㨽の 1 例}

昭和大学藤が丘病院 病院病理科", 同 外科 ${ }^{21}$

長野県がん検診センタ一病理部"),

昭和大学第 2 病理学教室 ${ }^{11}$

O北村隆司(CT) ${ }^{11}$ ，光谷俊幸(ID) ${ }^{11}$ ，渡㲽紬(ID $)^{21}$ ， 土屋眞一(ID) ${ }^{3)}$, 太田秀一(ID $)^{4}$

異胞形成を示す乳癌には，震胞内癌および扁平上 皮澢などがあげられる。また，その内容物は一般的 に非粘液性分踥物であることが多く，粘液性分脑物 であることは極めて稀である. 今回，われわれは著

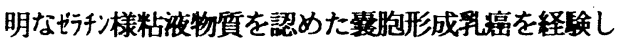
たので報告する.

【应例】患者: 77歳女性 主訴: 左乳房腫罾. 既 往歷 : 特記すべきことなし. 現病歷 : 左乳房に20年 来クか大の腫㨨を認めたが不変のため放置していた。 しかし，平成 7年 1月より同部腫范の急速增大を認 め, 当院外科を受診した，初崄時，腫放は左乳房全 域に及ぶ弾性硬な不整形腫䝷であった，US検査に て境界明暸・内部エコー均一な腫䓪像を呈していた。 穿刺吸引細胞診を施行したところ, 約 4m1程のゼラチ 様物質か吸引され，細胞検查の結果Class $\mathrm{V}$ (腺㾤) と診断され，悪性腫鸹の疑いのもと同年 2月22日非 定型的乳房切除術か施行された。

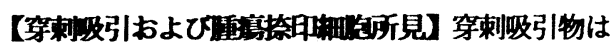
粘稠性が高く，喀荻式すり合わせ法により標本を作 製した．本標本には多量の粘液を背景に少数の泡沫 細胞と大型で著明な核異型を示す悪性細胞を認めた。 腫堭摘出後，乳頭状に隆起する腫部部分の压挫摽本 を作製した，本標本にはクロマチン増量にはそしい ものの著明な粘液産生性を示す腫瘍細胞が正常垔管 腺細胞に類做した列を示し出現していた。

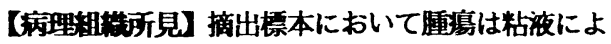
る巨大衰胞を形成し，貫胞壁には乳白色の乳頭状腫 瘤を認めた，組織学的には著明な粘液産生性を示す 腫瘍細胞が間質結合緒を伴い乳頭状增殖を示してい た.一部浸溜所見を認め，乳頭腺管富と診断された。
210 Glycogen-rich clear cell carcinoma

の 1 例

\author{
東海大学病院病理診断科 ${ }^{11}$ \\ 同医学部病態診断系病理学 21 \\ $\bigcirc$ 宮嶋葉子 $(\mathrm{CT})^{11}$, 伊藤 仁 $(\mathrm{CT})^{11}$, \\ 赤塚由子 $(\mathrm{CT})^{11}$, 安田政実 $(\mathrm{CT})^{21}$ \\ 梅村しのぶ(MD $)^{22}$, 堤 寬 $(\mathrm{CT})^{1)}$, 2) \\ 長村義之(MD, FIAC) ${ }^{12 ， 2)}$
}

【はじめに】乳腺の Glycogen-rich clear cell carcinoma（GCC）は、1981年に M. T. Hull らによ り報告され、その頻度は全乳癌の1.4\%といわれて いる。今回われわれは GCC の一典型例を経験した のでその細胞組織像を報告する。

【症例】44歳、女性。右乳房に腫瘤を触知し来院。 超音波検查にて C 領域に $28 \times 20 \times 32 \mathrm{~mm}$ 、石灰化

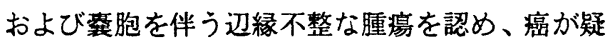
われた。また、右腋下リンパ節に腫瘤を認めたが 反応性が疑われた。乳腺穿刺吸引細胞診が行われ クラス V、腺癌亡診断され、非定型的乳房節除術 およびリンパ節郭清術が施行された。

【穿刺吸引細胞所見】背景に多量の壊死物質を伴 い、比較的大型の癌細胞が集塊を形成し出現して いた。クラス V、乳頭腺管癌、面胞型と判定した。 腫煌細胞は著明なクロマチン増量を示し、N/C 比 が大きく、胞体が厚い癌細胞と、 $\mathrm{N} / \mathrm{C}$ 比が小さく、 明るい胞体を有する泡沫細胞類似の癌細胞が混在 していた。後者は、ときに大型の癌細胞を混じる ものの、ほとんどは泡沫細胞類似の異型性の少な い癌細胞であった。

【病理組織所見】明るく広い胞体を有する癌細胞 が癌胞巣を形成し充実性に增殖していた。胞巣の 中心部は壊死に陥り、また、一部は浸潤性乳管癌 の像を呈していた。癌細胞はPAS 染色陽性、ジア スターゼ消化試験で消失するグリコーゲンを有し ていた。ズダン黒染色で、脂肪滴は指摘されなか った。免疫組織化学的検討では EMA, CA15-3 など の上皮性マーカーが陽性を示した。 
211 血性乳頭分泌物から診断し得た

男性乳癌の一例

松村総合病院検査科1）渡辺クリニック2）

自衛隊中央病院病理3)

蛭田昭夫 (CT) "古川記志子 (CT) "

渡辺進 (MD) ${ }^{2}$ 桑原紀之 (MD) ${ }^{31}$

【はじめに】男性非浸潤乳癌は、極めて稀で報告 は数少ない。今回我々は、乳頭分泌物及び、乳管 洗浄細胞診にて、乳癌と診断し得た一症例を経験 したので報告いたします。

【症例】68才、男性。H7年 10 月右乳頭分泌 に気付き来院。分泌物性状は純血性に近いもので あった。ほかに乳腺内には、睡瘤は触知しません でした。

【細胞所見】はじめの乳頭分必物細胞は古い血液 成分を背影に、睡瘍細胞が散在性又集塊を形成し 軽度大小不同、核小体は目立つ、クロマチン微練 顆粒状で胞体はレース状、一部貧食梯像も喼める 。組織球も否定できない為クラスIII Follow upとし た。次に洗浄細胞所見は裸核状細胞が集塊を形成 しクロマチン顆粒状で核小体は小さく一部には核 縁の切り込み、大小不同も目立ちクラス と診断 した。

【画像診断】マンモグラフィにて腫瘤、石灭化像 は認めないが、超音波にてやや拡張する乳管と腫 瘤像を思わせる所見を認めた。乳管内内視鏡では

乳管口からすぐに白色一部黄色で光沢のある腫 瘤を認め、乳管内に充渵する乳頭状腫瘤を認めた 【組織所見】乳頭状に增生する病変をみとめ、部 分的に震胞状を呈していた石灰化を伴う乳管内乳 頭癌に相当する所見であった。周囲への浸洞像は 認められない、非浸潤性乳管癌であった。

【まとめ】血性乳頭異常分泌より、細胞診にて、 診断し得た男性乳癌であった。腫瘤触知不能虎で あり、しかも病理組織学的に非浸洞性乳疾の一例 であった。

\section{2 乳腺癌肉腫の一例}

\section{大阪警察病院 病理科}

$\bigcirc$ 黒川和男 (C T ), 辻本正彦 (MD), 林 真奈美 ( C $\mathrm{T})$ ，大西あゆみ( $\mathrm{C} \mathrm{T})$ ，野口教彦 $(\mathrm{MT})$ ，奥田敏美 ( C T ), 浦岡孝子 ( $\mathrm{C} \mathrm{T})$, 橋本康弘 $(\mathrm{MT})$,

寺尾壽幸 $(M D)$, 滝一郎 $(M D)$

乳腺に発生する癌肉腫は極めて稀である。我々 は両側乳癌患者にみられた乳腺癌肉腫を経験した ので報告する。

患者は53歳女性で平成7年6月頃より右乳腺腫瘤 および左乳頭の変形に気づき、8月中旬より右乳 腺腫瘤が増大してきたため当院外科を受診した。 腫瘤は両側にみられ、右側は一部に霬胞様の部分 を含み、A C E 領域に存在し $5 \times 4 \mathrm{~cm}$ 大であった。 左側は乳輸直下に存在し $3.5 \times 3 \mathrm{~cm}$ 大であった。術 前の腫瘤穿刺吸引細胞診 (A B C) では多数の悪 性細胞を認めた。9月19日、両側乳房の切除術が 行われた。手術材料の組織診断は、右側は紡鍾型 異型細胞と共に扁平上皮癌、アポクリン癌、充実 腺管癌がみられ、癌肉腫と診断された。左側はア ポクリン癌の像を示した。

右側乳腺腫瘤の術前 A B C および腫慮捺印標本 では、壊死性の背景に細胞質はオレンジまたはラ イトグリン好染で、層状構造やオタマジャクシ型 異型細胞を認める扁平上皮癌細胞が主体であった。 その他には大型核、大型核小体を有する異型細胞 が不規則重積性をなし、細胞質内にアポクリン顆 粒を有しアポクリン癌を疑う細胞と、クロマチン は細顆粒状で核縁が薄く、細胞質はライトグリン に淡染し細胞㧅縁が不明瞭で紡鍾形を呈するもの や多核の異型細胞など肉腫を疑う細胞が出現し、 組織像と一致する像であった。この稀な乳腺癌肉 腫の細胞所見について詳細な検討を加え報告する。 


\section{3}

$$
\text { 乳腺の恕性リンハ腫の一筹例 }
$$

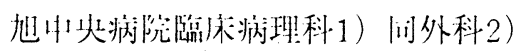

问検售科 3)

○古泪克已(CT)1，林光雄(CT)1，部政…

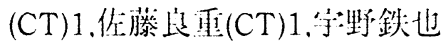

(CT)1,点阔勝之(CT)1，鈴木良夫

(MD)1，登政和(MD)2, 大江健 - (MD)3

【はじめに】乳腺に発生する琹性リンバ腫 は比較的稀であるとされるが今回我々は穿 刺吸引細胞診で悪性リンパ腫を疑い切除さ れた一症例を経験したので報告する。

【症例】 52 才女性。1995年2月左乳房に 腫瘤を自覚した。その後腫瘤が急速に増大 したため同年3月1日当院外科外来を受診し た。腫瘤は充実性であり $\mathrm{E}$ 領域を中心に径 $5 \mathrm{~cm}$ の大きさであった。腋窩、頝部などの リンパ節に腫脹は認めない。MMGで腫溜は 大部分境界明暸であるが、一部不明瞭の部 分が認められた。同日行われた穿刺吸引細 胞診の結果悪性リンパ腫を疑い後日非定型 的乳房切除術が施行された。その後経過は 順調であったが術後の胸部エックス線撮影 で左肺下葉に径4 c m大の腫瘤が認められ 転移が強く疑われたが気管支鏡検査の結果 転移ではなく腺癌と診断され切除された。

【穿刺吸引細胞】直接塗沫された細胞は散 在性で核異型が強く悪性リンパ腫を疑った が、充実性腺管癌との鑑別が必要と思われ たためpap染色を脱色し酵素抗体法を行っ

た。LCA抗体陽性のため悪性リンパ腫と䛦 断した。

【組織像】乳腺腫瘤は筫型リンパ球がびま ん性に増殖し憙性リンパ腫 diffuse large cell lymphoma と診断された。

肺腫瘤は左肺下葉原発の腺癌であった。 免疫組織学的検討を加えて報告する。

\section{4 乳腺原発悪性リンパ腫の 2 例}

済生会川口総合病院病理 ${ }^{11}$, 同 外科 ${ }^{21}$, 新潟大 学第二病理 ${ }^{31}$, 埼玉医大第二病理 ${ }^{11}$

O川嶋活彦 (CT) " 金守 彰 (CT $)^{11}$ 栗田佳子 (CT) " 近内明子 (CT $)^{11}$ 前川勝治郎 (ND $)^{21}$ 長谷川剛 (ND ${ }^{31}$ 伴 慎一 (MD $)^{41}$ 清水禎彦 (MD $)^{41}$ 高浜素秀(MD) ${ }^{11}$

乳腺の悪性リンパ腫は、比較的稀で乳腺悪性腫 瘍の $0.004 \sim 0.5 \%$ と報告されている。今回我々 は、乳腺原発悪性リンパ腫の 2 例を経験したので 報告する。【症例 1】61才、女性。20 年前に 左胸郭形成術の既往あり。2 2 月前より左乳房の しこりに気付く。左乳腺 $\mathrm{C}$ 領域に径 $2 \mathrm{~cm}$ 大の腫瘤 が認められ、超音波検查では、線維腺腫が疑われ た。1 月月で径 $5 \mathrm{~cm}$ 大に増大し葉状腫場が疑われ た。呀刺吸引細胞診、左乳腺部分切除術施行。腫 瘍は、弾性硬・径 $5 \mathrm{~cm}$ 大で、割面は比較的境界明 瞭・乳白桃色調を呈していた。穿刺吸引細胞診で は、少量の良性乳腺細胞之散在性に小型円形細胞 が見られ、それらは、核小体を有する小〜中型幼 若リンパ球と混在する小型リンパ球細胞で、一部 でやや多彩な細胞像を呈していた。組織学的には、 比較的小型の異型リンパ球系と大型の異型組織球 系の細胞が混在し、B細胞マーカー陽性で、びま ん性 B 細胞性混合型リンパ腫であった。【症例 2】 50 才、女性。1 年前より右乳腺 B 領域の乳腺症 で Follow up。右乳腺 $A$ 領域のしこりに気付く。 超音波検查では、径 $2 \mathrm{~cm}$ 大の衰胞性腫瘍が疑われ た。第刺吸引細胞診にて悪性リンパ腫が疑われ、 右乳腺部分切除術施行。腫瘍は、弾性硬・径 2.5 $\mathrm{cm}$ 大で、割面は境界不明瞭・乳白黄色調を呈して いた。穿刺吸引細胞診では、散在性性に小型円形 細胞が見られ、それらは、核小体を有する中型幼 若リンパ球系細胞主体で大型細胞を混じていた。 組織学的には、乳腺組織への浸潤を伴いながら増 生する、大型で明瞭な核小体を有する単一な細胞 が認められ、B細胞マーカー陽性で、びまん性 B 細胞性大細胞型リンパ腫であった。 
215 乳腺低悪性度リンパ腫の 1 例 一乳腺内リンパ節との比較 -

\section{東海大学病院病理診断科 ${ }^{12}$}

同医学部病態診断系病理学 ${ }^{2}$

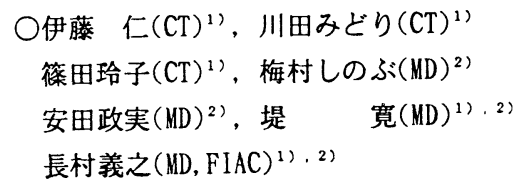

乳腺原発の悪性リンパ腫は稀であり、とくに小細 胞型の非ホジキンリンパ腫は、乳腺内リンパ節と の鑑別が重要である。今回われわれは、乳腺原発 の悪性リンパ腫、小細胞型と乳腺内リンパ節を経 験したので、両者を比較し報告する。

【悪性リンパ腫】

[症例] 38才、女性。左乳房 EC 領域に $25 \times 15 \mathrm{~mm}$ の限局性腫瘤が触知され、穿刺吸引細胞診、腫瘍 摘出術が施行された。

[穿刺細胞像] 多数の小型リンパ球に混在し、小 型リンパ球よりやや大型で、くびれた核を有する リンパ球が認められた。小型リンパ球が多数みら れたこと、異型性にそしかったことから、リンパ 組織の存在を考えたが、悪性リンパ腫を積極的に 疑うことは困難であった。

[病理組織像]〈びれを有する小型リンパ球より やや大型の核と、明るく広い胞体を有する異型リ ンパ球がびまん性に增殖を示していた。上皮細胞 内に侵入し、リンパ上皮病変を形成する像が認め られたが、形質細胞浸潤は認められなかった。

【乳腺内リンパ節】

[症例] 46才、女性。右乳房 C 領域に $10 \times 8 \mathrm{~mm} の$ 限局性腫瘤が触知され、穿刺細胞診、腫瘍摘出術 が施行された。

[穿刺細胞像] 小型リンパ球から大型の免疫芽球 様細胞まで、多様なリンパ球が認められ、tingib le body macrophage も散在性にみられた。

[病理組織像] 境界明瞭で被膜を有し、組織学的 にはリンパ濾胞の形成を伴うリンパ節であった。

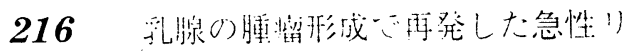

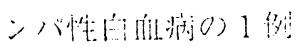

帝京大学㑂院病理湖

(赤嶺亮 $(\mathrm{CT})$. 小鼠贵 $(\mathrm{CT})$. 森本典江(CT).

河野純…(CT), 不卟美樹-(CT), 島田智子 (CT), 田讲文浐(MD)

乳腺に腫瘤老形成：一浸澗”。白血病はき わめて稀とされているが、今回わ机わ机は 乳腺穿刺吸引細胞診で白血病浸潤を診断し た1例を経験したので報告する

(症例) 41 藏女性。平成 3 年 6 月に出血傾 向在主訴として発症:した急性りンパ性白血 病で、adriamycin,vincristine.prednineによる化 学療法にて筧解獐入に成功したが、平成 7 年 7 月に左乳房!ご×4 cmo）腫瘤を触知し て外科受診、乳管诰影上超音波断層検査に て悪性老疑わ扎た，穿刺細胞診にて白血病 細胞の浸潤々判䇥さ扎て非定型的乳房切除 術を施行さ机たなな招手術時には骨䯠拉よ び他臓器に再発を諗好ていない

(細胞所見) 細胞は小型でN/C比が高く、狐 立散在性に多数出現していた。核は類円形 で一部に切扎迟みを有し、核クロマチンは 細顆粒状に堌量、㤥緣の肥厚はなく、小型 の核小体を認めたままた緗胞質は淡く不明 瞭であった

(組織所見) 著明な㤥縁不整を示す小型で 均一一な異型細胞が腺管の間質にびまん性に 浸潤して抢引、白的病の再発上診断された。 悪性りンハ蕾との䠄别も問㩆となったが、 腫瘍細胞は凮囲と境界された胞㫪を形成せ ずにびまん性に目常乳腺組織に浸潤してい ることから自血病浦発上する方が妥当と思 机礼。 


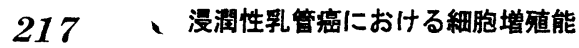
BrdU, PCNA，MIB-11による免疫組機学的検索-

組耭型並びにGrade分類による比較検討

高知医科大学附屬病院検㚗部 1 、同第一病理 ${ }^{21}$

O森木利昭 (MD) "，高橋保(CT $)^{11}$ ，植田庄介 (CT $)^{11}$

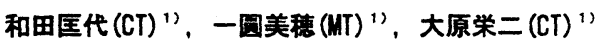
橋本真智子 (MD) ${ }^{1}$ ，弘井誠 $(M D)^{2}$ ，清久泰司 (MD ${ }^{21}$

【目的】乳癌における細胞增殖能を Bromodeoxyuridine $(B r d U)$. Proliferating cell nuclear antigen (PCNA)および MIB-1 (Ki-67)を用いて梌索し、 各組織型やGradeとの関係について比較検討した。 【材料と方法】未治療の浸洞性乳管癌の生検、手 征30例について、新鮮摘出組織をin vitroでBrdU を投与し 1 時間培益、エタノール固定後パラフィ ン包埋した。抗BrdU抗体で免疫染色を行うととも に同材料について抗PCNA抗体でも染色し、陽性細 胞率を算定した。MIB-1の染色はホルマリン固定 材料で行い、ほほ同様な組織像を示す部分で陽性 細胞の割合を検索した。浸泪性乳管癌の組織分類 は乳癌取扱い規約に従い、Gradeについては、Nottingham methodに準じてG|-GIIIに分類した。

【結果】漫淍性乳管癌細胞のBrdU標識率は $1-30 \%$ 、 PCNAの陽性率は6-74\%、MIB-1陽性細胞は4-70\% であった。BrdU標傤率とはPCNAよりもMIB-1の方 が強い相関が認められた。乳頭腺管癌、充実腺管 癌、硬癌に分類した各組織型間における細胞増殖 能には有意差は認められなかった。しかしながら Grade別にみるとGI (高分化癌)，GII，GIII(低分 化癌)となるに従いBrdU標識率とMIB-1陽性細胞の 割合は增加し細胞增殖能と腫瑒の分化度に相関が みられた。

【考察】MIB-1はPCNAL比較し、BrdU標識率と高い 相関が認められ、細胞增殖能をより正確に表現し ているものと考えられる。浸洞性乳管癌のGrade 分類は乳癌の細胞增殖能を反映しているものと考 えられ、組辌分類に付記すべき有用な所見と思わ れる。
218 FISH法による乳腺腫瘍染色体の数的 異常の検討

清水市立病院検查科病理 ${ }^{1}$ )、東海大学医学部病態 診断系病理学部門2)

O望月裕夫 $(C T)^{1)}$ 、関戸恭子 $(M T)^{1)}$ 、渡辺隆 $(M T)^{1)}$ 、渋谷 誠 $(M D)^{2)}$ 、森 一郎 (MD) 1)

【目的】 FISH(Fluorescence in situ hybridization)法により間期核における遺伝学 的診断が可能となり、一般検查室い゙ルで染色体の 数的異常が簡便に検出できるようになつた。さら に、染色体数異常と生物学的悪性度との関連性の 解析により、予後判定や術式を決定する指標にな りうる可能性がある。今回我マは乳腺腫瘍の染色 体数異常をFISH法によつて検索し、臨床病理学的 所見との関連性について検討したので報告する。

【材料と方法】外科的に切除された乳腺腫瘍33例 （悪性26例、良性8例）のスタソブ標本において、妈 1-\|l 酢酸で固定し風乾後、ONAを $75^{\circ} \mathrm{C} 2$ 分間熱変 性させ、1、3、11、17番染色体のセ吅Pに対する ビ 杆化probe (Oncor社)を用いて

hybridizationし、FITC-Pt“ジ ンで可視化し、PI (propidium iodide) で核染後、虽光影微鏡下 に間期核1個あたりの虽光㳢“怆数を100個の細胞 についてか力外した。

【結果】 $80 \%$ 以上の悪性乳腺腫瘍においていずれ かの染色体の数的異常が認められ、そのほとんど がtrisomy以上を呈し、17番染色体において核1個 あたり8個以上の沙゙卟数を示す腫瘍も見られた。 monosomyは、17番染色体において認められた。良 性腫瘍での数的異常は見られなかつた。

【考察】乳腺悪性腫瘍において高率に染色体の数 的異常を呈していることが判明した。本法は、良 悪性の診断が困難な症例の診断に対して有用であ ると思われた。 
1 例

国立東京第二病院口腔外科 1 )、臨床検查科病理 2$)$ 、 臨床研究部 3 )、産婦人科 4 )

○大鶴 洋 $\left.(\mathrm{D} \mathrm{D} \mathrm{S})^{1)}, 3\right)$ 、吉武 輝 $(\mathrm{D} \mathrm{D} \mathrm{S})^{1}$ )、 小野田 登 $(\mathrm{MD})^{2)}$ 、竹内 廣 $(\mathrm{M} \mathrm{D})^{2)}$ 、沼田 ますみ $\left.(\mathrm{C} \mathrm{T})^{2}\right)$ 、大貫敬司 $\left.(\mathrm{C} \mathrm{T})^{2}\right)$ 、和田とも 美 $\left.(\mathrm{M} \mathrm{T})^{3}\right)$ 、和泉 滋 $\left.\left.(\mathrm{M} \mathrm{D})^{3}\right), 4\right)$ 、福武公雄 $(\mathrm{D}$ D S $)^{1)}$

線維肉腫は皮下組織、骨膜、腱などから発生す る非上皮性の悪性腫湯で、口腔領域では稀な疾患 であると言われている。今回、われわれは硬口蓋 に発生し、線維肉腫が疑われた非上皮性悪性腫瘍 の1例を経験したのでその概要を報告する。

【症例】84歳、女性。約 2 か月前上り左側硬口蓋 部の腫張を自覚するも放置。その後、上顎の義歯 不適合が生じたため近医を受診、当科を紹介され 来院した。初診時、左側硬口蓋を中心に $35 \mathrm{~mm} \times$ $35 \mathrm{~mm}$ 弾性硬の有茎性腫瘤が認められた。

【細胞所見】手術検体の捺印細胞P $\mathrm{ap}$ 標本におい てライトグリーン好性の淡い細胞質をもつ紡錘形 の細胞が孤立散在性に出現。核は大きく棈円形、 細顆粒状均一分布のクロマチン、核膜は薄く、核 小体が目立ち、非上皮性の性格をそなえていた。

【組織所見】初回生検時の組織は紡錘型の異型細 胞の密な增殖で、錯走配列しており、核小体の目 立つ卵円形の核を有し、核分裂像は多く(高倍 10 視野に20個以上) 認められた。非上皮性悪性腫湯 を思わせたが紡錘細胞癌も否定できなかった。手 術検体では紡錘型の異型細胞が充実性に増殖して おりマンソン染色陽性、Vimentin陽性などの所 見より線維肉腫が強く疑われた。

【フローサイトメトリーによるDNA解析】手術時 検体の凍結組織においてDNA二倍体： S 期細胞比 率は20\%を示した。
220 䨋腺腫長期経過観察例における p 53 遗伝子産物の動態および細胞増殖能の検討

順天堂大学共同病理 ${ }^{11}$ ，同第一外科 ${ }^{21}$, 太田 総合病院消化器外科 ${ }^{3)}$, 杏林大学細胞診断学 ${ }^{41}$

O古旗 淳 $(\mathrm{C} T)^{11}$, 中村眞二 $(\mathrm{CT})^{11}$,

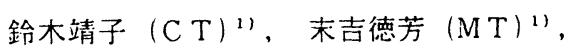
卜部元道 $(M D)^{21}$, 溝㴊昇 $(M D)^{2)}$,

権田厚文 $(M D)^{3)}$, 沢田好明 $(M D)^{4)}$

【目的】癌抑制遗伝子 p 53 は胃の腺腫から癌へ の進展に深く関与し、その陽性率と細胞学的悪性 度には密接な関連性があることを前回の本学会に おいて報告した。今回われわれは胃腺腫の長期経 過観察例の生検材料におけるp 53 遺伝子産物の 局在の変動および細胞増殖能を検索し、のちに癌 が発見された胃腺腫経過観察例を対照として比較 検討したので報告する。

【対象および方法】対象は1983年5月から現在ま で当院第一外科にて胃生検を施行し腺腫と診断さ れ、現在まで経過観察中の 4例で、経過観察の期 間は平均 7年 7か月である。生検材料についてp $53 、 \mathrm{~K} \mathrm{i}-67$ を免疫染色し、その陽性率を検 索した。また肝細胞堌殖因子受容体の c - M e t 遗伝子の動態についても調べた。さらにAgNORs染 色におけるNORs数および細胞 1 個あたりの総面積 と、择印細胞による細胞学的变化について画像解 析を行なった。

【結果】対照群と比較し $\mathrm{p}-53$ 、 $\mathrm{K} \mathrm{i}-67$ は むしろ早期より高值傾向を示した。また $\mathrm{p}-53$ は経過観察中に増減を示し最終的に高値傾向を示 した。K i - 67 もほぼ同様の傾向を示した。c 一 M e tも経過とともに染色性を示すようになっ た。NORsでは数は低值を示したが総面積は対照群 と変わらなかった。細胞学的変化はほとんどみら れなかった。

【まとめ】腺腫のまま長期経過観察されていた例 でも将来癌化するかもしれないという potential があることが示唆された。 
221 RLHに続発した残胃悪性リンパ腫の 1 例

鳥取赤十字病院外科 ${ }^{1)}$ 、同中検病理 ${ }^{2)}$

$O$ 工藤浩史 $(M D)^{1)}$ 、植嶋輝久 $(C \mathrm{~T})^{2)}$ 、 植嶋しのぶ $(\mathrm{C} \mathrm{T})^{2)}$ 、山村章次 $(\mathrm{MT})^{2)}$

Reactive lymphoid hyperplasia(RLH)はMA LTリンパ腫との関連性もいわれており、悪性リン ハ腫が発生するとの報告むみられる。今回、我々は 悪性リンパ腫の自然経過を推測した残胃悪性リンパ 腫の 1 例を経験したので報告する。〔症例〕61歳、 女性。平成 4 年11月胃前庭部の多発潰瘍にて胃切 除術施行。組織学的に RLHと診断された。同 7 年 10 月心窩部痛あり、内視鏡検查。残胃の多発潰瘍と 診断され、当科紹介。術前腫瘍マーカーは異常なし。 生検組織診では悪性所見なく、その捺印塗沫細胞診 では悪性リンパ腫を疑った。初回の細胞診でも悪性 を疑った。〔残胃透視・内視鏡所見〕初回と同様、 白苔を伴った多発潰瘍を認めるも初回の残胃相当 部は正常。〔切除標本〕初回標本では前庭部に白 苔を伴う 2 個の潰瘍が見られ、残胃標本の 3 個の 潰瘍屯同所見。〔初回組織所見〕ULIIの pept ic ulcerで、著名なR L H を伴っていた。〔初回細胞 所見了数個の好酸性核小体を有する $\mathrm{N} / \mathrm{C}$ 比大の小 型細胞が少数見られ、核分裂像を認めた。〔残胃組 織所見了粘膜下から筋層にかけて、B細胞由来の大 型細胞がびまん性に浸潤していた。non - Hodg kin's, diffuse, Large cell type の悪性リンパ腫であ った。〔残胃細胞所見〕 N/C比大、核クロマチン 粗く、核小体を数個有する大型リンパ球を散在性に 多数認めた。〔考察〕R L H 胃切除後の残胃悪性》 ンパ腫の 1 例を経験した。臨床的所見は両者ともほ とんど同様であった。 R L H は多発するてとが知 られており、初回残胃部に臨床的異常は見られな かったものの、R L H 病変が隠れていたてとも 予測される。乙れが 3 年間で悪性リンパ腫に転化 した可能性も考えられ、悪性リンパ腫の自然経過 推測の一助となるおもしろい症例と思われた。
222

小腸類上皮平滑筋肉腫の 1 例

茨城西南医療センター病院検查科病理 ${ }^{1}$ 、

O高谷澄夫 (CT) ${ }^{1}$ 有川良二 $\left(\mathrm{C}^{\prime} \mathrm{T}\right)^{11}$

同外科 ${ }^{2)}$ 、小川功 $(\mathrm{MD})^{2)}$

筑波大学基礎医学系旃理 ${ }^{3)}$

渡辺照男（MD） ${ }^{3)}$ 、下鉒達朗（MD） ${ }^{3)}$

小腸に発生した類上皮平滑筋肉腫の 1 例を絴験 したのでその徖印細胞像を中心に報告する。

（症例） 48 才女性。平成 7 年 7 月喝吐、腹痛、

腹部膨满感を主訴に来院。腹部X P、CTで晹重 積症を強く疑い手術を行った。

（手術所見）小腸腫軥を先進部とした腸重積症で

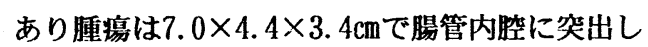

易出血性で㳀弱であった。

（挎印細胞所見）腫煌細胞は境死を伴った出血背 景の中に小集地ないし散在性に多数出現していた。 ライトグリーンに淡染した胞体は多稜形から類円 形であった。核は円形から類円形でクロマチンの 細顆粒状增量、核縁の肥厚、核扲不整、核小体の 腫大を認めた。細胞集塊部分は重積性をもつ上皮 様結合を示していたが、紐胞境界は不明暸だった。

（組織所見）腫愓細胞は多稜形の豊富な胞体を持 ち、核は著しく不整で核分裂像もしばしは見られ た。一部に細長い紡䥔形の腫煌細胞や細胞質内空 胞を持つものも見られた。免疫組織化学的所見は ビメンチン、SMOOTH MUSCLE ACTIN (SMA) 、

SARCOMERIC ACTINは組織標本、細胞標本共に陽性 で、ケラチンは細胞標本のみ陽性、EMAは組織 標本、細胞標本共に陰性であった。

（電影所見）多くの腫場紏胞で胞体内のミトコン ドリア等の細胞内小器官が豊富であった。一部の 細胞にはPINOCYTIC VESICLE の形成や基底膜が認 められ平滑筋への分化が確認された。

（まとめ）類上皮肉腫では上皮性マーカーのEM Aやケラチンが陽性となることもあり、上皮性お よび非上皮性マーカーの複数での娭索が必要と思 われる。 


\section{3 術中捺印迅速細胞診が有用であった} 小腸腫瘍の 1 例

東京都立広尾病院検查科病理 ${ }^{11}$

東京医科歯科大学病理学教室 ${ }^{21}$

O小川浩美 $(\mathrm{CT})^{1)}$ ，春日好幸 $(\mathrm{MT})^{1)}$ ， 福井真紀 $(C T)^{11}$ ，市川智士 $(M T)^{11}$, 田中道雄 (MD) ${ }^{1)}$ ，青木望 (MD) ${ }^{2)}$

今回我々は術前、小腸粘膜下腫㾇を疑われ術中 迅速診断にて異物肉芽腫と䛦断し、細胞診が有用 であった 1 例を経験したので報告する。

[症例] 60才男性、昭和 41 年某大学病院に て腎孟炎の為、左督摘を受ける。平成6年 12 月 脂肪肝のスクリーニング目的で腹部超音波検查を 施行、偶然に脾後面に直径 $3.8 \mathrm{~cm}$ 大のほほ円形 のmas s が発見された。上腹部C T検查の結果、 空腸から漿膜下に発育した粘膜下腫瘍（平滑筋腫） が疑われるという結果であった。

平成 7 年 1 月に開腹手術施行、直径 $3.8 \mathrm{~cm}$ 大 ほほ円形の腫瘍で割面は黄灰白色の材料が提出さ れ，迅速䛦断と同時に捺印迅速細胞診を施行した。 [細胞所見］ 赤血球と壊死物質を背景にして多 数の組織球が出現し、その中に長短入り混じった 䄉維状の物質が認められた。その他、こく少数の 異物巨細胞が散在性に出現しているのみで、腫瘍 を示唆する細胞の出現を認めなかった。以上によ り既往歴をかんがみ、迅速細胞診断として、異物 による反応性変化と判断した。

[組織所見］中心部の壊死物質に混じって、長

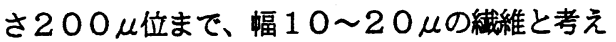
られる物質が多数存在していた。壊死物質辺縁に は、異物型巨細胞やマクロファージの出現がみら れ、出血やフィブリン析出もみられた。周囲は厚 さ4〜 $5 \mathrm{~mm}$ の密な洀痕状組織で囲まれ、その中 にも偏光により明瞭化するガーゼの䋐維と考えら れる物質が散在性に認められた。

以上より、Gauze granulomaと殓 断した。

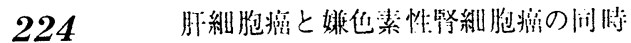
禹被発为:の一例

鳥取大受绝学部第 ...外科

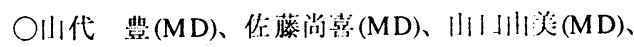

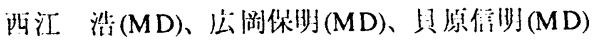

【はじめに】色秦嫌性婜細胞癌住、最近知られて きた概念で比較的稀な疗患であると雪われている が、過去の症例で婜細胞癌混合型と判断されてい るものの中にも5〜10\%の割合で存在していたと いう報告もある。今四我々は肝細胞㺃と嫌色素性: 婜細胞癌の同時重複発症という稀な一例を経験し たので報告する。【症例】48歳、男性、'79年:B型 肝炎の診断にて、近医で入院加療受けるも以降放 置していた。'95年3月全身倦急感出現するも放置、 増悪するため7月近医受診、肝機能低下とUSにて 肝にSOLを瑟め、紹介受診となった。精丛の結果 肘 $S 8$ に径約 $3 \mathrm{~cm}$ の HCC、右腎. 1 極に径約 $3 \mathrm{~cm}$ の RCCの術前診断にて'95年10月3日肝部分切除術

（S7、8）、胆裂摘出術および后婜摘出術を施行

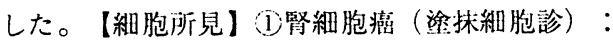
火小不同の立方状の細胞で、細胞質には微細な泡 沫状の颗精を有する。核はN/C比の比較的小さい 剉形〜類緣形で大小は不同であり、クロマチンパ ターンは紐粒状であった。細胞に集簇悩等特斺な パターンはなかった。(2)肝細胞洺(染抹細片診)： 縕胞は腎細胞澏とほほ同じ大きさであるが、細胞 睤の顆粒は腎細胞癌より大きく目つ荒く、グリコ

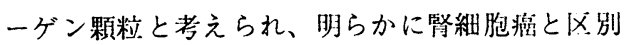
できるものであった。【病理組織所見】门筒細胞

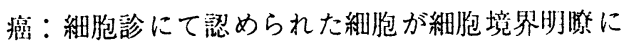

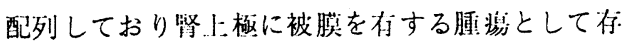
在していた。コロイド鉄染他にて瀿性の細片質を 有しておりpT2、pN0、pM0、pV0、G2、INF $\alpha$ で あった。(2)肝細胞癌：肝は慢性活動性烀炎であり、 腄演は絬節性で、低分化型 trabecular typeであっ

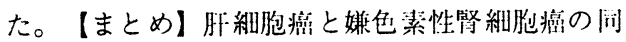
時重複発症のの例を経験したので報留した。 


\section{5 肝臓癌肉腫の 1 例}

成田赤十字病院検査部病理

○安見和彦 $(\mathrm{MD})$ 、斉藤 忠 $(\mathrm{CT})$ 、暮生吉彦 $(\mathrm{CT})$ 、 栢尾純子 $(\mathrm{CT})$ 、須藤一久 $(\mathrm{CT})$

成田赤十字病院外科

大多和哲(MD)

千葉大学医学部第一病理

張ヶ谷健一(MD)、三方淳男(MD)

肝臓癌肉腫は非常に稀な腫瘍である。我々は手 術例において癌肉腫と診断しうる腫瘍を経験し た。そして剖検時に再発した同腫瘍より择印細胞 診材料を得られたので病理組織像と比較検討し報 告する。

[症例] 40 才女性。既往歴なし。平成 6 年 5 月発 熱、その後肝機能異常を指摘され、平成 6 年 6 月 当院受診、画像検査にて肝左葉を占める腫瘤を指 摘され入院。臨床的に肝細胞癌が疑われ7月肝左 葉切除術施行。肝葴原発癌肉腫と診断された。そ の後、腹壁、腹腔内などに再発し、イレウスを併 発、平成 7 年 6 月死亡した。剖検時、腫瘍は腸管 を巻き込み巨大腫瘤を形成していた。

[病理組織所見] 被膜不明瞭な結節性病変で広範 な壊死が認められた。組織学的には偽腺管構造を 持つ肝細胞癌と、骨形成を認める異型紡鍾細胞か らなる肉腫様の部分からなっており肉腫様の部分 には異型腺管が混在していた。いずれの腫湯細胞 間にも移行像は認められず、肝臓原発の癌肉腫と 診断した。転移部には主に肉腫様成分と異型腺管 成分が認められた。

[細胞所見］剖検時の腫瘍捺印標本において、類 円形、不整形核を有し、軽度重積性を示す腺癌由 来と思われる細胞集団と、紡錘形で異型性の強い 肉腫由来と思われる細胞を散在性に認めた。
226 胆汁細胞診の陽性例における細胞像と 嵒関連遺伝子变異の解析

平蝔総合病院検査科病理 '外科 内科 $^{3}$, 秋由 大学医学部第一病理', 公立豊里病院内科

O大倉一雄 $(C T)^{\prime}$, 斉藤昌宏 $(M D)^{\prime}$ ', 高橋雅之 $(C T)^{\prime}$ 加藤雅絵 $(\mathrm{MT})^{2}$, 松岡富男 $(\mathrm{MD})^{2}$, 大久保俊治 $(\mathrm{MD})$ 豊原時秋 $(\mathrm{MD})$

【はじめに】膵・胆道系は生検が難しいため、細 胞の採取及び質的診断法として、胆汁細胞診が有 用である。我々は胆汁細胞診で陽性と判定した症 例を対象として、胆汁中の細胞像と組織学的背景 を調べた。さらに胆汁中の細胞ならびに組織標本 から p 53遺伝子及び $\mathrm{K} \cdot \mathrm{ras}$ 遺伝子の変異の解析を 試みた。【材料】手術抢よび剖検により組織診断 の確定している胆汁細胞診陽性例23例を対象とし た。内訳は胆管癌 13 例 (乳頭部癌 1 例)、膵癌 5 例、 胆囊病変 5 例 (癌 2 例、dysplasia2 例、再生異型を 伴った慢性胆囊炎1例)である。【方法】免疫染色 は抗p 53蛋白モ)クローナル抗体DO7 (NOVOCASTR A社)を用い、Microwave前処理を加えた ABC法で行 った。p 53exon5〜8、K-ras codon 12 13,61領域 をPCR法で増幅し、精製の後cycle sequencing 反応 を行い、ABI373A DNAsequencerで塩基配列を直接 決定し、遺伝子变異を解析した。【結果】胆汁細 胞診陽性例23例のうち、悪性は20例ですべて腺癌 であった。2例は胆囊dysplasia、1例は再生異型を 伴った慢性胆囊炎と診断された。異型細胞の出現 形態をみると、乳頭状腺癌や高分化型管状腺癌で 100個以上の細胞集団として出現する割合が高いの に対し、低分化腺澏では50個以下の集団のことが 多かった。またdysplasiaや胆囊炎では100個以上 の異型細胞集団は観察されなかった。p 53蛋白は、 胆管癌の 13 例中 10 例、膵癌の5例、胆囊癌の 2 例が 陽性であった。胆囊dysplasiaの2例は、散在性に 陽性像が観察された。p 53 遺伝子変異を認めたの は23例中9例で、すべて点突然変異であった。 $\mathrm{K}$. ras遺伝子变異は23例中 4 例に㭘出された。 
227

脾原発Inflammatory pseudotumorの一

例

岡波総合病院検查部 1)、同外科 2)、三重大学 医学部病理 3 )

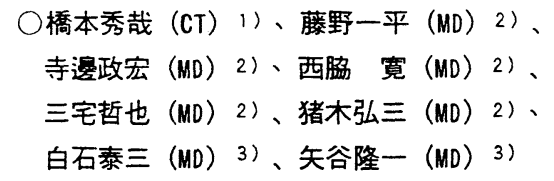

我々は腹部打撲による精査で、偶然発見された 脾原発Inflammatory pseudotumorを経験したので 穿刺吸引細胞診を中心に報告する。

[症例] 23歳、男性。平成7年11月11日、交通事 故による胸腹部打撲で、某病院受診。精查目的 の為、平成7年11月13日本院外科入院、腹部超音波 検査、C T検査で偶然脾腫瘍が認められた。腹部 血管造影、MRI検査で、器質化および血栓化をきた した血管腫が疑われ、脾臟摘出術が施行された。 術中所見では脾以外に腫瘤は認めなかった。［穿 刺吸引細胞所見] 軽度の炎症細胞背累に、紡鏵型 細胞が散在性または疎な結合を有する集塊で認め られた。紡錘型細胞は比較的小型で、一部に核の 切れ込みを認めるが異型が弱く、名泘ンは微細顆粒 状、核小体は1個認められた。細胞質はライトグリ ーン淡染性であった。 [肉眼所見] 摘出脾重量260 8、割面にて脾実質内に $6 \times 5 \mathrm{~cm}$ の境界明瞭で比較 的均一な孤在性結節の腫瘤を認めた。被膜形成は 認められなかった。[組織所見］脾実黄内に結節 性に膠原線維の密な增生がみられ、血管を中心と した同心円状の配列と軽度の単核炎症細胞の浸潤 が認められた。線維芽細胞、内皮細胞は少なく、 炎症細胞も少数で全体的に細胞成分に乏しい腫瘍 であった。以上の所見から脾原発Inflammatory pseudotumorと診断された。
228 唾液腺穿刺吸引細胞診に㧍ける多型 腺腫の)細胞像の検討

長崎市立市民病院病理科

○浦壁順一郎（C.T)、松江圭子（C.T)、 丸尾俊昭（MT）、河合紀生子（MD）、

長崎大学医学部病理学第二教室

入江準二 (MD)

近年、唾液腺穿刺吸引細胞診が多く行われるよ うになり、当院においても唾液腺腫瘍に対して術 前の診断として定着しつつある。

唾液腺には、種々の良悪性の腫瘍がタられるが 最も頻度の高い多型腺腫の細胞像の把握は重要で その組織像の多彩性により、多様な像として標本 上に出現している。

今回我々は、術前に穿刺吸引細胞診により多型 腺腫と診断し、組織診断も確定した 3 例について 組織像と対比しどのような細胞像として出現する かを再検討した。

病理組織学的には、線維性被膜を有し小型骰子 形細胞の線管状〜索状あるいは充実性の増殖が見 られ多型腺腫と診断された。

細胞像は組織像を反映し 2 例では定型的な像を 呈していたが 1 例においては、多型腺腫を推測し うる所見がタられたが、それに加え散在性あるい は小集塊状の上皮性や非上皮性の性格を有する細 胞に大型化、核の腫大、核形不整、核小体の明瞭 化が認められ、多型腺腫における細胞の多形性が うかがえる症例であった。

唾液腺穿刺吸引細胞診は今後さらに活用される ものと考えられるが、今回、細胞像で多型性の見 られた 1 例を中心に細胞像を検討したが多型腺腫 においては、特にその組織像に習熟することが重 要であり、今後さらに症例を重ね、また他の組織 型についても検討していきたい。 
229 胆汁細胞診の検討(過去 3 年間の検討)

鹿児島市医師会病院・病理部

O宮原幸実(CT), 肥田信子(CT), 前田ゆかり (CT) 大原正行 $(\mathrm{CT})$, 黒木 力 (CT), 内村清孝 $(\mathrm{CT})$ 末吉和宣 (MD), 清水 健(MD), 田中貞夫(MD)

【はじめに】胆汁細胞診は, 胆道系腫瘍の診断に 有効な手段の一つと思われる。この領域では細胞 異型の弱い分化型癌が多く, 胆汁作用による変性 も加わり，その判定は必ずしも容易でない。今回, 当院における過去 3 年間の胆汁細胞診成績の検討 を行ったので報告する。

【対象】1992年から1994年の胆汁細胞診は211件 (168例)で陰性158件(74.9\%), 疑陽性26件(12.3 $\%$ ），陽性27件 (12.8\%)であった。168例の内, 組 織学的に診断の判明した116例(良性46例, 悪性70 例)を検討対象とした。

【成績】細胞診と組織診の成績を表に示した。

\begin{tabular}{c|rc|c}
\hline 細胞診 & 良性 & 悪性 & 計 \\
\hline 陰 性 & 43 & 38 & 81 \\
疑陽性 & 2 & 12 & 14 \\
陽 性 & 1 & 20 & 21 \\
\hline 計 & 46 & 70 & 116 \\
\hline
\end{tabular}

細胞診が陰性で組織診が悪性であった38例は再 検討により，24例(63.2\%)が上皮細胞の含まれな いいわゆる不適当材料であった。組織診が悪性で あった70例の内訳は胆管癌42例, 胆霊癌13例, 乳 頭部癌 5 例, 膵臓癌 3 例, 十二指腸癌 3 例, 転移 癌他 4 例であった。胆管癌では 42 例中 23 例 ( 54.8 \%)に細胞診で疑陽性以上の異型細胞が認められ たが, 胆囊癌では異型細胞の認められたのは13例 中わずかに 3 例(23.1\%)であった。また，他の癌 でも細胞診の陽性率は低い傾向がみられた。

【まとめ】胆汁細胞診の成績の向上には, 多数標 本による細胞像の詳細な観察と共に, 検体採取法 の再検討による不適当材料の減少に努めることが 重要と思われた。
230 膵癌における術中穿刺吸引紺胞診の 有用性に関して

済生会今治病院病理1), 香川医科大学第一病理2) 济生会今治病院外科 3 ), 同内科4)

羽場礼次 $(\mathrm{MD}) 1)$, 小林省二(MD)2), 野間勝之 (CT)1), 矢野好人 $(\mathrm{CT}) 1)$, 黑河達雄 $(\mathrm{MD}) 3)$, 梅田政 吉(MD)4)

膵癌の術前の確定診断が困難な症例は, 術中迅速 診断に依存している。しかし，術中の膵組織の採 取は出血が多く難かしい場合があり, 膵癌手術時 における術中穿刺吸引細胞診の有用性について検 討した.

【材料と方法】脺癌25例のうち術前に確定診断が 困難で, 術中穿刺吸引細胞診が行われた8例之非 癌例1例を比較検討した.

【結果】癌例では細胞の大小不同性と多形性とも 高度で, 細胞配列は散在性, 平面的あるいは重積 性と多彩であった．また核の大小不同性は著明 で, 高いN/C比と核の偏在傾向を䜑めた. クロマ チンは微細から粗大顆粒状と多彩で, 核小体は類 円形，一部不整形で1個のものが多かった.さら に強い壊死や炎症性背景を認めた。非癌例では細 胞と核の大小不同性とも軽度で, シート状の配列 を認めたＮ／C比は低く核は細胞の中心性に位置 しており, 細顆粒状のクロマチんは均等に分布し ていた。 また核分裂像の增加は認めなかった。

【考察】手術中に穿刺吸引細胞診を行った全例で 術中に確定診断が得られ, 術前の確定診断が困難 で術中の癌部の組織採取が難かしい症例では，呀 刺吸引細胞診が非常に有用で, 手術方式の決定に 非常に役立つものと考えられた。 


\section{Papilloma 状発育を呈した外陰癌の 1 例}

国立只病院・中国地方がんセンタ一産婦人科 1$)$ 同臨床検查科 2$)$

O沢崎 隆 $(M D)^{1)}$, 藤井恒夫 $(M D)^{1)}$, 木岡寬雅 $(M D)^{1)}$, 重政和志 $(M D)^{1)}$, 中田奈央 $(M D)^{1)}$, 戸田 環 $(\mathrm{CT})^{2)}$, 福田 智 $(\mathrm{CT})^{2)}$, 山根哲実 $(\mathrm{MD})^{2)}$, 片山正一 $(\mathrm{MD})^{2)}$

外陰癌は全女性性器癌の $1 \sim 2 \%$ とされ，60歳 台以降に好発し, 最近 H P V との関連性も示唆さ れている。今回, 我々は papilloma 状発育を呈し た外陰癌を経験したので, 細胞病理所見に加え H P V についても検索したので報告する。

【症例】 61 歳, 会社員。2 年前より外陰部左側に 小腫瘤を自覚していた。H 7 年 11 月急速に增大傾 向を認めたため，外陰癌を疑われ当科を紹介受診 した。初晾時, 左大陰唇下部を中心に白色カリフ ラワー状を呈する約 $3 \mathrm{~cm}$ 大の腫瘤が認められ, 一 部は腟入口部に達していた。外陰部擦過および择 印細胞診は $\mathrm{class} \mathbb{I I} て ゙$, 生検にて高分化型扁平上 皮癌と診断した。外陰癌皿期にて 12 月 5 日, 広沉 性外陰切除術+両側鼠径, 大腿りンパ節郭清術 分首植皮術を施行した。

【細胞所見】外陰擦過細胞診ではオレンジ G 好性 で濃縮した核を有する細胞が散見された。腫瘍掩 印細胞診では細顆粒状のクロマチンを有し，大小 不同の核を持つ細胞集塊が喼められた。裸核細胞, dyskeratocyte， 2 核細胞もみられたが，明瞭な koilocytosis を示す細胞は認められなかった。

【組織所見】角化傾向を認める高分化型扁平上皮 瘦で, parakeratosis, acanthosis を示し, 角化 真珠を多数認めた。基底部では核異型が強く間質 への浸潤性増殖を認めた。また, 腫瑏に近接して koilocytosis を示す部位も観察された。以上より H P V の関与が疑われるため， H P V D N Aの 検査結果も併せて報告する。
232 バルトリン腺原発外陰癌の 1 例

秋山記念病院

○永井義雄 (MD)，佐藤 眞 (CT)，野島俊二(MD)

槙本 深(MD)，秋山實男(MD)，

外陰癌は女性性器癌の $1 \sim 2$ 你を占める悪性腫 瘍であるが、その中でもバルトリン腺原発の外陰 癌は極めて稀で、腺開口部の細胞診が重要な診断 手技となる。今回我々はバルトリン腺原発の外 陰癌を経験したので報告する。

【症例】58歳、女性。0妊、0産、閉経50歳。平成 6 年 12 月頃より外陰部腫癛に気づく。平成7年 3 月 27日当院を受診。左外陰バルトリン腺に一致し て $4 \times 3 \mathrm{~cm}$ 大の硬結を有する腫癛を触知。子宮付属 器には異常なし。左バルトリン腺腫瘍として摘 出手術を予定。4月19日腫曒摘出術を試みたが、 周囲結合組織と強固な㦄着を有し、一部組織の試 験切除とバルトリン腺開口部よりの分泌物細胞診 検査を行った。細胞診で扁平上皮癌、class V と 判定。試験切除組織でも扁平上皮癌と診断した ため、5月19日外陰切除術、営径リンパ節郭清術を 施行した。リンパ節腫大なく進行期 11 期と診断。 【細胞所見】開口部の細胞診では、中等度の細胞 萎縮を呈する中に核增大、N/C比增大、クロマチン 增量、核形不整を伴った異常細胞を認めた。比 較的小型の細胞が主体であるが、核の大小不同、配 列の乱れの著明なものであった。摘出腫瘍の捺 印細胞診でも多数の壊死物質を背景に上述と同様 の異常細胞を認め、癌は明らかであった。

【組織所見】未熟な扁平上皮癌が左バルトリン 腺の領域に増殖を示し、ductに沿って開口部に伸 展している。腫瘍組織中に萎縮した小葉が残存 し、バルトリン腺原発と考えられた。 Honnanの診断基準では、『(1)解剖学的に正しい位 置にある、(2)大陰唇の深部にある、(3)表面に健常 な皮虐を有する、(4)正常な腺組織を一部に認める』 等を条件にしている。本症例は全てを満たし、バ ルトリン腺癌と診断された。 
233 外㓌肉腫の1例

大宮市医師会41、日゙ーざター1 、日本医科大学付属多

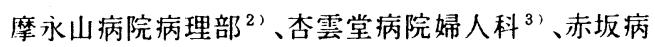
院 $^{4}$ 、東京慈恵会医科大学産婦人科 ${ }^{5}$ 、埼玉県がん さンタ一臨床病理部 ${ }^{6)}$

○小花登代子 $(C T)^{1)}$ 、加藤昭 (MD $)^{1)}$ 、前田昭太郎( $D)^{2)}$ 、室谷哲弥 $(M D)^{3)}$ 、岩田正晴 $(M D)^{4}$ 、佐々木宽 $(M D)^{51}$ 、黑住昌史 $(M D)^{6)} 、$ 岸紀代三 $(M D)^{6)}$

外陰腫瘍の非上皮性腫瘍としてはmalignant mela nomaが大部分をしめるがそれ以外の外陰原発と思 われる肉腫を経験したのでその細胞像を中心に症 例の報告をする。

[症例]71歳女性 4妊2産 53歳閉経 既往歴は結核 他特記すべき事はない。外陰に鶏卵大の腫瘍がみ られ擦過細胞診を施行。同時に頚部と体部の細胞 診も行われた。外陰摖過標本に於いて上皮性 或い は非上皮性由来との鑑別が困難な悪性細胞が認め られClass V と診断した。その後腫瘍の一部が生検 されその組織診断はsarcoma of the vulvaと診断 された。

[外陰擦過細胞診]炎症性背景中に紡錘型やbizare な形態を示す悪性練胞が合胞状或いは散在性に少 数出現していた。細胞質は薄いものから厚いもの まであり小空胞状であった。核は円 不整まで出現 し一部は偏在していた。核縁は薄いものから厚い ものまでみられクロマチンは細顆粒状で核小体は 円形で大型のものが1 2個認められた。我々は扁平 上皮癌或いはsarcoma系統の腫瘍を考えたが確定 することはできなかった。

[組織診断]広範な壊死部分を伴いその中に紡錘形 ないしはくさび形の核を有している異型紐胞の浸 潤、増殖が認められる。腫瘍細胞の核は卵形ないし は紡錘形で細胞質の豊かな像を呈している。免疫 組織化学ではsmooth muscle actin(t)、myoglobin $(t)$, sarcomeric muscle actin $(t) 、 \operatorname{NSE}(t) \tau$ rhab domyosarcomaの可能性が高く現在電顥にて検索中 である。

\section{4 外陰悪性黒色腫の症例}

\section{福井医科大学産科婦人科学教室 ${ }^{11}$}

同中央検查部 ${ }^{2)}$

○吉田好雄 $(M D)^{21}$, 鈴木由里子 (MD $)^{2}$, 川上由香

$(M D)^{1)}$ ，黑川哲司 $(M D)^{\nu}$ ，久住煡一 $(M D)^{1)}$ ，佐々木博正

$(M D)^{1)}$, 竹内 譲 $(M D)^{1)}$, 紙谷尚之 $(M D)^{12}$ ，富永敏朗

$(\mathrm{MD})^{1)}$, 今村好章 $(\mathrm{MD})^{2)}$, 森 正澍 $(\mathrm{CT})^{2)}$

腟原発の悪性腫湯は非常に頻度が低く，大部分が 扁平上皮短であり，悪性黒色盾は極めて稀である。 最近我々は典型的と考えられる症例と肉眼像，細 胞診所見で强く本症を䈐ったが組織像では明確な メラニン顆粒が認められなかった症例を経験した ので報告する。

（症例1）66歳，5回経姡3回経産婦。不正性器出血 を主訴に受診。肉眼的には後胵壁に大豆大で黒色 のポリープ状を示す腫㢚がみられた。腫瘤の擦過 細胞診では細胞質内に色素顆粒を持つ核の大小不 同が者明で核小体が明暸な腫浯細胞がみられた。 租織検索では異型の強い腫場細胞がび慢性に増殖 しており，胞体内に色素顆粒を認める，典型的な 悪性黒色腫の像であった。（症例2）96葴，4回経 妊4回経産婦。不正性器出血を主訴に受診。肉眼所 見は臸腔内に花野菜状に発育する腫湟塊がみられ 易出血性であった。擦過細胞診では出血，壊死物 質に混じり孤立散在性に大小不同で胞体内に粗大 な色素顆粒を有する腫曒細胞が多数見られた。租

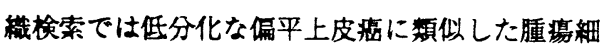
胞がび慢性に增殖していたが，腫場細胞に色素顆 粒は認められなかった。現在組織化学的手法で検 察中である。 
鹿児島大学産婦人科 ${ }^{1)}$, 同 第 1 病理 2

$\bigcirc$ 松元保 $(M D)^{1)}$ ，小林知惠 $(M D)^{1)}$, 牛垣由 美子 $(M D)^{1)}$, 松尾隆志 $(M D)^{1)}$, 森田洋一郎( M $D)^{1)}$,三輪勝洋 $(M D)^{1)}$, 沖利通 $(M D)^{1)}$ ，田中 亨 $(M D)^{2)}$, 吉田愛知 $(M D)^{2)}$, 永田行博 $(M D)^{1)}$

産婦人科領域で外陰部発生の腺癌は極めて まれである。今回当院で外陰部原発の腺癌と 診断した症例を経験したので報告する。患者 は63才の女性で1993年11月頃より外陰部腫瘤 感を認め, 当院皮虑科を受診し，腟前庭部に 小指頭大の腫瘍を指摘され，1994年 5 月 9 日 に当科紹介受診となる。腫瘤の擦過細胞診で はやや重積性に出現する円形，または類円形 の核を有した腺細胞を認めた。核は肥大し， N/C 比の高い，核小体をもつ細胞であった。 8 月 1 日, 根治的外㓌摘出術を施行した。病 理所見では高分化型腺癌で, 原発巣は不明で あった。全身を精査するも特に所見を得ず， 腟前庭部発生の腺癌と思われた。発生部位と しては汗腺を疑った。今回腟前庭部が原発と 思われた腺癌を経験したので報告する。
鹿児島大学産婦人科 ${ }^{1)}$, 同 第一病理 ${ }^{2)}$ 小林知恵 $(\mathrm{MD})^{1)}$, 牛垣由美子 $(\mathrm{MD})^{1)}$, 松尾 隆志 $(\mathrm{MD})^{1)}$, 森田洋一郎 $(\mathrm{MD})^{1)}$, 三輪勝洋 $(M D)^{1)}$ ，家村和千代 $(M D)^{1)}$, 大塚博文 $(M D)^{1)}$, 沖 利通 $(\mathrm{MD})^{1)}$, 松元 保 $(\mathrm{MD})^{1)}$, 山元慎一 $(M D)^{1)}$, 堂地 勉 $(M D)^{1)}$, 吉永光裕(MD) ${ }^{1)}$, 高崎隆志(MD) ${ }^{2)}$, 吉田舜知 $(M D)^{2)}$, 永田行博 $(\mathrm{MD})^{1)}$

腟癌において、腺扁平上皮癌の発生はまれ である。今回我々は、腟に発生した腺扁平上 皮癌の症例を経験し若干の知見を得たので報 告する。

67才女性。52才時に子宮筋腫の診断で子宮 腟上部切断術を施行していた。95年7月より 極く少量の不正性器出血を認めたため、某医 を受診し、腟壁に小指頭大の腫瘤を指摘され た。腟壁腫瘤の組織検査で腟癌を疑われ、当 科に紹介になった。当院外来の検查で、病変 部の擦過細胞診では class IV と悪性病変が疑わ れたが、子宮腟部細胞診ではclass II であった。 腟壁腫赦の組織はadenosquamous carcinomaで、 一部に adenoid basal cell 様の部分も認められ た。最終診断を腟癌とし、胵壁切除、 radical hysterectomy および放射線治療を施行した。 現在外来定期検診中で再発所見はみられてい ない。

腟のadenosquamous carcinoma の症例を経験 した。今回は、細胞診像および組織診像を中 心に供覧する。また、高齢者の原因不明の性 器出血を認める場合子宮癌ばかりでなく、腟 癌も念頭におき、腟壁の詳細な観察が必須で あることも再認識させられた。 
237 胵原発 malignant melanomaの一例

富山医科薬科大学産婦人科

茜村正樹 (MD)。 山川義寞 (MD), 伏术 弘 (MD).

堀 慎一(MD), 泉 陸- (MD)

富山医科薬科大学第一病理

前田宣延 (MD)

腟壁原発悪性黑色腫（malignant melanoma）は非 常にまれな腫場である。その頻度は腔原発悪性腫 瘍の約 5\%, malignant melanoma 全体の約 1\%を占め るとされている。今回我々は胵原発 malignant melanomaを経験したので，その細胞所見と共に報 告する。

症例は74歳の女性。1992年10月に胃癌にて手術 を受けているが現在に至るまで再発徴候はない。 1995年4月11日より3日間の不正性器出血認めら れたため当科受診。診察時, 前腟壁に出血点を認 めた。同部位より採取した組織の病理診断は malignant melanomaであり，腫瘍細胞は表層上皮下 $2 \mathrm{~mm}$ に至万まで浸潤していた。なお，腫瘍細胞は S.100蛋白陽性であった。腔壁の擦過細胞診で は，比較的きれいな背景の中に，ややクロマチン が増加し細顆粒状の核を有する，N/C 比の高い腫 瘍細胞の集ぞくを認めた。細胞質はライトグリー ン好染性であり色素顆粒は認められなかった。全 身の検索では, 転移を示唆する所見は認められな かった。家族の希望により腫瘍局所の腟粘膜を大 きく切除するのみの治療とし，ての後は後治療を 行わず経過を観察する方針とした。6月1日胵壁切 除術施行。術後の経過は良好で, 術後14日目に退 院。現在, 術後7カ月を経過しているが再発徴候を 認めず経過良好であう。

\section{8 細胞診よりみた人工造胵術の比較}

防衛医科大学校産婦人科 ${ }^{1)}$ 同検查部 ${ }^{21}$

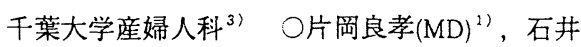

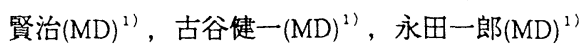
安齊幹雄 $(\mathrm{CT})^{2)}$, 杉田道夫 $(\mathrm{MD})^{3)}$

人工造腟術は，腟欠損症に対して性交可能となるこ とを目的として施行される形成手術の1つである。 従来は大腸移植法と皮膚弁移植法が主であったが, 最近では腹腔鏡補助による腹膜利用法などいくつか の手法が加わってきた。近年, 我々の施設では胵腔 をあけてプロテーゼを挿入するだけで腟上皮形成を 促すWharton法を腹腔鏡下にて数例試みている。そ こでRokitanski症候群の患者に対して人工造腟術と して皮周弁移植法とWharton法を施行し, 細胞診に よりその造腟経過を比較したので結果を報告する。 術後1ヶ月目より細胞診を施行した。腟形成の評価 は有核の扁平上皮細胞，デーデルライン桿菌の出現 と好中球の増加にておこなった。皮唐弁移植法では 術後1ヶ月目では無核の扁平上皮細胞が多く，好中 球はまだ出現せず，術後4ケ月目でも好中球はほと んど出現していなかったが, 無核の扁平上皮細胞に 混ざってところどころに有核の扁平上皮細胞がみら れるようになってきた。術後 9 ケ目では有核の扁 平上皮細胞と好中球の著しい増加を認め, 従来の胵 上皮と類似した状態となった。Wharton法では術後 1ヶ月目では泡沫状の細胞質をもつ間質由来と思わ れる細胞及び少数の好中球を認めたが，有核の扁平 上皮細胞に関してはほとんどみられなかった。術後 3ヶ月目では間質細胞と思われる部の中に有核の扁 平上皮細胞を認めるようになった。術後 1 年目では 有核の扁平上皮細胞と好中球がかなり増加し, 組織 球と思われる核小体のない間質細胞の出現も認めた が，腟腔の完全な上皮化には至っていない。 Wharton法は皮虚弁移植法に比べ，胵上皮の形成が 長くなるという短所はあるが, 手術侵襲が少なく, 美容上の観点からも有効な造腟術であると思われ た。また，当科にて施行したMac Indoeおよび Davidoff（腹膜利用法）についても同様に言及し 文献的考察を加える。 
239 急激な経過をたどった侵入奇胎の一例

聖マリアンナ医科大学東横病院産婦人科 1 , 同病理 2 , 聖マリアンナ医科大学横浜市西部病院病理 3 , 聖マリアンナ医科大学産婦人科 4

$\bigcirc$ 吉田典生 ${ }^{1}(\mathrm{MD})$, 木口一成 ${ }^{1}(\mathrm{MD})$, 鈴木廉三朗 1 $(\mathrm{MD})$, 腰高 豊 $^{2}(\mathrm{CT})$, 品川俊人 ${ }^{3}(\mathrm{MD})$, 雨宮 章 ${ }^{4}(\mathrm{MD})$

最近我々は, 胞状奇胎婏出後, 急激な呼吸困難およ び腹腔内出血によるショック状態を呈したが, 直ち に腹式単純子宮全摘術を施行し, その後の化学療法 により，寛解を得た症例を経験したので報告する。 [症例] 25 歳, 女性, 2 妊1産. 平成7年9月不正性 器出血（無月経10週4日）を主訴として当院受診.

子宮は内診上双手拳大. echoにて胎児・胎桽はみら れずvesicle echoを認めたため, 胞状奇胎と診断. 入 院後, 奇胎婏出術を施行. 数回の子宮内容除去術時 の病理所見およびMRIにて侵入奇胎と診断した. 20 日後に大量出血のため再度入院. 雨肺への転移を認 めた。数日後急激に発症した呼吸困難と腹腔内出血 のため, 直ちに腹式単純子宮全摘術を施行. 術後に MAC療法を3回施行した結果, 現在肺転移巣の縮 小・HCGの低下などの著明な効果が得られている。 [細胞診所見] (1)初回子宮内容除去術時検体：ラン グハンス細胞は軽度の核異型を伴い、ジンチジウム 細胞は微細顆粒状のクロマチンおよび軽度の核の大 小不同を認めた。 (2)手術検体：ラングハンス細胞は 大型の異型核および粗大顆粒状のクロマチンの他, 一部に腫大した核小体を数個認めた。

[病理所見] (1)初回子宮内容除去術時検体：変性壊 死に陥った脱落膜と共に大型で水腫状を呈する絨毛 がみられた。 (2)手術検体：main tumorは子宮体部内 腔の殆ど全体を占め, 筋層 $1 / 2$ まで漫閏. その他体 部筋層内に2ヶ所, 頚部筋層内に1ヶ所tumorが存在. 体部後壁のtumorが漿膜まで到達し, ruptureしてい た. 異型を伴うトロホブラストが䄉毛形態を伴わず 子宮筋層内に染く増殖していたが, 周囲組織の出 血・壊死は著明ではなかった。
240 婦人科覀性腫瘍胵断端再発に対する CDDP呞所注入療法時の細胞像の变化について

仙北組合総合病院産婦人科 ${ }^{11}$ 、同 検査科 ${ }^{21}$ 佐藤康美 $(M D)^{11}$ 、五十嵐信一 $(M D)^{11}$ 、加藤幸一 $(\mathrm{CT})^{2)}$

卵单癌 2例、子宮体癌 1 例の胵断端再発 3 例に 対し、CDDPの局所注入療法を行い、細胞学的効果 、臨床的効果を検討した。[症例 1] 卵巣癌 III c 期。平成 5 年11月、単純子宮全摘術、両側附属器 切除術施行。平成 6 年 12 月、胵断端に再発し、大 量の出血を来したため、止血効果を期待し、CDDP の局注を行った。( 細胞像) 局注後、約 1 か月の 細胞像では、細胞質の染色性の低下、核の膨化、 大型核小体の出現を認めた。[症例 2] 子宮体癌 I a 期。平成 5 年 12 月、準広沉子宮全摘術、骨盤 内リンパ節郭清術施行。平成 7年 8 月、腟断端に 再発。CDDPの局注を行なった。( 細胞像) 局注後 2か月目の細胞診では細胞質の染色性の低下、核 の膨化、クロマチンの凝集化が認められた。[症 例3]卵巣癌IV期。平成 7年 2 月、子宮全摘術、両 側附属器切除、小腸部分切除*端々吻合術施行。 平成 7年 9 月、胵断端に再発。出血も伴ったため 、CDDPの局注を行なった。( 細胞像) 局注後 1か 月目の細胞診では、核形の不整、核縁の肥厚、細 胞内空胞などの所見を認めた。

[まとめ] 3例とも、CDDP局注後、腟断端よりの 出血は止まり、CDDP局注は臨床的有効と判断され

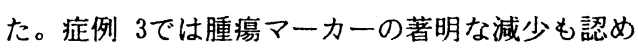
た。細胞学的にも抗腫瘍効果が認められ、CDDP局 注は婦人科悪性腫瘍腟断端再発例に対する有効な 治療法と考えられた。今回、我々はCDDP局注の抗 腫瘍効果を細胞学的に検討したので、報告する。 
241 後腹膜原発漿液性腺癌の一例

川崎医科大学病理学教室 ${ }^{12}$ 、川崎医科大学附属病 院病院病理部 ${ }^{2)}$ 、

$\bigcirc$ 坂元和宏 $(M D)^{1)}$ 、清水道生 $(M D)^{1}$; 、広川満良 (MI) $)^{1)}$ 、香栄 $(\mathrm{CT})^{2}$

後腹膜原発の漿液性腺癌を経騃したので報告す る。

【症例】53歳、女性。腹部膨満感及び全身倦怠感 にて近医を受診し、腹部 C Tにて腹部大動脈周囲 のリンパ節の腫脹が認められた。CTガイド下で の穿刺吸引細胞診にてClass $V$ 、腺癌と診断され た。転移性腺癌の診断にて消化器を中心に全身の 検索を行ったが、原発巣は認められず、CA125の 著明な上昇がみられたため、卵巣癌の疑いにて、 産婦人科に転科となり、試験開腹を行った。後腹 膜の大動脈周囲のリンパ節の著明な腫脹がみられ たが、子宮及び卵巣には病変は認められなかった。 組織学的には腺癌の像であった。術後、シスプラ チンを主体とした化学療法を行い、一時、腫瘍は 縮小したものの約 2 年後、腫瘍による悪液質のた めに死亡した。

【細胞所見】吸引穿刺細胞診では、リンパ球を背 景として、上皮様の細胞集塊が多数出現していた。 これらの細胞はN・C比が大で、大小不同が目だち、 核の不整、クロマチンの增量が認められた。

【組織所見】やや小型の異型細胞が小胞巣をつく り、周囲に結合組織を伴って增殖し、砂粒体も散 見された。一部の腫瘍細胞の胞体内にはジアス夕 一ゼ抵抗性PAS陽性の粘液を認めた。また免疫組 織化学では腫瘍細胞はケラチン、EMA、CA125が陽 性で、ビメンチンは陰性であった。

【剖検所見】剖榆時、腫瘍は後腹膜を中心として 大動脈、下大静脈、尿管を巻き込み一塊となって おり、一部で腹腔内にも播腫が認められた。

【まとめ】原発巣の推定が困難であった後腹膜漿 液性腺癌の一例を報告した。
242 組織球性壊死性リンパ節炎の細狍像 とアボトーシス

秋田大学医学部附属病院中央検䄳部病理検䄳空1) 同第一病理学教室2)

O藤原登美子 ${ }^{1)}(\mathrm{CT}) \quad$ 斉藤昌宏 $^{2)}(\mathrm{MD})$ 藤田 㭮 $\left.^{1}\right)(\mathrm{CT})$ 作藤 智 ${ }^{1)}(\mathrm{CT})$ 渡辺粘子 ${ }^{1)}(\mathrm{MT})$ 、提 鴆真人 ${ }^{1)}(\mathrm{MD})$ 土非侄子 ${ }^{2)}(\mathrm{CT})$ 牙源顺( ${ }^{-1)}(\mathrm{MD})$

はしめに 組䋨球性塤死性リンバ節炎は、組織学 的に旁皮質を主作に桨状壊死を伴い、組䋨球と非 球化リンバ球の增殖を特徽とする。我々はこの病 変の細胞・組織像について、病垐の進行度やアポ トーシス像の出现との関係を解析した。

材料 組織球性坮死性リンバ節炎16例（雓印標不 を検索できた症例 9例）を対爱とした。

方法アポトーシス（DNAの断片化）の検出 ApopTag-Plus (oncor社) を几いてアボトーシスに 陷った細胞を㭘出した。

結果 アポトーシス（DNAの断片化）の指標とな るDNAの3'OHを兑疫組織学似に検出した絬果、 壊死倾向の弱い例では核涱繀を示す小型りンパ球

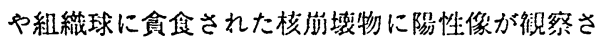
れたが、組繀球などほかの細狍には陵性像は見ら

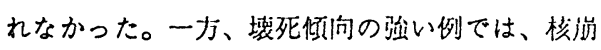
垻物を貪食した組織球の核にも妈い陵性像を認心 た。これらの䎋性核はまだ核クロマチンや核队㩐

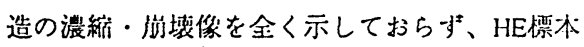
では細胞死を認識できない像であった。燷死侕向 の強い例に扔いては食食組織球にもアポトーシス （DNAの断片化）が起きていることが叮らかに なった。

考察 捺印標本と組䋨標本の锶察と出现縕狍の僻 析から、壊死候向の妈い型と強い型に大別され、 これらはそれぞれ病変の早期と進行甽に相当する 変化と推定された。

本病変でのアポトーシスの意莪については、病 变の進行沏に起る会企像を伴う㙘死域の昖大過程 て、、食食縕䋨球にもDNAの断片化が起きており、 病变部全体の樏死に至る糸化と考えられた。 
243 唾液腺に発生したMALT 型リンパ腫 の) 1 例

福島県立医大付属病院病理部 1 、福島県立医大第 1 病理 ${ }^{2}$

○中村直哉 $(\mathrm{MD}))^{1}$ 、安倍裕子 (CT) '、渡辺一男 $(\mathrm{MD})^{1}$ 、阿部正文 $(\mathrm{MD})^{2}$ ?、鈴木利光 $(\mathrm{MD})^{1}$

左耳下腺に発生したMALT型リンパ腫を経験し たので報告する。

症例：66 歳、女性。Sjögren 症候群の診断の下に 加療を受けている。以前より両側耳下腺の腫脹を 認めていたが、平成6年10月頃から左耳下腺下部 に腫瘤を触れるようになり、平成 7 年 6 月、精査目 的に当病院耳鼻科に入院した。入院時、両側耳下 腺はびまん性に腫張し、左耳下腺下部に約 $3 \mathrm{~cm}$ 大 の腫瘤を認めた。echoでは、明らかな境界明瞭な 充実性の腫瘤として認められたが、CTでは、両側 耳下腺が均一にenhanceされ、腫瘤影は認められな かった。針吸引細胞診を施行したが、確定診断が つかなかったため、腫瘤の生検を行い、悪性リン パ腫と診断された。stage I として化学療法 (CHOP 4 クール）を施行し、現在、経過観察中である。

細胞診所見：N/C 比大の小円形細胞が多数認めら れ、その多くは裸核状でクロマチンの増量を伴わ ない小型類円型核を有する小型リンパ球と考えら れた。そのなかに小型リンパ球よりやや大きく、 ライトグリーン好性の少量の胞体と軽度の核の切 れ込みを有する細胞が混在していた。核クロマチ ンはやや増量し、粗顆粒状を呈し、核小体を有す るものも少数認められた。

病理組織所見：腫瘍細胞は小型リンパ球より大 型で、びまん性に増殖し、小型リンパ球が種々の 程度に混在した。核は軽度の切れ込みを有し、胞 体はやや豊かであった。リンパ上皮性病変 (lymphepithelial lesion) が散在性に認められた。腫瘍細胞 は、CD20 陽性、CD3 陰性のB 細胞の形質を示し た。これらの結果から低悪性度 B 細胞性 MALT型 リンパ腫（びまん性中細胞型）と診断された。

\section{4 腹水細胞診で診断されたNatural Killer marker 陽狌のT細胞性リンパ腫の一例}

関東违信病院病理診断科，自治医科大学病理 ${ }^{*}$ O荒井政和 (CT), 島田素子(MD)，原田弥生(CT)， 川岸克博(CT), 原田美貴(MD), 望月 真(MD), 畔川一郎(CT), 松本荻乃(CT), 牛島友則(CT), 深山正久(MD)*

【はじめに】今回我々゙は、腹水細胞䛦で、 large granular lymphocyte(LGL)の形態を示す Natural Killer（NK）細胞マーカー陽性のT細胞性リンパ腫 と診断された症例を経験した。

【症例】62歳 女性。既往歴は特記事項なし。 1995年10月から腹部膨満感があり、超音波にて大 量腹水が見られた。精查のため10月19日当院消化 器内科入院。表在リンパ節腫大なし。肝脾腫なし。 鼻腔著変なし。血算及び骨髄穿刺で異常なし。EBV 抗体価に有意な上昇なし。腹水細胞診にて、リン 八球様大型異型細胞が見られた。フローサイトメ トリー及び免疫組織化学に於いて、CD3, CD8, CD56 等が陽性を示し、NKマーカーを持つT細胞性リン パ腫之診断された。10月26日汎発性腹膜炎にて緊 急開腹術施行。小腸に多発性の結節性病变が見ら れ、その一部が穿孔。腸間膜、後腹膜リンパ節腫 大。小腸部分切除材料にて、組織学的にも悪性リ ン八腫之診断。術後化学療法を行い、腹水消失、 リンパ節腫大も軽快し、経過観察中。

【腹水細胞像】 $20 \mu \mathrm{m}$ 前後で朸立散在性の異型細 胞が多数出現。Giemsa染色では細胞質は好境基性 で、胞体内に数個のアズール顆粒を有する。核は くびれが強く核小体は 1 数個見られた。

【小腸組織像】小腸㸃に但往 $4 \mathrm{~cm}$ 大の円盤状の結 節があり、全覑性に中〜大型のリンパ球様細胞の 密な増殖が見られた。anらiocentricな增殖がごく 軽度見られた。

【まとめ】腹水中の細胞像とフローサイトメトリ 一からNK細胞マーカー陽性のT細胞性リンパ腫と 診断が下せたことは稀である。 


\section{5 恥骨原発軟骬肉腫の一例}

富山協立病院病理"，同 整形外科"，富山医科薬科 大学第二病理"), 同 整形外科 ${ }^{4}$, 城北病完病理 ○堀 隆 $(\mathrm{CT})^{1}$, 若木邦彦(MD) ${ }^{3}$, 市村和徳 $(M D)^{2)}$ ，金森晶彦 $(M D)^{4)}$, 袖本幸男 $(M D)^{5)}$

軟骨肉腫は中高齢者, 男性に多い。好発部位は 骨盤, 大腿骨, 胁骨, 上腕骨, 肩甲骨で, 予後は 比較的良好のものが多い。私達は恥骨部に発生 した低分化型軟骨肉腫の吸引細胞診の一例を経験 したので報告する。

【症 例】 54 歳, 男性。平成6年10月右鼠径部 痛, 同部のしこり, 右坐骨神経痛と足背部のし びれを自覚し, 近医で腰椎椎間板へルニアとして 保存療去を受けていた。坐骨神経痛としびれは改 善したが, 右鼠径部の痛み, 歩行時の大腿部痛と 跛行があり，鼠径部の腫瘤も増大し，平成7年7 月4日当院受診した。骨盤X線では恥骨の破壊像 を認め, CT, MRIでは low dense な腫瘤が右骨 盤腔を占拠し, 上方は腹壁直下から, 左方は膀胱 直腸を圧排している。画像上根治術の適応外と考 えられ，腫瘤圧迫による疼痛軽減と排尿排便障害 の改善を目的に姑息的腫瘍怪爬術を行なった。腫 汮は腹壁直下に存在し, 被膜を有し緊満してい た。被膜切開時に血腫様血餅塊に腫湯の混入した ものか噴き出し，それらを怪爬した。

【細胞像】腹壁右鼠径部より穿刺吸引細胞診を行 ない, 少量の血性泥状物を得た。背景には種々の 変性像を伴った組織球と多量の微細線維状または 均一無構造の matrix が出現し, これはパパニコ ロウ染色で淡青緑色, ギムザ染色で異染性を示 し, PAS反応とアルシアン青染色で強陽性を呈し た。matrix内には核周の不染性ないし淡染性の 明軍を伴う腫大した核を有する細畹があり，二核 性のものも見られた。核クロマチンの増量は少な く, 小型核小体を認め, 軟骨肉腫と診断した。 組織像は多数の壊死を伴う低分化型軟骨肉腫で あった。
246 捺印細胞彰が有用であった胞樂状軟部 肉腫の 1 例

国立弘前病院研究検查科1)、同 整形外科2)、 弘前大学第一病理 3 )、青森市民病院臨床病理部4) ○松本一仁 $(\mathrm{MD})^{1)}$, 池崎福治 $(\mathrm{CT})^{1)}$, 柿崎筧 $(\mathrm{MD})^{2)}$ 八木橋法登 $(\mathrm{MD})^{3)}$, 吉岡治彦 $(\mathrm{CT})^{4)}$

【はじめに】胞栄状軟部肉腫は若年成人の下肢、 上肢、頭頸部に好発す’る稀な恶性軟部死瘍である。 今回我々は左大腿部に発生し捺印細胞診が診断に 有用であった本症の 1 例を経験したので報告する。 【症例】12才男子。平成 6 年夏左大腿外側の腫熘 に気付く。腫瘤が次第に増大するため某医を受診、 筋肉内血腫が疑われ、平成 7 年 6 月 1 日当院整形 外科を紹介された。初診時、左大腿外倒広筋内に $3 \times 4 \mathrm{~cm}$ 大、紡鍾形の腫瘤が認められ、6月 8 日 試験切除術が施行された。

【捺印細胞像】大型類円形の腫瘍細胞が散在性、 一部集簇性に出現、2 4 核の腫瘍細胞も散見さ れる。胞体は広くライトグリーン好性で微組顆粒 状を呈し、辺縁は不明瞭。裸核細胞も多く、数珠 玉状の配列も観察された。核は類円形で偏在し、 軽度の大小不同を示す。核縁は薄くクロマチンは 顆粒状で、1 個の影著な核小体を有している。ギ ムザ染色では胞体内に赤紫色の顆粒や針状結晶が しばしば観察され、胞巣状軟部肉腫と診断した。

【組織所見】好酸性の広い胞体と類円形〜不正形 の核を有する大型の腫瘍細胞が繊細な血管線維組 織に境され胞巣状に増殖している。胞体にはしば しば顆粒状〜針状の結晶構造が認められ、これら はPAS 染色陽性、ジアスターゼ抵抗性であった。

【免疫組織所見】腄場細胞は myoglobin、NSE、 lysozyme、 $\alpha_{1}$-antichymotrypsin が陽性、S-100、 desmin、vimentin、cytokeratin は险性であった。 【まとめ】本腫煌の細胞学的診断には特徴的な顆 粒や針状結晶の証明が重要であるが、パパニコ ロー染色のみでは識別が困難であり、PAS 染色 と共にギムザ染出の併用が極めて有刖上考えられた。 
横浜市立大学浦舟病院中央検查部

○大津久美子 (CT), 稲垣貴子 (CT)，原田章子 (CT), 田山三郎 (CT), 清水薰 (CT), 下山潔 (MD), 原正道 (MD)

〔目的〕核内封入体及び空胞は、甲状腺の乳 頭癌などで特徵的に見られ診断根拠の一つと なっており、又、他の器器においても多々見 られる所見である。今回、我々は蹃膜腫につ いてこれらの出現頻度及び性状について検討 したので報告する。

〔方法〕1989年から1995年の7年間に髄膜腫 と診断された組織 50 例を対象とした。対物 100 倍で 20 視野検鏡し、腫瘍細胞に対する核 内封入体及び核内空胞を示す細胞を計数した。 また、MIB-1,PCNA抗体で免疫染色を行った。 細胞診標本が得られた症例も同様に行った。 一部については電影的検索も行った。

〔結果〕組織では核内封入体は98\%(49例)に 見られ核内空胞は68\%（31例)に見られた。各 々の1症例あたりに見られる頻度は、核内封 入体が平均 $1.1 \%$ 核内空胞が $0.3 \%$ であた。 組織型別では、分泌型に多く(封入体 $3.0 \%$ , 空胞 $0.6 \%$ )、線維型では少なかった（封入体 $0.5 \%$, 空胞 $0.1 \%)$ 。細胞診では 1 症例あたり 核内封入体が $1.8 \%$ 、核内空胞が $0.1 \%$ であっ た。核内封入体及び核内空胞を有する核はMI B-1抗体(-),PCNA抗体(+)であった。電影的に 核内封入体は細胞質封入であり、核内空胞は 細綿毛状ないし空胞状であった。

〔まとめ〕蹃膜腫では高頻度に核内封入体が 認められ、また、核内空胞も半数以上に認め られた。PCNA抗体が陽性であり、細胞増殖に 何らかの関係があるものと推測される。これ らの所見は、觬膜腫の細胞診断上意義のある ことと思われる。

\section{8 多形黄色星膠腫の 1 例}

香川医科大学第一病理 1), 香川医科大学病院病 理部 2)

○小林省二 (MD) 1), 平川栄一郎 $(M D) 1)$, 舩本康申 ( C T ) 2), 岸田不二夫 (C T ) 2), 河野幸治 (CT) 2)

多形黄色星膠（細胞）腫は比較的若年者の大脳 半球の表層部に発生し、その多形性を示す組織像 にもかかわらず長い経過をとる星膠腫の variant で ある。

症例は 21 才男性。約 2 ケ月前から視野障害が 出現し、頭部 C T 検査で右側の側頭から後頭葉 にかけて、直径 $5 \mathrm{~cm}$ 位の境界鮮明な腫瘤がみられ た。手術時、腫厡は暗赤色弹性軟で易出血性で あった。

腫湯の圧挫細胞診像では、腫瑒細胞の多くは類 円形ないし長円形の核を持ち、双極性あるいは星 芒状の星膠細胞様細胞であるが、核の大小不同性 は著名であった。単核や多核の大型細胞や、奇異 な形の巨細胞もみられるが核分裂像はごく少数で あった。核クロマチンは微細で核縁の肥厚は目立 たないが、核不整は著明であり、核小体も目立つ ものが認められた。また大型の組織球様細胞やリ ンパ球、形質細胞、好中球なども認められた。血 管はよく発達しているが内皮細胞の腫大はほとん どみられなかった。

組織学的には多形性に富む星膠細胞の充実性增 殖がみられ、不完全な束状の交織性增殖像や細胞 間隙の開いた星芒状細胞の增生像などがみられ た。とくに単核あるいは多核で細胞質の豊富な巨 細胞が目立ち、炎症反応とともに大型の組織球様 細胞も散在していた。

組織学的には琹性度の高い星膠腫や膠芽腫との 区別は比較的容易であるが、細胞像については必 ずしも明確ではなく本腫瑒との鑑別点についても 比較検討する。 
249 中枢神経系細胞診における血管所 見について

横浜市立大学浦舟病院中央検查部 ○稲垣貴子 (CT), 大津久美子 (CT), 原田章子 (CT), 田山三郎 (CT), 清水薫 (CT), 下山潔 (MD), 原正道 (MD)

我々は、第 35,36 回本学会で神経系細胞診 の基準像作成を試み、平均細胞数, 細胞像を 報告した。今回これらの基準像を背景として、 血管の数・性状・走行性について正常媨と媨 腫湯（星状膠腫）の比較検討を行った。

【方法〕対象は成人剖検脳 6 例と脳腫瘍（良 性および悪性星状膠腫）6例。標本は前回と 同様のものを使用した。均一に㬁沫され、1 〜2層の重積の視野を倍率X400倍で観察し、 血管の数・性状・走行性を観察した。さらに 出現毛細血管 $250 \mu \mathrm{m}$ 中の内皮細胞数を数え、 100 箅所の平均值を算出した。

[結果]正常脳では、1 視野平均血管数は圧 挫で約 1 本、择印で 0.5 本であった。又、毛 細血管 $250 \mu \mathrm{m}$ 中の内皮細胞数は約3.5個であ った。脳腫瘍の良性星状膠腫では、血管数は 压挫で䄪 2 本、捺印で0.1本であった。毛細 血管 $250 \mu \mathrm{m}$ 中の内皮細胞数は約 5 個であり 正常より増加が見られた。又、覀性星状膠腫 では血管数は全体的に少なく、圧挫で 0.5 本、 捺印で0.1本であったが、各血管径は太くな り、多数・多様の分岐が見られた。血管内皮 細胞数の増加や核腫大も見られた。

[考察〕今回我々は、正常脳と脳腫瘍との血 管数・性状・走行性の違いを明らかにした。 正常脳と良性星状膠腫の違いは 1 視野平均血 管数と血管内皮細胞数であった。脳腫㿋では 血管の分姐が多くなることがわかった。悪性 星状膠腫捺印での数の減少は血管径の増大が 関与している。血管の数・性状・走行性は㻅 断上重要な所見と考えられる。
250 境界明暸なグリオーマは，「境界明暸 なグリオーマである」と，正しく（堂々と）診断す るために.

東京都神経科学総合研究所病理 1 , 都立神経病院病理科 2 , 同脳外科 3 小島英明 (MD) 1) 2), 望月 衛 (MD) 1), 若林富枝 (CT) 2), 井出勝久 (MD) 3 ), 小田雅也 (MD) 2)

症例：10歳男児. 意識消失発作を主訴に当院入 院. 画像上, 左頭頂葉内側の脳表近くに壁在結節を 伴う裹胞あり，均一にエンハンスされた。「良性グ リオーマ」と臨床診断され, 腫場切除術を施行. 肉眼上, 腫瑒は比較的境界明暸, 易出血性. 組織所 見: 細胞は大小不同の異型核をもち核内封入体もあ り多彩。明らかな核分裂像はない。細胞質から細線 維が出，アストログリア由来の腫瘍. その線維が比 較的粗な所と密な所があり（二相性パターン），顆 粒小体を散見。毛様細胞性星細胞腫を疑った。しか し, 核の大小不同が著しく, 脂肪顆粒が無く細胞密 度も異なるのでPXAでもなく，膠芽腫の否定ができ ず. 萚印細胞所見：核は大小不同。核縁の肥厚はな く,クロマチンは顆粒状. 特徴的所見は，1)巨核の 細胞も含めてどの細胞の細胞質も，2本の細い「毛 の様な」突起をもつ細長い紡錐形を示した，2)血管 内皮細胞が多数認められた，3）顆粒小体（顆粒は Pap染色では不明暸）を散見，4)細線維が束になっ ている所見がよく解る，5)壞死がない.念のため迅 速診断時に術場で画像を確認し， WHO（1993）の 定義にすべて該当するので，毛様細胞性星細胞腫と 診断. 考察: 脳腫瘍病理の林改訂版 (1993) での強 調点の一つは「境界明暸なグリオーマ」と「びまん 性グリオーマ」を積極的に区別し診断する点にあ る.つまり, 治痛切除可能である場合があり, 不要 な放射線照射を避けられる点は画期的である. しか し実務上組織診断のみでは本例の如く診断が難し く, 細胞診の活用が必須である. なお, 患児は今元 気に学校に行っている. 再発も無い. 
251 耳下腺の粘表皮癌の細胞診

高松赤十字病院病理部

$\bigcirc$ 荻野哲朗 (MD), 青木芳子 (MT), 長町健一(CT)

粘表皮癌は，大唾液腺の全腫瘍の5 10\%を占め る比較的頻度の高い悪性腫場である. しかし, 種々 の異型度を示すために的確な細胞診断は必ずしも 容易ではない，粘表皮癌 2 例の細胞像を提示し， 細胞診断上の問題点について考察する.

症例 1.60才，女性. 左耳下部の辺縁不整な腫 瘤から穿刺細胞診が行われた．背景に少量の粘液 がみられ，上皮細胞が孤在性およびシート状集塊 として多数認められた．異型の軽度な高円柱状細 胞が主体で，少数の扁平上皮様細胞が混在してい た．細胞診では良性病変を推定したが, 病理学的 に高分化粘表皮癌之診断された。

症例 2. 21 才, 女性. 高胞部と充実部の混在す る右耳前部の腫瘤から穿刺細胞診が行われた. 好 中球の多い炎症性背景の中に, 多稜形から類円形 の上皮細胞がシート状に多数みられ, 一部の細胞 に層状構造や核周囲空胞, 細胞間橋が認められた. これらは核クロマチンの軽度增加と大型核小体を 示した。粘液細胞は集塊中に少数混在していた。 細胞診では粘表皮癌を疑い, 病理学的に中分化型 粘表皮癌と診断された。

考察粘表皮癌は粘液産生亡扁平上皮への分 化を同時に示すことが特徵であり，スメア中に扁 平上皮細胞, 粘液細胞及びこれらの中間的細胞が 検出できれば診断可能である. しかし, 高分化型 は異型が軽度なために偽陰性になり易く, 異型が 強いと他の低分化癌との鑑別が困難である.この ため、穿刺細胞診による診断率は 37〜 50\%にとど まっている. Cohenらは, 粘表皮癌の細胞所見を解 析し，1）重積性の細胞集塊，2）粘液細胞，3）中間 細胞の 3 所見の重要性を指摘している(Acta Cytol $34: 43$ - 49, 1990）.これらの所見に着目すれば, 提示した 2 症例についても組織型推定が可能と考 えられた.
252 腺癌への分化を示した鼻腔原発神経芽 腫の捺印細胞像

: 鼻腔原発神経芽腫の発生母地に関する一考察

いわき市立常磐病院病理科1,

いわき市立絵合磐城共立病院病理科2, 同細胞診 3 , 東京都神経科学総合研究所病理 4

望月 衛 (MD) 1) 2) 4), 吉田京子 (CT) 3),

蛭田道子 (CT) 3 ), 森 菊夫 ( $\left.\mathrm{CT})^{3}\right)$,

山崎一樹 $\left.(M T)^{2}\right)$, 小島英明 (MD) 4$)$.

腺癌への分化を示した鼻腔の神释芽腫を経験し た. 捺印細胞像を報告し, 鼻腔原発神経芽腫の発生 母地につき考察する. 症例：84歳男性. 鼻出血を主 訴に近医受診. 右鼻腔腫場生検で嗅覚神経芽腫と診 断され当院紹介受診. 初診時, 右鼻腔を充満する腫 汮あり。画像上右鼻腔，上頻洞，上咽頭におよふ腫 湯陰影を認めた。右上頻洞試験開放術を施行. 肉眼 上腫場は肌色から灰白色を呈し, 脆く易出血性. 嗅 裂部に腫瘍を認めず．萘印細胞診細胞像：N/C 比 高く, 裸核状の腫舓細胞が小細胞集塊を形成するも のと, 重積性を示す中型細胞集塊を形成するものが 混在. 核は類円形〜楕円形. 前者の核クロマチンは 微細顆粒状で增量は軽度. 核縁の肥厚は目立たず, 核小体は小型でカリオソームとの鑑別が困難であり 神経芽腫の細胞像であった。後者の細胞は核縁肥厚 をみとめ核小体が目立ち, 腺癌の細胞像であった. 病理組織所見：N/C 比高く, 核クロマチン繊細な 小〜中型異型細胞の充実性增殖を主体とし, 小範囲 に腺管形成性增殖部が混在. 移行像を認めた. 前者 の細胞はS-100, Synaptophysin 陽性, 後者はCEA, EMA, keratin 陽性であった. 考察: 本例は神経芽 腫と腺癌の間に移行像があり, 腺癌への分化を示す 神経芽腫と診断した. 本例の神経芽腫の細胞像は核 クロマチンの凝集性にそしく，小細胞癌との鑑別を 要するが, 核クロマチンの增量にそしく鑑別可能と 考えた. 本例は鼻粘膜の神経内分䎵細胞よりの発生 が推測され，鼻腔の神経芽腫の発生母地が多様であ ることを表す所見と考えた。 


\section{3 悪性多形性腺腫の 2 例}

京都府立医科大学付属病院 病院病理部 ○由木るる美(CT), 岸川敏治(CT), 山口一美(CT), 渋谷有希子(CT), 吉村 亮(MT), 京谷憲子(MT), 平 井栄美(MD), 村田晋一(MD), 真崎 武(MD), 杉原 洋行(MD), 土橋康成(MD)

良性多形性腺腫がはじめにあって、長年月後、悪 性腫瘍が二次的に発生したと考えられる悪性多形腺 腫の 2 例を経験したので報告する。

く症例 $1>67$ 歳、女性。40年前に耳下腺腫瘍を摘 出された（詳細不明）。30年前頃より同部に腫瘍を 指摘されていたが放置していた。最近、腫瘍が増大 したため、摘出目的で本大学付属病院に入院した。 術前の穿刺細胞診では、粘液様物質を背景に、多数 の筋上皮細胞とともに、少数の核形不整や核クロマ チンの細顆粒状増量を示す異型細胞が認められた。 摘出された腫瘍は、重さ1.94kgの巨大腫瘍で、良性 多形腺腫の組織像の中に悪性筋上皮腫の所見が見ら れた。

<症例 $2>47$ 歳、女性。10年前より、右耳下腺部 腫瘤の診断を他院で受けていたが、本年になって急 激に増大しため、摘出目的で本大学付属病院に転院 した。術前の穿刺細胞診では、粘液様・軟骨様物質 を背景に、小型上皮細胞に混じって、核形不整、核 クロマチン増量、核小体著明な間質由来を思わせる 紡錘型の細胞が散在性にみとめられた。摘出された 腫瘍組織には、腺癌の組織像とともに軟骨肉腫や悪 性筋上皮腫を示唆する肉腫の所見が䜑められ、真性 悪性多形腺腫と診断された。

くまとめ>いわゆる悪性多形腺腫は、良性多形腺腫 の中に上皮性悪性腫瘍を伴うものが大部分であり、 今回報告したような肉腫成分（症例 1) あるいは癌 腫・肉腫の両方の成分（症例 2) を伴うことは極め て稀である。本 2 症例の術前穿刺細胞診では、多形 腺腫を示唆する細胞出現パターンの中に強い異型細 胞が散見されたが、悪性と判定することが躊躇され た。今回は、これらの腫瘍細胞の特徵を示すと共に、 当施設における良性多形性腺腫19症例の細胞像との 比較を合わせて報告する。
254 耳下腺に生じ細胞像が腺様囊胞癌と

きわめて類似した基底細胞腺癌の1例

東京歯科大学市川総合病院臨床検査部病理

○田中陽一 (DDS)、宜保一夫 (CT)、小野田雅美

(CT)、荒井義雄 (MT)

喠液腺悪性腫瘍は1992年の́WH0分類で、細かく分 類されたが、新たに追加された腫場に関しては、 その細胞像は明確な記載がなく、推定診断の際に 旧分類の既知の細胞像に頼る傾向は否めない。今 回我々が提示する症例も、FNACでは腺様豪胞癌 (ACC) と極めて類似した細胞像を呈し、鑑別が困難 であったことから、摘出材料を用いて検討した。 症例は53歳、女性で、小型類円形の濃染する核を もった細胞質の不明瞭な細胞が小さなclusterを形 成しており、一部では好塩基性のamorphousな物質 が単独にあるいは周囲に上記の細胞を伴って観察 された。Clusterの多くは辺縁不整で細胞境界は不 明であった。ACCに類似の所見であったため悪性腫 瘍に準じた摘出手術がなされた。組織学的には周 囲耳下腺組織に浸潤するtubular typeを辺縁に伴 つたsolid and membranous typeの基底細胞腺癌で あった。Touch smear材料を用い、細胞像と組織像 を検討すると、FNACでみられたmucous ball様の像 は、辺縁のtubular typeの部分が主に採取された 可能性が高く、特徴的な3つの細胞像のうち（口腔 病変の細胞診、永末書店), central core をもつ 細胞集団, 細胞境界の明瞭なtumor cell islandの 像が明瞭でなく、ACCとするには不十分であった。 


\section{5 尿細胞診標本作製法の検討}

宮城県立がんセンター

武田内科クリニック ${ }^{2)}, \mathrm{J} \mathrm{R}$ 仙台病院 ${ }^{3)}$ ○小室邦子 $(\mathrm{CT})^{11}$, 佐藤郁郎 $(M D)^{11}$, 武田鐵太郎 $(\mathrm{MD})^{2)}$ ，大沼真喜子 $(\mathrm{CT})^{1)}$ ，植木美幸 $(\mathrm{CT})^{11}$, 阿 部美和(CT $)^{1)}$, 桑原正明 $(M D)^{1)}$, 中村克宏 (MD $)^{1)}$, 立野紘雄 $(M D)^{1)}$ ，川村紀子(CT $)^{3)}$

尿細胞診では、標本作製過程における細胞の喪 失はある程度避けられないが、標本上の細胞数の 多寡は診断にとって重要な因子である。当施設で は、尿の検体処理に不归 法と $2 \%$ ホリエチレンングリコ一 几加 $95 \%$ I夕ノール固定液（又はサ卭液）による標本 作製法を併用しているが、両者の塗抹細胞量を検 討したので報告する。

【対象】細胞診依頼のあった自排尿のうち両方法 により同時に標本作製した89例である。

【方法】尿量 $50 \mathrm{ml}$ を 1500 回転 5 分遠心、上清を队ス ピレーターで吸引廃棄し後の沈洹について、

A法：一部〜 1/2量を 外州法にてM・G·G染色（A -1) とPapanicolaou染色 (A-2) 用に標本作製。

B法：残りの沈渣に $2 \%$ ホリエチレン゙リコーれ加95\%エタルー $n$ 固定液約 $3 \mathrm{ml}$ lを加えて覞挷し 30 分以上放置。再 度遠心し沈椬をすりあわせ又はビ・外の軸にて引 き延ばし完全に乾燥した後Pap. 染色施行。沈渣の 層が肉眼的に 2 層以上に分かれた例では、各層ご とに処理した。血性検体では固定前に溶血操作を 行った。

【検討事項】各方法および各層の標本上の10個以 上の細胞からなる集塊数を数えた（ ジト状の表層 扁平上皮細胞を除く）。

【結果】 A-1、A-2、B 法での集塊数の平均値は それぞれ4.4 個、2.5個、9.2個であった。ウ伅多 ンの符号つき順位和検定で、A-1はA-2に、B 法 はA法に比べ、危険率 $0.1 \%$ 以下で有意な細胞集 塊数の増加が認められた。

【まとめ】A法は、沈淔量の多い検体では採取部 分を誤ると観察すべき細胞を見落とす危険がある。 $\mathrm{B}$ 法は、変性や剩離が少なく多数の細胞の観察が 可能である。 $50 \mathrm{ml}$ 中の細胞成分を観察するのに少 量の固定液で充分であり経済的にも優れている。
256

自動プレスクリーニング装置 A U T O-CYTEの実用性について（第一報）

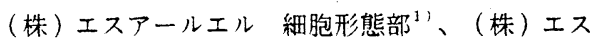
アールエル細胞病理研究所 ${ }^{2)}$ 、日本ロシュ株式会社 ${ }^{3}$

O内藤雅嗣 $(C T)^{11}$ 、赤木聡 $(C T)^{11}$ 、 木村光子 $(C T)^{11}$ 、高橋正宜 $(M D)^{21}$ 、 伊传正弘 ${ }^{3)}$

今回、自動プレスクリーヒング装置AUTO-CYTE （RIAS社 USA）を使用する機会を得たのでその実 用性について報告する。

本装㯰は陰性スライドを取り除くことを基本コン セプトに置き、Auto-scope及びコンピューターシス テムによりハードが構成されている。Auto-scopeは CYT0-RICH（RIAS社 USA）にて作製された標本を最 大40 0枚までセットすることができ、標本を 1 枚 ずつ鏡検ステージへ自動搬送、スキャンニングする ことができる。コンピューターシステムの制御によ りスライド上の塗抹部分をフィールドに切って、す ベての細胞をスキャンニングする。通常の細胞検査 士が用いる判断基準、及びコンピューター固有の特 定値を用いた判断基準を有したアルゴりズムを用い ることによって1スライドあたりもっとも異型度の 強い細胞を含んだ 120 個の単一細胞と、6視野の 細胞集塊を大画面で高解像度の画像として表示す る。モニター上で細胞の良悪を細胞検查士が判定 し、システムにインプットすることによりAUTO-CYTE による判定と比較することが可能となっている。

今回、AUTO-CYTEにより選別された異型細胞や、 感染症の細胞像が確実に画面表示されているかどう かに重点を置き検討を行ったので報告する。 
258 自動プレスクリーニング装置

A U T O - C Y T E の実用性について（第二報）

（株）エスアールエル細胞形態部 11

(株)エスアールエル細胞病理研究所 ${ }^{21}$

日本ロシュ株式会社 ${ }^{3)}$

O渡辺永二 (CT $)^{11}$, 内藤雅䏤 (CT $)^{11}$ 赤木聡 $(\mathrm{CT})^{11}$, 木村光子 $(\mathrm{CT})^{11}$

高橋正宜 $(M D)^{21}$, 伊佐正弘 ${ }^{31}$

前回我々は、細胞診自動塗抹染色装䈯 CYTO-RICH PREPARATION SYSTEM(以下 CY TO-RICH法)を用い、婦人科細胞診の有用 性、喀痰への応用について報告した。

今回、尿細胞診への応用について従来 法、サイトスピン法との比較検討を行っ たので報告する。

同一尿娭体(陰性例)を従来法、サイト スピン法、CYTO-RICH法の3 方法で塗抹 染色し、それぞれの塗抹細胞数と染色性 について検討した。また同一尿検体 (虏 症例)に対して上記の 3 方法で塗抹染色 し、それぞれの叙抹細胞数及び異型細胞 数をカウントしその結果より塗抹細胞数 に対する異型細胞数の割合についてもあ わせて検討を行った。

CYTO-RICH法は従来法、サイトスピン 法に比べて良好な染色性、均筫な分布を 示した。また、3方法において塗抹細胞 数に対する異型細胞数の割合についても 良好な結果が得られた。

細胞診検查は標本作製の優劣により成 績も左右される。特に従来法は手技の個 人差が問題になるが、CYTO-RICH法は標 準的な標本作製にとどまらず高品質な標 本作製が可能となり精度面の向上も見込 まれる。

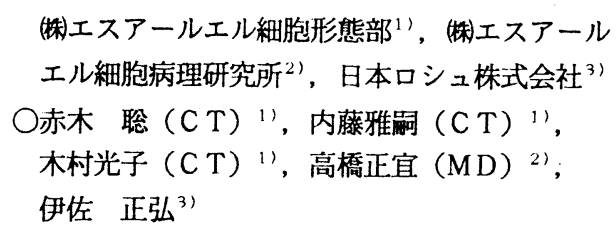

第一報において婦人科材料（子宮胵部・子宮頸 管・胵内容）を用い，自動プレスクリーニング装 置A UTO-CYTE（R I A S 社, USA）が どのように標本をスキャンニングし画面上に表示 するかの概略とこの装置の目的について報告した。 又、A U T O-CYTEにて異型細胞や、感染症 症例が確実に画面表示されているかに重点を置き 検討したことについても報告した。

今回我々は、A U T O - C Y T Eが標本上の異 型細胞を確実にp i c k u pできるかどうか、 本装置の再現性や染色性の差による影響はどうか について検討したので報告する。 細胞診自動塗抹装置 C Y T O-R I C H (R I A S 社, U S A) で作製した婦人科慓本の内、数 名の細胞検査士がスクリーニングし明らかな異型 細胞を認めた 50 症例を用いA U T O - C Y T E が異型細胞を確実に p i c k u pするかの確認 をした。それと共に同症例を用い複数回 A U T O ーC Y T Eにプレスクリーニングさせ再見性につ いての検討も行った。又、異型細胞が出現した同 一患者の標本を用いCY T O-R I C Hで染色性 を变え複数枚作製し A U T O - C Y T E が異型細 胞を確実にp i c k u pするかの检討も加えて 行ったので報告する。 
259 穿刺液の塗抹標本作製法における 細胞分布について

愛知県厚生連安城更生病院臨床検査技術科 ${ }^{11}$ 同病理科 ${ }^{2)}$, 恒吉クリニック ${ }^{31}$

$\bigcirc$ 稲垣清剛(CT) ${ }^{1)}$, 成田 淳 $(\mathrm{CT})^{1)}$, 梅村寿男 (CT) ${ }^{11}$, 石川一博 (CT $)^{11}$, 太田敏夫 (CT $)^{11}$, 小林寿男 $(\mathrm{CT})^{1)}$, 早川清順 $(\mathrm{MD})^{2)}$, 柏田直俊 $(\mathrm{MD})^{3)}$

[目的］胸・腹水など穿刺液の塗抹標本作製法 では、手技によって細胞分布に不均等が生じる が, 出現細胞をすべて同定する細胞種類検査で は，その成績に影響を与えかねない。このたび， すり合わせ法と引きガラス法について標本上の 細胞分布状態を検討したので報告する。

[方法] 材料は胸水 49 検体, 腹水 30 検体, 心囊 水3検体の計 82 検体を用いた。遠心後, 各検体 をすり合わせ法と引きガラス法で塗抹し, MG染 色を施して細胞分類を行った。すり合わせ法は 全体を, 引きガラス法では引き終わり, 辺縁, 中間の各部位から各々出現細胞を $300 〜 500$ 個同 定し百分率を求めた。

[成績] リンパ球：平均出現率はすり合わせ 46 \%,引き終わり $32 \%$, 辺縁 $40 \%$, 中間 $52 \%, S D$ は 7. 43 , CVは17.6\%であった。以下同様に主な細胞の数 值を列挙すると好中球：19\%，18\%，19\%，21\%, SD 1.10, CV 5.7\%。組織球：17\%，27\%，22\%, $12 \%$ ，SD 5.79，CV 29.1\%。佊細胞：6\%，9\%， $8 \%, 3 \%$, SD 2.37, CV 36. $4 \%$ 。上皮性腫場細胞: $15 \%, 28 \%, 17 \%, 10 \%$, SD $6.78, \mathrm{CV} 39.2 \%$ 。非 上皮性腫瘍細胞: $51 \% ， 55 \% ， 46 \% ， 47 \% ， S D 3.57$ CV 7.2\%であった。

[まとめ]大型細胞すなわち組織球や中皮細胞, 上皮性腫瘍細胞は引き終わりや辺縁に集まりや すく, 今回の成績でも立証された。一方, 比較 的均等分布したのは好中球や単球, 白血病及び リンパ腫細胞であった。腫瘍細胞の意義は 1 標 本あたりの出現率と無関係だが, 経過を追う場 合や各細胞を\%で報告する細胞種類唡査などで は, 観察部位を均等にすることが重要である。
260 濃度共起行列とランレングス行列を用 いた細胞核クロマチンパターンの定量化

京都府立(医科大学・病院病理部1)、同第一病理2)、

大分医科大学・第一病理 3 )

○村田晋一 (MD) 1,2), 寺内邦彦2)、古谷昌則2)、

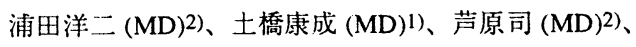
山下裕人3)

[目的］私達が研究してきたイメージサイトメト リーは、デジタル画像処理法にテクスチャ解析法を 導入し、細胞内物質の分布パターンを定量的に解析 する手法である。今回、この手法を甲状腺細胞診標 本に応用し、核クロマチンパターンの数值化を試み た。［材料·方法］対象は、腺腫様過形成 8例、滤 胞腺腫 11例、乳頭癌 9例、滤胞癌 11 例の型通り に固定・パパニコロウ染色を施した甲状腺の穿刺細 胞診材料である。各症例 100 個、計3900個の細胞の 核像をCCDカメラで撮像・デジタル化し、ランバー ト・ベール変換の後、画像画素データとした。この 画像画素データをもとに濃度共起行列とランレング ス行列を作成してテクスチャ解析を行い、計17種類 の統計量を抽出した。[結果・考察］17種類の統計 量の中に細胞核の大きさや形状に影響さるためにク ロマチンパターンの正確な評価ができないものが あった。それらを除いた10種類の統計量を用いた 良・悪性症例の比較では、滤胞腺腫と乳頭癌の間で クロマチンの濃淡を表す統計量に差が見られた。濾 胞腺腫と滤胞癌の間では、一つひとつの細胞核のク ロマチン分布に差はなく、むしろ細胞間のクロマチ ン分布の違いに差が認められた。以上より、甲状腺 腫瘍細胞診に打けるテクスチヤ解析の応用は、従 来、パパニコロウ染色で主観的に診断されてきた核 クロマチン分布パターンの客観的な評価を可能にす るものと考えられた。 
261 静止画像伝送システム(テレサイト ロジー）に上る術中迅速細胞診

○安達博信 (MD)、井藤久雄 $(\mathrm{MD})$ 、神田美津 子 $(\mathrm{CT}) *$ 、野津元秀 $(\mathrm{MT}) *$ 、村上ルミ $(\mathrm{MT})$ $*$ 、立石英男 $(\mathrm{MT}) *$ 鳥取大学医学部一病理、 *松江市立病院検查科

（目的）我々の教室と松江市立病院で1993年7月 より静止画像伝送システムを用いて術中迅速晾 断を開始し、1995年11月までに136例の診断を行 った。現在、正診率は $94.8 \%$ であ。このシステ ムによる迅速診断の補助的手段として迅速細胞 診を試みたのでその結果を報告する。(万法) シ ステムは第35回臨床細胞学会で報告したものと 同様で,ISDN回線を用いている。迅速診断に提出 された材料の择印細胞診標本を作製し、DiffQuick染色を行なう。CT及びMTが検鏡し、問題 となる細胞を2-5画像鳥大一病理に伝送する。指 導医がこの細胞像を検討し術中迅速診断の補助 とする。その後、作製された迅速標本の伝送画像 で最終診断を行い手術場への画像伝送と同時に 結果を報告する。(結果) 細胞診標本の作製には 3-5分必要であった。1995年11月までに迅速細狍 診を28症例、32欌器に行なった。内訳は乳腺 10 例、甲状腺 - 肺 - 胆囊各 5 例、脳 2 例、その他5例

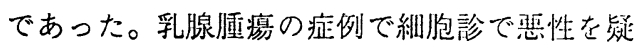
い、組織で悪性と診断できなかった湅結橴本を媣 切りし、癌と診断した症例が1例あった。䛊診症 例は乳腺2例、膵1例、副粲1例で正診率は $87.5 \%$ となった。(まとめ) 伝送画桦による迅速細胞診 は遠隔術中組織診断に有用な補助手段であるが 以下の問題点がある。誤診の原因の一つとして、 乾燥固定のための胞体、核とも大型化があり、迅 速細胞診の伝送画像になれる必妿がある。又、迅 速組織標本作製と同時に細胞標本の作製、検鏡、 伝送を行う為に、技仰の労働量の増加があり、今 後これらの点も含めてさらに検討する必珐があ る。

\section{2 日常業務に組み込む試み \\ 顕微鏡画像ファイリングを}

京都府立医科大学 病院病理部

○真崎 武 $(\mathrm{MD})$, 岸川敏治 $(\mathrm{CT})$, 山口一美

$(\mathrm{CT})$, 由木はる美 $(\mathrm{CT})$, 渋谷有希子 $(\mathrm{CT})$, 吉村 亮(MT), 京谷憲子(MT), 磯島喜孝

(MT)，村田晋一(MD)，杉原洋行 (MD)，

土橋康成 $(\mathrm{MD})$

京都府立与謝の海病院 病理検査室

藤田幹雄 $(\mathrm{CT})$

私たちは、1993 年にマッキントッシ 工 $(\mathrm{Mac})$ の部内ネットワーク (LAN) 上に病理 業務システムを構築し、病理画像を電子フ アイルとして扱うことを試みてきた。今回、 顕微鏡画像の電子ファイル化を、日常業務 に組み迈んで運用することに成功した。

方法：複数の顕微鏡で、病理診断時に写 真を撮影する。症例デー夕は、その場で表 計算ソフトに入力し、そのファイルはLAN上 で共有する。写真は秘書がスライドスキャ ナで読み取り、JPEG圧縮後、共有ファイル とする。

この結果、診断業務中に、重要な顕微鏡 画像をファイルでき、どのMacからも検索と 参照が可能になった。

本年、部内LANが、学内LANとインターネ ットに接続されたため、画像は他教室から も参照可能となり、WWホームページでも一 部のライブラリを公開した

(http://mac02.cl inpath. kpu-m.ac. jp/)。 また、一部の画像はパソコン通信を利用 して、与謝の海病院へ伝送し、症例検討を 行なった。

（結語）画像データベースを用いず単純な 画像ファイリングにとどめ、秘書の協力を 得ることで、画像ファイルの運用が可能に なり、多方面に活用できた。 


\section{3}

RT-PCR法を用いた体腔液緗胞診材料 からの CEA mRNA 検出系の確立

杤木県立がんセンター研究検査部

○井村 鍫二 (MD) , 古沢 三枝 (MT)

菊池 史江 (MT), 谷 祥子 (MT), 松村 京子

(MT)，大山茂 (MT)，鈴木 兼一 (CT)

圓谷 勝 (CT), 岩谷 靖央 (CT)

五十嵐誠治 (MD), 星 和栄 (MD)

【目的】RT-PCR法は細胞内で微量に発現している mRNAを検出する優れた方法である。この方法を 用いて、種々の検体から癌細胞のみに発現して いる $\mathrm{mRNA}$ を捕捉することは、これら検体内に癌 細胞が存在することと同義であると考えられて いる。今回、我々は、nested RT-PCR法を用いて、 Carcinoembryonic antigen:CEAをコードする mRNAを体腔液細胞診検体から検出する検討を試 みたので報告する。

【材料と方法】基礎的検討材料として、CEAの産 生が確認されている肺癌由来細胞株A549 と大腸 癌細胞株WiDr の培養紐胞株を用いた。臨床材料 としては、非悪性腫瘍あるいは担癌患者から採 取された胸、腹水ないしは術中体腔洗浄液であ る。これら材料から細胞成分を回収後、 DYNABEADS 0ligo (dt) 25 (Dynal Inc.) により mRNAを抽出し、逆転写反応により cDNAを合成し た。更に、これを鋳型とし、CEAの目的とするイ ントロン部分を含むように設定されたプライ マーを用い、nested-PCRにより当該部分を増幅 した。これら PCR 反応産物をアガロース電気泳 動、エチジュームブロマイド染色後、目的とす るバンドが認められたものを陽性と判断した。 【結果及び結語】培養細胞株では、何れも高い発 現でCEA mRNAを検出した。一方、臨床材料では、 非悪性腫瘍患者からは検出されず、担癌患者か らの胸腹水において有意な発現を示す症例を経 験した。本法は、細胞診検査の補助手段として、 従来加ら免疫組織学的検討に加え、高感度測 定系として意義があるものと考えられた。
264 良・悪性梱胞におけるAgNOR 染色、 FISHおよひ ISH法による核小体形成部位の锤察

杏林大学保健学部湅胞祅断学教室 ${ }^{11}$ 、同病理学教 室 ${ }^{21} 、 川\left(\right.$ 奇製鉄千葉病院病理 ${ }^{31}$

O椎名军雄 $(\mathrm{CT})^{1)}$ 、郡 秀一 $(\mathrm{CT})^{1)}$ 、尾野 绿 $(M T)^{1)}$ 、飯島淳子(CT $)^{11}$ 、大河戸光章 $(C T)^{2) 、}$ 畠山良紀 $(\mathrm{CT})^{3)}$ 、福网 貢(CT $)^{3)}$

【はじめに】正常ヒトrRNA道层子はDおよび群 染色体短㹸上にあり、これが核小体形成部位(nucleolar organizer region: NOR)と呼ばれるもの で、ポリメラーゼ、によって枟写され、リボゾー 厶を合成する。このNOR には銀に粯和性のある蛋 白が存在するため、銀染色によってその部位を確 認することが可能であり、それがAgNOR 染色とし て一般に普及している。また、核小体中にも銀に 䙿和性のある蛋白が存在し、特にC23（ヌクレオ リン) はrRNA遺层子の枟写調節、rRNA成熟の調整、

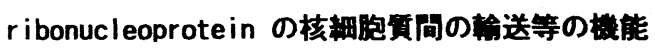
が知られている。我々はAgNOR 染色および抗ヌク

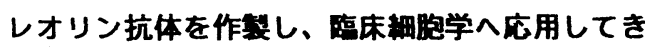
た。今回は組模およひ紐胞でAgNOR 染色、FISHお よひISH 法による acrocentric chromosome $\beta$ satellite の局在性を光影的に雉察し、丙者の比 較と診断的意意について梌索したので報告する。 【研究材料および方法】AgNOR の検出、FISHおよ ひISH 法にはホルマリン固定パラフィン切片と垔 抹後速やかに醀メタノールおよび95\%エタノー ルで湿固定したものと舴嬠後固定した标本を使用 した。FISHおよひISH 法には Oncor社筫acrocentric chromosome $\beta$-satellite $(13,14,15,21,22)$

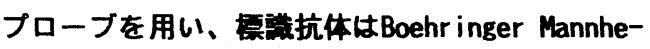
i社製を使用した。

【結果】核小体著明な食道扁平上皮焉㑑のパラフ イン切片における ISH法で、陽性シグナルは核小 体、特に核小体周辺部分に小柆子として出現し、 AgNOR 染色の局在性と異なる所見を呈した。また、 その数は梱胞间でかなりの相違が锥寮された。 
265 共焦点レーザー走查型顕微鏡を用い た薬剤の細胞内分布の観察

北海道大学医学部第一内科

O磯部 宏 $(M D)$ 、得地令郎( $M D)$ 、岡本佳裕 $(M D)$ 、 上村明 $(\mathrm{MD})$ 、尾島裕和 $(\mathrm{MD})$ 、石田卓 $(\mathrm{MD})$ 、

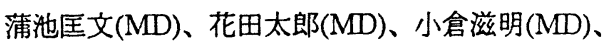
川上義和 $(\mathrm{MD})$

目的：共焦点レーザー走査型䫓微鏡を用いて、 抗癌剤の効果を細胞診で判定することの可否を検 討した。

対象と方法：薬剤は Doxorubicin ないし THPadriamycinの自家蛍光を有する anthracyclins 系 を用いた。癌性胸膜炎患者の胸腔内に薬剤を局所 投与し、投与後に採取した癌細胞に対して共焦点 レーザー走査型影微鏡を用いて、薬剤の細胞内分 布パターンを観察した。

結果: 薬剂は核内、核膜周囲、胞体内小器官に 分布し、症例により分布パターンに差異があった。 なお共焦点レーザー走査型顕微鏡の利用により、 核内分布と核膜分布とを区別できた。核内にびま ん性分布を示す症例が局所療法で著効を示した。

結論：共焦点レーザー走査型顕微鏡の利用によ り、自家蛍光薬剤の細胞内分布を細胞診断学の一 つとして観察できた。また抗癌剤の効果の一部は 薬剤の細胞内分布が関与しており、細胞診でこれ を評価することは意義あることと考えられた。
266 単一レクチンと混合レクチンにおける 結合様式の比較ーパラフィン切片における検討一

杏林大学保健学部梱胞診盺学教室 ${ }^{11}$ 、同保健学部 解剖学教室 ${ }^{2)}$ 、同医学部第二解剖学教室 ${ }^{31}$ O飯島淳子 $(\mathrm{CT})^{11}$ 、椎名毒雄 $(\mathrm{CT})^{11}$ 、西山文明 $(\mathrm{Ph} \mathrm{D})^{2)}$ 、平野 寛 $(\text { MD })^{3)}$

【目的】我々はこれまでレク，チンの組機化学を梱 胞診に応用し、子宮内膜や乳腺においてDAB, PNA, SBA, HPA, GS-1, VWL, BPA, MPA等が良・悪性佣胞でそ の結合パターンが異なることから、些別猃断にお ける有効性を報告してきた。また一連の検索を通 し、同一裙鎖を諗愎するレクチンにおいてもその 結合性にかなりの相異が見られることから、一度 に数種のレクチンを検索する必要性が明らかにな

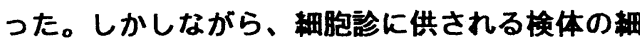
胞量には限界があるため、少ない標本でより効果 的なレクチンの選択が本法を応用するための条件 と思われた。

そこで今回は単一レクチン染色、レクチンの二 重染色および混ぜ合わせた混合レクチン染色を行 い、混合レクチンの有効性と問題点について検討 したので報告する。

【材料・方法】材料はホルマリン固定パラフィン 切片、レクチンはVectorおよびEY社製、虽出は peroxidaseおよひalkaline phosphatase 標丵streptavidin (DAKO社製) を使用し、発色はdiaminobentizine とfast red (Biogenex社製 immunostaining kit）を使用した。

【結果】混合レクチンでは単一染色で得られた個 々の反応が重複した所見を示した。また認讙姞顉 が異なるレクチンの混合においても同样の成棈が 得られ、混合レクチンの有効性が確認された。一 方、二重染色では一回目の反応は単一染色と同じ 所見を呈したが、二回目に本来陰性の部位に誤陽 性反応が出現し、課題が残つた。今後隔床診断に 有効なレクチンの蒀合せを検討したい。 
267 頭頝部扁平上皮癌の放射線療法によ るアポトーシスの出現

大阪厚生年金病院病理唡査科, 耳鼻咽喉科*

$\bigcirc$ 小林 晏(MD), 山崎 大(MD), 高田直樹(CT), 豊岡昭宏(CT)，馬場哲郎(CT)，坂井邦彦(CT)， 藤井和子(MT)， ${ }^{*}$ 仙波 治(MD)

1971年Kerrらが形態的にネクローシスと区別さ れる細胞死があることを報告し，これをアポト一 シスと名付けた。アポトーシスを起こした細胞は 核膜に沿って核クロマチンが疑集すると共に細胞 は断片化しアポトーシス小体を形成する。この細 胞片は食食消化されるため炎症は起こらない。 1980年Wy 11 ieらは断片化した細胞のD NA 抽出 しアガロースゲル電気泳動にかけてみると $185 \mathrm{bp}$ の整数倍の DNA-fragmentの ladder（梯子状）パ ターンが認められることを報告した。最近では in situ hybridization を用い, 光顕でアポトー シスの検出が可能になった。

頭頝部扁平上皮癌の放射線療法によって誘発さ れるアポトーシスを腫瘍の捺印標本を用いて検討 した。腫瘍細胞は放射線照射によって種々の変化 きたす。変化が進むと核の濃縮・融解が起こり細 胞が死滅する。核・細胞質共に最初は腫大するの でN/C比の増大はみられない。照射後時間が経 つとシート状の異型細胞集団が出現する。これら 放射線照射をうけた捺印パパニコロー標本を脱色 し同じ標本について In Situ Cell Death Detection Kit, POP(ベーリンガーマン八イム社)によ り染色しアポトーシスに陥った細胞を観察した。 放射線によるあまりに強い形態的変化をきたし崩 壊・壊死に陥った細胞ではアポトーシスはみられ ないか種々の放射線効果を示した細胞ではその多 くが陽性であった。しかし, 染色性の強度之形態 的変化とは必ずしも相関せず，両者の所見を比較

・娭討し, 文献的考察を加味して若干の知見を得 たので報告する。
268

胸部腫瘍に施行された通電療法によ

る細胞变化

東京医科大学霞 $ヶ$ 浦病院呼吸器科 ${ }^{1)}$, 同病院病理 部 ${ }^{2)}$, 東京医科大学病院外科第一講座 ${ }^{31}$

O米山一男 $(M D)^{11}$, 魏 柏栄 $(M D)^{11}$, 司馬清輝 (MD) ${ }^{11}$, 中嶋 隆 (MD) ${ }^{11}$, 大塚光一 $(C T)^{2)}$, 福島良明 $(C T)^{2)}$, 草間 博 $(M D)^{2)}$, 加藤治文 $(M D)^{3)}$

[目的］経皮的針生検の手技を用いて、胸部腫瑒 に対し電極を刺入し、新規開発した直流通電機器 を用いて通電療法を行う。腫場の退縮傾向の有無 と細胞変化を検討する。有効の場合は、通電する 最適電気量と腫瘍容積の関係を検討する。

[材料と方法] 肺腫瘍に対する経皮的針生検の要 領で16G．テフロン製血管留置針を $1 \%$ キシロカ イン局所麻酔下に腫㾴辺縁まで刺入する。0.3mm のウレタン・コーティングした白金電極を捚入し、 最初に設定した電気量を通電した。通電前後に、 針吸引生検も行い、細胞を採取した。細胞標本を 観察し、通電量との関係を調へた。

[結果及び考察］通電により、細胞質は均質で境 界不明瞭となり、核は膨化、変性し、あるいは消 失する。しかし、効果の少ない部位では、腫瘍細 胞が散在性に残存していた。これらの変化は、in vitroの実験の報告ではapoptosisとされている が、今回の細胞標本には、その典型的な核破砕の 所見が認められず、さらに電気量を細かく分けて 細胞の变化をみる必要があると思われた。 
269 肺門部早期肺癌の $\mathrm{p} 53, \mathrm{bcl}-2$ 免度組織染色と細胞像

大阪府立羽史野病院 病理診断科 ${ }^{11}$ 第二内科 ${ }^{21}$ O細野芳美 (CT $)^{11}$ 浅井浩次 (CT $)^{11}$ 相野美栄子(CT ${ }^{11}$ 横山朝夫(CT $)^{11}$ 福田春樹(MD) ${ }^{11}$ 菊井正紀 (MD) ${ }^{11}$ 小宮武文 $(M D)^{21}$ 平島智徳 $(M D)^{21}$ 楠 洋子 $(M D)^{2)}$

（目的）癌遺伝子として発見されたbcl-2 はリン 八球の細胞死を㧕制する活性をもつと言われ、ア ポトーシス関連因子として注目されている。又、 癌抑制遺伝子 $\mathrm{p} 53$ は細胞周期を抑制的に制御する と考えられ、アポトーシスと p53、その他の遺伝 子発現との関係が明らかにされつつある。前回本 学会において、肺非小細胞癌 110 例の $\mathrm{p} 53$ 発現と 細胞像について報告したが、今回対象を変え、bc 1-2、p53 の発現と細胞像について検討したので 報告する。

（対象と方法）当院で肺門部早期扁平上皮癌と診 断され、PDT を施行した 21 例、及び扁平上皮化 生組織と診断された 18 例を対象とした。材料は 気管支鏡下生検、サッカ材料を用いた。組織は脱 パラフィン後マイクロウェーブ処理、DAK0社LSAB kit で bcl-2、p53 の免度組織染色を行った。 サッカ材料はパパニコロウ染色後核、クロマチン 、核小体等を観察した。又、早期癌例のパラフィ ンブロックから DNAを抽出、PCR-SSCP法とdirect sequence法で p53遺伝子異常を調べた。

(結果) 免疫組織染色で早期癌 21 例中p53 陽性 12(57X) bcl-2 陽性 7(33X)、扁平上皮化生18例 中 p53陽性 2(11X) bcl-2 陽性 2(11X)。細胞像 は、p53 bcl-2 共に陰性例 7(33\%) では核小型〜 中型、クロマチン微細、核小体 1 3 個。共に陽 性例 5(24X) では核の大小不同、クロマチン粗で 濃染の傾向が見られた。p53 遺伝子異常は、PCR 可能であった 9例中 $4(44 X)$ に認めた。

免疫組織染色結果、遺伝子異常と予後の関連に ついては、分析中である。
270 甲状腺疾患におけるurokinaseの免 疫細胞学的検討

医療法人野口記念会野口病院 研究検査科病理 丸田淳子 ( C T )

\section{【緒言】}

細胞外マトリックスを破壊して癌細胞が浸潤し てゆく際に産生するplasminogen activator、特 にurokinase(u-PA)は、種々の癌で増殖能や転移

と関連するいわれている。今回、甲状腺疾患にお いて免疫染色を行いその有用性について検討した ので報告する。

\section{【材料・方法】}

当院で手術摘出された乳頭癌31例、濾胞癌3例、 滤胞腺腫21例、腺腫様甲状腺腫24例の捺印標本を 対象とし、SAB法にてu-PA染色を施行した。染色 結果と年齢、性別、組織型、腫揚径、リンパ節転 移との関係をみた。

\section{【結果】}

乳頭癌および虑胞癌の陽性率は、 $71.0 \%$ (31例 中22例)、 $66.7 \%$ (3例中2例)であり、濾胞腺腫、 腺腫様甲状腺腫の $19.0 \% 、 12.5 \%$ に比べ有意に高 かった $(\mathrm{P}<0.001)$ 。年齢、性別との関係は見られ なかった。

乳頭癌陽性例での平均腫瘍径は2.5(s.e. :0.3) $\mathrm{cm}$ であり、陰性例の1.6(s.e.:0.1) cmに比べ大き かった $(\mathrm{P}=0.07)$ 。滤胞腺腫でも同様に陽性例、

陰性例では、3.6(s.e. :0.6) cm、2.9(s.e.:0.3) cm であった。

リンパ節郭清を行っている癌については、陽性 例のうち $90.5 \%$ (21例中19例)に転移がみられ、陰 性例では77.8\%(9例中7例)であった。

【結語】

urokinaseは、甲状腺分化癌で高率に陽性とな るがリンパ節転移との関連はあまり見られなかっ た。 
271 胸腺への分化が示唆された特異な甲状 腺癌 (C A S T L E) の一例

NTT東北病院臨床検查科" ${ }^{1}$, 同外科 ${ }^{21}$ 国立仙台病院臨床検查科 ${ }^{31}$

○亀 セツ子(CT) ${ }^{11}$, 佐藤三枝子(CT) ${ }^{11}$ 渡辺至 $(M D)^{2)}$, 手塚 文明 $(M D)^{3)}$

甲状腺穿刺吸引細胞診にて、悪性と診断、手術 摘出後の病理診断にて、胸腺への分化が示唆され た特異な甲状腺癌（CＡＳTLE）の一例を経験 したので報告する。

【症例】 32 才女性。既往歴：20才の時、家族 性ポリポーシスのため結腸全摘。現病歴: 平成 6 年 11 月前頸部腫塯にて当院受診、甲状腺機能を 含めた生化学検査およびその他の諸検査成績では いずれも特記すべき所見はなかった。穿刺細胞診 の所見から、甲状腺㿥が疑われ、12月8日甲状 腺全摘術が施行された。

【細胞所見】背景は血性で壊死を伴い、腫瘍細胞 はN / C 比大で、不規則な重積性樹枝状集塊およ び散在性として出現していた。核は比較的小型で、 類円〜楕円および紡鍾形、核の大小不同は軽度で、 全体的に均一性であった。クロマチンは微細〜細 顆粒状、核小体 1 〜数個あるが目立たなかった。 又、うず巻き状の不明小体が散見された。

【肉眼・組織所見】腫瘍は、甲状腺左葉下極から 右葉に進展、 $4.5 \times 3.5 \mathrm{~cm}$ 死白色で硬いが被膜外へ の浸潤はなかった。割面で壊死、ヒアリン化、石 灰化が著しかったが、出血や慗腫形成は見られな かった。腫瘍は、濃染する円形ないし紡鍾形の核 を有する未分化な上皮性細胞から成り、浸潤、核 分裂、壊死が著明であった。一部に小球状ヒアリ ン化を示す細胞が少なからず認められた。Grimel ius 陰性、抗力ルシトニン陰性、アミロイドも証 明されなかった。電顕によりHassal小体類似の構 造が認められ、また腫瘍組織からThymocinが抽出 され、胸腺への分化が示唆された。
272 当院における甲状腺エコー下穿刺吸 引細胞診の現状と分析

山口県立中央病院耳鼻咽㮢科 ${ }^{12}$ 、病理科 ${ }^{2)}$

○日吉正明 (MD) ${ }^{12}$, 緒方正彦 (MD) ${ }^{1}$, 新田暢圭 $(\mathrm{MD})^{12}$, 橴田秀美 $(\mathrm{CT})^{22}$, 金子真由美 $(\mathrm{CT})^{2)}$, 亀 井敏昭 $(\mathrm{MD})^{2)}$

【はじめに】甲状腺腫瘍性疾患の診断には超音 波エコーガイド下穿刺吸引細胞診 (以下USカイ ド下FNA と略）が有用である。今回我々は過去 2年3カ月間のUSガイド下FNAの施行にあたり 穿刺針の太さ、穿刺目標の検討および穿刺吸引 の確実性について検討したので報告する。

【方法および検討対象】対象は平成5年9月より 平成 7年 11 月までにUSガイド下FNA を実施し た 149 例（17.7\%、全エコー843例）である。全 期間を穿刺針 $23 \mathrm{G}$ および $22 \mathrm{G}$ の時期 (第一期)、 $21 \mathrm{G}$ に変更した時期 (第二期)、穿刺目標を内容 液から壁ほかの実質性構造に変更した時期（第 三期）および細胞検查士立ち会いのもと穿刺直 後に採取物を染色し確認した時期 (第四期) に分 け検討した。

【結果】判定結果は検討期間全体で、検体不良7 例、陰性 111 例、疑陽性 11 例および陽性 20 例で あった。第一期は22例にUSカイド下FNAを施 行、正診率は $77.3 \%$ であった。第二期は 14 例に 施行、正診率は $85.7 \%$ であった。第三期は 27 例 に施行、正診率は $88.9 \%$ であった。第四期は 86 例に施行、正診率は $90.5 \%$ であった。

【結語】USガイド下FNAを2 年3カ月間に 149 例に施行した。全期間を四期に分け検討した結 果 : (1)穿刺針はPTC 針が使いやすく、21G が最 適であった。(2)穿刺目標は内容液ではなく壁な どの実質性構造に変更する事により正診率が改 善した。(3)細胞検查士立ち会いのもと穿刺直後 に採取物を染色し確認する事により検体不良を なくすことができた。以上の結論を得た。 
273 髄様癌細胞診におけるアミロイド物塤 の検討

東京医科大学外科 ${ }^{1}$ 、都立大塚病院外科 ${ }^{2}$ 、伊藤

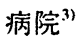

$\bigcirc$ 岩㴊 裕 $(M D)^{1)}$ 、鳥屋城男 $(M D)^{2)}$ 、简井英光 $(\mathrm{MD})^{3)} 、$ 中嶋英治 $(\mathrm{MD})^{1)}$ 、伊藤國彦 $(\mathrm{MD})^{3}$ )、平野隆

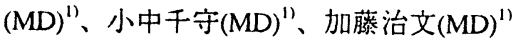

䯣様癌は間質にアミロイド沈着を認め、穿刺吸 引細胞診標本中にも検出されてくる。しかし、細 胞診で認められるのは約半数としている論文が多 く、コロイドとの鑑別も困難なことがある。そこ で、今回我々は自験例の細胞標本を用いてアミロ イドの出現状況およびその鑑別診断法について検 討した。

対象は1986年から94年末までに病理組織学的に 䯣様癌と診断された39例のうち術前穿刺吸引細胞 診検査も受けていた35例とした。病理組織標本で アミロイドの確認された症例は35例中 24 例、 66.7\%であった。一方、穿刺吸引細胞診標本でア ミロイド様物質のみられたのは35例中16例、

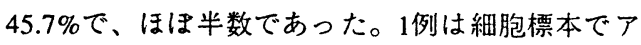
ミロイドを疑ったが、組織標本ではアミロイドは 認められずコロイドであった。

アミロイドの証明はコンゴー赤染色を行い偏光 を確認する必要があるが、我々はパパニコロー染 色標本のままでも偏光を認める例の存在するのを 確認し、全体で16例中13例にみられた。偏光の認 められなかった例ではアミロイド様物質がごく僅 かに採取されていた例であった。細胞診標本をコ ンゴー赤染色したところ同部位に偏光を認め、ア ミロイドであることが証明できた。一方、コロイ ドは全く偏光を認めなかった。以上の結果は、パ パニコロー染色標本でのアミロイドの鑑別診断に 有用であると考えられた。
274

細胞診における滤胞癌の現状と問題点

について

北里大学病院病理部細胞診" 、同医療衛生学部臨 床細胞学 ${ }^{21} 、$ 同医学部病理 ${ }^{31} 、$ 同外科 ${ }^{4)}$ 、同産婦 人科 ${ }^{51}$

O横山 大(CT $)^{11}$ 、大野英治 $(\mathrm{CT}, \mathrm{PhD})^{2)}$ 、服部 学 $(\mathrm{CT})^{21}$ 、小林明子 $(\mathrm{CT})^{11}$ 、豊永真澄 $(\mathrm{CT})^{11}$ 、 柿沼廣邦 $(C T)^{11}$ 、岩渕啓一 $(\text { MD })^{31}$ 、大部 誠 $(\mathbf{I D})^{3)} 、$ 刑部東治 $(\mathbf{M D})^{4)}$ 、藏本博行 $(\mathbf{M D})^{51}$ 、

亀谷 徹 $(\text { ID })^{31}$

甲状腺疾患の細胞診において、今なお最重要課 題とされているものは濾胞状腫瘍であろう。今回 我々は 7 年前に当院で作製し、第28回日本臨床細 胞学会秋期大会で発表した、港胞癌の診断基準を

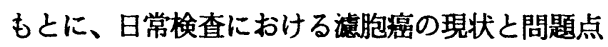
について検討した。

【対象】1989年 5 月から1995年11月までの過去 6 年半に渡る甲状腺穿刺吸引細胞診で、かつ手術標 本にて病理組織学的に滤胞癌と猃断された 13 例に ついて検討した。

【結果】陽性 3 例（23\%）、疑陽性 4例（31\%）、 疑陽性以上のpick up 率は、54\%であり陰性は 6 例 (46\%) であった。

【結語】滤胞状腫瘍の穿刺吸引細胞診は、現段階 では未だ問題があるものの滤胞湟でも、細胞診で 診断できる症例が存在すると思われた。また細胞 診にて疑陽性とした 4 例の中に、1例ではあるが 榩胞腺腫と診断された組織標本を再検討した結果、 一部被膜浸潤が確認された症例も存在し、細胞診 の有用性が確認される例もあり、細胞診にて濾胞 癌を疑うような例の場合、より慎重な精查が望ま れる事が示唆された。他の問題点についても、組 織学的考察を加え報告する。 
275 尿沈渣用検体を使った細胞晾標本作製 法とその有用性 一尿沈渣検查と細胞診の連携一

吳共済病院臨床病理科 ${ }^{21}$, 中央検査科 2 ○山本津由子 $(\mathrm{CT})^{1)}$ ，青木 潤(CT ${ }^{12}$ ， 平松ふみ子 $(\text { MT })^{2)}$, 洲脇美智子 $(\text { MT })^{2)}$, 佐々木なおみ(KD) ${ }^{12}$ ， 谷山清己(MD) $)^{21}$

【はしめに】我々は尿細胞牾用の固定液を改良し， 容易に良好な標本が作製できる尿標本作製法を報 告した（吳共済病院法）。この方法で尿沈渣検查 の残りの検体を使って細㽛診を行なったところ， 大変効率が良く有用であったので報告する.

【対象，方法】1994年10月～1995年10月の尿沈 渣検查検体のうち異型細胞 (+)とした検体と, 剥 離した移行上皮細胞の多い検体を対象とした，尿 沈渣検查はSternheimer染色で行い, 対象とした 検体の残尿に，第 1 固定液(50\%エタノーNにアジ化リーダ を0.2x，EDTA-3Kを0.8x添加）を直ちに加え，1時 間以上固定した。一度水洗いした沈渣に第 2 固定 液（95\%价プロピ を一滴加え，シランコート済スライドグラスに玨 抹した. Papanicolaou染色後, 尿沈渣担当技師之 ともに鏡検した，疑陽性以上の検体については主 治医に報告して細胞彰伝票を提出してもらい，細 胞部断を行った。

【成績】尿沈渣検查検体は66,447件で，うち細胞 診標本を作製したのは204件(156症例)0.31\%であ った. 尿沈椬検査で異型細胞 $(+)$ としたのは88件 (63症例)で, その細胞診結果の内訳は, 悪性29件 （33\%），疑陽性19件(22\%)，良性40件(45\%)であった。 剥離移行上皮細胞が多い検体は116例(93症例)お り,細胞診結果は悪性11例(10\%)，疑陽性6例(5\%)， 良性99例(85*)であった。全検討症例156例中，細 胞診で疑陽性以上とした症例は43例(28\%)で，こ の43例のうち 33 例 (77\%)は, 組織診断や臨床部断 で悪性と最終晾断された。悪性診断された 33 例中 の6例(18\%)は，臨床侧はまったく癌を疑っていな かった（膀胱癌4例，叒孟癌1例，子宮頙癌1例）. 【考察】尿沈渣検查は幅広く多くの疾患, 訩療科 によって依頼されるため，細胞診と連携させるこ とにより，臨床的にまったく予測されていない癌 も効率よく発見できることが分かった．互いの利 点を活用することで，尿検査は更に精度・重要度 が高まると考える. 連絡先：0823-22-2111
原三信病院臨床病理部1)、同泌尿器科 ${ }^{2}$

○渡辺寿美子 $(C T)^{1}$ 、高島扶貴子 $(C T)^{1} 、 川$ 岸淳子 $(C T)^{1)}$ 、金城 満 $(M D)^{1)}$ 、和幸 $(M D)^{2)}$ 、濱野 克彦(MD)

【目的】自然尿中細胞診は患者に苦痛を与えるこ となく、頻回に行える診断法として、膀胱腫場の 䛦断、治療後のfollow upなどに用いられている。 尿中細胞の良悪性の判定はしばしば困難を伴い、 尿中細胞診の普及を妨げる要因になっている。わ れわれはより客観的な尿路移行上皮癌の判定基準 を検討してきたが、今回尿中に出現する pair cellの 意義について検討し若干の知見を得たので報告す る。【材料㧍よび方法】平成6年6月より平成7年11 月までの間に尿中細胞診が提出され、組織所見の 得られた移行上皮癌例（22例）および非腫瘍症例 (26例) のパパニコロウ染色のなされた治療前の 尿中細胞診標本をレトロスペクティブに検討した。 pair cellの出現形態は今回の検討のために、2 個の 細胞からなる single pair cells、3 個の細胞からなる double pair cell、それ以上の細胞からなる multicellular pair cellの 3 種類に分類した。【結果お よび考察】非腫輅群の 26 例ではいづれの形態の pair cellも確認できなかった。注意すべきは細胞相 互の単純接着を pair cellとしないことであった。腫 湯群では21例中21例（100\%）にpiar cellの出現を認 めた。移行上皮癌の異型度との関連では、G1は 3 例で、 single pair cell が多く、G2は 8 例でsingle pair cell の出現を見たものが多く、multicellular pair cell は1例(12.5\%)に見られた。G3は11例でpair cell の出現は多様で、36.4\%にmulticellular pair cellが見 られた。今回の検討から、pair cellの出現はほとん ど移行上皮癌にのみ出現し、非腫場群では出現し ないことから、移行上皮癌の細胞診断上で有用な 所見と思われた。異型度との関連ついてはなお症 例を重ねて検討する。 
277-自然尿中に出現する大型核細胞の検討

北里大学医療衛生学部臨床細胞学教室"、同 病 院病理部細胞診 ${ }^{2)}$ 、同 医学部病理 ${ }^{3)}$ 、同 泌尿 器科 ${ }^{4)}$ 、同 産婦人科 ${ }^{57}$

○服部 学 $(\mathrm{CT})^{\prime \prime}$ 、大野英治 $(\mathrm{CT}, \mathrm{PhD})^{\prime \prime}$ 、横山 $大(C T)^{2)}$ 、小林明子 $(C T)^{2)}$ 、豊永真澄 $(C T)^{2)}$ 、 柿沼廣邦 $(C T)^{2)}$ 、大部 誠 $(M D)^{3)}$ 、内田豊昭 $(M D)^{4)}$ 、葴本博行 $(M D)^{5}$ 、亀谷 徹 $(M D)^{3)}$

尿細胞䛦は泌尿器科領域の癌診断には欠かせな い検査であるが、まれに良性病変であっても大型 核を有する異型細胞が出現し、しばしば診断に苦 慮する場合がある。そこで今回、光顕的検索に加 え画像解析装置C A S 200 を用い良性疾患例な らびに癌例に出現した大型核細胞の解析を行い比 較検討を行った。対象は1995年に北里大学病院 泌尿器科によって採取された自然尿で、臨床的. 耪胱鏡的・カテーテル尿細胞診的に良性疾患とさ れた 8 症例と尿細胞搒・耪胱鏡・病理組織学的検 查が施行されG 3 移行上皮癌とされた 11 症例で ある。その結果、画像解析では良性疾患と癌例の 大型核細胞では、細胞面積・核面積および核染色 濃度は癌例で高い傾向にあり、細胞異型度・核異 型度は有意差なく、N／Cは良性疾患で高い傾向 にあった。また、光顕的検索では䏅死性背景は癌 例でのみ見られ、移行上皮系細胞・大型核細胞の 出現頻度は共に癌例で多く、特に癌例では小型濃 染核細胞が多数出現していた。また、良性疾患で の大型核細胞の核所見は粗顆粒状・粗網状淡染核 および無構造謈染核であったのに対し、癌例では これらに加え細〜粗顆粒状濃染核が多く認められ た。

以上の所見をより詳細に観察することで、自然 尿に出現する大型核細胞の良・悪性の釷別はある 程度可能であると思われたが、更に症例を重ね、 検討する必要があると思われる。
278 連続観察法 (光䫓一走查型一透過型 電顕）による尿細胞診断一第功報一

藤田保健衛生大学医学部病態細胞

○金子千之 (CT)，新美 元 (MT)，

新里雅範 (MT)，長田明子（MD）,

柳田隆正 (C T), 社本幹博 (MD)

我々は昨年本学会において泌尿器科領域細胞診 への連続観察法を試み, 主として膀胱原発の移行 上皮癌について報告した。今回, 上部尿路系腫瘍 と転移性癌について検討したので報告する。

材料及び方法：材料は腎癌，惄监癌，膀胱への 胃癌，大腸癌の転移症例を用いた。方法は尿をス ライドガラスと自家製のフィルムスライドに塗抹 し $1.25 \%$ ルタールアルデハイドで固定し，パ パニコロー染色した。以後の操作は第34回本学会 で報告した方法に従った。

結果及び考察：全ての癌症例において光顕観察 ではN／C比は比較的大きく,クロマチンは粗大 顆粒状で增量していた。また大腸癌症例では核小 体が明瞭であった。走查型電顕観察で腎癌の細胞 表面は球状の短い突起で覆われ, 胃癌や大腸癌で は微絨毛で覆われていた。透過型電顕による腎血 癌及び大腸癌の観察で, 核は不整形, 核小体は明 膫で, ヘテロクロマチンは增量していた。細胞内 小器官は豊富でミトコンドリアやリボソーム, コ ルジ装置などが観察された。また胃癌では細胞質 内に粘液様物質，腎癌では脂肪滴等が観察された。 尿細胞診では変性した細胞が出現するために移行 上皮癌(G1)と classIIIとの鑑別，原発か転移か， 更には上部尿路の細胞判定には苦虑する場合があ る。泌尿器科領域に連続観察法が導入できれば判 定困難な症例のみならず上部尿路系腫瘍や転移性 癌の診断に役立つむのと思われる。 
279

尿細胞診における腎上皮

黒部市民病院病理

○小野寺平 $(\mathrm{CT})$ 、宮崎珨子 $(\mathrm{CT})$ 、田中敬子 $(\mathrm{CT})$ 、原武讓二 $(\mathrm{MD})$

【初めに】尿細胞診で腎上皮を確認する機会は稀 であり、当施設の 5 年間約 10,000 件の尿細胞診中 留上皮と確認猃断しえたものは 2 例であった。尿 中腎上皮の形態や堅捺印細胞との比較、尿中堅上 皮出現の意義などについて報告したい。

【材料と方法】症例 1 は 16 歳男性であり、交通 事故直後の尿細胞診で、多数の腎上皮が観察され たため精查し、右腎動脈の完全途絶による堅梗塞 之診断された例。症例 2 は 76 歳女性、左尿管下 部の移行上皮癌に伴う左水督症の 1 例である。 対照剖検例：堅に病変がない症例の剖検時に、腎 の各層から捺印細胞を採取して、上記 2 例の細胞 と比較対照した。

【細胞所見】第 1 例：細胞成分に富み、中心性の 核と細胞質にライトグリーン好性顆粒を有する細 胞が多数見られた。結合性に乏しい散在性の細胞 に混じって管腔形成が窥われる部分むあり、尿細 管上皮と考えられた。第 2 例：N／C比とクロマ チンの增加を示す異型細胞が多数見られた。核縁 の不整や重積性も目立ち、移行上皮癌細胞とみな された。これに混じって第 1 例目と同様の形態を 示す一般検查で言う上皮円柱類似のものが多数観 察された。雍照择印細胞との比較: 剖検時に得ら れた腎各層の择印細胞と比較すると、第 1 例の細 胞は曲尿細管上皮と類似していた。ペラフィ切片で 近位、遠位曲尿細管上皮の鑑別の補助となる刷子 縁や、集合管の淡明な細胞質などは、対照の择印 細胞診でも確認困難であり、2症例に観察された 腎上皮が近位遠位いずれに由来するのか、判定は 困難であった。

【まとめ】1）尿細胞診に多量の腎上皮を認めた 2 例を報告した。2）1例では多量の腎上皮を認 めたため精查し、腎動脈血栓症による堅全体の梗 塞を確認しえた例であり、尿細胞診が腹部外傷直 後の腎傷害の目安に成り得ると考えられた。3） Papanicolaou染色による通常尿細胞診では、近位 遠位尿細管上皮の鑑別は難しかった。
280 尿中に腫瘍細胞の出現した肺扁平上皮癌 腎転移の一例

久留米大学一病理 ${ }^{1)}$ 、同二病理 ${ }^{2)}$ 、同病院病理部 ${ }^{3)}$ ○自見厚郎 $(M D)^{12}$ 、中島明彦 $(M D)^{21} 、$ 河原明彦 $(C T)^{31}$ 吉田友子 $(\mathrm{CT})^{3)}$ 、横山佼朗 $(\mathrm{CT})^{3)}$ 、杉島節夫 $(\mathrm{CT})^{3)}$ 井上通朗 $(M D)^{11}$ 、渡辺次郎 $(M D)^{11}$ 、神代正道 $(M D)^{11}$

転移性腎癌の原発蔵器は肺、“消化器、卵巣・精巣 が多く、肺癌の腎転移率は剖検例で約 $24 \%$ である。 腫演細胞が腎の転移巣から剥脱し尿中に出現するこ とは少ない。今回、肺扁平上皮癌の右腎転移巣から 尿中に腫湯細胞が出現し、腎蔵が摘出された症例を 経験したので、尿細胞診所見を報告する。

[症例] 54藏、男性。平成 6 年 6 月に肺癌（扁平上 皮癌) のため左肺上葉切除術を受けた。平成 7 年 5 月頃から右側腹部痛が出現し、C T ・超音波検查の 結果右腎上極に境界明瞭な内部不均一の結節性病変 が発見された。尿中の扁平上皮癌の出現および血中 $\mathrm{scc}$ 值が $3.9 \mathrm{ng} / \mathrm{ml}$ と上昇し、扁平上皮癌、特に肺癌か らの転移か捸われ、9月に右腎摘出術が施行された。

[尿細胞所見] 少数の赤血球・炎症細胞・变性した 細胞があるが背景は比較的きれいで、腫汮細胞は孤 立性一小集団を構成し、大型集塊もみられた。細胞 は比較的小型で細胞質はライトグリーンないしオレ ンジ $\mathrm{G}$ 好性で、紡錘形一多稜形と種々の形態を示し た。核は中心性で、核形は類円形〜長棈円形を示し、 核クロマチンは顆粒状で增量し、核濃縮を示すもの もみられた。

[摘出腎の病理所見] 境界明暸で腫瘤 $(6 \times 4 \times 5 \mathrm{~cm})$ で、 腎被膜の菲薄化が認められた。割面は白色・分葉状・ 充実性で一部に壊死が認められ、腎盉にも露出して いた。光顕的に著明な角化傾向・壞死を伴いながら 腫畼細胞は小胞巣を形成し、腎の被膜外および腎孟 へも発育漫潤していた。右堅動脈周囲および下大静 脈右側リンパ節に転移が認められた。

[結語]肺癌の腎転移における尿中細胞像を報告し た。転移性腎癌では、腎孟に浸潤・露出すれば尿中 に腫湢細胞が出現し、背景は比較的きれいだった。 
281 蛽胞状リンバ節転移を伴ったベリニ管

癌の 1 例

順天堂大学浦安病院泌尿器科 ${ }^{11}$

順天堂大学浦安病院検查科 ${ }^{2)}$

$\bigcirc$ 新井隆広 $(M D)^{11}$, 能登顕彰 $(M D)^{11}$, 岩田真二 $(M D)^{1)}$

川地義雄 $(\mathrm{MD})^{21}$, 石 和久 $(\mathrm{MD})^{22}$,

古谷津純一 $(\mathrm{CT})^{2}$, 喜納勝成 $(\mathrm{CT})^{2)}$

今回経験したベリニ管癌における組織学的およ び細胞学的所見とそれらの診断意義について報告 し、更に免疫染色についても検討を加える。

【症例】42歳、女性。右側腹部痛を主訴に受診。 尿沈查、尿細胞診に異常を認めなかった。CTにて 右腎に内部不均一な腫韵性病変と腹部大動脈前方 に直径 $3 \mathrm{~cm}$ 大の襄胞状転移リンパ節を認め、右 腎摘出術およびリンパ節郭清術を施行した。

【肉眼所見】腫瑒は黄褐色で右腎の下極を占拠し ており、腎孟拉よび腎被膜に浸潤していた。腫晹 内部には出血壊死を伴い、傍らに孤立性腎囊胞も 認められた。

【組織所見】腫瘍は好酸性の胞体を有する円柱型 の細胞がホブニール状配列を示しており、乳頭 状、一部に管腔形成性の構築が認められた。

【細胞所見】震胞状リンバ節穿刺液において細胞 学的特徵が顕著であった。多くは乳頭状、一部 シ一ト状の細胞集塊が認められ、個々の細胞は類 円形ないし円形の小型の細胞で、N/C比が大き く、核の大小不同が認められた。核クロマチンは 顆粒状から粗顆粒状で1〜2個の大小様々の核小体 を有していた。

【まとめ】ベリニ管癌は、その発生母地を遠位尿 細管から集合管に持つ比較的希な腎癌であり、そ の診断には以前より、臨床的及び組織学的特徵の 他、免疫組織学的娭討が有用と報告されている。 自験例は、襄胞状リンパ節転移を有し、その穿刺 液細胞診で、通常の腎癌や移行上皮癌と異なった 特徴を認めた。これらの知見は今後、特に穿刺液 細胞診における鑑別診断に有用と考えられた。

\section{2 胸膜悪性中皮腫 10 例の細胞診}

国立療養所南福岡病院臨床検査科 ${ }^{11}$, 外科 ${ }^{21}$, 内科 ${ }^{3)}$, 福岡大学医学部病理学教室 ${ }^{41}$

山口県立中央病院病理科 ${ }^{5}$

O西 国広 $(\text { CFIAC })^{11}$, 藤重 晴久 (MT $)^{11}$, 安藤 陽一郎 $(\mathrm{MT})^{11}$, 本廣 昭 (MD) ${ }^{2)}$, 中嶋 俊一 $(M D)^{3)}$, 岩崎 宏 $(M D)^{4)}$, 亀井 敏昭 $(M D)^{51}$

【はじめに】悪性中皮腫は墏膜に発生する比較的 稀な腫瘍であり, 病理組織学的に通常は上皮型, 二層型（混合型），肉腫型に分類される。一般に 悪性中皮腫の $80 \%$ は上皮型および二層型であり 腺癌との鑑別が必要となり, 免疫組織化学染色を 含む特殊染色がその鑑別診断に利用されている。

【症例内訳】当院において平成元年より 7 年まで に11例の胸膜中皮腫が組織学的に診断され, 1 例は限局型で良性とされ 10 例は悪性であった。 男女比は $8: 2$ で平均年齢は 60 才 $(32$ 才 83才 ) で，9例は左胸膜に発生し, 内 2 例は裹胞を伴 っていた。アスベスト曝露は1例のみであった。

胸水は 8 例にみられたが胸水細胞診が陽性であ ったのは僅か 3例で, 陰性とされた5例をretrospectiveに検討した。

また胸水や胸膜穿刺細胞診で悪性とし, 組織型 推定が困難であった 3 例についてもその細胞像を 検討した。

【結果】胸水細胞診陰性とされた 5 例では背景に 多数のリンバ球の出現と少数の中皮細胞を認める のみで, ごく少数の腫瘍性中皮細胞類似の異型細 胞を検出できたのは 1 例のみで異型の弱い中皮腫 細胞と反応性中皮細胞との鑑別は非常に困難であ った。あえて，鑑別点を上げるとすれば小型なが $5 \mathrm{~N} / \mathrm{C}$ 大, 中心性の円形核, 細胞質好塩基性の増 加（特に辺縁が層状に強染）に注目し, 臨床所見 の詳細な把握が必要と思われた。

胸水あるいは胸膜穿刺細胞診で悪性とし組織型 推定が困難な症例では, PAS-alcian blue 染色は 鑑別染色法にはならず, 中皮腫はケラチン $(+)$ , ビメンチン $(+)$, EMA $(+)$, CEA $(-)$, EA (Ber- EP4) (ー), デスミン (ー), CA 125 ( 一) などの所見が重要かと思われた。

また胸膜悪性中皮腫の中には, 胸水初発症状で 来院し病理組織診による確定診断がつき難く、結 核性胸膜炎として治療され手遅れとなる症例があ り胸水細胞診の重要性が再認識された。 
283

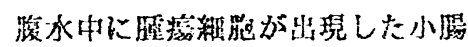

Epithelioid leiomyosarcomaの 1 得

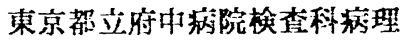

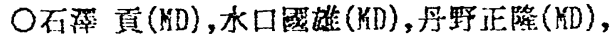

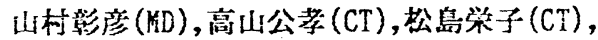

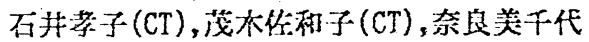
(CT), 中村恭二(ND)

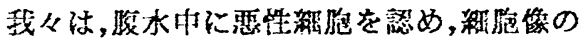
診继に苦虑したEpithelioid leiomyosarcoma を経﨏したので辩皆する。

【㱏侧】63崴女性.1995年6月,下腹部腫痹で当

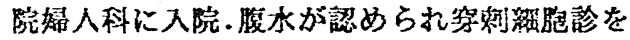
施行.入院中にileus症状が出現し, 算急手街と

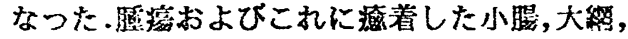
睹脂壁の一部を摘出した。

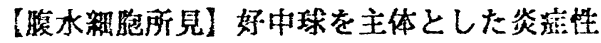
細胞を背景に,円形〜類门形の大型䣋胞が散在 笙あるい你骑い結合を示す小焦塊を形成し出 現.核は類円形で在し，核小体は1倨ないし数

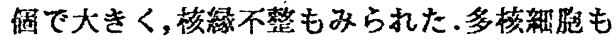
多数混在した。憫胞質は境界明瞪で厚くlight

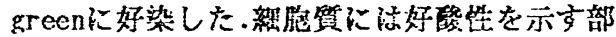
分や空跔椂に淡染する部分も热められた。

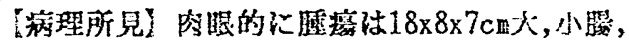

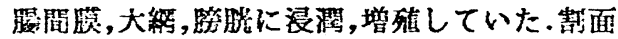

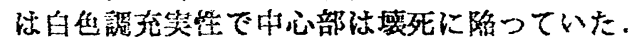

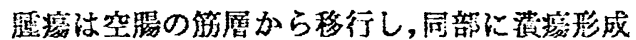

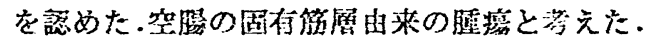

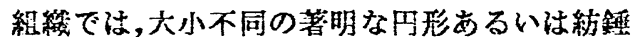

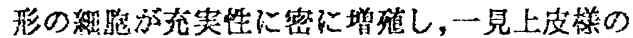
楼筑を示した.Mitosisは多い.镀銀染色では做

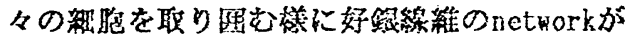
みら礼た。免疫染色では ENA(+), $\operatorname{keratin}(+)$ ， vimentin $(t), \operatorname{actin}(t)$, myoglobin( $(-)$. 電瑗で,

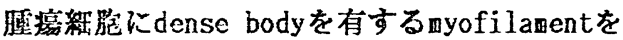
認めた・以上の所見から小腾の Epithelioid leiomyosarcomaと診㘧した。

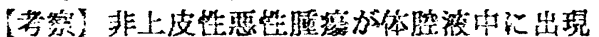

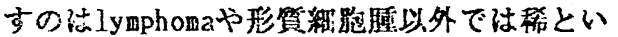

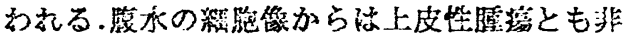

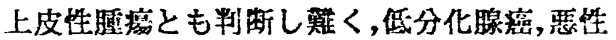

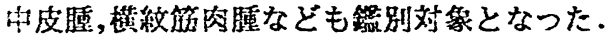

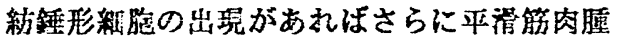

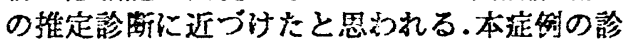
断は股本の維跑像のみからは四整であつた。
284 卵巣漿液性表在性乳頭状腺癌の免疫 細胞学的検討 一悪性中皮腫との比較を中心に一

富山市民病院中央研究検查部病理科

富山市医師会健康管理センタ-*

○島崎栄一（CT），今村伸一（CT）, 山岸智子（CT）

齋藤勝彦（MD）, 高柳尹立（MD）*

【はじめに】卵巣漿液性表在性乳頭状腺癌（以 下SSPC）は，卵巣皮膜の被覆'細胞に由来する稀な 腫瘍であるが, 体腔液細胞診上, 墨性中皮腫との 鑑別がしばしば問題となる。今回, 腹水中に出現 したSSPC細胞と悪性中皮腫細胞を臨床細胞学的,

免疫細胞化学的に比較検討した。

【対象および方法】対象は病理組織学的に確定 診断されたSSPC, 上皮型覀性中皮腫各 4 例で, 腹 水塗抹細胞及びセルブロックを用いた。上皮マ一 カーとしてKeratin, EMA, CEA, CA125, Ber-EP4, 非上皮マーカ一としてVimentin, 中皮マーカーと してThrombomodulin, HBME-1の免疫染色を行った。 【成績】SSPC 4 例は卵巣腫大を認めず, 腹膜播 種が著明であり, 術前の腹水細胞診では悪性中皮 腫との鑑別が困難な例もあった。免疫細胞化学的 検討結果を表に示す。

\begin{tabular}{l|cc} 
& SSPC & 悪性中皮腫 \\
\hline Keratin & $4 / 4$ & $4 / 4$ \\
EMA & $4 / 4$ & $4 / 4$ \\
CEA & $1 / 4$ & $1 / 4$ \\
CA125 & $3 / 4$ & $4 / 4$ \\
Ber-EP4 & $4 / 4$ & $0 / 4$ \\
Vimentin & $2 / 4$ & $3 / 4$ \\
Thrombomodul in & $0 / 4$ & $3 / 4$ \\
HBME-1 & $4 / 4$ & $3 / 4$ \\
\hline
\end{tabular}

Ber-EP4はSSPC全例に陽性であり，悪性中皮腫 では全例陰性であった。逆に, Thrombomodulinは SSPCでは全例陰性であり，悪性中皮腫では 4 例中 3 例に陽性であった。Keratin, EMA, CEA, CA125, Vimentin, HBME-1 では差は認められなかった。 【まとめ】Ber-EP4はSSPCの, Thrombomodul in は悪性中皮腫のマーカーとして両者の鑑別に有用 と考えられた。 
285 両側血気胸を繰り返した胸膜子宮内 膜症の胸水細胞診

赤穂市民病院呼吸器科 ${ }^{11}$, 同 検査部 21

京都大学医学部付属病院 検疽部 31

○塩田哲広 (MD) ${ }^{11}$, 田渕 亨 ${ }^{21}$, 米津宗徳 ${ }^{21}$ 中嶋安涁 ${ }^{3 \prime}$ (M D)

症例は 30 歳, 女性. 主訴注呼吸困難. 平成 7 年 5 月 3 日（月経開始 4 日目）咳濑, 右胸痛あり 5 月9日当科受診. 胸部レ線にて, 右昌然気胸と診 断したが, 軽度であったため安静のみで軽芙した 。5月23日（月経開始 1 日前）咳嗽, 右脢痛あっ たが放置していた。6月17日（月経開始 1 日前） 咳濑, 呼吸困難, 肩痛を認めたがやはり放置して いた。 7 月11日（月経開始 1 日前）咳嗽, 肩痛, 呼吸困難が出現. 軽快しないため 7 月 14 日当科外 来を受診. 胸部レ線にて両側気胸と診断し両側胸 腔ドレナージを施行した。耐肺の再膨張は良好で あったが7月16日 (月経開始5日目) 突然両側ド レーンから血性排液がみられた。特に左側で多く 1 日血性排液量は $(25 \mathrm{ml}, 160 \mathrm{ml}, 100 \mathrm{~m} 1,20 \mathrm{ml})$ と推 移した. この胸水の細胞診を施行した. 胸水中に は比較的円形の核を持ち, クロマチンは均等分布 を示し, 若千の核腫犬, 核小体の腫大を認める紬 胞が多数孤立散在性に認められた。8月4日（月 経開始 1 日解) やはり肩痛が出垷し, 8月6日外 来を受診, 胸部し線にて闭側気胸と診断した。た だちに両側胸船ドレナージを施行した８月 8 日 からGnRHアゴニストであるスブレキュアを投与し た.9月9日に軽い気胸が確認されたが安静のみ で軽快. 生理が完全に消失した後は, 現在までに 気胸はおこしていない。胸膜子宮内膜症の診断は 臨床的には比較的容易であるが組織学的に子宮内 膜細胞を証明される事はあまりない。また胸水細 胞診で子宮脱落膜細胞が確認されれは確定診断で きるとされているが, 反応性の胸膜中皮細胞との 鑑別が困難である。

\section{6 腹水湅胞診で確定診断し得た腹膜原発 要性中皮腫の一剖検例}

岐阜県厚生連岐北松合病院病理 ${ }^{11}$ 同内科 ${ }^{2)}$ 岐皋大学医学部病理学第一講座 ${ }^{31}$

户島 $(C T)^{11}$ 新井 正 $(M D)^{21}$ 伊東祐二(MD ${ }^{21}$

早川和良 $(M D)^{21}$ 高屋忠丈 $(M D)^{21}$ 吉見直己 $(M D)^{3)}$

安田 洋(MD) ${ }^{21}$

中皮腫は近年增加項向にあるが依然として稀な疾 患として報告されている。腹膜中皮腫は胸膜中皮 腫に比べ頻度は低いとされ、生前に診断がつく症 例は稀とされている。今回我々は、腹水紐胞診、 腹水セルブロック法により悪性中皮腫と診断し、 後に多藏器に播種、転移した一剖検例を経鈋した ので報告する。

【症例】67歲、女性、主訴: 高血姞の精榃目的 現病歴:4 5年前から高血压、高血裙を指摘される も放置していた。2 3日前より特に誘因なくめま いが出現し当院内科外来を受猃。腹水を指摘され 精查目的で入院となる。

【細胞所見】腹水湅胞診で得られた尾演細胞の罢 列は、全体にシート状配列を示すか、一部にまり も状集塊をなすものがみられた。湅胞質はライト グリーン好性、核は大型でやや偏在し類円形で一 部不整形を示した。クロマチンは不整顆粒状で明 㹉な大型核小体を1 2個認めることから、腺癌ま たは悪性中皮腫が強く疑われた。特殊染色におい ては、睡場細胞はPAS染色弱陽性、アルシアン青 は紐胞質辺縟に陽性で、ヒアルロニダーゼでとも に消化された。以上の所見をあわせて悪性中皮硬 と診断した。尚、剖検時の腹膜、肝藏、監の組模 標本にて、上皮型の中皮腫と診断、確認された。 【まとめ】腹膜原発で腹膜播種を呈し、肝、堅、 卵巣に転移した上皮型德性腹膜中皮隀の一剖検例 を経呀した。本症例は腹水沺胞誩所見から中皮隀 と確定祅断しえた稀な症例であったので、その細 胞診所見を中心に、剖検時に得られた耘移器器の

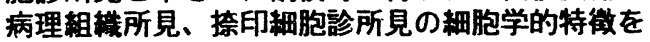
免疫染色所見とともに報告する。 
聖マリアンナ医大横浜市西部病院・病院病理部 ${ }^{1}$, 同内科 ${ }^{2}$, 同外科 ${ }^{3}$, 同医大病理 ${ }^{4}$

○半田留美子 $(\mathrm{CT})^{1}$, 諏訪秀一 $(\mathrm{CT})^{1}$, 安田玲子 $(\mathrm{CT})^{1}$, 品川俊人 $(\mathrm{MD})^{1}$, 菅 誠 $(\mathrm{MD})^{2}$, 小森山広幸 $(\mathrm{MD})^{3}$, 田所 衛 $(\mathrm{MD})^{4}$

【はじめに】非機能性膵内分泌腫瘍 (島細胞腫)は 比較的稀な疾患であるが, 今回, 我々は肝臓に転 移を認めた非機能性膵悪性内分泌腫瘍を経験した ので，その捺印細胞像を中心に報告する。

【症例】47才, 男性。吐血にて近医入院し, CTに て膵腫痬を指摘。一年後再吐血で入院し, 膵腫瘍 の大きさが不変であることから精查目的で再入院。 腫瘍マーカーや血中ホルモンは異常を認めず，エ コーと CTで膵腫瘍の脾浸潤,及び肝に転移巣を認 め手術を施行された。

【細胞像】比較的疎な結合で, 不規則な配列を示 す細胞集塊を認めた。腫瘍細胞は N/C 比は大で, 集塊形成細胞の細胞質はそしく，ライトグリーン 好性で細胞境界は不鮮明であった。散在性のもの は裸核状に見られた。核は円〜類円型で, 大小不 同が見られ，クロマチンは粗顆粒状で 1 〜 個の 核小体を有し, 核緑の肥厚は認めなかった。ロゼ ット様やリボン状配列を思わせる構造むあったが 不明瞭であった。膵臓部も転移巣もほぼ同様の細 胞像を示した。

【病理所見】肉眼的に出血壊死を伴う膵体尾部の 腫瘍が脾に浸潤し，17 $88 \times 5 \mathrm{~cm}$ 大の腫瘍を形成 し, 肝に $2 \times 2 \mathrm{~cm}$ 大の転移巣を認めた。組織学的 に腫瘍細胞は充実性, 索状, リボン状に配列し, グリメリウス染色陽性で, 免疫染色ではNSE, chromogranin A, Leu- 7 は陽性であり，悪性の 膵内分泌腫瘍と, その肝転移と診断された。
1 例

千葉市立海浜病院検查科病理 1 , 同 外科 ${ }^{2 \prime}$, 帝京大学市原病院病理部 ${ }^{31}$, 同 電顕室 ${ }^{11}$ ○高橋年美 $(\mathrm{CT})^{11}$ ，西野武夫 $(\mathrm{CT})^{11}$ ，藤畸和仁( T) ${ }^{1}$ ，太枝良夫 $(\mathrm{MD})^{21}$, 磯野敏夫(MD $)^{2)}$, 勝浦誉 介 $(\mathbf{M D})^{21}$, 高橋 均 $(\mathbf{M})^{21}$, 鍋嶋誠也 $(\mathrm{MD})^{21}$, 营 野勇 $(\text { ID })^{31}$, 長尾孝一 $(\text { ID })^{31}$, 棟方 滋 $(\text { MT })^{11}$

腺房細胞癌が少数の内分泌細胞を散在性に伴う ことはよく知られている。今回我々は, 多数で多 種の内分必細胞への分化を認め, NDHA症状・肝転 移を伴った稀れな 1 例を経験したので報告する。

[症例] 45歳, 男性。水梯性下浰, 体重減少を主 訴に近医受診。止㢉剂による改善がみられず当院 紹介入院となった。入院時検查で低 $\mathrm{K}$ 血症, 低Cl 血症, 高Ca血症を示し, 二ューロベタタイトY, リマトスタチン, クルカコンガストリ等の異常高値を認めた。腹部US, Crで膵尾部に径約 $3 \mathrm{~cm}$ の腫場, 肝に多発性の転移 性腫瘍像を認め, 膵体尾部切除術が施行された。

[細胞所見］腫瘍細胞は小型で偏在項向の円形核, 俥度の大小不同性を伴い凝集性ク口マチ\%，境界不明 瞭な淡い細胞質を有していた。ロゼット様配列を 示し腺房細胞または島細胞に類似していた。

[病理組織所見] 膵尾部に $35 \times 20 \times 30$ の腫瘍を認 め, 白色調の弾性硬之褐色調弾性軟の結節からな っていた。組織学的には血管に富む充実性腫瘍で 腫瘍細胞は類円形の核, 好塩基性細胞質を伴い腺 房細胞，SC腫瘍細胞に類似していた。乳頭状構造，

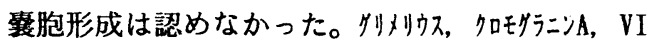
P, A A T, PP染色に陽性で, CA19-9染色では一部 の管状部に陽性であった。フォンタナ・マッッ，インスリン， ガストリン、リマトスタ千ンクルカコ染色は陰性であった。 電顕的には千モーケ顆粒, 首状粗面小胞体の発達し た腺房様細胞と 200 300 nmの神経分泌顆粒をもつ 明るい細胞質の内分必細胞を認めた。微䄉毛を伴 う腺房構造も散見された。多ホルモン産生性の島 細胞癌之腺房細胞癌の併存腫瘍之診断された。 
289 脳転移にて発症したHC G 産性脭巨 細胞癌の 1 例

大分市医師会立アルメイダ病院病理"、 同外科 ${ }^{2} 、$ 同脳神経外科 ${ }^{3}$

O吉川敏雄(CT) ${ }^{1}$ 、政池コズエ (CT $)^{11}$ 、柳井豊秀 $(C T)^{1}$ 、橋本博信 $(C T)^{\prime \prime}$ 、高橋哲哉 $(C T)^{11}$ 、染矢 誠一郎 (CT) " 、工藤洋一(CT) ${ }^{11}$ 、渡辺清一(CT) " 、

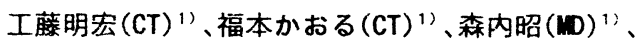
白鳥敏夫 $(M D)^{22}$ 、涻宮陸博 $(\text { MD })^{2)}$ 、佐藤智彦 $(\mathbf{M D})^{3)}$

而側小脳半球への転移によって発症したHCG産性 膵巨細胞癌の1例を経験したので報告する。 【症例154歳、男性。平成元年胃癌 $\left(\mathrm{tub}_{2}, \mathrm{sm}\right)$ の既往 あり。平成 6 年、後頍部痛が出現し、当院紹介入院 となる。血清HCG值は $13 \mathrm{~m}|\mathrm{U} / \mathrm{m}|$ と高值を示し、両側 小脳半球腫瘍の診断のもとに腫瘍摘出術を施行。 全身検索では、他に明確な tumor形成は認められな

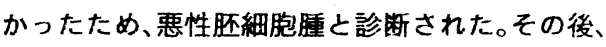
外来経過観察中(7ケ月後)、腹部CTなどから脺頭部 腫瘍が判明し腫瘍摘出術が施行された。

【捺印細胞像】腫瘍細胞は膵、小脳とも基本的には 同様の細胞像であった。単核および多核の腫瘍細 胞がシート状ないし孤立散在性に出現。細胞形は、 円形ないし多辺形、一部に有尾形態を示し、大小不 同性は強く、大型明瞭な核小体、クロマチンは粗顆 粒状に增量、細胞買は豊富で泡沫状であった。

【組織像】摘出された膵腫瘍は、出血巣を伴い,pleo morphicな巨細胞を多く含む未分化な癌であり、免 疫染色は、HCGa，PALP, cy toker at in, viment in陽性, HCGB, HPL, SP-1, AFP陰性であり、HCGa産性膵巨細胞 癌と診断された。脳腫瘍では、粘液産生性, ker at in, PALP、HCG 陽性像を示し、膵睡憆が判明するま ではteratogemic tumorも考えたが、HCGBが陽性以 外は膵腫㕫之ほほ同样の特殊染色所見であり、組 織像も同样の部分が認められ、HCG産性膘巨細胞㾇 の転移と考えた。【とめ】本症例は、HCGを産性し た膵巨細胞癌で稀な一例と考えられる。
290 粘液産生を伴った膵管内覢頭董疪（い わ中る枮液産生䏽瘇瘍）の 2 例

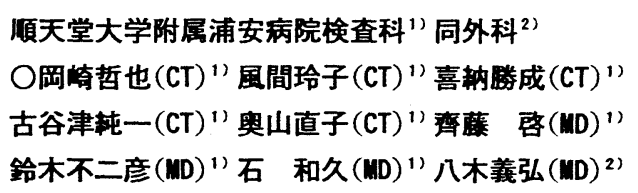

粘液産生膵厘瘍は，比較的稀な疾患である。今 回、我々は粘液産生を伴った睤頭厡瘇及び一部癌 化を伴った㲘頭腺董の計 2例を経験したのでそれ ら相炮像を中心に報告する。

[症列1]69歳女性. US・CT・ERCPにて搼頭部に多 房性の夏胞と軽度の主膵管坑張を認めた. ERCP施

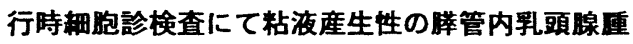
を疑い群頭部十二指腸切除術が施行された。

[症列2]71歳男性. CT ・ ERCPにて主睡管拡張、US にて睡管内隆起病変を焉めた. ERCP施行時棚胞診

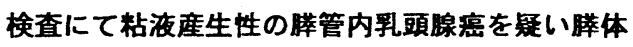
尾部椫臤合併切除術が施行された。

[梱胞所見] 症列1:背景に多量の粘液が認められ

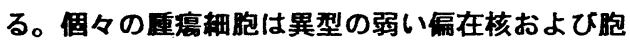
体に粘液を有した高円柱状で、多くは大集団、一 部粍頭状集塊として詡められた。

症例2:基本的には症列1と同様の所見に加え、一 部に小型核小体を 1〜 3個含むさらに大型の異型 相盷を散在性に単個または極性の乱れを示す細胞 集団として認めた. さらにN/C 比大で核にくびれ やシワを有する異型細胞も混在または一部䟘頭状 集塊として認めた.

[粗機所見] 症列 $1 \cdot 2$ 共に高円柱状の粘液産生

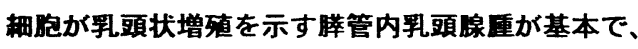

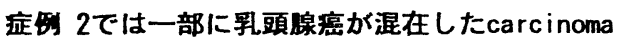
in adenomaの像を呈していた. 間質内への漫閏は 㑇められなかった.

[まとめ] 粘液産生群董㾇は、梱胞異型に乏しい ため眿厘と虎の鑑別に苦慮する場合がる. しか し、梱胞内外の粘液の有無・出現様式・核異型に 注意することで、ある程度推定可能と考えられた。 
291 Signet-ring cell样の細胞像を呈した腊 のSolid and cystic tumorの一例

\section{医痛法人雷の洫盈マリア病院病理部}

久留米大学第一病理学教室"

O伊藤裕司(MD)、塚本孝久(CT)、楳田明美(CT)、 大田桂子(CT)、中野祐子(CT)、原武晃子(CT)、 伊算国江(CT)、大田喜孝(CT)、中村廉宽(MD)、 自見厚郎(MD)*

Solid and cysti tumor(以下SCT)は、膡外分泌腫

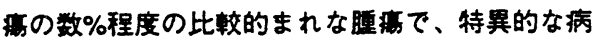

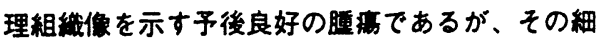
盷像についての報告はほとんど見られない。今回 我々は、術中迅速細胞剘にて、Signet-ring cell梾の 細胞像を呈し、良覀性の判断が非常に困難であっ たSCTの一例を経験したので、若干の文献的考察 を加えて報告する。

【症例】42才、女性。1995年7月頃、左腰背部 痛のため近医受舎したところ、蛋白尿を指摘され、 投薬加療を受けた。その後䁌機能は改普したが、

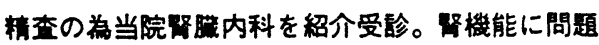
はなかったものの、画像浾断にて、膡尾部付近の 腫的を指摘され、覀性腫被の可能性も考えられた 為、11月30日当院外科にて膡体尾部切除術が施行 された。

【術中細胞韧所見】核が偏在し盷体内に大形の 空胞形成を示す異型細胞を多数認める。核はクロ マチン染色性が增加し、一部明䁖な核小体も有し ており、Signet-ring cell carcinoma、もしくは低分 化腺癌との鉃別が困䧺な像であった。

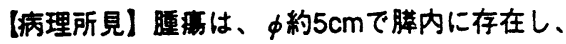
線維性の厚い被膜により周囲とは良く境界されて いた。内部には、充実性の部分と、烄死により cysticな变化を来した部分とが見られた。組織像で は、roundな核を有した多角形の腫的細胞が、毛細 血管を中心とする盷䉾状もしくはpapillaryな增殖を 認め、一部胞体内の空胞形成が著明な部が見られ た。
$J R$ 東京総合病院検查科病理 " 1 同外科 ${ }^{2)}$

O船山英明 (CT $)^{11}$, 今野久美子 (CT $)^{11}$

深井光一郎 (CT $)^{\prime \prime}$, 宇佐美一彪 (CT ${ }^{\prime \prime}$

丹野正隆 (MD) " , 早川欽哉 (MD) "

田中潔(MD) ${ }^{21}$

【はじめに】膵のsolid and cystic tumorは、主 に10歳後半から30歳代の若年女性に好発する比較 的稀な腫瘍である。

最近我々は当院にて solid and cystic tumorと 思われる 1 例を経験したのでその細胞学的所見及 び組織学的所見を含め報告する。

【症例】16歳、女性。平成 7 年 7 月腹痛を主訴に 他院受診。腹部超音波検查にて膵頭体移行部に約 $4 \mathrm{~cm}$ 大の腫瘤が認められ精查目的のため入院。CT、 MRI、Angiography にてsolid and cystic tumorが 疑われ同年 8 月手術目的にて当院受診、同年 9 月 腫瘍核出術が施行された。

【捺印細胞所見】腫瘍細胞は小型で、孤立散在性 または結合疎な集塊を形成して多数出現しており、 一部にはロゼット様配列や乳頭状配列も認められ た。主体となっている細胞は細胞質が境界不明瞭 で泡沫状、核は円〜類円形、クロマチンは細顆粒 状で均一な分布を示していた。また核小体も小型 ながらも 1 個認められた。

【病理組織所見】摘出された腫瘍は、 $4.0 \times 3.5 \mathrm{~cm}$ 大、割面像は中心部に出血壊死による液状の部分 とその周囲に黄白色で充実性の部分が認められ、 $1.0 \sim 3.0 \mathrm{~mm}$ の線維性被膜により包まれていた。 組織学的には、小型で円〜類円形核、好酸性の胞 体を有し多角形を呈する腫瘍細胞が充実性に增殖 していた。本症例は組織学上形態的にもsolid and cytic tumor に相当するものと思われた。 


\section{3 多数の炎症細胞を伴った 細胞 リンパ䀯の1症例}

松下纪念病院中央臨床検查部病理 中国弘美 (CT)、井上鞂雄 (CT)、廷部 鞂 (ND) 安连 弘 (MD)、寺町公男 (MT)、伊意美奈子 (MT) 过本 (

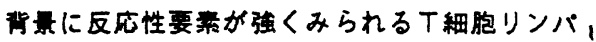

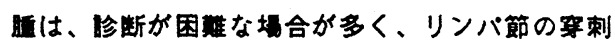
細胞翏においても、性事はかなり低い。今回我 々は、多数の资症細胞を伴った丁細胞リンパ膘を 経填したのてその撩印細胞像、並ひに組織像を供 筧する。

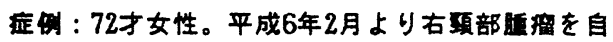

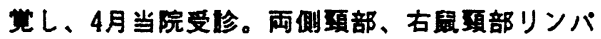

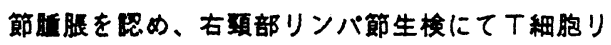

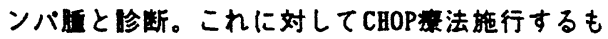
治婊中断し自己退院。10月中旬上り再度両倒到部、

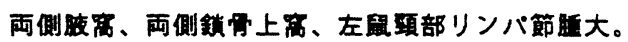
これに对して再度CHOP害法を、さらにTh12に骨転

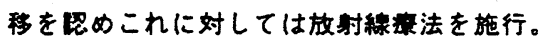

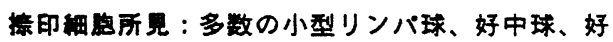
酸球、形算細胞、組織球の中に、中型(一部大型) のリンバ球を照める。このリンバ球の核は円また は掼円形て、クロマチンは粗く不規則に分布して おり、中には核形不整の細胞や、核小体の目立つ 細胞を琹める。

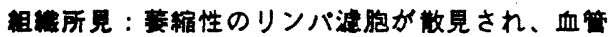
は龧加しているが、榯枝状の分岐の形はあまりみ られない。また集族した組䄉球は、皟上皮細胞の 形をとっていない。多数の反応性細胞に混しって、 择印でみられた核形の不整を伴った中型の大をさ のリンバ球が、限局した籍囲に集族して出現して いる。

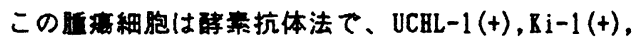
し-26(-), PCNA(+)であった。

本症例は、多数の炎症細胞によって腰粮細胞の 存在が琴めにくい十細胞リンバ敛の1症例である。
294 髄液中に腫場練胞を認めたPrecursor NK-cell leukemiaの細胞像

国立がんセンター中央病院臨床検查部 ${ }^{11}$ ，同薬物 療法部 ${ }^{2 !}$ ，同研究所 ${ }^{3)}$, 国立がんセンター東病院 臨床検查部4)

○長谷川 達朗 $(\mathrm{CT})^{11}$ ，渡部 庸一 $(\mathrm{CT})^{11}$ ，

日吾 雅宣 (CT $)^{11}$, 當銘 良也 (CT ${ }^{11}$,

野本 清明(CT $)^{11}$, 山岸，紀美江 (CT $)^{31}$ ，

川村 公彦(CT ${ }^{41}$, 飛内 賢正 $(M D)^{21}$ ，

竹中 武昭 (MD) ${ }^{11}$ ，島村 香也子(MD) ${ }^{11}$

近年natural killer (NK) 細胞が異常に增殖する 智患が注目されているが、Precursor NK-cell leukemiaについての報告は世界的にみても殆どな されていない。今回我々は髄液中に腫湯細胞を認 め急激な臨床経過を示した Precursor NK-cell leukemiaを経験したので報告する。 [症例]60才男性。平成7年1月より38度台の発熱が 持続。近医で急性白血病を疑われ2月当院入院。入

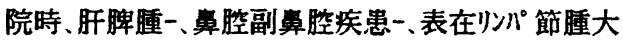
十、沉血球減少を認めた。末梢血及び骨髄中に多数 のleukenic cellが認められ、骨髄単核球の免度学 的表現型はCD2+、CD3-、CD16-、CD56+、TdT活性+であ ることによりPrecursor NK-cell leukeniaと診断 した。3月䯕液中に腫凊細胞が認められた。化学療 法施行後4月に完全寛解.7月再発。再ひ化学療法施 行するも敗血症と真菌性肺炎を併発し8月死亡。

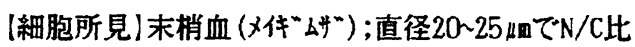
上界、核型不整、粗網状吅利、数個の円形大小の核 小体、少数のアズール顆粒を持つ細胞質の異型リンク゚ 球 椂腫癌細胞を認めた。骨髄 (メ伴“ムザ); 細胞の大小 不同が強く多彩でよりN/C比の高い吅チン顆粒状い 細網状の芽球栏細胞も認め、アズール顆粒は不明瞕で あった。䯣液(メ伴゙ムザ); 円型でN/C比が高く、核型 不整、吅手細網状の腫港細胞を認めた。末梢血電 顕では小型、少数のアズール顆粒が確認された。

NK細胞白血病の同定には形態学的検索に加之て 免度学的表現型の検索が重要である。 


\section{5 胃A T L LO 1 例}

小山田記念温泉病院病理，三重大学学学部第。-

病理学教室 ${ }^{2}$

O永岡昌光 $(C T)^{1}$, 白石泰三 $(M D)^{2}$
矢谷隆一 $(M D)^{2}$

【はじめに】成人 T細胞白血病ノリンバ腫（ $\mathrm{AT}$ LL）はHTLV‥10関与によりおこり、九州 日本西南地域に多発する下細胞性腫瘍である。今 回我々は、胃生娭より診断されたA T L L O)一例 を経験したので報告する。

【症例】51歳男性。平成 7 年 5 月上旬上腹部痛 出現、近医受診し上部消化管造影にて胃の隆起性 病变を指摘され、精查のため本院八入院。胃内視 鏡生娭及び擦過細胞診が施行された。内視鏡所見 は胃角部後壁に $5 \times 5 \mathrm{~cm}$ 、胃角部小弯側に $2 \times 2 \mathrm{~cm}$ の) B II 样病变を認め、胃全摘術が施行された。他の 部位には腫瘍は認められなかった。血中HTLV-1抗 体は高値であった。

【細胞所見】腫瘍細胞はN/C 比大で散在性に認め られた。核形は切れ込み、不整なものから類叫形 核の大小不同、クロマチンは粗網状から粗顆粒状 で不均等分布と多彩性を示し悪性リンバ腫が疑わ 机た

【病理組織所見】粘膜下層を中心に不整形核を有 する、異型リンパ球のびまん性增生が見られた。 免疫組織化学染色により $03(+) 、 \operatorname{CD4}(+) 、 \operatorname{CD5}(+)$ 以上よりA T L Lと診断された。
296 核分葉を示す腫場細胞の出現をみとめ た小腸原発 B 細胞性リンパ腫の捺印細胞像.

いわき市立常磐病院病理科1, 同・内科 2 .

高橋勝美 (CT) 1), 望月 衛 (MD) 1$)$,

江尻晴博 (CT) 1), 比佐純孝 (MD) 2)

核分葉を示す大型リンパ腫細胞が出現し, 捺印細 胞診上 $\mathrm{T}, \mathrm{B}$ の鑑別に苦慮した小腸原発 $\mathrm{B}$ 細胞性リ ンパ腫の1例を報告する.

症例：43墄男性. 嘔気，嘔吐を主訴に某病院を受 診. 腸閉塞, 腹部腫瘤と診断され，精查加療目的に 当院紹介受診.下行結腸腫腸の術前診断にて開腹. トライツ勒帯より約 $15 \mathrm{~cm}$ 肛門側の空腸に大きさ約 13 $\times 13 \times 10 \mathrm{~cm}$ の腫場あり, 下行結腸に直接浸潤. 回腸 末端部より約 $1 \mathrm{~m}$ 口側の回腸にも大きさ $8 \times 4 \times 4 \mathrm{~cm}$ の 腫瘍をみとめ, 下行結腸切除術, 小腸部分切除術を 施行. 術後12日目より化学療法を開始. 術後 4 力月 が経過し，現在外来経過観察中である。

銴印細胞診細胞像：中〜大型異型リンパ球が多 数出現. 異型リンパ球は核クロマチンの㠜集性を示 し，粗大な核のくびれを有するものが主体であった が，核小体明瞭で核分葉を示す核型不整の著しい細 胞が混在. 細胞質は比較的豊かで淡明であった.

病理組織所見：中ー大型異型リンパ球のび漫性 增殖を認めた。異型リンパ球は核の多形性 (pleomorphism）に富み，類円形核を持つものから，粗大 な核のくびれを示すもの，多分葉核を持つ大型異型 リンパ球が混在し出現. 細胞質は比較的豊かであっ た．部分的に間質の線維增生を伴っていた．免疫染 色では，腫瘍細胞は L-26 陽性, CD3, UCHL-1, CD43 㓌性.び漫性リンパ腫大細胞型と診断した。

考察：Bリンパ腫にも腫漡細胞の核に分葉をみる ことがあり, multilobated B-cell lymphoma と呼 ばれ，本例もこの範蹄に入ると考える．本例の捺印 細胞像では, 異型リンパ球の細胞質は通常の大細胞 型リンパ腫に比し淡明かつ豊かであり，Tリンパ腫 とmultilobated B-cell lymphoma との細胞診上の 鑑別点として重要と考えた. 
297 眼瞼結膜原発と考えられる低悪性度 $\mathrm{B}$ 細胞性粘膜関連リンパ腫のー例

日本医科大学多糜永山病院病理部 ${ }^{1)}$, 同眼科 2), 日本医科大学第二病理学 ${ }^{3)}$

○細根 勝 $(\mathrm{MD})^{1)}$, 前田昭太郎(MD) $)^{1}$, 中山滋章 $(\mathrm{MD})^{2}$, 片山博德 $(C T)^{1)}$, 磯部宏昭 $(C T)^{1)}$, 浅野伍朗(MD) ${ }^{3)}$

【緒言】節外性飞発生するリンパ腫の中でも, 構成 細胞の大部分が小型の成熟リンバ球様細胞からなる ものは, H-E形態像のみでは反応性病変なととの 鑑別がしばしば困難である。今回，我々は，細胞診 による詳細な形態観察を行ら, 新鮮材料の細胞表 面マーカー,および免疫グロブリン遺伝子の再構成を 検討し, 通常のH-E組織像と合わせ, 最終的に低悪性 度 $\mathrm{B}$ 細胞性粘膜関連りンハ腫々診断し得た一例を経験し たので報告する。【症例】54歳, 男性。【主訴右下眼 瞼腫瘤。【現病歷平成 6 年 9 月下旬頃上り右下眼瞼腫 瘤を自覚, 経過観察していたか症状改善しないため同 年 11 月近医受猃。同腫瘤の生検飞て悪性リンハ腫が疑 われ, 当院眼科転院, 細胞診, 生検が施行された。病理 学的検索】捺印細胞診ではてれらの細胞は通常の小型 成熟リンバ球と比べやや大型であり，をた，中型りンパ 球と比へやや小型で,核のくびれ，核小体が認められ,ク ロマチンは成熟傾向を示した。これらは, centrocyte-

like cell 亿一致する像と考えられた。H-E組織像では 病変部は異型性にそしい小型成熟リンバ球様細胞の単 調な增殖により形成されており,てれらはLCA陽性, L -26, MB-1陽性, UCHL-1, MT-1 陰性を示した。 た, sIgM陽性, sIgD陰性を示した。細胞表面マーカー は, $\mathrm{CD} 10$ (39.2\%); $\mathrm{CD} 19(61.0 \%) ; \mathrm{CD} 20(56.9 \%)$ お よびHLA-DR( 66.2\%) また, CD2 (20.6\%); CD3(22.8 \%);CD5 (17.6\%);CD7(10.4\%)であった。また, $\mathrm{J}_{\mathrm{H}}$ 領 域の monoclonal な再構成を認めた。考察】これらの 所見を総合し, 眼瞼結膜原発の低悪性度 B細胞性粘膜 関連リンパ腫と診断したが，自験例では検体量も少な く, H-E組織像のみでは, 偽リンパ腫, 小細胞性リン八 腫なととの鑑別が困難であり, 細胞診を併用するととによ りはしめて正確な鑑別知断か可能となった症例と考えられた。
298 C I) 56 -Positive Angiocentric L y m p hom a 2 例

山形県立日本海病院臨床検査科1 ${ }^{2}$ 同病理科 2 同皮覤科 ${ }^{3}$ 山形大学医学部病理学教空 ${ }^{4}$ 荘内地区健康管理セン夕一病理 ${ }^{5)}$

(の)誀訪しのぶ(CT) ${ }^{11}$ ，櫅藤裕紀(CT $)^{11}$ ，

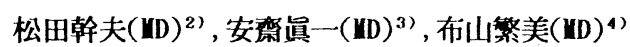

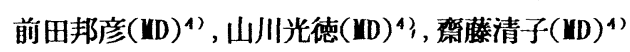

CD56-positive 1ymphomaは皮㞕，粘膜などの 節外脿器を多く冒し, 組䋨学的にangiocentric の像を示し，予後不良の悪性リンパ腫として近年 認識されている。今回我々は皮下に腫瑝を多発し， 組織学的にangiocentric lymphomaの像を示し腫 瘍細胞の表面形質CD56+, CD2+, CD3-を示した2症例 を経験したので報告する。症例 $1: 61$ 歳, 女性。 3 年前より四肢を中心に皮虞, 皮下腫瑒を多発。 次第に難治性漬堭を形成して当院皮痛科紹介。治 療後 6 力月で死亡。剖検にて腫場細胞の浸潤は皮 洁, 筋肉, 脾脿, 骨餚に認めた。

症例 $2: 56$ 歳, 女性。1 力月前より躯幹, 四肢の皮 下之右乳腺に腫演形成。肺にも腫場陰影。その他 肝脿，鼻腔粘膜にも腫場細胞の浸潤著明。化学療 法無効にて全経過5力月で死亡。剖検は行われな かった。

（細胞診所見）2症例ともほぼ同様の細胞所見を 示した。ギムザ染色では，胞体内にアズール顆柆 と思われる暗赤色の顆粒が見られ，いわゆる L G L (large granular lymhocytes)に類似した形態 を示すものも見られた。症例2の乳腺穿刺吸引細 胞診では，核異型の強い間質細胞様の集塊と散在 性に異型細胞を認めた。これらは,クロマチンに 富む中型の異型細胞で類円形の核を有するものが 多く，不規則な切れ込みや分葉状の核も見られた。 数個の核小体を有し，胞体は比較的淡明で豊富で あった。class III と判定し, 非上皮性腫場の疑い としたが, その後の組織診及び免疫染色により表 記の疾患之診断された。 
299 睪丸網原発が考えられた、陰震内乳 頭状轂胞腺虚の1例

佐野厚生総合病院娭查科病理 ${ }^{1}$

群馬大学医学部臨床娭查医学講座 ${ }^{2}$

○細村泰夫 (MD) '、須黒和美 (CT) '

桜井貞広 (CT) ' 、城下 尚 (MD) ${ }^{2}$

【はじめに】蟠丸付属器の癌腫は、きわめてまれ であり、悪性中皮腫や転移性腫瘍との鑑別が問題 となる。我々は箤丸網原発が考えられた、院㝨内 乳頭状佘胞腺虚の1例を経験したので報告する。 【症例】60歳、男性、平成7年1月より、左陰佘の 腫大に気付き、当院泌尿器科を受診。左陰裻内に 一部充実性病变を有する、直径 $8 \mathrm{~cm}$ 大の絸胞が認 められ、穿刺吸引細胞診が施行され、血性の内溶 液が吸引された。内溶液の腫瘍マーかーは、CEA、CA 19-9、HCG陰性、CA125高値であった。細胞学的に は、Class V、乳頭腺虏ないし悪性中皮腫と診断 された。シンチおよび全身CTでは、陰嘉以外に腫場 性病変は、認められなかった。

【第刺吸引細胞所見】腫瘍細胞は、結合性が強く 乳頭状集塊を形成し、この中心部にう仆グリー䒵染 の粘液様の物質を有していた。腫湯細胞には、核 遍在傾向がみられ、核小体は大型で1〜3個認めら れ、核加マチンは細顆粒状で、細胞質には、核の反 対側に笑起が認められた。

【マクロ、組織学的所見】歖胞病変は、睪丸に接 して存在し、充実性病変周囲には睪丸網と考之的 れる管腔が認められた。組織学的には、高円柱状 の腫瘍細胞が乳頭状に增殖し、一部で砂粒体がみ られた。免度染色では、EMAおよびCA125が陽性、 ケラチン、CEAおよびビメンチンは陰性であつた。電顕で

は、腫瘍細胞表面の短いmicro-villiやdesmosome が認められた。

【まとめ】腫瘍細胞の乳頭状增殖や電䫓所見から 本腫痬は、乳頭腺癌と考えられ、存在部位や睪丸 内に腫泊を認めなかったことから、睪丸網原発と 考えられた。

\section{0 精上皮腫に出現する \\ “tigroid pattern” の緗胞形態学的娭討}

川崎医科大学附属病院病院病理部"

同病理学教室 ${ }^{2>}$

○有光佳苗 (MT $)^{1)}$, 鐵原拓雄 (CT $)^{12}$

成富真理 $(M T)^{1 ;}$, 畠栄 $(C T)^{1 ;}$, 広川満良 $(M D)^{23}$

【はじめに】精上皮腫に見られる、“tigroid pat tern (以下TP)”は乾燥固定 Nright-Giemsa染色 標本の背景に出現する、虎の縞模様に似た構造の ことで、精上皮腫を診断する際の一助になると言 われている。今回われわれは、精上皮腫の烝抹標 本にてTPの出現状態を観察した結果、TPは精上皮 腫細胞の細胞質が破碎されてできたアーチファク トであることが判明したので報告する。

【対象及び方法】過去11年間（1985年〜1995年） に組織学的に精上皮腫と診断した症例のうち、冈r ight-Giemsa染色あるいはDiff-Quik染色が施行さ れた㳒抹標本が存在する6症例を検討対象とした。 これらの症例をTPが出現した症例と出現しなかっ た症例の2群に分け、年咸、腫瘍の大きさ、個数、 原発部位、腫湟の進展、組織型、叙抹細胞像など について比較検討した。

【結果】6症例中4例はTPがびまん性に、1例は散 在性に見られた。残りの1例ではTPは観察されな かった。年龄、腫瘍の大きさ、個数、原発部位、 腫演の進展、組織型などとTPの出現の有無には関 係がなかった。組織学的に腫瘍細胞のPAS反応やP LAPは全症例で陽性で、PAS陽性物質は全症例ジア スターゼで消化された。腫漡細胞の大きさやN/C 比はTPの出現に関係がなかった。1000個の腫湯細 胞を観察したところ、裸核細胞の出現率は、TP陽 性症例で79.0〜88.5\%であったのに対し、TP陰性 症例では43.1〜 58.3\%であった。また、TP(-)症 例の腫瘍細胞は核クロマチンや細胞質が無構造 で乾燥固定が不良であった。

【まとめ】TPは、細胞破砕によって作られるアー チファクトであり、腫湯細胞が豊富なグリコーゲ ンを有していること、細胞が密に配列しているこ と、良好な乾燥固定が行われていることなどの条 件が満たされている場合に出現すると思われた。 
301 左鎖骨上窝リンパ節穿刺吸引細胞にて 診断された性腺外肧細胞腫瘍

鳥取赤十字病院中央検查部病理 1), 同外科 2) 同泌尿器科 3), 鳥取大学医療短大病理 4)

O植嶋輝久 (CT) 1), 植嶋しのふ（CT）1）, 山村章次 (MT) 1), 工藤浩史 (MD) 2), 河村秀樹 (MD) 3), 吉田春彦 (MD) 4)

左鎖骨上窩リンパ節穿刺吸引細胞診にて診断さ れた後腹膜原発, 性腺外胚細胞腫瘍の 1 症例を経 験したので, その細胞像について報告する.

【症例】患者は35歳,男性. 1995年 4 月左陰檋の不 快感と背部痛を主訴に, 当院泌尿器科受診した。 両側精巣は正常. 左精巣上体に軽い圧痛と軽度の 精索静脈瘤を認め，CTにて腎門部周囲リンパ節 腫脹が認められた．精查途上に左鎖骨上窩リンパ 節が有痛性に腫脹した為, 同部位の穿刺吸引細胞 診を施行した。肧細胞腫瘍が疑われ，諸検査の結 果後腹膜原発の性腺外胚細胞腫瘍と診断された.

【入院時現症及び検查所見】腫瘍マーカーは H C $\mathrm{G}-\beta: 0.3 \mathrm{ng}$ 血， $\alpha$-fetoprotein: $12 \mathrm{ng} / \mathrm{ml}$ と高值 を示し, 生化学検查では L DH : $454 \mathrm{U} / 1$ と上昇し ていたＬDH分画には異常を認めなかった。

C T所見：腎門部リンパ節に腫大が認められた。

【穿刺吸引細胞診所見】壊死性背景の中に大型裸 核状細胞を集合重積性に認めた。核は不整形で, くびれを有し，核クロマチンは顆粒状で大小の好 酸性核小体を数個認めた。

【病理組織所見】壊死物質に混じって異型性の強 い大型細胞が小さな nestを形成しており, 近傍に はmyxoidな間葉系組織が見られた。胚細胞腄㕫が 考えられた. 免疫組織染色ではHCG 陽性, $\alpha-$ feto protein, CEA, EMAは陰性であった。

【まとめ】左鎖骨上窩リンパ節穿刺吸引細胞診に よって肧細胞腫瘍と診断され的確な治療の選択に 極めて有用であり，現在良好な経過をたどってい る 1 症例を経験したので報告した。
302 剖検にて肧細胞腫の診断を得た後腹膜 原発円形細胞腄瘍の-..例

市方四日市病院中央梌在部?、社会保険中京病院” O奈良佳治 (MD) 、竹内 純 $(M D)$ ）中垣 茂男 (C T ) ! 鳥后洋子 (C T ) ! 村上策 (M D) ${ }^{2}$

〔はじめに〕穿刺吸引細胞診で診断が困難であり、 剖検にいたった後腹膜腫瘤の十例を経験したので、 剖㭘所見と免疫組織化学染色を併せて報告する。

[症例】 55 歳男性。死亡 1 年半前より左側腹部 痛と下㾥で近医を受診し、L D H 異常高值を指摘 されるも放置。半年後に当院内科を紹介されて入 院となった。精査にて後腹膜に $8.5 \mathrm{c} \mathrm{m}$ の腫瀷を認 めて生検並びに穿刺吸引細胞診が施行された。〔細 胞診所見】ライトグリーン淡好性の胞体に類円形 の多きな核を有する練胞を認めた。核は明瞭な 1 個の核小体を有していた。部分的に結合性を有し ており、胞体が明るく拻けるものもまじえていた。 [組織所見]針生検が施行され白色混濁様の組織 を得た。壊死が強く不良検体だが免疫芽球様の悪 性リンパ腫が最も疑われた。〔経過〕墨性リンパ 腫桷慢性大細胞型としてV A B C O P P 穜法が施 行され一旦は腫癌は縮小したが、再度腫大して化 学燎法を受けるが敗血症をきたして死亡した。〔剖 検所見了後腹膜大動脈周囲には細胞診所見と同じ 円形の大きな細胞よりなる腫瘍を認めた。腫瘍細 胞はHEの所見からは胚細胞腫、未分化癌、墨性 リンパ腫の可能性が考えられた。免疫組織化学染 绝にて、胎盤性アルカリフォスファターゼ $(+) 、$ EMA (一)、S 100 (一)、広籁囲ケラチン $(-), \mathrm{LCA}(-), \mathrm{L} 26(-), \mathrm{UCHL}$ 1 （一）を呈し、肧細胞䏦と最終䛦断された。付 随する組織所見としては、特徵的なリンパ球の混 在は認めないが、線維性結合織の発垟による柴状 化を認めた。〔まとめ〕生殖器においてはありふ れた肧細胞腰の診断も、非生殖器由来の检体にお ける確定部断は時に困難であろらと思われた。 
金沢医科大学病院病理部

○寺内利恵 (CT)，山下 学 (CT), 朝倉善史 (CT)，中野万里子（CT）, 佐々木恵子（YD）。 松能久婎（MD），野島孝之（ID）

〈はじめに〉尿道の原発性悪性黒色腫は極めて稀 な腫演であり、報告例は少ない。私達は、尿中に 悪性黒色腫細胞が出現した尿道原発の悪性黒色腫 を経験したので、尿細胞診像を中心に報告する。 〈症例〉69才、男性。楉尿病の既往あり。尿道㹟 窄のため当院を受診し、尿道内悪性腫煌を指摘さ れ陰宔切断術が施行された。鼠径リンパ節に転移 を認め、術後6个月の現在局所再発をみるが、遠隔 転移は認めない。

〈病理所見〉腫癔は1.3×1.2×2.6 cm、暗赤色充実 性で、組䢂学的には、一部に褐色色素を有する類 円形〜紡鍾形の腫晹細胞が充実性塊状に増生して いた。HMB-45とS-100 蛋白の免度染色は腫瘍細胞 の細胞質内に陽性を示し、Fontana-Yasson染色で は一部の細胞で陽性であった。腫煌は尿道に沿っ て進展し、影微鏡的に膀胱まで達していた。 〈細胞診所見〉自然尿では、多くの炎症細胞、赤 血球、移行上皮細胞、扁平上皮細胞を背景に、類 円形の腫場細胞が単独または少数個の集団で散見 された。腫漡細胞はN/C 比が高く、円形核で核縁 は肥厚し、クロマチンは顆粒状〜粗顆粒状、核小 体は著明なものを $1 ， 2$ 個有していた。細胞質は 鈍いライトグリーンに染まっていた。洗浄尿では、 少数の炎症細胞の中に、シート状〜乳頭状に大小 不同の目立つ類円形の属演細胞が認められた。核 小体は自然尿程目立ず、また、細胞質はライトグ リーンで自然尿より大きかった。経過を通して明 らかなメラニン顆粒は諗められなかった。核内細 盷質封入体は、経過が進むと共にわずかであるが 認められた。治抹紐胞では、Fontana-Masson染色 は除性であったが、HIB-45とS-100 蛋白は細胞質 内に陽性を示した。

〈考察〉尿道に発生する悪性黒色腫は極めて稀で あるが、尿中に出現することもあり、鏡検する上 で十分考慮する必要があると考える。
自治医科大学附属大宮医療センタ一検査部”

同病理部 ${ }^{2}$

自治医科大学附属病院病院病理部 ${ }^{31}$

○河野哲也(CT) ${ }^{1}$ 小濃啓子(CT) ${ }^{\prime}$

高山美紀 $(C T)^{11}$ 山田茂樹 $(M D)^{21}$

金井信行 $(M D)^{3)}$

原発性前立腺移行上皮癌は，比較的稀で前立腺癌 の $5 \%$ 以下といわれ，前立腺導管の遠位部から発生 すると考えられている。今回我々は，原発部位の検 索に難淽した症例を経験したので報告する。

【症例】 68 才, 男性. 平成 2 年 11 月頃より尿道 痛, 頻尿を主訴に来院. 前立腺炎, 膀胱炎として治 療するも軽快せず。平成 3 年尿細胞診にて, 大小不 同が著しく孤立性出現の悪性細胞を多数認めclass V 低分化癌 低分化腺癌>移行上皮癌 G III と診断した. 平成 5 年に膀胱生検を 2 回施行するも悪性所見は得 られず，同年の尿細胞診においては計 6 回の検査を 施行しており，すべて陽性であった。また，同年 9 月に前立腺針生検が施行され, 細胞診と同様な大型 異型細胞を認めたが, 組織型の推定は困難な低分化 像であった。同年 12 月根治的前立腺摘出術が施行 された。 以後, 尿細胞診での悪性細胞の出現は消失 した.

【細胞学的所見】術前までの細胞像においては, 高 度の炎症性背景で壊死物質は目立たなかった。出現 する異型細胞は大小不同が著しく, 散在性から重積 性に認めた。多くの核は変性により濃染していたが 均一の増量を呈し核縁の肥厚を認めた。N/C比は増 大し，大型核ほど核小体が目立った，胞体はそしい ものから豊かなものまで認め, 移行上皮癌と腺癌の 判定に苦慮した。

【組織学的所見】尿道周囲の下部前立腺右葉内側に 割面上 $20 \times 16 \mathrm{~mm}$ 大の腫瘤形成を認めた。組織学的 には一部に移行上皮癌の分化形態を示す低分化病巣 で, 前立腺部尿道粘膜にわずかの浸潤と, 右精虽腺 浸潤を伴っていた.リンパ管内浸潤と導管内進展が 目立ち, 上部前立腺にも広範囲に病変を認めた。

Transitional cell carcinoma of the prostate と診断され た.

【まとめ】異型の強い低分化癌は, 通常移行上皮癌 GIII 疑うが，膀胱鏡・膀胱生検において異常を認 めない場合, 稀ではあるが前立腺原発も考慮し早急 に精査することが重要であることを再認識した。 
稲沢市民病院臨床検查科病理 ${ }^{1}$, 泌尿器科 ${ }^{2}$

○野村七夫 (CT) ${ }^{1}$, 江崎正則 (MT) ${ }^{1}$, 澤 勲夫 (MT $)^{1}$

腚川キリスト教病院 病理部

谷口大介 $(M T)^{1}$, 加藤一夫 $(M D)^{1}$, 傍島 健 (MD) ${ }^{2}$

前立腺ポリープは若年者血尿の一因とされてい るが、今回我々は、その尿細胞診で膀胱乳頭腫と 鑑別を要した症例を経験したので報告する。

症例：39才、男性。主訴 : 腰痛、影微鏡的血 尿。既往歴：20才時、疛核、前立腺炎。家族歴 : 父、脳梗塞。母、子宮笳腫。

現症：22才頃より血尿持続。95年 4 月、腰 痛にて当院受診。尿一般検查にて影微鏡的血尿。 膀胱鏡検查にて尿道前立腺部に乳頭状腫瘤。膀胱 鏡後尿細胞診施行。パパニコロウ染色標本に移行 上皮細胞と小型円柱上皮様の青緑色調細胞を認め た。移行上皮の核は円〜楕円形、クロマチンは軽 度䈔染、粗網状および細顆粒状均等分布、核小体 は 1 個認めるものが多い。一部に 5 層程度までの 乳頭状集団を認めた。小型円柱上皮様細胞の核は 円〜楕円形、軽〜中等度漂染、クロマチンは微細 〜細顆粒状均等分布。核小体は一部に小型のもの を 1 〜数個認めた。同じく May-Grunwald Giemsa 染色標本で、移行上皮細胞、小型円柱上皮様細胞 とも赤紫色の核、灰青色の細胞質を有し、核形、 クロマチン、核小体、細胞集団の形態は、パパニ コロウ染色と同様であった。7月、尿道前立腺部 の乳頭状腫瘤を一部切除。

組織標本では前立腺円柱上皮の乳頭状増殖を認 め、血管、リンパ管拡張增生、緎維増生が認めら れた。組織診断は Prostatic polypであった。

移行上皮の細長い細胞と円柱上皮とは核の偏在 に注意して鑑別すべきと考えられた。 
307 膀胱癌に併発した尿道尖圭コンジロ -マの1例

青森県立中央病院病理 ${ }^{1}$, 同 泌尿器科 ${ }^{2)}$, 八戸 市民病院病理 ${ }^{3)}$

○浜谷幸子 $(\mathrm{CT})^{11}$, 横山慶 $-(\mathrm{CT})^{1)}$, 槍山美佐江 $(C T)^{11}$, 永澤茂行 $(C T)^{11}$, 今井 督 $(M D)^{11}$, 菅三 知雄 $(M D)^{11}$, 田中 聡 $\left(M D^{2)}\right.$, 方山揚誠 ${ }^{3)}$

尖圭コンジローマは外陰部に好発するが，時に 尿道にも発生する. 今回は, 膀胱癌の腫瘍切除後 に併発した尿道尖圭コンジローマの症例を経験し 尿細胞診所見について観察したので報告する.

症例は64藏の男性で，昭和56年12月に膀胱癌（ 移行上皮癌）のため膀胱部分切除術，平成元年 10 月に再発のためTUR-Btを施行された. 平成 7 年 1 月に再度の再発をきたして入院し, 化学療法施行 後の 4 月にTUR-Btが行われた. その後の尿細胞診 で異型局平上皮細胞が出現したため, 尿道鏡を施 行したところ, 前部尿道から内尿道口にかけて広 く全周性に乳頭状腫瘤の所見が認められ, 生検組 織診では尖圭コンジローマを示した. HPV の免疫 染色（醉素抗体法）では一部の細胞の核に陽性像 が認められた。

膀胱癌治療後の尿細胞診では成熟扁平上支細胞 が集合性や散在性に多数出現してみられた. 細胞 質はエオジンやオレンジGあるいはライトグリー ンに好染性で, 核の腫大やクロマチン増量を示し 中には核周囲ハロー, 均質無構造核や濃摍核もみ られた。核異型性は軽度から中等度で, 中には高 度のものも認められ, 当初は扁平上皮癌も推定さ れたが，比較的きれいな背景，細胞の多形性・角 化・核異型性などの程度から, 尖圭コンジローマ に相当する細胞所見と考えられた.

\section{8 膀胱神経内分泌临の 1 例}

兵庫医科大学第一病理 ${ }^{11}$, 八尾德洲会病院中検病 理 $^{21}$, 同内科 ${ }^{31}$, 同泌尿器科 41

O杉原綾子 (MD) ${ }^{11}$, 名方保夫 (MD) ${ }^{11}$, 浜田 勝 (C $T)^{21}$, 森 栄 $(M T)^{21}$, 窪田 彬 (MD) ${ }^{11}$, 仲谷宗久 $(\mathrm{MD})^{3)}$, 寺川知良 $(\mathrm{MD})^{41}$

膀胱原発神経内分泌虞の 1 例を経験したので, 細胞像, 病理組織像および超微形態像に若千の文 献的考察を加えて報告する.

症例 : 59歳, 男性.

現病歷: 1994年 2 月頃より無症候性肉眼的血尿 が出現し, 3 月 4 日に八尾徳洲会病院泌尿器科を 受診した。尿細胞診でClass V,エコー検査で膀胱 媳室に発生した腫汮と診断, 同部の生検で悪性と 診断されたため 3 月 30 日に部分的膀胱切除術が施 行された. 腫瘍は右側壁の覟室に存在し, $2.0 \times$ $2.0 \mathrm{~cm}$ の大きさであった. その後化学療法を施行 したが、両肺、肝等への転移をきたし、7月8日 に死亡した.

尿細胞像 : N/C 比は增加し, クロマチンはやや 粗造で増大した比較的大小不同の少ない核を有す る腫瘍細胞が少数認められた。

捺印細胞像：結合性および重積性のある腫瑒細 胞塊が認められた. 腫湢細胞の核クロマチンはや や粗造で，核の大小不同は少なく, N/C 比は増加 していた.

病理組織像 : 腫場細胞は小型で比較的均一であ るが，核分裂像は多数認められた．ロゼット形成 像も認められ，また一部に腺虏への分化を示す部 分も見られた.グリメリウス染色陽性で，NSE，ク ロモグラニンA,サイトケラチン, CEA が陽性であ った。電顕的に神経内分泌顆粒が認められた。

まとめ：膀胱癌は移行上皮癌 (TCC) の頻度が圧 倒的に高く, 細胞診断学的に本腫場との鑑別が問 題となる。しかし核クロマチンの所見, 細胞の重 皘性の有無, 核の不揃の有無などから、TCC との 鑑別は可能ではないかと考えられた。 
岸和田徳洲会病院 臨床検查科病理 ${ }^{(1)}$

大阪市立大学 第一解剖 ${ }^{(2)}$

○楖引健一 (CT) ${ }^{(1)}$ 、川口佐知子 (CT) ${ }^{\text {(1) }}$ 中村陽一 (MT) (1) 、太田 善夫 (MD) (1) 前田光代 (CT) (2)

Von Recklinghausen's Disease によるNGBにて経過 観察中に膀胱内にSolid tumorを指摘され精查及び 治療目的で入院となり、膀胱摘出標本にて骨外性 骨肉腫と診断された症例を経験したので報告する。 【症例】Von Recklinghausen's Disease がベースに ある59歳女性で、全身倦急繰り返す尿路感染症、 水腎症、胆石、NGB にて経過観察中であった。

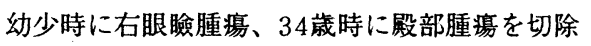
している。当院に初めて紹介された 5 年前当時よ り超音波で、膀胱の変形と軽度の壁肥厚を指摘さ れてはいたが経過観察中には著変を認めなかった。 平成7年7月に膀胱頂部に充実性腫㰾病変を認め TUR-Bt を施行。病理組織結果にて Fibrosarcoma の所見を得た為、膀胱摘出となった。摘出された 腫瘍は内腔に突出し手拳大の大きさであった。 【捺印細胞像】出血性一部壊死性背景で、類円形 一紡錘形の細胞が主体をなした多彩な細胞像であ り、核は類円形 楕円形で大小不同を認め、ク口 マチンは細顆粒状不均等分布を示し、核小体は類 円形のものが $1 \sim 3$ 個程度認められた。細胞質は ライトグリーンに淡染性であった。一部には多核 巨細胞や軟骨様細胞も認められた。

【組織所見】光影像では、核小体の目立つ多形異 型核を有する紡錘形、多形異型細胞が充実性に増 殖し広い範囲にわたり類骨や成熟骨、軟骨の形成 が見られ各所に核分裂像が認められた。電影像で は、核内に染色質間顆粒が見られ細胞質内には、 E Rの発達が著明であり、細胞間には膠原線維が 存在し無機物の沈着が認められた。

【まとめ】摘出された腫堭は内腔に突出していた が、術前に提出されていた尿細胞診では、移行上 皮様の異型細胞が少数認められた程度で明らかな 腫瘍細胞は認められず、病理組織結果との関連を 特定するには困難であった。

\section{0 尿管の移行上皮内分泌細胞癌の 1 例}

新潟大学医療技術短期大学部" 器科 ${ }^{2}$, , 同検查科 ${ }^{3)}$

○岩㴊三哉 $(M D)^{11}$ ，内山武司 $(M D)^{2)}$ ，塩田吉 一郎 ( C T $)^{3)}$

内分泌細胞癌 (小細胞癌) と移行上皮癌とが共存

した下部尿管癌の 1 例を報告する。

症例：70藏女性。右腹部痛を主訴に受診し、右 側下部尿管癌と診断された。

尿細胞診: 腫㾤細胞は孤在性〜重積性小集団で 出現した。腫演細胞は小型(く短径約 $10 \mu \mathrm{m}$ )で、N/ C比大で、細胞質は狭く裸核状であった。核は類円 形で、クロマチンは微細で増加し、ときに小型核 小体が数個みられた。対細胞、木目込み細工配列 あみられた。少数の異型移行上皮細胞すみられた。 病理所見: 右側腎尿管全摘除術が施行された。 転移はなかった。腫緜は全周性で灰白色調の非乳 頭状隆起 (綐径 $20 \mathrm{~mm}$ 、横径 $17 \mathrm{~mm}$ )であった。組織学 的に、腫境は筋層周囲に浸潤していた。腫堭組織 は、腫堭細胞のシート状充実性增殖部(優位)と層 状充実性の移行上皮癌から構成されていた。シ一 卜状充実性增殖部では、腫境細胞はN/C比大で、核 はほぼ均質に小型(く短径約 $10 \mu \mathrm{m}) 、$ 類円形で、絰 密〜粗なクロマチンが増加し、核小体は小型ない し目立たなかった。細胞質は弱好酸性で狭く、境 界不明暸であった。核分裂像は高頻度であった。 腫瘍細胞の壊死巣が散在した。腺腔形成、粘液産 生、扁平上皮様变化はなかった。腫堭細胞は免疫 染色でcytokerat in、EMA、NSE陽性、内分泌顆粒 一カー陰性であり、電顕で少数の円形内分泌顆粒 (径 $130 \mathrm{~nm}$ )を有していた。以上より、本例は移行上 皮内分泌細胞癌と診断された。

経過: 術後化学瘖法を施行。術後12月経過し、 腫㾮の再発や転移はなく、経過良好である。

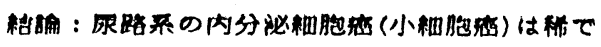
はあるが、存在に留意する必要がある。 
311 CASで解析されたDNA ploidy pattern は組織標本と細胞診材料を対象した場合 とでは異なるか。一腎癌細胞を対象として

東京医科大学病理学教室 ${ }^{1}$, 病院病理部 ${ }^{2}$

○洪 建偉 $(M D)^{\prime}$, 海老原善郎 $(M D)^{\prime}$, 工藤玄恵 $(M D)^{1}$ 清水 亨 $(\mathrm{MD})^{2}$, 藤田浩司 $(\mathrm{CT})^{2}$

〔はじめ〕病理組織標本を使った核DNA のploidy pattern の解析が生物学的悪性度や予後の判定基 準の一手段として用いられているが, 組織材料と 練胞診検体との比較検討はあまりなされていない。 今回, 腎細胞癌の細胞診検体之同部位の組織切片 を用いて，核DNA を测定し，ploidy pattern を 比较検討した。

【方法〕腎細胞癌12例を対象とした。組織覀型と 異型度の内訳は, 淡明細胞 7 例 $\left(G_{1}: 1, G_{1}>G_{2}: 2\right.$, $\left.G_{1}>G_{3}>G_{2}: 1, G_{2}: 3\right)$, 顆柆細胞 2 例 $\left(G_{2}: 1, G_{3}: 1\right)$, 湿合細胞 2 例 $\left(\mathrm{G}_{2}\right)$ ，オンコサイト 1 例 $\left(\mathrm{G}_{1}\right)$ 。組織 切片はホルマリン固定、パラフィン包埋材料を 5 $\mu \mathrm{m}$ とたもの。細胞診材料は通常の純アルコー ル固定材料を用いた。組織材料および細胞診材料 とも 1 検体につき 2 力所採取。両者とも Feulgen 染色を行い, CAS 200 Image Analyzerを用いて核 DNA ploidy patternを惻定した。

〔結果〕組織材料で核DNA diploidy patternを示 したものは 4 例( 淡明細胞 $\mathrm{G}_{2}$ の 2 例, 混合細胞 $\mathrm{G}_{2}$ の 1 例, オンコサイトG,の 1 例 ), 残り 8 例は aneuploidyであった。細胞㟝材料のploidy patternは組織材料の娜定結果とほぼ一致したが，組 織切片でaneup loidyであった 1 例は細胞診材料で tetraploidy patternを示した。

〔まとめ〕対象とした腎癌には異常に変形した核 をもつものが含まれていない。これは組織切片と 細胞診材料で ploidy pattern がほぼ一致してい る理由であると考えられる。
312 胞巣型横紋筋肉腫の 1 例

山口大学医学部検查部 ${ }^{11}$ 、同臨床検査医学 ${ }^{2)}$ 、 同第一病理 ${ }^{3)}$

○平岡芙美子 $(\mathrm{CT})^{1)}$ 、伊世悦子 $(\mathrm{CT})^{1)}$ 、高橋睦夫 $(\mathrm{MD})^{2)}$ 、村上喜信 $(\mathrm{CT})^{3)}$ 、山下勝 $(\mathrm{CT})^{3)}$ 、河野裕 夫 $(\text { MD })^{3)}$ 、権藤俊一 $(\text { MD })^{3)}$ 、石原得博 $(\text { MD })^{3)}$

胞巣型横紋筋肉腫は覀性度の高い肉腫の 1 つで あり、最初、骨䯣穿刺による転移で発見され、上 腕部の腫瘤の生検により本腫瘍と確定診断された 症例を経験したので報告する。

【症例】13才、男子。2年前より右上腕、右腋窩、 前胸部に多発性の皮下腫瘤を認めていた。本年 8月末頃より、発熱が持続し、検査の結果、血小 板の減少が認められたため、本学小児科に入院。 入院時、CTにて右胸水、胸腺腫大が認められた。 9月、右上腕部腫瘤の一部より生検が施行された。 【細胞所見】骨䯣穿刺標本では、胞体内に多量の グリコーゲンを有する小型〜中型の異型細胞が小 集簇性に認められた。腫瘤の捺印標本では、腫瘍 細胞は結合性に乏しく、淡明で豊富な胞体を有す る小型〜大型の細胞よりなっていた。核は円形〜 長楕円形でgroove状の都が認められ、微細顆粒状 のクロマチンに富み、核内に2〜数個の小型なが ら明瞭な核小体が認められた。同様の細胞からな る多核の巨細胞も散見された。

【組織所見】硝子化した結合織中に多核の巨細胞 を混じて、小型〜中型の腫湟細胞が大小の胞巣を 形成して認められた。多くの部で、胞巣の中心部 が空隙様となり、变性・壊死に陥った腫瘍細胞が その空隙内に遊離していた。免疫染色では、 sarcomeric actinなどが陽性であった。

【電顕所見】腫演細胞の胞体内には、多数のグリ コーゲン顆粒がみられ、稀にabortiveな横紋構造 が認められた。

【まとめ】本症例は、最初、骨䯣穿刺標本で異型 細胞の起源の同定に苦慮したが、組織学的には、 典型的な胞栄型横紋筋肉腫であった。 
313 大蔵外側広筋内に発生した myxoid le iomyosar coma (MLS) の 1 例

諏訪赤十字病院病理部 1 / 中央検查部 ${ }^{2}$, 市立岡 谷病院研究検查科 ${ }^{3} /$ 病理科 $^{4}$

○征矢涼子 (MT) ${ }^{\prime}$, 下村雅彦 (CT $)^{\prime}$, 矢島元雄 (CT) ${ }^{1}$, 唐木幹次 $(C T)^{2}$, 飯塚好伯 $(C T)^{3}$, 藤 原正之 (MD) ${ }^{4}$, 中村智次 (MD) ${ }^{1}$

症例：50歳・男性.約10年前より右大腿の滕 蓋骨外側上方の腫瘤に気付いていたが, 最近増 大傾向があり, 軽度の疼痛も出現した. 術前の 生検で悪性と考えられたが，画像上腫演が凌関 節に接しており，関節腔内への漫潤も疑われた ため, 関節機能を温存したままの広範切除は不 可能と判断し, 大服切断を施行した.

肉眼所見：腫癔は $11 \times 10 \times 6 \mathrm{~cm} .$, 外側広筋内に あり全体が著しく myxoid であった. 深部筋膜 や㬵関節包に接し，筋膜を越えて漫潤していた。 細胞所見：腫瘤の捺印標本では，背景に多量の 粘液状基質が認められ，細胞成分はこれに混じ て巻合い状ないし連珠状配列を示していた。細 胞は紀錘型のものが主体で軽度の大小不同・核 不整があり，核内空胞を有するものもみられた が，核分裂像は殆どなかった。

組織所見: Myxoid stroma (Alcian blue 陽性, hyaluronidase 感受性) の間に好酸性の胞体を 有する平滑筋細胞類似の spindle cells が索状 增殖を示す部分が主体で, 一部では細胞密度が 高い部分も認めたが, mitosisはそしかった。 筋膜や関節包に接している部分ではこれらへの 漫潤がみられた．免疫染色ではvimentinのみ 陽性で, desmin, smooth muscle actin 䧣性像 は得られなかったが, 電顕的に少量の microfilament の疑集を認めた.

考察：大腿部に発生した leiomyosarcoma の一 部が myxoid な変化を示すことは稀ではないが， 本例のように腫癔全体が MLS の像をとる例の報 告は文献上みられず，極めて稀な例之思われた。
314 大腿筋肉内に発生した類上皮肉腫

弘前市医師会成人病検診センター '), 国立弘前病 院研究検査科 ${ }^{21}$, 同 整形外科 ${ }^{3)}$

()長沼孝雄 ( C T ) "), 中村洋子 ( C T ) "),

大高昌子 ( C T ) ${ }^{1)}$, 池崎福治 ( C T $)^{2)}$,

松本一仁 $(M D)^{2)}$, 柿崎 寛 $(M D)^{3)}$

類上皮肉腫は思春期ないし若年成人の手および 手指などの四肢遠位部に好発する比較的稀な軟部 腫瘍である。今回我々は、右大腿筋肉内に発生し た本腫瘍を経験したので、その捺印細胞像、組織 像および免疫組織化学所見について報告する。

【症例】73歳、男性。平成 4 年12月より右大腿前 面の腫瘤に気付く。腫瘤は徐々に増大し、膫屈曲 制限が出現したため、平成 5 年 7 月某医を受診。 生検の結果、右大腿転移性軟部腫瑒と診断され、 同年同月、手術目的のため国立弘前病院整形外科 に入院。C T所見より右大腿軟部腫瘍之診断され、 広範切除術が施行された。

【捺印細胞所見】出血およびへモジデリンを領食 した組織球を背景に、比較的大型類円形ないし多 稜形の腫瘍細胞が㻋な結合を示す平面的集塊また は孤立散在性に出現、紡錘形細胞や 2 核細胞も散 見された。細胞質は比較的豊富でライトグリーン 好性、核は類円形で偏在し、時に切れ込みの著明 なものも混在していた。核縁は薄く、クロマチン は顆粒状で増量し、小型の核小体が数個認められ た。以上の所見から非上皮性悪性腫瘍と推定した。 【組織所見】類円形〜紡錘形の腫瘍細胞が線維性 組織に囲まれ多結節状に増殖し、結節中心に壊死、 硝子化を伴っていた。免疫染色では keratin、EM、 vimentin が陽性で、CEA、S-100は陰性であった。 以上の所見から類上皮肉腫と診断された。

【まとめ】本腫瑒は上皮様結合を示す細胞が出現 するため、転移性癌や二相性滑膜肉腫との鑑別が 必要である。以上、大腿筋肉内に発生した比較的 稀な類上皮肉腫の一例を報告した。 
315 右第1,2趾間に発生した 明細胞肉腫の一例

岸和田徳洲会病院 臨床検査科 病理 ${ }^{(1)}$ 大阪市立大学 第一解剖 ${ }^{(2)}$

$\bigcirc 太$ 围夫 (MD) ${ }^{(1)}$ 、櫛引 健一 (CT) (1) 川口佐知子 (CT) (1)、中村陽一 (MT) (1) 前田 光代 (CT) ${ }^{(2)}$

clear cell sarcomaは、1965年Enzingerらによって 記載された特異な腫鿰である。若年成人に発生す ることが多く、経過は比較的長いが、手術後しば しば再発し、末期には遠隔転移を来す。今回は、 右第 1,2 趾間に発生した明細胞肉腫の一例を経験 したので、細胞学的、組織学的に検討した。

【症例】 27 才女性で、22才の時に右第 $1 、 2$ 趾間に 腫瘤の形成を認め、当院を受診し生検の結果clear cell sarcoma と診断された。腫瘤は摘出され、放 射線療法、化学療法が併用されたが 4 年後に再発 し再手術を施行された。

【捺印細胞像】再手術時に腫瘍の捺印により得ら れた細胞所見は類円形〜紡錘形細胞がシート状に 出現しており、細胞質はライトグリーンに淡染し 辺縁は不明瞭である。核形は棈円形でクロマチン は細顆粒状に増量しており、核小体は腫大した単 個のものが多い。なお光顕的観察において胞体内 に、明らかなメラニン色素は認められなかった。 【組織所見】初回手術時の切除標本では、腫場細 胞は円形または紡錘形で、細胞質が広く淡明で、 所々にメラニン色素を含んでいた。これらの細胞 は胞巣状を呈しており、線維性結合織により分け られ分葉状を呈していた。再手術時に得られた標 本では、前回に比べて核異型がより著明となり明 らかなメラニン色素は光顕的にも、電顕的にも認 めらず、形態は滑膜肉腫に類似した紡錘型細胞が 主体であった。

【まとめ】 clear cell sarcomaの組織発生について は、電顕的観察から滑膜起源と考えられ、また一 方では、胞体内にメラニン色素を有する事から悪 性黒色腫の一種とされている。これらの事から clear cell sarcomaを synovial typeと melanotic typeに わけ、それぞれ形態学的、臨床経過に違いがある とされている。今回の症例では、形態がmelanotic typeからsynovial typeに変化しており両者が移行 する可能性が示唆される。

\section{6 穿刺吸引細胞竞にて未分化癌と診断し た滑膜实腫の一例}

川口市立医療セン夕一診療局検查科病理

O松永英人(CT)，鈴木忠男(CT)，高野通彰(MT)， 坂田一美(MD)，山本雅博(MD).

日本大学矤学部附属練馬光力゙丘病院病理部 㯒庭義巳(CT), 張寧美(CT).

(財) 東京都保揵医療公社東部地域病院険查科 岡野匡雄(MD)

【はじめに】今回我々は、66歳の人の足中足骨関節 発生で、穿剌吸引細胞剅にて未分化癌の転移を疑つ た症例を経䂇したので報告する。【症例】66歳男性、 1995年6月に右足甲部の腫張に気づいたが放置。9 月当院整形外科を受䕀、右足甲部に直径約 $5 \mathrm{~cm}$ の腫 瘤力舅められ、穿刺吸引細胞煏及び生検を施行し、 その後足首切断術か施行された。紐胞像】重積を 示す多数の細胞集塊、又は散在性に分布する異型細

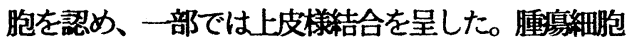
は円〜類円形のほほ均一の大きさの核を持ち、N/C 比は高く、クロマチンは増量し微册顆站状、核小体 は小型であった。紐胞質はライトグリーン好染性で あり、裸核状の細胞も混在していた。転移性の未分 化癌を疑った。【組炼像】生検では腫汮は小几中型 の類円形紐胞力流実性に堌殖し、隔壁構造を混在し 未分化癌を疑った。手術検体では上記所見に加えて、 管腔様構造力悲められ円柱上皮の形態を呈していた。 一部に紡狳形細胞の堌殖も認めら九 二相性パ夕ー ンを示しており、最終的には滑膜肉腫と診断した。 【ま之め】今回の症例は組織学的にも上皮様䋥胞及

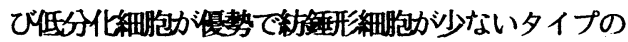
滑膜肉腫であった。細胞䣓検体を見直すと、同じく

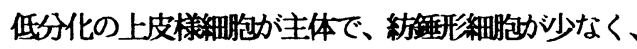
診断に苦慮した。骨、软部発生の腫場については、 発生部位、年龄、経過などを参考にする事が重要で、 さらに病変局在があることを创頭におき、腫婸が大 きい場合などは数力所からの紐胞採取をおこなうべ きと考えた。 
317 仙骨部の脊索腫の 2 例. その細胞学的 所見.

東京医科大学病理第 2 褠座 ${ }^{1}$ ，病院病理部 2

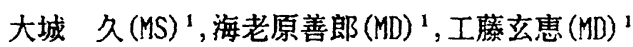
芹沢博美 $(\mathrm{MD})^{2}$, 斉藤美子 $(\mathrm{CT})^{2}$, 武田久美子 $(\mathrm{CT})^{2}$

症例: 症例 1 (57才, 男性)。症例 2（50才，男 性). 2 例とも仙骨部の疼痛と排尿障害・便秘を 主訴とする。下肢に知覚・運動障害はない，CTscan などの画像診断で，仙骨 $S_{3} \sim$ 尾骨を軸に 発育腫瘍梾病変を認め, 膀胱・直腸を強く区迫し ていることを共通とする，症例 1 では，腫㿋は筋 膜と壁側腹膜に包まれており，腫湯性骨組織と共 に完全に切除された。庭例 2では仙骨の融解所見 が著しく，周囲組織への浸潤性発育も著しかった。 腫葟の切除は不成功に終わり，放射線照射などが 試みられている。

組織学的所見 : 腫瘍細胞は類円形核と豐富な細胞 質からなることを特徵とするが，症例 1では毛細 血管と共に充実性胞巣を作るところが有意である。 症例 2では，血管が少なく，粘液腫様の基質に索 を作って分布し，細胞成分はむしろ少ない。 細胞学的所見 : 腫湯細胞は孤立性あるいは数個ま でのものが索状配列を示して認められる．核は類 円形で，微細〜粗大顆粒状のクロマチンがびまん 性に分布する，核小体の明瞭なものは殆ど認めら れない，細胞筫は豊富で，細胞膜は明瞭である。 大型細胞では大小の空虚な空胞が多数認められ， 蜂の巣状に見える. 他に小型のリンパ球様細胞が いろいろの程度に分布する. 以上を共通所見とす

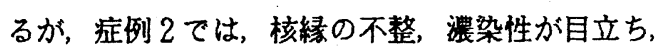
核内封入体も目立った。

コメント：2例とも発生部位, 組織像が定型的な 脊索腫である。細胞異型の軽度な上皮様細胞が主 体であるので，高分化腺澺との鑑別が問題となる。 細胞所見の熟知はこの希有な腫湯の細胞学的診断 に役立つ。

\section{8 後腹膜に焱生した Paraganglioma}

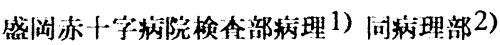

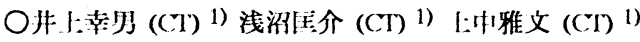
水野幸人（MT) ${ }^{1 ）}$ 荻池俊 (MT) ${ }^{1 ）}$ 門間信博 (MD) ${ }^{2)}$

後股膜に発生した大きな Paraganglioma を経験した のでその紼肘像と組織像について被告する。

[刻例]

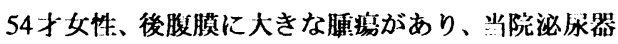
科切切除。

腫㻛は薄い被膜で被われており暗赤色を早し、大き さは20 × $15 \times 13 \mathrm{~cm}$ 、割面では充実性の部分と血波を 合む大小の装胞形成を兒た。

[紐胞像]

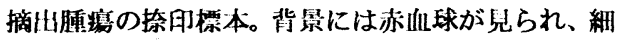
胞は平面的で割とルーズな上皮㥞結合を示す集塊とし て出現。また毛絒血管も見られた。核は5 30 $\mu$ と大 小不同は見られるものの核は類们形で、核形不整は無 く、クロマチンは粗顆粒状で均一に分布。大きな核に は核内細胞質封人体が見られた。核小体は存在するが めだたなかった。細胞質は此較的豊富で辺䋑不明瞭で あり、核の偏在性が見られた。また胞体内には袺色の 顆粒状色素が瑟められた。

[病理組織像]

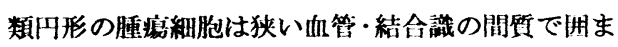
れた充実性の胞柴を形成。核は阿形で大小不京を示し たが、pleomorphism は見られなかった。胞体には neuromelanin が諗められた。ときに血波で满たされた cystic space の形成を見た。

腫理䌈胞は Grimelius (+)、桲絭抗体法でクロモグ ラニンAは除性であった。

[電顥像]

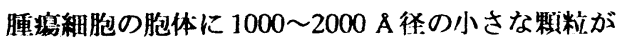
認められ Paraganglioma に䂆盾しない像であった。 [まとめ]

本腫韵は後腹膜に発生:した Paraganglioma で、核内 細胞質封入体と neuromelanin の敒任が特幑的であっ た。細胞形態から悪性腫垉は考えにくかった。 
319 後腹膜原発墨性神経内分泌腫境の 1 例

青梅市立総合病院 外科 ${ }^{12}$ 検查科 ${ }^{21}$

東京医科橎科大学 病理学第 2 講座 ${ }^{3)}$

O中浜 暃夫 $(M D)^{11}$, 平原 芳弘 $(M T)^{21}$, 澤森 ちさと $(C T)^{21}$, 传野 広美(MD) ${ }^{11}$, 正木 幸善(MD) ${ }^{11}$ ， 山田 忠義(MD ${ }^{11}$ ， 根本 哲生 $(\mathrm{MD})^{3)}$

今回, 我々は手術切除材料において悪性神経 内分泌腫疱之診断された症例を経験したので, その迅速挎印細胞揨で得られた細胞像につい て報告する。

[症例］53歳女性。H7年2月, 体重減少と左 上腹部痛を主訴に入院となった。左上腹部に 手拳大の腫留が触知された。瓜液生化学デー夕, 睡煌マーカ一に著変なし。腹部C $\mathrm{T}$, 血 管造影にて膵腫瘍之診断され, 開腹手術が行 われた。腫瑒は左後腹膜組織队にあり, 膵体 尾部前面之強く愈着していた。傍大動脈りン ハ節の腫大なし。摘出腫瘍は $16 \times 13 \times 10 \mathrm{~cm}$ 大 の軟らかい充実性腫溜で被膜を有していた。 割面は黄白色，分葉状で光沢を帯びており出 血巣が散兒された。迅速捺印細胞診で未分化 腫場と診断された。

[細胞診] 腫痬細胞は大型，ほぼ均一でシート状列を呈し，結合性に乏しく，しばしば 裸核状を示す。核は大型円形，核の大小不同 は軽度, 核クロマチンは粗大顆粒状, 大型の 核小体を有する。胞体は細顆粒状で淡い。

[組織所見] 腫湯細胞は大型で密な充実性增 殖を示す。ロゼット様構造あり。核は円形で 1〜2個の大型核小体を有する。核分裂像はほ とんど兒られない。胞体は好酸性で粘液産生 なし。膵実質内人の浸潤あり。免疫組織学的 にクロモグラニンA, N S E が晹性を示し, 電湿学的に直径 $200 \mathrm{~nm}$ 前後の神経内分泌顆粒 が瑮められた。
320 悪性神経鞘腫の細胞像 一他の紡錘型細胞腫㕫との比較-

腚川キリス卜教病院病理部

○武田善樹 (MD)、葛西里美 (C T)

福島成之 (C T) 、田中里美 (C T )

田保 徹 (C T)、志田しげの（C T)

47 才男性、仙骨前腫湟の穿刺細胞診にて非上 皮性の悪性とのみ診断した1例があった。後の組 織診と、Von Reckl inghausen氏病であるとの情報 から悪性神経鞘腫と診断した。

他に鑑别にあがってくる紡錘型細胞腫湯につい て、神経鞘腫、脂肪肉腫、悪性線維組織球腫、平 滑筋肉腫等との区別が可能であるか検討した。

悪性神経鞘腫の核クロマチンパターンは脂肪肉 腫に類似し、核形は平滑筋肉腫に類似しており、 胞体は一部で悪性線維組織球腫に似ているが、多 数の細胞を観察できれば細胞像から悪性神経鞘腫 の診断を付け得ると思われた。

今回、数例の他の軟部腫瑒の細胞像と比べて、 墨性神経鞘腫の細胞像、組織像、電影像を呈示し ます。 
321 悪性腫瘍との鑑別が困難であった神経 鞘腫の 1 例

東邦大学付属大森病院病理 ${ }^{2}$ 整形外科 2

同 佐倉病院病理 ${ }^{3}$

$\mathrm{O}$ 井手忠 $(\mathrm{CT})^{11}$, 前田陽子 (CT ${ }^{1}$ ', 佐々木久美子 (CT) ${ }^{1}$ 浜谷茂治 (MD) ${ }^{1}$, 辻本志朗 (MD) ${ }^{2}$, 三浦 妙太 (MD) ${ }^{1}$ '月本正 (MD) ${ }^{2}$ 龟田典章 (MD) ${ }^{3}$

「はじめに」神経鞘腫は、Antoni-A、Antoni-B、 Verocay body、nuclear palisadingなど、特徵的 な組織像を示す事から、その細胞診標本において も診断に有用な所見を比較的容易に見出すことが できる。しかし、今回、我々は摘出された軟部腫 瘤の圧座標本から悪性腫瘍が示唆され、組織像に おいても悪性との鑑別を要した非定型的な神経鞘 腫を経験したので報告する。

症例 54才、男性、2年前に左前腕の軟部腫瘤を 触知、徐々に增大し半年前から疼痛も出現したた め本院整形外科を受診した。諸検査にて良悪性判 定困難な筋間腫瘍として摘出術が行なわれた。

「細胞診所見」グクリール時の新鮮組織から圧座標本 を作製した。腫瘍細胞は、細胞密度の高い集塊性 および孤立散在性に認められ、核注卵円形一短紡 鍾形、核吅乎はは細顆粒状に増量していた。核 小体恃不明暸であうたが、核分裂像が認められた。 細胞質は淡明青緑色で、辺縁は不明瞭、散在性の 細胞は裸核状であった。以上の所見法通常の神経 鞘腫の細胞像からは程遠く、むしろ悪性腫瘍が示 唆されるものであった。

[病理組織所見」腫瘤は $4.5 \times 2.5 \times 2.0 \mathrm{~cm}$ 大。被 膜を有し境界は明瞭、割面には充実性部と啇胞部 が見られた。充実性部では、短紡鍾形細胞が富細 胞性に增殖し、核分裂像も多数認められた。しか し、異型は乏しく、ほとんどすべての腫湯細胞が S - 100 蛋白陽性であった。以上より、富細胞 性增殖と虽胞変性を伴った非定型的神経鞘腫と診 断された。
322 診断に苦虑した高齫者の胸壁 small round cell tumorの 1 例

藤田保健衛生大学病院臨床検查研究部,

同 病理科 ${ }^{1}$, 同 医学部病理学教室 ${ }^{2}$.

○伊藤裕子 (CT), 須藤健助 (CT), 澤田浩秀 (CT), 平沢浩 (CT)，舟橋正範 (CT)，黑田 誠(MD) $)^{1}$, 安倍雅人 $(M D)^{2}$, 溝口良順 $(M D)^{2}$, 笠原正男 $(M D)^{2}$.

【症例】 80 歳女性。平成 7 年 2 月、左前胸部の 腫瘍を自覚し、当院外科受診。腫疱は可動性がな く、US画像上、乳腺には腫瘍は認められなかった。 また胸部 CT・MRIで肺の原発巣と考えられる所見 す検索されなかった。穿刺吸引細胞診が施行され、 small round cell tumor が疑われ、同年 4 月、

胸壁軟部腫瘍として腫瘍摘出術が施行された。

【肉眼所見】腫瘍は $6.5 \times 3 \mathrm{~cm}$ 大で割面は白色調、 充実性で光沢を有し、中心部に黄色調の壊死巣と 出血巣が認められた。腫瘍は固く境界は比較的明 瞭で、小胸筋と瘉着があり神経を一部巻き込んで いたため神経原性腫瘍が疑われた。

【細胞所見】多くの腫瘍細胞は胞体の乏しい小型 の円形〜類円形の細胞であった。細胞間の結合は 緩く、散在性あるいは集合性を示す部分すあった。 核縁は薄く、核形不整が目立ち、クロマチンは増 量し小型の核小体を 1 〜 個認めた。

【組織所見】裸核状の胞体に乏しいsma11 round cellより構成される充実性の腫瘍でロゼット形成 が目立ち、細胞異型は高度で核分裂像は強拡 1 視 野に数個認めた。PAS 反応は陰性、免疫組織学的

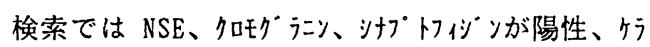
千\%、EMAMIC-2 が陰性であった。電顕所見では、 グリコーゲ顆粒、中間径フィラネル、接合斑を認めたが、 明らかな神経分泌顆粒は確認できなかった。以上 の所見より悪性の神経内分泌腫瘍が疑われた。

【まとめ】穿刺吸引細胞診の所見からは、肺小細 胞癌の転移等む考虑された small round cell tumorであり、PNET 等の鑑別診断に苦虑した。 
323

Intra-abdominal desmoplastic

small cell tumorの 1 例

東邦大学佐倉病院病理部1) 同外科 ${ }^{2)}$
○小林貴代 $(C T)$, 山口みはる (CT)
阿部 淳 $(M T)$, 戸羽美佐子(MT)
蛭田啓之(MD), 鲁田典章(MD)
堀 浩司 (MD), 山口宗之(MD)

Intra-abdominal desmoplastic small cell tumor (IDSCT)を経験したので報告する。

【症例】17歳、男性

【臨床経過】平成5年11月より左側腹部痛と腹部 膨満感が出現し近医を受診。内服治療するも症状 増悪のため同医を再診したところ、腹部に巨大腫 瘍が認められ当院外科に紹介された。血液生化学 的にはCRP,LDHが上昇し、腫瘍マーカーはNSEに若 干の増加が認められるのみであった。試験開腹に て、腹腔内は後腹膜から大網にかけて腫瘍が一塊 となり摘出不可能であった。化学療法を行うも効 果なく、初診から4カ月後に死亡した。

【腹水細胞所見】血性背景に、小型腫瘍細胞が集 塊状に認められた。核にはくびれが目立ち、クロ マチンは細顆粒状に増量し、1～2個の小型核小体 を有していた。細胞質は乏しく、一部の腫瘍細胞 にはLG好染性の封入体様構造物が認められた。

【剖検時拪印細胞所見】壊死性背景に、腫瘍細胞 は孤立散在性に出現し、明らかな集塊形成は認め なかった。個々の腫瘍細胞は腹水中の細胞とほぼ 同様の所見であった。

【組織所見】小型の多角形〜類円形腫瘍細胞が充 実胞单形成性に増殖し、紡鍾形細胞増生による線 維性隔壁を伴っていた。免疫組織化学的にはサイ トケラチン, ビメンチン, NSE, デスミンが陽性 であった。

以上の所見からIDSCTと診断した。IDSCTは比較 的新しいdisease entityで、若年者の腹腔内に発 生するまれな腫瘍である。細胞学的には上皮様性 格を示し、中皮腫や癌との鑑別が問題となった。
324 隆起性皮有線維肉腫における捺印 細胞像及び免疫組織化学所見の㭘討

慈恵医大附属病院中央検査部病理科 1), 同病理学教 室学教室2),同健康医学センター3)

池田奈麻子 $(\mathrm{CT}) 1$ )、塩森由季子 $(\mathrm{CT}) 1$ )、加藤弘枝

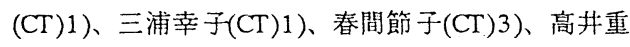
治(MD)2)、原田徹(MD)2)、牛込新一郎(MD)2)

【緒言】隆起性皮虑線維肉腫(以下DFSP)は体幹. 四肢の真皮に好発し、不完全な手術では局所再発 しやすい腫瘍である。その起源に関しては、線維 芽細胞・組織球・未梢神経由来など末だ定説はない。 今回、DFSPの細胞組織像と免疫組織化学所見を観 察し、線維肉腫(以下FS) と比較検討した。【材料. 方法】DFSPはBednar 1 例を含む 3 例、FSは乳幼览 型1 例、成人型2例であった。免疫組織化学はPAP 法·ABC法に従い、Vimentin(以下Vinl.) D Desmin(以下 Des.)·CD34・GFAPを中心に実施した。【結果・考察】 [細胞像] DFSP例は紡錘形細胞が主体で集塊状に 認められた，個々の細胞は棈円形核で核縁は滑ら かであり、ク听ンは細顆粒状で均一に分布していた。 これに対し、FS例は紡錘形細胞が集塊状或はその 周辺に散在して認められ、核は多形性に富み、大 小不同が著明であった。細胞像での雨症例の鑑別 は困難な場合があり、免疫染色等での確認が必要 と思われた。[組織像] 組織学的にはいずれも紡 鍾形細胞より成り、DFSPでは花むしろ様配列を、 FSでは部分的ながら焦骨様配列を示していた。 Bednarでは色素を含有する細胞が散見され、また、 乳幼児型のFSでは、魚骨様配列がむしろ乏しかっ た. 従って、両者の組織学的鑑別は、紡鏵形維胞 の配列の違いである程度は可能と思われた。[免 疫組織化学] DFSP·FS全例でVim.・Des.ぶ陽性であ った。また、CD34はDFSPで䧄性、成人型FSで陰 性、乳幼児型FSでは陽性となった。これらの所見 より、CD34はDFSPと成人型FSの鑑別に有用であ ると思われた，更に、同じFSでも成人型と乳幼児 型で発現が異なることが興味深い結果となった。 
325 色素性隆起性皮膚線維肉腫 (pigmented DFSP, Bednar tumor)再発例の圧挫 細胞像

日本大学医学部附属駿河台日大病院病理部1) 同第二病理 ${ }^{2}$

$\mathrm{O}^{1)}$ 古瀬慶子 $(\mathrm{CT}) 、{ }^{1}$ 飯島和子 $(\mathrm{CT}) 、{ }^{1)}$ 三浦 千映(MT)、“来柄 明(CT)、1, ${ }^{21}$ 長田宏已 (MD)、 ${ }^{1.21}$ 根本則道(MD)

[はじめに]色素性隆起性皮膚線維肉腫 (PDFSP)はDFSP全体の $5 \%$ 以下を占める稀 な腫瘍である。我々は最近本腫瘍の術後再 発例を経験したのでその細胞像ならびに組 織像について報告する。[症例] 49 歳、 男性。約 20 年前より左足背部に $3 \mathrm{~cm}$ 大の 腫瘤を認めていたが放置していた。H 6 年 8 月頃より増大傾向を認め当院皮膚科を受 診し、DFSPの臨床診断のもと切除された。 初回病理：腫瘤は灰白黄色充実性で一部黒 色の色素沈着を伴い、不完全な分葉が認め られた。組織学的には血管周皮腫パターン を伴うPDFSPと診断されたが、すでに高悪 性度腫瘍の像を伴っていた。[術後経過] 初回手術から7か月後に腫瘍の再発を認めた ため左下腿切断術が行なわれた。［病理所 見］再発腫瘍は、 $8.5 \times 6.5 \times 6.5 \mathrm{~cm}$ で割面は 灰白色で出血を伴っていた。組織学的には DFSPパターンは認められたが、線維肉腫様 の像が優位を占め、メラニン色素含有細胞 はもはや認められなかった。圧挫細胞像： 腫瘍細胞は中等大、比較的均一で類円形〜 短紡錐形核を有し、核質は細顆粒状で核小 体は小型で不明瞭であった。細胞質はライ トグリーンに淡染し、しばしば裸核細胞も 観察された。細胞集塊部では血管との蜜な 関係が示され、herringboneパターンおよび不 完全な花耑パターンの表れと考えられた。 巨細胞、多形細胞の出現はなかった。細胞 像からは線維肉腫として矛盾しない所見で あった。[考察] 初回手術時、すでに高悪 性度腫瘍の像を伴っており、正確な先行病 変としてのPDFSPの存在期間は不明である が、年余を経て高悪性度腫瘍に脱分化した PDFSPの一症例と考える。
326 心菭厘瘍 3 例の臨床䎩胞病理学 的検討

$J R$ 東京秷合病院臨床検查科”、杏林大 学保煡学部 ${ }^{21}$ 、都立府中病院病理 ${ }^{31}$

O丹野正隆（MD）、船山英明（CT）、 今野久美子 ( C T ) 、深井光一郎 ( C T ) 、字佐美一犮 (CT)、早川敛哉 (MD) “)、藤井雅彦 $\left.(M D)^{\prime}{ }^{2}\right)$ 、石沢貢 (M D) 、中村恭二 $\left.(M D)^{3}\right)$

[はじめに]当院で経験した心藏属瘍 3 例について臨床䎩胞病理学的に検討した。 [症列1] 70 歳、女性；心不全にて、 入院。心共炎にて、笑剩を施行。穿刺梱 盷診は核多形性を有する大型の相盷が空 胞変性を有して見られ、中皮属もしくは 腺癌が疑われた。解剖の桔果、心外㬺由

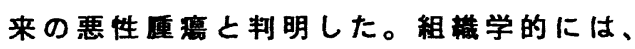
悪性中皮属であった。

[症洌 2 ] 49 歳、女性; 心藏重瘍にて 当院に入院。穿刺䎩胞㓌では、非上皮性 厘瘍、特にMFHが疑われた。解剖の站 果、左房由来のMFHであった。

[应湖 3] 52 歳、女性；健診にて、胸 部X一P異常陰影を昆め、エコーにて右 房厓瘍を指摘され、厘㾇切除術施行。手 術時、抾印耦胞猃では、血管内皮と考え られる紡箠形の梱胞が翟められ、血管厘 と考えられた。組樴像も同样であった。 [まとめ] 1 例は心蕰原公の中皮厘、も う1列は左房由来の悪性楾雄性組樴球厘 (MFH)、それに右房原発の血管董で あった。 
327 パパニコロウ染色の客钼的評価法

（I）染色性の具体的表示方法の検討

松浪硝子工業 (1)

和歌山県立医科大学第一病理学教空

○阪本米和 $(\mathrm{PhD})$ “谷口恵美于 (CT,IAC) 覚道健一 (MD,FIAC)

パパニコロウ染色法は、染色液や染色方法の改 良も数多く行われ、現在では、多数の染色液や染 色方法が存在している。この染色法での細胞の種 類による色調の違いや染色方法の違いによる染色 性の差は、これまで感覚的に捕らえられているも のの具体的、客観的に示されていなかった。そこ で今回、これらの差を具体的に把握する手法とし て、標本細胞の色調を、纎維染色等で採用されて いる L * a *b *表色系（1976年、国際照明委員会 で制定）を用いて数値で表現する方法を開発した。 〈材料及び方法>

口腔、胸水のパパニコロウ染色標本を、同一条 件にて撮影、印画した顕微鏡写真をもとに扁平上 皮細胞、腺細胞、組織球等の核および細胞質を分 光測色器で反射光を測定しその色調を求めた。 <結果>

L*a ${ }^{*} b$ *表色系では、L*は、明度を示す。 $a$ *は、互い注補色関係にある赤と緑の位相、 b * は、同じく補色関係にある黄と青の位相を示し、 $a{ }^{*} b$ *の位相で色相と彩度を特定することができ る。具体的には、A社の染色液を用いたパパニコ ロウ原法による染色法でのライトグリーン、オレ ンジおよびエオジン好染扁平上皮細胞の細胞質の 色調は、 L*a *b*でそれぞれ (85

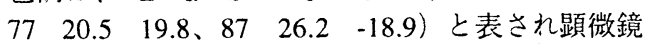
観察下での赤の色調が強いという印象をうらずけ る数值を示した。この方法でパパニコロウ染色の 染色性を具体的に把握することが可能と考えられ る。
328

パパニコロウ染色の客観的評俩法

（ＩＩ） 市販染色液の比較

和歌山県立医科大学第二病理学教室

○谷口恵美子( CT,IAC), 阪本米和 $(\mathrm{PhD})$, 中村圭吾

(MT), 西村千枝子(MT)), 中村靖司(MD), 横井豊治

(MD), 覚道健一(MD,FIAC)

はじめに了細胞診断業務において我々は日常パパ ニコロウ染色を用いている。このパパニコロウ染 色には、5種類の色素が含ま,れており、その色調 によって角化の程度の識別、細胞型の推定、又核 クロマチンの増量の程度を知ることができる。し かし、それらは感覚的、主観的であり、検鏡する 者によって評価に若干の差があると思われる。そ こで今回我々は、エオジン、ライトグリーン、オ レンジG、ヘマトキシリンの色調を数值化するこ とによりパパニコロウ染色を客観的に評価できる のではないかと考え、市販の 4 社それぞれの色調 の違いを測定し、比較を行ってみた。方法] 材料 は喀痰、胸水、口腔内擦過物について、同じ条件 で染色を行い、扁平上皮細胞の細胞質、腺癌細胞 の細胞質、核の一カ所を選び、へマトキシリン、 オレンジG、エオジン、ライトグリーンのそれぞ れの色調の測定を行った。測定結果は明度をL*、 色相と彩度を $\mathrm{a}^{*} 、 \mathrm{~b}$ *で表した。結果] 口腔内扁 平上皮細胞の細胞質におけるライトグリーンの色 調はB社でL*.69.21 と明度が最も低く $a *$ *19.06, b* -9.31と緑が濃いことを表していた。又、エオジン の色調は、A社で明度が最も低く、 $a^{*} 23.39$ とよ り赤に近いことを表し、オレシジの色調はC社の

$L^{*} 69.22 、 b^{*} 20.98 、 A$ 社の $L^{*} 77.52 、 b^{*} 22.74$ で黄色 に近いことを表していた。腺癌細胞の核において は、D社のL*41.6が最も明度が低く、 $\mathrm{a}^{*}-4.64 、$ b*-20.67とより紫に近いことを表していると思わ れた。さらに、A社の染色液において、染色条件 を変えることにより、腺癌細胞の核はL*39.5、 a *0.78、b* ${ }^{*}-17.7$ と、より青紫色に近く、良好 な染色色調に変えることが出来た。まとめ） 4 社 のパパニコロウ染色液の色調をL*a* $\mathrm{b}^{*}$ 表色系を用 いて測定した。その結果 1) 我々が、緑、ピンク オレンジ又は濃い、薄いと表現している色調を数 值で表し比較することが出来た。2）日常感じて いる色調とほほ同様の違いを数値の差として表す ことが出来た。3）それぞれの液に合わせた染色 時間の設定が必要であり、各施設での好みの

し*a* ${ }^{*}$ *表色系の数值を決め、その数值に近い值に 染色することが可能であると思われる。 


\section{9 細胞保存液の検討（第一報）}

京浜予防医学研究所病理 ${ }^{11}$

帝京大学溝口病院病理 ${ }^{21}$

\begin{tabular}{|c|c|c|}
\hline ○木村 & 文一 $(\mathrm{C} \mathrm{T})^{31}$, & 南出めぐみ (C T) \\
\hline 森 & 裕二 $(\mathrm{C} \mathrm{T})^{11}$, & 鈴木 文子 $(\mathrm{C} \mathrm{T})^{11}$ \\
\hline 津 & 悦子 $(\mathrm{MT})^{11}$ ， & 山内 勝彦 $(\mathrm{MT})^{11}$ \\
\hline 烈地 & 義昭（MT） ${ }^{11}$ & \\
\hline 吉元 & 真 $(\mathrm{C} \mathrm{T})^{21}$ & $(M D)^{21}$ \\
\hline
\end{tabular}

前回我々は乳腺・乳頭状病変の検討を行ない細 胞の乾燥防止や細胞採取量の不足を補う方法を今 後の課題とした。今回我々はこれらの欠点を補う ことを目的として細胞保存液の検討を行ったので 報告する。

\section{【方法】}

保存液は酷酸ナトリウムなどの電解質溶液とメ タクリル酸系単量体（モノマー）を生理食塩水と 同等の浸透圧になるように調製し、尿・体腔液・ 子宮内膜・気管支洗浄液から得られた細胞を用い 、保存液中に約 12 時間細胞を保存した。対照と して生理食塩水・YM式液状検体固定液を使用し た。1500rpm 遠心沈殿後、すり合わせ塗抹法にて 標本を作製し、パパニコロウ染色にて標本を観察 した。

\section{【結果】}

電解質溶液は調製時に溶解困難なものや結晶が 析出したものがあった。メタクリル酸系モノマー でも一部同様であった。これらのうちメタクリル 酸系モノマーと酶酸ナトリウムが比較的細胞の保 存状態が良好で、溶液の性状も生食や、Y M 式液 状検体固定液とほほ同様であった。

【考察】外部からの刺激に対し比較的強いとされ ている扁平上皮・移行上皮細胞や日頃外気にさら されている気管支腺上皮は比較的保存状態が良好 であった。細胞の保存には浸透圧・pH ・ 細菌の 繁殖防止など種々の要因が関係してくる。また、 今後、標本作製時のアーチファクト等も考慮して いく必要があるように思われた。
330 メンブレンフィルターを用いた穿刺吸 引材料の集細胞法についての検討

大津赤十字病院 細胞診

O今村真治（C T ），植田千晶（C T ）

穿刺吸引細胞診は，細い針を用いて行われる為 細胞採取量が少なく場合によっては判定に困難を 来す場合がある。今回我々は，メンブレンフィル ター（センシンメディカル製）を用いて, 穿刺吸 引材料の集細胞法について検討したので報告する。 【方法】腫瘤を穿刺吸引後スライドグラスに直接 塗抹Coating固定し直接塗抹法とする。次に生食を 注射器の針をついたまま吸引し注射器内を洗浄し 洗浄液とする。洗浄液は,メンブレンフィルターで 集細胞し標本作製。直接塗抹法と洗浄液のメンフ レンフィルター法とで比較検討した。

【結果】1，洗浄液のメンブレンフィルター法は, 直接塗抹法に比べ遥かに多くの細胞が回収でき， 細胞判定が容易であった。

2 , 直接塗抹法では, 出血性背景が細胞判定の障 害になる場合があるが, 洗浄液のメンブレンフィ ルター法では, 赤血球を通過除去できるため細胞 所見の観察が明瞭であり細胞判定が容易であった。 【まとめ】穿刺吸引材料では, 直接塗抹後も針や 注射器, 針と注射器の接合部に多くの細胞成分が 残っており，生食で洗浄することにより又メンブ レンフィルターを用いることにより効率良く細胞 が回収でき，染色過程における細胞の剥脱もほと んど無い為, 洗浄液のメンブレンフィルター法は 優れた集細胞法であると考えられた。 
331 喀痰検診のための早期肺癌細胞の

digital albumの作成

福島県立医大放射線科 ${ }^{1}$, 福島県保健衛生協会 ${ }^{2}$

O森谷浩史 (MD) ${ }^{1}$, 渋谷広子 (MT $)^{1}$, 宍戸文男 $(M D)^{1}$, 飯澤祥江 (CT $)^{2}$, 吉田晴美 $(\mathrm{CT})^{2}$, 高橋一弘 $(\mathrm{CT})^{2}$, 木村恭子 $(\mathrm{CT})^{2}$, 富田 健 $(\mathrm{MD})^{2}$

はじめに)

集検喀痰細胞診の判定は光学顕微鏡下の形態観 祭によるか、基本的に経験に裏打ちされている。 しかし、早期肺癌（特に上皮内癌）の発見自体が 少ないことや精検結果が適切に集検実施施設にフ イードパックされない場合があることなどから、 経験の蓄積と共有は精度向上の課題と思われる。

近年、personal computer の普及に伴って画像 の digital化が簡便に行えるようになったので、 上皮内癌細胞の digital albumを作成し教材とし て利用している。 方法)

発見・切除した上皮内癌数例の発見時喀痰細胞、 過去の標本の見直し、気管支鏡所見、精検時直接 採取細胞、切除病理組織を再検討し、画像を選定 した。

静止画像はPhotoCD作成、動画はCCDによる vid eo captureによって digital化した。 結果)

1)画像のdigital化は簡便に行いえた。 2)CDROM、MODなどによる複製、配布は容易であり、 personal computerがあればどこでも利用できた。 3)複数画像を一覧表示できる点が特に有用と思わ れた。

4)静止画による質感の再現には限界があり、動画 によって、ある程度対応できる可能性がある。 5)画像処理（面積測定、RGBヒストグラム、ed ge検出による解析など）は容易であり、Papanico laou染色肺癌細胞の胞体の検討に利用している。
332 小規模LANを用いての細胞診データーベー スの構築 第2報 作製法の実際

医療法人雪の聖母会聖マリア病院病理部

○伊藤園江 (CT)、大田喜孝 (CT)、原武晃子(CT) 中野祐子(CT)、大田桂子(CT)、楳田明美 (CT) 塚本孝久 (CT)、伊藤裕司 $(M D)$ 、中村康寛 $(M D)$

我々は、パリコンによる小規模LANを構築し、細胞 診業務のデーターベース化を行なうことで受付、仮台 帳印刷、ラべル印刷、診断結果入力、報告書印刷、 本台帳印刷、統計計算までをつ切卫ー拠理に移行す ることができた事を前回紹介した。今回はおもに その作製法の実際について報告する。

【システムの概要】サーバーとしてPower Macintosh 7100 54M/500M，クライアントしてPower book 520 他3 台，リトはクラリス社のフア似ーカープロを使用した。

【作製方法】1) フィード定義は標本番号，受付日， PID，採取日，氏名，年龄，性，病棟，検体，件 数, 点数など 54 のフィーイドからなる。2) 作成画面 は受付画面, 結果入力画面, 台帳画面, 報告書印 刷画面, 統計印刷画面, ラベル印刷画面など16 画面 からなる。3）画面切り替え，検索，印刷操作は 自動ス林プトを作成しボタ操作にする。4）標本番 号の下 4 桁とフア价番号を一致させるため毎年 ファ仡 を新たにする。5）細胞診の他にPID，所属，診断， 診断者，所見などのフア价を別に作成し簡略入力法 (川ックアップ）を利用し、すべてコード番号で入力。6)

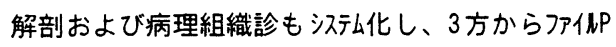
IDへデータを定期的に送り、総合的な検索はこのファイ IPID で可能。また、それぞれの受付の際にはこの フP价ID から属性情報をルツクアリプする。

【考按】本沃么は医療業界で比較的普及率の高い Macintosh とその定番外のフア价メかープロを用いた ものである。最大の利点はその簡便な操作法のた め、細胞診業務に携わる者が直接シスデを構築でき ることにある。したがってコスト゚フォオーマスに優れ施 設によって異なる様々の細胞診業務形体入適応を 期待することが出来るものと考える。 
333 共焦点レーザー顕微鏡を用いた細胞内 抗原の検出法について

千葉大学肺癌研究施設外科 1 、同大高次機能七 - 遺伝 子情報 2

尾辻瑞人 $1 、 2(\mathrm{MD})$ 、斉藤隆 $2(\mathrm{MD})$ 、木村喜光 $2(\mathrm{MD})$ 、 馬場雅行 ${ }^{1}(M D)$ 、山口 豊 1 (MD)

[目的| 癌患者や担癌マウスにおいてTCR CD 3 複合体 の構造異常がおこり、特にCD3 鎖が消失することが 報告されている。担癌マウスでは脾蔵内へ浸潤した マクロファージとの相互作用によって、脾㛾丁細胞の ら鎖が消失することを免疫沈降法およびSDS PAGE法 を使い報告した。しかしin vivoで同様な現象が誘導さ れているかは未だあきらかでないことから、共焦点 レーザー顕微鏡を用いてら鎖消失について解析した ので報告する。

|方法| BALB/c マウスにマウス大腸癌細胞を皮下接 種し、担癌マウスを作製した。その脾臓丁細胞をビオ チン化した後、免疫沈降法によりち鎖および他の CD3complexを比較すた。同時にT細胞を paraformaldehydeで固定し、0.5\% TritonX.100で処理 した捘、抗CD $3 \varepsilon 、$ 抗CD $3 \zeta$ 抗体で蛍光染色し共焦点 レーザー顕微鏡で観察した。

[結果および考察| 担癌状態の長期化に伴い、マウス の脾臓ではnonTnonB細胞群が浸潤し、splenomegalyを 認めた:このとき表面標識脾 T細胞のライセートの免 疫沈降から細胞表面の 鎖は隇少、消失した。同じ 脾臟了細胞を喾光染色し、共焦点レーザーで観察した ところ 鎖は消失した。以上より in vitroでの蛋白 化学的検出と同様にin vivoにおいても 鎖が消失して いることが判明した。共焦点レーザー顕微鏡は細胞 内抗原の検出に有用であり、今後細胞内の蛋白の局 在を含め、より動的な解析もできると考える。

\author{
334 \\ コロイド鉄染色と核D N A 解析との \\ 比較検討
}

東邦大学医学部付属大橋病院病理部

○藤田正志 (CT)、田口勝二(CT)、岩原実 $(C T)$ 、村石佳重 $(C T)$ 、渡辺祐子(CT)、甘利 保子 $(C T)$ 、渋谷和俊 $(M D)$ 、高橋啓 $(M D)$ 、 若山恵 (MD)、直江史郎( MD)

[はじめに] これまでに我々は、数年に亘り 反応性中皮細胞における核D N A 量について報 告してきた。一方、前回の学会では従来酸性粘 没多糖を染め出すために用いられているコロイ ド鉄染色で、核内に陽性の滴状搆造物が観察さ れる事を見いだし、Ag-NOR染色と同样の核小 体形成領域を染め出している可能性を指摘した。 今回は、各症例ことに核DNA定量解析とコロ イド鉄染色及びAg-NOR染色を施行し、これら の相関について検討した。

[材料・方法] 未固定で提出された組洨や液 状検体に対し凍結切片、捺印標本及び叙沫標本 を作成し、エタノール固定後コロイド鉄染色、 A g - NOR染色を施行し、核内に認められた コロイド鉄陽性構造物及び Ag- NOR陽性構造物 を直径 $2 \mu \mathrm{m}$ 以下、2-3 $\mu \mathrm{m}$ 及び $3 \mu \mathrm{m}$ 以上 に大別して核 1 個当たりのそれぞれの個数を計 測した。また同時にDAPI染色を施し影微営 光測光にてploidy pattern と核DNA量を測 定した。

[結果・考察] 同一症例内の検索対象とした 細胞における、コロイド鉄染色陽性構造物は Ag-NOR染色陽性の核小体形成領域とほほ一致 した。また、この陽性棰造物の大きさや数は、 それらの核DNA量とも、ある程度の相関があ ると推定された。さらに、この陽性構造物の形 態や各DNA量はいくつかの疾患では、特街的 なパターンを示すと思われた。これらの点から、 コロイド鉄染色と核D NA解析を行う事により、 良・悪性病変の鑑別や、また胸水・腹水に出現 する畽瘍細胞の原発篾器の推測に役立つ可能性 が示唆されるので報告する。 
335

体腔液におけるEpithelial

Specific Antigen(ESA)の検討

一中皮細胞と悪性細胞との比較一

\section{関西医科大学病院産婦人科細胞埥断室 ${ }^{11}$}

関西医科大学病院病理 ${ }^{21}$

O浜口記久子 (CT ${ }^{11}$ 坂井仁美 (CT) ${ }^{11}$ 冨名腰重子 (C T) ${ }^{1}$ 松波光代 (CT) ${ }^{1}$ 梅寺圭吾 (MD) ") 安田迪之 (MD)

1) 中島徳郎 (MD) ${ }^{11}$ 神崎秀陽 (MD) ${ }^{11}$ 岡村明治 (MD) ${ }^{2)}$

従来，胸腹水や心重水の細胞跈梌查において， しばしば中皮細胞か上皮性由来の悪性細胞か繿別 困難な場合に，PAS染色，アルシアン青染色のほか 種々の免度染色法が取り入れられ，総合的診断が なされてきた。

今回，我々は従来より用いられているCEAと， 最近，上皮特異性抗原として報告されたESAを用 いて，体腔液等で检討し，興味ある結果が得られ たので報告する。

[対象と方法］当院にて得られた胸腹水，挎印

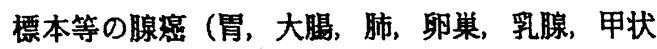

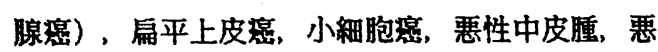
性リンパ腫, 計 35 例, 反応性中皮細胞 10 例を 対象とした。

Papanicolaou染色からの戻し標本を用い，一次抗 体に，ESA(モ)タローナル/斺ストラ社）を使用。

Streptavidin-biotin法にて免废染色を行った。

[結果] 腺窟は全例強陽性。扁平上皮空，小細胞 瑟は㖨陽性。悪性リンバ腫, 悪性中皮腫, 反応性中 皮細胞は陰性であった。

[結語] 今回换討したESAは対比したCEA(DAKO社) 染色に比へて，好中球，組織球のNCAの反応はなく， 背贯の共染も少なく判定しやすかった。さらに， 反応性および悪性中皮細胞は陰性で，上皮性悪性

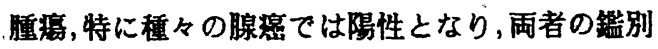
晾断に有用であった。
336

眼瞼に発生したメルケル細胞癌の一例

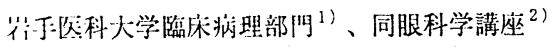

O川泪螌幸 $(\mathrm{CT})^{11}$ 、安保淳- …(CT $)^{11}$

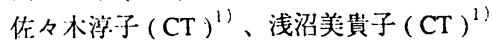

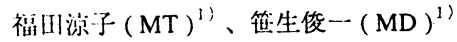

中村黄一 - MD ) "

管原訴史 $(M D)^{2)}$ 、田澤 豊 $(M D)^{2)}$

[はじめに] メルケル細胞癌は、表皮基底層に存在 するメルケル細胞抖来と考えられているきわめて まれな恐性腫瘍である。今回我々は、メルケル絊

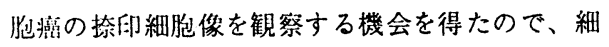
胞㟝所見を中心に報告する。

[症例] 85 藏、女性:。平成 7 年 1 月に右上眼臉に腫 㹿が出現。近医で切開術を受けたが、徐々に増大

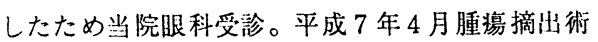
が施行された。

[肉眼・組織所見]，摘出された腫瘍の大きさは $23 \times$ $15 \times 15 \mathrm{~mm}$ で弾性:硬。割面は黄白色・充実性で、一 蔀纯卹様であった。組織所見は、比較的均一な小 型で多们形〜队形の腫湯細胞が充実性增殖を示し、 分裂像も多く諗めた。

[細胞所見] 類円形で 比較的小型の細胞で、結合は 緶く軽度の大小不同を認めた。N/C比は高く細胞質 に乏しい。核クロマチンは細顆粒状で、小さい明 胶な核小体を1〜数㫦 認めた。また、一部で核の切 れ込みが見られ核分裂像が目立った。

[危疫組織細胞化学的所見] クロモグラニン、NSE, ニューロフィラメント、サイトケラチン、EMAに 隄性像を㤠めた。

[電顕所見] 細胞質内に内分泌顆粒を認めた。また 核の陷入部にフィラメントの集蔟を認めた。

[結語]メルケル絒胞熟の診断に細胞診はあまり用 いられないが、縕胞像は比較的特徽的であり臨床 所見を参考にすればこの疾患を推定できると思わ れる。また免疫組織細胞化学染色では、パラフィ ン切片で陰性で細狍診で陽性の抗体もあり、細胞 渗での免疾組織細把化学染色が有効であると思わ れる。 
337

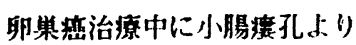

検出さ狆た腸トリコモナスについて

東京都教職員互助会三楽病院検査科病理

○岩潤祐子 (CT) 、上野久美子 (CT)

同 産婦人科、三島みさ子 (MD) 、手岛英雄 (MD) 、木村好秀 (MD)

東京医科菌科大学病理学教室、谷澤 微 (MD)

苗理子純 (MD) 、江石我信 (MD) 。

同医野物学教室 赤尾信明 (MD)

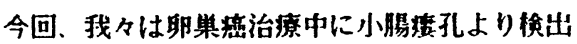
さ机た腸トリコモナスの1例を経呀したので報告 する。

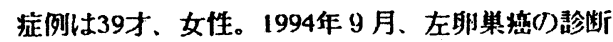
で子宮及び雨恻卵笨切除。手術後化学療法を施行。 1995年9月、疾性腹䐜炎及びイレウフにて小腸褯造 設。11月10日，小腸溃千ューフより排出さ机た偐汁 よりトリコモナス原虫を模出した。本人に海外波航 歴はない。

腸トリコモナスは熟带の発展途上地域に見られ

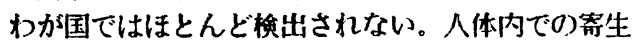
部位は小晹の媵端から大晹内で譄殖する。大きさは

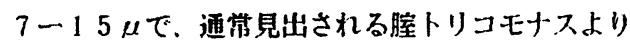
やや小型である。野物ではサル、ネスミ、等に見ら れ、ヒトに感染するとされる。本虫は病原性を有し ないとされている。この為、通常の検索刘象よりは すれ、検出の可能性を滅少させているとも考えられ る。検出にはギムザ染色や小リコーヒナス培地での

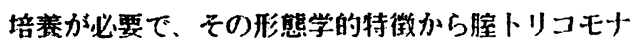
スとの鑑別は可能であるが、このような原虫等の存 在を考庶し、㛟索することも必要ではないかと思わ れる。

\section{8 明細胞癌の綝胞像}

足利赤十字病院臨床検䍒部病理" '同産婦人科 ${ }^{2}$ 国立杤木族院摩婦人科 ${ }^{3}$ 群馬大学医学部臨床 検查医学1

須永義市(CT)" 中村雅哉(CT $)^{1}$ 柏瀨芳久(CT)" 泉福明子 $(\text { MD })^{2}$ 春日義生 $(\text { UD })^{2)}$ 高橋峰夫 $(\text { ID })^{3)}$ 小島 勝(MD)" 城下 尚(MD)

【はじめに】今回我々は、比較的まれな腫煌で ある明細胞癌（卵巣明細胞癌 9 例、子宮内膜明 細胞癌 1 例）を経験したので、その細胞像を中心 に報告する。

【材料と方法】1990年5月〜1995年9月までの卵巣 明紐胞癌 9 例の術中捺印標本と、子宫内膜明細 胞煰 1 例のエンドサイトによる摖過標本に、パ パニコロウ染色、PAS染色を施した。

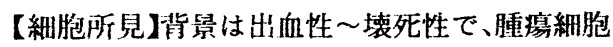
は、やや平面的で大小の集団を形成し、胞体は 豊富で资明、核は大小不同が見られ円形〜類订 形で、核縁は薄く、クロマチンは細顆粒状で 明睹な核小体が1〜2個みられた。又、一部では 核が集塊の外縁に並ひ、外方に实出して兒える いわゆるhobnail patternや、核腫大が著名で裸 核状の細胞が散在性にみられ、一見 肉腫を思わ せる細胞もみられた。

【まとめ】今回経験した10例の明細胞癌の細胞像 組織像、免疫学的所見を併せ報告する。 
339 卵巣境界悪性漿液性表在性乳頭状腫瘍 の1例一表在性乳頭状腺癌との比較も交えて一

石川県立中央病院病理科 ${ }^{12}$ 、同産婦人科 ${ }^{21}$

○湊 宏 $(M D)^{12}$, 車谷宏 $(M D)^{13}$, 西本秀明 $(M D)^{2}$, 朝本明弘 (MD) ${ }^{22}$, 太田浩一 $(C T)^{2}$, 宮本真紀子 $(\mathrm{CT})^{1)}$, 松岡克優 $(\mathrm{CT})^{1)}$, 屋敷玲子 (CT $)^{1)}$, 小川哲 $(\mathrm{CT})^{1)}$, 佐野百加里 $(\mathrm{CT})^{1}$

卵单漿液性境界要性表在性乳頭状腫場 (以下SSP B) は比較的稀な腫瘍で、その細胞像に関する報告 は乏しい。今回我々は、子宮筋腫手術時に発見さ れ、右卵巣に限局したSSPBの捺印細胞像を得たの で、当院で経験された表在性乳頭状腺癌 (SSPC) 4例の細胞像との比較も交えて報告する。

（症例）2経娃2分婏の47歳の女性で、子宮筋腫の 手術目的で1995年 9 月19日に当院紹介入院となった。 同年11月7日に手術が施行されたが、術中、右卵巣 表面に腫瘍が認められ、迅速組織診でSSPCと診断 された。

(病理組織所見) 右卵巣は表層に黄色カリフラワ 一状の腫瘍がみられ、全体では $10 \times 7 \times 6 \mathrm{~cm}$ 大であ った。組織学的には腫瘍は表在增殖型の漿液性腫 瘍で、著明な乳頭状発育を示すが核異型は軽度で あり、核分裂像も乏しく、明らかな間質浸潤像は 認められなかった。同時に採取された左卵巣、大 網には腫瘍は認められず、子宮には平滑筋腫のみ が認められた。以上より、右卵巣表層に限局した SSPB診断した。

(細胞所見) 術中の腫瘍の捺印細胞診では比較的 平面的な乳頭状細胞集塊がみられ、個々の細胞で は核の大小不同や小さな核小体、やや粗なクロマ チンを認めるが、核縁の不整は軽度であった。少 数に核内細胞質封入体が認められた。SSPCとの比 較では重積性、大小不同の程度、核小体の数・大 きさと核/細胞質比などが両者の鑑別に重要である と考えられた。尚、腹水は $50 \mathrm{~m} 1$ のみであり術中採 取された腹水の細胞診は陰性であった。
340 Serous surface papillary carcinoma (SSPC) of the ovary $の 1$ 例

聖マリアンナ医科大学産婦人科 ${ }^{1)} 、$ 同病理 ${ }^{2)}$ 、同病 院病理部 ${ }^{3)}$

○小林陽一 $(M D)^{1)}$ 、小杉一弘 $(M D)^{1)}$ 、庄司潔 $(M D)^{1)}$ 、水原 浩 $(M D)^{1}$ 、岩田正範 $(M D)^{1)}$ 、

斎藤 警 $(M D)^{1}$ )、雨宮 章 $(M D)^{1)}$ 、高木正之 $(M D)^{2}$ 、 田所衛 $(M D)^{2)}$ 、星川咲子 $(C T)^{3)}$

（症例）６1才、主婦。腹部膨满感を主培に他院 受誩。腹水細胞診にてクラスV、腺癌細胞を認めた。 上部および下部消化管検索にて異常を認めず、 $\mathrm{CA} 125$ 高值 $(3658 \mathrm{U} / \mathrm{ml})$ のため卵紧癌疑われ、 当科紹介され、精查加療目的のため平成 7 年 9 月 5 日入院となった。入院時腹水肭留著明であった か、、内誩上腫㾇は触知せず、腹部CT上も卵巢は正 常大で腫瘍性病変は認められなかった。SSPCを疑 い、プラチナ製戍を主体とした化学療法を2クー ル施行したが、腹水の隇少傾向が認められないた め、10月31日開腹手術を施行した。子宮およ び付属器は正常大で肉眼的には腄病を認めなかっ た。タグラス离に黄色の壊死性病変を認め、腹膜 表面にも粟粒大の腫瘤を多数認めた。また大網に も転移を思わせる睡湆を形成していた。単純子宮 全摘、両付属器切除、大網切除術を施行した。 （腹水細胞彭）細胞䨘内に空胞を有する細胞を㒛 める。クロマチンは微細顆柆状、核の大小不同、 核縁の肥厚、著明な核小体を認め、腺細胞由来の 悪性細胞と診断した。

（病理組織所見）両側卵趽表面に、乳頭状に発育

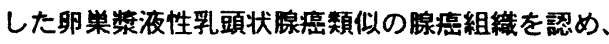
一部に砂粒体を認めた。大網の転移果も同様の組 織像であった。これらの所見から、SSPCと診断し た。 


\section{1 腹膜の漿夜性乳頭癌の一例}

帝京大学市原病院病理部 ${ }^{11}$ 同 産婦人科 ${ }^{21}$ 同 電䫓室 ${ }^{3)}$

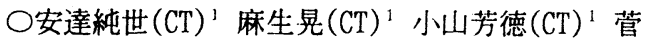

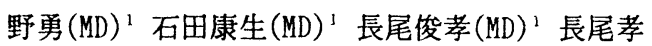
一 $(M D)^{1}$ 梁善光 $(M D)^{2}$ 貝原学 $(M D)^{2}$ 棟方滋 $(M T)^{3}$

腹膜の墏夜性乳頭癌（S P C) は正常大卵巣癌 症候群（N S O C S ）を来すことはよく知られて いる。今回、我々は、著名な腹水で発症したSPC でCDDP治療が著効しほぼ完全緩解になった症例を 経験したのでその細胞像、組織像について報告す る。

症例は68才、女性（2Ｇ２Ｐ）。経過は平成 7 年 7 月下腹部膨満感を主訴として近医を受診し、

腹水細胞診にて腺癌細胞、ClassVと診断され同年 7 月当院を紹介された。検査ではCA125:3200u/m1 と著高を示したが他には異常なし。原発巣不明の 癌性腹膜炎であつたが 8 月開腹術を施行するとダ グラス窩に乳頭状腫場を、大網には小結節状の多 発病変を認めた。両側の卵巣には異常がなく、所 謂N S O C S の所見であった。両側付属器を含む 子宮全摘出術と腹膜切除が行なわれた。細胞所見 は術前腹水にて不規則な重積性のある大型の集塊 を形成し、核は偏在傾向、クロマチンは細顆粒状 で、大きめの核小体を伴う細胞を認めた。腫煌の 撩印細胞像では、P A S 陽性の粘将様空胞も認め られた。

組織像では乳頭状癌で部分的には篩状、充実性 を示し多数の石灰化小体も伴っていた。P A S と アルシアンブルーに弱陽性の粘夜顆粒が少数の細 胞に確認された。両側の卵巣は加齢による萎縮だ けで腫瘍は認めなかった。免疫染色では C E A

(一)，Ber-EP4（十）、ケラチン (十) であった 電顕的には比較的長い微絨毛を伴うが、トノフ イラメントは認めなかった。

以上より中皮腫の可能性は否定された。
342

卵巣の奇形腫より発生した 脂腺癌の一例

岸和田徳洲会病院 臨床検査科病理

中村 陽一（MT） 櫛引健一 (CT) 川口 佐知子（CT） 太田 善夫（MD）

皮様整胞腫の発生頻度に対して、これより発生し たと思われる悪性腫湯は稀である。今回は、皮様 亚胞腫から発生したと思われる脂腺癌の一例を経 験したので、細胞学的、組織学的に検討した。

【症例】 41 歳の女性。下腹部に腫癐を触知し、上 腹部痛、下肢の浮腫が出現したので当院を受診し、 精查の結果卵巣腫瘍と診断され手術を施行された。 【肉眼所見】卵巣は両側とも著しく腫大（右径 $22 \mathrm{~cm}$ 、左径 $3.5 \mathrm{~cm})$ すると共に、右腫瘤は小腸に 浸閏し一塊となっていた。右卵巣の割面は単胞性 で内腔には、黄色の脂肪塊、おから状内容物、毛 髮が充满していた。小腸と一塊となった部位は堅 く充実性であった。左卵巣は充実性で堅かった。 【捺印細胞像】背景は出血性及び壊死性で、出現 している細胞成分は角化傾向を示す異型扁平上皮 細胞と境界不明瞭でライトグリーン淡染性で明る い胞体を有する腺系を思わせる細胞が集塊状配列 を示し散在していた。後者の細胞は異型の軽いも のから強いものまで多彩な像がみられ一部には、 両者の移行像を示す所見が認められた。

【組織所見】内面を角化扁平上皮に囲まれ内腔に 多量の皮脂、毛髮、コレステロールの針状結晶を 入れ、大きく搪張したcystの形成がみられた。上 皮の大部分は剥離しているが、上皮の一部が異型 細胞におき換えられ内方へ大小梯々な胞巣をつくっ て增殖浸潤していた。これらの異型細胞は、皮脂 腺への分化を示しており、胞巣の中心部には胞体 内に脂肪滴を有する細胞がみられ、一部には角化 傾向が認められた。同様の細胞は、連続的に小腸 に浸潤していた。左卵巣にも同様の異型細胞の増 殖がみられた。 
343 卵巣原発甲状腺腫性カルチノイト の一例

東京医科大学八王子医療セン夕一臨床検査部 11 同 病院病理部 ${ }^{2)}$, 同 産婦人科 ${ }^{3)}$ O工藤圭美 $(C T)^{1)}$ ，桑原 淳 $(C T)^{1}$ ， 㩧井千鶴子 (CT) ${ }^{11}$ ，石川由起雄 (MD) ${ }^{2)}$ 岡部一裕 $(M D){ }^{3)}$

卵巣原発のカルチノイドは稀で，すべてのカ ルチノイドの $0.1 〜 0.9 \%$ されており，甲状腺 腫性カルチノイドはさらに稀である。 今回我々は卵巣甲状腺腄性カルチノイドを経験 したので報告する。

【莚例】64歳女性。2 経妊 2 経産。閉経46歳。 下腹部膨淦感を主訴として近医を受診。卯巣腫 瑒疑いにて当院を紹介された。骨盤CT梌查の 結果, 両侧卵巣の成熟型奇形腫を推定し開腹, 単純子宮全摘術と禹側附属器切除術を行った。 【挎印細胞所見】淡いレース状の胞体をもつ腫 瘍細胞が，比較的ゆるやかな結合を示しシート 状，索状，ロゼット状に配列し，ときに軽度重 積も認めた。核は小型で円形，大小不同はほと んどなく，クロマチンは顆粒状で增量していた。 他に、コロイド様の無椿造物筫が認められた。 【病理所見】右卵巣は手拳大で，大小䨳胞状部 分と充実性部分が認められた。大小露胞状部分 は，粘液様物質で满たされ，小型円形核を有す る扁平又は立方状の細胞が好酸性コロイドを含 む摅胞を形成し，またThyroglobul in 染色陽性 であり甲状腺組織と考えられた。充実性部分は 灰黄色で比較的硬く均一であり，小型円形核に 顆粒状クロマチンを有する円柱状厓瘍細胞か， 索状あるいはリボン状に配列し，索状カルチノ イドの像を呈していた。これら腫演細胞は， Grimel ius 染色陽性て, ChromograninA 抗体に よる免疫染色も陽性を示し，カルチノイド診 断された。左卵巣は新生児頭大で, 成熟型奇形 腫であった。

\section{4 稀な明然の性索閒質性腫場の1例}

宗都市立病院娭查科病理 同産婦人科

$O$ 三宅秀一 ( C F )、黑木登美子 (CT)、

金岡明博（CT)、衣笠松男（CT)、川辺民昭

(CT)、古市佳也 ( C T ) 、金 栄治 (MD)、

摩栄晃昌 (MD)、小畑 義 (MD)

我々は、稀な卵巣の性索間質性腫瘍を経験した ので、その組織像や掎印細盷像等を報告する。

症例は 31 歳女性で、平成 6 年 9 月頃より不整 性器出血があり、当院受診。諸唡査上、左卵巣の 充実性腫瘍と血中テストステロンの上昇を認めた。 同部ホルモン産生腫痬の診断の下、翌年 1 月両側 卵宩切除術を施行した。睡瘍の大きさは $6 \times 5 \times$ $4.5 \mathrm{c} \mathrm{m}$, 重さ $130 \mathrm{~g}$ 。肉眼上境界鲜明で球 状弾性やや硬。割百は黄赤色調灰白色で、粘液変 性や大小の震胞を有した。

組織学的には2種の腫瘍が混在し、相互移行像 を呈した。1つは線維芽細胞あるいは線維細胞類 似の異型紡鍾形細胞か、不規則束状に交錯し、所 々粘液腫様を呈して增生する苏膜細胞腫の所兒と 見られた。他方は、多形性を示す模と好酸性や明 るい胞体からなる細胞が、索状、管状、雾胞状や 充実性に顕著に增生する所見茫示した。部分的に 原始卵胞類似の構造も認め、顆粒膜䄄胞腫に合致 する像と見なされた。

以上より本腫瘍は、性索間質性の莢膜顆粒膜細 胞腫と診断し、臨床所見等考慮し、苦年型顆粒膜 紐胞腫に合致すると思われた。

捺印稩胞像は、比較的小型の細胞が身団をなし、 あるいは孤立散在性に出晲し、所々大型の裸模様 細胞をまじえた。前者は多稜形から紡鍾形で盷体 はライトグリーンに淡染し、核は類円形、核網は 細顆粒状て核襚薄く、核小体は少数に認めた。集 塊の一部は、ロセット様や腺管状を呈し、中心に P A S 陽性のCall-Exner bodyを認めた。大型裸 核様紐胞の核網は顆粒状で核緑は薄く、核渆を呈 した。免疫染色の結果を併せて報告する。 
345 卵巣顆粒膜細胞腫の 1 症例 一若年型顆粒膜細胞腫との比較一

兵庫医科大学産科婦人科学教室 1 ()同病院病理部2)

O内藤 子来 $(M D)^{1)}$ 、満尾 瑞 $(M D)^{1)}$ 、

中村 嘉孝 $(M D)^{1)}$ 、小笠原利忠 $(M D)^{1)}$ 、

辻 芳之 $(\mathrm{MD})^{1)}$ 、竹村 正 $(\mathrm{MD})^{1)}$ 、

鳥居 良貴 $(\mathrm{CT})^{2)}$ 、山本 格士 $(\mathrm{CT})^{2)}$ 、

平良 信弘 $(\mathrm{CT})^{2)}$ 、西上 隆之 $(\mathrm{MD})^{2)}$ 、

八十嶋 仁(MD $)^{2)}$ 、植松 邦夫 $(M D)^{2)}$ 、

症例は 48 歳、 $G(4) 、 P(4)$ 。平成 6 年 5 月検診にて左側 卵单腫鹊を指摘され、同年6月当科受診。画像診 断では、 $6 \mathrm{~cm}$ 大の充実性腫瘍を認めた。平成7年2

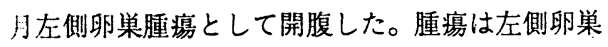
より発生した小瑟卵大、充実性腫瘍で表面はやや 玔消不整であったが被膜の破綻はみられなかった。 子富、右側卵巣、腸管漿膜及び壁側腹膜に異常は なく、腹水も認めなかった。この腫境の術中病理 榇断は、顆粒膜細胞腫であったので両側付属器切 除術及び単純子宮全摘術を施行した。腫瘍割面の 掩印細胞標本では数個から十数個の細胞からなる 重積性の集団が散見された。これを構成方る細胞 は、細胞境界は不明暸だがほほ類円形であり、胞 体は少ないものが多かった。核は長円形で小リン バ球の約2倍大で、クロマチンは粗網状又は細顆 粒状で、核小体は軽度に増大していた。核の grooving は少数の緗胞に見られたが、むしろ核縁 の切れ运みが目立った。以上の細胞所見を演者ら 污坏に報告している若年型顆粒膜細胞腫（産婦人 科の進歩41：783、1989）と比較すると、本例の

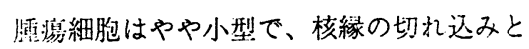
yrooving が存在したことが鑑別に有用と考えられ た。
346 穿刺吸引細胞診が有効であった顆粒 膜細胞腫の 1 例

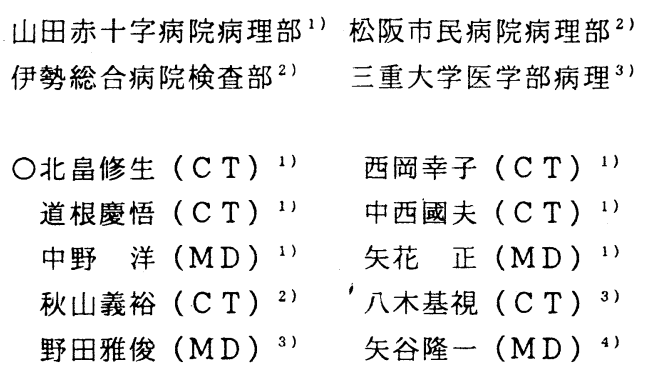

【はじめに】術後 9年で転移再発をきたし穿刺吸 引細胞診で卵巣の顆粒膜細胞腫を示唆できた症例 を経験したので報告する。

【症例】 58 歳。女性.閉経49歳

既往歷: 昭和 61 年、顆粒膜細胞腫およびその茎捻 転で左卵巣摘出術を受けた。現病歷 : 腹部膨満感 を訴え来院. 左横隔膜下に径 $15 \mathrm{~cm}$ 大の腫瘤を触知 し肝を強く圧排していた。平成 7 年 7 月12日同部 位および右腋窩リンパ節の穿刺吸引細胞診が施行 された。臨床検査所見では CA125が446 U/ml、血 清エストラジオールが $49 \mathrm{pg} / \mathrm{ml}$ と、共に高値を示した。 なお腹水を認めたが細胞診は陰性で、子宮窑部ス メアではエオジン好性の表層細胞が多数みられ右 方移動を示した。

【穿刺細胞所見】両材料ともに腫瘍細胞は重積性 の強い大小の集塊を形成し、あるいは孤立散在性 に多数みられた。細胞は比較的小型で裸核状を呈 し大小不同性はなく、結合性は比較的弱かった。 核は類円形で、クロマチン分布は均等で、核縁の 肥厚は目立たなかった。核縦溝をもつ細胞が散見 され、核小体は1ないし2個認められた。小濾胞状 構造を示す細胞集塊が認められたがCall-Exner小 体は確認できなかった。

【組織所見】左横隔膜下腫瘤針生検: 腫瘍細胞は 小型でびまん性に増殖し小滤胞構造を呈し、核溝 が一部に認められた。初回手術時の組織と比較す ると細胞は小型化しているが再発と考えられた。 


\section{7 男化徵候をきたした卵巣腫瘍の 2 例}

北里大学産婦人科 ${ }^{11}$ 同病院細胞診 ${ }^{2}$ 同病理 ${ }^{31}$ O新井正秀 (MD $)^{\prime \prime}$ 上坊敏子 (MD) ${ }^{1}$ 佐藤倫也 (MD) ${ }^{\prime}$ 岩永久美 $(M D)^{1}{ }^{1}$ 原田由香 (MD) ${ }^{\prime}$ 蔵本博行 (MD) 横山 学 $(\mathrm{CT})^{2)}$ 服部 大(CT $)^{2)}$ 渡辺 純 $(\mathrm{MD})^{3 \text { ? }}$ 龟谷 徹 $(M D)^{3)}$

卵㫦腫瘍のうち、男性ホルモンを産生する腫瘍 は大変稀である。我々は男化徴候を来した卵巣腫 㾇を 2 例を経験したので、その臨床経過、病理所 見、細胞所見について報告する。

症例 1 は 43 歳、症例 2 は 34 歳、共に経産婦 で、主訴は無月経、多毛であった。血清Testoste rone値はそれぞれ506ng/dl、484ng/dlと高值であ った。共に術後 1〜2 日目には正常範囲に回復し た。病理学的には、症例 1 では出血、壊死の目立 つ中に、Sertoli like cell がびまん性に浸閏增 殖し、一部で索状配列を認めるものの、成熟型の 腺管構造はみられなかった。Leydig cell は僅に 見られるが、Reinke crystalはみられなく、中分 化Sertoli stro-mal cell tumor と診断した。 症例 2 では出血、壊死はなく、線維腫様の組織の 中に好酸性胞体とReinke crystalを有する成熟 Leydig cell が島状に増生しており、Stromal tu mor containing Leydig cells と診断した。なお、 粘液性腺腫と共存していた。

症例 1 の捺印細胞診では、壊死物質を背景に班 立散在性または結合性疎な集塊を形成して腫瘍細 盷が出現していた。核は小型で類円形〜棈円形で 軽度の大小不同を認める。クロマチンは敏細顆粒 状で、核小体は目立たなかった。細胞質は淡く、 比較的豊富だが、裸核状の細胞も多くみられた。 症例 2 では、环立散在性または踈な結合性を有す

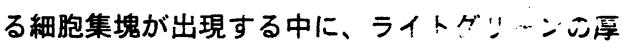
い細胞啠を有するやや大型の細胞集塊がみられた。 この核は、円形〜長円形で小型の核小体を 1 個認 めた。また、Reinkecrystal が多数出現していた。
348 外陰扁平上皮内癌 (ボーエン病)

の 1 例

埼玉県立がんセンター婦人科 11 、病理部 ${ }^{2)}$

O高橋道子 $(\mathrm{MD}))^{1)}$ 、中川俊介 $(\mathrm{MD}){ }^{\prime \prime}$ 、

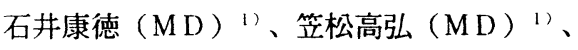

白水健士 $\left.(M D){ }^{1}\right) 、$ 松澤䢐澄 $(M D){ }^{1)}$ 、 佐野裕作 $(\mathrm{C} T)^{2)}$ 、桑島良夫 $(\mathrm{MD})^{2)}$ 、 上原敏敬 $(M D)^{2)}$ 、岸紀代三 $(M D)^{2)}$ 、

外陰の扁平上皮内癌は、角化上皮が表層にあ ることや釘脚の肥大が特徵的であり、いわゆる ボーエン病の組織像を示すことが多い。われわ れは、本症の1例を経験したので、その細胞像 の検討を試みた。

症例は 59 歳であり、6 年前に子宮頸癌IIIb 期にて放射線治療を施行し、外来で経過観察を していたが、右小陰唇に白色から、やや赤みがか った丘疹状の隆起を認めた。その部の擦過細胞 診では、核の腫大と不整をともなった扁平上皮 系の異型細胞を認め、N/C比大でクロマチンの 増量した細胞もあり、悪性細胞と考えられた。 生検では、上皮内に限局する扁平上皮癌を認め、 ボーエン病と思われた。

右外陰病巣切除術を行った。摘出物の捺印細 胞診では、無核の扁平上皮細胞が多数みられる なかに、 $\mathrm{N} / \mathrm{C}$ 比の高い異型細胞がシート状に出現 した。摘出物の病理組織検索では、表層に角化上 皮を有し、核の大小不同のみられるボーエン病 の所見が認められた。また、摘出物の検索で、 本症の原因ウイルスではないかといわれている HPV16型が検出された。 
349 外陰部Sebaceous carcinoma の一例

日本医科大学附属病院病理部 ${ }^{11}$ 、同第一病理学 教室 ${ }^{21}$ 、同附属多摩永山病院病理部 ${ }^{31}$

○松原美幸 $(\mathrm{CT})^{11}$ 、川本雅司 $(\mathrm{MD})^{2}{ }^{2}$ 、田村浩一 $(\mathrm{MD})^{1}{ }^{\prime}$ 、渡会泰彦 $(\mathrm{CT})^{11}$ 、永井祥子 $(\mathrm{CT})^{1}$ ，、前田 昭太郎 $(M D)^{31}$ 、杉绮祐一(MD) ${ }^{11}$

Sebaceous carcinoma（S C) は眼睑のマイボー 么腺から発生するものが多く、外陰部発生の S C は稀である。今回我々は、その一例を経耠したの で細胞所見を中心に報告する。

【症例】78歳、女性。6 力月前より外陰部に無痛 性腫瘤を認め、1993年11月に当院を受診。初診時、 左小陰唇の約 $2 \mathrm{~cm}$ 大の腫瘤と、左鼠径部リンパ節 腫大を認めた。外陰部擦過細胞診およびリンパ節 呀刺吸引細胞診で Class V。組織診で確認後、外 陰切除十左鼠径部リンパ節郭清術施行。術後放射 線療法を施行し、経過観察中である。

【細胞所見】外㓌部、リンパ節ともに基本的には 同様の所見で、背景に泡沫細胞（脂助会食組織球） を伴う結合性の強い細胞集塊が認められた。集塊 を構成している細胞は類円形で、細胞質には明瞭 な泡沫状あるいは空胞状構造を認めた。核は中心 性で類円形、クロマチンは細顆粒状で増量し、核 小体は小型で $1 \sim 3$ 個認められた。

【組織所見】腫惱は表皮と連続性で、充実性胞巣 状構造を示した。腫諨細胞は主に核中心性の明る い細胞質を有し、スタン染色陽性であった。また 一部に好酸性細胞質を有する細胞も認められ、S C と診断した。リンパ節の転移も認められた。

【考察】本例は細胞診上他の悪性腫演、特に腺癌 との籃別が必要であった。腺癌と比較して本例は 中心性の核と、より明瞭に抜けた泡沫状あるいは 空胞状構造を示す細胞質が特致的であった。これ らの構造はスタン染色陽性の脂肪滴であり、本腫 洎の性格を示すものと考えられた。なお、胞巣内 に混在する脂肪領食組織球との鑑別は、核所見お よび結合性の点から十分可能である。
350 n”叫腺由来の腺様震胞癌の弿 刺吸引,捺印細胞像

王子総合病院診療部中央検查科11) 同産婦人 科 ${ }^{2)}$ 北海道大学医学部第一病理学褠座 31

府中 基伸 $(\mathrm{CT})^{1)}$, 石倉 浩 $(\mathrm{MD})^{3)}$, 蜛名 康彦 $(M D)^{2)}$ ，市村 英毅 $(M D)^{2)}$ ，高橋 麻美 ${ }^{1) ， ~}$ 吉木 敬 $(\text { MD })^{3)}$.

今回我々は,左外陰部由来の腺様震胞癌の 一例を経験したので,穿刺吸引,挎印細胞像 及び病理組織像を中心に報告する。

〈定例〉55歳,女性. 左几“忆归腺に䳕卵大の比 較的硬い腫瘤を触れ，当院産婦人科を受診. 初診時分泌物を回収し病理組織学的検討を 加えるとともに数回の穿刺吸引を行い細胞像 を観察した.その後左外陰切除及び左甪経归 $n$ ”節郭清を施行. 肉眼的に多慗胞愿合結節状 の粘調液を含む一塊の腫曒であり,捺印細胞 診及び病理組織学的镜察を行った。

〈穿刺吸引細胞像〉低倍像にて比較的細胞結合 性がよく,大小の粘液震胞を取り囲むように 立体的配列を持った異型中等の上皮細胞集団 を認める.高倍像にてそれら上皮細胞の核は 比較的小さく,円-類円形である.核の大小不 同,核型不整が少なく,核小体1-2ケ程度でさほ ど目立たない.PAS及びAI-b染色では粘液囊胞 は陽性に染色された.以上から腺様㲠胞癌と 考えても良い細胞所見であった。

〈病理組織所見〉病理組織学的には腫堭は大小 の小集構造を持つ一様な上皮細胞の增殖より なるもので,明暸な被膜をもたず周辺軟部組 織へ浸潤性增殖を示していた.その組織構造

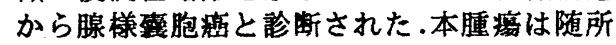
で神経周囲浸潤を示していた。

〈まとめ〉希有なバ忺师腺由来の腺様震胞癌の 細胞像,病理像を報告した。㕰液腺等に発生 する腺様霍胞癁と細胞像,病理像はほぼ同一 と考えられ,生物学的態度についても，唾液腺 原発症例と同様の神経周囲浸潤を示し， 同様の臨床経過をとるものと考えられる。 
351 婦人科スメアに出現した子宮外腫瘍 症例の細胞病理学的検討

鹿児島市立病院 病理研究検査室" 同産婦人科2 O藤绮人美 (CT $)^{1)}$ 小山田誠朋 (CT $)^{1)}$ 田代幸恵 (MD) ${ }^{1)}$

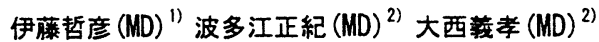

【はじめに】婦人科スメアにてまれに転移性腫瘍 の細胞款が経験される。我々は、婦人科スメアに おけるこれら子宮外腫瘍の鑑別点を明らかにする ことを目的に自験例の検討をした。

【材料】1989年 1995年までの 7 年間の婦人科ス $\times ア(63.371$ 件) の内、子宮外腫瘍細胞が出現した 49 件 37 症例を対象とした。

【結果】37症例のスメアの部位別および原発臓器 の内訳は、子宮頸部擦過10例（卵巣 1 - 結腸 5 直腸 $3 \cdot$ 眼瞼 1) 、内膜吸引11例 (卵巣 $7 \cdot$ 結腸 1 ・胃 1 ・リンパ節 1 ・乳腺 1)、両スメア共に 出現 5 例（卵单 $3 \cdot$ 胃 $1 \cdot$ 胆異 1 ）、眰擦過 3 例 （直腸 $2 \cdot$ 卵巣 1 ）、断端擦過 8 例（卵巣 $6 \cdot$ 結 腸 1 ・直腸 1)であった。頸部では、消化器系が 多いのに反し内膜では卵巣腫瘍が多かった。 これら 37 症例のうち、2 8 症例では大網、腸間 谟および腹水のいづれかまたは複数に転移が確琶 された。また、標本鏡検時に、すでに子宮外腫場 の既往または転移・漫洞の可能性が示されていた のは2 5 症例で、1 2 症例はスクリーニングによ って示咬された。

【まとめ】形態的には殆どの症例で、子宮原発腫 瘍とはその異型性を異にするが、一部に爁別困難 な症例もあり、充分な臨床情報の提供が必要であ る。

\section{2 乳癌の腹腔転移の3症例}

群馬大学医学部産科婦人科" ${ }^{2}$ 、同医潦短期 大学部 ${ }^{21} 、$ 同中検病理 ${ }^{31}$

○飯塚真理 $(M D)^{11}$ 、宇井万津男 $(M D)^{11}$ 、水沼 英樹 $(M D)^{1)}$ 、大和田傮夫 $(M D)^{2)}$ 、伊吹令人 $(M D)^{1)}$ 、堀越美枝于 $(C T)^{3)}$ 、食林良张 $(M D)^{3)}$ 、城下尚 $(M D)^{33}$

症例 1 は53才の女性。乳癌術後 1 年、子宮体 癌術後了カ月で尿閉を主訴に来院した。超 音波断層法にてダグラス䆚に径 $8 \mathrm{~cm}$ の腫溜 と両側水㫮症がみられた。尿中細胞診で異 型紋胞が出現していた。入院後17日で死亡 し、剖検を施行した。腫瘳の浸潤は骨盤壁 から梋盤内臟器全体に及び、組織学的には 未分化癌の像を呈し、原発は乳癌であるこ とが示唆された。症例2は48才の女性。4年 前および1年前に左右の乳癌手術歷があっ た。左卵渠腫場と子宮筋腫にて子宮全摘術 と両側付属器摘出術を施行した。腹水細胞 診では乳癌の転移を疑わせる異型細胞が出 現していた。しかし、摘出標本の組織型は 平滑筋腫と内膜症性慗胞で项性所見は認女 られなかった。淀例3は44才゙の女性。7年前

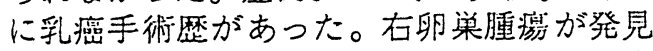
され、術前検査では㥿性所見があった。牌 水細胞診は陽性であり、摘出標本の病理組 織で転移性卵巣癌と診断され、これは7年 前の乳癌の組織型と一致した。

乳澞の卵巣転移の頻度は約 $10 \%$ といわれ、 閉経前の比較的若年婦人に、より高い頻度 で起こるという報告がある。これら3症例 を経験して乳癌の既往歷のある妌人の場合、 手術時にはより詳細な腹腔内病変の検索が 必要であると思われた。 
353 アスベスト暴露歴を持つ腹膜原発 びまん性悪性中皮腫の一例

鹿島労災病院病理 内科*1 O石川昌文 (CT) 長坂宏一(CT), 阿部 武(MT), 岩瀬裕䐚 (MD) 土屋正一 $(M D)$ *)

『はじめに』びまん性悪性中皮腫（以下DMM と略す。）はアスベストと密接な関係があると 言われているが、今回我々は、過去において アスベスト暴露歴を持つ腹脱原発DMMを経臨 したので報告する。

『症例」69歳男性。約50年前、2年間アスベス 卜関連の仕事に従事。平成 6年11月初め頃より 食思不振、腹淦出現。11月14日当院受殓し、 腹部エコーで大量の腹水と肝右葉下面に tumor を嚁めたため同日入院。腹水細胞診や諸検查に より原発不明の癌性腹膜炎と診断。対症療法を 行うも平成 7年 2月16日死亡。死後 1時間 30 分 で解剖を行った。

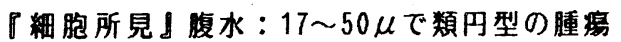
細胞が眭度重積性集団や散在性に出現。核は

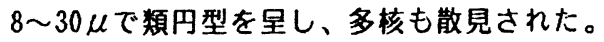
クロマチンは細顆粒〜顆粒状で、類円型核小体 を1コ認めた。細胞質はライド゙リー好性で泡沫状、 一部重厚感のあるものも見られた。

腫煌挎印材料：腫煬細胞は多辺形で平面的集団 や散在性に出現し、100 $\mu$ 以上の多核細胞も 散見された。細胞質はライドグリー好性でレース状、 また空胞を持つものも見られた。アルシアン青 は細胞及び空胞の辺緣に陽性であった。

『組载・電影所見』核の大きな腫痬細胞が乳頭 状構造をとり上皮様に增殖していたが、一部 肉腫样配列も見られた。アルシアン青は細胞 辺縁や間質に陽性でとア あった。電影では細胞間結合のtight junction が確㒛され、細胞の表面には多数の長いmicrovilliを䖵めた。

『まとめ』剖検により腹膜原発DMMと診断さ れた本例の腹水及び腫挥印材料の細胞像を 中心に、さらに免度組樴学的検討を加え報告 する。

\section{4 朐膜悪性中皮腫 2 症例の細胞所見}

\author{
高岡市民病院中央検查部病理科 \\ 高越祐子 (MT)、森田正雄 (MT) \\ 富山医科薬科大学第 1 病理 \\ 岡田英吉 (MD)、前田宜延 (MD)
}

胸水細胞診で悪性胸膜中皮腫と彰断され、組織学的に も確認された 2 症例を供覧する。

\begin{abstract}
症例 1：56 歳女性。平成 4 年 7 月検診胸部 $X$ 線写真 にて胸水を指摘され当院を受診。胸水細胞診で腺癌に よる癌性胸膜炎を疑われた。胸腔内抗癌剂注入で胸水 消失、退院。平成 6 年 6 月胸水再発にて再来院。朐水 細胞再検およひ前回細胞再検討で悪性中皮腫と疑診し 胸膜生検組織診で確診を得た。

胸水細胞所見 : 粘液性の背景中に孤在性細胞、2-3 個の細胞からなる小集団、或いは10個以上の細胞か らなる大型乳頭状集団を形成する細胞が出現。細胞は 類円形ないし多角形で胞体は中心部厚く辺縁部は薄く 周囲に fade out していた。胞体辺縁に微絨毛を有する 部位もあった。核縁は均等、明瞭、平滑で核小体は1 個ない2 個で目立っていた。クロマチンは瀻細で増量 は軽度であるが沈殿様の偏在傾向を認めた。これらと は別に合胞体性と思われる多核巨細胞がみられた。 組織所見 : epithelial mesothelioma と診断した。
\end{abstract}

症例 2:52歳 男性。平成 7 年 8 月呼吸困難を訴え 当院内科受診。胸部X線で両側胸水を認めた。胸水細 胞診で胸膜悪性中皮腫と診断する。

細胞所見：好中球を背景とし多数の乳頭状細胞集団が 出現、周囲に同样の細胞で孤在性のものも多く認めら れた。これら細胞の胞体の所見は症例 1 とほほ同様で あった。しかし、細胞は更に大型で、クロマチンは細 顆粒状で均等に增量していた。エオジン好性の核内細 胞体封入体が多数認められた。合胞体性と思われる多 核巨細胞も出現していた。

組織所見 : epithelial mesothelioma と診断した。

考案：2症例とも上皮性格優位の胸膜悪性中皮腫であ つた。症例 1 は腺癌と誤診したが胞体の性状、異型性 の程度に注意すべきであった。患者が生存し再来院し た事が再検討のきっかけとなった。症例 2 は前症例の 教訓があり比較的容易に正診を得られた。細胞所見で は両症例ともに合胞体性と考えられる多核巨細胞が出 現していた点が注目される。この細胞に関しては一部 の成書で言及はしているものの詳細な記述は乏しい。 この細胞については詳しく供筧したいと考える。 
355 結核性胸膜炎との鑑別を要した胸膜 悪性中皮腫の 1 例

東京派信病院第一臨床検査科 ${ }^{12}$, 同呼吸器内科 ${ }^{2}$ ○西山みどり $(\mathrm{CT})^{11}$, 山崎志寿子 (CT $)^{1 \text {; }}$

吉田康雄 $(M T)^{1}{ }^{1}$, 高橋剛 $(M T)^{11}$, 岸田由起子 (MD $)^{11}$ 薬丸一洋 $(M D)^{1)}$, 島貫由里 $(M D)^{2)}$

[はじめに $]$ 胸水貯留を伴う炎症性病変として結核 が挙げられる.この際出現する中皮は, 反応性中 皮様であっても中皮腫の可能性もある. 今回我々 は初回の胸水細胞診で, 結核性胸膜炎を疑った悪 性中皮腫の 1 例を経験したので報告する.

[症例]52才男性, 石綿暴露歷不明, 結核の既往歴 なし, 平成7年3月頃より労作時息切れを主訴とし 当院呼吸器内科を受診, 初診時左胸水があり, 精 査のため入院. 胸水細胞診では多数の小リンパ球 と中皮細胞を認めた。中皮は結核等の炎症による 反応性中皮が考えられた。 また原因特定できず, 外来でfollowされていた. 同年7月, 再び息切れ が増悪し精查加療目的に再度入院した. 胸部超音 波エコー下生検を施行した結果, 生唡時スタンプ 標本では悪性中皮腫を疑い, 組織診にて上皮型悪 性中皮腫と診断された。治療は化学療法を行ない 現在外来にて経過観察中である.

[細胞所見] 1 回目の胸水細胞診をretrospective に観察した. この結果背景のリンパ球と共に多数 の中皮細胞がみられた。これらは乳頭状のものや 単核・多核の細胞で, 大きいがN/C比の增加は殆 どなく, 核クロマチンの増加は軽度, 核不整はみ られたが軽度で, 核小体も目立たなかった。

[組織所見]胸膜生検の結果, 腫瘍細胞は類円形〜 多角形の広い好酸性の胞体, 大小不同ある類円形 核をもち，主として充実性に增殖していた。一部 に乳頭状の増殖もみられた。また特殊染色を行な った結果, 悪性中皮腫と診断された。

[まとめ]セルブロック標本での特殊染色の結果及 び反応性中皮と中皮腫との細胞的鑑別について娭 討し報告する。

\section{6 上皮型悪性中皮腫の 4 例}

総合病院土浦協同病院中央検查科 ${ }^{1)}$ 、同病理部 2)、 同内科 ${ }^{2)}$ 、同心臟血管呼吸器外科 4

○木村 博 (CT $)^{11}$, 深沢徳行 (CT $)^{1)}$, 池田 聡 (CT $)^{1)}$, 芝田敏勝 $(M D)^{12}$ ，鈴木恵子 $(M D)^{2)}$ ，筥原陽子 $(M D)^{3)}$ ， 船越尚哉(MD)

悪性中皮腫は比較的まれな疾患で反応性中皮細 胞や腺癌との鑑別を要し細胞判定が困難なことが 多い。今回我々は、上皮型覀性中皮腫 4 例を経験 したので報告する。

〔症例 1〕69歳、男性。(細胞所見)好中球多数の 背景に核り叹チ顆粒状增量、明瞭な核小体 (大部分 は 1 個)を伴う核中心性の腫場細胞であった。細胞 質は辺縁明るく、核周囲重厚性であった。大部分 は环立散在性に出現していたが、一部pair cell状、 または、 $2 \sim 3$ 個集合性にみられた。全体的に腫 湟細胞は少なく、細胞診Class III と判定した。

〔症例 2〕63歳、女性(細胞所見)リンパ球が散在 する背景に、大小不同性の腫勍細胞が出現してい

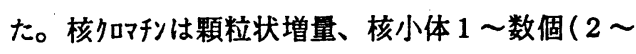
3 個が多い)伴い、核中心性の腫演細胞がシート状、 散在性に多数みられた。

〔症例 3〕50歳、男性(細胞所見)リンバ球多数の 背景に核々叹利顆粒状增量、核小体 $1 \sim 4$ 個 ( 1 個 のものが多い)伴う、核中心性の腫疱細胞がシート状、 散在的に多数みられた。

〔症例 4〕54藏、男性(細胞所見)リンパ球散在す る背景に核ク吼顆粒状す增量、類円形の明瞭な核 小体 ( $1 \sim 4$ 個)を伴う核中心性の腫福細胞が乳頭 様に集合して多数みられた。核分裂像も教見され た。 4 症例とるにPAS染色では細胞質に顆粒状ある

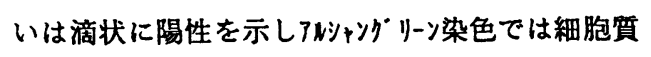
辺縁に陽性であった。また、七アk酸はいづれる高 値であった。

〔組織診断〕 4 症例とすに上皮型悪性中皮腫であ った。以上、免度染色及び電顕所見を加えて報告 する。 


\section{7 上皮型悪性中皮腫の細胞学的㭘討}

袋井市民病院病理部 ${ }^{1}$ 県西部浜松医療センター胸 部外科:

O城崎俊典 $(C T)^{1 /}$ 有吉啓子 (CT $)^{1}$ 石堂 統 $(C T)^{1}$ 加藤智行 $(M T)^{1}$ 伊藤以知郎 $(M D)^{1}$ 半澤 㑺(MD)

くはじめに> 今回我々は, 細胞診で悪性中皮腫を 疑い,組織学的に上皮型覀性中皮腫と確定診断され た4症例について細胞所見を再検討し若干の知見を 得たので報告する。

<症例 >症例1: 91 才, 男性.腹部膨満感を主訴に当 院受診.アスベ不暴露歴なし.C Tで腹水および肝門 部に腫瘤を認めた.腹水細胞診より悪性中皮腫が疑 われたが確診は得られず剖検にて湧慢性上皮型腹 膜悪性中皮腫と診断された.症例2:53才,男性.下腹 部膨満感を主訴に当院受診.職歴は青石綿を使用す る職業に従事. C T で多量の腹水を認めた.腹水細 胞診より覀性中皮腫が疑われたため腹腔鏡桯査を 施行. 病理学的に上皮型腹膜悪性中皮腫と診断され た.症例 $3: 58$ 才, 男性.下腹部膨満感を主訴に当院受 診.職歴は自動車製造工場勤務.肝機能異常, 腹水が 認められたため腹水細胞診を施行.細胞学的には陰 性で反応性中皮細胞と診断.以後外来で経過観察を 行っていたが,全経過1年8力月で死亡.剖検にて洒 慢性上皮型腹膜悪性中皮腫と診断された.症例 $4: 6$ 4歳, 男性.アスベ不暴露歴なし.胸部 X線写真に左胸 部異常陰影が出現し増大傾向がみられるため, 胸 壁腫瘍の診断にて腫瘍摘出術を施行. 病理学的に上 皮型覀性胸膜中皮腫と診断された.<細胞所見のま とめ>1)異型の乏しい小型中皮様細胞が乳頭状や 羽状など立体的な集塊でみられた.2)ラ仆グリーンに 好染した豊富な細胞質と細胞周囲に微䋐毛梾構造

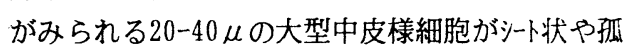
立散在性にみられた.3)大型多核中皮細胞がみられ た.4)背景にライドリーンに好染する粘液様物質がみら れたなどが特徵的な細胞所見であった.また,悪性 中皮腫のマーカーとして注目されている抗Thrombomod ulinの免疫染色についても考察する予定である.
358 慢性関節リウマチ患者に見られた特異 的な胸水細胞診所見

東京医科歯科大学病院病理部

○森山美樹 (C T) 、山本嘉子 (C T) 、根本哲 生 $(\mathrm{MD}) 、$ 江石義信 $(\mathrm{MD})$

【はじめに】慢性関節リウマチ (rheumatoid arthritis; 以下RA）には肺・胸膜病変を合併す ることがあり、胸膜炎はしばしは胸水を伴う。今 回我々は、RA患者の胸水中に特徽的な細胞像を認 め、RAに伴う胸膜炎と診断し得た一例を経験した のでここに報告する。【症例】53歳男性。1991 年时関節痛を主訴とLRA と診断される。その後、 治療するも軽块せず、1995年関節痛増悪、同時に 胸部線にて胸水貯留か認められた。胸水中グル コースは $2 \mathrm{mg} / \mathrm{dl}$ と低值。胸水細胞診とともに、 結核菌の培養及ひPCR検出を行ったか結果はとも に陰性であった。【細胞像】胸水中には、マクロ ファージを多数認めた。膂鉭形あるいは長細く引 き延ばされたようなマクロファージや大型、円形 の多核マクロファージか㳻見された。背景には顆 粒状無定型物質を認めた。リンハ球、好中球は少 数。正常の中皮細胞はごく少数であった。【考察 】今回我々か経験した細胞像は、胸膜上のマクロ ファージの梱状配列やリウマチ結節様の壊死を伴 う肉芽腫性病変を反映していると考えられる。 Nayl arらはRAに伴う胸水の細胞像を検討し、今 回のような所見はRAに伴う胸膜炎に特異的と報告 している。胸水中グルコース低值、結核菌か検出 されないこととあわせてRAに伴う胸膜炎と診断さ れた。 
359 腹膜および大網に巨大腫瘤を作り 腹水中に腫瘍細胞の出現した，睪丸原発と考え られる混合型胚細胞腫瘍の 1 例

東京医科大学病院病理部

$\mathrm{O}$ 三宅真司 (CT)，芹澤博美 (MD)，小池说子(CT)， 清川真理子(CT)，清水亨 (MD)，廣田映五 (MD)

〈症例〉 39才男性. 7 年前腹部膨满感を訴之画 像所見で後腹膜腔に巨大腫瘤を認めた. 左鎖骨 上䆚リンパ節の生検で転移性胚細胞腫瘍と考之 られたが，原発巣は特定されなかった．臨床的 には血清NSE 高値であること, 後腹膜腔に主腫 瘤があることから神経芽細胞腫の疑いもあると みて化学療法および放射線㞠法が施行された。 その後腫瘍は縮小, 增大を繰り返したが本年大 網および左側腹部に新たな腫瘍が出現したため これを摘出，同時に腹水細胞診を施行した． 1 カ月後精巣原発疑いのもと左精栄を摘出した. 〈腹水細胞所見〉腫漡細胞は N/C 比が高く集 塊あるいは孤立散在性に出現した。腫瘍細胞に は明暸な核小体と大型円形核を特徵とする細胞 質淡明な細胞と，核小体が不明暸で核縁がやや 肥厚した不整な棈円形核をもつ細胞，それらの 中間的な細胞とに区別された．クロマチンは微 細顆粒状のものが多く，細胞質内にはグリコー ゲンと考えられる PAS 陽性の顆粒をもつ細胞 やヒアリン小体样構造も見られた.

〈組耭所見〉左鎖骨上䈪リンパ節では精上皮腫 のみの像が見られ，大網部および左側腹部では 精上皮腫, 胎巟性癌, 卵黄腫瘍からなる複合 型胚細胞腫瘍であった. 原発巣として颎った左 精巣は長径約 $5 \mathrm{~cm}$ に腫大し，その大部分は結節状 の㾿痕組織であり，腫瘍は見いだせなかった。 これは化学療法による癜痕化あるいは burned out tumor とみられ，睪丸原発と推測された。 〈まとめ〉転移性肧細胞腫瘍の場合，睪丸の潜 在虞や burned out tumor の存在を考虑し，徽 底した桯索がなされるべきである。
360 心囊液細胞診で診断された ホジキン病の心膜浸潤

東京都老人医療センター病理部門 11 東京都老人総合研究所臨床病理部門2)

○小池 昇 (CT $)^{11}$, 小岩井英三 (CT ${ }^{11}$ 沢辺元司 (MD $)^{1), ~}$ ，田久保海誉 $(\text { MD })^{2)}$

【緒言】ホジキン病の浸潤は一般にリンパ装置 を連続性に侵し、本来リンパ装置の乏しい心膜 にこれをみることは比較的稀である。我々は心 車液細胞診で Reed-Sternberg 細胞を認め、心 膜浸潤と診断された一例を経験したのでここに 報告する。

【症例】症例は84歳、男性。1991年 9月に発熱 で当院に入院し、そけい部のリンパ節生検によ りホジキン病 (混合細胞型) と診断された。化 学療法を受け退院するも、1994年10月に呼吸器 症状が出現し再入院。気管支擦過細胞診で腫瘍 細胞を認め、また腋窝りンパ節生検で再発が確 認された。化学療法を受けて一旦退院するも、 1995年 3月、喘鳴、浮腫のため 3 度目の入院と なった。入院時、多量の心囊液がみられ、これ より多数の腫癔細胞が検出された。患者は心不 全により 4 月に死亡、剖検の結果ホジキン病の 再発、心膜浸潤が確認された。

【細胞像】心囊液にみられた腫熉細胞は、多数 の組織球とともに散在性に出現する中型から大 型の類円形細胞で、分葉状核や 2 核鏡像、大型 核小体などから Reed-Sternberg 細胞と診断さ れた。胞体は比較的明るく、中皮細胞との鑑別 は容易であった。また免疫細胞化学的にも Ki-1 陽性を示した。

【結語】ホジキン病の腫瘍細胞がリンパ節以外 の材料にみられる場合は、多くは浸潤をきたし た結果である。細胞診断に際しては既往の所見 が参考となるが、診断に苦慮する場合は免疫細 胞化学的娭索か有用でよる。 
361 肺癌切除症例における開胸時胸腔洗 浄細胞診陽性例の検討

\section{新潟県立がんセンター病理部}

○渡辺芳明 ( C T ), 桜井友子 ( C T ), 西村広栄 ( C T ), 宇佐見公一 ( C T ), 須貝由美子 ( C T ), 泉田佳緒里 ( C T ), 佐藤由美 ( C T ), 本間慶一 (MD)，根本啓一(MD)

【目的】肺癌例に於いて胸膜浸潤の有無は、重要 な予後因子である。今回、明らかな胸水貯留を認 めない症例に対して開胸時に胸腔内洗浄細胞診を 施行し、陽性であった症例の検討を行ったので報 告する。

【対象と材料】対象は1993年〜94年の 2 年間に当 院に於いて原発性肺癌にて肺切除術を行った E0 の209例。症例の内訳は腺癌128例、扁平上皮癌70 例、小細胞癌 7 例、大細胞癌 1 例、腺扁平上皮癌 1 例、悪性リンパ腫1例、悪性黒色腫1例である。材 料は開胸時、50〜100m の生理食塩水にて胸腔内 を洗浄し、20mlを回収して行った。標本作成方法 は遠心沈殿後、ドライ標本を作成する。次いで沈 殿物に $1.2 \%$ シュ酸アンモニウムを加え溶血後、 オートスメアを用いて塗沫し、アルコール固定を 行った後、パパニコロウ染色を施し検鏡した。

【結果】209例中、15例 (7.2\%) に癌細胞が認め られた。組織型では腺癌13例（13/128、10.2\%）、 扁平上皮癌 1 例 $(1 / 70 、 1.4 \%)$ 、小細胞癌 1 例 (1/7、14.3\%) であった。T因子別では T $1: 4$ 例。 T 2:3例。 T 3 : 2例。 T 4 :6例。N因子別で はN0：9例。N $1: 3$ 例。N $2: 3$ 例。胸膜浸潤別 では $\mathrm{p} 0: 1$ 例。 p 1 : 4例。 p $2: 7$ 例。 p $3: 3$ 例で あった。

【結語】今回の成績、陽性率 $7.2 \%$ は山岸らが報 告した $7.0 \%$ と、ほぼ一致した結果であった。組 織型別では、扁平上皮癌で低率、腺癌、小細胞癌 で高率であった。特に、p 0、p1の5例が陽性で あったことが注目される。更に、陽性例の臨床経 過の検討を加え、報告する。
362 胸水中に認められた悪性血管内皮腫 細胞の免疫組織化学的検索

滋賀医科大学病理学第二講坐 ${ }^{11}$, 同第一講夾 ${ }^{21}$, 同中検病理 ${ }^{31}$,同第二外科 41

○片岡秀夫 ${ }^{\prime \prime}$, 天野 殖 ${ }^{2}$, 早瀨ヨネ子 ${ }^{1}$ ， 池原ゆずる 21 ，服部隆則 2)，岩井宗男 ${ }^{31}$ ，宮平良満 ${ }^{31}$ ， 大久保貴子 ${ }^{31}$ ，岡部英俊 ${ }^{31}$ ，手塚則明 41

墨性血管内皮腫は血管内皮由来の茞掦であり、 組織学的には管造形成を特徵とする。胸水細胞㟝 では管燃形成確認は困難であり、加えて細胞形態 も多彩であるため確定診断が難しい。今回、胸水 中の腫湐細胞について血管内皮由来であることを 証明するため、免疫組織化学的 (IHC)およひ、奄子 顕微鏡 (EM) 検索を行ったので報告する。

【症例および方法】73才女性。'94年12月頭頂部に 直径 $1 \mathrm{~cm}$ 大の連㴼出現。'95年2月当院受部時には㨁 径 $5 \mathrm{~cm}$ 大の易出血性䏸耀に增大し、生検にて血管肉 庫と浾断された。Radiation、免疫賦活港法を施行 後退院するむ、7月胸水出現のため再入院となった。 検索は胸水細胞および頭部皮組織を用いた。IH CはFactorVIII(F), Trombomodurin(T), Vimentin(V), CEA (C)をLSAB法にて行い、EM検案は皮床組織を用 いて通常の方法で行った。

【結果および考察】頭部皮床組䋨は多角形核をも つ大型の翼型細胞加、上皮細胞類似の形態を示し た。胸水細胞は類円形細胞が环立性、細胞集団と して認められた。核周囲に厚い細胞質、変在した 類円形核そして核小体も著明であり血管肉属とし て矛盾しない所見であったか、確定には至らなか った。IHCの結果F(+)、T(++)、V(+++)、C(-)で、 胸水中の腫瑒細胞に二種の血管内皮マーカーが確 認された事より、細胞診での覀性血管内皮腫の坅 断が可能となり、IHCの有用性が確諗された。EM検 索の結果、内皮細胞に特異的な䄱ibel-Palade bodyは確認できなかったが Desmozome、actin \& myosin filamentを認め、墨性血管内皮盾として矛 盾しない所見であった。 
363 胸水中に異型細胞の出現をみた類 上皮血管内皮腫の1例

産業医科大学病院病理部", 同第一病理学教室"

○岩井幸子(CT $)^{\prime \prime}$, 岡 春子 (CT $)^{\prime \prime}$, 藤原 仁 (CT $)^{n}$ ， 小原光祥 (Cr $)^{11}$, 溜田哲夫 (MD $)^{11}$, 笠井孝彦 $(M D)^{2)}$, 橋本 洋 $(M D)^{2)}$

【はじめに】Epithelioid hemangioendothelioma （EH）は稀な腫場で、肺、肝、軟部、骨などに発生 するといわれている。今回我々は、胸水中に出現 した異型細胞がEHの腫嗱細胞である可能性を考え、 検索を行った。その細胞像を中心に報告する。

【症例】65才男性。1993 年検診にて左肺の異 常陰影を指摘され、精查を目的として当院受診。 同年10月開胸肺生検施行。その後、1995 年1月 には肺内に多発する小結節を、同年10月には柴肉 に潰漡の多発を認め、歯肉の生検が施行された。 同時期に胸水の急速な貯溜があり、胸水細胞診に て異型細胞を認め、class四と診断された。

【細胞所見】胸水は肉眼的に黄色やや混濁。背景 は線維樣物質を含む血性で、多数のリンバ球が認 められた。少数の異型細胞が弧在性あるいは平面 的小集団で出現。核は情円形で偏在㑯向が強く、 多核や不整形のものも認められた。細胞覧は淡明 で、個々の細胞境界は比較的明膫。細胞朢内空胞、 核内空胞を有する細胞が散見された。パパニコロ 一染色脱色後の免疫染色ではFactorVII陽性の所見 が得られ、これらの所見からEHが強く疑われた。

【組織所見】一部肺組織を含む胸膜及び歯肉組織 ではいずれも著明な線維性肥厚がみられた。その 中に资症細胞浸潤を伴って、索状あるいは小胞巣 を作る上皮様腫愓細胞が認められた。睡愓細胞は 免疫染色にてFactorVIII, CD34, CD31, vimentin陽性、 cytokeratin, EMA陰性。以上の所見よりEHと診断さ れた。 